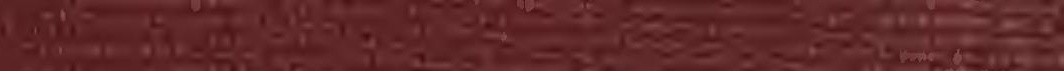

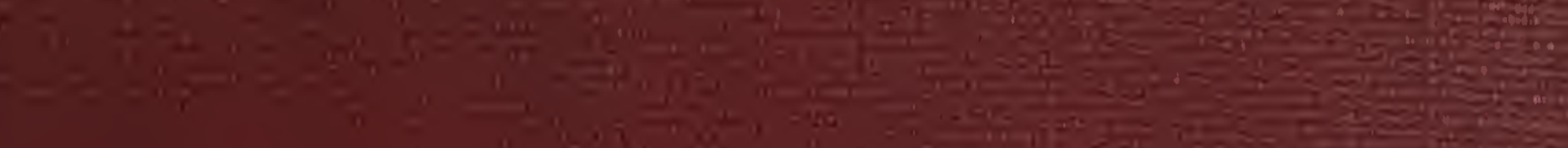

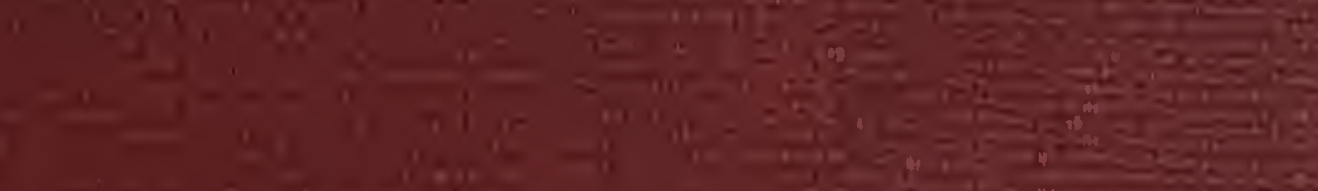

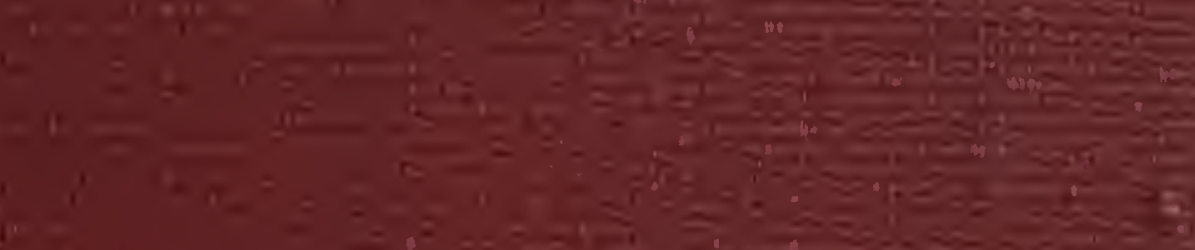

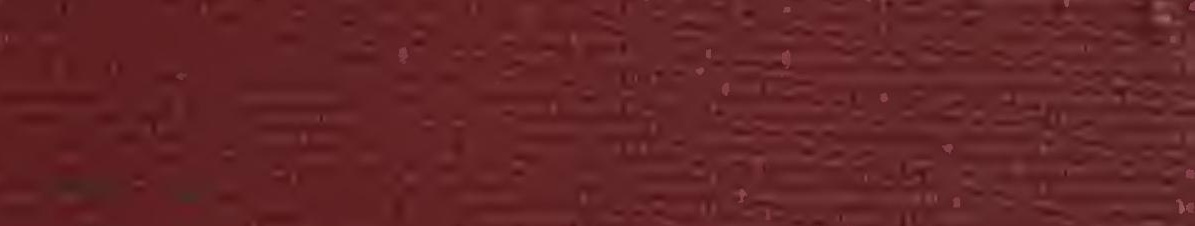


UNIVERSITY OF ILLINOIS

LIBRARY

$016.973^{\text {Book }} \cdot F 529$ 
ats

Return this book on or before the

Latest Date stamped below. A charge is made on all overdue books.

University of Illinois Library

\section{JUL 291968}

$\mathrm{L} 161-\mathrm{H}+1$

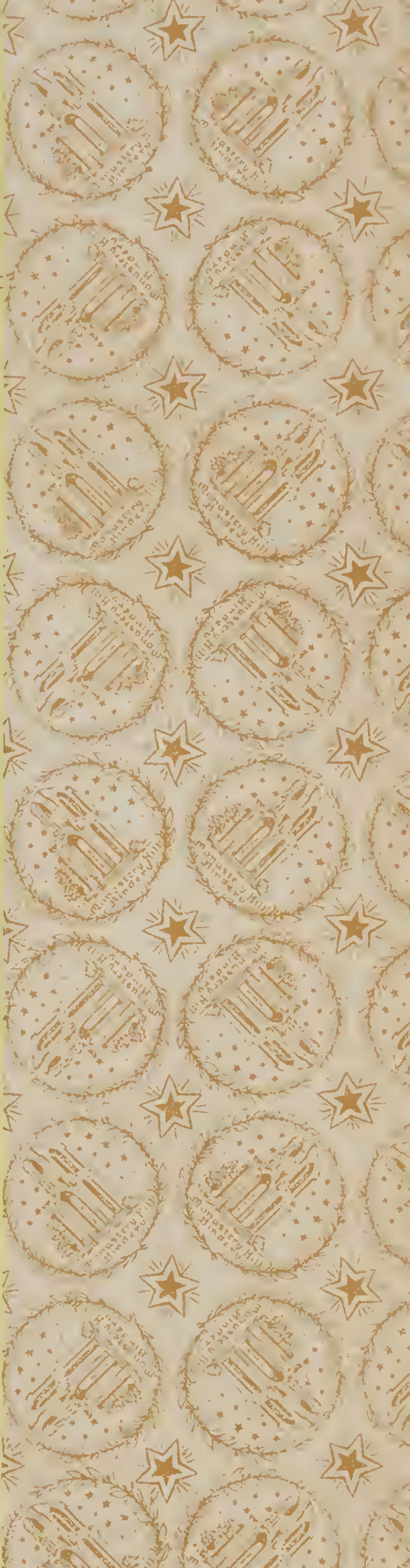

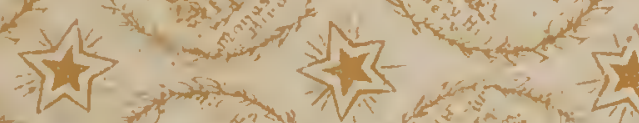

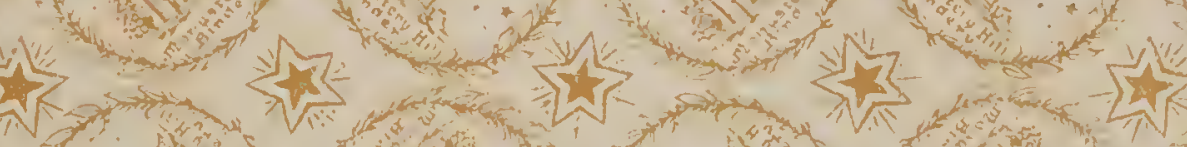
10

管

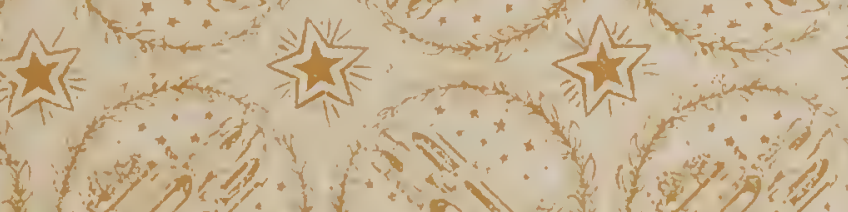
(3) $y=1,0$

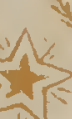

1. 





\title{
Guide to the Materials for American History in Roman and Other Italian Archives
}

\author{
BY \\ CARL RUSSELL FISH \\ Professor of American History, University of Wisconsin
}

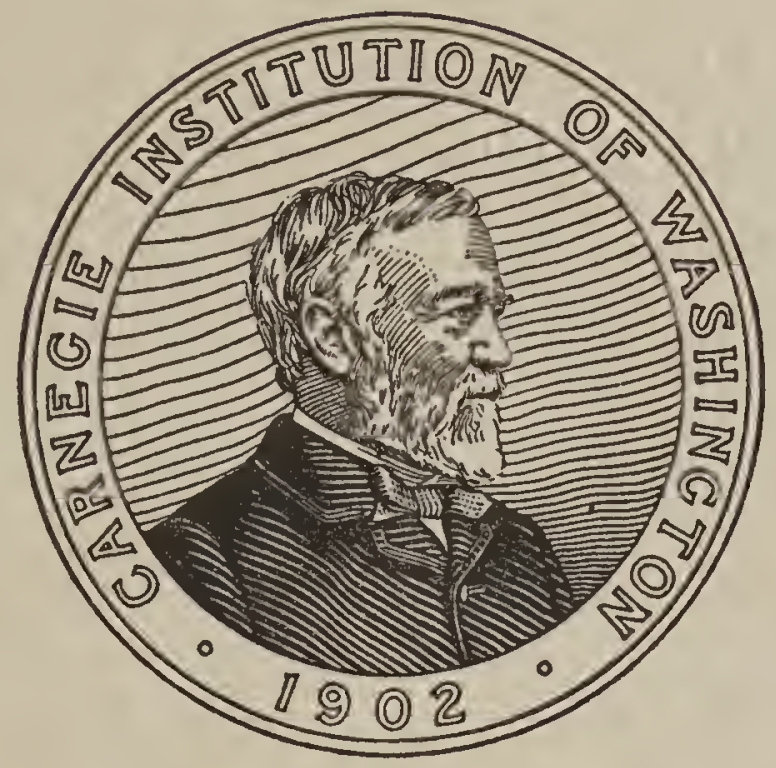

WASHINGTON, D. C.

Published by the Carnegie Institution of Washington $1911^{-}$ 


\subsection{3 \\ of 5 ing}

CARNEGIE INSTITUTION OF WASHINGTON

Publication No. 128

Papers of the Department of Historical Research

J. Franklin Jameson, Editor

¿Be Eord Otaltimore Opress

BALTIMORE, MD., U. S. A. 


\section{INTRODUCTORY NOTE.}

In any series of guides to the materials for American history in foreign archives, the Roman archives deserve a prominent position and early treatment. Two reasons justify this statement. In the first place, although the documents in those archives relate primarily to ecclesiastical affairs, yet religious history constantly deserves the attention of the student of civil as well as of ecclesiastical history, and the influence of the Catholic Church and the scope of its operations can never be appropriately defined within confessional limits. In the second place, of all the great national archives of Europe there are none that have been so little exploited for purposes of American history as those of Rome and Italy.

With these considerations in view, Dr. Carl Russell Fish, professor of history in the University of Wisconsin, was asked to give his aid to the Department of Historical Research as a Research Associate of the Carnegie Institution, and to undertake the preparation of the following manual. His work in Italy began in September, 1908, his labors in Rome in October of that year, and he left the country at the beginning of August, I909. That an exhaustive search of all the materials bearing on American history in the vast archives of the Roman Church, and in those of Italy, could not be achieved within the period of time indicated will, if not obvious beforehand, be plain to anyone who reads Professor Fish's explanations. The plan which he followed, and which is set forth on a later page, was adopted as offering the best solution of the problem, in what manner he who has at his disposal a single year in a great archive may present to the historical students of his own country the greatest amount of trustworthy information as to what that archive contains. The book is therefore offered as a preliminary chart of a region still largely unexplored, a chart on which accordingly large spaces are perforce left blank, but upon which many lines have been laid down upon the correctness of whose location the traveller may rely.

J. Franklin Jameson. 



\section{AUTHOR'S PREFACE.}

The countenance and active interest of so many persons were necessary for the prosecution of this work, and were extended to me so universally and so sympathetically, that my gratitude goes out to the whole community of scholars at Rome. In particular I wish to express my thanks for direct and fruitful assistance given me by: Their Eminences, Cardinals Gotti and Gibbons; Their Excellencies, the Spanish Ambassador to the Holy See and the American Ambassador to the Kingdom of Italy; Their Highnesses, Princes Chigi, Doria, and Teano ; the Most Reverend the Archbishop of Milwaukee; Mgr. Umberto Benigni, Sub-Secretary of the Congregation of Extraordinary Ecclesiastical Affairs ; the Right Reverend Father Gasquet, Presiding Abbot of the English Benedictines and Chairman of the Commission for the Revision of the Vulgate; the Right Reverend Father Ehrle, sub-prefect of the Vatican Library; Mgr. Wenzel, late director of the Vatican archives, with Mgr. Ugolini, the present director, and many other officials of those archives; the officials of the archives of the Propaganda; the directors of the archives of the kingdom of Italy at Florence, Naples, Rome, Turin and Venice; Director Kehr of the Prussian Institute at Rome and many members of that Institute, particularly Dr. Hiltebrandt; the late Mr. W. H. Bliss and Mr. C. G. Crump, and other representatives of the English Public Record Office; Professor Blok and Dr. Brom of the Dutch historical commission; Mgr. Duchesne, director of the Écôle Française ; to many members of the Dominican, Franciscan, Capuchin, and Jesuit orders, particularly Father Plapman, M. O., and Father Thomas Hughes, S. J.; to Professor D. Giuseppe Clementi ; to Professor Ettore Pais of the University of Rome; to Professor C. H. Haskins of Harvard University; to Professor Ramon de Santa Maria, archivist of the Spanish embassy to the Holy See; to the Rev. Mr. Bannister, Fellow of All Souls, Oxford; to Dr. Arnold O. Meyer, professor in the University of Rostock; to Abbé J. Fraikin ; and to Cav. H. Nelson Gay. Without swelling the list to undue proportions, it would be impossible to include the names of all those whose help it will be a pleasure for me to recall.

Carl Russell Fish. 



\section{TABLE OF CONTENTS.}

INTRODUCTION

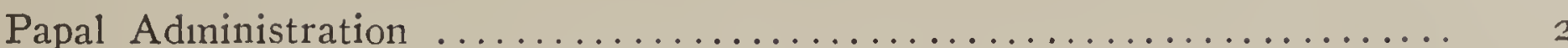

Conditions of Study.................................... 7

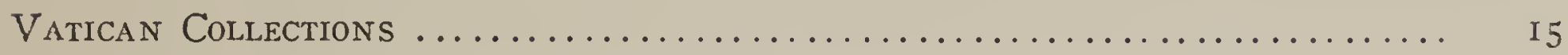

Vatican Archives: Archivio Segreto.................................. 20

Papal Registers ......................................... 20

Regesta Vaticana ...................................... 2I

Regesta Lateranensia .................................. 24

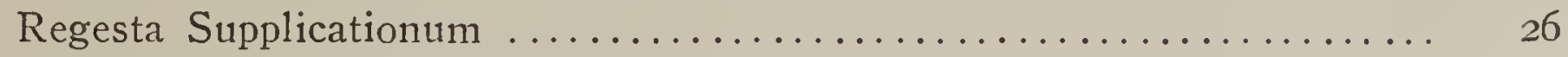

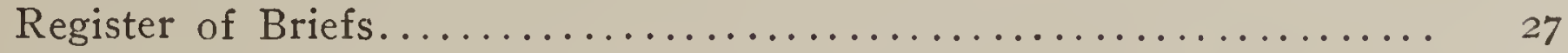

Register of Briefs to Princes and Latin Letters................... 30

Lateran Briefs ............................................. $3 \mathrm{I}$

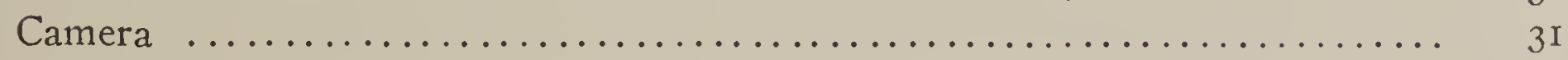

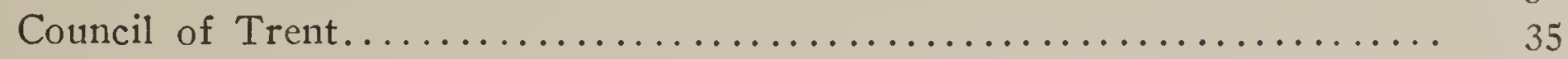

Remaining Armadii of the Archivio Segreto inventoried by De Pretis....... 35

Consistorial Archives ................................. 36

Archives of the Secretary of Bricfs.............................. 42

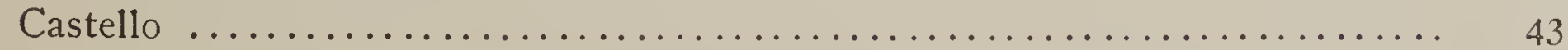

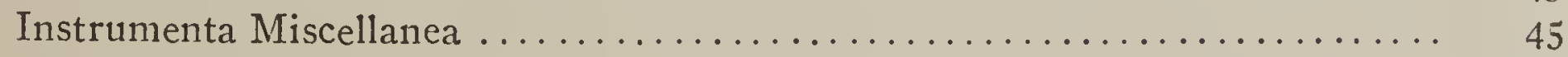

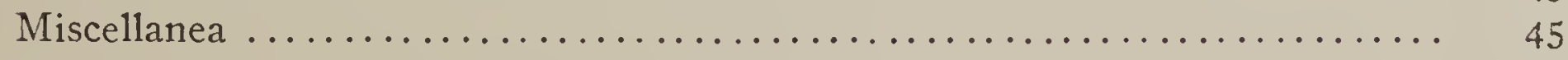

Vatican Archives: Archives of the Secretary of State.............. 52

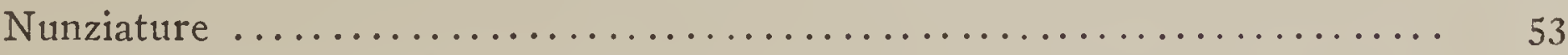

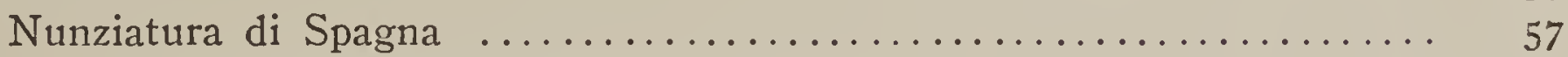

Nunziatura di Francia ................................... 71

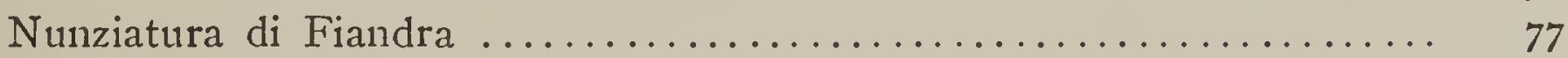

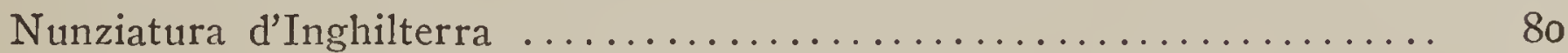

Nunziatura di Portogallo ............................... 82

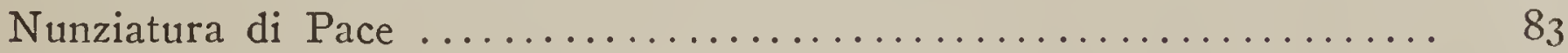

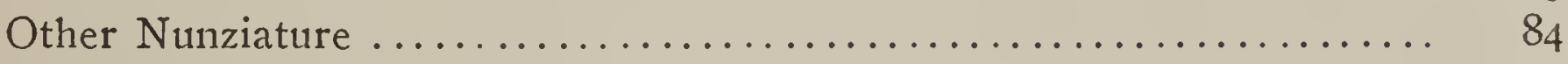

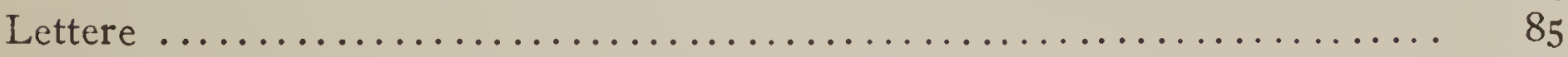

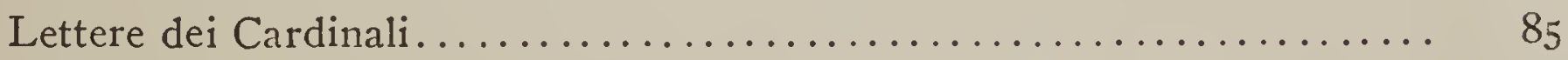

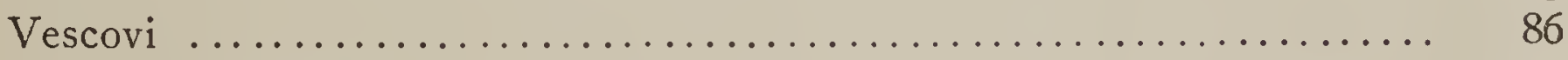

Principi e Titolati............................................... 87

Lettere dei Particolari................................. 89

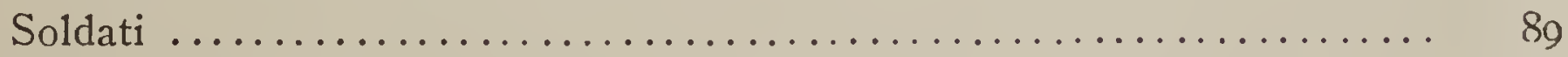

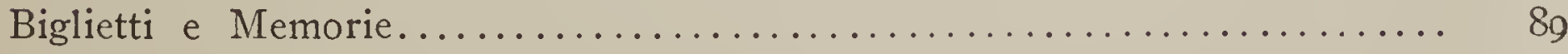

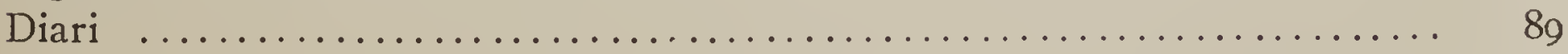

Vatican Archives: Minor Collections........................... 90

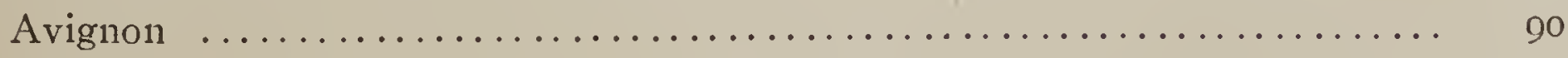

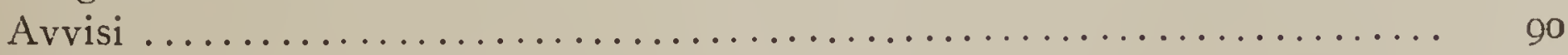

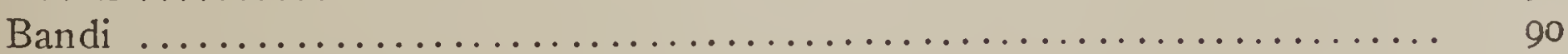

Biblioteca Bolognetti ...................................... 9 I

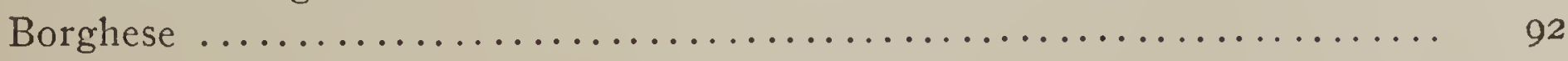

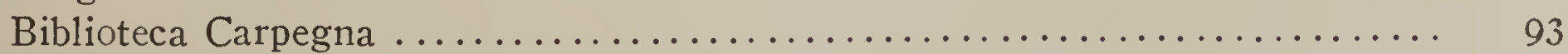

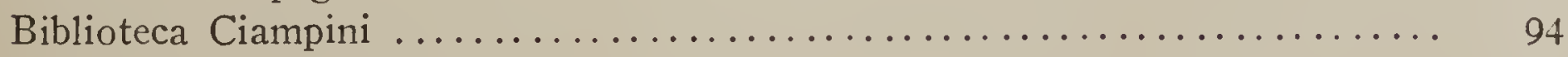

Collection of Clement XI.................................. 94 
Vatican Archives: Minor Collections-Continued. Page

Confalonieri Collection ............................... 96

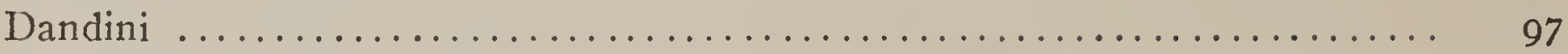

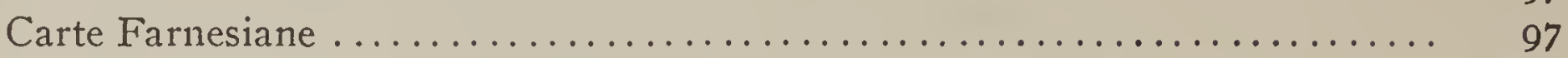

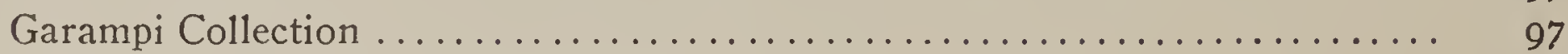

Instrumenta Monastica ............................. 98

Biblioteca Pio ....................................... 98

Biblioteca Ronconi ............................... I00

Rossi Collection ................................. I00

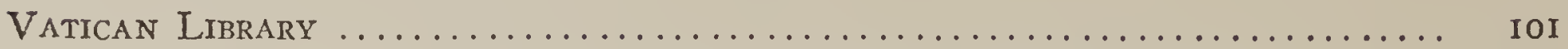

Barberini Archives $\ldots \ldots \ldots \ldots \ldots \ldots \ldots \ldots \ldots \ldots \ldots \ldots \ldots \ldots \ldots$ IoI

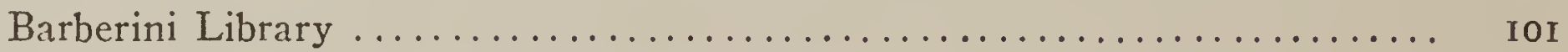

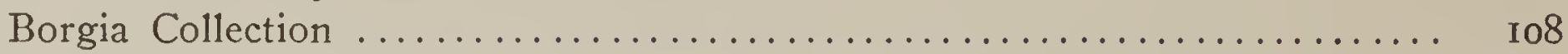

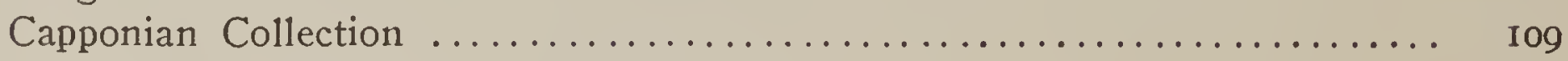

Ottobonian Collection .............................. Io9

Fulvio Orsini Collection. ............................. III

Palatine Library ..................................... II

Library of the Queen of Sweden .......................... III

Urbinate Collection . .............................. II

Bibliotheca Vaticana ............................. II6

Visconti Collection $\ldots \ldots \ldots \ldots \ldots \ldots \ldots \ldots \ldots \ldots \ldots \ldots \ldots \ldots \ldots \ldots \ldots \ldots$

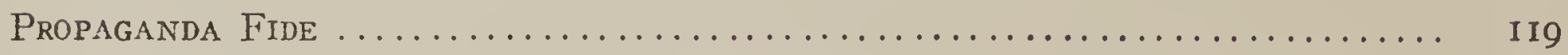

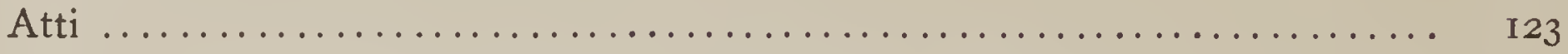

Scritture Originali Riferite nelle Congregazioni Generali............. I47

Scritture Antiche .............................. 48

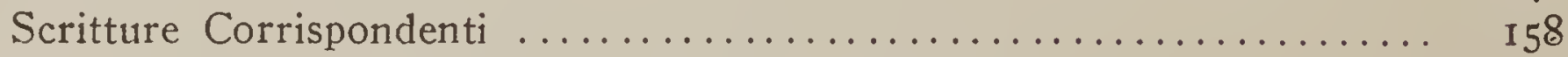

Scritture Riferite nei Congressi; or, Scritture non Riferite........... I58

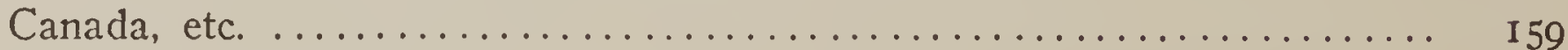

America Centrale ............................. 169

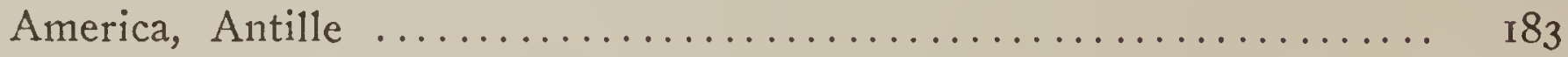

America Meridionale $\ldots \ldots \ldots \ldots \ldots \ldots \ldots \ldots \ldots \ldots \ldots \ldots \ldots \ldots \ldots \ldots \ldots \ldots$

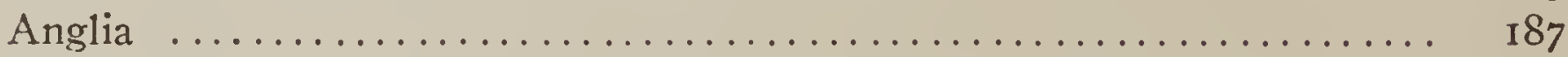

Francia, etc. $\ldots \ldots \ldots \ldots \ldots \ldots \ldots \ldots \ldots \ldots \ldots \ldots \ldots \ldots \ldots \ldots$

Lettere della Sacra Congregazione....................... I 88

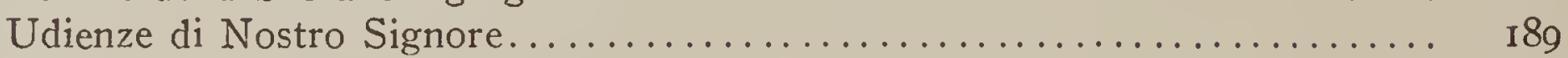

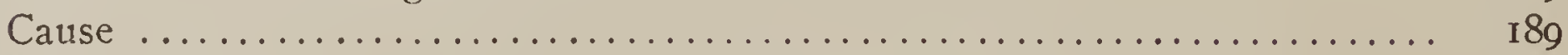

Memoriali $\ldots \ldots \ldots \ldots \ldots \ldots \ldots \ldots \ldots \ldots \ldots \ldots \ldots \ldots \ldots \ldots \ldots \ldots \ldots \ldots$

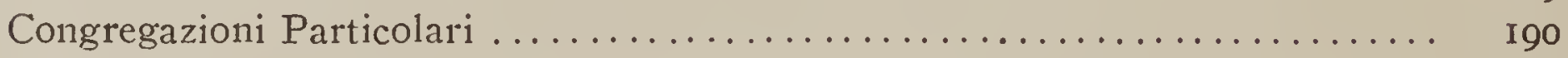

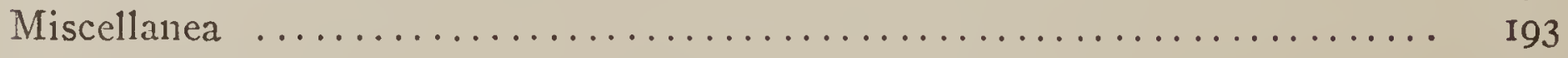

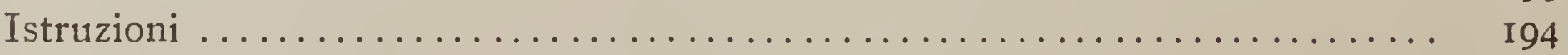

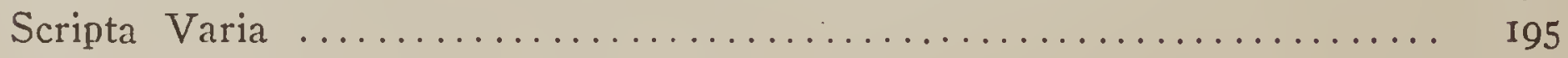

Visite e Collegi..................................... 195

Museo Etnografico de la S. C. de Propaganda Fide................. 195

Other Ecclesiastical Collections in Rome..................... I96

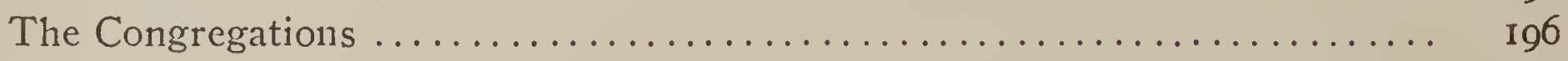

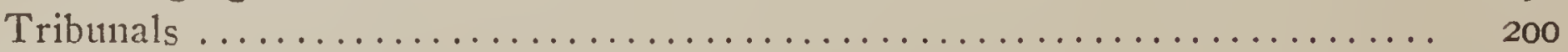

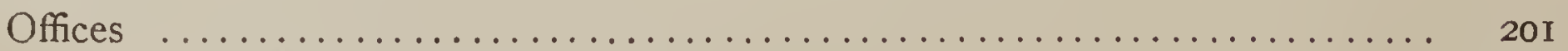

Archivio dei Maestri delle Ceremonie........................ 202

Monastic Orders ..................................... 203

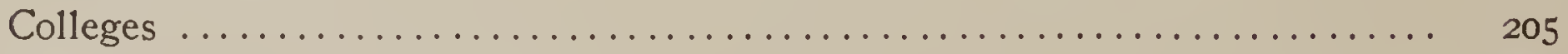

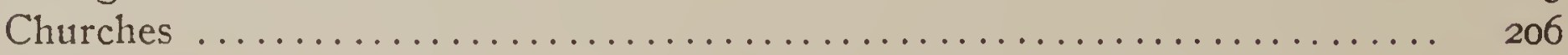


PAGE

Public Archives and Libraries in Rome.......................... 207

Biblioteca Alessandrina ............................. 207

Biblioteca Angelica ................................... 207

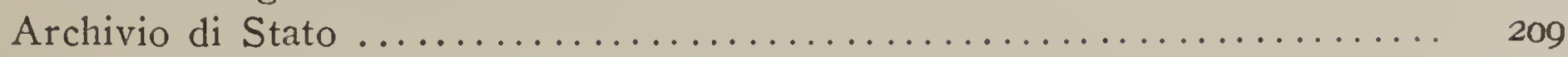

Biblioteca Casanatense .............................. 210

Corsini Library .................................. 212

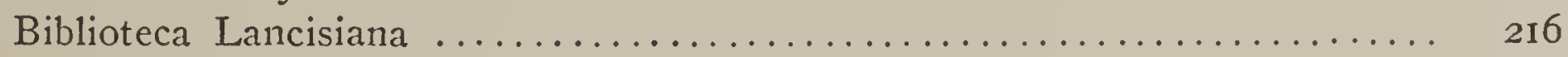

Biblioteca Vallicelliana ............................ 2 I6

Biblioteca Nazionale Centrale Vittorio Emanuele.................. 2I

Municipal Collections .................................. 220

Embassies and Rerigious Institutions of Foreign Governments at Rome.... 221

Archives of the American Legation. ..................... 221

French Embassy to the Holy See. . . . . . . . . . . . . . . . . . . . . . . . 222

Spanish Embassy to the Holy See.......................... 222

English Diplomatic Archives............................... 223

Archivo de los Reales Establecimientos Españolas.................. 224

St. Louis des Français. . . . . . . . . . . . . . . . . . . . . . . 224

Private Libraries in Rome................................ 225

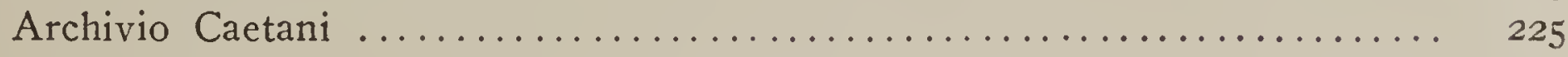

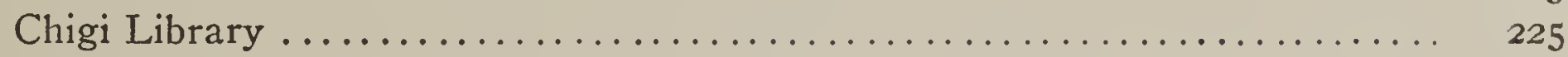

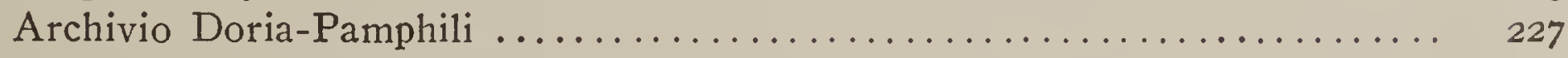

Private Libraries not investigated...................... 227

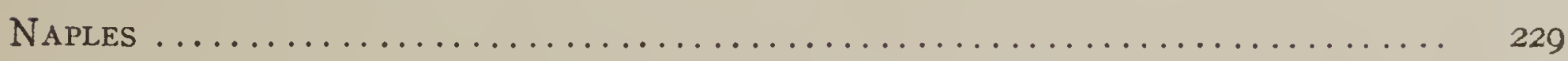

Archivio di Stato.................................. 229

Archivio Farnesiano ............................... 230

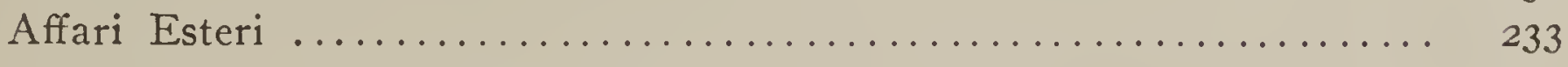

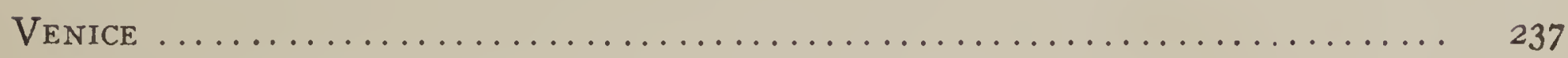

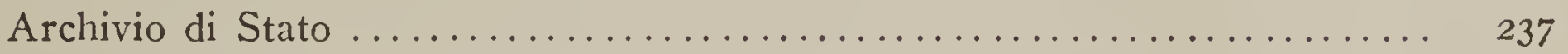

Lettere Ducali ................................. 237

Deliberazioni Secrete del Senato......................... 237

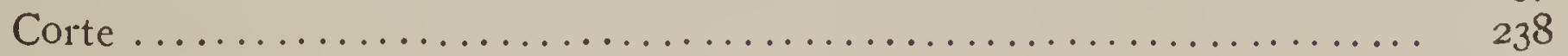

Relazioni ...................................... 238

Dispacci al Senato................................... 239

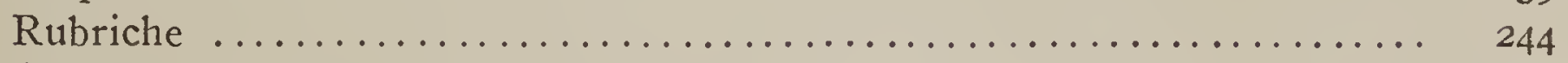

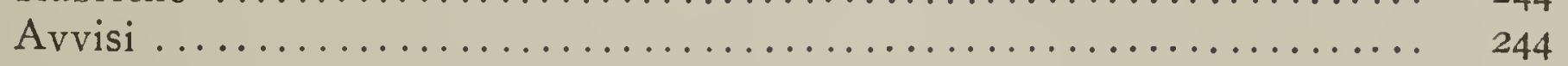

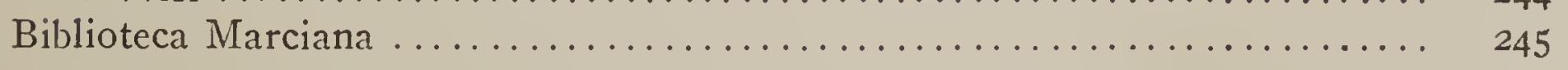

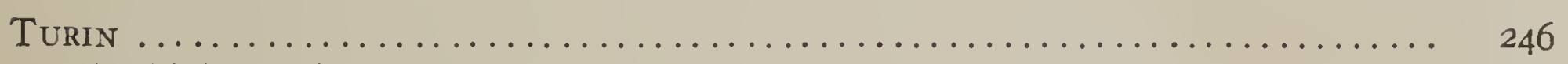

Archivio Nazionale . . . . . . . . . . . . . . . . . . . . . . . . . 246

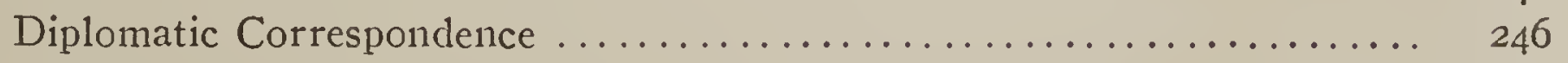

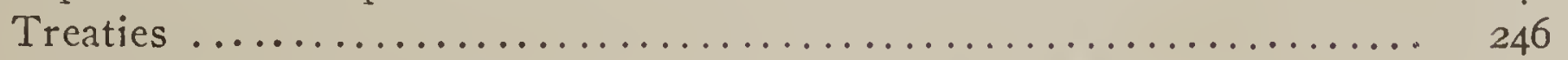

Miscellaneous Documents ........................... 246

Museo Storico dell' Archivio di Stato..................... 248

Biblioteca Nazionale ............................. 248

Florence ........................................ 249

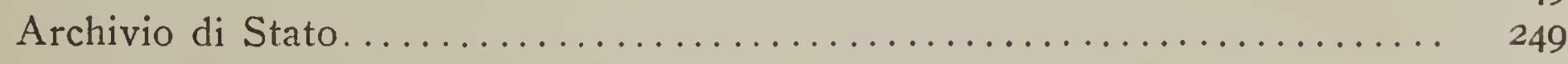

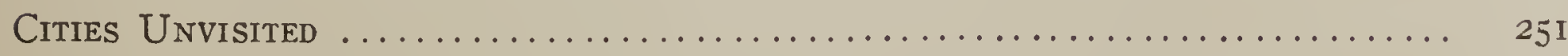

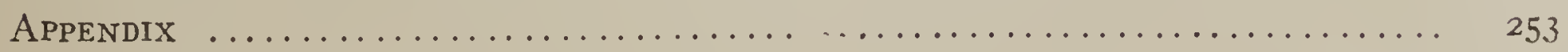





\section{Guide to the Materials for American History in Roman and Other Italian Archives}

\section{INTRODUCTION.}

The aim of this study is to render available to students the unprinted sources for the history of the United States and Canada existing in Italy, and particularly at Rome; its character has necessarily been determined by the condition of the material and the amount of time disposable. As compared with what is in the archives of England and of Spain, the total bulk of material is small, and such as exists is almost never found in collections or series special to the subject, but dispersed at large. This fact made it useless to give merely general descriptions, while on the other hand it was impossible exhaustively to examine every volume where an American document might lurk. The method employed was to study thoroughly a few volumes of every set which might be supposed to contain anything relating to America, and to give here, in addition to the description of the whole, the exact findings in these volumes, as well negative as positive.

In this portion of the work of searching foreign archives it seemed unwise to insist closely upon the strict limitations of the subject. It was often possible, without additional effort, to determine the absence of reference to both of the Americas, and it seemed worth while to make note of such cases. Occasionally where nothing relating to the United States and Canada was found in the volumes used, reference has been made to other American items, to show the scope of the series. All general references to America or the Western Indies and all documents of interest for general American history are mentioned; together with everything relating to Cuba and the northern provinces and bishoprics of Mexico, because of their connection with the missions of Florida and the Western states. In the use of catalogues, inventories, and indexes, it was necessary to exercise the greatest liberality, as their makers never had in mind the needs of American students. The name America rarely occurs, the names of Canada and the United States almost never, and the only safe method seemed to be to make the range of investigation as wide as possible, even at the expense of much time that might have yielded more definite results elsewhere.

Of the relations between Italy and America which have from time to time left their record in Italian archives, the most important and the most continuous has been that of the Catholic Church. This relation began with the first discovery, and extended with, and often far in advance of, the settlement of the country, retarded only in New England and the Southern states. The records of that church are, therefore, organic archives for Canada and for the larger portion of the United States during their entire history; and these records, or more particularly those of its central administration, were the main object of investigation. Essential archives, also, are the records of the diplomatic relations between the various governments which have from time to time controlled the United States and Canada, and those of Italy. As, how- 
ever, diplomatic activity is determined by actual relationships, these make but slight definite contribution, except in the case of the Papacy, where the existence of the Church in America was the cause of abundant controversy. For the general history, however, of that titanic struggle of European powers for sea power and colonies, which to so great an extent fixed the conditions of American development, Italian diplomatic correspondence is unexpectedly rich, for apart from their own share in these conflicts, the ambassadors of the Italian states were unsurpassed in the discovery and transmission of news. Even during the American Revolution the courts of England and France were scarcely better informed of the progress of events than those of Italy. Everything that seemed possible has been done to help in the use of this material.

The part played in the discovery and exploration of America by Italian navigators constitutes another very distinct bond of relationship, but no special search was made for sources on this subject; partly because the activities of these navigators were purely individual, so far as Italy was concerned, and consequently traces of them are even more scattered than in the case of other relationships, and partly because it was obvious that no valuable contribution could be made with the scant time that might be taken from other work, in a field so well tilled by investigators, both Italian and American. What was found by the way, is recorded. The great bonds of immigration, trade, travel, and intermarriage are so modern that they fall within the period for which archives are not regularly open, and private documents have not fallen into public custody. Only slight reference can at present be made to these subjects, but when the right time arrives they will properly command attention.

\section{PAPAL ADIMINISTRATION.}

For the use of the pontifical archives, some knowledge of the papal system of government, and especially of the central administration, is necessary. A brief sketch of its main features follows here, and some more detailed studies of individual departments are given in connection with their special collections. The year I908 saw more radical changes in this organization than had taken place for three hundred years. As these changes affect the archives of the future and not those now in existence, they are not given here, but many of them are noted in the chapter on "Other Ecclesiastical Collections". As to the earlier period, the papacy has, of course, undergone constant minor changes, and some important ones necessitated by the change from medieval to modern conditions. As, however, these latter had to a great extent been brought to pass before the affairs of America began largely to engage its attention, and as they involved not the destruction, but the modification of the old system, it is possible, in so short a sketch, to regard the organization almost as static, between 1492 and 1908 .

The fundamental devices of government are not numerous and the papacy differs from other governments rather by the combination, than by the character of its organs. In contrast with the United States, the fundamental theory of the Holy See has been the unity, instead of the separation of powers; but the distinction between executive, legislative, and judicial functions exists here as elsewhere, and the extent to which they were exercised by the several branches of the government will be noted.

The power of the Pope is supreme in all departments, save for the limitations of his capacity for work and the weight of routine; but not only are these limitations of great moment, and increasingly so as the importance of 
the matter in hand diminishes, but also his authority must be exercised according to established methods. In effect the Pope stands not alone, but as the head of the hierarchy.

After the Pope, comes the Curia or college of cardinals, to a certain extent the legislative body of the Papacy. The meetings of the college are known as consistories, and are of two kinds. ${ }^{1}$ The secret consistory is of regular occurrence; in it, appointments of bishops, the erection of episcopal sees, and such matters are dealt with. The public consistories are occasional; in them the creations of cardinals, beatifications, and canonizations are announced, papal allocutions are delivered, and the speeches of ambassadors, or at times of attending royalties, are received. Since the time of Sixtus V., neither meeting has been deliberative, and the unforeseen practically never happens. ${ }^{2}$ Their proceedings are important for fact, but not for motive, and the pontifical orations are not, like the speech of the king of England in Parliament, an outline of policy suggested, but of one adopted.

Most of the business of the college of cardinals is performed in the congregations. Here matters to be presented to the consistories are prepared, and many affairs of importance finally determined. The system of congregations was established by Sixtus V., in 1587, and at once assumed the leading place in the organization of the papacy which it has since maintained. A congregation is practically a standing committee. Its prefect is the Pope or a cardinal, and generally other cardinals, sometimes all, are members." In addition there is a secretary, not a cardinal, and other outside members or councillors who do not vote, and an administrative staff. Membership is of course for life, barring contingencies. Each congregation has charge of some great branch of business, and the greater portion of its work falls to it as a matter of course ; but, as in the American Congress, special cases are sometimes assigned to congregations to which they might not naturally fall, and border lands of obscure jurisdiction exist; while congregations frequently refer matters, the one to the other. In case of a disagreement as to jurisdiction, the intervention of the Pope is always to be obtained. Over the subjects that fall to its charge the powers of a congregation are extraordinarily great. It is, in fact, an executive and administrative, and at times a judicial body, as well as a legislative committee. It is the possession of this final power of determination within certain defined limits, its permanence represented by the secretary, and its touch with supreme authority, represented by its curial members, which combine to render the congregation so powerful and so distinguished an institution.

${ }^{1}$ Joseph Korzeniowski, Excerpta ex Libris Manu Scriptis Archivi Consistorialis Romani, 1400-I590 (Cracow, I890, pp. I5I). See pp. I-4.

${ }^{2}$ Note the disturbance caused when Cardinal Borgia, on Mar. 8, 1632, violated this convention and attacked Urban VIII.

${ }^{3}$ See Félix Grimaldi, Les Congrégations Romaines, Guide Historique et Pratique (Siena, I890, pp. xii, 556). This is more comprehensive than its name implies, treating nearly all the departments of papal government. It is the most useful account of present-day administration, though rendered somewhat out of date by the administrative changes of Pius $\mathrm{X}$.

'Paul III. (I534-I550) instituted the Cangregation of the Inquisition. Sixtus V., Jan. 22, I587, by the bull Immensa aeterni Dei, created fifteen congregations. Grimaldi, p. 146 .

"The Pope is prefect of the congregations of the Inquisition, the Consistory, the Holy Apostolic Visitation, and for the Reunion of Dissenting Churches.

"In some congregations there are a series of officials, each with special duties, but there are always several known as consoltori, or by some similar title, whose functions are general. 
The procedure of the several congregations is much the same. There are regular meetings or congregations, which may adjourn from date to date, much in the fashion prescribed by English parliamentary law. The regular pontifical congregations often appoint congregationes particulares, ${ }^{\top}$ or special committees, some of which are for the permanent reference of branches of the work, and others temporary, for special cases. Thus under the Propaganda, there has long been a special congregation for the East Indies, and there was at one time a special congregation on certain temporary conditions in the Western Indies. These subordinate congregations have, of course, no organic powers, and their action is effective only when approved by the parent congregation. It is difficult to distinguish precisely between these congregationes particulares, and the commissions which also exist under the general direction of the regular congregations; possibly it is that the latter need not have a cardinal member. ${ }^{8}$

The congregations whose range of activity may possibly have included the United States and Canada will be dealt with separately later, and their functions briefly described.'

Individually the cardinals act as "protectors" of kingdoms, monastic orders, and other institutions, thus being brought into contact with the whole life of the Church; but this relationship has been during the modern period largely a formal one.

To put into prescribed form, as bulls, to register, and to expedite the formal decisions of the Pope and the Curia, is the work of the chancery. The head of this department, the vice-chancellor, is always a cardinal. He is assisted by the college of abbreviators di parco maggiore, who enjoy ex officio the rank of prelate, and who aid in the preparation of the bulls. There is also a staff of secretaries and clerks. ${ }^{10}$ It is plain that a department of this character may assume an importance far beyond that indicated by its obvious functions. As is well known, the vice-chancellor was at one time one of the leading factors in determining papal policy. In the registers of chancery are found, in the time of Alexander VI. and Julius II., instructions to nuncios. The rise of the congregations and of the secretary of state has, however, tended to relegate the chancery to the performance of its immediate duties. Pius VII. decidedly reduced the number of its employees, ${ }^{11}$ and while its dignity remains, its powers are merely those arising directly from the work assigned it.

Somewhat similar functions are performed by the office of the secretary of briefs, which might almost be termed a subordinate chancery. ${ }^{12}$ Briefs are less formal in character than bulls, but it is difficult to trace the line of division. Vital offices of the Church, bearing emoluments, are conferred by bull, honorary ones by brief. Usually the decisions of the congregations in those matters over which they have final authority, take form in briefs. In addition to the duty of giving expression to the will of others, this office itself has a determining power over a few subjects, as dispensations with regard to the age for taking orders, and the use of private oratories. It has been in existence

${ }^{7}$ La Gerarchia Cattolica, la Famiglia e la Cappella Pontificia, le Amministrazioni Palatine, le Sacre Congregazioni, e gli altri Dicasteri Pontifici (Rome, r907, pp. 626). See pp. 464-504.

${ }^{8}$ I bid.

${ }^{9}$ See pp. 196-200.

${ }^{10}$ Grimaldi, pp. 43I-447; Gerarchia.

${ }^{11}$ Grimaldi, p. 44I.

${ }^{12}$ Ibid., pp. 469-487. 
since $\mathrm{I} 3 \mathrm{I} 7$. The authority is vested in a cardinal secretary, but the greater portion of the work is performed by a substitute and a staff of subordinates.

The chief executive officer of the papacy is the secretary of state. ${ }^{13}$ This office is entirely modern, its prototype dating only to 1484 , its importance beginning under Leo X., and its present status only from the time when Saint Carlo Borromeo held it. Its functions resemble those of a first minister in a temporal state, holding in addition the special charge of foreign affairs. Under the Pope, the secretary has been, since I 560 , the chief director of the policy of the Holy See. The secretary is assisted by a substitute, a secretary of letters to princes, a secretary of Latin letters, and a large number of subordinates.

The chief financial organ of the papacy is the Camera. ${ }^{14}$ This office is directly responsible to the Pope. It has never had so complete a control of finance as is usual in the case of government exchequers. The Curia, the congregations, and other bodies, have each their own financial officers, ${ }^{15}$ and their accounts seem never to have been correlated by the apostolic chamber. Aside from the revenues of the papal estates which have always been important, and the political revenues of the Papal States, the income of the papacy has been chiefly derived from the annates, being the whole or a specified portion of the first year's fruits of benefices in the gift of the Holy See; the quindeni, or similar payments made every fifteen years in the case of benefices held in mortmain; the censum, or a tax paid in return for temporal protection; the spolia, or receipts from the estates of holders of papal benefices; the revenue, during vacancies, of sees in the gift of the Pope; visitationes, or taxes on bishops in acquittal of visits to Rome on occasions when they were required to come there; procurationes, or taxes on the right of hospitality enjoyed during diocesan visitations; fees for services performed by the papal court, such as, servitiae communes of a new bishop, and the preparing of bulls; the fees for favors granted by the Dataria and the congregations; Peter's pence and other free-will offerings. ${ }^{10}$ The collection of most of the required payments was a duty of the Camera, and its collectors at one time travelled throughout Europe. With the improvement of means of communication, these special agents ceased to be necessary, and business became more concentrated at Rome. During the modern period the chief occupation of the Camera was with the Papal States, and when these were incorporated into the kingdom of Italy, its importance declined. At the present time another of its leading duties, the administration of the papal properties, is performed by a special commission apparently independent of it. $^{17}$ The Camera is administered by the Cardinal Camerlingo and a staff of subordinates.

The administration of the papal family is, of course, a matter of great importance. The head of this department is the master of ceremonies, whose duties are those naturally suggested by his title. After him is the master of the chamber, whose special charge is the making of introductions to the Pope. Under them serves a numerous corps of subordinates. ${ }^{18}$

${ }^{13}$ Ibid., pp. 13-23. See also pp. 52-53.

${ }^{14}$ See pp. 3I-34.

${ }^{15}$ See Gerarchia.

${ }^{10}$ See references in note 38, p. 32 ; and Grimaldi, passim. In particular, Berlière, Obligationes et Solutiones, p. iv; Bourgin, Archives Pontificales, pp. 50-5I. Also the archives themselves.

${ }_{17}$ Gerarchia.

${ }^{15}$ Grimaldi, pp. 4I-54. 
The chief judicial organ of the papacy is the Rota. ${ }^{18}$ This court was organized by John XXII. It acted as a supreme court of appeal for the Papal States in all causes, and a supreme court for all Christianity in spiritual causes. This second function was the less important during the modern period, as the congregations intercepted the greater portion of its work. The occupation of the Papal States by the Italian government put an end to its temporal activity, and it became of small importance, until I908, when Pius X., by a reorganization of administration, replaced it in a position where it will receive many cases previously settled elsewhere. ${ }^{20}$ The court is composed of nine auditors.

The Segnatura Papale di Giustizia acts, to a certain extent, as a court of equity."

There remain several bodies with functions peculiar to the requirements and customs of the Holy See. Of these, the penitentiary is of greater dignity than the chancery. ${ }^{22}$ The penitentiary frames and expedites its own decisions. Its functions are in a way judicial, but the cases arising under it are merely one-sided, a petition and an answer. It deals purely with such cases of conscience as fall beyond the range of the ordinary confessional. The greater portion of its work is with individuals, but it confers annually upon bishops certain general powers. Dispensations from vows, permission to hold ecclesiastical property confiscated by the state, and to receive interest, are among the subjects of which it treats. Its head is the grand penitentiary, always a cardinal, who is supported by a regent and a numerous staff of subordinates. Its favors being purely spiritual, no fee is required.

Ranking in the papal hierarchy after the chancery, is the Dataria, one of the busiest departments of the Holy See. ${ }^{23}$ Here are received, examined, and annotated all kinds of petitions addressed to the Pope. These for the most part have to do with matrimonial dispensations not involving matters of conscience, and with the granting of benefices. The head of the department is invariably a cardinal, but as this has not always been the case, and as a cardinal can not with dignity hold an office not of curial rank, he is known as the Pro-Datario. Under him is a very numerous body of subordinate officials and clerks. The Dataria acts as collecting agent for a large portion of the papal revenue, for the favors which it grants are among the most expensive which the Holy See accords, and its responses are not forwarded until the fees are paid.

Finally, there is the office of the cardinal secretary of memorials, a position of great dignity and giving very close relationship with the Pope. ${ }^{2 t}$ The greater number of the favors granted here are spiritual, the majority being papal benedictions with plenary indulgence in articulo mortis. It also deals with favors not specially relevant to any special office or congregation. In addition to the cardinal secretary, there is a large staff.

It seems to be a tendency, at the present time, to entrust the management of new topics as they arise to commissions, ${ }^{23}$ with less general range and less

${ }^{18}$ Grimaldi, pp. 57-58. See also p. 20r.

20 "Regolamento per le Sacre Congregazioni, Tribunali, Offici della Curia Romana", in La Civiltà Cattolica, Nov. 7, r908, pp. 346-358.

${ }^{21}$ Adolf Gottlob, "Das Vaticanische Archiv", in Historisches Jahrbuch, VI. 272.

${ }^{23}$ Grimaldi, pp. 405-430.

${ }^{23}$ Ibid., pp. 449-468.

${ }^{24}$ Ibid., pp. 24-40.

${ }^{23}$ See Gerarchia. 
independent powers than the congregations, thus concentrating power in the hands of the palatine administration, the Pope and secretaries. ${ }^{20}$ At the same time the recent legislative changes of Pius X. in I908 lessen the activity of the congregations by increasing the powers of the bishops and diminishing the amount of business to be brought to Rome on the one hand, and on the other hand by sending much of what will come, to the Rota ${ }^{27}$ and other tribunals.

The system of government of the Church at large, by bishops and archbishops, is too well known to require comment, and at the same time an understanding of it is not so essential to the use of the Roman archives. Unfortunately for the historian, the control of these local prelates by central administration was not, especially in America before the nineteenth century, so close as is sometimes supposed. Payments for bulls of appointment, and the necessity of requesting at regular intervals certain special powers necessary in America because of the difficulty of communication and other local conditions, formed almost the only uniform bonds; and, in the absence of a nuncio or other regular representative of the Curia, special occasions were often met by an assumption of authority on the part of those on the spot. The monastic system was better knit, but even here the American provinces of the several orders were not held in hand as were those of Europe; nor was the American work of European provinces so carefully supervised, at least until the coming of the Propaganda; while the control of the Curia over the orders was never detailed. The conflicts between the monastic and episcopal systems, however, and between the several orders, caused frequent reference to Rome. In regions without a bishop, the orders were at first supreme; but in time the Propaganda, for many years the most vigorous arm of the pontifical administration, made its power felt, and here, perhaps, the control of Rome was most direct.

\section{CONDITIONS OF STUDY.}

Pontifical Archives. The pontifical archives are much dispersed. First in importance is the collection in the Archivio Vaticano, begun by Paul V. in 1611 . This has been formed by transferring, from time to time, records from departmental archives to this general depositary, by the incorporation of the archives brought from Avignon, and by the purchase or gift of private collections rich in archive material. The bodies best represented are the consistory, the chancery, the secretariate of briefs, the Dataria, the Camera, and the secretariate of state. There are also many documents belonging to other departments, but it is not always evident whether they are originals or copies. In general, these series are open to call, down to 1815 , the date to which, until not many years ago, European archives were generally accessible; and where the deposits extend to a later date, as in the case of the correspondence of the secretary of state, individual documents may sometimes be obtained.

Current records, and in very many cases complete files, are still in the custody of the several departments, as transfers are not regulated by any general law. The availability of these archives depends wholly upon the attitude of the department, but access in all such cases is a matter of special grace.

\footnotetext{
${ }^{23}$ For term palatine, see Grimaldi, pp. I3-23.

2 See p. 201 , note 38 .
} 
The papal archives thus preserved are far from complete. In the vicissitudes to which Rome has been exposed in the last five centuries many have been destroyed or lost, especially in the sack of the city by the army of Charles V. in I 527, and in the troubles of the French Revolution, culminating in the transfer of the archives from Rome to Paris in I8IO and I8II, and their return in I8I5. On the latter occasion some were left in Paris, although by no means so considerable a portion, as in the case of the works of art. The occupation of the city of Rome by the Italian government in I870 did not result in depredations by the soldiery, but many records were hastily transferred and lost sight of in the fear of confiscation, and those of the offices of the Camera were actually seized and incorporated with the Italian Archivio di Stato.

Moreover, during the fifteenth, sixteenth, and seventeenth centuries, many papal officials merged public with private archives and left both to form one of those collections for their heirs, which were so esteemed a distinction of princely families. In fact the papers of the state department were regarded as private rather than Church property. When such a collection was made by a Pope or a cardinal secretary of state, it is likely to contain an appreciable portion of the more important records of the period. Such collections usually contain documents for twenty years before the elevation of the founder to the papacy, as he was sure to have been at least for such a period prominent in affairs, and in many cases for a number of years after his death, as other members of the family were apt to remain in positions of importance. The collection covering the largest period is that of the Barberini, which has valuable material for the first three quarters of the seventeenth century. All such collections contain vastly more copies than originals, and it will be the work of many years and many scholars to tell how far they supplement and how far they duplicate the records officially preserved. The most important of these collections are: that of the papers of the Medici (Leo X., I5I3-I522, and Clement VII., I523-I534), which is in the Archivio di Stato at Florence; of the Farnese (Paul III., I534-I550), which is for the most part in the Archivi di Stato at Naples and Parma; of the Borghese (Paul V., I605-I62I), which has been purchased by the Pope and added to the Vatican archives; of the Barberini (Urban VIII., I623-I644), which has also been purchased by the Pope and annexed to the Vatican library ; and of the Chigi (Alexander VII., I655-I667), which is still in the possession of that family. Less important but still considerable collections are those of the papers of Saint Carlo Borromeo, in the Ambrosian library at Milan; of Pietro Ottobuoni (Alexander VIII., I689-I69I), in the Archivio Vaticano; and of the Albani (Clement XI., I7OO-I72I), of which some are in the Archivio Vaticano, and some in the Corsini library. Still in the possession of the respective families are those of the Buoncompagni-Ludovisi (Gregory XIII., I 572-I 585, and Gregory XV., I62I-I623); of the Doria-Pamphili (Innocent X., I644-I655); of the Rospigliosi (Clement IX., I664-I670) ; and of the Odescalchi (Innocent XI., I676-I689). The collections left by cardinals and by minor dignitaries of the Church, which contain material necessary to establish a complete schedule of the extant records of the Holy See, are too numerous to permit individual reference here. It is, of course, obvious that these collections, in addition to such archive material, contain much else of great importance.

Archives of the Orders. The archives of the monastic and other orders have, naturally, always been dispersed, but their present plight renders an ordered account of them especially difficult. The archives themselves are still, for the most part, in the hands of the several organizations. The libraries 
which grew up about them, and which contained much archive material, have been seized by the government. This has resulted in some concentration of collections, although the number kept open under public control is still large; but on the other hand the dispossessed orders have begun collection anew, and the net result is a decrease in centralization.

National Archizes. The archives of the several states of Italy ${ }^{27 a}$ have, on the whole, fared better than those of the Papacy, and are rich and very complete. Many good reasons, however, have prevented the present Italian government from attempting to establish a great central record office, like those of London and Paris. Every capital of a state once sovereign retains such archives as it has, and local collections are preserved in the locality, though under the control of the national law. The archives of the kingdom of Sardinia are at Turin, of the present kingdom of Italy to I870 at Florence, and after that at Rome. Travel, and a familiarity with dates, are therefore necessary for the completion of any considerable study.

Private Libraries. More than other nations, have the Italians enjoyed the Caccialibraria, and the number of private collections of manuscripts is appalling. Ultimately the majority of them fall into the hands of some great library, but in such cases they are not assimilated, but retained intact as monuments to their founders. These collections tend to resemble one another. There were certain works, as for example certain relations of Venetian ambassadors and the correspondence of certain papal nuncios, which every collector felt bound to possess, and the great bulk of each library consists of copies rather than originals. Such copies lost most of their value to scholars by the opening of the papal archives, and, so far as the modern period is concerned, these libraries would have little value were it not that here and there are originals, or unique copies of which the originals have disappeared, making it unsafe to neglect those seemingly most unimportant.

Access to Collections, and Use of Libraries. As so many collections are in private or ecclesiastical hands the question of access to them is important. In this respect the opening of the Archivio Vaticano by Leo XIII. in I880 to all persons of approved scholarship, no matter what their religion, amounted to no less than a revolution. They had indeed been opened before this date in special cases, and not everything is accessible as yet; but this step was accompanied by others, indicating a firm conviction that the papacy could stand, and would profit by, publicity. There can be no doubt of the sincerity with which this view is held by those in control of the central archives of the papacy, and of their desire to further research in every way. ${ }^{28}$ The influence of this action has extended also to the keepers of minor ecclesiastical collections, but not always to the extent of a full acceptance. Lack of familiarity with their collections often leads to fear that disagreeable material may be found; the admission of persons slightly vouched for (for introductions are but too easy to obtain), requires supervision and causes trouble; and there is often a desire to reserve their own material for their own use. These two latter motives influence also many of the owners of private collections. The key to one library may be a bar to the next, and while at least nine-tenths of all the documents desirable, are directly available, to gain the other tenth is

${ }^{27 a}$ General survey in Ordinamento delle Carte degli Archivi di Stato Italiani: Manuale Storico Archivistico (Rome, I9Io, pp. xiv, 3I2).

${ }^{28}$ Élie Berger, "Léon XIII. et !es Études Historiques", in Bibliothèque de l'École des Chartes, LXIV. $444-447$. 
a labor of patience and skill. Even in public libraries the student is not always welcome, and in particular, there is often found an unwillingness to allow the use of catalogues and inventories. In the state archives, on the other hand, courtesy and helpfulness seem universal. Permission to use these archives is not a matter of course, as in the case of the public libraries, but is readily granted upon proper introduction from an official representative of one's government. Application must be made, upon a regularly prepared blank, to use certain classes of documents, and should be framed in as broad terms as possible. Special requests for particular volumes are afterward made as they are needed.

Those using a library for any considerable time, should not neglect to fee the ushers who bring the books. Such fees should not be large; for a year during which I worked in many libraries and received universally the best of service, the total amounted to fifteen dollars and six cents.

Arrangements as to Time. An important consideration is the division of time. The number of holidays is so great as to interfere seriously with continuous work. In the year I908-I909 the Archivio Vaticano was open on I70 days, the Biblioteca on I72, and one or the other on I78. The holidays observed by the government libraries are almost as numerous, but are somewhat different, allowing adjustment. Those observed by both are: Sundays, All Saints' Day (November I), the Immaculate Conception (December 8), at least a week between Christmas and New Year's Day, the Epiphany (January 6), the last Thursday and the last Tuesday before Ash Wednesday, Ash Wednesday, about a week at Easter, Ascension Day, Corpus Christi Day, SS. Peter and Paul (June 29), the Assumption of the Virgin (August I5), and the Nativity of the Virgin (September 8). Ecclesiastical libraries are closed, in addition, on the last Thursday in October, the Purification of the Virgin (February 2), St. Joseph's day (March I9), a few days longer at Easter, St. Philip Neri's day (May 26), St. John's day (June 24), and Thursdays when a consistory is held. On some of these festivals the government libraries are open for half time only, and they observe in addition the king's birthday (November II), the queen dowager's birthday (November 20), the queen's birthday (January 8), and the anniversary of the death of King Umberto (March I4). Very few are open in the afternoon or evening, and distance makes it difficult to profit by slight differences in closing hours. By careful calculation, however, it is possible to be at some library nearly every morning between October I and July I, except at Christmas time and Easter, nearly every afternoon for about an hour, and to go later to some reference library, as that of the Prussian Institute. During July, August and September the Vatican and most ecclesiastical libraries are closed, and it is scarcely profitable to be in Rome unless for some definitely arranged piece of work. In other Italian cities where the national archives (which are open throughout the year and observe the fewest possible holidays), are more important, one is assured of as much work as the climate renders desirable.

Condition of Material. For the most part the various collections of manuscripts are well inventoried, though according to methods somewhat out of date, and are in good physical condition. Those of the fifteenth and first part of the sixteenth centuries are often somewhat difficult to read, as this was a period of transition from the medieval hands to the modern Italian script; the abbreviations are irregular, and the combination of characters sometimes singular. This is more true of documents of French or Spanish provenance than of the Italian, and on the whole there are fewer palaeographic difficulties 
than in the case of English documents of a much later period. After the first third of the sixteenth century there is little trouble, except in the case of some legal documents, and from sheer bad writing. The larger part of the material is in Italian, often very strongly dialectic and often bad. A great portion is in Latin, which, while not perfect, shows some effect of Renaissance study. There are many Spanish and French documents, and one attempting any considerable study must be able to use these languages, with, of course, German for reference purposes. Need for Dutch and Portuguese, also, occasionally arises. As for speaking knowledge, there is probably no city in the world where so many languages are useful as in Rome, and where so few are necessary. Anyone with sufficient knowledge of Italian to work profitably with the manuscripts, will soon acquire all that is necessary for speaking purposes, while French, German, or English, whose usefulness is probably in the order named, will smooth away practically any obstacles which will yield to language.

Institutes. Since the opening of the Vatican archives nearly every nation in Europe has made arrangements to have workers permanently at Rome for historical study. ${ }^{20}$ The French school was already in existence, and was instrumental in securing that change of policy. It is located in the Farnese palace, and possesses a very good library, but its interests remain chiefly archaeological. ${ }^{30}$ The leading historical institution is undoubtedly the Prussian Institute, which occupies extensive quarters in the Giustiniani palace, and under the direction, formerly of Director Friedensburg, and now of Director Kehr, has issued a continuous series of valuable publications, including the periodical Quellen und Forschungen aus Italienischen Archiven. ${ }^{81}$ The Austrian Institute, of which there is a Bohemian branch, has published many admirable studies and collections, ${ }^{32}$ and Dutch and Belgian institutes are constantly productive, while England, though without an organization, has always at least two men employed by the government to calendar and copy documents. In addition to these national institutions there are many of a semi-official character. The Görres-Gesellschaft, a German Catholic society, has a Roman Institute, and publishes various volumes under the general title of Quellen und Forschungen aus dem Gebiete der Geschichte. ${ }^{33}$ Hungarian and Polish associations support representatives and have published especially admirable studies. The brothers of St. Louis des Français have adopted a comprehensive scheme of publication which it will require many years to complete, and the various monastic orders detail many of their members for scientific work in Rome. Nearly all those belonging to these bodies are trained

${ }^{29}$ Dom U. Berlière, Aux Archives Vaticanes (Bruges, I903, pp. 46) ; G. Bourgin, Les Archives Pontificales et l'Histoire Moderne de la France (Besançon, 1906), pp. 4-9; Alfred Cauchie, De la Création d'une Ecole Belge à Rome (Congrès Archéologique de Tournai, I895); C. H. Haskins, "The Vatican Archives", in American Historical Review, II. 40-56.

${ }_{80}$ M. A. Geffroy, L'École Française de Rome, Ses Premiers Travaux (Paris, I884), particularly pp. 69-76. See also Mélanges d'Archéologie et d'Histoire, passim.

${ }^{81}$ Walter Friedensburg, Das Königlich Preussische Historische Institut in Rom in den dreizehn ersten Jahren seines Bestehens, I888-I90I (Berlin, 1903, pp. I54).

${ }_{82}$ Th. Sickel, Bericht über die bisherigen Arbeitcn des Istituto Austriaco di Studi Storici in Rom (Innsbruck, 1884 , pp. 25).

${ }^{2}$ Hermann Cardauns, Die Görres-Gesellschaft, I876-I901 (Cologne, 1901, pp. I10); Mgr. Stephan Ehses, Das Römische Institut der Görres-Gesellschaft im Jahre I906 (Munich, I906, pp. 4). 
scholars, with at least a doctorate or its equivalent. The Archivio is a laboratory but not a school.

That, in spite of this activity, pursued now for nearly thirty years, so much is unknown about the Archivio and other Roman libraries, is not a reflection upon the industry or scholarship of these men, but it reflects to some extent upon their capacity for cooperation. Not only has there been no general plan of procedure, but for the most part the scholars of each nation have devoted themselves to the documents pertaining to the history of their own country, with little regard for the plans, or even for the results of others. The primary task of making clear the methods of papal administration, in order to understand the relation of the various series of documents, has received too little attention, and unfortunately for American historians, most that it has received has been for the period antedating the discovery of America. Finally, the publications resulting from these studies are scattered through thousands of volumes and find their way into the most unexpected places. Not all the libraries in Rome afford copies of all such articles or editions. All the regular series of the various Roman institutions, and many others, were examined, and the articles of use to the American historian are cited later, but it would be rash to claim to have exhausted the number.

In addition to publications, there are a number of important collections of transcripts which have been made from Italian and particularly from Roman libraries. In the Bibliothèque Nationale at Paris, in the Moreau collection, there are many copies made in the eighteenth century. These are excellent in character, but seemed, on a hasty examination, not likely to contain American material. The Roman Transcripts of the Public Record Office at London were more carefuly examined, and are much more extensive. They are not well arranged, and the references they give are far from easy to interpret. Such of these as are of interest to students of American history will be cited in connection with the collections from which they have been taken. The Massachusetts Historical Society possesses an interesting collection of transcripts made by the late Mr. W. H. Bliss of the English Public Record Office, with here and there an original, or an old copy of a lost or inaccessible document. This collection was evidently made with reference to Great Britain, and the American material must be very occasional indeed. Its character is much that of the collection in London, and the contents of the two doubtless duplicate each other. ${ }^{34}$

Guides. Of the many descriptive books and articles dealing with material on a broad scale, the best for the pontifical archives as a whole, is that of Ricardo de Hinojosa, Los Despachos de la Diplomacia Pontificia en España, Memoria de una Misión oficial en el Archivo Secreto de la Santa Sede, published at Madrid in $1896 .^{35}$ In his introduction he briefly sketches the contents of the various repositories of material, and his work, although in some cases superseded, remains the most comprehensive. Much more detailed is Les Archives Pontificales et l'Histoire Moderne de la France, of Georges Bourgin,

3t This collection consists of eighteen volumes, one bundle, and one note-book. There are copies from all the well-known Roman collections, some made from the Propaganda during its short period of publicity. and some from the Archivio Doria-Pamphili.

${ }^{85}$ This was the result of a year's mission to Italy and particularly to Rome. In addition to this general introduction, he gives a careful study of diplomatic relations for the sixteenth century. This work is entitled vol. I., and the failure of a second to appear has caused universal regret, as, considering the time at the author's disposal, it is probably the best piece of work yet done on the modern period. 
published in I906. This is not always accurate, but clearness of arrangement and general usableness make it the most convenient handbook. ${ }^{30}$ The best accounts of general conditions of study at Rome are found in the report $D e$ la Création d'une Ecole Belge à Rome, by Professor Alfred Cauchie of the University of Louvain (I895) (i⿱ $^{3 \pi}$ and The Vatican Archives, by Professor C. H. Haskins (I896). ${ }^{38}$ A good cursory survey of the more important Italian archives is that published in I90I by Professor P. J. Blok, Verslag van Onderzoekingen naar Archivalia in Italie. ${ }^{39}$ The monumental studies by Director Kehr on papal sources in various regions of Italy, published from time to time in the Nachrichten der K. Gesellschaft der Wissenschaften zu Göttingen, ${ }^{* 0}$ unfortunately apply to too early a period, but are suggestive. The work of M. Gachard on Les Archives du Vatican, ${ }^{41}$ although published in I874, before their opening, still has a distinct value. The most recent publication, Guide aux Archives du Vatican, by Dr. Brom, is painstaking and useful."

Copies. The absence of a regular American institution at Rome makes the securing of copies of documents desired by American students, not at Rome, difficult. In the case of the Vatican collections the simplest plan is to write directly to the Archivio or Biblioteca with a request for an official copy. The tariff at the Archivio is regularly fixed. For copies of documents of a date previous to the year rooo the charge is 4 lire per folio, for those between IOOO and I 500, 3 lire, between I 500 and I700, 2 lire, and from I700 to the present day, I lira. Photographs of manuscripts may be readily obtained at reasonable rates. In these cases, of course, a precise description of the document is required. To have search made is not so simple, and on this subject, and that of copies required in other collections, the Carnegie Institution of Washington will supply information.

Usefulness for American History. As to the possibilities of contributions for American history from these various sources, the following pages are intended to give the American scholar some opportunity to judge for himself. It must not be forgotten that aside from its direct dealings with America, the whole history of the Church is a unit, and that this can be studied completely only at Rome. It is probable also, that for the fifteenth, sixteenth,

To This is published also in Bibliographie Moderne, IX. 25I-362. It is the most comprehensive account of the various minor collections in the Vatican, but does not treat so extensively of the departmental archives as the work of Hinojosa.

"See also Cauchie, Mission aux Archives Vaticanes; Rapport à $M$. le Ministre de l'Interieur et de l'Instruction Publique (Brussels, I892, pp. I8I).

${ }^{88}$ In the American Historical Review, II. 40-59. This gives a brief account of the history and the contents of the collections, of the various schools at Rome, and a brilliant review of the work done by them to that date.

${ }^{32}$ With special reference to the history of the Netherlands, published at the Hague in I90r, pp. 85. Of the many descriptions of documentary quests through Italy, this is probably the most useful to the American historian.

${ }^{40}$ No investigator has used a net with meshes so fine as Director Kehr, and for the regions which he has covered his publications supply the best directory for collections of historical material. As his period, however, is that of the early Middle Ages, most of these are of no interest to the student of American history, and some purely modern collections are not mentioned.

${ }^{4}$ Although travelling before the opening of the Vatican Archives, M. Gachard was allowed special privileges, and his descriptions of collections whose arrangement has not been altered are exceptionally good.

${ }^{42}$ (Rome, I9 Io, pp. $\mathrm{x}, 96$. ) This is practically a French version of the introductions in his Archivalia in Italië belangrijk voor de Geschiedenis van Nederland (Rijks Geschiedkundige Publicatiën), undertaken as a result of Professor Blok's recommendations, and of which two parts (Hague, I908, pp. xxx, 464, and I909, 465-III6), have been published. 
and seventeenth centuries, there is no one place where the world-movement of history is so well reflected as in the archives of the Church. The vital struggle of European nations, so profoundly affecting the future of America, might almost be written from them, and can not be completely written without them. The history of the East, which begins to link itself so closely with that of America, is nowhere else so well represented; Japan, China, and the Philippines all having received, to the beginning of the nineteenth century, more attention than the territory covered by this study. For South America, moreover, there is more material than for North, and the history of the West India islands, particularly of those belonging to France, is profusely illustrated. For America the first requisite is a Bullarium, but the limits of such a work should be seriously considered, that duplication may be saved. Probably there is no logical method of excluding any section, with the possible exception of Portuguese America. The Archives of the Propaganda afford material for just such a study of the organization and control of the missionary movement as a whole, as is needed, and such would afford a basis for works on the several orders, if their materials come to be more generally available. The neglect of their opportunity by Spanish scholars, with the brilliant exception of Hinojosa, affords a chance, if it does not create a duty, for American scholars to exploit the great masses of material relating to Spain, and so, indirectly, to great portions of America. Even where no special contribution is intended, a reasonable time spent in reading in the archives would afford the most valuable basis for an historian's career, which I can imagine. With regard to the archives of the Italian states, the outstanding fact is the enormous amount of material on the history of the American Revolution. While this material is for the most part secondary in character, its possibilities are too great to warrant neglect. 


\section{THE VATICAN COLLECTIONS.}

The public library collections of the Vatican are three; the archives, the library, and the library of consultation. The entrance of the first is from the Vialone di Belvedere. Students are permitted to reach this through the Porta di Bronzo and various stairs and courts, thus avoiding the circuit of St. Peter's necessary to the sightseer. Through a small hall one enters the room for the study of bound volumes of manuscripts, which is rather shabby, but well lighted, conveniently arranged, and slightly heated in winter. To the left of the farther end, a few stairs descend to the room for the study of unbound manuscripts, which runs parallel with the first, getting its light from an interior court. To the right of the steps, a door opens on a small hallway, to the left of which is the office of the director, in which are kept the inventories. To the right, one enters a suite of three rooms, of which the last is divided by stacks into three. In these, most of the shelves are open and the volumes may be freely used. There are also a few study tables. To the left of the second room of this suite, a few steps descend to the Biblioteca di Consultazione or Leonina. This is administratively connected with the Biblioteca Vaticana, rather than with the Archivio. The rooms are charmingly decorated and well lighted, on the one side from the larger Cortile di Belvedere, on the other from an interior court. ${ }^{2}$ They consist of the room joining the Archivio, and two parallel connecting rooms, at the end of which is a fourth similar to that first entered. From the further end of the left-hand parallel room, to the left, is a stair leading up to the cloak room of the Biblioteca. From this, one enters to the left the small, well-ordered, unventilated study room, while diagonally opposite is a door opening into the Galleria Lapidaria, from which students may descend to the Cortile di S. Damaso, and thence by the Scala Pia to the Porta di Bronzo, which route serves also for the entrance of those who come to the Biblioteca rather than the Archivio.

Permission to use these collections is freely granted to all who bring evidence of intention and capacity for serious study. A letter to Father Ehrle, sub-prefect of the Biblioteca Vaticana, is desirable; and in the case of women, special arrangements must be made.

The open hours in the archives are from 8:30 to $\mathrm{I} 2$, in the libraries from 8 to I. The collections are closed on Sundays and Thursdays, on the customary ecclesiastical holidays, on St. Peter's day, January I8; at Christmas, from December 24 to January I, inclusive; at Easter, the archives are closed from the Saturday before Palm Sunday to the Wednesday after Easter, inclusive; the libraries from the Wednesday before Easter to the Sunday after it, inclusive; both are closed the Saturday before and the Monday and Tuesday after Whitsunday, and both remain closed from the last Saturday in June to the first day in October not a Sunday or Thursday. ${ }^{2}$ The rules are simple. One using the archives has a seat assigned which he occupies throughout the year. He is expected to register every morning, stating the volumes he expects to use. He then fills out a prepared slip, giving his name, address, the number of his seat and precise indications of the volumes de-

${ }^{1}$ Antonio Sacco, Le Nuove Sale della Biblioteca Leonina in Vaticano (Rome, I893, $\mathrm{pp}_{2}$ 22).

Also occasionally for special occasions. as unusual anniversaries, feasts, and deaths. 
sired. This is given to an usher, who brings the volumes to the seat. Other rules have to do only with the care of the manuscripts. ${ }^{8}$ They are posted near the entrance and should be read, but are only such as would occur to a careful student. In the Biblioteca there is only one registration for the year, but a slip of dismission must be obtained on passing out, to be presented to the cloak-room usher. On descending from the Biblioteca to the Library of Consultation, one should obtain a numbered metal disk to present there. In drawing books from the Biblioteca it is necessary to fill out a stub, as well as a detachable call slip.

Biblioteca di Consultazione. This is quite new, having been founded in I892, for the use of those using the manuscripts. It is rich in periodicals, published archive material, and helps of all kinds. The books are arranged for the most part in a geographical order; but some are arranged by subjects, as popes, etc.; and some by classes, as catalogues, etc. There are two card catalogues, one of authors, and one according to the classification just mentioned. This system is somewhat difficult to master, especially as no key is furnished, but one has the compensating advantage of being able to go freely to the stacks.

Biblioteca Vaticana. This is one of the oldest libraries in the world, but it still remained comparatively small when Nicholas $V$. and other popes of the Renaissance began their endeavors to make it the greatest manuscript collection in Christendom. Since that time its history has been one of constant growth. Napoleon, it is true, did in I797 send 500 volumes to Paris, but these were returned in I8I5, with no more than two or three exceptions. Particularly of late years many whole libraries have been added by gift or purchase. Some of these have been preserved in their independence, and others amalgamated with the Vatican collection proper. Where the provenance of such collections is important it is noted in the subsequent chapter on this library. The helps to the use of these manuscripts are well ordered, and for the most part made with extreme care. For each collection there is an inventory and an index. Generally manuscripts in Latin, Greek, Hebrew, and other scripts are treated separately. These guides are all free of access on shelves in the study room.

Archivio Vaticano. If the archives which it contains have an origin of questionable, at any rate of remote date, the Archivio has a birthday, and that in modern times. Although the idea of collecting the archives from the several departments and making one general collection had been long in contemplation, it was Paul V., by bulls of I6I I and I6I3, who took the actual step, and founded the Archivio upon its present basis. ${ }^{7}$ Since then, as has been mentioned, the successive popes have continually enriched it by special orders, until it contains, undoubtedly, the great bulk of the pontifical archives

\footnotetext{
${ }^{3}$ The printed rules in the Archivio require that all notes be submitted for examination, but this rule is not enforced.

${ }^{4}$ M. Ugolini, La Nuova Biblioteca Leonina nel Vaticano (Rome, I893, pp. I7 with plan).

"See Franz Ehrle, S. J., Historia Bibliothecae Romanorum Pontificum (Rome, I89o, pp. 775); Paul Fabre, La Bibliothèque Vaticane (Paris, I895, pp. II2) ; G. B. Rossi, La Biblioteca della Sede Apostolica ed i Catalogi dei suoi Manuscritti (Rome, 1884, pp. 68); Eugène Müntz and Paul Fabre, La Bibliothèque du Vatican au XVe Siècle (Paris, 1887, pp. viii, 380).

"Léopold Delisle, "Les Archives du Vatican", in Journal des Savants, 1892, pp. 42944I, 484-50I.

"F. Gasparolo, "Costituzione dell" Archivio Vaticano e suo primo Indice sotto il Pontificato di Paolo V.", in Studi e Documenti, 1887, pp. I-64.
} 
of historical significance down to I8I 5, although the absence of a general rule leaves regrettable lacunae which might be supplied from the offices.

The Archivio suffered severely in its removal to Paris in I8Io and I8II and its return in $\mathrm{I} 8 \mathrm{I} 5$ to $\mathrm{I} 8 \mathrm{I} 7 \mathrm{.}^{8}$. In some way a very large collection of volumes and bundles, both manuscript and printed, belonging to the Congregation of Rites, was left there ; first in the Archives Nationales, and then moved to the Bibliothèque Nationale, where they are now classed under the heading H. 359A.' Some other administrative series were sold at the same epoch by the first papal agent and repurchased, but no longer complete, by a later. ${ }^{10}$ Finally an enormous mass of the records of the Holy Office was burned to save the cost of transportation. On the whole, however, it has grown constantly more complete, as it has secured from time to time the collections of archival material made by great prelates and long retained in their families. ${ }^{11}$

The traditions handed down from the early days of its history, formed when ideas of archive management were crude, have so far prevented a scientific arrangement of material. There is no distinction between the archives of the government of the Papal States and of the government of the Church; the archives of the several offices are not kept separate; and for the most part the annexed collections are kept as they are secured, without separation of archive material.

There is no general inventory, nor even a list of the collections constituting it. There are, however, nearly 700 indexes and inventories of every sort relating to portions of it. ${ }^{12}$ These are kept in the room of the acting head of the Archivio, and are freely accessible for consultation-a privilege which has not always accompanied permission to use these or similar archives. As a guide to these there is a manuscript "Inventarium Indicum in Secretiori Archivo Vaticano unica serie existentium," prepared by Mgr. Wenzel in I90I, and with later additions. This classes them in the following nine groups :

I-9. "Ex fragmentis nonnullorum indicium et Thesauri Pontificalis inventariis."

10-70. "Ex archivi S. Angeli indicibus."

7x-195. "Ex indicibus secretioris Vaticani."

196-239. "Ex indicibus diversarum Bibliothecarum."

240-324. "Ex indicibus Bullarum Regestorum Vaticanorum nec non Brevium Apostolicorum."

325-436. "Ex indicibus Bullarum Regestorum Datariae Apostolicae."

437-556. "Ex collectione Garampiana (Schedario)."

557-669. "Ex indicibus Bullarum Regestorum Avenionensium." 670-68I. "Collectio Garampiana (Miscellanea)."

${ }^{8}$ Delisle, as above.

- Analecta Bollandiana, V. I47-16r, contains a catalogue of these papers. They include inquisitions, interpretations, conclusions, objections, summaries of responses, etc.

${ }^{10}$ Delisle, as above.

11 There are many accounts of the history of the Archivio. For the period to about 1800 the best is by Gaetano Marini, Memorie Istoriche degli Archivi della Santa Sede, reprinted by Laemmer in his Monumenta Vaticana (Freiburg, I86I), pp. 43I-453. For the later period see G. Palmieri, Manuductio, introduction. The most comprehensive modern summary is in Bourgin, Archives Pontificales, pp. II-42.

${ }_{12}$ Bourgin, Archives Pontificales, pp. 23-34; Louis Guérard, Petite Introduction aux Inventaires des Archives du Vatican (Rome, Paris, Igor, pp. 39). Also, "Notes sur quelques Inventaires des Archives Pontificales", in Annales de St. Louis des Français, IV. 479-508. 
This vast collection consists of schedules prepared in the various pontifical offices to facilitate reference to their archives; inventories and indexes prepared for private collections before their incorporation in the Archivio; and the work of Vatican officials. They are made upon an immense variety of plans, and probably form the most interesting body of material in the world for the study of the history of library methods. Their value and accuracy are, naturally, as varied as their mode of attack. Of the work done in the Vatican the most interesting is that by De Pretis and Garampi, who used respectively the two typical methods of dealing with such problems.

De Pretis, who worked in the second quarter of the eighteenth century, produced inventories, or practically shelf-lists, of the Archivio Segreto, indice 133; of the material from the office of the secretary of state, indice 134; and of the Miscellanea, indice 136. The descriptions are very brief, giving the number of the cupboard or armadio in which the volume is found: the individual number within the armadio; generally the extreme dates of its contents; and a description in three or four words. Although the location of the volumes has in many cases been changed, this system of reference has been retained; additions have been internumbered or otherwise provided for, losses have been noted; and the work of De Pretis still stands as a finding list and as a means, albeit with labor, of exhaustively examining most of the material he set in order.

The more ambitious plan of Garampi was to index the archives preparatory to the production of a great work on the orbis Christianus. ${ }^{13}$ Under his direction a force of subordinates, of whom the chief was Pistolesi, worked during the third quarter of the eighteenth century, and even after his death the scheme was not abandoned, for portions of the material come down as late as I808. Each item was noted on a small slip of paper, scheda, of which about a million are said to have been collected. These were then pasted in the order desired on large sheets which, by the care of Mgr. Wenzel, have lately been bound and made available. The series into which they have been united are:

Indici 437-440, "Apparatus ad universalem Orbis Christiani notitiam"; 442, "Patriarchatus, archiepiscopatus et episcopatus in partibus infidelium";

445-474, "Beneficia" ;

475-511, "Orbis catholicus seu series episcoporum ";

512-534, "Miscellanea";

535-537, "Abbates", which is incomplete;

538-549, "Indice chronologico," A. D. 163 to I808;

550, "Papi" ;

551, "Cardinali ";

552-554, "Offici ";

555, "Chiese di Roma";

670-681, another "Miscellanea".

All these are alphabetically arranged except that described as chronological. There are also other volumes of indexes bearing the name of Garampi, but not belonging to this general series. It is never easy and it is sometimes impossible to tell just what collections were examined to produce each of these sets. It would also be laborious, but quite necessary, to discover the content of each collection at the time when it was examined. The whole is subject,

\footnotetext{
${ }^{13} \mathrm{Kehr}$, Papsturkunden in Rom, pp. 392-394.
} 
moreover, to the fallibility of all indexes, that it is impossible to list all the relationships of a particular document. Here only the simplest are given, such as names of persons or places cited in the preamble. It is obvious, then, that these series can not be used with the idea of exhausting the material on any subject. On the other hand the positive information given is often suggestive and important, though references are often hard to trace and are sometimes lacking. Those bearing upon the subject are given in the Appendix.

The remaining volumes of indexes are of the most varied utility. Some refer to collections which have disappeared or are dispersed, in some cases the method of reference has been changed, many are too inaccurate to trust. On the whole, however, most of the indici have some interest, if their value be slight. There are in addition inventories and indexes in the archivist's room which are not mentioned in the Inventorium Indicum, others which are listed with collections; and many volumes contain individual apparatus of some kind. All such aids as seem useful, will be noted in connection with the series to which they apply.

One has no surety that by examining the indici one has exhausted the archives. As will be seen from the following special studies, many of the most important collections are entirely without such guide, and probably no one person is aware just how many such series exist hidden, or rather not yet brought to light. 


\section{VATICAN ARCHIVES: ARCHIVIO SEGRETO.}

The distinction between the Archivio Vaticano and the Archivio Segreto seems to rest upon the fact that De Pretis gave the latter title to his inventory of 78 armadii containing the regular office series, except for the department of state, as they existed in his time. As the term is without logical significance, it would perhaps have been better to keep it for that single collection, but in fact it is used in many senses. Here it is used, quite arbitrarily, for the regular office series as they exist to-day, except that of the department of state whose longer treatment makes separation convenient. The several collections annexed to the archives made a third division. The inventory of De Pretis, indice 133, corrected to 1908, still serves in large measure as the regular finding list for the older archives, but many series have been extended, and many new ones added. The arrangement of De Pretis is followed as closely as possible, but material not listed by him is inserted where it seems naturally to belong. The chronological register of the Archivio Segreto, by Garampi, found in indici 168-184, actually contains few references to this material, dealing chiefly with the collections of the secretary of state.

\section{THE PAPAL REGISTERS.}

Apostolic letters are of two kinds, bulls and briefs. ${ }^{1}$ The first are more formal. They are characterized by being written on a special parchment, before 1878 in the scripta bollatica; by an elaborate phraseology based on traditions inherited from the chancery of the Roman Empire; by the method of dating from the year of the incarnation ; ${ }^{2}$ and by a seal with the heads and initials of Saint Peter and Saint Paul, which was formerly, and in the most formal cases is now, stamped in lead. Bulls are classified according to lines of division which, while subject to change, are on the whole constant. These classes are: bulls de curia, issued on the motu proprio of the Pope, and paying no taxes; secretae, issued on petition, but not subject to tax; communes or di cancelleria, ${ }^{3}$ issued on petition and subject to the regular taxes; in forma commissoria and in forma dignum, issued to bishops conferring the right to appoint an individual named, to an office; in forma rationi congruit, issued on petition made to the predecessor of the reigning Pope; and half bulls,

\footnotetext{
${ }^{1}$ A good brief account of the technical characteristics of these is found in Grimaldi, Les Congrégations Romaines, pp. 43I-440. More elaborate accounts are: E. von Ottenthal, Regulae Cancellariae Apostolicae; Die päpstlichen Kanzleiregeln (Innsbruck, I888, pp. 315); Regulae Ordinationes et. Constitutiones Cancellariae Apostolicae Sanctissimi D. N. D. Leonis D. P.P.XII. (Rome, I823, pp. 83); and Riganti, Commentaria in Regulas Cancellariae Apostolicae (Rome, I75I, four vols.). An instructive but not entirely accurate discussion, is that by the Count de Mas Latrie, "Les Eléments de la Diplomatique Pontificale", in Revue des Questions Historiques, XXXIX. 4I5-45I, XLI. 382-435. See also A. Giry, Manuel de Diplomatique (Paris, I894), pp. 693-704. The rules of chancery had a broader significance than might at first appear, as they applied to other departments charged with the drawing up of documents, as well as to the Cancellaria. Archives Historiques de la Gascogne, an XII. (I896), pp. i-lxxx, an introduction by Abbé Louis Guérard.

${ }^{2}$ From Nov. I, I908, all letters are dated by years beginning Jan. I.

${ }^{3}$ It might be sufficient to distinguish these three classes, grouping under the third all the others except the last, which represents, really, a different line of division. See L. Duchesne, "Rapport sur la Publication des Registres Pontificaux", in Mélanges d'Arch. et d'Hist., XXV. 443-450. From Nov. I, I908, all bulls are issued per viam cancellariae.
} 
issued in slightly different form, during the time between the election and the coronation of the Pope.

To draw up bulls is the function of the chancery and of the dataria. The matter in hand having been decided by the proper authority, a note of it is sent to the chancery or the dataria endorsed: "Fiat ut petitur." In the case of petition, this is often written on the back of the original, in the case of business originating with the Curia, a brief statement of the case is submitted. A minute is then prepared by the college of abbreviators, and this is signed by the Pope. This minute is preserved by the department concerned, which issues, on this warrant, the formal bull, bearing the signature of various chancery officials, and in rare instances, as in the case of a bull of canonization, that of the Pope.

A brief is, as its name indicates, a shorter document. Its phraseology is less formal; it is dated by the year of the Nativity; and it is sealed, except in rare instances, with the seal of the Fisher, though briefs may be found with the seal of Saint Peter and Saint Paul, in lead. ${ }^{\circ}$ Briefs are prepared by the department of briefs. The preliminary steps are similar to those in the case of bulls, but briefs bear only the signature of the secretary of briefs or his substitute.

Together, the bulls and briefs represent practically the sum total of the official decisions of the Holy See, though the letters of the secretary of state, and the decrees of congregations are scarcely less important. The signatura, or decision not put in the form of bull or brief, is used only for minor matters. The originals of the bulls and briefs are scattered throughout the world, and a complete collection of them would be impossible, but various official collections of registers and minutes exist at Rome, which constitute, on the whole, the most important part of the historical material thrown open to stu1dents by Leo XIII. A discussion of these several series follows.

It is unfortunate that the great wealth of learning and research which has been expended on the regesta has been devoted almost entirely to the period previous to the discovery of America, particularly as it is quite unsafe to deduce from the practice of one century the practice of the next. The papacy is indeed conservative, but this very conservatism has led to the conservation of institutions in their ancient forms, after their cbjects have become changed or nonexistent, and similarities become traps for the unwary. Of the different series the Regesta Vaticana have always received the most attention.

\section{REGESTA VATICANA.}

This register is made up by the combination of several independent registers, which were united, and in I6II were transferred from the Camera to

\footnotetext{
"By the constitution of 1908 the college of abbreviators was abolished, and this work was transferred to the college of protonotaries.

"Grimaldi, Congrégations Romaines, pp. 431-440.

- The best discussion of the Regesta Vaticana is that by E. von Ottenthal, "Die Bullenregistrer von Martin V. und Eugen IV." (Innsbruck, I885, pp. I89), printed in the Mittheilungen des Instituts für Oesterreichische Geschichtsforschung. Another admirable description is that by Camelli Kropta, "Acta Urbani VI. et Bonifatii IX. Pontificum Romanorum ", part I., I376-1396 (Prague, 1903), in the Monumenta Vaticana res gestas Bohemicas illustrantia, V. I-I9. See also W. H. Bliss, English Historical Revierw, IV. 8ro-8rr, on contents of bulls; L. Duchesne, "Rapport sur la Publication des Registres Pontificaux", in Mélanges d'Arch. et d'Hist., XXV. 443-450, on problems of publication; Gregorio Palmieri, Ad Vaticani Archivi Romanorum Pontificum Regesta Manuductio (Rome, I884, pp. xxviii, I76), for a brief description of chancery methods; and Hinojosa, Los Despachos, pp. xxxiv-xxxvii.
} 
the Archivio. In the first place there is the register kept by the Camera itself, in which were registered bulls expedited by that office, and occasionally others specially ordered to be registered in this series. The volumes of this register may generally be distinguished by the serial titles of "Libri Officiorum", "de Curia", "secretarum", and "patentium". Secondly, there are the volumes of bulls expedited by the chancery. These consist of the series labelled "Expectatio" and containing prospective appointments, to take effect when vacancies should occur, and "Diversorum", of which the contents are suggested by the title. Thirdly, there is the register of "Litterae communes", registered by the secretaries and containing a great variety of matter, including much of a political nature. Among the earlier numbers of the Regesta are some volumes of bulls of the Dataria, of which the separate register is described later, and occasionally briefs are found registered with the bulls. For the earlier period these Regesta are largely duplicated by those of Avignon, but not subsequently to I492.

The Regesta Vaticana consist of 2019 numbers of which 29 are double, making 2048 volumes in all. The extreme dates are from the pontificate of Innocent III. to 1605 , but the volumes after I572 are but few. There have been four systems of reference. First, the books of each class were numbered separately for each pontificate and the label gives, generally incorrectly, the years of the reign included in each. Later all the books of each pontiff were numbered consecutively. De Pretis in his "Inventarium Archivi Secreti Vaticani", now indice 133, listed the volumes as he found them in the first 29 armadii of that archive. All these methods of reference have been used by historians, and the volumes may still be drawn from the shelves by the last. The official method of reference, however, is that of Palmieri, who in his Manuductio ${ }^{\top}$ lists the whole series with a consecutive numeration, giving the popes whose bulls are registered in the various numbers and the years. This work is very unsatisfactory, as it gives no cross reference to the older systems of citation, and its lists of the years included in the several volumes are incorrect. ${ }^{8}$

The bulls are not entered in the registers in chronological order, their order being such that in many instances it is evident that the registration could not have taken place for several years after the issuance of the bull. Often several bulls on the same subject or to the same person are found together. It seems also that the copies were not usually entered in bound books, but on loose sheets or rather sheaves of sheets, which were sometimes prepared at the homes of the scriptores, and which were afterward bound. Thus there was a double chance of loss, and the registers are not, in fact, complete. On the left-hand margin at the head of each bull is the signature of the clerk who copied it. At the foot is occasionally the signature of a collator. Occasionally the official seal is sketched in, and the names of signers of the original bull added.

Although the folios are numbered, reference is not easy. This difficulty is, to a certain extent, lessened by the fifth class of indici. These are, apparently, office reference books. They vary in character and completeness for the various pontificates, but in general consist of rubricellae, or inventories

\footnotetext{
${ }^{7}$ See preceding note.

${ }^{5} E$. g., no. 880, Palmieri says 2 and 3 , whereas there are none of 2 , and several of $\mathrm{r}$; 881 , Palmieri, 2, 3, 5, actually $\mathrm{I}, 2,3,4,5 ; 882$, Palmieri, 4 to Ir actually, 4, 7, 8, 9, IO, II, and one of Pitis IV.

Numbers 240-324.
} 
of the bulls, bull by bu1l, and book by book. Usually each volume covers one class of bulls for one pontificate. In many cases where no such general inventory exists, the several volumes of bulls have individual rubricellae. The general rubricellac were found, where tested, complete, except that in some cases one or two stray bulls bound in at the end of a volume were not mentioned. The folio references are often incorrect, but as the bulls are mentioned in order, it is not difficult to find them. The mbricellae give, in addition to the folio number, the name of the person addressed, his diocese, and a word or two on the character of the business; as, indulgence, or, concerning a parish. To find a particular bull is difficult; the most useful references to have are the name of the person addressed, and the diocese, the opening clauses, and the year of the pontificate. In some cases the original bull itself bears a reference to the register. On the other hand to go through the collection as a whole or for a period, for some particular subject, relating to a particular diocese or country, is only laborious.

Alexander VI. The register of Alexander VI. consists of II 3 numbers, 772-884. Of these 772-866 are litterae communes; 867-873, litterae secretae;

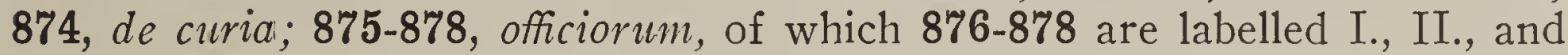
III., respectively, while 875 is without such class number; $879-883$, litterae diversae, of which $\mathbf{8 7 9 - 8 8 2}$ are numbered I., II., III., and IV., while 883 is without class number: 884 , expectatio. The whole series is also numbered 1 113 in the order given. The total number of bulls amounts to about 17,000 . Indice 276 contains rubricellae of the litterae communes, the other volumes, except $\mathbf{8 7 2}$, have individual rubricellae, but these are not reliable. The litterae communes were examined so far as the rubricellae allowed, but one could not be sure of exhausting American material without reading all bulls addressed to Spanish dioceses, and perhaps those of Portugal, for which time did not suffice. The other series were thoroughly gone through. There are large lacunae in the series of litterce secretae, some of which are mentioned in marginal notes dated Apr. 26, I532. The series of litterae diversae also seems incomplete, as years I, 3, 4, 9, ro, and II are represented by almost a complete volume each, while there are no bulls of year 6 and very few of year 2 . It is possible that the latter gap accounts for the absence of the bull of Sept. 26, I493, to Ferdinand and Isabella, confirming and extending the original grant of rights in the New World, dated May 3, I493; while it seems probable that the bull of Nov. r6, I50r, granting the ecclesiastical tenths of the new lands to the king, has disappeared from 871 , where folios 7 to I9 are missing; the bull registered on folios 3 to 6 being such a grant of tenths for the kingdom of Granada. Groups of bulls on similar subjects or to the same person are often found together. No bulls directly relating to America and not already printed, were found.

The references to such as there are, follow:

775. ff. 42-43. May 3, I493. To Ferdinand and Isabella, Inter caetera.

777. ff. I22-I24. June 25, I493. To Bernardo Buil.

ff. I92-I93. May 4, I493. To Ferdinand and Isabella, Inter caetera.

879. f. 234. May 3, r 493. To Ferdinand and Isabella, Eximiae.

Besides these there are some other bulls of interest.

869. Contains many bulls granting favors to Ferdinand and Isabella. It would require careful study of the phraseology of some to determine whether they extended to the Indies or not. 
870. The same is true here. A bull of June I7, I494, on ff. I57-I 59, grants certain rights " in Castile and Leon and Aragon and whatever other kingdoms and lordships are subject to them".

871. A bull of May 9, I 502, ff. 253-258, "Ad perpetuam rei memoriam", grants the Spanish sovereigns certain favors in all their "regnis, terris, insulis, locis, ac dominiis".

873. Bulls of Nov. I2, I494, on ff. 89-99, and 99-I04, use similar phraseology in making grants to the Spanish sovereigns, as does one of Feb. I3, I 496, ff. 408-409.

Pius III. Indice 277 gives rubricellae of volume 885 , which contains the bulls of this short pontificate. There is nothing relating to America.

Leo $X$. Of this pontificate only the littcrae secretae were examined. Of these there are I2 volumes, numbers 1193-1204, for which there are rubricellae in indice 279.

The bulls pertinent to the subject are the following:

1196. ff. 80-85. Dec. 6, I5I4, year 2. To Ferdinand, king of Aragon, etc., and governor general of Castile, etc., "Ad perpetuam rei memoriam". Granting cruciata, "in Regnis et D'niis Terris Insulis ac Locis eisdem Regi et Regine subjectis".

ff. I34-I4I. Aug. II, I5I8, year 6. "Universis Ch'ti fidelibus p'ntes lrās", indulgences to all the faithful in Castile, Leon, Aragon, "et aliis regnis ", to further the rebuilding of St. Peter's.

1197. ff. 279-283. March 24, I5I7, year 5. "Ad futuram rei memoriam", confirming [to Charles V.?] indulgences granted to said Ferdinand by preceding Popes for Aragon, etc., "et aliis quibus omnibus Regiis Dominiis Terris Insulis et Locis et (. . .?) Maris Indior' vel Oceani ".

1199. ff. I49-I5I. Dec. 9, I5I8, year 6. To Alfonso de Molina, “Dudu' siquid' postq' divina favore clementia ", concerning an abbey in the island of St. James " als Jamaica in finibus indie Maioris".

f. I5I. Note of an oath taken by said Alfonso de Molina, Jan. I4, I5I9, and a marginal note, Mar. 3I, I 524.

1200. ff. I I8-I25. June 25, I 5I9. To [the king?], "Ad perpetuam rei memoriam ", granting cruciata, "in Regnis et dominiis terris insulis ac locis eisdem Regi et Regine subjectis".

\section{REGESTA LATERANENSIA. ${ }^{11}$}

This series was transferred in I892 from the Lateran to the Archivio. It was formerly known as the Regesta Cancellaria, as the Archivio di Bolle, under which title Garampi refers to it, and as the Regesta della Dataria." It consists of bulls only, but contains not only those emanating from the

\footnotetext{
I" This and the bull in 1197 are addressed to Ferdinand, but the dates given are after his death. This discrepancy appeared too late for me to resolve it.

${ }_{11}$ The best discussion of this series is that in the Repertorium Germanicum (Berlin, I897), vol. I., by Robert Arnold, pp. xx-xxxiv.

${ }_{12}$ P. Kehr, Aeltere Papsturkunden in den Päpstlichen Registern von Innocenz III. bis Paul III. (Göttingen, I902), pp. 402 seq. Kehr refers to this register as continuing that of Avignon, but its range is different from that, as is evident. It does not, moreover, so far as I was able to find in an exhaustive examination of the volumes for the short pontificate of Pius III. (1503), and a running comparison at other points, particularly for the reign of Paul III. (I534-I550), duplicate the Regesta Vaticana, as does that of Avignon.
} 
Dataria, but also consistorial bulls, prepared to execute decisions announced by the Pope in consistory, and issued by the chancery.

It consists of $2 \mathrm{I} 6 \mathrm{I}$ volumes extencling from the reign of Boniface IX. (I389-I 404) to $\mathrm{I}^{80} 3{ }^{13}$ and later volumes not yet accessible. Those made public have been inventoried by Fiocchi in indice $310 \mathrm{~A}$, which serves also as a concordance between the old system of numbering by years of each pontificate, and the new continuous numeration. Still further, it notes the volumes missing from the complete series, which are very numerous, the collection having suffered on the journey to Paris.

This register is of paper, in volumes of from 300 to 320 pages, octavo size. The copies seem to have been made on bunches of sheets, subsequently bound together. The arrangement is not chronological. The apparatus for the use of these volumes is found in indici 325-436. It does not, for the most part, consist, as in the case of the Vatican Register, of mbricellae, ${ }^{15}$ nor are there such in the individual volumes. Here the aids are indexes. Each index volume serves for the registers of a given period, the index being by dioceses. All the A's of the first volume to be indexed are brought together, then the A's of the second volume, and so on, through the several letters and volumes. Director Kehr of the Prussian Institute found Garampi's references to the series useful, ${ }^{16}$ but this would hardly be the case with a person not thoroughly familiar with the Archivio. All these aids refer to the complete series, and their references, therefore, can not always be verified now that so many volumes have been lost.

These bulls have to do in the first place with the conferring of ecclesiastical dignities, benefices, and emoluments; then with ecclesiastical indulgences, dispensations, and privileges ; and finally with matters of ecclesiastical polity, such as the erection of congregations and general regulations for religious practices and the control of religious organizations.

In search of American material many volumes of indexes were used, but the only portions exhaustively examined were the following: Indice 405, "Index Bullarum Clementis XI., Innocentii XIII., Benedicti XIII., Clementis XII., Benedicti XIV., I700-I740." This is not complete, and the line of selection is not obvious. It refers to a decree for the canonization of a former archbishop of Lima, ${ }^{17}$ to rules for regulars in the regions of the Indies, ${ }^{18}$ to a grant of decimae in the Western Indies of Spain for their defence, ${ }^{19}$ to the revocation of a decree of Pius $\mathrm{V}$. on the employment of regulars in parishes in the Western Indies, ${ }^{20}$ and other decrees of general application. Indici 406-410 index the bulls of Benedict XIV. (I740-I758), dealing with benefices. ${ }^{21}$ The American material occurs regularly. There are two or three

${ }^{13}$ Hinojosa, Los Despachos, pp. xxxiv-xxxvii, gives the number as 4200 and the dates as extending to Gregory XVI. (I83I-1846). This number probably includes the briefs, which are here mentioned separately. The date is doubtless correct, but the later volumes are, of course, not yet regularly accessible.

1* "Concordantia numeri rubricellarum regestorum Lateranensium, seu veteris cum novo numero, An. 1903."

${ }^{15} \mathrm{~A}$ number are described in the Inventorium Indicum as rubricellae, but are really indexes.

${ }_{16}$ Kehr, Aeltere Papsturkunden (Göttingen, I902), p. 402.

1: Benedict XIII., vol. IV., f. 7.

${ }^{13}$ Benedict XIV., vol. VI., f. 72.

${ }^{10}$ Benedict XIV., vol. XII., f. I40.

${ }^{20}$ Benedict XIV., vol. VII., f. 323 .

${ }^{21}$ "Epitome Bullarum Beneficialium SS. D. N. Benedicti XIV." 
bulls issued to every newly appointed bishop. In fact the registration of such bulls seems to be complete in this whole series, from the beginning, except of course where the volumes have been lost. There are many indulgences for confraternities. The greatest number have to do, however, with dispensations to take orders in spite of illegitimacy or defect in birth. One dispensation permits an inhabitant of the diocese of Mexico to take orders in spite of being a mulatto. ${ }^{22}$ There are also dispensations for irregularities, but none for a defect in age. Indici 411-415 index the matrimonial bulls for the same pontificate. It is at once evident that while the control of the clergy was kept in the hands of Rome, the administration of the rules with regard to matrimony was, in the New World, given to the bishops, by means of special faculties. In all these volumes there were noted only two matrimonial bulls applying to either of the Indies. One of these, anno I., volume X., folio I82, was issued to a man of the diocese of Bordeaux, and a woman formerly of that diocese, but at the time of Quebec. Evidently the bull was issued because of the European residence of the prospective bridegroom, and the same may be true of the other case, anno XII., volume VII., folio 55, diocese of Manila; but as the volume was lacking, this could not be proved.

\section{REGESTA SUPPLICATIONUM. ${ }^{24}$}

When petitions were received by the office of the Dataria, they were registered, the originals being sent on to the several departments which were to handle them, ${ }^{25}$ and coming finally, in most cases, to the chancery or the office of the secretary of briefs. This series of registers was formerly kept at the Lateran, and was in 1892 transferred to the Vatican archives. ${ }^{26}$ It is inventoried in indice 195, "Inventarium Supplicationum Datariae Apostolicae a Clemente VI." (I342-I352) "ad Pium VII." (I800-I823). ${ }^{27}$ This gives 7OI I numbers, corresponding to 8630 of an older numeration. It gives also a concordance with still another system of reference, according to which the volumes for each year of a pontificate were numbered as a separate series. Many volumes are lacking.

These registers are of paper, large folio size. They are made up of quinterna of Io folios. At the head of each quinternum is the name of the scriptor,

${ }^{22}$ Anno X., vol. X., f. I8r.

${ }^{23}$ Cardinal J. Hergenröther, Leonis $X$. Pontificis Maximi Regesta (Freiburg i. B., I884), (Mar. I3, I5I3-Oct. I6, I5I5), gives two references to this register touching America. One, no. 4656 from vol. 3, of the Lat. Reg. of Leo X., f. I54, Sept. 24, I5I3, is a bull to John, bishop elect of "S. M. de Lantiqua in India", permitting him to take several Franciscan friars " in ea Indiae parte quam Castellam ameam [auream, i. $e_{\text {., }}$ "Castilla del Oro'] appellant". The other, no. I0044, vol. 38, of the Lat. Reg. of Leo X., f. 283 , June 30 , I5I4, grants certain privileges for a hospital at Teneriffe, and "pro navigantibus in Indias quam pro commorantibus in ead" insula".

${ }^{2 *}$ Dom U. Berlière, Suppliques de Clément VI. (1342-I352) (Rome, I906), the first volume of the Analecta Vaticano-Belgica of the Belgian Historical Institute, introduction; H. Denifle, Désolation des Eglises de France pendant la Guerre de Cent Ans (Paris, 1897, I899); M. Miltenberger, in Historisches Jahrbuch, XL. 252; P. Kehr, "Bemerkungen zu den Päpstlichen Supplikenregistern des I4. Jahrhunderts," in Mittheil. des Inst. für Öst. Geschichtsforschung, VIII, 84-102; G. Brom, Archivalia in Italië, pp. $467-472$.

${ }_{25}$ In the earlier volumes, the original supplication; or the abstract made for use in considering the case and signed; or the roll on which numbers of such abstracts were written so that one signature could serve for the whole, appears to have been placed in the register, but for the later period, the volumes are as described.

${ }^{20}$ Hinojosa, Los Despachos, p. xxxi.

${ }^{27}$ Hinojosa, ibid., gives the extreme years as 1417 and 1846. 
and usually two quinterna by the same scriptor are together. The total number of folios is usually 300 , and there are in many cases as many as fifteen petitions on a single folio. The numbering of the pages is often incorrect. In the margin is some brief indication of the class to which the petition belongs. The petitions in a single quinternum are often of dates extending through the entire year. No method of referring from the register of bulls or briefs to the register of supplications or vice versa was discovered. The use of these registers is consequently very laborious, and the labor is increased by the writing, which is usually very bad.

The variety of the contents of these petitions is limited practically only by the variety of non-spiritual favors which the papacy can grant. ${ }^{29}$ They include requests for benefices; for dispensations to receive orders within prohibited ages and conditions of birth; for permission to exercise ecclesiastical functions and enjoy pluralities; to reside outside canonical districts; to be freed from impediments to matrimony; for the amplification, confirmation, and extension of extraordinary privileges; for the creation and change of parishes and dioceses; for privileges regarding the right of patronage, etc. They come from individuals, from kings and others asking favors extending to classes of the population, and from corporations, as universities. Sometime similar petitions are grouped by the Dataria for treatment together.

The American material, of course, corresponds to that described as in the Regesta Lateranensia, and the Archivio dei Brevi, but there are more petitions than grants of gifts and graces. Considering the formal character of the petitions during the modern age, the extreme paucity of American material, and the unmanageableness of the series, it would seem that such material as does exist, should be left, until the work of those who can expect greater return for their efforts shall have rendered the volumes more approachable.

\section{REGISTER OF BRIEFS.}

The apostolic letter in the form of a brief has been in use from very early times. Under John XXII. the office of secretary of briefs came into existence, and, with many changes and some interruptions, has continued to the present day. ${ }^{20}$ Leo X. enlarged that secretary's powers, making him dependent on the Pope alone, or in difficult cases upon a cardinal di segnatura. ${ }^{30}$ In effect the office of the secretary of briefs was a sort of chancery, subordinate to the regular chancery only in dignity. During the modern period an increasing amount of business went through his hands, particularly such as was of a political or of an exceptional nature, including orders, instructions to nuncios, statutes and constitutions, changes of organization, in the sum total making the briefs of much more general interest than the bulls. In addition to formulating the will of the Pope and the congregations, the secretary of briefs had certain powers which he exercised without reference. These included dispensations with regard to age, private oratories, reservation of the sacrament in non-parochial churches, the blessing of crosses, the granting of plenary indulgence in certain cases, the conferring of the apostolic benediction, etc.; while he had general charge of the subject of papal decorations and titles. ${ }^{31}$

${ }^{2 s}$ Ibid., p. xxxix.

${ }^{29}$ Grimaldi, Les Congrégations, Romaines, p. 473.

${ }^{50}$ Carga, in Laemmer, Monumenta Vaticana, pp. 457-468.

${ }^{31}$ Grimaldi, Les Congrégations Romaines, pp. 469-489. 
At the present time the office of the secretary of briefs has been assimilated with the secretariate of state. His independent powers are now exercised by a "Substitutus pro Negotiis Ordinariis," while the business of expediting briefs is in the hands of the "Cancellarius Brevium Apostolicorum."

The earlier registers and minutes of briefs have largely disappeared, and those that remain are widely scattered. Some are in the Archivio, some in private libraries in Rome ${ }^{33}$ and elsewhere, ${ }^{34}$ and some individual briefs are registered with the bulls. During the modern period they have been better preserved, and are found in two main collections, one of which has been long in the Archivio and was inventoried by De Pretis in indice 133, and the other is in the Archivio Brevi.

The briefs of the first collection were at the time of De Pretis in armadii 32 , and 38-45. Notes in the margin record the loss of the majority of the volumes there enumerated with the surmise that they disappeared at the time of the removal to Paris, and with a statement of a regrouping in indice 133 to a smaller number of armadii. Some volumes marked as lost, when called for by the original numbering of De Pretis were, however, promptly brought. It would therefore be impossible, without calling for every number, to be certain as to the exact present state of the collection. Note is here made: first of the number of volumes for the period after I492 originally in each cupboard, and then of those volumes marked as still existing. ${ }^{35}$

Arm. XXXII. Numbers 10, 23, and $\mathbf{2 4}$ are divers briefs, and 27, briefs II7II594. These are all extant.

Arm. XXXVIII. There were originally 27 volumes of registers of autograph briefs for Leo X., and Clement VIII. to Clement XI., of which the following are marked as still existing:

1. Leo $\mathrm{X}$.

2-4. Clement VIII.

5. Leo XI.

7. Paul V.

9. Gregory XV.

10-11, 13, 16. Urban VIII.

17-18, 20. Innocent $X$.

Arm. XXXIX. There were originally 44 volumes, numbers 22-65, of registers of autograph briefs, from Julius II. to Pius IV., of which the following are marked as still existing:

22-39, 41-60, 64-65. Julius II. to Pius IV.

Arm. XL. There were originally 53 volumes, numbers 1-53, of minutes of briefs, from Leo X. to I 535 , of which the following are marked as still existing, the numbers through 38 being in arm. XXXVIII:

3-4. Leo X.

5-11, 13-18, 20-21, 23-32, 38. Clement VII. I 523-I53I.

3anctissimi Domini Nostri Pii Divina Providentia Papae X. Constitutio Apostolica de Romana Curia (Rome, I908, pp. 69) ; see p. I6.

${ }^{23}$ Arnold, Repertorium Germanicum, pp. xiv-xv.

${ }^{34}$ Römische Quartalschrift, VII. 23I-232.

${ }^{35}$ In $\mathrm{arm} .52$, nos. 31 and 32, of the Archivio Segreto, are orders for the expedition of briefs with extreme dates of I537-I580. They correspond to the endorsed supplications, etc., which accompany the original minutes found in the volumes of the Archivio Brevi. 
Arm. XLI. There were originally 72 volumes of minutes of briefs, from I 536 to I554. Those marked as remaining, all in arm. XL., are the following:

2-3. $\mathrm{I} 536$.

21. I $54 \mathrm{I}$.

39. I 547 .

50. 1537.

51-54. I 534-I 549 .

Arm. XLII. There were originally 63 volumes of minutes of briefs, fron: Julius III. to Urban VIII. The following are noted as remaining, and as at present in arm. XL:

9-10, 12. Paul IV.

14. Pius IV.

37-38, 40-42. Gregory VIII.

48-51. Clement VIII.

52-57. Paul V.

58-62. Urban VIII.

Arm. XLIII. There were originally 32 volumes of minutes of briefs, fron: Urban VIII. to Clement X. Those noted as remaining follow, of which the numbers through 13 are at present in arm. XL.:

1-5, 7-13. I630-1649.

14-15. Innocent $X$.

16, 18-24. Alexander VII.

26-28. Clement IX.

29-30, 32. Clement X.

Arm. XLIV. and XLV. contain briefs to princes which are separately discussed later.

Indici 290-319 index this series of briefs. The first I 3 numbers were the work of many years. They were finished in 1626 , and cover well the period 1523-r549. The subsequent volumes through $31 \%$, which were less carefully done, continue the same scheme down through Urban VIII. The arrangement is chronological and alphabetical. The references for each year form a unit. These are divided according to the initial letter of the diocese, or occasionally according to subject, and those falling under each letter are again divided according to the month-a system less cumbrous to use, than to describe. There are no references to the volumes other than what the date gives, for there was at the time of compilation no inventory, but the volumes were probably ordered chronologically. Later, when De Pretis made his inventory, the arrangement seems to have become disordered, and reference is now a matter of labor and uncertainty. There are no later index volumes except one by Garampi, "Rerum et Negotior” S. A. S. a Pio IV. ( 560 ) ad Innoc. XII. ( 1700 ), Synopsis ex Regriis Brevium quae in Archivo Secretiore Vaticano asservantur". This is a fragment only, numbers 318 and 319 representing the first two of the four parts of which it was, or was to be composed. This index is geographically arranged, and in the missing parts there were to be references to the Indies. The parts existing are barren of anything pertinent to the subject.

Indice $31 \%$, for the briefs of Urban VIII., again refers to nothing local to the subject, but to many briefs for Lima and Mexico, containing statutes for universities with the right to grant degrees, indulgences, and dispensations to enter the priesthood in spite of defect in birth; for ladies to have com- 
panions or servants in convents, to have private oratories; regulations for monastic orders, etc.

The following volumes of briefs were examined, and all American material noted:

\section{ARM. XLII.}

No. 15. Briefs of Pins IV. I56r. After f. 387 the volume is rotted.

No. I2 I, f. 222. May 22. Grant to Philip II. of subsidies on the ecclesiastical revenues of all subjects of Spain.

No. 16. Briefs of Pius IV. I56I.

No. 322, ff. I67-I70. Oct. I4. " Ad futuram rei memoriam”, concerning ecclesiastical fruits in all the kingdoms of Spain (probably referring to Spain proper).

f. I7. Oct. I4. "Pro camera apostolica", powers and instructions to the collector-general of spoils in Spain.

No. 17. Briefs of Pius IV. I562. To f. I46 rotted.

No. 20I, ff. 337-338. Aug. I2. To Philip II., conferring indulgences for the Western Indies, regarding substitutes for fish on fast-days, and referring to previous grants by Clement VII. and Paul III.

No. 23I, f. 396. Oct. 3. For Diego de Ybarra, son-in-law of Don Luis de Velasco, viceroy of New Spain, regarding a defect in birth.

No. 233, f. 398. Oct. 3. Similar license to Marshal Franc. de Villagran, governor and captain-general of Chili.

No. 18. Briefs of Pius IV. Jan. to June, I563.

No. 249, f. 454. June Io. "Dilectis filiis generali aliisq' prepositis et p'bus [patribus] Societatis Jesu", granting dispensation to Indian neophytes, for twenty years.

No. 19. Briefs of Pius IV. July to Dec., I563.

Dec. 28. To the nuncio in Spain, conferring rights of visitation for the purpose of effecting reforms "in quibusvis provinciis et Dominiis".

\section{REGISTER OF BRIEFS TO PRINCES AND LATIN LETTERS.}

Arm. 44 and 45, according to De Pretis's inventory of the Archivio Secreto, contained registers of letters "ad principes et alios magnates". These are not to be confused with the collection "Principi" noted later as coming from the office of the secretary of state, which consists of the minutes of letters. The two should duplicate each other, and are supplementary only where losses have occurred. Arm. 44 contained 59 numbers, for Clement VIII., Julius III., Paul V., and Gregory XV.; Arm. 45, 35 numbers, from Paul V. to Clement XI., 7 numbers, $37-43$, from cardinals to princes during vacancies in the Holy See, and 67 additional numbers, transferred to the Archivio by Benedict XIV., and extending from the reign of Gregory XIII. to that of Benedict XIII.

To this collection other volumes have been added, and the whole is now listed in an unnumbered inventory, entitled: "Catalogo, Litterae ad Principes". This gives 222 numbers, extending from Pius IV. ( I 560) to Pius VII. (I809), with lacunae for the years I566-I569, I587-I 588, I600-I606, I6I9-1620, I692-I693, I695-I696, and I698-I699. This catalogue gives the years of the pontificate covered by each volume, and lists also the Latin letters ; 140, 192, and 212 are registers of autograph letters of popes. Only one volume was examined, as the character of the collection was sufficiently ob- 
vious from the study of the Lettere, Principi e Titulati, discussed on pages 87-89.

83. (I7O0-I7O2).f. 303. June 20, I702. Clement XI. to the Archbishop of Mexico, introducing the Patriarch of Antioch, about to pass through Mexico on the way to China.

f. 3II. June 20, I702. Same, to Viceroy of Mexico, on the same subject.

\section{LATERAN BRIEFS.}

This is a collection of 852 volumes included among those recently transferred from the Lateran. They are inventoried in indice 195A: "Inventarium Voluminum Brevium Lateranensium seu Datariae Apostolicae". The extreme dates are 1490 and 1800 . The first part of the series is defective and irregular, but it is apparently complete after $\mathrm{x} 535$. The volumes contain about 1500 folios each, and there are usually three volumes for the year, or four months to the volume. Within each volume the briefs are grouped by the month, and within the month the arrangement is fairly chronological. In form they resemble the minutes of briefs in the Archivio Brevi, each brief being on a separate sheet, often accompanied by a note of the case, and of the amount of the tax. It hardly seems, however, that they can be original minutes, for the subject matter is not such as fell to the independent jurisdiction of the secretary of briefs and the only signature is that of an official of the office of briefs. The briefs in the Archivio Brevi are not, to be sure, signed, but there is a signed paper accompanying them. Owing to the lack of time, it was impossible to determine whether the original minutes for these briefs are to be found in the regular series of the Archivio Brevi, but from such examination as was made, it seemed unlikely.

These briefs relate entirely to dispensations regarding the priesthood and matrimony. Of the first there are many referring to America. Of the latter there are relatively few, as the powers of the bishops extended to the great majority of cases. ${ }^{38}$ The one great exception was that made by the French West Indies, where there was no bishop, and whence the great majority of cases had to come to Rome. The difference made by the facoltà granted to bishops is illustrated by the fact that in the year I790, in which all cases were noted, there were 27 such cases from the French islands, and only one from the remaining portions of America. Such a fact illustrates the pressure brought to bear in favor of establishing a bishopric in these islands, to which some references are given in the chapter on the Propaganda.

Number 819, which was examined, was entitled: "Computa R. C. A." a Mense Maii I787 usque ad totum Mensem Decembris I790". In this, the payments for every brief were noted, and accounts were made up at the end of every month, with a statement of the total receipts; of the amounts credited to the Prefect of Briefs; to the R. C. A.; and to the Master of Briefs, and for the payments made by the latter to the College of Briefs; to the registrars of supplications; to the writers of briefs; and for the blank forms.

\section{CAMERA.}

The archives of the Camera are the most perplexing of all papal records, both because of their intrinsic lack of organization and of the scattered condition in which they at present exist. They have indeed, since the opening of

\footnotetext{
${ }^{36}$ See p. I2I.

${ }^{37}$ Reverendae Camerae Apostolicae.
} 
the Archivio, formed the basis of many brilliant studies, ${ }^{28}$ which begin to make clear the management of papal finance, but these are for the most part confined to periods before the discovery of America. In fact the greater number of the series into which the Camera material found in the Vatican is divided end before that event had begun to affect the finances of the Holy See, and for the history of the United States and Canada the whole is almost negligible. Probably more than three-quarters of the whole collection pertains to the Papal States. The various series are as follows, corresponding in some degree to the various branches of income mentioned in the introduction.

Introitus et Exitus. ${ }^{30}$ This is now an independent series of 608 numbers. It is also inventoried by De Pretis in the general inventory of the Archivio Segreto, indice 133, arm. 65-74, and 79 and 80. A concordance between the two sets of numbers is to be found in indice 194. Mixed with the series are volumes of manualia, or palace accounts. The main series consists, first, of volumes of receipts from the census, the visitations, bulls, common services, and other sources, and secondly, of expenses. It extends only to r 528. Volumes $558,559,560$, and 561 , covering the years I $5 \mathrm{I} 8$ to I $52 \mathrm{I}$ and I 528 , were examined and found to contain nothing with reference to America, nor is it probable that other volumes would prove more fruitful. Many volumes belonging to this series, but scattered in other collections both in and out of the Vatican, and covering later years, have been examined equally without result.

Libri Censunm. ${ }^{40}$ These give the accounts of the census, a tax levied on benefices and other property in return for protection. It was paid to the papacy, therefore, only in the Papal States and a few other regions where some constructive protection was afforded. This is the same tax as the decima levied on the clergy of the Western Indies, to assist in protecting those regions from the pirates and which was so often a source of discussion between Spain and the Holy See, but in this case it was paid to the Spanish

${ }^{38}$ Dom Ursmer Berlière, O. S. B., Inventaire Analytique des Diversa Cameralia des Archives Vaticanes, au point de vue des anciens Diocèses de Cambrai, Liège, Thérouanne et Tournai, I389-I500 (Rome, I906, pp. 327) ; id., Inventaire Analytique des Libri Obligationum et Solutionum (Brussels, 1904, pp. 315); Paul Fabre, Etude sur le Liber Censuum de l'Êglise Romaine (Paris, I892, pp. vii, 233) ; Abbé J. Fraikin, "Les Comptes du Diocèse de Bordeaux de II36 à I453, d'après les Archives de la Chambre Apostolique", in Annales de St. Lonis aes Français, III. 527-604, V. 5-74, VIII. 47-88; Emil Göller, "Der Liber Taxarum der Päpstlichen Kammer", in Quellen und Forschungen aus Italienischen Archiven und Biblioteken, VIII. II3-I73, 305-343; Adolf Gottlob, Aus der Camera Apostolica des i5. Jahrhunderts (Innsbruck, I889, pp. 3I7); Joseph de Loye, Les Archives de la Chambre Apostolique au XIVe Siècle, I. (Paris, I899, pp. x, $274)$; E. von Ottenthal, "Bemerkungen über päpstliche Cameralregister des I5. Jahrhunderts", in Mittheil. des Instituts für Ocster. Geschichtsforschung. VI. 6I5-626; Ch. Samaran, "La Jurisprudence Pontificale en Matière de Droit de Dépouille (Jus Spolii)", in Mélanges d'Arch. et d'Hist., XXII. I4I-I56; Ch. Samaran and G. Mollat, La Fiscalité Pontificale en France au XI IVe Sic̀cle (Paris, I005, pp. 284). Also, on the archives, Cauchie, De la Críation d'une École Belge à Rome, pp. I6-I9.

${ }^{39}$ A series bearing this name is found listed in indice $\mathbf{1 4 5}$, which gives the volumes contained among the archives brought from Avignon, but whether this is a separate collection, or had been added to the Archivio Segreto in the time of De Pretis, was not established, as this Avignon series, at any rate, ends with I42I.

${ }^{40}$ The Liber Censum is being published by the French School. Volume I. contains the book of Cencius Camerarius, with appendices; vol. II., supplements to the end of the fifteenth century. 
government." These volumes, of which 50 , covering most of the years from I 525 to 1766 , are found in $\mathrm{arm}$. 33, numbers $40-90$, and others scattered in many places, should therefore contain nothing on America, and an examination of number $90, \mathrm{arm} .33$, and of many of the scattered volumes, confirmed this supposition.

Instrumenta Cameralia. Arm. 34 contains 52 volumes of this designation, extending to I 586 . They contain deeds and other legal documents. Volumes $25,28,30$, and 31 were examined and found to contain no American material, nor did it seem probable, though not impossible, that the other volumes would prove more fruitful.

Diversa Cameralia. The main collection of 253 volumes is found in arm. 29 and 30 , but there are many volumes scattered elsewhere. It consists of letters, orders, and other writings of the cardinal camerlingo, of the clerks of the Camera, and even of the Pope. It extends from I389 to I585. Indice 133 , De Pretis, gives the years covered by each volume, its material characteristics, the number of folios, and whether it contains an index or not. The material within the volumes is not arranged in strict chronological order. The contents are so extremely miscellaneous that examination is particularly laborious, and no volumes were completely exhausted, as it seemed that no information of value could be gained. The great bulk of the material has to do with the Papal States. Wirz, in 90 volumes, found I6 items relating to Switzerland. ${ }^{22}$

Other material in the Archivio Segreto of De Pretis relating to the Camera and of date subsequent to the discovery of America, is as follows:

Arm. XXXIII. This contains volumes of quindenae, taxae, decimae, and other special accounts. All the volumes of possible interest for America, 3-7, 10, 24, 25, 27, 28, 30-33, 36, 37, were examined and found to contain nothing relevant.

Arm. XXXVI., XXXVII. These contain volumes informationum cameralium, of a miscellaneous character. Of these the registers of R. P. D. Bottini, from $\mathrm{I} 690$ to $\mathrm{I} 708$, arm. 37, numbers $33-36$, were examined and found to contain nothing relevant.

Collectoriae. This series perhaps belongs to the Archives of Avignon. Certainly the majority of the volumes were brought from there and the only inventory discovered is indice 145, "Indice delle Scritture d'Avignon, che loro stanno nella sala di sopra l'Archivio Secreto nell' Palazzo Apostolico di S. Pietro in Vaticano, I67I". In this list, the numbers of the volumes have been corrected to date, but other volumes added to the series are not mentioned. The collection stands accessible in the room for the study of unbound manuscripts, which renders an inventory less necessary. It contains reports and papers of papal financial agents resident in the various countries of Europe, who were often charged, before the establishment of resident nuncios, with important diplomatic missions. The total number of volumes is 504 . They begin in 1337 and end before the discovery of America in the case of those countries whence American items might arise. At a later period the collectors, where that office remained, corresponded with the secretary of state, and many of their papers are found among the nunziature.

${ }^{12}$ See pp. 6o-6r.

${ }^{42}$ Wirz, Bullen und Breven, p. xiii. 
Obligationes et Solutiones. ${ }^{3}$ This collection, like the last, belongs, perhaps, properly to the archives of Avignon as the majority of its volumes came from there, and belong to the Avignon period of the papacy. The only official inventory found is the same indice 145. This series also stands accessible in the room for the study of unbound manuscripts. It is possibly incorrect to place it under the head of documents relating to the apostolic Camera, since it contains actually the accounts of the Camera of the college of cardinals, for the fees for the common services, the incidence and the removal of which are here noted, were divided, half and half, between the Pope and that college. The 88 volumes which form the main collection, beginning with 1295 , end before the foundation of American dioceses, but the supplementary volumes containing items for the years I490-I678, and I540-I 553, respectively, may possibly contain something. ${ }^{44}$ They were not examined, as work with later volumes in the Archivio di Stato, which will be noted later, made their character familiar.

Quindenae. This collection is mentioned here, because it belongs to the archives of the Camera, and, if it does not properly belong to the Archivio Segreto, at least it seems to have no other specially assigned place. It consists of 75 volumes, for the years I 572 -I776, in several different series, which are to be found in the third or last room on the ground-floor suite of the archives. It contains the account books for the fifteenths which are described in the introduction to this volume, and an examination of the indexes of many volumes established the absence of material relating to the subject.

Beneficiorum ab anno I6oo usque I70o pro quibus fuerunt soluta annata. This collection of 8 volumes, bound in green, is, like the last, without inventory, number, or description, and is in the same room. The benefices are placed in alphabetical order. The one volume examined contained an item relating to Lima.

Attention is called to the fact that the late records of the Camera, to 1870 , are to be found in the Archivio di Stato. ${ }^{45}$ Also it should be noted that in this division of archives, much has been lost, or lost sight of. As this material may yet come to light, brief mention is made of some items that should prove profitable for the subject in hand. In the Vatican are many inventories of the volumes preserved by the Camera, the best being 221 and 222, both of the year $1747^{48}$ The later volumes of the introitus and exitus might, though they probably would not, contain something. More probably, material would be found in the Collettorie dei Spoglie, covering almost completely the years I550-I68r. Still more likely to be of interest would be the accounts of the nuncios. These are most complete in the case of Spain, where it will be remembered the nuncios performed many functions, extending with few breaks from 1506 to I7I5.

${ }^{43}$ See Mgr. P. M. Baumgarten, Untersuchungen und Urkunden über die Camera Collegii Cardinalium für die Zeit von I295 bis I437 (Leipzig, I898, pp. 378). This contains, pp. iii-xiii, an inventory of the collection, I295-I509; J. P. Kirsch, "Administration des Finances Pontificales", in Revue d'Histoire Ecclésiastique, I900, I. 275.

${ }^{44}$ Berlière, Inventaire Analytique des Libri Obl. et Sol., gives 92 volumes instead of 88. He points out that certain volumes contain other matter.

${ }^{45}$ See pp. 209-2IO.

${ }^{40}$ The title of 221 reads, "Ristretto di Materie esistenti nell" Archivio della Computisteria Generale della Rev. Cam. Apost." 


\section{COUNCIL OF TRENT.}

This collection is inventoried in indice 133, where it is described as occupying armadii 62 and 63 . It consists of 154 volumes, of which 60 have been added since the time of De Pretis. These include the acts and decrees of the council ; registers of the council, some general, and some on special subjects, such as "regulars"; letters and diaries written by legates, cardinals, and other attendants at the council, and relations by ambassadors; and a collection of bulls, orations, and miscellany relating to it. Numbers 32 and 33 form an index, probably only to the first 95 volumes, if to so many. None of the volumes of this collection were examined, but some material relating to the council in other collections has been inspected, and some idea obtained of its contents. A description of what was found relating to the subject is given in connection with the Biblioteca Vittorio Emanuele, numbers 1280-1282, and Biblioteca Vaticana, number 3198. American material would occur only by chance, and probably exists only in infinitesimal amount. ${ }^{47}$

\section{REMAINING ARMADII OF THE ARCHIVIO SEGRETO INVENTORIED BY DE PRETIS}

The collection which De Pretis undertook to inventory under the title of Archivio Segreto, in what is now indice 133, occupied 78 cupboards, but of these the inventory does not deal with 75-78. Many of the cupboards contain collections purely local, dealing with Ferrara, Urbino, etc., which were not examined. The remaining material is not of such a character as to make it likely that items on America exist, and it seems safe to say that the following references include practically everything at all relating to the subject.

Arm. XXXI. This contains copies of bulls made from the registers. Numbers 66, 67, and 79 were examined and nothing pertinent found. There remain of bulls after I492, the following:

68. Paul III.

69. Paul IV.

70. Clement VIII.

71. Paul II. to Alexander VIII.

80. Sixteenth and seventeenth centuries.

81. Pius IV. to Alexander VII.

Arm. XXXII. Copies of bulls made from the registers, of which those of possible interest are noted below:

3. Ad Hispaniam pertin.

10-11, 18-19, 21-37, 44-47. Divers bulls.

51. Decretals of Clement VIII.

59. Bulls relating to the Augustinians from the time of Innocent III. to that of Benedict XIV.

60. Bulls of dispensation and motu proprio.

61. Julius II.

62. Bulls of indulgences. I7II-I7I6.

4: Garampi refers to arm.62, no. 27, Jan. 21, 1578, faculty conceded to the archbishop of Mexico, to dispense from the third and fourth degrees of consanguinity; to letters of the same of Mar. 25, 1578, Dec. 29, 1580, Apr. 20, 1582; and, pp. 686, 703, a letter of Gregory XIV., in answer to one from the archbishop of the same see, congratulating him on his exaltation. 
Arm. LII. A rather miscellaneous collection of Signaturarum, audientiarum, commissionum, etc. Numbers 31 and 32 were examined and found to contain nothing pertinent. The following belong to the period:

1. Signaturarum of Julius III.

16. Signaturarum of Urban VIII. I640.

17. Regestrum audientiarum. I566.

22-22A. Regestrum audientiarum. I602.

23. Regestrum commissionum. I 564 .

24. Regestrum commissionum. I 564-I 570 .

25. Regestrum commissionum. I667.

26. Regestrum commissionum. 1670-1671.

27. Regestrum commissionum. I672.

28. Regestrum commissionum. I672.

29. Regestrum sive chirografi. Paul V. to Alexander VII.

30. Regestrum Clementis X.

Arm. LIII. "Volumina ad Datariae et cancellariae stilum pertinentia." 32 and 34 were examined and found to contain nothing pertinent. Volumes 29, 50, 55, 58, 60, and 61 were missing. References to American material found in other volumes follow:

33. f. 65. Erection of cathedral " in civitate Imperiali in partibus barbarorum et Infidelium" (Lima).

f. 66. Proemium pro collegio Scholarum ad "Darengo".

f. I6o. Erection of the church of St. Martha in the Indies.

The other volumes contain registers or formularia of bulls and briefs of various kinds, including those for new benefices, decrees, offices, dispensations, absolutions, confirmations, coadjutorships, bishoprics, priories, and monasteries, for the Camera, for pensions and reservations, for bulls of the Chancery and of the Dataria, and miscellaneous objects; and material relating to other administrative questions, as the practices of the chancery, the taxes of apostolic writers, etc.

Arm. LXIV. Miscellaneous collection relating to various countries, chiefly Germany. 30,31, 32, and 33, relating to France and Spain, the only ones that seemed likely to contain American material, were examined and found to contain nothing pertinent.

\section{CONSISTORIAL ARCHIVES.}

The consistories are the formal meetings of the Pope and the college of cardinals. ${ }^{48}$ They are of two kinds: first, the ordinary, so-called secret, consistories, at which cardinals are created, patriarchs, archbishops, bishops, coadjutors, bishops suffragan, abbots, and nuncios and legates, are formally appointed, and the erections, divisions, and other similar changes in dioceses are announced; and secondly, the public consistories. The latter are sometimes divided into semi-public consistories, for the creation of cardinals, and extraordinary, for canonizations, beatifications, and the reception of royalties

${ }^{48}$ The best account of the consistories is that found in the introduction of Joseph Korzeniowski, Excerpta ex Libris Manu Scriptis Archivi Consistorialis Romani, I409I590 (Cracow, I890, pp. I5I). See also Grimaldi, Les Congrégations Romaines, ch. VIII. This describes the ceremonial of the consistories. 
and special missions ; but this distinction seems hardly supported by the facts. ${ }^{40}$ The word secret really has little significance in this connection, as the acts of the consistories are such as publish themselves at once to the world. Their proceedings are, in fact, as was noted in the introduction, almost purely formal. It is not that the material contained in the consistorial acts or journals is not important, but it is such as has for the most part been digested into history. Those acts remain the final source for ecclesiastical chronology, and the allocutions of the popes are valuable as pronouncements of papal policy. The range of these latter is wide. The only mention found in the papal archives of the Huguenot settlement in Florida was in a speech of Pius IV. to the Swiss ambassadors in $1565^{50}$

The formal appointment of bishops was, of course, preceded by preliminary processes and investigations into life and morals, while before the erection of new dioceses, reports were necessarily made as to the need for, and ability to support, such an officer. The records of these preliminary steps are less important in the case of Spanish America than might be expected, owing to the fact that the king's nomination and his recommendation of diocesan charges were practically final, any preliminary negotiations being with the nuncio at Madrid. ${ }^{51}$ Moreover Sixtus V., in his general reorganization of administration, erected a consistorial congregation, charged with relieving the consistory of all but the last step of the various processes systematized by the Council of Trent, in the case of all episcopal appointments out of Italy ; while the congregation for the examination of bishops did a similar duty in the case of Italian dioceses, ${ }^{62}$ and the Propaganda came to perform the same duty for America.

The consistorial archives in general may be divided into two classes. First are the acta or journals, of which there are several varieties. Those kept by or for the vice-chancellor have perhaps the most official character, but are most brief. A second set was kept by or for the camerlingo. These latter always give the amount of tax involved in each appointment, which is sometimes omitted in the first set, and relate in extenso many of the speeches of the Pope and of ambassadors, which are there simply mentioned. Finally, many cardinals kept private records of consistorial proceedings, often, apparently, copying the records of the chancellor, but adding notes of their own. ${ }^{53}$ While these are not strictly archives they serve to supplement them. Secondly, there are the processi or records of preliminary canonical proceedings and investigations into life and morals, the praeconia or descriptions of dioceses drawn up for circulation among the cardinals before the consistorial meeting, and various other documents belonging to the preparatory stages.

The American material in these sets occurs regularly, and several extracts have been published. Dr. Ehses has given several documents on the founding

4y Hinojosa, Los Despachos, p. xvii. Nearly every account of the distinctions between consistories varies. An early seventeenth century MS. in Archivio Consistoriale, Misc. 50, ff. I-6, states that the secret consistories are for nominations, semi-public for beatifications and appointments except of cardinals, and public, for that purpose, and receptions of ambassadors and others.

6u Archivio Consistoriale, Misc. 11. Oration of June 8, 1565.

31 See pp. 59-60.

${ }^{32}$ Korzeniowski, Excerpta, p. 4.

${ }^{53}$ For instance that of Cardinal Santa Severina, which is often found in MSS., and of which part is published: P. Tacchi Venturi, Diario Concistoriale di Giulio Antonio Santori, Cardinale di S. Severina, I570-I576 (Rome, I903, pp. 235). 
of bishoprics in the Römische Quartalschrift, ${ }^{54}$ and the American Catholic Historical Society of Philadelphia has published material for the years I 577I600. ${ }^{55}$ The majority of the American items in Garampi's index come from this series. A further study would be useful in completing and correcting Gams's lists of bishops. ${ }^{58}$

Archivio Proprio. The actual archives of the consistories or of the sacred college are now, as for a long time, in the lower floor of the wing north of the court of San Damaso. ${ }^{57}$ Until Igo4 they were under the direct charge of the secretary of state, by whom scholars were occasionally admitted to use them. In that year the records previous to 1830 were made over to the charge of the Archivio Vaticano. As this department has not yet found itself able to order and transfer the collection, it remains at present (I909) inaccessible. Fortunately, its contents have been described by Pastor ${ }^{58}$ and Korzeniowski. It consists of about 450 volumes which are not numbered, but are arranged in fourteen numbered armadii. The following account of their contents is taken from Korzeniowski, such volumes as obviously do not refer to America being excluded: ${ }^{\text {s }}$

Arm. I.-IV. About I9o volumes entitled "Processus Ecclesiarum”. I543I792.

Arm. V. 6 volumes continuing the same series. I793-I830.

I4 volumes entitled "Juramenta Fidelitatis et Professiones fidei ", forming an incomplete series. I670-I809.

Arm. VI. 27 volumes entitled "Praeconia et Propositiones". I670-I827. Arm. VII. About 80 volumes of "Acta S. Congregationis Consistorialis". I 589 -I7 I7.

Arm. VIII. About 80 volumes of the same series. I7 I7-I772.

Arm. IX. Acta Consistorialia. I772-I8I7.

Arm. X. Acta Consistorialia. I409-I70 I. ${ }^{\circ 0}$

Arm. XI. Acta Consistorialia. I 523-I 798.

Arm. XII. Acta Consistorialia. I 529-I700.

3 volumes of miscellaneous material.

Arm. XIII. Volumes IX.-L. of "Positiones Congregationis Emmor. Capitum Ordinum ". I772-I796.

Arm. XIV. About 50 volumes entitled "Libri Cedularum et Rotulorum". I 565-I 802 .

I volume, "Sac. Card. Collegii Mandata et Litterae". I600-I676.

2 volumes, "Sacri Collegii Liber Quinden." Fifteenth century.

I volume, "Registro o Rincontro di Entrata e Uscita del Sacro Collegio delli Emmi. e Rmi. Signori Cardinali con la Depositaria de' Signori Nerli ". I663-I669.

"Dr. Stephen Ehses, "Aus den Consistorialakten der Jahre I530-I534", Röm. Quart., VI. 220-236.

${ }^{55}$ Records, XI. 6I-66, 208-210, 308-313, 454-460, "America in the Consistorial Congregations". Congregation is here used in the sense of meeting, not of special committee, and the documents used were acta. None of these items relate to the United States or Canada.

${ }^{5}$ P. B. Gams, Series Episcoporum (Ratisbon, I873).

${ }^{57}$ Hinojosa, Los Despachos, p. xvii.

${ }^{5 s} \mathrm{~L}$. Pastor, Geschichte der Päpste, vol. I. (Freiburg i. B., I886), pp. 64I-644.

${ }^{59}$ Korzeniowski, Excerpta, p. 6.

${ }^{80}$ These are originals only from 1517. Pastor, Geschichte der Päpste, I. 64I-644. 
I volume, entitled "Rotulum Libri cum aliquot Epistulis Blosii". I 505I 522 .

I volume, 7Io ff.: "Notitiae Ecclesiarium".

I volume, "Apochae". I657-I710.

Archivio Consistoriale. In addition to the above collection, there is in the Archivio Vaticano, in the third or last room behind the sala di studio, along the Vialone di Belvedere, an uninventoried collection of about Ioo volumes with this title. Nearly all these volumes are provided with elaborate indexes, often giving separately the names of churches, of monasteries, and of matters. These indexes are, however, rather deceptive, as their elaboration does not ensure correctness. In one volume with thirty-two actual references to American dioceses, there were fourteen omissions and two other errors. A list of the volumes follows, with a few references to American material:

(Acta Cancellarii.) The first bears the title: "11 "Rerum Concistorialium Leone Decimo et Adriano VI. Pontificibus Maximus expeditarum per me Julium de Medicis S. Vicecancell". The subsequent volumes have similar titles.

1. I5I7-I 523. $232 \mathrm{ff}$. and index.

2. I523-1536. I9I ff. and index.

3. I $527-1536$. I $80 \mathrm{ff}$. and index.

4. I 535 -I 546 . $285 \mathrm{ff}$. and index.

5. Nov., I 546-I 549. IO 4 ff. and index.

6. I $549-1555.283 \mathrm{ff}$. and index.

7. I 556-1559. I $78 \mathrm{ff}$. and index.

8. I559-1564. r87 ff., with unbound index.

(Acta Camerarii.) Volume 5 contains the following note: "Acta consistorii, ad sacrum R ${ }^{\text {nor }}$ Dnór S. R. E. Cardinalium Collegium pertinentia, et a $\mathrm{R}^{\mathrm{mis}}$ Dnis eiusdem sacri collegii camerariis Manu proprio olim perscribi solita. Dum postea scripta fuerit à diversis $\mathrm{R}^{\text {mor }}$ Collegii Camerarior' secretariis, et aliis, adeo ut non idem semper scribendi modus ubique servatus sit, neq' eadem cura, quae fortasse rebus ipsis et collegio fuit necessaria, quamobrem $\mathrm{R}^{\mathrm{mo}}$ in Chro Pri et Dno D. Jo. Petro tunc sancti Sixti Phro. Car ${ }^{\mathrm{li}}$ ac dicti sacri collegii Camerario, decentius ac melius fore multis de causis visum est, si sola unius ex Duobus ipsius collegii clericis Manu, acta ipsa scriberentur. Et ita fieri mandavit. Quod ego Jo Franciscus Binus eiusdem S. Coll. ex Natione Italica Cl'icus, in novo hoc libro, anno Dní millesimo quingentisimo quadragesimo Primo, quinto id. Januarii, observare incipiam, sicute dinceps sequetur."

1. I489-I 503. I $20 \mathrm{ff}$. and index.

2. I535-1536 (thus title, really to I540). I I $4 \mathrm{ff}$. and index.

3. $1529-1545.26 \mathrm{Iff}$. and index.

4. I540-I 545 . $\quad \mathrm{I} 86 \mathrm{ff}$. and index.

5. I54I-I 546 . I65 pp. and index.

6. I 546-I 549. $216 \mathrm{pp}$. and index.

7. I 546-I 549. 273 pp. and index. Duplicates the first 187 pp. of 6 , and contains a little additional.

8. I546-I550. I74 Pp. and index. I42 pp. duplicate 7.

9. I $559-\mathrm{r} 568$. I $76 \mathrm{ff}$. and index.

10. $\mathrm{r} 568-\mathrm{r} 583$. $344 \mathrm{ff}$. and index.

These titles are loosely given, that of the index often varying from that of the volume. 
11. I 584-I 59I. I $78 \mathrm{ff}$. and index.

12. Apr. 23, I 596-Nov. 22, I600. I 8 pp. +95 ff. and indexes. First 42 pp. lacking. Entitled "Provisiones Clementis 8". "Propositiones, Provisiones et Acta ... juxta Relationes”. Contains brief relations of churches in addition to usual material.

(Acta miscellanea.)

1. I409-I434. $246 \mathrm{ff}$. and index. "Liber Provisionum Sacri Collegii."

2. I489-I 503. $235 \mathrm{ff}$. and index. "Provisiones", transcribed from old and decaying manuscripts, by "Augustinus Favoritus secretarius", for the use of the sacred college.

3. I492-I5I3. $72 \mathrm{ff}$. and index. "Acta" and "alia gesta ", transcribed as in the case of 2 .

4. I550-I 559. $720 \mathrm{pp}$. and index. Printed title-page, dated Rome, I626.

5. I489-I 503. I80 ff. and index.

6. Not found.

7, 8, 9. I $534^{-\mathrm{I}} 546,298 \mathrm{ff}$. and index ; I 534 -I $546,545 \mathrm{ff}$. and index ; I 546I 555, $4 \mathrm{I} 9 \mathrm{ff}$. and index. Books of Cardinal Alexander Farnese.

10. I $550-\mathrm{I} 564.454 \mathrm{ff}$. and index.

11. I $563^{-1} 565$. About I $50 \mathrm{ff}$. and index.

12. I 563 -I $572.242 \mathrm{ff}$. and index.

13. I 570 -I 595. About $500 \mathrm{ff}$. Notes of Cardinal di Santa Severina. A poor copy.

14. I $5^{8} 5^{-1} 590.220 \mathrm{ff}$. and index.

15. I $590-1597.224 \mathrm{ff}$. and index.

16. I $598-1605.275 \mathrm{ff}$. and index.

17. I560-I $567.290 \mathrm{ff}$. and index. Copied from the records of the camerlingo.

18. I 5 I 7 -I $585.867 \mathrm{ff}$. and index. "Provisiones."

19. I 5 I 7-I $548.463 \mathrm{ff}$. Part I., see 20.

20. I 548-I 585. $625 \mathrm{ff}$. Part II. A note by Garampi states that part of these is copied from the vice-chancellor's records, and part is original.

21. Four books. I., I 498-I 569, 97 ff., "Excerpta notabior". II., I 518I 585, 5 I ff. III., I 563-I665, I63 ff. IV., I 570-I 575, I $20 \mathrm{ff}$. Copy of Santa Severina.

22. Four books belonging to a set begun in 21. V., I 575-I 578, I I7 ff. Copy of Santa Severina. VI., I 579-I 585, 98 ff. VII., I 585-I 595, I 7 ff. VIII., I 597-I644, I04 ff.

$23,24,25$. A set in vellum. 23, I 565-I 572, Io8 ff. 24, I 572-I 585, I $99 \mathrm{ff}$. 25, I 585-I 590, $200 \mathrm{ff}$. All have indexes.

27. I $572-\mathrm{I} 585.349 \mathrm{ff}$. and index. From vice-chancellor's records.

28. I 590-I 597. $87 \mathrm{ff}$. and index. From vice-chancellor's records.

29. I 598-1605. I06 ff. and index. Continuation of 28.

30. I590-I600. I76 ff. and incomplete index. From the Biblioteca Pio.

31. I $534-\mathrm{I} 549.220 \mathrm{ff}$. and index. " Acta Diversa."

32. I 55O-I 555. $244 \mathrm{ff}$. and index. " Acta Diversa."

33. I 560-I 599. 28I ff. and index. " Acta Diversa."

34. I 566-I 572. $333 \mathrm{ff}$. and index. " Acta Diversa."

35. I 570-I 595. $393 \mathrm{ff}$. and index. "Acta Diversa." 
36. I 596-I605; and I 585-I 591. 207 ff. and index.

37. 1605-1623. $266 \mathrm{ff}$. and indexes.

38. I498-I644. Contains an index; a summary of the records of the vicechancellor.

39. I 585-I 588. $357 \mathrm{ff}$. Diary and propositiones.

40. I 589-I 59I. $355 \mathrm{ff}$. Diary and propositiones.

41. I5I7-I5I8. Diary and propositiones.

41. I 5 I 7 - I 5 I 8 .

42. I 579-I58I. 24I ff. Contains mostly original propositiones.

43. I 570-I 598. I I $74 \mathrm{ff}$. Good copy of Santa Severina.

44. I 498-I499. 7 I ff. and index. From the Biblioteca Pio.

45. I54I-I552; and a few notes to I700. About $30 \mathrm{ff}$. copied from the records of the camerarius.

46. Not found.

47. I 575 - I 578 . ff. $369-690$.

48. I492-I 521. About 70 ff. ff. 28-30, July I8, I5I I, on the erection of dioceses in America.

49. I 5 IO-I 585 .

50. Largely without date. I79 ff. with index. "Acta" with letters and financial notes. ff. I-6, "Discursus quidam de consistoriis".

51. I 493-I 564 (actually the first date is I 505). I32 ff. From the library of Cardinal Bartolommeo Cesi.

52. Not found.

53. I 582-I 585. $295 \mathrm{ff}$., of which a few are printed. Chiefly propositiones.

54. I 592-I628. Journal and notes in sections, largely unpaged.

55. I 56I-I 584. I $32 \mathrm{ff}$. Records by Cardinal Caraffa.

56. Items largely without date, most falling between $\mathrm{I}_{560}$ and $\mathrm{I} 600$. Entitled "C. S. Severin. Consistorial. Proposit. Eccles. et alia".

57. I $563-\mathrm{I} 565.653 \mathrm{ff}$. and index. Records by Cardinal Gambara.

58. Not found.

59. Compilation of items chiefly obligationes pro quindeniis, largely without date. Those dated run from I4O3 to I 524 . I45 ff.

60. I $570-$ I $576.394 \mathrm{ff}$.

(Unmumbered.) There are certain volumes without arrangement. Some of these have an old numeration and these are listed first.

C. 3079 . I60 I-I606. I63 + ff. "Acta."

C. $3081.1605-1621.378$ pp. and index. "Acta."

C. 3082. I605-162I. I64 ff. and index. "Acta."

C. 3086. I62I-I623. $87 \mathrm{ff}$. and index. "Acta."

C. 3088. I62I-I623. 5I ff. and index. "Acta."

C. 3089. $1624-1636.260 \mathrm{ff}$. and index. "Acta."

C. 3092. I623-1628. $254 \mathrm{pp}$. and index. "Acta."

C. 3093. I623-1628. 329 pp. and index. "Acta."

C. 3096. I628-1632. $223 \mathrm{ff}$. and index. " Acta."

C. 3383 . I628-1633. I02 ff. and index. Formerly Pio 359.

C. $3389.1623-1630.169 \mathrm{ff}$. and index.

C. 3390. I64I-I65I. Unpaged. Notes.

C. 3394. I655-1669. I42 ff. and index. Formerly Carpegna 91. From the archives of the consistory, where it bore the number 7-III.-I907.

C. 3553. I565-1576. Unpaged. Scant notes. 
C. 3554. I623-I644. $335 \mathrm{ff}$. and index. "Acta diversa.",
C. $355 \%$ I I667-I676. $4 \mathrm{I} 2 \mathrm{ff}$. and index. "Acta diversa.",
C. 3558. I676-I69I. $305 \mathrm{ff}$. and index. "Acta diversa."

There is also a set of acta, the volumes of which once had numbers similar to those preceding, most of which are now illegible. They are from the records of the camerarius. They have been renumbered as follows:

C. 10. (3071). I 592-I605. 4 I6 ff. and index. Sometimes cited as A. C. VIII.

C. 11. (3080). I605-I6I4. $550 \mathrm{ff}$. and index.

C. 12. I6IO-I624. $27 \mathrm{I} \mathrm{pp.} \mathrm{and} \mathrm{index.}$

C. 13. I6I 5-I624. I $39 \mathrm{ff}$. and index.

C. 14. I624-I63I. $384 \mathrm{ff}$. and index.

C. 15. I632-I640. $204 \mathrm{ff}$. and index.

C. 16. I640-I644. $2 \mathrm{I} 2 \mathrm{ff}$. and index.

C. 17. $1644-1656.286 \mathrm{ff}$. and index.

C. 18. $1657-1662.206 \mathrm{ff}$. and index.

C. 19. $1663-1668.219 \mathrm{ff}$. and index.

Without number are:

"Acta consistorialia", I 570-I 595. About I000 ff. Copy of S. Severina. I 585-I 590. $220 \mathrm{ff.} \mathrm{"Acta."} \mathrm{Sometimes} \mathrm{cited} \mathrm{as} \mathrm{C.} \mathrm{S.} \mathrm{V.}$

I590-I59I. "Acta”, cited as CMIMC.

"Acta consistorialia", I 595-I6I4. In the same hand.

I746-I749. I97 ff. and index. "Liber Provisionū et actor' consistorialium." From the records of the camerarius.

"Acta congregnis consistorial.", I660-I663. Several thousand ff., apparently journal of the congregation of the consistory. There is nothing pertinent to the subject. Belonging to the same set are volumes for I655-I662 and I664I666, which likewise contain nothing relevant.

("Mandata.") I600-I675. This volume contains nothing pertinent to the subject.

(Other collections.) Consistorial acta are found in many other places. For instance, there are many in the Avignon registers. ${ }^{62}$ In addition in nearly every private library good sets of copies of acta and occasional praeconia are found, which are referred to in the proper places.

\section{ARCHIVES OF THE SECRETARY OF BRIEFS.}

This is an enormous collection recently removed from the office of the secretary of briefs to the Archivio. It is said to consist of about 8000 volumes extending from the middle of the fifteenth century to the present day. There is no inventory and the collection is not yet readily accessible, as requests for volumes must be made at the office, and not of the regular ushers. The pressure of business occasioned by the death of Mgr. Wenzel prevented as careful an examination as had been intended and various points were left in doubt. The material is arranged chronologically and can be called for by date alone. Any document accidently misplaced would be, for the present, effectually lost. The volumes bear serial numbers recently placed, and probably fureshadowing an inventory and greater accessibility.

Bulls. Toward the end of the sixteenth century it became the common practice to have bulls registered in this office instead of by the Camera. Thus

${ }^{62} \mathrm{U}$. Berlière, Inventaire Analytique des Libri Obligationum, cites numbers 66, $\mathbf{7 2}$, $\mathbf{8 2}$, and 83 as belonging to this category. 
in addition to the series which had long been registered by the secretaries, the bulls per viam secretam, of consistorial provisions, and de curia are to be found here; apparently, in fact, all except those in the Lateran registers. The registers found in this Archivio, therefore, continue the series which for the previous period are collected in the Regesta Vaticana. ${ }^{63}$

Briefs. It was not possible to determine the relation of the briefs of this collection and those inventoried by De Pretis as forming part of the Archivio of his day. The two series are alike in character, and it would seem that they must supplement each other, but the basis for the selection of the portion first sent to the Archivio is not plain.

The volumes of this series contain from 700 to 800 folios. The material does not consist of registered briefs, but of the minutes from which the briefs were prepared. With the brief is also the supplication which called for it, in case it was issued on petition. These supplications are originals, and are not all prepared by procurators. On the supplication is endorsed its history. Often note is made of reference to a congregation, whose decision is endorsed and validated by the seal of the cardinal prefect. Sometimes instead of a supplication is a note from a congregation requesting the expedition of a brief. All supplications are finally signed: "Illmus annuit", or with some qualification, as, "juxta decreta", or "cu' solitis restriction". With the minute and the supplication are occasionally other documents, as doctors' certificates in the case of petitions to eat meat on fast days. Occasionally, also, original briefs are bound in. The briefs within the month are not chronologically arranged, being rather grouped by subjects. Where several briefs are issued in identical terms, as in the case of granting a dispensation with regard to age to a class of novices, only one minute is in full, the others noting merely the individuals' names. The American material is not quite so varied as the general contents of the collection, because trivial requests were less apt to be sent such a distance, but they are in the total numerous. In the volumes examined the only one noted in any way within our field was one of Clement XI., Feb. I7, I7OI, found in the volume for March, folios I54I55, for the future conservation of books in the library of the Franciscans in the city of Guadalaxara.

\section{CASTELLO.}

The collection from the Castello Sant' Angelo was, in a way, the predecessor of the Archivio Vaticano. Founded by Sixtus IV. (I47I-I484), ${ }^{64}$ its purpose was to bring the most valuable papers of the papacy together for safe keeping in its strongest fortress. Preserved there under special precaution, not so much for secrecy as for safety, it remained an independent and growing depository until the entrance of the French troops in 1797 , when the sanctity of the Vatican seemed a more secure protection than the walls of the Castle. As a result of their removal, they were made, in $\mathrm{r} 798$, to all intents and purposes, a part of the Vatican archives.

The contents are most varied, consisting rather of individually important documents than of series. They include deeds of donation to the papacy, treaties, autograph letters of royal and other persons of importance, original

${ }^{\omega}$ Cardinal G. Simeoni, and Raphael de Martinis, Juris Pont. de Prop. Fide (Rome, I888 seq., 7 vols.), passim. Also Piux X., Constitutio, etc., sup. cit., p. I8.

os P. Kehr, Papsturkunden in Rom, pp. II5-120.

${ }^{\text {es }}$ Bourgin, Archives Pontificales, pp. 79-80. Hinojosa, Los Despachos, p. xxx. 
bulls, grants and rules of monastic orders, and all kinds of legal instruments. ${ }^{\text {as }}$ They were arranged by Confalonieri about I630, who placed them in two series of armadii; a lower, numbered from I. to XVI., and to which two others, XVII. and XVIII., were subsequently added; and an upper, A-M. In the armadii were placed numbered capsole or cases, within which were the documents, also numbered. It is necessary to give the document number in calling for material, as the cases are often divided, two having one number. There are also some series of bound volumes which are not thus placed in cases. This arrangement is still preserved although the collection is in much disorder and many portions of it have disappeared. Many inventories and indexes to this material have been prepared, which now stand as numbers 10-70 of the indici of the Vatican archives. None of these are satisfactory and most are in poor condition. They do not note losses.

It is obvious that a collection of this character is not apt to contain much American material. In the search for what might exist, only indici 69 and 70 were examined. These form a chronological index to the whole, arranged by Garampi, the first volume running from 344 to I 539, and the second from I540 to I803. They did not give an impression of completeness, but it did not seem worth while to spend more time here. ${ }^{67}$ The American material found is listed as follows:

Arm. II. Caps. I. No. 38. July Io, I5I9. Letter from Charles V., from Barcelona, to Cardinal Giulio de' Medici, on the erection of a cathedral in the province of Peru. Original.

No. 68. May 20, I520. Letter from Charles V. to Leo X., in favor of F. Bernardino de Monachelis (?), nominated to the archbishopric of "Nov' Cartegnis". Original.

Caps. IV. No. 36 was lacking. Nos. 37 and 38 were original papers relating to concordats between the Holy See and Spain in I7I 7 and I738, and contained nothing on America.

Arm. IV. Caps. III. No.3. Apr. I2, I67I. Bull of Clement X., concerning the canonization of the Blessed Virgin Rosa of Lima. Original with the signature of the Pope and of cardinals.

Arm. VII. Caps. V. No. 8. I59I. Copy of bull of Innocent IX., in which he created the archbishop of Mexico patriarch of the Western Indies.

No. I3. Feb. I4, I576. Letter of the Archbishop of Mexico to Gregory XIII., thanking him for relics, and asking that members of the Society of Jesus be sent him. Original, with autograph and seal.

Arm. XI. Caps. I. No. I8I. July I8, I 533. Letter from Charles V. to Clement VII., asking for the confirmation and consecration of Father Thomas de Berlanga, of the Order of Preachers, as Provincial in the Province of the Indies. Original with seal.

Oct. I5, I533. Same to same, nominating Father Thomas de Tiro, of the Order of Preachers, to the church of Carthagena in the Indies. Original with seal.

${ }^{\text {CB }}$ P. Fabre, "Notes sur les Archives du Château Saint-Ange", in Mélanges d'Arch. et d"Hist., XIII. I-I9; states that when the Archivio Vaticano was founded, documents were exchanged between the two despositaries, with the intention of preserving in the Castello the archives of the Camera. Such exchanges ceased with the coning of Confalonieri in I629, and do not seem to have resulted in any very comprehensive separation of field.

${ }^{67} \mathrm{Kehr}$, as above. For instance armadii XVI. and XVII. are not to be found. 
Arm. XIV. Caps. IV. No. 93, p. 23. Copy of a letter from Spinosa to the King of Spain, written July 2I, I533, from Panama, on the gold, silver, and other commodities of Peru.

Also Hinojosa notes in his Despachos, p. 76, that in arm. VIII., ord. I., letter N., there are letters from the nuncios of Spain during the pontificate of Paul III. ( $1534-1550) .^{68}$

\section{INSTRUMENTA MISCELLANEA.}

This is a collection of original documents occupying $I_{5}$ armadii, within which the documents are contained in cases like those of the Castello. They extend from 996 to $1542{ }^{69}$ and consist of documents belonging to the Camera ${ }^{70}$ and others of a political character. ${ }^{71}$ There is no inventory, though one is in preparation, but the documents are chronologically arranged, and the chronological index of Garampi refers frequently to them. This collection was not examined, as the date makes the existence of American material improbable, and investigation can be so much more economically made after the completion of the inventory.

\section{MISCELLANEA. ${ }^{72}$}

This very varied collection was contained at the time of De Pretis in I6 armadii, and while this arrangement has been greatly changed, the method of reference is unaltered. The working reference list is in indice 136, De Pretis, which has been corrected to I904. The Miscellanea of Garampi includes these documents among those it attempts to index. The portions of this collection which are or may be of interest are noted below.

\section{ARM. I.}

Of the I88 volumes listed here, number 57 was examined and found to contain nothing of importance. References to material found, follow:

59. "Avvisi da Parigi", I680-1685, by Abbé Lauri. p. 50. Feb. 24, I68I ; interview between Louis XIV. and the Spanish ambassador regarding pirates in the Indies.

p. I70. June 29, I682; effect on French merchants, of arrival of the galleons in Spain.

p. 20I. Nov. 30, I682; similar notice.

131. "Registrum Abbreviatoriae Apostolicae Hispan." I7II-I7I3. Interesting illustration of the activities of this officer though containing no special references to America.

133. No. 3. I8 ff. Papers of the collector, during the vacancy of the church of Carthagena in the Western Indies. I7I3. They include: $7 \mathrm{ff}$., an inventory dated Feb. 2, I7I3; a copy of the same; and, 5 ff., a

${ }^{65}$ Many schedae referring to the Archivio Segreto have been placed here by mistake.

They may be detected by the failure of the reference to refer.

${ }_{69}$ Bourgin, Archives Pontificales, p. 80.

${ }^{70}$ Joseph de Loye, Les Archives de la Chambre Apostolique an XIVe Siècle (Paris,

${ }^{1899)}$, p. X. Comptes Rendus de la Commission Royale d'Histoire (Belgique), fourth ser., X́VI., pp. $5 \mathrm{I} 7-528$.

${ }_{72}$ Bourgin, Archives Pontificales, pp. 75-79; P. Kehr, "Papsturkunden in Rom", in Nachrichten der K. Gesellschaft der Wissenschaften zu Göttingen, I900, pp. I20-122; and Wirz, Bullen und Breven, p. xxx, class this as part of the Archivio Segreto. 
legally attested paper of Apr. 23, I7I3, relating the contest between the ecclesiastical and regal officers.

The remaining volumes of possible interest are the following:

29-41, 45, 46. Miscellaneous material relating to France, I666-I704, especially collectanea.

47. Miscellaneous material relating to France and Spain.

60. Material relating to the Prince of Orange and the religious wars in France.

86-95. "Collectanea di Spagna."

99. Relations of Charles III. and Philip V. of Spain, by the papal collector.

108, 110. Registers of letters of the nuncio in Spain.

109, 111-112. Registers of letters to the nuncio in Spain. I 565-I 58I.

123-134. Miscellaneous material relating to Spain. 123-126, trial before Cardinal Spinola, I7II-I7I3; 128, spoils, I7 I I-I7I7 ; 131, supplications; 132 , vacancies; 133 , ordinations.

\section{Arm. II. Varia Politicorum. ${ }^{73}$}

Of this collection of $I / 3$ volumes of the most varied content, the first II 3 are indexed in indice $110,{ }^{34} \mathrm{pP}$. I-I39. The volume-numbers of De Pretis and this index correspond from 1 to 30 ; after that, $31-113$ of De Pretis correspond to 30 (double) -112 of the index. Dr. Schlecht of the Görres-Gesellschaft inventoried the collection in 1890 , but I am not aware that this inventory has been published. ${ }^{75}$ Volumes 162, 163, 170, 175, and 176 are lacking.

The first I I 3 volumes were examined by the aid of the index, and the subsequent volumes, 117,120 , and 158 , were examined and found to contain nothing worthy of note. The references to pertinent material follow:

3. ff. 507-5I7. "Relatione della Corte di Spagna da Mons. Visconti Nuntio, à Pio P. P. IV." I 564. f. 5 I I gives mention of the Indies.

12. f. I92. Relation of Spain by Giovanni Correro, Venetian ambassador, I 570, referring to the interruption of the navigation of the Indies by the Huguenots.

34. ff. 37-39. From the Pope to the Archbishop of Rossano, nuncio in Spain, I 566, on the method of governing Spanish America and propagating the faith there.

54. f. I55. Instructions for the Bishop of Lodi, destined nuncio in Spain. Apr. 30, I 58I.

81. ff. 27I-283. "Oratio ad Sixtum V. P. M. et invictissimum Philippum Hispaniarum Regem de Bello Brittanico suscipiendo." f. 275 connects the question with the Indies.

82. f. 355. Instructions to Mgr. Rinuccini, sub-collector general for Spain, giving brief sketch of the papal financial administration there.

ff. 432-434. Instruction to the Archbishop of Rossano, same as in 34, except that it contains an introduction omitted in that copy.

84. ff. IO7-I IO. Edict of Philip II., Mar. 3I, I568, against those who preyed on navigation.

91. ff. 302-377. Relation of Spain by M. Ant. Tiepolo, Venetian ambassador, Oct. I I, I 567 , discussing French designs on Florida and the Indies.

${ }^{73}$ Hinojosa, Los Despachos, pp. xvi-xviii.

it "Index Librorum II2 diversarum scripturarum confectum a Rev. domino Felice Contelario et unitorum per me Joannem Bessaigham fuit compactum an. I694."

${ }^{i s}$ Bourgin, Archives Pontificales, p. 77. 
102. ff. I2-35. Relation of Spain by Venetian ambassador, I566; ff. I3-I5 discuss the Indies.

ff. 36-46. These folios are lacking. According to the index they related to Peru, Florida, and India, and contained letters of Pius V. (I566I 572) to "Francisco a Toledo Proregi Peru, Petro Menendal Floride Proregi, Consilio regio Indico, Regi Catholico, Cardinali Spinose ", and instructions to the nuncio with regard to the conversion of infidels.

113. ff. I36-339. " Relatione Intitolate i Commentarii dell' attioni del Regno di Francia concernenti la Religione", from I556. f. I 58 mentions Huguenot preachers in America.

158. Relation of Spain by Sig. Dominico Zane, Venetian ambassador, I662. Refers to the effects of English naval supremacy on the Indies, but only briefly.

The volumes not yet examined, but which might possibly repay examination are the following:
123-125, 127-130. "Varia."
132. "Varia Clementis VII."
133. "Francia e Card. Barberini."
134. "Relatione di Spagna."
135. "Francia e Card. Barberini."
136. "Varia."
137. "Nunziatura di Francia straordinaria."
138. "Card. Barberini."
139-141. "Varie."
142-144. "Riccordi Politici del Maretti."
146-147. "Diversi."
151-157, 159. "Relazioni di diverse Corti."
164. "Relazioni di Spagna e Roma."
177. "Instruzioni ai nunzii."

Nunziature Diverse.

Following the Varia Politicorum in the De Pretis inventory of arm.2, and the Biblioteca Pio in the actual arrangement of books, is this collection, which supplements the regular division of the Nunziature. None of the volumes were examined. Those of possible interest are the following:

France.

A 32. From nuncio. I $56 \mathrm{I}-\mathrm{I} 565$.

36-80. Letters from the nuncio, extending in different series from I607 to 1657 .

81-106. Ciphers to and from the nuncio, regular series. I644-I689.

245. Instructions from Innocent VIII. to the nuncio. Spain.

107-111. Letters of the nuncio. I 560-I 572 .

112. Letters of Spanish ministers to the nuncio. $1624-1626$.

113-118. Letters of the nuncio. I624-1626.

119. Letters to the nuncio. I629, etc.

120-131. Letters of the nuncio. I605-1615, I624-1625, I627-1631, I653I658. Irregular series.

132-144. Ciphers to and from the nuncio. I644-1677. Irregular series. 
205. Letters to various persons in Spain. I606-1607. Flanders.

201. Letters to the nuncio of Flanders and Cologne. I605-r6og. Miscellaneous.

209-233. Ciphers to and from nuncios residing in various courts of Europe under Innocent XI. I676-I685.

195 bis, 234-240. Ciphers, letters, and instructions. I607-r685.

249. Instructions under Gregory XV.

250, 251. Instructions by Cardinal Ludovisi. I62 I, etc.

253-255. Letters and instructions. I 555-1698.

260. Various legations.

264-273. Miscellaneous political affairs.

276. Letters of cardinals, bishops, princes, and individuals. I674-I690.

2\%\%. Letters of Cardinal Buglione with minutes of replies by the secretary.

282. Letters of Mons. Gio. Battista Agucchio. I $597-1598$.

28\%. Various instructions. I62r.

288. Instructions of Cardinal Ludovisi during all the pontificate of Gregory XV. ( $162 \mathrm{I}-\mathrm{r} 623)$, prepared by Mons. Agucchio, secretary of state.

289. Letters. I514-1754.

\section{ARM. III.}

The 239 volumes of this armadio contain chiefly relations, and similar material covering a wide range of countries and interests. Volumes 31-50, which in addition are lettered in the sequence $A-I, L-T, V, X$, are from the library of Cardinal Cena, and for these there is a separate index, indice 218, pp. I-89, which, however, is complete only through the letter $\mathrm{C}^{76}$

Volumes $34,40,42,44,45$, and 48 were examined without revealing matter of interest. References to material found follow:

32. (Cena B, second volume).

f. 75. "Lettera dell' Ingoli circa la linea della divisione dell' Indie."

f. 76 . Another letter to the nuncio in Spain, on the same subject.

40. (Cena L).

ff. 220-326. Several documents, chiefly printed, relating to the reform of the tribunals of the Nunziatura in Spain, r640. Only of indirect importance for America.

42. (Cena N).

ff. I33-I49. "Tratato sopra La Monarchia di Spagna." Time of Charles

$V$. Unimportant references to the "new world".

Material of interest may possibly be found in the following volumes:

3. France and Alexander VII.

\%. Relations of France.

13. Spain.

15. England and Portugal.

21. France and Innocent XI. English Revolution.

35. ff. 386-398. "Memoriale degli amba di Spagna demandando sussidii ", etc.

${ }^{76}$ Not volume $\mathrm{C}$, but subjects and names beginning with $\mathrm{A}, \mathrm{B}$ and $\mathrm{C}$. 
35. First numbers, instructions to the Archbishops of Conza (Lagonissa) and of Thebes (Falconieri), nuncios to Flanders in I627-1634, I634I637. ff. I 507-I 548, relation of France by Mons. Scotti. See p. 2 I3.

37, 38, 41. Miscellaneous documents relating to France and Spain.

47. Correspondence of Mons. Cena, nuncio in France. 1633.

49. Miscellaneous documents relating to various congregations.

148. "De Occidentalibus Insulis" (lacking).

241-243. Letters to Clement XII. from Spanish bishops and heads of orders, concerning the doctrine of the Immaculate Conception.

\section{Arm. IV. AND ARM. V.}

These divisions contain material almost wholly relating to the government of the Papal States, and extending to 1834. It is hardly conceivable that they contain material interesting to America, unless it be something by chance erroneously placed here. ${ }^{\text {T }}$

Arm. VI.

These volumes relate chiefly to theology and the monastic orders. Volumes 112 and 138 were examined without result. The following is of some interest:

42. "De Eccles. in Indiis Orienta1. et Occiden." This volume is one of several from the dispersed library of Ciampini, giving a general view of the churches of the world, drawn chiefly from the consistorial praeconia. ${ }^{78}$ The date of collection seems to have been about i67o. Cuba, Durango, and Guadalaxara are found in proper alphabetical order.

34. Collection of writings concerning divers Indian nations, is noted as having been transferred to the Archives of the Propaganda, but could not be located there.

138. Diary, I788-I8I5, was not examined.

\section{Arm. VII.}

Records of the Congregation of Visitation, whose activity is confined to the immediate diocese of Rome.

\section{ARM. VIII.}

The first volumes are from the Congregation of Bishops and Regulars. Volume 60 was examined without result. Volumes 78 and 79 , from the library of Ciampini, belong to the same set as volume 42 , arm. VI., giving the churches of Christendom, A to $\mathrm{F}$; and in partibus infidelium, respectively. The latter phrase at this period seldom includes partes Indiarum. The following references to material were found:

59. ff. 76-79. Brief of Innocent X., Jan. I, 1646, granting indulgences to the Jesuits, and letter of the general of that order, on the extension of the same to the Western Indies.

81. "De Episcopatibus in diversis Regnis, Provinciis et Civitatibus." Also from the library of Ciampini. The descriptions are very brief and the enumeration not exhaustive; Cuba was found. In addition:

82. Tax book of churches was not examined.

${ }^{77}$ These are denominated "Bolle e Bandi", and consists of two series. A third series is separately inventoried in indice 194, see page 90.

${ }^{i s}$ See p. 37. 
Arm. IX.

The first volumes relate to the Congregation of Confines. There follows in the inventory the list of the Bolognetti collection, which is treated separately on page $9 \mathrm{r}$.

ArM. X.

This armadio formerly contained records from the Congregation of the Holy Office, of the Propaganda Fide, and of Rites. The greater portion of these volumes are now missing, having been for the most part, it seems, restored to the archives of the congregations whence they originated respectively. Of the volumes remaining, 112 and 113 were examined without result; 109 is the relation of the state of missions, by Cerri, so often found, ${ }^{79}$ and no other seemed likely to be of interest.

Arm. XI.

The main feature of this armadio consists of the lives of the Popes. The only volumes which seemed likely to contain American material, 76 and 86A, were examined without result.

ArM. XII.

Numbers 1-104 contain diaries of the masters of ceremonies, covering the period I463-I680. Numbers 100 and 101 are indexes. There formerly followed a rather large collection of consistorial acts, but the majority of these have been removed to the separate consistorial collection. Those which remain and are of possible interest are the following:

122. Years I 5 I 7 -I 534 .

126. Years I $566-\mathrm{I} 572$.

130. Years $1628-1644$.

131. Years $1644-1654$.

137. Years I632-I636.

139, 140. Indexes.

141. Consistorial votes.

There follow a few volumes relating to kindred subjects. Of these 155. "Pro Sac. Cong. Consisi information. et Sac. Cong. de Prop. Fide Decreta super Provis. Concistorial.", from the library of Ciampini, contains, ff. 85-94, references to the church of Lima and the subject of the taxes of coadjutors in the Western Indies. About I628.

Other volumes of possible interest are:

150-153. Tax books giving lists of churches.

185. Propositions of churches and petitions of bishops.

ARM. XIII.

Here is found a variety of consistorial material, including some from the Congregation of the Consistory; and some papers from the master of ceremonies. The following was found to be of interest:

54. "Creationes Cardinalium et Episcoporum ab anno i632 ad i7oo." Vol. 2 contains indexes of churches, of monasteries, and of matters. Many notices of American churches.

Of possible interest are:

49. "Acta Diversa."

52. "Monasteria Consistorialia et Cameralia."

${ }^{70}$ See p. I94. 
66-70. "Propositiones quarundam Ecclesiarum." I 577-I648, I675-I745.

74. "Consistoria Clementis IX.", vol. 2.

76. "Folia consistorialia Clementis IX."

77. "Consistoria ab anno I689-I699", vol. 2.

79. "Consistoria secreta." I7I7-I7I9.

80. "Acta consistorialia." I727.

81. Same. I728.

82. "Cedulae et contracedulae, Pii VI., pertinentes ad Creationem Episcoporum." I775-I799.

83. Same, Pius VII. I800-I80I.

84. "Suppliche di Vescovi per dim. di Tassa per le Bolle." I804.

85-92. Matters concerning coadjutors. I6 $12-\mathrm{I} 763$.

93. "Consistorialia, seu Provisiones Ecclesiarum Benedicti XIV.", I740I754, vol. 4 .

\section{ARM. XV.}

The leading features of this armadio consist of documents relating to the papal system of government, and relations of conclaves. Volumes 77 and 89 were examined without result. The following reference to material was found:

62. "Registro di Lettere Scritte à diversi da Mons ${ }^{r}$. Sacchetti in tempo che era Nuntio in Spagna." May 3I, I634, to the cardinal secretary of state, on fear of an uprising in Mexico. June 7, 1634 , to the same, on accident to the fleet, and political effect of the same in Spain.

The following volumes may prove to contain matter of interest:

99, 100. Political relations and discussions.

103. Same, of the sixteenth century.

104. Same, of the seventeenth century.

158. Various relations.

Arm. XIV. and Arm. XVI. do not appear in the inventory of De Pretis. 


\section{VATICAN ARCHIVES: ARCHIVES OF THE SECRETARY OF STATE.}

This collection now amounts to about 6000 volumes. ${ }^{2}$ In 1656 Alexander VII. sent into the Archives the first papers from the office of the secretary of state, his example was followed by Alexander VIII. (I689-I69I), and the collection has been added to by continual papal orders for similar transfers, for transfers of appropriate books from other collections, and by gifts. ${ }^{4}$ At the present time it contains the great bulk of the documents belonging to this office for the period before I8I5, thus conforming to the general European custom that before a given date to reserve documents shall be the exception, whereas after it they shall be accessible only by exception.

De Pretis inventoried the collection in what is now volume 134 of the indici. This inventory is of the most summary character, merely assigning to each volume a number, giving the extreme dates of its contents, and some such legend as: "Lettere dal Nuncio di Francia ", "Diversi di Francia ". It gives the regular series of the secretary's office; first the nunziature, or correspondence with nuncios and legates, divided into 2I groups, 20 according to the countries or provinces, in which they resided, and I of special missions of peace; then the letters of cardinals; of bishops and prelates; of princes and persons of title; of individuals; and of soldiers. This inventory has been corrected to I905. Missing volumes are enumerated at the end of each collection, and are sometimes checked in the list. In cases where they have been transferred to other collections this is sometimes mentioned and sometimes not. In the case of additions, volumes are usually placed somewhere near their natural position by means of internumbering. The provenance of such volumes is frequently, but not always, given. The collection is indexed chronologically in indici $168-184$, by Garampi, but many volumes have been added since this work was done, and it is therefore incomplete.

The office of secretary of state belongs to the modern age, being the most important of those developed to meet the needs of increasing business, brought to the papacy, as to all governments, by the growing complexities of life. Its origin is found in the creation in 1487 , by Innocent VIII., of a secretarius domesticus. After this date, however, the chancery continued to conduct some diplomatic correspondence, and several volumes of bulls contain instructions.

${ }^{1}$ Dom R. Ancel, O. S. B., "La Secrétairerie Pontificale sous Paul V.", in Rerue des Questions Historiques, LXXIX. 408-470; Giovanni Carga, "Informatione del Secretario e Secretaria di Nostro Signore et di tutti gli Offitii che da quella dipendono", I574, Urbin. 854, ff. 29-57, and published by Laemmer, Monumenta Vaticana, app. II. See also Urbin. 859, ff. 72-93; Alfred Cauchie, Mission aux Archives Vaticanes; Rapport à $M$. le Ministre de l'Intérieur et de l'Instruction Publique (Brussels, 1892), pp. 24-27. See also P. Richard, "Origines et Développement de la Secrétairerie d'Etat Apostolique, I4I7-I823", in Revue d'Histoire Ecclésiasiique, XI. 56-72, 505-529, and $728-754$.

${ }^{2}$ Hinojosa, Los Despachos, pp. xliv-xlv.

Ibid., pp. xxvii-xxviii.

'De Pretis, Indice 134, notes such additions, passim. Also Hinojosa, Los Despachos, pp. xxvii-xxviii.

"P. Richard, "Origines des Nonciatures Permanentes", in Revue d'Histoire Ecclésiastique, VII. 333-334. 
It was only under Leo $\mathrm{X}$. that this new officer began in an orderly and regular manner to take charge of the whole diplomatic correspondence, and it is only with his pontificate that the archives of this office begin to be full and important. The first secretary of the new type was Pietro Ardinghelli, and he was not independent in his action, as he was controlled by a cardinal delegated with the papal signature. This cardinal was Giulio de' Medici, and under him the office of giving the papal signature to the writings of the secretary of state became the first in actual importance in the papacy. In I537 the department of state was organized, with a secretary of state, and secretaries of letters to princes, of ciphers, and of Latin letters.

Under Gregory XIII., in 1572 , the offices of secretary of state and of the cardinal di segnatura became combined in the person of the Cardinal di Como." From this time it became customary for the "cardinal nephew" to exercise this office, to which accrued the immense prestige and power, inevitable from such close connection with the Holy Father: ${ }^{8}$ Practically the secretary of state became first minister, and his control of foreign affairs was but one field of his activity. The archives reflect this general interest, although they remain chiefly diplomatic. This period of nepotism was brought to a close by the bull of Innocent XII., in I69I, which severely curtailed the privilege of the nephews of the popes. ${ }^{\circ}$ The traditions of the office, however, proved sufficiently strong to endure the change, and the secretary of state continues to be, to all intent, first minister, though the archives show some restriction of field, due to the more clear-cut articulation of public business. It is obvious that the material of the collection is of the widest scope, as will be found more particularly explained in the introductions to the several subdivisions.

\section{NUNZIATURE.}

The organized system of papal representation followed closely the development of the secretariate of state. ${ }^{10}$ In fact for centuries the papal collectors had resided in every country of Europe, and while their functions were chiefly financial and their correspondence was with the Camera, ${ }^{11}$ they were quite obviously the prototypes out of which the later system of nuncios developed. The legates a latere, also, who from time to time represented the interests of the papacy when important crises arose, contributed to make the idea of representation familiar and to create a technique of diplomacy. The nuncio in in Spain was from I 528 also a legate, ${ }^{12}$ and generally had the title and exercised the function of a collector-general, thus inheriting the traditions of those of-

- Hinojosa, Los Despachos, pp. 29 and 37.

${ }^{7}$ Grimaldi, Les Congrégations Romaincs, p. 13; P. O. von Törne, Ptolémée Gallio, Cardinal de Como (Paris, 1907), pp. 107-I35.

${ }^{8}$ Ibid. Also Anton Pieper, Die Päpstlichen Legaten und Nuntien in Deutschland, Frankreich und Spanien seit der Mitte des XVI. Jahrhunderts (Münster, I897), pp. I2I-I24.

${ }^{\circ}$ Grimaldi, Les Congrégations Romaines, p. 15.

${ }^{10}$ Anton Pieper, Zur Entstehungsgeschichte der ständigen Nuntiaturen (Freiburg i. B., I894); P. Richard, "Origines de la Nonciature de France: Nonces Résidants avant Léon X.", in Revue des Questions Historiques, LXXVIII. 1 36 seq.; id., "Origines des Nonciatures Permanentes: La Représentation Pontificale au XVe Siècle (I450-I5I3)", in Revue d'Histoire Ecclésiastique, VII. 52-70, 317-338; S. Steinberg, "Die Facultäten eines päpstlichen Nuntius im I6. Jahrhundert", in Mitthcilungen des Instituts für Oesterreichische Geschichtsforschung, XIX. 327-342.

337.

${ }_{11}$ P. Richard, "Origines des Nonciatures", in Revne d'Hist. Eccl., VII. 54-56, 319-

\footnotetext{
Hinojosa, Los Despachos, p. I3.
} 
fices. ${ }^{13}$ Under Julius II. and Leo X., most of the collectors-general disappear, and promptly a corps of nuncios, at first temporary and with special missions, but quickly becoming resident and with general powers, succeeded them. ${ }^{14}$

The functions of the nuncios varied from country to country, and such differences, where significant, are rlescribed in connection with each particular collection. In general the diplomat of the sixteenth and seventeenth century was far from holding himself aloof or impartial, and the papal representative stood not for a power which was wholly foreign, but for one which permeated with influences material and spiritual the country in which he resided. In most cases he had recognized relations not only with the sovereign but with the people, and his position called for unusual breadth as well as skill. The character of the experience obtained was such, indeed, that it was a usual line of promotion to the papacy.

The correspondence which a nuncio was expected to carry on with the department of state was voluminous, and soon acquired a definite and prescribed character. This is perhaps best exemplified in the copies of the dispatches of the seventeenth century which are found in the Barberini library. ${ }^{15}$ Each courier carried a letter in cipher, or several such letters, each on a special subject; a plain letter; of news-letters, one for each country; and, finally, enclosures. In return the nuncio received, at times, a general instruction as to his mission as a whole, but this was more often given verbally before he left Rome; continuous instructions as to minor points; and such news of Rome and the world as might affect his purposes. Dispatches both to and from the nuncios were sent ordinarily in duplicate or triplicate. ${ }^{18}$ The valedictory relations, characteristic of the princely diplomacy of Italy, are rarely found in that of the papacy.

The ciphered letters passed through the hands of the secretary of ciphers, an officer of great dignity. ${ }^{17}$ These were naturally the more important, for while the ciphers were seldom impenetrable if they fell into the hands of a foreign court, they at least rebuffed vulgar curiosity. ${ }^{13}$ The three classes of letters, however, represented an over-elaboration of method, and no definite indications as to just what should be looked for in the plain letters and in the ciphers can be given. It was, perhaps, the best practice to put all strictly diplomatic material in cipher and make the plain letter a running comment on the news-letters. Often a portion of a letter was ciphered, while the rest was plain.

The news-letters contain the bulk of the material relating to America. They were highly regarded, made with great care, and read with anxiety. The papal court constantly stimulated the activity of its agents in collecting news, and apparently desired to receive whatever of importance came to their knowledge. In I6I I the secretary of state wrote to the collector in Portugal: "Accettissimi sono stati gl'avvisi d'Africa, delle filippine, et di Inghilterra, et ogni altro, che verrà à sua notitia, si come si leggerà volontieri, cosi non lasci di

${ }^{13}$ Hinojosa, Despachos, pp. 19-22.

${ }^{14}$ Richard, l. c., p. 320.

${ }^{15}$ Note analogy with the registers. L. Duchesne, "Rapport sur la Publication des Registres Pontificaux", in Mélanges d'Arch. et d'Hist., XXV. 447.

${ }^{10}$ Hinojosa, Los Despachos, pp. I6-17.

${ }^{17}$ Grimaldi, Les Congrégations Romaines, p. 18.

${ }^{19}$ Aloys Meister, Die Geheimschrift im Dienste der Päpstlichen Kurie, vol. XI. of Quellen und Forschungen aus dem Gebiete der Geschichte . . . Görres-Gesellschaft (Paderborn, I906). 
comunicarlo": The nuncios, however, often regarded this portion of their duty as a burden, and strictly confined the news they sent to the regions for which they were especially responsible. ${ }^{20}$ The Cena collection contains an instruction for the secretary of a nuncio, as to the collection of this news. ${ }^{21}$ A wide personal acquaintance and open ears were the chief requisites. The intent seems to have been to send verified news only. Thus the collector of Portugal in I586, after receiving reproofs from the secretary of state and the nuncio in Spain, because of the little news he sent of the Indies, replied: "Che credo in ciò non haver punto mancato, quando ho havuto cosa vera et relevante, che l'altri novelle non è molto mia professione scriverli". "The nuncio of Spain, also, wrote in 1587 : "Quello chè si sà di certo delle cose di Drake si scrive nelli avisi. Qua dirò solamente alcune cosi, chi si vanno discorrendo tra personi di giuditio ". ${ }^{23}$ In spite of this care the news-letters do not escape false and surprising rumors. ${ }^{24}$ Probably the value of the information they contain decreases in direct ratio with the distance of the events described from the person of the nuncio. For the courts to which they were accredited the news is accurate and important, the value of that from out of town depends upon the source from which they derived it. On the whole the nuncios had about as good opportunities as any news-collectors of the time, and as they very frequently mention their sources, the reader can exercise the usual historical tests.

The papal news-gatherers were quick to avail themselves of the printed gazette. In I666 the nuncio of France mentions the custom of sending the Journal des Sçavans, ${ }^{25}$ and after this, news-letters bear evidence of being chiefly founded upon such material, often containing long translated extracts. With this development their value diminishes, and after the seventeenth century they are of little use. During the eighteenth century the plain letters, in which the nuncio comments upon the news in the light of personal information, conversations, etc., became the more valuable. These news-letters of nuncios should be distinguished from the ordinary news-letters of unofficial character which circulated so freely in the sixteenth and seventeenth centuries, and which contained, on the whole, more of gossip and less of accurate reports.

With their dispatches the nuncios sent many enclosed documents. After the middle of the seventeenth century, there is nearly always to be found a list of the several pieces brought by each courier. Such enclosures included letters forwarded through the nuncios, reports of their administrative work, copies of public documents of the countries to which they were accredited, and printed books and papers. These enclosures were ordinarily forwarded to

${ }^{19}$ Nun. di Portogallo 12, Aug. I6. Other examples are, same vol., Oct. I7, I606: "delle novi delle Indie desiderevamo d'intendere migliore nuove. Forsi piacerà a Dio che arrive a salvamente la flotta che si aspettave in Spagna, che saria bene secondo ii nostri bisogni di quà, dove habbiamo una estrema penuria di danaro, in tempo che per la pertinace e ostinatione dei Venetiani che à tutto lor potere vogliono contaminare l'Italie con la heresia, siamo in una precisa necessità spendere profusamente." Ailso. Angelica 1220 (S-6-12), Jan. I9, I6I3.

${ }^{20}$ Dom R. Ancel, M. D. R., "Etude Critique sur quelques Recueils d'Avvisi", in Mélanges d'Arch. et d'Hist., vol. XXVIII., no. vi., pp. II5-I39, esp. p. I27.

${ }^{21}$ Misceilanea, arm. III., 34, ff. 599-606, "Modo di procurare gli Avvisi, e distendere il Foglio continuato d'essi per il Segrio d'un Nuntio".

${ }_{22}$ Nun. di Portogallo 1 A., f. 77.

${ }^{23}$ Nun. di Spagna XIX., f. I97, Aug. Io.

${ }^{2:}$ Nun. di Spagna 4., f. 22.

${ }^{23}$ Nun. di Francia CXXXI., Mar. 5. 
the departments or individuals directly concerned, and but a small proportion is retained in these archives.

The great bulk of the material properly belonging to the department is extant, and to be found in the 4000 volumes of the archives, which have, of late, been made more complete by additions from various private libraries recently acquired by the papacy. ${ }^{23}$ There are still, however, gaps, often important, and masses of material in other collections which would supply some of these; all of which will be more particularly described in connection with the several nunziature and collections. There is also to be found here much that would not logically be expected. The papal diplomatic system was elastic, and not only were extraordinary missions numerous, but agents were frequently employed who possessed no special diplomatic rank. Much of the correspondence with sovereigns and individuals, moreover, which might be looked for in the special collections that follow, is included here. In many cases, also, the registers kept by the nuncios contain not only their letters to Rome, but also to each other, and to correspondents within the country in which they resided. The collectors-general, also, where that office survived, as in Portugal, corresponded with the secretary of state. On the other hand certain letters, even of the nuncios, were handed over directly to the congregations involved. Many are to be found in the Propaganda, and many doubtless in the Holy Office and elsewhere. ${ }^{27}$ Many letters to nuncios, moreover, are found registered as bulls or briefs.

Nearly all ciphered documents are found deciphered in the archives. Where ciphers are found unaccompanied by plain versions, they are generally duplicate dispatches, of which a translation can be, or should be, found elsewhere. The amount of material existing in cipher alone must be nearly negligible.

This collection is the most important at Rome for the study of the political history of the modern age; probably for the sixteenth and seventeenth centuries it is the most important in existence. Its special contributions for. American history are discussed in the pages that follow, but while these are comparatively small, it must not be overlooked, that for the broader study of influences affecting our history, its value can be realized only by use. For the vast world-conflict which so constantly affected the development of America, and particularly for the naval contest for the control of the Atlantic, of commerce, and of colonies, it is to a great extent unique and possibly unequalled. Quite apart from research for special monographs, no student of American history could find a few months' reading in the munziature of Spain and Portugal amiss. For the general study of the administrative methods of the papacy, its value is unexpectedly great, as so much general business passed through the hands of the nuncios. On the other hand papal diplomacy was to a certain extent reticent, and a negative could never be proved by the use of this correspondence. Certain papal policies were so well defined as to need no insistence, and much was doubtless communicated verbally. In so great a mass of material, however, while details may be lost, large facts can scarcely escape expression.

For American history this is virgin material. Historians have been actively at work since the opening of the archives, but the field is so extensive that comparatively little could have been accomplished had their efforts been united

\footnotetext{
${ }^{26}$ De Pretis, indice 134.

${ }^{27}$ Barberini 6335, register of letters of the Holy Office, 1626 , contains many letters to nuncios.
} 
by organization. This, unfortunately, has not been the case, and consequently the groups for the various countries are very unequally known. That of Germany has been most efficiently worked, owing in large part to the mutual agreement between the Prussian Institute, the Austrian Institute, and the Görres-Gesellschaft. The first of these institutions undertakes the years I 533I560, part I. ; I573-I 585, part III. ; and the seventeenth century after I628, part IV.; the Austrian Institute those from 1560 to I572, part II.; and the Görres-Gesellschaft, those from I585 to 1605 , and those of the nunciature of Cologne. ${ }^{28}$ The plan was at first to publish everything, but the task has proved so colossal that a compromise between printing entire and calendaring has been adopted, at least by the Prussian Institute. Almost equally effective work has been done on the nunciature of Flanders, as is described in the special section on that division. ${ }^{29}$ While but few have worked on the Spanish collection, the single publication of Hinojosa takes high rank. Various special studies have been made from the French collection, but systematic attack has just begun by members of the Society of Archives of the Religious History of France, although the project has been long in contemplation. ${ }^{30}$ Other divisions have been used for special articles, but not to such an extent as to preclude important and unexpected discoveries in the future. There are indeed few portions of the collection as yet so studied that one can speak definitely of the completeness of the archives, or say whether missing documents can be supplied from other Roman libraries, and, in the absence of originals, what copies are most to be relied on.

Special studies on the nunciatures most valuable for the history of North America follow, arranged in the order of their importance, Spain, France, Flanders, England, Portugal, and the missions of Peace, and following them is a list of all the nunciatures.

\section{NUNZIATURA DI SPAGNA. ${ }^{31}$}

This collection is inventoried in indice 134, De Pretis, pp. 33-43. Here are cited 470 numbers: $1-439$, except $29,30,40,49,57$, and 58 ; plus $4 \mathrm{~A}, 29 \mathrm{~A}$, $30 \mathrm{~A}, 40 \mathrm{~A}, 49 \mathrm{~A}, 57 \mathrm{~A}, 58 \mathrm{~A}, 60$ (A, B, C, D, E), $91 \mathrm{~A}, 92 \mathrm{~A}, 99 \mathrm{~A}, 104 \mathrm{~A}$, $111 \mathrm{~A}, 204 \mathrm{~A}, 210$ (A, B), $211 \mathrm{~A}, 215 \mathrm{~A}, 237 \mathrm{~A}, 244 \mathrm{~A}, 247 \mathrm{~A}, 250 \mathrm{~A}, 268 \mathrm{~A}$, $270 \mathrm{~A}, 273 \mathrm{~A}, 278 \mathrm{~A}, 313 \mathrm{~A}, 348 \mathrm{~A}, 364$ (A, B, C, D); some of which include more than one volume. ${ }^{32}$ The greater number are bound volumes containing from 400 to 600 paper folios, and consisting of original letters, registers of letters or of minutes of letters, and registers of deciphered correspondence. These

${ }^{28}$ Georges Bourgin, Archives Pontificales, pp. 40-4I; H. von Sybel, "Vorwort", in vol. I. of the first series of the publication (Gotha, I892). The general title of the series published by the two institutes is Nuntiaturberichte aus Deutschland nebst ergänzenden Actenstücken; the Görres-Gesellschaft volumes form part of their series of Quellen und Forschungen aus dem Gebiete der Geschichte.

2:" See p. 77.

${ }^{30}$ Abbé J. Fraikin, Nonciatures de Clément VII., vol. I. (Paris, I906).

${ }^{31}$ Ricardo de Hinojosa, Los Despachos de la Diplomacia Pontificia en España. This admirable study gives in its text the names, dates, and missions of the various nuncios, with illuminating accounts of the problems of the time. In the notes are lists of the documents of the nunciature for the periods treated in the several chapters, as they exist not only in this collection, but in the various libraries of Rome. Unfortunately only volume I., extending to I605, has been published. See also Aloys Meister, "Zur Spanischen Nuntiatur im XVI. und XVII. Jahrhundert", in Römische Quartalschrift, VII. 447-48I; and Bolognetti collection, 116, Pp. I33-235, "Avvertimenti per la Nunziatura di Spagna", etc.

${ }^{32}$ Hinojosa, p. 7, note, gives 572 volumes. He described the collection before the inventory was brought up to date. At that time there were 276 uninventoried volumes. 
are sometimes paged and the letters are nearly always arranged chronologically, though not perfectly so. About I4O numbers are loose sheets in pasteboard covers. In these the items are not often numbered, but are arranged chronologically. There are two buste or cases with loose sheets. Many of the volumes originally numbered by De Pretis have disappeared, but Hinojosa says that these losses may be made good by the use of other collections, except in the case of $\mathbf{7 5}$ and $278 .^{33}$ The extreme dates of the documents are I 524 and I 808 .

For the period before Sixtus V. (I 585-I590) there exists but one register of letters from the secretary of state to the nuncios, that between Dec. 26, I 56I, and Oct. 3I, I563; there are, however, many of the original letters brought back from Spain by the nuncios. ${ }^{\text {at }}$ From that date, the original dispatches are not to be found at Rome, but the registers of letters or minutes of letters are complete. Of the letters of the nuncios there are some registers covering their general correspondence, but chiefly the letters themselves are preserved in bound volumes. There are for most periods special registers of the ciphered correspondence, the deciphered answer being found in the same volume with the secretary's letter. In addition there is correspondence with the numerous nuncios extraordinary, and with the collectors, for such times as that separate office existed. Still further, there is much miscellaneous correspondence with minor ecclesiastical officials, with Spanish ecclesiastics and other Spaniards of importance, with the Spanish minister at Rome, besides papers properly belonging to the nunciature of Portugal.

The nuncio of Spain was always an important, and from the resignation of his estates by Charles $V$. to the treaty of Westphalia, the most important diplomatic representative of the papacy. In addition to the innumerable political points of contact between the Holy See and Spain, the financial relations were mutual and more intimate than in the case of any other country. In Spain alone, outside of Italy, the papacy retained the right to the "spoils" of bishops and the fruits of vacancies." The Spanish government was indebted to the Pope, moreover, for the privilege of taxing the enormously wealthy clergy of Spain. Under Philip II. the ecclesiastical revenues of the Crown amounted to $6,000,000$ in gold (scudi?), ${ }^{33}$ and after the middle of the seventeenth century the question of decimae in the Western Indies became one of great moment. The financial interests of Rome in Spain had originally been represented, as in other countries of Europe, by a collector; out of this office developed that of the nuncio, and the two, while separate in theory, were in fact nearly always united. ${ }^{37}$ The Spanish nuncio, moreover, at the request of Charles V., enjoyed special ecclesiastical functions as legate a latere. ${ }^{38}$ This gave him extraordinary ecclesiastical powers and meant that many of the dispensations, indulgences, favors, and privileges ordinarily referred to the Dataria at Rome, were adjudged and granted in Spain. As the granting of such supplications involved the payment of fees, a large revenue accrued, ${ }^{39}$ and in 1628 he was expected to provide for himself, and remit

${ }^{33}$ Hinojosa, p. 7.

${ }^{34}$ Ibid., pp. 13, 15-16.

${ }^{35}$ Richard, "Origines des Nonciatures Permanentes", in Rev. Hist. Eccl., VII. 320.

${ }^{38}$ Confalonieri collection, 46, f. r49.

${ }^{87}$ Richard, "Origines des Nonciatures Permanentes", Rev. Hist. Eccl., VII. 56-59.

${ }^{38}$ Hinojosa, p. I3.

${ }^{39}$ Ibid. 
3000 in gold (scudi?) monthly to Rome, whereas the nuncio in France received 300 a month. ${ }^{40}$

This very self-sufficiency of the Spanish nuncio in some measure limited the range of his correspondence, and it was also true, unfortunately for the historian, that he had less to do with Spanish America than might be imagined. On the authority of the bull of Alexander VI., issued May 4, I493, the kings of Spain claimed the entire patronage of the Western Indies and the direction of the propagation of the gospel therein. ${ }^{11}$ The erection, division, and provision of dioceses was formally confirmed at Rome, and the new bishops paid their proper taxes, ${ }^{43}$ but the entire actual supervision was in the hands of the Council for the Indies. This council discouraged the interference of the nuncio. Mgr. Castagna, in his note of instruction to his successor in I57I, wrote: "Quanto all'Indie patirà V. S. ancora qualche difficoltà dal Conseglio che le governa, e sentirà forse scrupolo nell' essercizio delle sudette sue facoltà in quelle parti, quando siano non più chiare delle mie "." In I6I $3_{3}$ the secretary of state wrote the nuncio: "Nell' Indie come procedono le cose della Religione non è facile haverne avvisi corti per gli impedimenti, che mettano di molto i ministri non si sà per qual cagione" ". In the instructions to Mgr. Sachetti in I623 no room for doubt was left as to the powers of the nuncio, but complaint was still made that they were still in large measure ineffective: "A Regni dell' Indie soggetti alla Corona Cattolica non si sà come gl' altri nuntii habbino arrivato, e procurato d'assicare con la loro autorità apostolica, onde è bene che $\mathrm{V}$. E. vada con i dovuti termini della ragione d'essa introducere dove la più che possible sia ".4 In fact the Spanish government preferred to conduct all business possible through the minister at Rome. ${ }^{47}$

This failure of the nuncios to play an active part in the Indies was extremely annoying to the papacy. Although "spoils," the fruits of vacancies, and other revenues began in the second half of the sixteenth century to accrue from these regions, it was reasonably felt, as the nuncio wrote in 1586 , that greater care in their collection would result in a notable profit to the Holy See. ${ }^{48}$ Moreover, the ecclesiastical authorities felt a deep interest in the welfare, religious and temporal, of the slaves ${ }^{40}$ and Indians, and by no means approved the policies of the Spanish government with regard to them. ${ }^{50}$ Finally, the religious institutions of the New World were felt to require regular and authoritative visitation. ${ }^{\text {s1 }}$

${ }^{\Perp}$ Arch. Seg., arm. 33, 33, f. I. "Coll'anea dell'Entrate e Spese della Camera."

${ }^{11}$ Arch. Propaganda, "Scrit. rif. nelle Congregazioni", 258, f. Io. Apr. 30, I659, from the nuncio.

${ }^{42}$ See p. I2O.

${ }^{43}$ See p. 210.

${ }^{44}$ Corsini, cod. 507, col. 33-E-I3.

${ }^{45}$ Corsini, cod. 468, col. 38-A-21, p. I4. Apr. I3.

${ }^{46}$ Casanatense, cod. 2046 , pp. I7I, I92, and cod. 4247, pp. $7,8$.

${ }^{47}$ Nun. di Spagna 16, p. 60. Sept. 9, 1572. Philip II. to the Pope.

${ }^{4}$ Ibid., pp. 87,88 . Oct. 26.

${ }^{40}$ Ibid., 3, p. I72. Oct. I57 I, from nuncio.

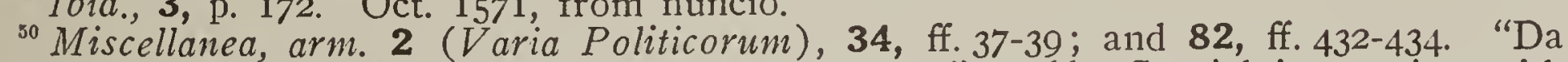
parte di N. Sre. ad Mons. l'Arcivescovo di Rosano", I566. Special instruction with regard to the propagation of the gospel and its relation to the government of the Indies. Corsini, cod. 691, col. 35-B-20, ff. 887-891. Instruction to the Patriarch of Alexandria, nuncio, Apr. I, Í́2I. Casanatense, cod. 2046, as above to Mgr. Sachetti .... "importando molta che cio' si faccia per servitio speciale spirituale di quei nuovi christiani".

${ }^{51}$ See following calendar of references passim. 
Under these circumstances it became a leading point of papal diplomacy to establish in America an official directly responsible to the Holy See and possessing broad powers. The creation of a Patriarch Indiae Occidentalis in $1524,{ }^{62}$ might seem to be a first step toward the establishment of effective ecclesiastical jurisdiction, but this was a title purely honorary, being described in the consistorial acts: "quià sede Patriarchali et cap'lo caret, et cuius fructus nulli sunt". "In fact, so separate were the functions and the title that in I 568 it was proposed to erect a patriarchate with an actual seat in America. ${ }^{\text {st }}$ This, however, would hardly have met the situation, as the incumbent must have been nominated by the king, and there was, in addition, the danger that so great an ecclesiastic, and one so little dependent upon the Pope, might wax into a rival power. The proposition was dismissed: "per il pericolo, che non si levasse un giorno contra la chiesa Romana "." The papal plan was to send to reside in America a nuncio, appointed at Rome and revocable, or a visitor whose office might grow into that of nuncio. The idea of a nuncio with functions confined to a portion of the empire and residing at the court of the viceroy instead of that of the king, was a natural one, as there were nuncios from time to time at Brussels, Naples, and Lisbon, as well as at Madrid, but the Spanish government was opposed, as always, to any interference with its colonies. In 1568 it seemed that a compromise might be reached in the appointment of a nuncio for a term of years to correct abuses, ${ }^{s}$ but this plan failed, and the Spanish government was successful in its resistance.

It is with the discussion of this question that the correspondence of this collection is concerned between 1560 and 1630 , rather than with actual conditions in America. Yet the efforts of the papal administration to obtain information were constant. In 1586 the collector of Portugal, having been brought to task by both the nuncio at Madrid and the secretary of state, wrote explaining the difficulty of securing news. ${ }^{57}$ The congregation of the Propaganda Fide was at first no more successful. On Apr. 30, 1659, the nuncio wrote the cardinal prefect of that congregation that the ministers of Spain resented any attempt to interfere with their exclusive control of missions, and in 1677 , Cerri wrote of Mexico: "The Sacred Congregation obtains from the Holy See the sending of Bishops to these Dioceses: but when they are sent, they quite forget the Apostolical See, and the Congregation, and never

${ }^{52}$ P. B. Gams, Series Episcoporum.

${ }^{53}$ Arch. Consist., Acta Cancel., 4, f. 282. Aug. 27, I547.

${ }^{54}$ Corsini, cod. 506, col. 33-E-I2, ff. I39-I40. Mgr. Casagna to the secretary of state, Oct. I, describing the special committee, "avanti Cardinale Spinosa per le cose dell'Indie. Vi sono intervenuti non solo quelli del Conseglio d'India, ma altri professori di Teologia, e di Canoni".

${ }^{55}$ Ibid.

${ }^{B}$ Ibid.

${ }^{57}$ Nun. di Portogallo 1A, f. 77. Oct., to the secretary of state.

${ }^{58}$ Arch. Propaganda, "Scrit. rif. nelle Congregationi", 258, f. Io. "Informationi dal P're Provinciale de' Cappuccini sopra il contenuto dell' humanma Lettera di V. Emza de 25 di Gennaro dell' esserci inviati alcuni P'ri Cappuccini della Provincia d'Aragona per Missionari all' Indie; ha saputo la notitia portata a V. Emza proviene dà medemi superiori di quella Provincia per il sentimento, che hanno di vedersi privati de migliori soggetti ai' essa; e qui nocandosi pero nel sapporto che sia cio' stato fatto con mia licenza, poichè queste missioni procedono dalla sola dispositione di Sua Maesta Cattca per mezzo del Consiglio dell' Indie, in virtú della Bolla che allegano di Papa Alessandro sesto, spedita à 4 di Maggio di I 493 ed altra della santa mema. di Pio Quinto de 24 Marzo del I567, senza che vi sia intervenuto alcuna mia participatione, della quale i Ministri Regis non pretendono vi sia di bisogna." 
give any account of their dioceses, in which there are still a great number of Infidels ". ${ }^{\circ}$ About this latter date the desire of the Spanish government to obtain permission to tax the ecclesiastical revenues of America somewhat strengthened the position of Rome, and the Spanish colonies were much in the eye of diplomacy between I670 and I720. Here again, however, the discussions were rather about, than of, America, and the increasing intercourse of the eighteenth century was carried on rather by the Propaganda than by the secretary of state. In I 772 the latter officer wrote to the secretary of the Propaganda, inquiring the method of sending letters to American bishops. ${ }^{60}$

Of this collection the following numbers were examined: 1-39, and 367 and 368, which contain documents of the extreme dates of I524 and I67I, and all those previous to I 590 - the bulk of them, however, lie between I 560 and I590; 61-65, which contain letters to and from the nuncios and others, between I62I and I626;244 A-247, containing ciphers and letters of the nuncios, between I734 and I742; 271-273, containing letters from the nuncios between $I 778$ and $I 783 ; 306,308$, and 310 , containing the letters of the nuncios of 1800 , I802, and 1804 , respectively ; 357 , containing letters to the nuncios from I687 to I692; 435 and 438 , containing ciphers to the nuncios between I776 and I78I, and I785 and I790, respectively. As nearly all references to America were general, those few local to the territory not covered by the subject of the guide were included, except such as referred to Portuguese America. Numbers 4 A, 9, 13, 15, 18, 20, 21, 23, 25-27, 37, and 61 were found to contain no pertinent material. References to that found in the remaining volumes follow:

1. ff. I3I-I33. Oct. I 5, I567. Letters of Cardinal Alessandrino, regarding the Duchess of Veragua.

f. I37. Oct. 24, I 567. Letter of the same, recommending Stephano Fruffino to the viceroy of Mexico, by the intervention of the nuncio with the king.

2. f. 434. I 572. Paper on marriage of Mary of Scotland with the Duke of Norfolk. "Si remeda al pericolo de la flotta de le Indie, à la quale già si sà che asperano gli Inglesi, giunti con quelli de' Rocella, il qual pericolo, non solo al Rè Catiolico, ma tocca à tutto la Chrisianità."

3. f. I72. Oct., I57 I. Cardinal Rusticucci to Cardinal Alessandrino, on proposition to send a nuncio to Peru to look into the question of slavery.

4. f. 22. Oct. 3, I 568. Archbishop of Rossano to Cardinal Alessandrino, on rumor of the Turks in Florida.

f. I43. Aug. I6, I570. Same to same, mentioning the receipt of letters from the viceroy of New Spain.

f. I47. Oct. 8, I570. Same to same, reporting action taken with regard to Stephano Fruffino.

5. f. 72. Aug. I, I 572. Archbishop of Rossano to Cardinal di Como, on the French in the Azores and the navigation of the Indies. The previous half dozen letters discuss other aspects of the same movement.

6. f. 75. Apr. 2 I, I 568. Cardinal Alessandrino to Archbishop of Rossano on the subject of a nuncio for the Indies, "che dependesse immediamente da questa $\mathrm{S}^{\text {ta }}$ Sede."

${ }^{59}$ English translation of his Stato della Religione Cattolica (London, I7I5), p. I72.

"o Arch. Propaganda, "Scrit. rif. nei Congressi", Am. Cent., I., Feb. 4. 
f. 82. Aug. I4, I568. Same to same, forwarding the instruction drawn up by the congregation of four cardinals newly deputed by the Pope on the conversion of infidels. The enclosure is not in place.

f. 352. Mar. I9, I572. Cardinal Rusticucci to nuncio, recommending a gentleman of New Granada to the president of the Indies.

7. ff. I 52-I57. "As Causas parq, el Rey meo Sor naõ podé esti anno apudar a armada da liga, cum armada qual elle deve mandar e q' possa importar pera com affeita e' somma saõ as séguintes." Mentions expense of defending the Indies.

8. ff. 284-286. Oct. I6, I 579. Nuncio to Cardinal di Como, a personal letter regarding the president of the Indies.

f. 625. Dec. 20, I 575. Same to same, on the subject of the fruits of vacancies in the Indies.

10. f. I5 I. May I3, I576. Nuncio to Cardinal di Como, on the Jesuits in the Indies.

f. 240. July 24, I 576. Same to same, mentioning the arrival of the fleet from the Indies.

11. f. 94. Nov. 25, I 577. Bishop of Ripa to Cardinal di Como, on the powers of the Archbishop of Mexico.

f. I53. Feb. 2, I 578. Same to same, on the trial of certain monks of Mexico, in Spain.

12. f. 73. Aug. I6, I577. Collector to Cardinal di Como, on the arrival of the fleet from the Indies after a fight with the English.

f. 74. Same subject.

14. f. 4I 5. Without date. Unimportant note on the Jesuits in the Indies.

16. f. 29. Aug. I9, I572. Bishop of Padua to Cardinal di Como, on the suspicious activity of the French fleet.

f. 6o. Sept. 9, I 572. Philip II. to the Pope, on certain concessions with regard to the Indies, of which Juan de Cuñega, the Spanish minister at Rome, will give particular information.

f. 200. Dec. I, I572. Bishop of Padua to Cardinal di Como, on the arrival of the fleet from the Indies.

17. ff. I4-22. June 28, I 572. Archbishop of Rossano to Cardinal di Como, on the English and Dutch and the navigation of the Indies.

f. 56. Without date. On the suspicious activity of the French fleet about the Azores.

19. No. 36. Oct. I8, I 586. Nuncio to Cardinal Rusticucci, on Drake and the Indies.

pp. 60-62. Jan., I 587. Same to same, on request of the king for powers of visitation for the Archbishop of Goa. Suggests that the Holy See offer a visitor, and make this an entering wedge in the matter of the Western Indies.

p. 83. Feb. I2, I587. Same to same, on Drake and the fleet from Peru.

p. 98. Mar. 6, I587. Same to same, requesting license for the Archbishop of Mexico to come to Spain, with the information that he was already on his way.

p. I02. Mar. I3, I 587. Same to same, on visitation in the Indies.

p. I37. May 6, I 587. Same to same, on Drake and the fleet of the Indies.

p. I38. Duplicate of preceding.

p. I82. May 6, I587. Same to same, cipher, same subject. 
22. ff. 2I-22. Jan. 26, I 579. Nuncio to Cardinal di Como, on objection of the Council of the Indies to the exercise of his powers in those kingdoms. Suggests the sending of a nuncio to reside there.

f. I59. Apr. 25, I579. Same to same, on subject of nuncio in the Indies. ff. I66-I68. I579. Note by Bishop of Piacenza, nuncio in Spain, on reasons for sending a nuncio to reside in the Indies.

ff. I9I-I92. May I5, I 579. Nuncio to Cardinal di Como, on same subject.

ff. 376-385. Notes on subjects treated by the Bishop of Piacenza from his coming into Spain until Sept. I2, I 579, including 380, "Monarche del Mexico" ; and, 382, "la provisione per le Indie".

f. 543. Dec. I2, I 579. Nuncio to Cardinal di Como, on nuncio for the Indies.

24. f. 307. Aug. 28. Account of the division of the contents of the fleet of the Indies.

ff. I I9-I 20. June 25, I 582. Nuncio to Cardinal di Como, on the French, English, and Portuguese in the Azores.

f. I 33. July 23, I 582 . Id.

ff. I38-139. Aug. I6, I582. Id.

f. I 40 . July 30,1582 . Id.

f. 333. July 27 , I 583 . Id.

f. 334. Aug. 29, I 583. Id.

f. 427. Oct. I7, I 583. Same to same, on nuncio for the Indies.

29 A. f. 422. Sept. I8, I 581. Same to same, on arrival of the fleet.

30 A. f. 41. Apr. 2, I 582. To the nuncio, on nuncio for the Indies.

f. 327. June 5, I 583. To the same, on the protest of the Jesuits of Mexico against the opposition of the other religious orders.

f. 328. June 6, I583. To the same, on the ecclesiastical revenues of Mexico and other subjects.

f. 329. Without date. Note on the same subject.

f. 350. Aug. I, I 583. To the same, on the nuncio for the Indies.

f. 427. Feb. 5, I584. To the same, on same subject.

f. 427. Mar. I5, I 584 . To the same, on the admission of natives to the religious orders in the Western Indies.

ff. 440-442. Copy of petition on preceding subject.

f. 462. May I 5, I 584. To the same, on visitation in the Indies.

f. 47 I. June II, I584. To the nuncio, requesting good offices for I2 Capuchins on the way to the Indies.

f. 485. July I 5, I 584. To the same, on visitation in the Indies.

f. 533. Jan. I, I585. To the same, on same subject.

31. p. 63. Mar. 7, I 584. Nuncio to Cardinal di Como, on same subject.

p. 96. Apr. 6, I584. Same to same, same subject. The king has not responded to memorial: nuncio will press the matter.

p. II I. May 30, I584. Same to same, same subject. The king defers the subject to Oct. I.

p. 2II. Oct. I2, I584. Same to same, on Capuchins mentioned in 30, f. $47 \mathrm{I}$.

p. 276 . Feb. 4, I585. Same to same, on visitation in the Indies.

32. ff. I6-I7. Jan. I I, I586. Nuncio to Cardinal Rusticucci, on Drake in the Western Indies.

f. 66. Mar. 8, I 586. Same to same, same subject. 
f. 8o. Easter, I586. Same to same, on Drake in the straits between Florida and Cuba, and fear of heretical influence of English on the newly converted in the Indies.

f. 255. Aug. 23, I 586, and f. 394, Sept. I, I 586. New nuncio to Rusticucci on Drake.

33. pp. 87-88. Oct. 26 (?), I 586. Same to same, on the "spoils" of the Bishop of Cuzco, and the general question of the administration of "spoils" and vacancies in the Western Indies.

p. I07. Nov. II, I 586. Same to same. Will recommend bishops for the Indies to the king.

p. II2. Nov. I2, I586. Same to same, same subject.

pp. 253-254. Mar. I I, I587. Cesare Parisano to the Pope, from Madrid, on vacancies in the Indies.

p. 258. Same date. Same to Cardinal Rusticucci, same subject.

p. 356. June 27, I587. King of Portugal to the Pope, seeking favors for new Christians.

pp. 489-493. Sept. 5, I587. Nuncio to Cardinal Rusticucci, on the departure of roo Dominicans for New Spain and China.

34. f. I07. Dec. I2, I587. Same to same, on license for the Bishop of St. Martha, president of the Indies, to remain absent from his see.

ff. II7-I I9. Dec. I4, I587. Same to same, on Drake in the Indies.

ff. I 52-I 54. Duplicate of preceding.

ff. I24-I26. Same date. Same to same, on visitation of the Indies and the Bishop of St. Martha.

ff. $157-158$. Duplicate of preceding.

f. I84. Jan. 9, I588. Same to Cardinal Montalto, on the Jesuits in the Western Indies.

f. 268. Jan. 26, I588. Same to same, on the Bishop of St. Martha and the Council of the Indies.

f. 440. Mar. I6, I588. Same to same, on letter to the Archbishop of Mexico.

ff. 525-526. Apr. 6, I588. Same to same, on the loitering of the Archbishop of Mexico in Spain.

ff. 538-539. Duplicate of preceding.

f. 605. May 7, I588. Same to same, on the Archbishop of Mexico and the Council of the Indies.

f. 626. July I3, I 588. Same to same, on the loitering of the Archbishop of Mexico.

f. 630. June 2, I588. Same to same, on the English in the straits of Magellan.

f. 690. June 29, I588. Same to same, on the misuse of the convoy for the fleet of the Indies.

f. 7r6. July 22, I588. Same to same, on the improbability that the Archbishop of Mexico will return to his see.

f. 793. Sept. 24, I588. Same to same, on proposed sale in perpetuity, to supply a new fleet, of vassalages in the Indies now held in commendam.

f. 8I 2. Oct. 9, I588. Same to same, on arrival of the fleet from Peru.

f. 873. Nov. I2, I588. Same to same. Has presented to the king the memorial on the visitation of the Indies. Response of the king. Has protested to the king on the prolonged absence of the Archbishop of Mexico and the scandal concerning the Bishop of Popayan. 
f. 909. Dec. IO, I588. Same to same, on Drake and the commerce of the Indies.

35. f. 35 o. Oct. I4, I 589 ; f. 795, Apr. 7, I 590 ; f. 799, Apr. 24, I 590. Gio. Batt'a Biglia to Cardinal Montalto, on the English and the fleet of the Indies.

36. ff. 6I-63. Sept. 23, I 588. Pedro Fernandez de Castro, subcollector of Seville, to Mgr., the collector-general, from Lisbon, on the will of Diego Garcia Salzedo of Peru.

f. 2 I9, May 6, I589; ff. 240-24I, May 27;f. 270, Aug. 5 ; f. 27 I, Aug. I 2 ; f. 283 , Aug. 29 ; f. 286, Aug. 26 ; f. 292, Sept. 3 ; ff. 302-303, Sept. I6; f. 306 , Sept. 23 ; f. 325 , Oct. 28 ; ff. 334-335, Nov. 4 ; f. 34 I, Nov. 28 ; f. 345 , Dec. 2 ; f. 347, Dec. 9, all of I 589 ; f. 388 , Mar. 20 ; f. 39 I, Apr. 28; f. 393, May I2, I 590. Gio. Batt'a Biglia to Cardinal Montalto, from Lisbon, on the English and the fleet of the Indies.

f. 405, June 2, I 590 ; f. 429, Feb. 9 ; f. 454, Feb. 23 ; f. 487, Apr. 6; f. 5 I 5 , June 23 ; f. 537, Aug. 24, I59I. Gio. Batt'a Biglia to Cardinal Sfondrati, from Lisbon, on the same subject as preceding.

f. 808 . Feb. 27, I 588. M. Bonziananni to Cardinal Montalto, from Lisbon, on same subject as preceding.

f. 903. Dec. 3, I 588. Names illegible, same subject.

38. f. I99. Mar. Io, I589. Protest to the Pope from the military order of St. John of Jerusalem in the Indies.

ff. 449-469. Letters from the Archbishop of Mexico from Madrid, dated June I2, I 588 ; May 27 (to the Pope) ; Mar. 3, I 590; Aug. I8, I590.

f. 645. Apr. 22, I 589. Mario Cabio to (?), on the property of Garcia (see Garcia, 36, ff. 6r-63).

ff. 945-963. Juan Mangarit to the Pope, from the city "De los Reyes" (Lima). Apr. 5, I 587, on the fortification of the straits of Magellan, and idolatry in the Indies; Apr. 24, I 588, on the fortification of the straits and the capture by the English of a vessel with money belonging to the Bishop of Cordova-in-Tucaman.

f. 967. Mar. I, I 588. Oath taken by the Bishop of Honduras before the nuncio in Madrid.

ff. $982-983$. Oct. 8, I 585 . Petition of the provincial synod of Mexico to the Pope, asking for certain ecclesiastical indulgences.

39. ff. 20-2I. Apr. 8, I 563. To the nuncio, requesting him to find a pension for Father Bernardino Managa of Salamanca who worked many years in the Western Indies.

62. f. Ioo. Nov. 8, I623. Nuncio, to secretary of state, on the Dutch and the fleet from Peru.

63. Nov. I4, I657. Letter concerning a memorial with regard to Bishop Palafox.

64. ff. 7I-72. Mar. 24, I624. Nuncio to the secretary of state, mentioning the Indies and the New World.

f. I80. May 3I, I624. Same to same, on ecclesiastical troubles in Mexico.

f. 2 I4. June 7, I624. Same to same, arrival of the fleet.

ff. 308-309. July 3, I624. Same to same, on the fleet of the Indies.

f. 433. Sept. 8, I624. Same to same, on the affairs of the Archbishop of Mexico, and the conflict of ecclesiastical and temporal powers.

65. pt. 2. Ciphers from the nuncio to the secretary of state.
p. 3. Dec. 2, I623. On the fleet of the Indies. 
p. 7. Dec. 5, 1623. Conversation with Count Olivares, who expressed his willingness: " nel caso estremo dar anco ad Inghilterra qualche parte dell'Isole".

p. 20, Feb. 8, 1624; p. 26, May 20, 1624; p. 36, July 5, I624; p. 218, Jan. 7, 1628 ; on the fleet of the Indies.

244 A. June I7, I737. Cipher from Sig. Abb. Griccioli, on the king's claim to the "spoils" and vacancies of the Indies.

July I8, I739. Cipher from the nuncio Valenti, on the designs of England and France on the commerce of America. The following $20 \mathrm{ff}$., to Dec. 22, continue the subject.

245. Letters from the nuncio to the secretary of state. I740.

June 5, I740. The English at Carthagena and some cases of maritime law.

Sept. 27, I740. The repulse of the English at St. Augustine.

Oct. IO, I740. The second repulse.

There are other references to the naval contest in America.

246. Letters of the nuncio to the secretary of state during the first half of $\mathrm{I} 74 \mathrm{I}$.

Mar. I4, I74I. Mentions enclosure of two letters from the Carmelites of Mexico, to the Pope and to a cardinal. The letters are not here. There are a few references to the war, particularly concerning the siege of Carthagena.

247. Letters of the nuncio to the secretary of state during the second half of I74I. A few references to military operations in Cuba and the West Indies.

271. Letters from the nuncio to the secretary of state. I778-I779.

Feb. I7, I778. Forwarding, with comments, a Spanish decree of Feb. 2, on extending the free commerce of America.

Same date. On forwarding letters to America.

July io, i779. On the rights of neutrals.

Same date. Letters and enclosures on the subject of privateers.

July i 3, I779. Declaration of war between Spain and England, and enclosing note of Floridablanca to the nuncio.

Aug. 3I, I779. Letters and enclosures on the motives of the Most Christian King with regard to the war with England.

272. Letters from the nuncio to the secretary of state. I780.

Jan. 25, Mar. 7, Mar. 28, I780. Cases and orders with regard to neutral trade.

May 2, I780. On the relations of Spain and Russia, with enclosures containing a letter from the Empress of Russia, and the Spanish reply.

June 20, I780. On Morocco ; enclosing French translation of a proclamation of the emperor of Nov. I, I779, recognizing the power of the French consul to act for the "Etat de l'Amérique".

Nov. 28, June 27, July 4, Aug. 29, Oct. I7, I780. Cases and discussions with regard to neutral rights.

273. Letters from the nuncio to the secretary of state. I782-I783.

Apr. 3, I78I. Case of neutral rights, with discussion in the Spanish court.

Without date. Report of an ex-Jesuit of Peru.

Dec. 25, I781. Similar report from Guatemala.

Jan. 29, I782. Report on ecclesiastical disorders in the Indies, from the city of Guatemala.

Feb. 5, I782. Report on the military and political affairs of Spain. 
Sept. I0, I780. On the anxiety with regard to Gibraltar.

Jan. 5, I783. Case of the ship Dorothea Margherita.

Nov. I I, I783. Enclosing a copy of the definitive treaty of peace (enclosure not found).

Nov. 28, Dec. 23, 1783. On same subject as preceding.

306. Unbound, deciphered letters, from the nuncio to the secretary of state. I 800 .

Sept. 30, 1800. Description of the ecclesiastical revenues of America.

$308 .{ }^{81}$

Oct. 25, I800. On the English at Tehuan.

310. Unbound deciphered letters from the nuncio to the secretary of state. I804.

Mar. I5, I804. Negotiation for the cession of Florida to France, to be revived.

June I 5, June 30, July I5, I804. On arrival of vessels from America.

357. "Registro di Lettere scritte dell' Emmo e Revmo Sig. Cardle Cybo al S. Cardle Durazzo, Arcivo di Calcedonia, Nuntio Apostolico", in Spain.

ff. 3-4, Jan. 12, 1687. Protest against the proposed use of money collected in America for the Holy Sepulchre at Jerusalem, for the war against the Turks in Hungary.

ff. $16-27$. On the inquisition, and ecclesiastical immunities in America and the Philippines. Included are letters, or copies of letters, from the Bishop of Carthagena in America; Innocent XI. to Philip IV., Oct. 6, I686; Innocent XI. to the Archbishop of Manila, Jan. I2, I687; four letters from Cardinal Cybo to the nuncio, all dated Jan. 24, I687; abstracts of two Latin letters of the Bishop of Carthagena to the Pope, dated May 26, I686.

ff. 83-84. Apr., i687. Cardinal Cybo to the nuncio on the agreement with the Dutch for the transportation of negroes.

ff. 86-87, Apr. 20 ; f. I I 5, June 2 ; f. I20, June I 5, I687. Same to same, on the case of the Bishop of Carthagena.

f. I4I. July I3, I687. Same to same, on the agreement concerning negroes.

f. 2 I0. Nov. 30, I687. Same to same, on the case of the Bishop of Carthagena.

f. 2I5. Nov. 30, I687. Same to same, on the agreement concerning negroes.

ff. 224-225. Dec. 28, 1687. Same to same, on conflict of ecclesiastical and temporal jurisdiction in Peru.

ff. 225-228. Dec. 28, r687. Same to same, on the memorial presented by the Spanish ambassador at Rome, regarding the pirates in America. The last two ff. contain the memorial.

ff. 230-23r. Dec. 28, 1687. Same to same, on the inquisition in Peru.

f. 244. Feb. 8, I688. Same to same, on the agreement concerning negroes.

${ }^{61}$ The notes on this volume were lost in a stolen pocketbook. I am able to list all pertinent passages, but not to cite the exact references. Letters regarding the suppression of four convents of Benfratelli, and commenting on the discipline of American monks, 4 ff. A letter from the nuncio to Cardinal Consalvi, introducing Charles Pinckney, minister to Spain, who was to travel in Italy. Same to same, introducing a Mexican ecclesiastic. Two letters on the arrival of the fleet from America, after the peace of Amiens. 
f. 245. Feb. 8, i688. Same to same, on the case of the Bishop of Carthagena.

f. 284. May i6, i688. Same to same, on certain books printed in relation to the conflict between the Archbishop of Lima and certain royal officials.

f. 306. June 27, I688. Same to same, on the edict of the Duke of Palata, viceroy of Peru, concerning ecclesiastical immunity.

f. 308 , June 27 ; f. 309, July I I, I688. Same to same, on the agreement concerning negroes.

f. 3I3. July 25, I688. Same to same, on the case of the Bishop of Carthagena.

f. 3I7, Aug. I8; f. 323, Aug. 22, I688. Same to same, on agreement concerning negroes.

ff. 330-33I. Sept. 5, I688. Same to same, on the case of the Bishop of Carthagena and ecclesiastical immunity.

ff. 339-340, Sept. I9; ff. 350-35 I, Nov. I4, I688; and f. 402, May, I689. Same to same on the case of the Bishop of Carthagena, the last noting his death.

f. 4I8. Here begins the register of letters written by Cardinal Ottoboni, successor to Cardinal Cybo, to the Patriarch of the Indies, successor to Cardinal Durazzo, Alexander VIII. having succeeded Innocent $\mathrm{XI}$. Some change of policy is noted in the decreased attention given to American affairs.

f. 434. Dec. 25, I689. Cardinal Ottoboni to the Patriarch of the Indies, enclosing the quinquennial indulgences for the Western Indies.

435. Letters of the secretary of state to the nuncio. $1776-1780$.

May 20, I776. On vacancies in the archbishoprics of La Plata and Mechoacan.

Aug. 5, I779. On the Spanish regulations for privateers in the war with England: "e delle regole a osservarsi riguardo ai Colonisti americani essendo questa una di quelle piazze che interessano la publica curiosità per la Relazione che ha la Materia al Commercio d'ogni altra parte".

Jan. 6, Mar. 23, June 25, July I3, July 27, I780. On maritime cases affecting the Papal States, including Dutch vessels, and one using the Neapolitan flag but apparently belonging to George Fox of Falmouth, England. For the replies concerning these cases see volumes 271-273.

Sept. 21, I780. On the new rules of neutrality.

Nov. 9, I780. On the Fox case.

Dec. 8, I78I. On the ecclesiastical troubles in Guatemala.

438. Letters of the secretary of state to the nuncio. I785-I790.

Mar. 3I, June 8, I785. On the port of Acapulco and the navigation of the Indies.

June 28, I786. Containing a request for a bishopric for Father Felice Bonet of Lima, of the Order of Preachers.

Jan. IO, I787. On the protest of Holland against the privileges of navigation granted to the Pope by Spain.

Feb. 28, I787. On vacancies in the sees of Popayan and Comayagua.

Feb. 28, I787. On Holland and the navigation of the Indies.

July I8, I787. On vacancies in South America. 
May I9, I790. Acknowledging the receipt of a sheet with the taxes of all departments of Spain and the Indies (enclosure not found).

Dec. I5, I790. Expressing gratification at the peace between England and Spain.

The remaining volumes which may contain American material are the following:

40 A. Letters of Milini. I 592-I 593.

41. Letters of archbishops and bishops. I 592-I 594 .

42. Miscellaneous writings concerning Spain. I 593-I 594.

43-50 (There is no 49, but 49 A.) Letters of the nuncio. I 592-I 599.

51, 52. Letters of grandees, etc., of Spain. I 597-I 599.

53-59. Letters of the nuncio. I600-I604.

60. Ciphers to the nuncio. I6 $\mathrm{r} 3$.

$60 \mathrm{~A}-\mathrm{F}$. Letters of the nuncio. I609-16r8.

61. Minutes of letters to the nuncios of Spain and France. I62I-I622, I623.

66. Register of ciphers to the nuncio. I626, I627, I628.

67. Letters from Spain. I627.

68. Letters of the nuncio. I628.

69. Register of ciphers of the nuncio. I628-1629.

70, 71. Letters of the nuncio. I629-I630.

72. Register of ciphers of the nuncio. I630-I63I.

73, 75. Letters of the nuncio. I63I.

76, 77. Ciphers of the nuncio. I634-I635.

78. Ciphers to the nuncio. I636.

79-90. Ciphers of the nuncio. $1636-165 \mathrm{I}$.

$91 \mathrm{~A}$. Letters of the nuncio. I644-I652.

92. Letters of the king, queen, etc., of Spain. I644-I653.

$92 \mathrm{~A}, 93$. Letters of the nuncio. I644-I645.

94. Ciphers of the nuncio. I645.

96. Letters of the nuncio. I646.

97. Ciphers of the nuncio. I646, I647.

98, 99. Letters of the nuncio. I648-I649.

$99 \mathrm{~A}$. Ciphers of the nuncio. I648-165I.

100-104. Letters of the nuncio. I649-I652.

$104 \mathrm{~A}$. Letters of the nuncio to various persons. I $652-1656$.

105, 106. Letters of the nuncio. I653-I654.

10\%. Ciphers from Spain and France. I654.

108. Letters of the nuncio. I654.

109. Letters of Campelli, Madrid. I654.

110,111 . Letters of the nuncio. I654-I655.

$111 \mathrm{~A}$. Letters of the auditor. I655-1657.

112. Letters of the nuncio. $\mathrm{I} 656$.

113. Ciphered correspondence with nuncio and auditor. I656.

114. Letters of the nuncio. I657.

115. Ciphered correspondence with the nuncios and auditor. I657.

116-118. Letters of the nuncio. I657-1658.

119. Ciphered correspondence with the nuncios. 1658 .

120. Letters of the nuncio. I659.

121-123. Letters and ciphers of the nuncio. I657-I660. 
$124,125,127,129,131-13 \%, 140-146$. Letters of the nuncio. I660-I676. $126,128,130,138,139$. Ciphers of the nuncio. I66I-I 665, I667-I676.

$147-151,153-155,157,159,160,162-169$. Letters of the nuncio. I670, I676-1689.

152, 156, 158, 161. Ciphers of the nuncio. I679-I689.

170. From Innocent XII. to the nuncio. I692.

171-173. Letters of the nuncio. I69I-I693.

174. From Innocent XII. to the nuncio. I693-I697.

175-179. Letters from the nuncio. I694-1698.

180. From Innocent XII. to the nuncio. I700.

181-183, 185, 186. Letters of the nuncio. I699-I702.

184. Ciphers of the nuncio. I 700-I706.

187. Letters of the nuncio extraordinary. I702.

188. Ciphered correspondence with the nuncio. I7O2-I7I3.

189-210 (including 204 A). Letters of the nuncio and nuncios extraordinary. I703-I7I3.

210 A. Letters of the nuncios extraordinary at Madrid and Paris. I7I3I7 I4.

$210 \mathrm{~B}, 211,211 \mathrm{~A}$. Letters and minutes of letters of the nuncio. I705I7I 5 .

212. Register of ciphers to the nuncios extraordinary at Madrid and Paris. I7I 3 -I $72 \mathrm{I}$.

213. Letters of the nuncios extraordinary. I7I4-I7I5.

215. Ciphers of the nuncios extraordinary. I7I5-I72I.

215 A. Letters and ciphers of the nuncios extraordinary. I7I5-I7I9.

216-229. Letters of the nuncio. I7 16-1730.

230, 232. Ciphers of the nuncio. I72I-I726.

231. Ciphers to the nuncio. I72I-I724.

233. Register of ciphers of the nuncio, I728-I730, and responses for all the pontificate of Benedict XIV. (I740-I758).

234-23\%, 238-244. Letters of the nuncio. I'730-I740.

237 A. Ciphers of the nuncio. I730-I733.

$247 \mathrm{~A}$. Correspondence of the nuncio with the secretary of state. I742I 744 .

248-250, 251-284, with 268 A, 270 A, 273 A, 278 A. Letters, registers of letters, and minutes of letters of the nuncio. I743-I797. Irregular series.

250 A. Ciphers of the nuncio. I743-1746.

285-295. Ciphers of the nuncio. I758-1765.

296-300. "Biglietti di ministro di Spagna presso la Sta Sede."

301-305. Ciphers of the nuncio. I766-I 668.

30\%, 309, 311-313 A. Letters and ciphers of the nuncio. I80I, I803, I805I808.

314-317. "Dispacci di Ministro di Spagna." I800-1807.

318. "Indice delle Lettere di Spagna di Cardinal Rusticucci." I 570I 57 I , I 585-I 587 .

319-324, 326-333. Letters and registers of letters to the nuncio. I592I 596, I 598-I607.

325. Ciphers to the nuncio. I 593-I 596.

334. Letters to divers persons of Spain. I605-I609. 
337-340. Letters, registers of letters, and minutes of letters to the nuncio. I607-16 18.

341. Letters to divers persons of Spain. I6I8-i6ig.

342-344. Letters to the nuncio and the nuncios extraordinary. I62II633.

345. Ciphered correspondence with the nuncio. I6 $632-1634$.

346-347. Letters to the nuncio. I643-165I.

348. Letters and ciphers to the nuncio. I644-1659.

348 A. Letters to Sig. Condiotti. I645-I65I.

349-356, 358-366. Letters, and registers of letters to the nuncio. I655I730. Irregular series.

352. Ciphers to the nuncio. I666.

364-364 D. Original letters to the nuncios extraordinary at Madrid and Paris. I7I3-I7I9.

369-392. Minutes of letters to the nuncio. I668-I72I. The first two volumes irregularly cover the greater period: 369 (I668-I692), 370 (I676-I7I7). Minutes of letters to nuncios extraordinary are included.

393-400. Original letters to the nuncios extraordinary at Madrid and Paris. I7II-I7I 5 .

401-418. Minutes of letters to the nuncios. I72I-I808. Regular series, except that 401 overlaps.

419-421. "Dispacci al Ministro di Spagna." I800-I808.

422-428. Letters to the nuncio. I732-I758.

$429-434,436,437,439$. Ciphers to the nuncio. I730-I796.

\section{NUNZIATURA DI FRANCIA. ${ }^{62}$}

This collection is inventoried in indice 134, De Pretis, pp. I5-3I. It consists of 669 numbers, 1-59, 61-354, 356-615, and $1(\mathrm{~A}, \mathrm{~B}), 74 \mathrm{~A}, 92 \mathrm{~A}, 110 \mathrm{~A}$, $111 \mathrm{~A}, 129 \mathrm{~A}, 147 \mathrm{~A}, 154 \mathrm{~A}, 172 \mathrm{~A}, 179 \mathrm{~A}, 227 \mathrm{~A}, 236$ (A, B), 250 (A, B), $311 \mathrm{~A}, 316 \mathrm{~A}, 317 \mathrm{~A}, 368 \mathrm{~A}, 370 \mathrm{~A}, 375 \mathrm{~A}, 376$ (A, B), $377 \mathrm{~A}, 378$ (A, B), 379 (A, B), $388 \mathrm{~A}, 389 \mathrm{~A}, 392(\mathrm{~A}, \mathrm{~B}), 445 \mathrm{~A}, 446(\mathrm{~A}, \mathrm{~B}), 447 \mathrm{~A}, 449 \mathrm{~A}$, $450 \mathrm{~A}, 452 \mathrm{~A}, 454 \mathrm{~A}, 455 \mathrm{~A}, 456 \mathrm{~A}, 458$ (A, B), $461 \mathrm{~A}, 462 \mathrm{~A}, 463 \mathrm{~A}, 485 \mathrm{~A}$, $528 \mathrm{~A}, 529$ (A, B, C, D), $558 \mathrm{~A}, 570 \mathrm{~A}$. The extreme dates are I 527 and I 809 . Numbers $394-435$ are from the library of Cardinal Spada, covering very fully the period between 1625 and 1662 , and specially indexed in number $411^{\circ}{ }^{\circ}$ The contents are less diversified than those of the Spanish nunciature, and the organization of the series is more regular. The use of the collection has hardly

${ }^{62}$ G. Bourgin, Archives Pontificales, pp. 60-62; also, "Liste des Nonces envoyés en France de I524 à I 592 ", in Bibliothèque de l'École des Chartes, LXV. 309-310; J. Fraikin, Archives de l'Histoire Religieuse de la France: Nonciatures de France, vol. I., Feb., I525-June, I527 (Paris, 1906); also "La Nonciature de France de la Délivrance de Clément VII. à sa Mort", in Mélanges d'Arch. et d'Hist., XXVI. 5I2-563, which is to serve as introduction to volume II. of the published material. P. Richard, "Origines de la Nonciature de France: Nonces Résidants avant Léon X.", in Revue des Questions Historiques, LXXVIII. I36 seq.; and "Origines des Nonciatures Permanentes", in Revue d'Histoire Ecclésiastique, VII. 52-70, 317-338. See also Revue Historique, LXXV. 47I seq., on the Société des Archives de l'Histoire Religieuse de la France, formed to publish the nunciature material of the sixteenth century.

${ }^{e 3}$ This index is by Abbé Giusticiani. Indici 238 and 239 constitute an index to the whole Spada library, but might prove of some use for this set of volumes. 
as yet corresponded to its importance, but the works of Richard, Fraikin, and Bourgin afford much assistance in approaching it.

As Monsig. Scotti was instructed in the time of Urban VIII.: "La Nunciatura di Francia è di quella stima che ben'ogni uno sà, non per la Giurisdittione spirituale, che non essercita come l'altre Regie, mà per riseder il Nuntio appresso un gran Monarca". Perhaps of all the nuncios, his functions were most purely diplomatic, because the definiteness of the French mind had most successfully systematized the relations of ecclesiastical and civil jurisdiction, and the government had reduced the former to what at the time seemed a minimum. The correspondence is important because of the international problems with which it deals, and the great religious controversies with which France was rent. During the eighteenth century, moreover, Paris became one of the greatest news centres of Europe. The nuncio had also an uncertain superintendence over the missionary institutions which were so active in France, ${ }^{65}$ and thus his attention was turned to Canada, from which it was not entirely diverted by the English conquest of that country; but most of this correspondence was with the secretary of the Propaganda rather than the secretary of state. He had also much to do with England; partly because, in the period before there was a resident nuncio at Brussels, ${ }^{66}$ such matters were attended to at Paris; and partly because even after that date the nuncio in France was apt to be instructed to be watchful over such matters, being usually a man of greater experience and ability. Finally, during and immediately after the American Revolution, he played a part in the adjustment of relations between the Catholics of the United States and the Holy See, and served as a means of communication between them. Much, also, of this correspondence was with the Propaganda, and is preserved in their archives.

The following volumes were examined: volumes 50 , and $\mathbf{5 2 - 5 6}$, letters, ciphers, and advices from the nuncio, г6ог-г6г6; 130-132, letters from the nuncio, I665-I666; 179, 180, 181, letters to and from the nuncio, I689, I69II $696 ; 452$, minutes of letters to the nuncio, I76I-I763;484, ciphers to the nuncio, I740-I744; 489, ciphers from the nuncio, I753-I754; 491-493, ciphers from the nuncio, I747-I755; 509-511, letters from the nuncios, I760-I 765 ; $\mathbf{5 2 9}$, letters of the French minister, I759-I769; 555,556 , ciphers from the nuncio, I782-I783; 562-570, ciphers from the nuncio, I775-I $784 ; 605$, letters of the secretary of state to the minister of France, I803. Of these, 50, 52, 55,

${ }^{64}$ Corsini 491, col. 36-G-I4. f. I.

${ }^{65}$ Ibid., ff. 4I-43. Also Bolognetti collection, 115, pp. 279-308. Apr. I, I634, instructions to the Bishop of Ascoli, p. 282. "Cominciarò dunque da quella parte ch'è più propria del Ministro Ap'lico, e nella quale egli deve premer più d'ogni altra cosa cioè da gli affari della Religne Catolica, e della più principal parte di essi, ch'è la propagatione della fede."

${ }^{\circ 6}$ Corsini 472, Apr. 4, I621, ff. I0-50; "Instruttione a Mons. Corsini archivescovo di Tarso per andare nuntio in Francia": "Benchè il nuntio di Fiandra sia più vicino à quell' isola nondimeno pche gia la sede apostolica non tenuta colà nuntio ordinario, se sempre usata di raccomandare le cose dell' Inghilterra al nuntio di Francia, anche v. s dovrà havere corrispondenza con l'archiprete dell'isola."

Corsini 2046, f. 26r, instruction to the Archbishop of Patras, appointed nuncio to France, I627: "Ma il peniero delle cose d'Inghilterra sà da esser molta propria dello zelo di v. s. poiche sebene sogliono appartener al nuntio di Fiandra, tuttavia sono state sempre raccomandate principalmente a chi risiede in Francia, et sarce maggiormente questa si farà perché v. s. hà con una gran lode felicemente maneggiate nelle nuntiatura di Fiandra." 
$56,179,489,511,529,562$, and 605 contained no material belonging to the subject. References to material found follow:

48.87

53. ff. 25-26. Mar. 4, I608. Nuncio writes of a fleet of i2 vessels, apparently French, to sail for the Western Indies; will inform the Spaniards.

ff. 3I-32. Mar. 27, I608. Jesuits sail to Canada with the first fleet.

54. f. I27. Oct. 29, I6 Io. Queen aids Jesuits in the mission to Canada, called New France. Request made for privileges similar to those granted to missionaries engaged in Peru and the other Indies.

130. ff. I I2-I26. I665. "Memoire du chevalier Derning [Downing] anvoyes extraordinaire Du Roy de la grande Bretagne presenté à Monsieur les estat Généraux Des provinces unie Du pais Bas."

f. 432. July I4, I665. French company of the Western Indies, and the war between England and Holland.

f. 677. Nov. I3, I665. Capture of St. Eustatius by the English.

131. Apr. I2, June I, June I5, June 29, I666. News of the progress of the war in the West Indies.

132. Dec. 26, I665. Relation by the English ambassador in France "de ce qui se passa à mon audience de Congé ".

Jan. 29, I666. Nuncio, on the negotiations between England and Spain with regard to the commerce of the Indies, Jamaica, etc.

180. Jan. 22, I69I. English lose vessels in an attack on Quebec.

Sept. 3, I69I. Nuncio, on the motives of the Bishop of Quebec in delaying his return to his see. Mention of instructions on same subject, dated Aug. 7, I69I.

181. Aug. I I, I692. Cipher to the nuncio containing an answer to the representation made by Cardinal Janson, regarding the concession by the Holy See to Spain, of the right to tax ecclesiastics for the better defence of the Indies.

Apr. 22, I693. Cipher from the nuncio, regarding the distribution of Spanish possessions.

Dec. 9, I693. Ciphers from the nuncio, on the terms of peace proposed by the king of France, "l'occupata nell'America".

Dec. 2I, I69.3. Cipher from the nuncio, on same subject as preceding.

452. ff. 280-296. Oct. 6, I66I. Instructions with regard to the general negotiations for peace.

Jan. 2, I762. Instructions to recommend to the king, Marchese Francesco Albergati of Bologna, because of his services in Canada.

462. Sept. 22, I779. To the nuncio; "le notizie ch'Ella prosegue a darmi di quanto va' accadendo non meno in Europa che in America tra le armate navale delle Potenze Belligerenti, si sono vedute con piacere, come con gradimento".

491. Ciphers from the nuncio.

Nov. 27, I747. On the ruin of the Indies and the fleet.

Dec. 4, I747. Cipher from the nuncio, on the commerce of Spanish America.

${ }^{67}$ Public Record Office, General Series, 87, gives an extract from this volume, f. 200 , containing news from England, Nov. 29, r603, to the effect that the anti-Spanish party were endeavoring to have the king propose as one of the terms of peace between England and Spain, access to both Indies, believing that such a condition would defeat the peace. 
Feb. 12, Feb. 19, May 6, I748. Ciphers from the nuncio on the capture of Cape Breton, the commerce of America, and the peace.

Aug. 26, Sept. 9, I6, Oct. 7, 21, I748. Ciphers from the nuncio on the commerce of Spanish America, the inability of Spain to defend it, and the peace.

Oct. 28, I748. Cipher from the nuncio, on the capture of Cape Breton, and the peace.

492. Ciphers from the nuncio.

Nov. I8, I754. On the meeting of the commissioners of England and France, with regard to American boundary line, expressing good wishes for their success.

493. Ciphers from the nuncio.

Apr. 28, May I2, I9, 26, June 9, 23, I755. News and conjectures with regard to the equipment of the French and English fleets.

Apr. 7, 2I, I755. Discussions by the nuncio as to the questions of peace and war.

Jan. 6, Feb. 3, I7, 24, I755. News of the preparations made in America for the war between France and England.

509. Oct. 20, I760. News of the fall of Canada on Sept. 8.

510. May 24, I762. French fleet sent to Santo Domingo.

Aug. 9, I762. Attack on Havana.

Oct. 25, I762. Capture of St. John's, N. F., and flight of Cav. di Ternay.

Nov. 21, I762. The question of peace.

Jan. I7, I $762(3$ ? ). News of the capture of Havana.

555. Letters from the nuncio, I782. These are not, during the Revolutionary period, definitely separated in character from the ciphers. Nearly every letter contains news of the war, and the source is nearly always given. In general it was drawn from the gazettes of France, Spain, England, and Holland, letters from England and conversations. The importance of Dr. Franklin as a source of American news is illustrated by the extract quoted in connection with no. 56\%. There are many enclosures of public papers, maps, etc.

May 20. Rumor of war between the Americans and Portugal.

Oct. 7. "Il ministro d'Inghilterra è assicurato, che li tredici Stati Americani uniti sono più che mai costanti per sostenere la di Loro Libertà, e indipendenza, e per non accettare qualunque proposizione di Pace senza il concorso del Re Xmo."

Dec. 2. News of the signing of peace.

Dec. 9. Preliminary articles made public.

556. Letters of the nuncio, I783. Give general news as above.

Jan. I3. On the advantages gained by the English in the West Indies.

July I4. Formal calls of Jay, Adams, and Franklin.

Aug. I I, Sept. 8, Oct. I3. Questions relative to the signing of the treaties.

562. July IO, I775. Cipher from the nuncio, giving news that the war in America favored the colonies.

Dec. II, I775. Cipher from the nuncio: "Le ulteriore nuove che si ricevettero da Londra, dopo la Carcerazione de Negoziante Americano Sayre, furono da me ne' consecutive ordinari comunicate a Vra Emza. Semprechè me ne pervengano delle altre non tralascerò di darlene ragguaglio, come feci della notabile mutazione in quel ministero". 
563. May I3, I776. Cipher from the nuncio. The English abandon Boston and retire to Halifax.

564. Ciphers from the nuncio.

Sept. 30, Oct. 14, 21, Nov. 12, 18, Dec. 2, 16, 1776. News of the war in America.

Nov. 25, 1776. On the neutrality of France.

Dec. I6, I776. Arrival of Dr. Franklin.

565. Ciphers from the nuncio, I777.

Jan. 27. Enclosure of the Declaration of Independence.

Mar.3. Lord Stormont and the insurgents. The capture of General Lee.

Apr. 7, I4, May I9. The departure of Lafayette.

566. Ciphers from the nuncio, I777.

Nov. Io. Defeat of Washington on Sept. II.

Nov. 24. Capture of Gen. Burgoyne.

567. Ciphers from the nuncio, I778.

Jan. I2. "Il Dottr. Franklin, sempre circospetto nel parlare, e certamente ben ragguagliato, non confirma le notizie, che vengono da Nantes, o dalle Corte dell'Inghilterra, anzi nulla dice, e col suo silenzio fa comprendere l'incertezza di quanto si va debitando capricciosamente."

Feb. 6 6. Relations between France and England.

Mar. I6. Rumors of treaty between the colonies and France.

Mar. 23. Reception of Franklin, Deane, and Lee.

Mar. 30, Apr. 6. English policy toward the colonies.

Apr. I3. Relations of France and England.

Apr. 20. News of D'Estaing. Arrival of Adams, and report of a conversation with him.

Apr. 27. From this date the volume is full of news, relating largely to naval events.

568. Ciphers from the nuncio, I778. Full of American news, particularly of military events.

Oct. I2. Letter regarding Franklin.

569. Ciphers from the nuncio, I778. Like preceding, contains much news of the war.

Feb. 22. Gives speech of $M$. de Bertignières in favor of a revision of laws against Protestants, in part grounded on the idea that when North America is pacified, it will attract them more than ever, if they be still persecuted at home.

570. Ciphers from the nuncio. I780, I78I. Like preceding, contains much news of the war.

A brief notice of the remaining volumes of possible value follows: ${ }^{\text {us }}$

1. Letters of legate in France. I 527-I 529.

1 A-3. Letters from nuncio, bishops, and others. I 534-I 554.

4-10, 12-18. Letters of nuncio. I $570-1586$.

11. Letters to nuncio, etc. I $576-1580$.

19-29, 31-35. Letters of king, queen, princes, nuncio, cardinals, and others, I $585^{-1} 592$, with a few (no. 21 ) to 1698 .

${ }^{68}$ Mgr. Benigni, under secretary of the Sacred Congregation of Extraordinary Ecclesiastical Affairs, who is very well acquainted with this collection, states that the newsletters for the whole reign of Louis XIV. contain much American material, and that in particular there is a great deal on the Scotch expedition to Darien. 
30. Divers instructions and advices. I590-I 59 I.

36-38, 41, 44 (3 vols.) -49. Letters of France. I 59I-I6o6.

$51,57,58,60-63,66-70,72,75-77$. Letters of the nuncio. I606, I62II632.

$59,64,71,73,74$. Ciphers from the nuncio. I623-1625, I629, I63I.

78, 80-87, 90-92, 94, 96, 98, 100, 103. Ciphers from the nuncio. I632I643, I644-I65I.

$88,89,92 \mathrm{~A}, 93,95,97,99,101,102,104$. Letters from the nuncio. I6441652.

105, 106. Ciphers of legates and nuncios of France and other countries. I652-I653.

107-110 A, 112, 113, 115, 117, 119, 121, 125, 127-129, 133-136, 138-142, $144-147,149,150,153-161,163,165,167,169,171,173-176,178$, 182-193, 195-206. Letters of the nuncios. I653-I703. Regular series, except that $I 69 \mathrm{I}$ is lacking.

$111,111 \mathrm{~A}, 114,116,118,120,123,126,137,143,148,151,152,157$, $162,164,166,168,170,172,177,194$. Ciphered correspondence, letters, and responses. I656-I700, except I660, I666, I690.

124. Letters of Mgr. Passionei regarding peace. I662-I663.

147. Correspondence between Cardinal Altieri and Abbé Catalomini. I672.

179 A. Divers letters.

207-210. Letters of the nuncio extraordinary. I7O2-I705.

211, 219, 225, 229, 232, 234, 236, $236 \mathrm{~A}, 236 \mathrm{~B}$. Ciphers of the nuncio. I702-I730. Regular series.

212-218, 220-224, 226-228, 230-231, 233, 235, 237-250 A, 255-268. Letters of the nuncio. I704-I740. Regular series.

251-254. Ciphers of the nuncio. I72I-I73O. Irregular and partly duplicate series.

269-273. Ciphers of the nuncio. I668-167I. Regular series.

274, 275. Ciphers. I668-167I. Regular series.

279-281. Registers of letters of the nuncio. I652-I657.

282-284. Minutes, etc., of letters to the nuncio. I 572 -I 575, I58I-I 583 , I667-I67I.

285. Register of letters of France. I 585 .

286-297, 299-301, 303-308, 310-311 A, 313-317, 318, 319. Letters, and minutes of letters, to the nuncio and others of France, with a few to Italy, Spain, etc., extending in an irregular series, I 585-I 587, I 592-I 594, I 596-I639, I642-I653, I655-I682, with a few (no. 314) to I7IO.

298, 302, 309, 320, 321. Ciphers to the nuncio. I618, I626-г627, I644I65I, I677-I682.

317 A. Miscellany.

$322-329,332,333,335-337,339,340,342,344,345$. Registers of letters and original letters to the nuncio. I676-I686.

$330,331,338,341,343$. Ciphers to the nuncio. I676-I686.

334. Ciphers of the nuncio. I676-1686.

346. Original letters to nuncio extraordinary. I632-I634.

$347-368,369,370,371-380$. Minutes of letters to the nuncio. I656, I667I7 Io. Irregular series.

$368 \mathrm{~A}$. Letters and minutes to the nuncio. I622-I7IO.

381-387, 388 A, 389 A-393. Letters, and registers, and minutes of letters, to the nuncio. I682-I733. Regular series. 
388, 389. Registers of ciphers to the nuncio. I7oo-r7rg.

394-435. Fondo Spada. Badly inventoried. Letters; ciphers to and from the nuncio; instructions; and miscellany; chiefly for the years r623-r627, but with some as late as r675. Nos. 419, 420, and 423 may be omitted.

436-440. Letters to the nuncio. 1670-1676.

441-442. Registers of ciphers to the nuncio. I730- 1758.

443-445. Registers of letters to the nuncio. I734-I758. Irregular series.

445 A-447 A. Minutes to the nuncio. I74I-I758.

$448,449,454,454 \mathrm{~A}, 456,457,458,459,460,462$. Letters to the nuncio. I758-I784. Irregular series.

$449 \mathrm{~A}, 450 \mathrm{~A}, 453,455,455 \mathrm{~A}, 461,461 \mathrm{~A}$. Ciphers to the nuncio. I758I779. Irregular series including some plain letters.

451, $463 \mathrm{~A}$. Notes to the French ambassador. I758-1794.

$452 \mathrm{~A}, 458$ (A-B), $462 \mathrm{~A}, 463$. Minutes to the nuncio. г760-г762, I769I791.

$465-466,474,477,480-483,485-489,494-504,506-508,512,524-528 \mathrm{~A}$, 549-559, 571-575. Letters of the nuncio. I72I-I738, I740-I785, I787-I791. Practically regular series.

560. Ciphers of the auditor of the nuncio. I773.

$467-473,475,476,490,505,513-523,530-548,561$. Ciphers to the nuncio, with some letters. I72I-I774. Regular series, except that nos. 542548 form a separate series of registers of ciphers, I767-I 773 .

478,479 . Notes of the French minister. I74I-I757.

576-579. Minutes of letters from the Abbé Pieracchi. I785-I79I.

580-582. Miscellany.

583. Minutes of letters to the Abbé Salomon. I79r-r $793 .^{.9}$

584, 586-595, 598-602. Correspondence between Cardinal Caprara, Cardinal Consalvi, and Mgr. Spina. r800-1808.

585. Letters of the nuncio. I787-1788.

596, 597. Letters of the French minister. r8or-r8og.

$603,604,606,607$. Letters to the French minister. I801-I802, I804I800.

610. Letters to the nuncio. I763.

611. Letters of Abbé Malani to the secretary of state. I70r-I708.

612,614 . Letters of the nuncio. I720-I722, I746-I748.

613. Minutes, etc., of the nuncio. I730-I739.

615. Original dispatches to the nuncio. I757-I758.

\section{NUNZIATURA DI FIANDRA. ${ }^{70}$}

A brief list of the volumes of this collection is given in indice 134, De Pretis, pp. I28-I 35. It consists of 244 numbers: 1-8, 11-194, and $3 \mathrm{~A}, 12 \mathrm{~A}, 21 \mathrm{~A}$, $25 \mathrm{~A}, 66 \mathrm{~A}, 135$ (A-I, L, N-V, Z, and Aa-Ii-Ll-Vv), an extra 136, 147 (A-C), and $153(\mathrm{~A}-\mathrm{C})$. Although the nunciature of Brussels was not formally estab-

69 This is published. Vicomte de Richemont, Correspondance Secrète de Salomon
(Paris, I898).
io Abbé Alfred Cauchie, De la Création d'une Ecole Belge à Rome; Congrès Archéo-
logique et Historique de Tournai en I895 (Tournai, I896), pp. 69. Pp. 24-34 give:
"Liste des Nonces et Internonces de Bruxelles ainsi que des Volumes renfermant leur
Correspondance avec la Cour Romaine." A. Cauchie and R. Maere, "Les Instructions
Générales aux Nonces des Pays-Bas Espagnols (I596-1633)", in Revue d'Histoire
Ecclésiastique, V. I6-46. This discusses their character and value, and serves as an 
lished until $1596,{ }^{71}$ representatives with the rank of nuncio had often resided there temporarily, and the extreme dates of the collection are I554 and 1796 , but there is a gap from I 556 to I59I, inclusive. Owing to the well-known energy with which historical studies are pursued in Belgium, this series has been more completely exploited than any other of the munziature. While these publications lighten the work of exploration, they do not reveal the American material.

One feature of importance in the position of the Belgian nuncio was that Antwerp was, during the seventeenth century, the great western news-centre for the Catholic world, as Lisbon had been during the sixteenth. Particularly was he expected to supply the Roman government with news of England, ${ }^{72}$ except during the short period when a separate nuncio was resident in that country. A special relation with portions of America was added in I623, when the Propaganda, in its division of the world into provinces for each of which a nuncio was responsible, included England and Holland in his share. ${ }^{\text {i3 }}$ With England went its American possessions, though this was, perhaps, not formally recognized until I 746; ${ }^{74}$ and with Holland, New Netherland. As a matter of fact this new function was quite largely discharged by the forwarding of documents prepared by the local vicars apostolic, and it remains true that this collection is important chiefly for the avvisi.

Sixteen volumes were examined, of which 17 , giving the letters from the nuncio, I630; 21, I632-I634; 24, I636-I639; 58, I670; 135 Qq, I782-I783; and 193, with letters to the nuncio, I779-I782; contained no relevant material. References to material found, follow:

18. Letters from the nuncio. I63I.

Feb. I. Arrival of the fleet from the Indies, in Spain.

Feb. 8. Joy in Antwerp over arrival of fleet.

24. Letters from the nuncio containing mention of letters forwarded from papal representatives in England.

44. Letters from the nuncio. I660.

June 19, 26. On the peace between England and Spain. This volume contains selections and abstracts carefully made by the nuncio, of news-letters from England and elsewhere, copies of important English documents, and copies of communications from the vicar apostolic of London, of which the originals were retained at Brussels.

introduction to the following edition of the instructions themselves. A. Cauchie and R. Maere, Recueil des Instructions Générales aux Nonces de Flandre (I596-I63.5) (Brussels, I904). M. Gachard, Les Archives du Vatican (Brussels, 1874); of which pp. 49-I05 analyze material relating to Flanders and Spain in the 25 volumes of Porfirio Feliciani, secretary to Cardinal Borghese (nephew of Paul V.), I608-I6I6, preserved in the Biblioteca Angelica. L. V. Goemans, "Tien geinventorieerde Nummers der Nunziatura di Fiandra", in Bulletin Gesch. Brabant, I906, containing an inventory of the first ten volumes. R. Maere, "Les Origines de la Nonciature de Flandre", in Rerue d'Histoire Ecclésiastique, VII. 565-584, 805-826. This study extends only to the end of the sixteenth century.

${ }^{71}$ Gachard, Archives, p. 52.

${ }^{2}$ R. Ancel, "Etude Critique sur quelques Recueils d" Avvisi", in Mélanges d"Archéologie et d'Histoire, XXVIII. I27; Angelica 1220, S-6-12, f. I89. June 4, I6Ir, to the nuncio: "Sono grate le diligenze che V. S. usà in darci avvisi delle cose di Inghilterra, delle quali con le sue lettere di I4 del passato habbiamo solito foglio. Perseveri in avvisar tutto quelo, che giudicherà degno di notitia."

${ }^{\text {i3 }}$ Propaganda Fide, Acta, vol. 1, f. 3, f. 230, no. I5.

${ }^{74}$ Ibid., year 1746 , f. I76, no. Io. 
45. Letters from the nuncio. I66I.

May 7. News of the prohibition of the planting of tobacco in England for the benefit of the traffic of the Indies, and to preserve the abundance of grain.

June 25. Spanish fears of the Portuguese marine in connection with the fleet of the Indies.

49. Letters from the nuncio. I664.

Feb. I6. Freedom of commerce allowed in Jamaica to attract immigrants.

May 3. Rivalry of England and Holland in the West Indies.

Nov. I, 2, 8. On the capture of "Nuova Olanda" by the English.

50. Letters from the nuncio, I665, containing much news of the war between England and Holland, but nothing particularly relating to America.

57. Letters from the internuncio. I669. Those written between Oct. 30 and Dec. 7, while the seat was vacant, are missing.

Feb. 2I. From the Hague. The West India Company desires to obtain a continuation of its privileges.

Apr. 5. From London. Theory of "war beyond the line", and designs of the English on America.

Apr. 29. From London. The French in Cuba.

June 7. From London. The insecurity of Spanish America.

Sept. I3. From London. War in the West Indies.

$135 \mathrm{Cc}$. Letters from the nuncio, I760, part 2.

July I. The attempt of Vaudreuil on Quebec.

There is a great amount of news from all the American colonies, with reference to war, trade, and Indian affairs, but practically no discussion or comment by the nuncio.

$135 \mathrm{Dd}$. Letters from the nuncio. I76I.

Jan. 20. Discussion on the obstacles to peace.

June 23. Discussion of the cession of Canada.

July 13. Criticism of a French historical memoir on the recent peace negotiation.

This volume and the two following contain regularly letters from England, apparently translations from some gazette; sometimes, also, similar letters from Holland. The letters of the nuncio contain comments on the news which are often based on more general information.

135 Ee. Letters from the nuncio. I762.

Jan. 5. On the Creeks in South Carolina. News.

Nov. 9. On the peace with the Creeks in South Carolina. News.

Apr. 6. Effect of English successes in America on Dutch trade. Letter.

July r3. Conduct, and anticipated effects, of the expedition against $\mathrm{Ha}-$ vana. Letter.

July 2I. On the Cherokees. News.

Aug. I7. Effects of the capture of Newfoundland. Letter.

Sept. I4, Nov. 9, 23, letters; and Nov.9, news. On the proposed terms of peace.

Nov. 30. On the cession to England of a portion of Louisiana. Letter.

$135 \mathrm{Ff}$. Letters of the nuncio. I763.

Jan. I I and I8. On differences with reference to the evacuation of places in America. Letter. 
Feb. 22. Trouble in Cuba between the captain-general, the Earl of Albemarle, and the bishop. News.

Mar. 22. Military estimates, and troops for North Carolina. News.

Nov. I. Parliament discusses plans for the American conquests, and fleets depart for the Banks and the Gulf of Florida. News.

Nov. 8. Activity of the Indians of Acadia. News.

Nov. 22. St. Pierre and the fishing on the Banks. Discontent in New York. Plans for a new colony. The Acadians in South Carolina and Georgia. The Creeks. News.

The other volumes possibly containing American material are the following:

1. Letters. I6 $53-1655$.

2. Letters of the nuncio. I $554-\mathrm{I} 555$.

3, 3 A. Letters of Mgr. Malvasia. I 592-I 594 .

4. Minister in Flanders. I 592-I 599.

5. Mgr. Matteucci, commissioner. I 592-I 593 .

6. Mgr. Cesare Bartoli. I 592-I597.

7. Divers of Flanders. I 592-1600.

8. Mgr. Malvasia. I 593-I 595 .

11. Collection pertaining to the Bishop of Tricarico, nuncio. I 596-I599.

12-16, 18-20, 22, 23, 28-53. Letters and ciphers of the nuncio or internuncio, and nuncios extraordinary, I607-I667, with a few as late as I707.

$54,59,66,66 \mathrm{~A}, 81$. Ciphers to the nuncio or internuncio, and nuncios extraordinary in Brussels, I667-I700, except $\mathrm{I} 690$.

55-115 (except 58, 59, 66, 66 A, 81). Letters and ciphers of the nuncio or internuncio, nuncios extraordinary, and others. I667-I724.

116-135 Vv (except $135 \mathrm{Qq}$ ). Letters of the nuncio or internuncio, nuncios extraordinary, and others. I724-I790.

136,137 . Letters of the nuncio. I72I-I73I.

136 (sic). Flanders. I605-I609.

$137-149$, with 147 ( A, B, C). Letters to the nuncio or internuncio. I609I6I 2, I623-I638, I644-I65 I, I655-I705.

150-153, with 153 (A, B, C). Registers of letters and ciphers to the nuncio or internuncio. I706-I769.

154-175. Minutes of letters to the nuncio or internuncio. I607-I740. Irregular series.

171-187. Dispensations of Cologne and Flanders. I644-I740.

188. Letters of the nuncio. I609-I6 Io.

189-192, 194. Minutes of letters and ciphers to the nuncio. I748, I758I785, I793-I796.

\section{NUNZIATURA D'INGHILTERRA.}

This collection is inventoried on page 65 of indice 134, De Pretis, where it is coupled with that of "Genove" (Genoa). ${ }^{75}$ It consists of eighteen volumes only, covering the short periods under Charles I. and James II. when a nuncio or official representative was resident in England, with some miscellaneous material relating to other representative persons. The extreme dates are I 575 and I704. The material for the period of Charles I. has been copied for the English Public Record Office, where the copies may be found. The

\footnotetext{
${ }^{75}$ There is some confusion as both of these are, in some places, referred to under the title of "Genove". According to the present arrangement, however, they are separate.
} 
collection has been used by the Reverend Father Thomas Hughes for his History of the Society of Jesus in North America. ${ }^{78}$ For certain other documents properly belonging to this collection refer to the Nunziatura di Colonia and the Barberini collection.

The chief interest of this collection is for the light it throws on the religious conditions of England during the great period of religion-impelled emigration; and after that, for its material relating to the foundation of Maryland. On the latter subject there is less than might be hoped, as the eyes of the nuncios were for the great question of immediate moment, and the Calvert family was remarkable for the successful avoidance of a dangerous publicity.

Seven volumes were examined: 4, giving fragments of the correspondence of Rosetti between 1639 and I68I; 6 and 7 , giving the correspondence of George Cuneo, between 1635 and 1639 ; and 10, 11, 12, and 13, giving the letters of the nuncio between 1685 and I689. The references to relevant material found in these volumes follow:

4. Fragments of the correspondence of Mgr. Rossetti in England and elsewhere. I639-I68I.

f. 56. Copy of petition addressed to the Congregation of the Propaganda, requesting facoltà for missionaries of Maryland.

f. 57. Copy of decree of the Propaganda, of Nov. I2, I64I, relating to the subject preceding.

ff. 60-63. Relation of Maryland.

ff. 64-66. Extract of a letter of May 3, I64I, from the superior of the Jesuit mission in Maryland.

ff. 66-67. Id.

f. 76. Form of oath suggested by Lord Baltimore.

ff. 78-79. "Questiones quaedam propositae à Dno Leugar Secretario $\mathrm{Illm}^{\mathrm{i}}$ Dñi Baronis, de quo fit mentio in Notandis."

ff. 8o-83. "Quaedam Notanda ad clariorem intelligentiam Punctorum ab Illmo Dñ Barone Baltimore propositorum."

f. 84. Feb. I, I642. Letter from the Propaganda to the Archbishop of Tarsus at Cologne, relating to Maryland.

ff. 94-95. Sept. 22, I64I. Letters of the provincial of England to Lord Baltimore. Copies.

f. I02. Odvardus Knolten (Edward Knott?) on Maryland.

6. Sept. 2, 1636. From George Cuneo, on the progress of a plan of the Ear1 of Arundel, possibly the one referred to in the letter of Rossetti of Sept. 30, I639. See Barberini 8646.

7. Apr. 16, I638. From George Cuneo, on Lord Baltimore and the Queen. May 13, 1636. George Cuneo, on the punishment of "Milord Sea e Bruck".

Mar. 4, May 6, i639. From same, on same subject.

11. Letters and ciphers from the nuncio. 1686.

Apr. 5, May IO, II. On the rivalry of France and Spain in the West Indies.

Sept. 5. Pirates from America in the East Indies, and the capture of "Sharp" in the port of "Vermuda".

Nov. 27. East India Company and the pirates.

${ }^{78}$ Vol. I., Text (Cleveland, I907) ; vol. I., Documents, part I. (ibid., 1908), part II. (ibid., I9Io). 
12. Letters and ciphers from the nuncio. 1687.

June 2I. On the raising of treasure from a sunken Spanish galleon. (Sir William Phips?.)

Aug. I 5. On the negotiation between England and Spain with regard to English privateers in America.

Dec. I2. On differences between England and France with regard to Hudson's Bay.

13. Letters and ciphers from the nuncio. I688.

Jan. I6. On the English and Spanish rivalry in America.

The volumes which were not examined and which may possibly contain material, follow: ${ }^{7 \pi}$

1. Letters, minutes, and references, Inghilterra, I $575^{-\mathrm{I}} 585$; Fiandra, I 574 -I 577 , I 578 , I 579.

2. "Diversi al Capitano Bastiano Sanioseffi." I 578 -I 584.

14. Letter and ciphers from the nuncio. I689.

15. Ciphered correspondence with the nuncio. I686-I689.

16. Register of letters to the nuncio. I686-Apr. 9, I689.

17. Minutes of letters to the nuncio. I686-I689.

18. Letters of the Patriarch of Antioch. I702-I704.

\section{NUNZIATURA DI PORTOGALLO.}

This collection is inventoried in indice 134, De Pretis, pp. 6r-64. It consists of a total of 220 numbers ; 1-204, and $1 \mathrm{~A}, 85 \mathrm{~A}, 86 \mathrm{~A}-\mathrm{E}, 87 \mathrm{~A}, 96 \mathrm{~A}$, $98 \mathrm{~A}, 104 \mathrm{~A}, 110 \mathrm{~A}, 119 \mathrm{~A}, 122 \mathrm{~A}, 158 \mathrm{~A}, 169 \mathrm{~A}$. The extreme dates are I 535 and I809. There is comparatively little material prior to I 580 when Philip II. became king. In fact during the sixteenth century Portugal was but a collectorship. ${ }^{78}$ During the eighty years of union with Spain, documents properly belonging to Portugal were very apt to stray into the Nunziatura di Spagna, and are still to be found there. For the period of recovered independence, the series seems complete, but as the collection seems not to have been examined by students since the opening of the archives, it is impossible to say that lacunae may not exist.

Although the bull of Alexander VI. confined Portuguese interests in America to the southern continent, Lisbon was, in the sixteenth century, and especially after its absorption into the Spanish empire, the greatest centre for news of the ocean and of the Indies. On March 8, I 586, the Bishop of Lodi wrote Cardinal Rusticucci that he supposed that the collector of Portugal had already written of Drake, as he would have information first: ${ }^{70}$ and on Aug. 23 of the same year the Bishop of Novara wrote: "ordinariamente le nuove vengono di Portugallo". ${ }^{80}$

Four volumes, $1 \mathrm{~A}, 4,12$, and 16, were examined, and of these, 16 was found to contain no pertinent material. Owing to the decline of Lisbon in the later period when the collection is richest, it did not seem probable that other volumes would contain more than casual items of interest.

${ }^{77}$ Copies from some of these are found in the British Public Record Office.

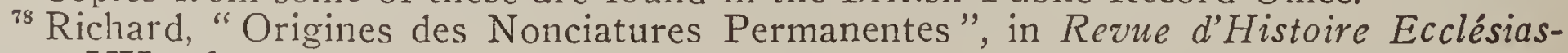
tique, VII. 56-59.

${ }^{79}$ Nimn. di Spagna XXXII. 66.

su Ibid., XXXII. 255. 
1 A. f. 25. Apr. 23, I585. From the collector, on Drake in the "India di Castiglia ".

f. 42 , Sept. I4 ; f. 45, Aug. I7 ; f. 46, Oct. I2, I585. From the collector, with news of the ships of the Indies.

f. 50. Jan. 2, I586. From the collector, on the English settlement in Florida.

f. 62. "Ristretto dell'Armata che la $M^{\text {ta }}$ Catt ${ }^{\mathrm{a}}$ fa priparare per mandare al Peru."

ff. 77-78. Oct., I586. From the collector, on the difficulty of collecting news of the Indies.

ff. 83-84. Jan., I 587. From the collector, on the question of "spoils", touching on those for the Indies. The "spoils" involved here were those of "apostati", not bishops.

f. I05, July I8; f. Io7, Aug. I5 ; f. ro9, Oct. I2, I 587. From the collector, on the fleet of the Indies.

4. f. I63, July I6; f. I69, Aug. 6; f. I7 I, Aug. I3 ; f. I84, Aug. 27 ; f. I9o, Sept. Io; f. I99, Sept. 24, I 582. From Francisco Mengacci, on the fleet, and the fighting about the island of St. Miguel.

f. 201. Sept. 24, I 582. From Juan del Monte on the same subject.

ff. 310-31r. Mar. 23, I582. From the Archbishop of Mexico, requesting relics. (Latin.)

ff. 320-323. Jan. 23, I576. From the Bishop Lacumensis [sic], on the dispute between the Dominicans and the Archbishop of Mexico.

f. 326. Dec. I6, I577. From the Archbishop of Mexico: "Uno de los descubrimientos que de Algunos anos questa parte sean ... desde este nuevo mondo, por orden de n'so catholico rey $d^{\text {no }}$ philippo es el de las Islas ocidentales comunmente nombrados las Philippinas."

ff. 327-328. Note on the disagreement between the Archbishop of Mexico and the Dominicans.

12. Oct. I7, I606. From the collector, with news of the fleet.

Mar. 2, I620. From the collector, on the question of "spoils"-in the Cape Verde islands.

\section{NUNZIATURA DI PACE.}

This collection consists of 59 volumes, of which an inventory exists in indice 134, De Pretis, p. 94, which is summarized by Hinojosa. ${ }^{81}$ It consists of the correspondence of the special papal nuncios or ministers, at general peace conferences between 1628 and I7I6. The material resembles that in the other collections of munziatura, except in that it is more purely diplomatic. Many English and Dutch documents, and translated extracts from gazettes, are enclosed. Volumes 35 , letters from Nimeguen, I678; and 49, 50, and 57, relating to the negotiations at Utrecht, were examined; of which $\mathbf{3 5}$ was barren. References to pertinent material found, follow.

49. Letters of Abbé Passionei, minister at the Hague and at Utrecht. I7 I2. Jan. I9. On the effect on the two maritime powers of the cession of Spain and the Indies to Philip V.

Jan. 2 I. Translation of a letter: "d'un courtier du change à un Gentilhomme de la Campagne touchant la Paix, et la Compagnie de la Mer du Sud", dated Nov. 20, I7II. 9 ff. Doubtless from an English gazette. Six similar articles, $5 \mathrm{ff}$., on the same subject, follow:

${ }^{31}$ Los Despachos, p. Io, note 2. 
Feb. I2. French proposal for the cession of Spain and the Indies to Philip V.

Mar. Io. Encloses a copy of the specific demands of the Queen of England upon France.

Mar. I I. On the cession of Spain and the Indies to Philip V.

Mar. I8. Enclosing an article of $24 \mathrm{ff}$., on the effect of the cession of Spain and the Indies to Philip V., glancing at its effect in the Indies. Another enclosure, dated Feb. 25, I7I2, contains references to the methods of warfare among the Indians.

Apr. I7. Admiral Walker sent to take possession of French cessions.

Apr. 22, May 20, 26. Comments on, and enclosures relating to, the English and Dutch, and the American slave contracts.

There is also a great deal of material relating to the general questions involved in the union of France and Spain and the Indies.

50. Letters of Abbé Passionei, as above. I7r3.

Jan. 6. On the question of fishing rights.

June 9. On the terms of peace between England and Spain, with regard to the commerce of America.

54. Ciphers of Abbé Passionei, as above. ryo8-i7i4.

f. I8. Mar. I5, I709. The emperor refuses to treat with France of the cession of Spain and the Indies, without the consent of England and Holland.

f. 21. Feb. 28, I709; ff. 57-68, Apr. 5, I7 Io; f. I03, May 7; f. I05, May I 5 ; f. IO7, June IO, I7II. Discussions of various suggestions looking to the division of the Spanish empire.

57. Ciphers to the Abbé Passionei. I709-I7I3.

f. 2 II. July 23, I7I2. On the unfortunate results of the treaty of Utrecht. The content of the remaining volumes is as follows:

1-13. Correspondence of Panzirola. I628-1632.

14. Instructions to Cardinal Ginetti. I636. ${ }^{82}$

15-22. Correspondence relating to the peace of Münster. I644-I65I.

29. Letters from Aix-la-Chapelle. I667-I672.

30-42. Correspondence relating to the treaty of Nimeguen. I677-1679.

43-45. Correspondence. I702-I703.

$46-48,51-53,55,56,58,59$. Correspondence relating to the treaty of Utrecht. I708-I7 16.

\section{OTHER NUNZIATURE.}

A list of the divisions of the nunziatura as inventoried in indice 134 , De Pretis, follows. ${ }^{83}$ None of the volumes in the divisions other than those above mentioned have been examined in manuscript, but practically all the material printed from them has been run over. The collection of Germany might reasonably have been expected to contain material during the period of Charles V., but beyond an occasional noting of the arrival of the fleet, this does not appear to be the case. Possibly something might be found for the

${ }^{82}$ This contains nothing on America.

${ }^{83}$ The lists of divisions as given in the various accounts of the archives curiously differ, generally giving a separate heading for Bavaria. This list is taken from indice 134 , as it stands in 1909. 
years of the American Revolution. ${ }^{84}$ Volumes 20, 21, and 22 of the division for Cologne, contain the correspondence of Mgr. Rossetti, during the years I64I-I643, when he was fresh from his experiences in England, and the greater portion of English business went through his hands. Such material as is found in these volumes is noted in the account of volumes 8646-8655 of the Barberini library.
I. Germania. ${ }^{85}$
2. Francia.
3. Spagna.
4. Polonia.
5. Portugallo.
6. Inghilterra.
7. Genova.
8. Venezia.
9. Napoli.
Io. Colonia.
I I. Svizzera.

\author{
I2. Firenze. \\ I3. Savoia. \\ I4. Fiandra. \\ I5. Malta. \\ 16. Legazione di Avignone. \\ 17. Legazione di Bologna. \\ 18. Le gazione di Ferrara. \\ 19. Legazione di Romagna. \\ 20. Legazione d'Urbino. \\ 21. Ministri per le Paci.
}

There is also a division entitled "Diverse", but these volumes have actually been transferred to appropriate places in the other divisions or to the Miscellanea.

\title{
LETTERE. ${ }^{86}$
}

This collection contains the originals or copies of many letters addressed to the secretary of state or through him to the Pope, and minutes or copies of many sent by him. There are large gaps for the reign of Clement VII. and Paul III., as well as that of Paul V., which latter, however, can be supplied from the Borghese collection. It is particularly strong for the period after the first half of the seventeenth century. These letters are classified in five groups, according to the official character of the correspondent. Studies of these several divisions follow.

\section{LETTERE DET CARDINALI.}

This collection consists of 205 numbers, 1-189, with I6 internumbered. It is inventoried in indice 134, De Pretis, pp. I64-I68, where the descriptions of volumes are of the briefest. The extreme dates are 1554 and I803. Letters to, and letters from, cardinals are, for the most part, bound separately. There is doubtless much diplomatic material, some of which may not be duplicated in the nunziatura collection.

None of the volumes were examined, and of those whose contents were at all specified by the inventory, only the following appeared of possible use:

7. "Spedizioni dal Cardinal Barberini al Nuncio di Francia."

8. "Lettere dai Cardinali al Cardinal Barberini sotto Urbano VIIr."

134 A. "Lettere al Cardinal Borghese dai Ministri."

*4 A few references may be noted to the fourth series of the Nuntiaturberichte, 1628 seq., vol. I.: Jul. 8, I628, nuncio to Barberini, on report that Holland had a powerful fleet in "Nuova Spagna"; Dec. 16, I628, Barberini to nuncio, on the robbery of the fleet of the Indies by the Dutch. Indice 121 gives supplementary volumes of this munziatura not given by De Pretis.

${ }^{85}$ Several of the volumes in this division contain letters to the nuncios of countries other than Germany.

${ }^{86}$ Bourgin, Archives Pontificales, pp. 72-75; Wirz, Bullen und Breven, pp. xlvi-xlviii; Archivio Vaticano, indice $\mathbf{1 3 4 .}$ 


\section{VESCOVI (E GOVERNATORI) ${ }^{87}$}

A brief list of the volumes in this collection is found in indice 134, De Pretis, ff. I70-I77. There are 374 numbers, but as one is doubled and nine internumbered, the total number of volumes is 384 . The extreme dates are 1506 and I797. The letters from bishops are originals and are bound in volumes containing from 500 to 800 each, the folios being in most instances numbered, and the order chronological. The volumes of letters to bishops are mostly registers, and many are indexed by names of dioceses, though not with entire reliability.

This collection is of fairly consistent character, though with a total of many exceptions. On the one hand it contains letters of the electoral archbishops, although more of these are found in the Principi; on the other, there are found some to and from persons not bishops, but occupying temporarily secular offices generally exercised by bishops. The great majority relate to the government of the papal provinces; some, as those of the bishops of Parma in the eighteenth century, resemble the news-letters of nuncios; and there are a considerable number to and from bishops in other countries. Abbé H. Surrel de Saint-Julien has drawn from this series unedited letters of Cardinal de Retz. ${ }^{88}$ Abbé A. Clergeac has calendared 6or, of French bishops between Feb. I3, I 59I, and Apr. 25, I677.

Volumes 93-96, covering the years I7OO-I702; $278-281$, covering the years $1760-1763 ; 292$, covering the year 1772 ; of the letters of bishops; and volumes 356, Jan. 2, I762-Dec. 28, I765; and 367-369, covering the years r $788-1791$, of the letters to bishops, have been examined, among which were found only the following letters relating to America:

93. f. r7r. Apr. 8, r7or. From the Bishop of Parma, referring briefly to American affairs.

96. f. 454. May 23, I702. From the Archbishop of Mexico.

368. ff. 292-293. Dec. I I, I790. "A Mgr Vescovo di Bertinoro" (Baltimore).

Garampi in his Miscellanea refers to a letter of the Archbishop of Mexico, supplicating the Pope to confirm privileges conceded by Gregory XIII. to the preceding archbishop, in 20, p. 202.

M. Clergeac cites a letter from the nuncio at Paris, relating to missions in the Western Indies, in 20, f. 84, Aug. r, r6r3.

The following list contains all those remaining volumes which may conceivably contain American material:

\section{LETTERS FROM BISHOPS.}

10, 11. I 573 -I 590.

13. $1639-1641$.

17. I609-16 10.

23. $1628-1664$.

24. $1644-1650$.

26. ( 2 vols.), $27, \mathrm{I} 645-1648$.

30-35. I648-I653.

36-54. I654-г708.

55-84. I669-1694.
87-92. $1695-1700$.

97-121. I7O3-I7I3.

123-125. I II 4 -I 7 I 5 .

127-137. I7I6-I72I.

139-140. I722-I725.

141-166. I724-I737.

231-27\%. 1738-1760.

282-322. I764-I791.

See also vols. 337-342 seq.

${ }^{87}$ Bourgin, Les Archives Pontificales, p. 73; A. Clergeac, "Inventaire Analytique et Chronologique de la Série des Archives du Vatican dite, Lettere di Vescovi", in Annales de St. Louis des Français, X. 215-268, 319-375, 420-470.

${ }^{88}$ Annales de St. Louis des Français, IV. 365-376.

${ }^{88}$ See note 87. 


\section{Letters to Bishops.}

167. I644-165I.

168-169. I655-I665.

169 A, B, C, D. " Minute di Segretario di Stato ai Principi, Cardinali, Nunzii, Prelati,

170. I666-т669. Particolari." I657-I665.

171-173. І $667-1679$.

174. I 680 , I688.

175. I687-г689, І692.

176, 177. г693-г 707.

179. I708-г 7 10.
185, 186. I $72 \mathrm{I}-\mathrm{I} 728$.

187, 188. г726-г730.

189. г6о6-г6г6.

190. $1609-1652$.

192. $\mathrm{I} 664-\mathrm{I} 683$.

193. $1670-1678$.

194. I684-1699.

195-230. I685-I739.

323-336. I 730-I76 .

337-342. "Lettere di Vescovi a Benedicto XIV. con Minute di Risposte." I744-I758.

\section{PRINCIPI E TITOLATI. ${ }^{20}$}

This collection owes its separate existence to the fact that for the last four centuries a special secretary of letters to princes has been a member of the papal organization. A brief list of the volumes belonging to the Archivio is found in indice 134, De Pretis, folios I78-185. There are 277 numbers, but as twenty volumes are nnnumbered or internumbered and one is lost, the actual number is 296 . Indice 231 is entitled, "Rubricella delli tomi tre di Minute di Brevi a Principi de Paulo V. e Gregorio XV.", but these volumes could not be identified. The extreme dates of the collection are $15 \mathrm{I} 5$ and I8I5. The letters of princes are originals bound in volumes containing from 350 to 500 each; they are arranged chronologically, though not perfectly so, and the folios are numbered. Those to princes, so far as examined, are minutes rather than registers, and are often illegible; the volumes contain about 400 folios each. Sixty-seven volumes of registers of letters to princes, extending from Gregory XIII. to Benedict XIII., are to be found in arm. $\mathbf{4 5}$ of the Archivio Segreto. Compare also the collection of Letters to Princes, noted on page 30 .

This collection does not by any means include all letters to and from princes, for such are scattered through many series. The title prince was used to cover varied forms of preeminence: sovereigns, princes of the blood, ministers of state, commanding generals, cardinals, archbishops, bishops, and occasionally nuncios. For the most part they are formal in character, letters of congratulation and courtesy, but some are of genuine historical importance. Each is rigidly confined to a single subject and they could easily be calendared. They have been used for various studies in European history, and letters relating to the special subjects have been published. ${ }^{91}$

Volumes 115-121 and 222, for the years I686-I69I, and I722-I724, of the letters of princes; and volumes 186, 187, 195, 196, for the years i6og-1614,

${ }^{20}$ G. Bourgin, Les Archives Pontificales, p. 73; W. Friedensburg, Nuntiaturberichte, vol. I., pp. xviii-xix ; also, "Regesten zur Deutschen Geschichte aus der Zeit des Pontifikats Innocenz X." in Quellen und Forschungen, IV. 236-285. See also pages 30 to $3 \mathrm{I}$.

${ }^{2}$ M. Rosi, "Alcuni Documenti relativi alla Liberazione dei Principali Prigioneri Turchi presi a Lepanto", in Arch. della Soc. Rom. di Storia Patria, XXI. I4I seq., XXIV. I seq.; Abbé H. Surrel de Saint-Julien, "Documents inédits pour servir à l'Histoire du Cardinal Mazarin", in Annales de St. Louis des Français, II. 354-380; "La Révolution Française et les Cours Electorales du Rhin, ibid., III. 25-57; Riva, "Lettres inédites de Muratori", in Studi e Documenti, XXI. 347 seq. 
I609-I699, I645-I679, and I664-I673, of the letters to princes, were examined and references to all material relating to America, except Brazil, are noted below.

115. f. 282. Oct. 3I, I686. Queen of Spain, by Don Garcia de Villagran y Maban, to the cardinal secretary of state, on the powers of the Bishop of Cuba and Havana.

116. f. I83. Aug. 2I, I687. Don Alonzo Caruero to Innocent XI., on the need of a grant from the ecclesiastical revenues of the Indies, to facilitate defence against the pirates.

f. I87. King of Spain to Innocent XI., Sept. 3, I687, on same subject.

118. f. I95. Sept., I688. Same to same, on same subject.

The following list enumerates all those remaining volumes of the collection which may conceivably contain American material:

\section{Letters from Princes. Arm. I.}

1. I $5^{\mathrm{I}} 5^{-\mathrm{I}} 590$.

2. To Leo X. and Clement VII. I 5 I $3-\mathrm{I} 524$.

3-8. To Clement VII. I825-I833.

10-11. I 528-I 567 .

$13,14,14$ A. From cardinals and bishops. I 539-I $549 .^{92}$

15. To the College of Cardinals. I 540I $55^{\circ}$.

19. I 55 I-I 554 .

21. I $55^{2-I} 555$.

31. From the kings of France and Spain, etc. I 566-I 57I.

32. To Gregory XIII. I 572-I 580.

33. France, Spain. I 572-I 58I.

45. I 588 - I 590 .

46. From Spain.

47. Duplicates of letters from nuncios and legates.
48. I 590 .

49. I 508-I 59 I.

50-52. I 592.

54. I 595-I606.

56, $56 \mathrm{~A}, 57$. г6о7-І63I.

58. I632, I635, I644.

64. From France and Spain. I644I655.

65. From Spain. I644-I653.

68-72. I645-1653.

75-76. I652-1653.

78-108, with 82 A and $87 \mathrm{~A}$. I652I68I.

109-146 A. I682-I740, a regular series except that 112 is additional for I683-I699. It will be observed that all references to America in volumes 115-121 are given above.

In the inventory there are placed here six unnumbered volumes of original letters, added by Mgr. Giocanelli, June 25, I764, and covering years I723I744.

207 A. From the emperor, etc. I $598-$ 1625 .

211. From the emperor, etc. I68II689.

208. From the emperor, etc. I665I68I.

212. I704.

213-267. I7I2-I80I, a regular chronological series except that the letters from I739 to I758, Benedict XIV., are arranged in classes by the titles of the writers.

\footnotetext{
${ }^{93}$ Hinojosa, Los Despachos, p. 77. Notes in these volumes, letters from Cardinal Farnese to the nuncio Poggio.
} 
$146 \mathrm{~B}, 146 \mathrm{C}$. I $54 \mathrm{I}-\mathrm{I} 542$.

$146 \mathrm{C}, 146$ D. I550-I 552 .

147. I 554 .

147 A. I 553 , I 555 - $155^{8}$.

148. 1563 et seq.

149, 150. From Sixtus V. and Gregory XIV. I 588-I59I.

151. "Registro di Lettere scritte dalle Segretaria di Stato ai Nunzii della Sede Apostolica." I 588I 590 .

152. From Gregory XIV.

153. "Registro di Lettere scritte per Segretaria di Stato ai Nunzii della Sede Apostolica sotto i Pontificati d'Innocenzio IX. e Clemente VIII."

154-159. I605- - 620.

162. To Italy and Spain. I6 12,1613 , I6I 5, i6i6.

164. To France. I6I5.

\section{Letters to Princes.}

166. I616, I6 17, I627.

169-180. I607-г 72 I, except I669-I676.

181,182 . I 575 -I 586 .

183. I $588-\mathrm{I} 589$.

184. I $553-$ - 6 I 3 .

185. I609-I6I I.

186, 187. See above.

188-194. І6 1 2-1620.

195, 196. See above.

197. I673-I691.

198. I675-I691.

199-201. I680-I 703.

202. I 700-I7I8.

203-207. I 706-I740.

268-270. I72 I-I 758.

271-273. I74I-I 769 .

274. I 776 .

275. I $779-\mathrm{I} 788$.

276. I 546-I III.

277. I7I4-I8I 5 .

See also Vescovi 169.

LETTERE DEI PARTICOLARI.

This collection consists of 325 numbers, 1-315, with Io internumbered. It is inventoried in indice 134, De Pretis, pp. I86-I92, which, in most cases, simply gives the dates of the correspondence in each volume. The collection is, however, divided into two great series, of letters to, and letters from the Holy See. The extreme dates are 1519 and 1803 .

None of the volumes were examined. An American Jesuit, who in the course of several months examined 60 volumes, found almost nothing on North America. An English Jesuit found a few letters of one of the secretaries of the Propaganda.

\section{SOLDATI.}

This group of 74 volumes for the years 1572 -I 710 , inventoried in folios I94-I96 of indice 134, De Pretis, seemed most unlikely to contain anything even of remote relation to American history.

\section{BIGLIETTI E MEMORIE.}

De Pretis, indice 134, ff. 206 and 207, notes 18 volumes in loose yellow covers, bearing this title, and belonging to the years I650-I700, and also 36 similar volumes, for the years I70I-I739.

On f. 208, he notes "Minute di Biglietti scritti per Seg'ria di Stato". I700I740.

\section{DIARI.}

This little collection of 12 numbers contains volumes covering the years

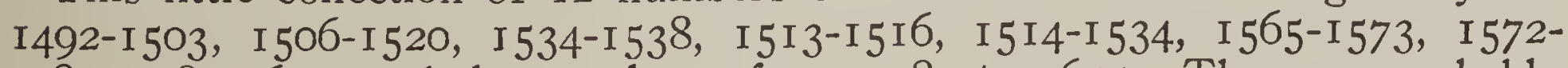
I 580 , I $582-1620$, and the conclaves from ${ }^{5} 55$ to 1655 . They are probably barren of American material, but none were examined. 


\section{VATICAN ARCHIVES: MINOR COLLECTIONS.}

\section{ARCHIVES OF AVIGNON.}

The archives which accumulated during the residence of the Popes at Avignon, were to a large extent left there when Saint Catharine led the papal court back to Rome. They suffered much from neglect, and somewhat from intentional destruction. What remained was brought to Rome, partly by order of Paul V., the founder of the Archivio Segreto, and partly in I783. All the archives brought from Avignon naturally antedate the discovery of America, but in some cases later volumes have been added to series composed for the most part of Avignon volumes, and it is useful to be aware of the designation. These merged series consist of Camera accounts and are mentioned under the heading Camera, under the Archivio Segreto. Indice 145 serves as an inventory of them, and there is a brief description in Wirz's Bullen und Breven, p. xxxi. The Avignon "registers" constitute an entirely independent series, quite too early to contain items interesting for American history.

\section{AVVISI.}

This separate collection of news-letters comprises 124 volumes. It is inventoried in indice 194, which simply gives the dates covered by the respective volumes. There are three series. The first consists of numbers 1-76, of which the first five cover the years I605-1607, I6II-1613, I6I8, I623-1627; and volumes 6-76 cover those from I639 to I709. The second consists of volumes 77-119, and cover the years I6I8-I689, except I633 and I634. Volumes 120124 contain leaves scattered through from I600 to I700. The general character of the material is similar to that described in connection with the nunziatura, page 55, and the Urbinate collection, page II2. Three volumes were examined, of which the description follows:

1. The material in this volume is neither paged nor arranged chronologically. A letter of June 24, I605, from Antwerp, states that the Dutch were seeking a port in Africa from which to impede the navigation of New Spain.

3. This better-ordered volume contains much on the question of peace between the Dutch and the Spaniards in 1607 , and the subsidiary questions of navigation in both Indies. A letter of Nov. 23, I607, notes the discovery of mines by the English in an island of which the name was illegible.

79. Chronologically arranged material for I630. There is much on the Dutch, English, and Spaniards in the West Indies, the fleet of New Spain, and the Dutch West India Company.

\section{BANDI:}

The third series of this collection is inventoried in indice 194 under the heading. "Serie 3 delle Bolle e dei Bandi collocati nella Camera, che mette alla Biblioteca di Consoltazione". It consists of 80 volumes, 1-4, I425-I657, and the remainder running regularly from that date to I854. Series one and two are inventoried in the Miscellanea of De Pretis, in armadii IV. and V. It seems hardly possible that any American material exists in the collection, and it was not examined.

${ }^{1}$ Bourgin, Archives Pontificales, p. 20; Wirz, Bullen und Breven, pp. xiii and xxxi. 


\section{BIBLIOTECA BOLOGNETTI.}

Of the 347 volumes of this collection, 284 came from the library of Count Bolognetti Cenci, and passing through the hands of Mariano, ${ }^{2}$ were incorporated with the Vatican Archives in r8ro. The unique and specially important manuscripts were collected by Cardinal Bolognetti, who died in 1756 , after having served for many years on the Propaganda and other congregations.

The volumes are listed in indice 136, the Miscellanea of de Pretis, on folios $40,42-46$, and $5 \mathrm{I}$, which are brought together between the lists for armadii IX. and $\mathrm{X}$. Indice $\mathbf{1 4 2}$ contains a valuable, though not entirely reliable, index to the material in the 284 volumes originally belonging to Count Bolognetti. This collection includes many Dutch and English documents, all of which are copies; and much valuable material relating to the war of the Spanish Succession.

By means of the inventory and index all volumes which seemed to promise any material relating to the subject were selected and examined. Of these, $5,10,14,41,56,88,101,106,107,115,130,134,141,154,158,166,167,171$, 203, 223, 235, and 260 contained nothing. References to material found, follow:

24. pp. I I9-I 50. "Relatione de' Regni di Spagna sommariamente, che fú fatto

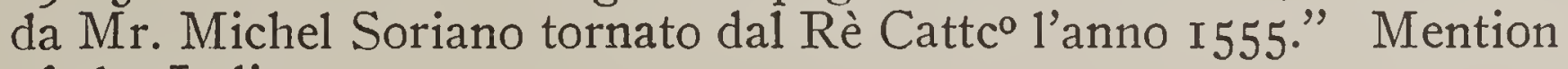
of the Indies.

pp. 649-69o. "Relatione del Clarissimo Misser Marino de Cavalli per Carlo Quinto l'anno I55I." Scattered references to the Indies, pp. 649-67I.

35. Relations of Spain by Sigri Scotti and Visconti. See p. 46.

38. pp. 373-380. "Storia di Guillemeva d'America." Story of the French court, time of Louis XIV.

39. Relations of Spain by Contarini and Tiepolo. See pp. Io4 and Iro.

56. “Tromba d'Europa, Spagna avvisata, Ipocrisia svelata, e Verità dichiarata." See Corsini 299.

61. pp. 40r-403. "Raggioni, che mossero Papa Gregorio XV. a levare nunciatura di Spagna al Patriarca d'Alessandria et abusi al tempo de Mons ${ }^{\text {re }}$ de Massimi." Question of spoils in the Western Indies.

77-80. "Giornale o Diario Universale", I792-I797. Year I794 was examined without result.

97-98. Letters of Mons. Castagna (afterward Urban VII.), nuncio to Philip II. See Corsini 506.

116. pp. 235-265. "Memoriale de Rè Cattolico alla Santità di Urbano VIII. sopra la Concessione della Contribuzione del Clero di Castiglia." I629. References to defense of the Indies.

117. pp. 389-419. "Istruzzione à Monsigor Sacchetti, Nunzio ordinario alla Maestà del Rè Cattolico in Spagna." Especially p. 390.

122. Relation of missions by Cerri. See p. I94.

137. pp. 237-279. "Raggioni vantaggiose à Carlo Terzo Rè de la Spagna contro Filippo Quinto." Jan. I, I 704. On pp. 253-254 references to commerce and religion in the Indies.

pp. 589-592. Letter of Clement XI. to Philip V. in favor of Jesuit missionaries in Philippines and California (peninsula).

${ }^{2}$ Indice 142, prefatory note.

"See F. Pometti, "Studi sul Pontificato di Clemente XI.", in Arch. della Soc. Rom. di Storia Patria, XXI. 290; XXII. Iog-I79; XXIII. I09-I79, 239-276, 449-5I5. 
143. "Nuovo Mondo ó vero le due Americhe Settentrionale e Meridionale dà Nicolo' Forteguerri." To Clement XI., July ıo, I7og. This is a portion of a general account of missions outside of Europe. There are 66 pages on North America. The author's information was limited, and he enlarges upon it unhappily.

144. "Relazione della Corte di Spagna." By Sig. Domenico Zane, Venetian ambassador to Philip IV. Pages 77-97 contain many references to the Indies.

151. "Registro di Lettere della Segretaria di Stato nel Pontificato della San M. di Paolo V. Scritte à Mons. Ubaldini Nuntio in Francia l'anno I609" (really through I6I I). P. 476, letter of Nov. 25, I6 Io, on proposition of the Jesuits to go to Canada.

157. Instruction to the Patriarch of Alexandria, nuncio in Spain. Apr. 5, I62I. See Corsini 691.

159. "Relazione d'Inghilterra fatta dell' Eccmo Sig. Pietro Mocenigo ”, Venetian ambassador. I67I. Pp. 56, of which 12 are on colonies and commerce, with other scattered references to the same.

165. pp. I55-49I. "Gl'Interessi d'Inghilterra, male intesi nella Guerra presente nel libro Inglese intit. 'England's Interest mettallen [mistaken ?] in the Present War', tradotto in Francese, e ora in Italiano." Pp. 247-256 on the commerce of America and Guinea, and 284-287 on fishing. See also same article in cod. 108.

176. Charles V. to Philip II., on the occasion of consigning to the latter his estates. See Ottobonian $125 \%$.

185. "Relazione dell'Isole (antisole) Americhe data da Corsino Brunetti al Seren $^{\text {mo }}$ e Rev ${ }^{\text {mo }}$ Sig $^{r}$ Cardinale Leopoldo de Medici." 20 pp. Does not touch the mainland.

251. "Relazione Politica della Spagna fatta all'Altezza Serenissima del Sre Duca di Parma da un suo Ministro stato residente in detta Corte." Time of Philip IV. Several hundred ff. Contains references to the Indies but its information is not strikingly accurate. See Ottobonian 1824.

275. Relation of England by Correro. Unimportant.

\section{BORGHESE.}

In 1893 the Vatican purchased the manuscript collection of the Borghese family. ${ }^{4}$ This was most important for the reign of Clement VIII. (I592I605), when Cardinal Camillo Borghese was an influential figure in the papal court, and for his own reign as Paul V. (I605-I62I). For this period they were indeed indispensable to the completion of the papal archives. The codices were given over to the Vatican Library, and the documentary material to the Archivio, where it is preserved as a separate collection. ${ }^{5}$ This is inventoried in indice 193, which was prepared by the Prussian Institute at a time when Prussia contemplated its purchase. It is brief and contains a statement to the effect that it is not complete. Indice 192 is a schedario, or collection of notes arranged in alphabetical order like the indexes of Garampi, by Posse-

${ }^{4}$ Wirz, Bullen und Breven, p. xlix. See also Hinojosa, Los Despachos, pp. xlv-xlvi; and Abbé Alexandre Pasture, "Inventaire du Fonds Borghèse au point de vue de l'Histoire des Pays-Bas", in Bulletin de la Commission Royale d'Histoire (Belgique), LXXIX. I-2I7, pp. I-25 giving a general description.

${ }^{5}$ L. Pastor, Geschichte der Päpste (Freiburg i. B., I886), III. I26. 
rini. Indice 199 is entitled, "Ripartimento di Manuscritti dell'Emmo Sigr Cardinale Scipione Borghese". The collection consists of about 2000 volumes, divided, on what seems on a casual examination no system, into four classes, 1-974, 1-521, 1-132, and 1-301.

This collection was not examined in detail, as members of the Prussian Institute, familiar with the contents, slated that it contained no material relating to North America." "Indie" occurs several times in the inventory, but doubtless relates to the East Indies and the Philippines.

\section{BIBLIOTECA CARPEGNA.}

This collection of 83 volumes was made by Cardinal Carpegna (d. I7r4). Indici 140 and 141 give an extensive but not wholly accurate index of the material. ${ }^{7} \quad$ It is also indexed in the Miscellanea of Garampi, whose references, also, are not always correct. Volumes 1, 6, 11, 30, 56, 57, and 80 were examined without result. The references found to be relevant to the subject, follow :

2. ff. 246-292. Documents of the special congregation appointed with reference to the petition of the Catholic King for permission to impose decimae on ecclesiastical goods in the Western Indies for the purpose of defence against the pirates. Copies. Included are reports of the Sacred Congregation of Sept. 20, I672, and June I, I673; and petitions addressed to it Mar. I5, I673, and Jan. 23, I674.

32. Congregation. Particular. Immunitat. This includes the following pieces relating to an appeal for a grant of the decimae subsequent to that involved in 2. Copies. The petition of the Spanish minister, Apr. I8, I687; letter from the papal secretary of state to the congregation, Oct. 29, I689, $2 \mathrm{ff}$. ; report of the congregation, Dec. I2, I689, $3 \mathrm{ff}$.; letter of the King of Spain to Alexander VIII., $3 \mathrm{ff}$.; meeting of the congregation, Dec. I2, I689, $4 \mathrm{ff}$.

54. Congregation. Particular. Immunitat. No. 6. "Hispaniarum Indulti." I9 ff. Copies. Letter of Gregory XIII., May I5, I573, granting original concessions; letter from King of Spain, I598, requesting extension of grant; relation to the council, Apr. I5, I698; relation of the Spanish minister, Apr. 2I, I695; relations by the provincial general of the Society of Jesus, the provincial general of the order of St. Augustine, the commissioner general of the order of Minores Observantes, the vicar general of the order of the Blessed Mary of Mercedes for the redemption of captives, the presiding general prior of the Spanish congregation of barefooted Carmelites; and a decree of the Congregation of the Council, Mar. 30, I680.

55. ff. I33-I34. Mar. I8, I698. Copy of letter reporting shipwreck of the galleons near Havana.

f. 212. Mar. I7, r7or. "Avvisi da Madrid." Changes in the government of the Indies.

55 (another volume in two parts). Material drawn from the archives of the Propaganda, chiefly relating to the East Indies and China.

ff. 335-342. Papers on the division of the world into provinces. I672.

\footnotetext{
${ }^{6}$ Hinojosa, Los Despachos, p. II, note I, refers to certain Spanish material.

"Index primus (secundus, otherwise similar) omnium Causarum spectan. ad Materias Canonicas, Morales, Theologicas, Mixtas etiam Sancti Officii, Datariae, quae variis codicibus Bibliothecae Carpineanae colligatae reperiuntur."
} 
f. 353. Responses to a demand for a relation of the state of missions of France.

65. Index to the manuscripts of Cardinal Pio. 1686.

\section{BIBLIOTECA CIAMPINI.}

This library is elaborately indexed in indici 210,211 , and 212. The volumes are now dispersed, many of them being found in the Miscellanea, especially arm. VIII. All those which seemed likely to contain American material were found, and are noted in the proper places.

\section{COLLECTION OF CLEMENT XI.}

This collection, also cited as Biblioteca Albani, of 265 volumes, pertains almost wholly to the long pontificate of Clement XI. (Albani, I700-I72I). ${ }^{8}$ It is very well inventoried in indici 143 and 144. The material was bound with relation to subjects or rather countries, so that the use of the inventory is less laborious. $108,154,158,163,164,168$ were examined without result. References to material found, follow. The volumes are not paged.

101. This contains material relating to religious persons and places in Spain in the time of Philip V. Note is made of, "Catalogo degl'Arcivescovi e Vescovi di Spagna e dell'Indie Occidentali Spagnole", and of, "Due Lettere di Mons. Michel Ant ${ }^{\circ}$ Vescovo di Cartagena nell'Indie Occidentali ", one to the Congregation of the Council and one to the Pope, on the question of his absence from his diocese.

103. This contains material relating to favors and privileges accorded by popes to kings of Spain and other countries. It was examined and note was made of, "Breve di Gregorio XIII.", Mar. 3, I573, extending the favor of a subsidy in the Indies, in behalf of the King of Spain. If.

104. Volume on the same subject. It was examined and found to contain, "Minuta di Breve dello ... [Clement XI.] . . . formato di proprio pugno per il Sussidio accordato da detto Rè nel I7I7", Jan. I6, I7I7, $2 \mathrm{ff}$. ; and copy of the brief in $6 \mathrm{ff}$.

Appendix II. contains writings concerning the subsidy demanded by Philip V., on ecclesiastical goods in the Western Indies, among which are, "Discorso, Informatione sopra il Sussidio", I I ff. ; "Informatione fatta al Rè di Spagna dal Commissario General della Cruciata ", 9 ff. ; "Progetto di XXIV navi da Guerra da mantenersi a spesa della Cruciata", 22 ff.; " Breve d'Innoc. XII. sopra gli Sussidii a lui accordati per Defesa dell'America infestata dagl'Eretici", July 4, I699, 4 ff. ; "Atti d'una Conge particolare di sei Cardinali ", July 12, I699, 2 ff. ; "Direzzione data al Nunzio di Spagna sopra questa materia ", 2 ff. ; "Traduzzione della Lettera del Marchese di Manzera scritta al Monsig. Nunzio Ap'lico nelle Spagne sopra la Contribuzione degl'Ecclesiastici Americani accordata da S. Sta al Rè Carlo II., alla 29 d'Agosto, I699”, I f. ; “ Due Lettere stampate di Monsig. Giuseppe Archinto A. V. di Milano, Nunzio nelle Spagne, e Collettore Generale della S. Sede promulgate in Madrid ", on the same subject, I699, $7 \mathrm{ff}$.

\footnotetext{
${ }^{8}$ The greater portion of the great Albani library was purchased by the Prussian government, and sunk on the voyage from Cività Vecchia; portions of it are in the collection of Count Hugo Buoncompagni, and elsewhere. This is an independent collection, but is sometimes, with resulting confusion, referred to as the Biblioteca Albani.
} 
109. Volume on the same subject. It was examined and found to contain, "Breve Suspensione della Cruciata e d'altri Sussidii e Grazie concesse dalla Sede Ap'lico al Re Filippo V.", June 4, I7r3, sent to all the archbishops and bishops of Spain. This is followed by documents on the reasons for the suspension, which have only the remotest relation to America.

149. Note of all the bishops of France who accept the constitution Unigenitus, in which it is stated: "L'on n'a pas ni les noms des évêques de Quebec, et de St. Tethleim [Bethlehem?], l'un n'ayant point de Territoire, et Quebec estant immédiat du St. Siège".

165. Documents relating to England.

Apr. I r, I715. Report of proceedings of Parliament on the treaty of commerce with Spain, and concerning Nova Scotia, Newfoundland, Cape Breton, etc. I f. French.

265. This volume, relating to America and the Western Indies, is lacking. It is said to be in the Propaganda, but was not found there. An abbreviated account of its contents as given in the inventory, follows :

Memorials presented to His Holiness by the priests of the Congregation of the Oratory of Rome concerning the crown requested by the priest Don Diego Malparrida of the city of Mexico.

Letters from Malparrida written from Mexico. Feb. 28, and May II, I702. Latin and Spanish.

Petition to the Pope of the Congregation of the Immaculate Virgin Mary delle Dolori cf the city of Mexico, for extension of indulgences and territory.

Letter of the superior and members of the monastery of Sts. Anna and Gioacchino in the city of Puebla de los Angeles, requesting favors for their institute. Feb. I6, I709.

Petition of the brothers of the Company of the Coronation of Christ Our Lord, of the city of Mexico, requesting indulgences. Nov. I4, I709.

Relation by the Bishop of Santa Croce della Sierra, of scruples troubling his conscience. Apr. 28, I7I7.

Oath taken by the same. Apr. 28, I7x7.

Letter from the same, same date, and of which the contents seem to be the same.

Letter to Father Orazio Olivieri, Jesuit, from Manillo de Valdiniesso of the city of Mexico. Feb. 22, I7r8.

Letter of the nuncio at Paris to the pontifical secretary of state, Aug. 25, 1696, with a memorial from the provincial and vicar-general in France, of the monks della Carità dell'Ordine di San Giovanni di Dio, asking for special facoltà in the islands of America.

Memorial from the Jesuits of Peru to Innocent XII., for the redress of grievances. Sept. I, I700.

Relation of the mission to the Moxos of Peru, made to Clement XI. by Father Idelfonso Messia, the provincial of the same. I7r3.

Map accompanying said relation.

Letter of Philip V. of Spain to his ambassador at Rome, Aug. 22, I704, concerning the cruelty of the English heretics at Ayuvale in the province of Apalache. 
Memorial relating to the money spent by Philip $V$. for the maintenance of missions in the islands of the Holy Trinity and of Guayana. I704I705.

Corrupt Bible of the heretics printed in London in the American language and distributed by the English in America.

Letter of the inquisitor-general of Spain to the Pope, Oct. 12, I709, in answer to the apostolic brief notifying him of this edition. Spanish with translations into Italian.

Letter of the same to the same, same subject. June 22, r7ro. Spanish with Italian translation.

Indulgence requested of Clement XI. by Philip V. to use the moneys of the churches of America for defense against the heretics, and not obtained.

Letter of the nuncio at Paris on the same subject. July 5, x702.

Two sheets di varie dottrine, and one Latin writing, sent by said nuncio to support said request. One with autograph note of the Pope.

Tenth demanded by the King of Spain on ecclesiastical goods and persons in the Western Indies.

Memorials from King Charles II. (III.?) on same subject.

Latin sheet on same subject.

Sheet of instruction for the special congregation appointed to deal with this request.

Another of the same.

Note of the secretary of the Congregation of Ecclesiastical Immunity, addressed to the said special congregation. Oct. 29, I689.

Vote of Cardinal Carpegna in said special congregation. Dec. 12 , 1689.

Resolutions and notes of the said special congregation made by Mgr. Albani, its secretary and later Clement XI. The index here refers back to vol. 104.

\section{CONFALONIERI COLLECTION.}

The Confalonieri who made this collection was, from $\mathrm{r} 626$ to $\mathrm{r} 636$, custos Castelli, and was an indefatigable bibliographer. He was employed also in Spain and Portugal. The collection of 89 volumes is inventoried in indice 194. Volumes 1, 2, 7, and 65 were examined without result. References to material found, follow:

26. Aug., x 598. Confalonieri to the Patriarch of Jerusalem, on the capture of vessels from the Indies.

Aug. r8, r 598. Same to same, on the fleet of New Spain, kept at Lisbon by the English.

32. Nov. I, I 597. Same to same, on the English and the fleet of the Western Indies.

146. f. I49. Discussion of the revenue from the Cruciata in Spain, Portugal, the Indies, etc.

At the end of the volume there is a list of the subcollectors in Spain. None are given for the Western Indies.

Other volumes of possible interest are the following:

$1-6,10,15$, and 16 . Divers writings.

7-9. "Informationes diversorum pro Signatura SSmi."

17. Arvisi of $\mathrm{x} 6 \mathrm{r} 3$ and following years.

27. Minutes of letters (from Spain) to Cardinal Aldobrandini. I592I 594 . 
29. Original letters of Cardinal Aldobrandini to the Patriarch of Jerusalem.

35. Material relating to ecclesiastical jurisdiction in Spain and Portugal.

48-53. Register of letters of Cardinal Montalto, nephew of Sixtus V. Volume 48 is incorrectly labelled letters to the same.

54. Minutes of letters to nuncios and princes, written while Confalonieri was pontifical secretary.

65-67. Avrisi. 1630-1637.

89. Divers Latin letters of the nunciature of France. I605-1622.

\section{DANDINI.}

This collection or archivio of six volumes was secured by Leo XIII. from the Conte Dandini de Cesena." Its most important contents are two volumes of original letters to legates and nuncios, during the pontificate of Paul III. (I534-I549), and of Gregory XIII. (I572-I585). The special permission of the director of the archives is required for its use, and, the death of $\mathrm{Mgr}$. Wenzel intervening, no volumes were examined.

\section{CARTE FARNESIANE.}

This collection of seven bundles was acquired in I893. Each bundle contains a mixed mass of letters and despatches. ${ }^{10}$ There is much nunciature material for the Farnese period, relating chiefly to the councils of Bologna and of Trent. ${ }^{11}$ None of the material was examined.

\section{GARAMPI COLLECTION.}

The Garampi collection originally consisted of 25 I volumes, but many are now lacking or have been transferred to other places. It is inventoried in indice 157, "Elenco delle Carte delle Ch: Me: del Cardinale Garampi", which is unusually good, but has not been brought up to date. It was left to the Archivio by Cardinal Garampi, the prefect, and contains the greater portion of his private library of manuscripts collected during his various diplomatic missions to Poland, and the various courts of Germany. Much of his correspondence while resident in these capitals is found here. References to the American material follow:

6. Unbound papers in paste-board covers.

N. "Nota Ministeriale delle Cose d'Inghilterra, e di Parigi, e notizie risguardanti la Guerra dell'America, delle Provincie Unite." By Sig. Abb. de la Seria, to Mons. Caleppi in Florence.

Jan. 3, I778. News from Paris. $3 \mathrm{ff}$. "Franklin nous promet dans la dixaine de grandes Nouvelles, il faut avouter que jusques ici il a tenu parole."

In addition, some of the volumes which are lacking seem to have contained material.

8. This contained consistorial acts, and was transferred to Miscellanea, arm. XII.

79. N. 2 contained a relation, "intorno alla nunziatura di Spagna".

172. A. "Geographico manuscritto con varie miniature dorate del 1496 circa."

'Hinojosa, Los Despachos, p. xxx.; Wirz, Bullen und Breven, p. 1.

${ }^{10}$ Friedensburg, Nuntiaturberichte, II. 3, n. 2.

${ }^{11}$ Hinojosa, Los Despachos, p. xxxi. 


\section{INSTRUMENTA MONASTICA. ${ }^{12}$}

This collection consists of documents placed on deposit for safe-keeping in the Vatican archives at the time of Napoleon I. No inventory exists and the indici contain no reference to its existence, but it is being ordered by $\mathrm{F}$. Melampo. There are documents belonging to the Augustinians, Basilians, Dominicans, and Franciscans. Of these, those belonging to the latter order only were examined.

Fondo Francescano. This collection consists of thirteen volumes and pamphlet cases, containing a great variety of material, chiefly of the eighteenth century, but with one volume from the archives of St. Isidor, arm. 2, no. 23, relating to 1464 -I488. There is also a collection of "instrumenti Francescani" in the Archivio Castello, caps. 81, but these are all of date previous to the discovery of America. No manuscripts seemed relevant to the subject, but the following pamphlet is of interest:

Tabula, et Constitutiones percelebris Capituli Generalis totius Ordinis Fratrum Minorum, celebrati in Vigilio Sacri Festi Pentecostes, juxta Praescriptum Seraphicae Regulae S. P. N. Francisci, anno Jubilari Universalis I7oo, die 29. Maij, Romae. 40 pp., of which 23-27 are "pro Natione Hispaniae".

\section{BIBLIOTECA PIO.}

This library is placed with the Miscellanea but is not inventoried by De Pretis. An inventory is, however, found in indice $219,^{13}$ and an index in Carpegna 65, pp. 193 and following. ${ }^{14}$ It once consisted of nearly 500 volumes, but many have been removed to complete regular series, and are now scheduled elsewhere, so that there are said at present to be $28 \mathrm{I}$ only. ${ }^{15}$ The numbering has not been changed, so that references extend to a much higher figure. Changes of location are not specifically noted. It was collected by Cardinal Pio, who flourished I654-1689, ${ }^{16}$ was annexed to the Archivio in I798, and is very rich in documentary material, particularly diplomatic. Comparatively few volumes were called for-72, 78, 79, 85, 245, 246, 255-as most of the material consists of copies, and the greater portion of that which does not duplicate the regular series has been removed. Of the volumes called for, 78 was missing - that is, probably, placed elsewhere-while 85 and 255 contained nothing relevant. The material discovered, and the volumes possibly containing items, are roughly classified as follows:

\section{Consistorial Acts.}

17. "Acta Concistorialia." I $490-{ }_{564}$

20. "Acta Concistorialia " of Cardinal Caraffa. I 552-I 584.

22. "Acta Concistorialia" of Cardinal S. Severina. I 570-I 595. "Acta Concistorialia" of Cardinal S. Severina. I 590-1600.

23. "Acta Concistorialia." I623-I644.

28. "Decreta Concistorialia." I498-1644.

29. "Acta Concistorialia." I 559-I 568.

${ }^{12}$ P. Kehr, "Papsturkunden in Rom", in Nachrichten der K. Gesellschaft der Wissenschaften zu Göttingen (I900), pp. 390-39I.

${ }_{13}$ "Reportorio di Manuscritti dell" Emmo Sigr Cardinale Pio." $20 \mathrm{ff}$.

14 "Indice de' MSS. del Cardinale Pio." I686. See also indice 168-184, the chronological index of Garampi.

${ }^{15} \mathrm{G}$. Bourgin, Archives Pontificales, pp. 69-70.

${ }^{13} \mathrm{~W}$. Friedensburg, Das Königlich Preussische Historische Institut in Rom, p. I6; P. Kehr, "Papsturkunden in Rom", l. c., p. 394. 
353. "Decreta Concistorialia." Innocent X. to I670.

354. "Acta Concistorialia." I600-I605.

355. "Acta Concistorialia." Innocent X. (I644-I655).

356. "Acta Concistorialia." Alexander VII. ( I655-I667).

357. "Acta Concistorialia." Clement IX. ( I667-I670).

358. "Acta Concistorialia." Clement X. ( I670-1676).

359. "Acta Concistorialia." Gregory XV. (I62I-I623).

360. "Acta Concistorialia." Paul V. (I605-I62I).

Acts of the Council of Trent.

225-226. "Acta Concilii Tridentini Cardinalis Paleotti."

Diplomatic Correspondence.

56. "Acta legationis Chisii in Francia."

62. "Lettere diverse."

65. "Istruttione al Mongr. Biche in riguardo degli spogli."

66, 67. Instructions of Urban VIII., and favors granted by him to the King of Spain.

70. Instructions to Mgr. Corsini, nuncio in France, and to the nuncio in Spain in the time of Clement VIII.

87. Letters of Cardinal Bentivoglio, nuncio in France. I6r6-I621. See 316-318.

123. Divers letters under Clement VII. (?)

127. Instructions to the legate in France, and letters to Mgr. Santa Croce, nuncio in France.

140, 141, 142. Letters of Cardinal Corsini from France.

171. Divers instructions, particularly under Paul IV. (I555-I559).

172. "Avvertimenti p'li nuntii in materia de'spogli."

173. Letters to Cardinal Corsini in France.

198. Instructions to P. Ignazio in France.

204. Letters of Mgr. Santa Croce, nuncio in Spain. I 560.

220. "Instruttione sopra Giurisditione del Nuntio in Ispagna."

221, 222. Divers instructions.

223. Letters of the secretary of state during the nunciature of Cardinal Sacchetti in Spain.

225, 226, 228. Letters of Cardinal Como, secretary of state under Gregory XIII. (I $572-1582$ ).

244. Letters of divers princes.

254, 255. Letters of the Cardinal of Florence, legate in France, and of Cardinal Aldobrandini, under Clement VIII. (I 592-I605).

256, 257. Letters of Mgr. Minuzio Minuzii, legate in Spain, I59I-I 595, and of the Bishop of Viterbo, nuncio in France under Julius III. (I 550I555) and Paul IV. (I 555-I 559).

270. "Avvertimenti sopra la Collettoria di Spagna."

271. Correspondence between the secretary of state and Cardinal Ubaldini, nuncio in France. I609-1616. First of a series, see 305, 311, 319322.

294. Letters to divers persons.

297. Letters to the nuncio in Spain. 1606.

301,305 . Belong with 271.

310. Letters to the nuncio in Spain. I6I3-I6I5. See 315.

311. Belongs with 271. 
315. Belongs with 310 .

316-318. Belong with 87.

319-322. Belong with 271.

333. Correspondence between the secretary of state and the nuncio in France. I643-1654.

365. Various instructions and letters.

397. Letters of the nuncio in Spain. June 8, 1652 -Oct. 1654.

70. Various relations.

\section{RELATIONS.}

72. Relation of France by Giustiniani. $25 \mathrm{ff}$. See page 238.

73. "Apocalisie d'Olanda, cioè contro il moderno Governo degl'Olandesi." See Casanatense 1570.

74 and 170. Relation of France by Correro. See Ottobonian 3184.

79. "Commentarii del Regno di Francia del Clarissimo Mr. Michele Suriano" (Venetian ambassador). I56I. P. 7, mention of the interest of France in "nove Indie".

86. "Delle Relattione del Cardinale Bentivoglio ", nuncio in Brussels. I6o9. Vol. II., f. 3, Dutch in the Spanish Western Indies.

162. Relation of France by Morosini. See Corsini 477.

191. Various political writings.

245. ff. I-34. Relation of Spain, I647, with bare reference to the Indies.

ff. I8I-204. Relation of France by Venetian ambassador, I658, with mention of France and Cromwell in the Indies.

428. Garampi in his index to Miscellanea refers to an item on the Jesuits in America, July I I, I680, p. 400.

\section{BIBLIOTECA RONCONI.}

This library consists of about 20 unnumbered volumes of copies of diplomatic material of the seventeenth and eighteenth centuries; no inventory exists, and it can be used only by permission of the director. It was not examined.

\section{ROSSI COLLECTION.}

Indice 138 contains an index "delle Scritture di Mgr. di Rossi fatte per servitio della Rev. Camera dall'anno I644 fino al I673", in I6 volumes. I do not know where these volumes are at present, but at any rate they contain nothing relating to the subject.

${ }^{17}$ G. Bourgin, Les Archives Pontificales, p. 69; Wirz, Bullen und Breven, p. xlix. 


\section{VATICAN LIBRARY.}

\section{BARBERINI ARCHIVES.}

This collection is not yet put in order, and while special, known documents may be used, it is impossible to make an exhaustive examination of the whole.

\section{BARBERINI LIBRARY.}

The Barberini Library of manuscripts was, before its recent purchase by the Vatican, the most important private collection in Rome. For the first three-quarters of the seventeenth century this family occupied a position of almost unique importance. Its leading member was Pope, as Urban VIII., from $\mathrm{x} 623$ to $\mathrm{x} 644$, and Cardinal Francesco Barberini remained for many years after that one of the leading men in the Curia. Imbued with orderly habits, scholarly tastes, and enormous activity, they made collections equalling their opportunities. It is still true that at present, and until the archives of the congregations be generally opened to investigation, the history of the papacy, at least for the reign of Urban VIII., can be better studied here, than in the papal archives; and there are in addition great masses of scholarly correspondence, extending all over Europe, and miscellaneous material of the utmost variety and extent.

This collection came to the Vatican so well ordered that its independence is, and probably will be, preserved. There is an inventory, which was used exclusively, and which is admirable. It is in 36 volumes, listing and describing I2000 numbers. As the first two volumes treat the Greek manuscripts which have a separate numeration, and among the others there is a certain amount of classification, it seemed necessary to use only volumes $3-30$, and 32 . The "Index Codicum MSS. Latinorum et Occidentalium" is in 42 volumes, with two appendixes. The items are on separate slips, fastened in extension covers. There is also a "Catalogo generale dei Carteggi Diplomatici in ordine alfabetico", in 55 volumes. These are all due to the labor of Alessandro Pieralisi, for many years librarian. Gachard, in his Archives Vaticanes, pp. 43-46, summarizes the nuntiature material. The following numbers were examined but no pertinent material found in them: $846,1158,1353-1357,1498,1502,1507$, $1513,1514,1522,1538,1596,1835,1947,2064,2177,2203,2384,2558,2559$, $2649,2687,2693,2735,2736,2832,2839,2868,3013,3092,3166,3185,3411$, $3527,3802,4394,4431,4574,5223,5227,5243,5245,5253,5256,5261,5269$, $5273,5274,5275,5332,5333,5339,5349,5366,5375,5391,5418,5427,5441$, 5477, 5537, 5562, 5585, 5607, 5649, 5682, 5721, 5748, 5757, 5815, 5868, 5968, $6442,6483,6541,7963,8222,8223,8522,8528,8529,8530,8532,8584,8585$, $8601,8618,8638,8645,8655,8822,8823$. References to material found relating to the subject, follow:

241. ("Latin", as are all the numbers cited.) "Libellus de medicinalibus Indorum herbis, quem quidam Indus Collegii Sanctae Crucis Medicus composuit, nullius rationibus doctus, sed solis experimentis edoctus. Anno Domini Servatoris, 1552 ." $63 \mathrm{ff}$.

324. ff. I3I-I33. "De Insula nova mense Julio anno I678 in Oceano Atlantico enata ad oram occidentem insulae Flandriae S. Michaelis." 
1496. "Decreta Cong. Sacrorum Rituum." I629-I63I.

ff. 5I, I4I, I 55-I 56. Six requests from Lima regarding rites.

f. 52. Request from the Jesuits of New Spain.

f. I62. Request from the Jesuits of the Western Indies.

1497. "Responsa Cong. Sacrorum Rituum." I6ro-1620.

ff. IOO-IOI, 23I, 24I. Orders with regard to rites in Mexico.

f. 243. Order regarding rites in the diocese of Santa Fé (Bogotá [?], South America).

f. 254. Order concerning the Archbishop of Lima.

2136. Letters of Cardinal Barberini, as protector of the Order of St. Francis.

f. Feb. 5, 1656. To Georgio di Lemoe (?) Lersandus, concerning charitable collections "in partibus Indiar" ".

2223. "Relatione dello Stato della Religione Cattclica nel Regno d'Inghilterra." I637. By Gregorio Panzani, to Urban VIII. $46 \mathrm{ff.}$

ff. 36-37. Mention of Lord Baltimore.

2626. An unpaged collection of material relating to Spain and its possessions, by bishoprics, with a few mentions of the New World.

2893. "Atti Concistoriali." I669-I67I. Vol. III., items on Cuba and Porto Rico.

2897, "Atti Concistoriali." I625-I630. Vol. V., items on Cuba, Guadalaxara, and Porto Rico.

3453. “Discorso sobra el Casimento q' se trata entre el Principe de Gales, y la Serenissima Ynfanta de España. Del Conde Don Antonio Xerley."

ff. $48-5 \mathrm{I}$. Relation of the marriage to the occupation of Virginia and the Bermudas.

3463. "Flores cogidas del Jardin de Christo n'ro Sr. Por su Siervo el benerable $\mathrm{Pe}$ y baron Appostolico fr. fran ${ }^{c o}$ Solano de la regular oserbancia De n'ro Pe San franco Natural de la Ciudad de Montilla, Marquesado de Phejo en la Andalusia, sacadas del processo hecho por autoridad Apostolica en las yndias ocidentales del piru." $46 \mathrm{ff}$.

3544. "Discorso contro li Stati d'Olanda nel qual si parla del modo da tenersi da Spogli per ritardarli la Navigne, trafica, Pesche, e commertio loro tanto nel mar Setten le che nel'Óceano et nell'Indie." About I6ro. $52 \mathrm{ff}$. Containing a good account of Dutch trade, with a few references to America.

3547. ff. 273-283. Edict of Louis XIV. establishing the company of the Western Indies. July, I664. Printed.

3560. ff. IOI-I32. "Relacion de la Corte de España regnando el Rey D. Filippo Tercero." Unimportant references to the Indies.

ff. I82-219. "Relacion acirca del presente feliz estado de las Indias Occidentales en la ap administracion de los Santos sacram ${ }^{\text {tos }}$, combersion de los Indios por los Religiosos de n'ro seraphico Padre San francisco-hasta el anno de I635."

3584. Primera Parte del Compendio y Descripcion de los Indios Occidentales. Pp. I-8o, printed, followed, with some overlap, by folios I-79, manuscript. The second part has pages $\mathrm{I}-32$, printed, and folios I-I64, manuscript. It dates from about I622. The first book treats, "dell'origen y decendencia de los Indios", the others give a description by governmental divisions. There are indexes of chapters and of towns. 
3585. "Gobierno del Perù, con todas las Casas pertenecientes a el y a su historia, por el Licendo Juan de Matienzo Oidor de Chancilleria de La Ciudad de La Plata." $405 \mathrm{ff}$. Copy made from the original. From the library of Dr. Tomas Tamayo de Vayas.

3603. ff. I 3O-I3I. "Clausula del Testamento y Mayorasgo de Don Cristoval Colombo q' en Hispagna se llama Colon."

ff. I73-I74. "Relazion de lo sucedido en el Consistorio que [tenió?] La Santidad de nuestro Smo Pré Urbano Papa Ottavo con los eminentissimos Cardinales in su Palaccio de S. Pedro lunes 8 de Marco I632." Attack on Pope by Cardinal Borgia, with mention of the Indies.

3604. ff. I86-218. Grants to Columbus. 1497. Spanish copies.

ff. 193-194. "Maijorasgo de don Christoval Colon."

ff. 200-218. "Diritti di D. Baldassar Colombo a succedere al maggiorasso ... fondato da Christoforo." Copy of writing of 1583 .

3605. ff. 4I-44. "Relacion de todos Audiencias, Arcobispados, y Obispados que ay en las Indias, y del Parage, y Parte in que esta cada uno; assi de la Nueva España", etc. Gives valuable and brief descriptions, with boundaries.

3615. f. I20. "Relatione di un Miracolo di S. Ludovico Bertrando fatto nell'Indie data al Papa Clemente X." I67r. Accomplished in New Granada.

4431. "Tabulae Nauticae Oceani, ac Mediterranei." By Giovanni Andrea di Vavassori, detto Valagnino. Dated Mar. 2, I536.

No. 8. This map, on large double folio, in colors, gives the non-European world, with navigation routes marked. The American coast line is interestingly traced.

No. 9. Map of the world, as above. Gives route of Magellan, and of the Peru fleet. Fills in land in America to the Arctic circle.

4592. f. 40 . Address of Pope to the Swiss, June 8,1565 , on the Bretons in Florida.

4605. Miscellaneous papers relating to the Propaganda. $486 \mathrm{ff}$.

f. 86. Rules observed in the reform of facoltà for missionaries.

ff. 99-roo. "Brevis Narratio rerum quae a [?] quatuor mensibus gesta sunt in diversis locis, pro maiori incremento sub prefectura Patrum Leonardi et Joseph Parisiensi' Ordinis Capucinorum." Refers to Canada.

ff. 229-233. Compendium of information sent by Pre Diego Collado, Dominican, regarding the ecclesiastical controversies regarding the Indies in the Council of Spain.

4624. The Relation of the State of Christendom by Cerri. See page I94.

5038. "Entrate et Uscite della Sede Apostolica."

f. 93. "Della Collettoria delli Regni di Spagna e Portougallo." No direct references to the Indies.

5091. "Lo Stato, e Forze ... di Spagna." r661. Many unimportant references to the Indies.

5114. ff. 96-127. Relation of Spain, I667, by A. P. d'Ambruno, ambassador extraordinary of France. Ff. I23-I24 refer, inferentially, to the Indies.

5118. Letters of Castagna. See Corsini 506. 
5121. ff. 2I 5-242. Instructions to the Archbishop of Patras, nuncio in France. Mar. I, I627. See Corsini 2046.

5208. ff. 23-28. Ludovico — to Innocent XII., proposing that the world be divided into twelve apostolic provinces, each with a procurator at Rome. Maps were enclosed but are missing. There were to be two procurators for America.

ff. 36-44. Instructions to the nuncio in France on his relations with the Congregation of the Propaganda in France, and that at Rome. No date or name. Time, Gregory XV.

ff. 69. To Mgr. Sachetti, bishop of Gravina, nuncio to Spain. Folio 76 discusses the question of the Indies.

5259. Summary relation of England about 1662 , with discussions of the Portuguese marriage, and trade.

5263. ff. I-I6o. Brief relations of all the monarchs and potentates of the world. Time of Elizabeth. Unimportant references to the Indies.

5264. "Breve Relatione di tutti li Dominii de Regni et Provincie delle quattro parti del Mondo."

ff. 42-47. America.

5304. ff. IO2-IO7. Instructions to sub-collectors of spoils. I 592.

5312. ff. 6-27. Apr., I635. Instructions to the Archbishop of Thebes, nuncio in Flanders: to correspond with the Propaganda; to exhort King of Spain to continue war with Holland, pointing out the danger of the Indies from the Dutch.

ff. 79-I29. Instructions to Sachetti. See 5208.

ff. I4O-I 48. Enumeration of favors granted the King of Spain by Urban VIII., in regard to both Castile and the Indies.

5321. No. 6. ff. 59-68. Relations by the nuncio of Flanders to Leo XI. ( I605) concerning, chiefly, England and the Puritans.

ff. I6I-I62. Instructions to sub-collectors of spoils in Spain.

5327. ff. 269-298. From Fra Girolamo Sera de Castros to Cardinal Barberini, Protector of the Order of Franciscans. "Relationi delle Provincie e Conventi di $\mathrm{d}^{\circ}$ Ordine nell'Indie del Pre ... già Visitatore delle Medo Emminent ${ }^{\mathrm{mo}}$ e Rev $^{\mathrm{mo}}$ Sigre." Descriptions of the various provinces.

5338. ff. 286-3 Io. Victory of the Marquis of Santa Cruz off the Azores. I 582 .

5341. ff. 5I-65. "Breve Trattato sopra il Governo di Spagna." Time of Philip III. ff. 57-6I on the Indies.

5342. ff. 67-I46. Relation of Philip II., by Tommaso Contarini. Apr. 20, I 596. See, however, Urbinate 833.

ff. I92-230. Relation of Philip II., by Vendramino. I 595. ff. 99-IOI on the Western Indies.

5439. Relation of the court of Spain at the time of Philip IV., by Antonio Minutoli, ambassador of the republic of Lucca. I662. II $2 \mathrm{ff}$. Casual references to the Indies.

5630. Instructions to Sachetti. See 5208.

ff. 4I-9O. Notes on Spain for Sachetti, with references to the fleet and the ecclesiastical revenue.

5641. f. I I9. Extract from letter from London, June 3, I688, with account of earthquake at Lima and other parts of America, Mar. 20, I688. 
5652. ff. I-7. Description of treatises on the four parts of the world by Carlo Giangolini. Unimportant.

5788. Instructions to nuncios.

ff. 338-346. Considerations on the marriage of the Prince of Wales with the Infanta. See 3453.

5835. Feb. I2, I594. Secretary of state to Caetano, nuncio in Spain, on the division of the Augustinian province of Mexico from that of Castile; and on the discipline of regulars in America.

5872. ff. 33, 83, I79. Jan. 23, I607. From Cardinal Barberini, nuncio in France, on the designs of the Dutch against the fleet of the Indies.

6335. Papers relating to the Holy Office.

ff. 312-313. Dec. 4, I627. From the Holy Office to the nuncio in Spain, on petitions from the brothers of the Order of Mercedes of Peru, with regard to street-preaching prohibited by the bishops.

8508. f. 75. Dec. 7, 26, I622. From Pietro Camerino, secretary of the Apostolic Camera, from Spain, on the disaster to the fleet.

8509. Letters from Pietro Camerino, secretary of the Apostolic Camera, from Spain. I608-162 I.

f. 63. Oct. 20, I6r7. Rumor that the English, Dutch, and Moors have occupied several islands to intercept the fleet of the Indies.

f. 86. Nov. I7, I6I2. Arrival of the fleet.

8512. ff. 47, and 6I-66. Jan. 31, 1623. From the fiscal of the collector of Spain, on controversies over the spoils of the Bishop of Chili.

f. 57. Nov. 2, I623. From Juan Spinosa, formerly General of the Franciscans of the Indies.

f. 57. News of the fleet, without date.

8583. ff. 44-46. June 30, I645. Juan Merinero, General of the Franciscans, from Madrid, to Cardinal Barberini, on the Franciscans and the Council of the Indies.

8620. ff. 67-68. Copy of the relation of Maryland sent by Mgr. Rossetti, when in London, to the Propaganda. I641.

8633-8637. These numbers contain the correspondence of Gregorio Panzani, relating to England, from Sept. 7, 1634, to May 7, 1637, which is here much more complete than in the nunziatura of England. Copies in the Public Record Office of London, "Transcripts from the Barberini Library", I., Miscellanea, no. XVII., were examined, and the references found in them are noted here. As the arrangement is chronological, the date is sufficient indication.

8634. Aug. 22, 29, Oct. 3, I635. Panzani to Barberini, from London, on Lord Baltimore's oath.

8635. Dec. 5, I635. From Rome to Panzani, response on same subject.

8636. Jan. I7, Feb. 27, I636. From Rome to Panzani, response on same subject.

8646-8655. These numbers contain the correspondence of Count Carlo Rossetti, from London and from Cologne, from June 16, I639, to August, r643, which is more complete here than in the munziature of England and Cologne. Copies of this correspondence are in the Public Record Office of London, "Transcripts from Rome", numbers 18-23. Whether these were made from these volumes or from those in the munziatura, is not clear, but as the arrangement is chronological, the notes taken apply to either set, and are given here. 
8646. Sept. 30, r639. News letter from Rossetti in London on the proposition of the Earl of Arundel to found a colony in "Malagascar", where Catholics may settle, which Rossetti has urged upon the King.

Nov. 5, Dec. 30, r639. Comments on progress of plan mentioned above.

8650. Oct. I9, I64I. "Mi dispiace che il stato delle cose di la non dimostrano aperture di momento ma tutto a dispositione del Parliamento et la nuova compagnia delle Indie et di Affrica quale si tratta strettamente da i mercanti di Londra e un mero effetto della nova Republica."

8690. ff. I73-I75. Sept. 7, I64I. Rossetti to Cardinal Barberini on Maryland. Printed in American Historical Revicw, XII. 584.

In addition to these specific references, the following material of possible importance is noted :

794-800. Declarations and decrees of the Council of Trent.

801-808, 810-812, 814-822, 824-827, 829-830, 833-842, 846-860, 862-868, $879-897$. Letters and other material relating to the Congregation of the Council.

1513-1521, 1537-1538, 1585-1586, 1593, 1596-1613, 1618. Decisions of

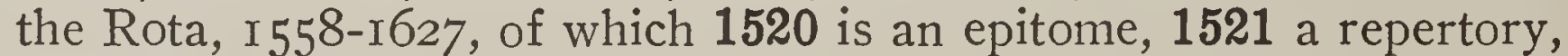
and 1538 an index.

1933-1936. Letters and bulls.

1937-1939. Letters of Cardinal Barberini to princes and learned men. r636-r649.

1961. Letters of Innocent X. and Cardinal Pamphili. r644-r647.

1980. Briefs of Pius V. and Sixtus V.

1981. Briefs to princes from Urban VIII.

1984-1985. Apostolic letters, Pius V. to Gregory XIV.

1988. Latin letters of Urban VIII. and Cardinal Barberini.

1992. Register of Cardinal Aldobrandini.

1998. Briefs to princes. 1623 .

2000. Briefs to princes. I605-I623.

2023. Brevia of Urban VIII.

2042. Letters of Cardinal Caraffa. r645-r655 (?).

2043. Brevia of Clement VIII.

2050. Index of letters of Cardinal Piccolomini.

2053. Letters of Cardinal Barberini, Paul V., Urban VIII.

2073. Brevia of Innocent IX., Clement VIII., Paul V., Gregory XV.

2086. Miscellaneous treaties. 399-r689.

2116. Letters of Ubaldini, legate in France.

2127-2128. Brevia, sixteenth and seventeenth centuries.

2166-2171, and 2189. Letters to Urban VIII. and Cardinal Barberini.

2190. Urban VIII. and England.

2193-2202, 2204-2206. Briefs of Urban VIII. to princes and others.

2412. Instructions.

2736. Instructions for nuncio in Spain from Paul IV.

2794-2821, 2845-2846. These numbers, and some others, contain diaries, for the most part those of the masters of ceremonies, the value of which is discussed in the account of that archive.

2837-2839, and 2845. Consistorial material, including votes, decrees, creations, acts, etc.

2841-2843. Brcvia, Clement VII. to Clement XI. 
2860-2863. Papal briefs, Alexander VI. to Paul IV. (I492-I 559).

2867-2933. Collection of acta of consistories. I492-I733.

2897, 2899-2901. Bulls of Urban VIII.

2934-2939. History of the Council of Trent.

3146-3149. "Acta Sacrae Congregationis Indicii", annotated. I6541704 .

3520-3526. News-letters, I650-1675, except I652, from various places.

$3620,3628,3638,4361,4997,5120,5155,5161,5168,5170,5182,5185$, $5198,5201,5214,5277,5280,5285,5302,5310,5337,5370,5452$, 5458, 5460, 5654, 5675, 5683, 5762. Relations of France and Spain. Many are in duplicate, triplicate, or even a greater number of copies. Most of them have been examined in other Roman collections, and the series as a whole is discussed in connection with Venice.

4785, 5041. Diary of the voyage of Cardinal Barberini in Spain in I626. 4993-4995. Histories of Spain. Portugal, England, France.

5150. No. 2. Spanocchi to Philip II. See 2512.

5235, 5314. Charles V. to Philip II., on consigning his kingdoms. See Capponian $125 \%$.

5691. Instructions to the Archbishop of Thebes, nuncio in Flanders. I635. See page 49.

5722-5725. Letters of bishops.

5741-5745. Letters and instructions to nuncios, under Gregory XIII., with some other letters.

5776. Letters of Cardinal Aldobrandini to nuncios. I 595-I 596.

5836-5844. Letters of Cardinal Aldobrandini to Caetano, nuncio in Spain.

5846. Letters of the nuncio in Spain. I 592-I 593.

5847-5851. Correspondence with the nuncio in Spain. r60o-r605.

5860. Register of ciphers with France.

5865. Register of ciphers with Spain.

5870-5871. Sheets and draughts of Cardinal Barberini, nuncio extraordinary in France under Paul V. ( $1605-1621$ ).

5873-5903, 5910-5911, 5913-5915, 5958. Correspondence with the nuncio in France. I609-1624.

5909, 5933-5934. Letters to nuncio and others in Spain. I605-16г 5, I621.

5917. Letters to the nuncio in Flanders.

5956. Letters to divers persons in Italy and Spain.

6004. Mazarini (afterward cardinal) to Cardinal Barberini. r631-1632.

6007-6008. Cardinal Barberini to nuncios. I623-1632, I642.

6013-6015. Cardinal Barberini to divers persons. I623-1639.

6094-6108. Correspondence with the nuncio in France. I624-1656.

6113-6132. Correspondence with the nuncio in Spain. I623-1643.

6138. Letters from the Venetian ambassador in London, to Venice.

6140-6142. Letters from the nuncio in Flanders. 1627-1638.

6149-6150. Ciphers from France. I625.

6151. Correspondence of Cardinal Barberini while in France, with divers persons. I625.

6152. Ciphers from Cardinal Barberini while in Spain. r621.

6154. Letters from France. I644.

6172-6173. Cardinal Mazarini to divers persons.

6203-6211. Correspondence with the nuncio in Flanders. I623-I644.

6212-6216. Correspondence with the nuncio in France. I623-I644. 
6230. Letters to the nuncio in Spain. I644.

6235. Letters to nuncios extraordinary. I628-I632.

6338-64:35. A collection of news-letters from Rome, Venice, Paris, Antwerp, and other cities, extending from I60 I to I760.

6438-6440. Letters and minutes of letters of Urban VIII. ( I623-I644).

There are also interspersed with the numbers cited from 5800 to 6559 many volumes of correspondence between Cardinal Barberini and princes, bishops, and individuals.

From this point the volumes are classed by countries, and the volume of the inventory is noted.

6792-6829 (vol. 25). These numbers relate to Flanders. There are some volumes of news-letters, and practically all the nuntiature material. I608-i674.

7938-8261 (vol. 30). These numbers relate to France. Practically all the correspondence with the kings, princes, bishops, and nuncios, from the reign of Henry IV. through the first half of the seventeenth century, is found here.

8262-8612 (vol. 3I). These numbers relate to Spain and Portugal, which were united during most of this period. In addition to the correspondence with royal persons, bishops, and nuncios, most of which is found in the regular series of letters of the secretary of state, there is much with minor papal officials, which I have not found elsewhere. Many of these were examined and are noted above. The others follow:

8508. Letters from the secretary of the Apostolic Camera.

8511. "Collectoria." I608-1644.

8520-8521. Letters from the fiscal of the collector. I606-I609, I636I64I.

8517-8519. Letters from the auditor of the nuncio. I637-I642.

8526. Letters from the secretary of the nuncio. I62I-I622.

8527. Letters from auditors. I62 I-I622.

8573-8583. Letters from bishops, among which, in 8577 , is a letter from the Bishop of Mechoacan, Mar. 22, I622, and from the Archbishop of Mexico, Mar. 8, I627.

8614-8773 (vol. 32). These volumes relate to England. All of these likely to contain material were examined except the following:

8671-8672. News-letters from London. I626-I64I.

The remaining volumes relate to the pontifical states.

\section{BORGIA COLLECTION.}

This collection was formerly in the Museo Borgia, in the palace of the Propaganda. It is maintained at the Vatican as a separate unit. There is a provisional inventory, which seems to be incomplete, and is without number, among the Vatican indices.

Numbers $32,45,47,49,50,62,70,77$, and 99 were examined without result. Number 65, "Scritti appartenenti alla S. C. di Prop. Fide", I708I $7 \mathrm{II}$, was at the bindery. Of possible interest is the following:

66. "Episcoporum: Breve Compendio di Decreti et Ordini fatti dalla Sac. Cong ne dei Vescovi, I604-1644" (actually I653). This contains many originals and descriptions of sources, and a subjectindex, but time did not suffice to complete its examination.

71. Second volume of the above, covering the same years. 
There are also belonging to this collection various maps, but these do not include the well-known large-size Borgia maps, which remain at the Museo Borgia, and the collection was not examined.

\section{CAPPONIAN COLLECTION.}

This collection was left to the Vatican by Marchese Alessandro Gregorio Capponi of Florence, in $1745^{.}$. It consists of 286 codices, and has been kept intact. There is a manuscript index, number 16, among the inventories of the Library. Numbers 5\%, 10\%, 108, 164, and 167 were examined without result.

Of some interest is the following:

179. ff. 62, 8I-88. From "Discorsi della Monarchia di Spagna”, I598, on the need of maritime education.

\section{OTTOBONIAN COLLECTION.}

This collection, brought together by Cardinal Ottobuoni, who subsequently became Alexander VIII. (I689-I69I), is preserved as a separate unit. An alphabetical index, which is not very reliable, and an inventory exist. By means of these the collection was examined. Numbers 579, 688, 797, 910, $1066,1100,1109,1111,1655,1853,2352,2355,2405,2413,2415,2416,2421$, 2432, 2455, 2457, 2480, 2481, 2482, 2484, 2485, 2514, 2515, 2519, 2628, 2647, 2689, 2705, 2713, 2716, 2725, 2726, 2820, 2963, 3056, 3077, 3138, 3144, 3172, $3175,3185,3194,3252,3255$ were examined individually, and found to contain nothing pertinent. References to relevant material follow:

597. "Seis Libros de la Historia del Sto Officio de la Inquisicion", in 2 pts. Part 2, ff. 40I-405. Reference to the discovery of America.

895. pp. I4-2I, and 2476, ff. 9I-97. "Entrate del Regno di Spagna di Portogallo e del Turco col $n^{\circ}$ de Consegli e loro Qualità." Slight references to the Indies.

1013 and 2441, p. I74 seq. "L'Apocalipse Olandese di Bambone." Slight references to the Indies.

1063. $\mathrm{ff} .5^{2-77}$. Instructions to the nuncio in Spain. I621. See 1103.

ff. I30-I79. Instructions to the nuncio in Flanders. I621. See 1103.

1103. Various instructions to nuncios by Mgr. Agucchio. I621. They include those to the Archbishop of Thebes, nuncio in Spain, to exhort the King to defend the Indies; and those to the Archbishop of Patras, nuncio in Flanders, to assume charge of affairs in England.

1257, 1782, 2434, 2480, 3140, ff. I I3-I 4I , 425\%. Charles V., " Ragionamento al Re Filippo suo figlio nella Conseguazione del Governo de' suoi Stati e Regni". Advice on government of the Indies."

1287. Relation of Spain by Domenico Zane. See Bolognetti 144, ff. 77-97.

1824. Relation of Spain. See Bolognetti 251, ff. I37-I46.

2206. ff. I37-I46. "Notizia sopra la Nuntiatura di Spagna." Printed in Römische Quartalschrift, VII. 447-48I. Without special reference to America.

${ }^{1}$ Catalogo della Libreria Capponi (Rome, I747) mentions numbers 18-25 and 29 as containing avvisi di Europa, I595, I620-I621, I632-1638. The relation of this library to that in the Vatican is not clear to me. There is still another library of the same name, that of Marchese Gino Capponi of Florence, of which a catalogue by Carlo Milannese, published at Florence in I845, exists.

${ }^{2}$ See B. Stübel, "Die Instructionen Carls V. für Philipp II.", in Mittheilungen des Instituts für Oesterreichische Geschichtsforschung, XXIII. 61 I-638. 
2245. On the ruin of the Spanish empire.

ff. IO7-I IO. On the Western Indies.

2417. ff. I68-300. Register of letters of Gregory XIII. to the nuncio in Spain. ff. I7I-I73. Feb. I, I579. On question of nuncio to reside in the Western Indies.

ff. I80-I8I. Mar. 23, I579. Same subject. Reference to discussion in the consistory. Question of augmenting the income of the churches of the Western Indies.

2432. ff. 28I-284; and 2604, ff. 376-43I, esp. 383-388; and 2708, ff. I4O-I65. Relation of Spain by Michele Suriano, Venetian ambassador. I 560. Reference to the Indies and their navigation.

2437. ff. 43-45. Relation of the nunciature of France. See Corsini 491.

2441. f. I33. "De classis hispaniae naufragio", near Florida.

p. I I4-I42. "Instrutt"ne per Monsig. Cena circa le cose d'Inghilterra l'anno 1632." To report to the nuncio of Flanders.

2447. f. I23. Account of the council for the Indies.

2471. Original letters of the nuncio in Spain, I645-I657, in 3 parts. Part I contains a calendar of all letters. Part I, f. 3IO. May I7, I648. Note of arrival of the galleons.

2486. f.285. Relation of Sweden in time of Queen Christina. English control navigation to the Indies.

2512. ff. 285-29I. "Discorso al Re Catto per l'Impressa d'Inghilterra del Cav ... Tiburtio Spannocchi." Mention of Drake's activities.

2527. ff. 298-301. Instructions to the Archbishop of Rossano, nuncio in Spain. See page 46.

2536. Miscellaneous letters of the Propaganda.

f. 45. Dec. 27, I625. P. Fran' Ingoli to Mgr. Agucchio, on the discovery of Avallonia by barefooted missionaries from England. See Propaganda, pages I23, I49.

f. I 50. Dec. 28, I630. Same to same, enclosing relation of New England.

f. I58. Said relation. See Propaganda, page I24.

f. I76. Same to same, on New Mexico.

2640. ff. I IO-I44. "Parezer sobre las Guerras con Hollanda, Inglaterra y del Stado desta Monarquia." Scattered references to the Indies.

2644. Instructions, I62 I-I624, all of which are noted elsewhere.

2675. f. 66. Relation of Spain by Antonio Tiepolo. I577. Short account of the revenue of New Spain. See also 2790, which is dated correctly, I568, and 3141, pp. 88-108.

2700. ff. 29-30. "Discorso sopra l'Indie de' Spagnuoli et Isole Canarie."

2721. ff. I-IO. Instructions to Mgr. Massimi, nuncio in Spain. Slight reference to the Indies.

This contains also various other instructions noted elsewhere, and at the beginning of an unpaged portion, a list of the countries and regions served by the various nuncios.

2723. "Een Korte Staet en Beschrijving van de Regeringe van de Zeven Vereenigde Provintien der Nederlanden.",

ff. 47-48. Discussion of the companies of the East and West Indies.

2730. ff. 290-309. "Relacion de todos los Consejos ... que residen en la corta di Espagna." 
3140. ff. I4I-I5I. "Ricordi del'Impe Carlo V. per suo Figluolo fatti Augusta l'anno I558."

f. I46. On the French in the Indies.

f. I 48. On the government of the Indies.

3155. f. 23. Copy of a brief of Clement X., prohibiting the publication of books on missions without the approval of the Propaganda.

f. 24. Letter of Mgr. Cerri on same subject. Mar. 20, I673.

f. 25. Copy of decree of the Propaganda on same subject. Mar. I, 1673.

3184. Extract from a relation of France by Gioan Correro, Venetian ambassador. I 57 r.

p. 384. Mentions the designs of the Huguenots on the Indies.

3189. pp. 326-330. Article, without date or signature, on the origin, force, and authority of the instructions to the first vicars apostolic. Addressed to Cardinal Passionei. (French.)

3206. f. I8I. To the Bishop of Padua, nuncio in Spain, on the voyage of Fra Francesco de Vittoria, Dominican, to India.

3218. Part II. f. 382. I62I. To the nuncio in Spain on "spoils".

3227. f. I I5. July 28, I629. Cipher from Abbé Giulio Massimi to the Bishop of Piacenza on Spanish pretense of peace to get fleet safely from the Indies.

In addition, the following may contain material:

594-595. Consistorial acts, I 570-I 574, by Cardinal S. Severina. Other acts are in 596, $5_{562-1565}$, by Cardinal Gambara; 913, I498-1644; 2481, I498-I620 ; 2961, Boniface VIII., Alexander VI., and Eugenius IV. ; 2419, p. 5 I 2 ; 2431, pp. 453-454, misc. ; 2519 contains consistorial "propositiones".

$682 ; 2519 ; 2604 ; 2829$, p. $198 ; 2648$, contain material on the Camera.

2449-2450, and 2458. Avrisi, 1646-1649, I65 I.

3337-3355, and 3358. Avvisi, I630-1653.

3356, 3357, and 3359-3363. Avvisi, 1690-1696.

There are also many lives and diaries of many popes.

\section{FULVIO ORSINI COLLECTION.}

This collection has apparently been absorbed into that of the Biblioteca Vaticana. A list entitled I Libri di Fulvio Orsino nella Biblioteca Vaticana, published in 1886 , reveals no American material.

\section{PALATINE LIBRARY.}

The books in Latin characters of this library are indexed in indice 13 of the Vatican Library, ${ }^{3}$ and the whole library in Ottobonian 1872. It is almost wholly ecclesiastical in character and for the most part antedates the discovery of America. No volumes were examined, and the inventories showed only one of possible importance to the subject: 1361, p. 486, "De ritu e moribus Indorum ", which probably refers to the East Indies. Ottobonian 2725, folio I86, gives an account of the acquisition of this collection.

\section{LIBRARY OF THE QUEEN OF SWEDEN.}

Much of the library collected by Queen Christina of Sweden during her long residence in the Corsini Palace has disappeared, but the larger part of

${ }^{3}$ It is also inventoried. Both seem reliable. 
it still remains as a separate collection in the Vatican Library. The manuscripts, ${ }^{4}$ except the Greek, are inventoried in the library indice 14, "Index Codicum Manuscriptorum Latinorum Reginae Suecorum ". The volumes of this collection are noticeably small and easy to handle, evincing the feminine taste of the queen. References to material relating to the subject follow:

603. Correr, "Relazione dell'Isola e Regno d'Inghilterra". See page 92.

650. "Relazione delle Dignità, Consigli, ecc. e tutt’altro spettante alla Corte e Regno di Spagna fatta nel Senato Veneto 1'anno" I620, ff. I-I28. ff. 32-34 on the Council of the Indies.

651. Relation of Spain by Leonardo Moro, Venetian ambassador. I627. ff. 55-6r. "Dell'America ò Mondo Nuovo."

659. "Indiarum Occidentalium, quae Hispanorum Regi parent, Descriptio et de Americanorum Politica ac Moribus; adjecta resolutione cujusdam casus. Apologetica Historia Summaria ... de las Gentes de las Indias Occidentales y Meridionales, cuyo Imperio Soberano pertenece a los Reyes Catholicos." 2 I6 ff.

793. "Indiarum Novarum Rectorum aliorumq ab Hispaniarum Regibus eo missorum ab anno I496 ad annum I 59I." 5I ff.

1608. "Illmo et $\mathrm{Rm}^{\circ}$ Card ${ }^{\mathrm{li}}$ Baronio . . . dedit Doctor Gerardus Vossius." I606. This volume contains various philological notes, among which on ff. $23^{-25}$ is, "Quaedam Vocabula Linguae indorú occidentaliú nuper inventorú, q' sunt in regione et insula quae Nova Hispania appellatur"; carent alphabeto ".

\section{URBINATE COLLECTION. ${ }^{5}$}

This collection, the great majority of whose volumes belonged to the dukes of Urbino and were brought to Rome shortly after the incorporation of that duchy with the Papal States, is preserved in the Vatican Library as a separate entity. It is elaborately indexed in Vatican indice 17, compiled in I797 by Maurus Coster, and transcribed in $1875 .^{\circ}$ The Latin codices, that is, those in Latin script, are inventoried in three volumes. ${ }^{7}$ The collection is miscellaneous in character, its excellent collection of news-letters being perhaps its leading feature. It was exhaustively studied for American material by means of both index and inventory, and many volumes were called for which proved on examination to contain nothing of value. ${ }^{8}$ The references to material found follow :

696. "Nota di quanto importa tutta la Collettoria di Spagna dal primo d'Agosto 572 in tutto il tempo che ristretto il Vescovo di Padova." Mention of America.

829. pp. 596-602. "Regni et Stati del Rè Filippo, et del Gran Turco, con le loro Entrate, et Spese, et altre cose notabile." Mention of America.

pp. 636-640. "Entrate del Rè di Spagna et del Rè di Portogallo et del Turco." Mention of America.

${ }^{4}$ These do not include her personal manuscripts or archives, which are now in the college of medicine of the University of Montpellier. See "Catalogue des MSS. de la Reine Christina", by W. I. L. Westzynthius, Nov. 8, I88I, among the Vatican Library inventories.

5 "Vaticano-Urbinas."

" Compilavit Maurus Coster Bibliothecae Vaticanae, Latinae linguae Scriptor Anno Domini MDCCIIIC. Codicium Manuscriptorum index."

'Cosimus Stornajolo, Codices Urbinates Latini, vol. I., I-500 (Rome, I902). Other volumes with similar titles.

$853,855,862,863,864,1020,1702,1705,1731$. 
pp. 645-670. "Nota di tutti li Titolati di Spagna con le loro Casate, et Rendita che tengono, dove hanno li loro Stati et Habitationi."

833. f. $475 \mathrm{seq}$. Summary of the relation of Tommaso Contarini, Venetian ambassador, concerning Spain. About I580. Mention of America.

ff. 559-588. "Relatione della Nuova, et più remota Christianità dell'Indie Occidentali, delle Philippine, del Sito et Qualità loro." ff. 559562 describe the route thither by way of America.

834. Relation of the Catholic King, by Michele Suriano, Venetian ambassador. I 560. Mentions the danger of rebellion in the Western Indies.

836. ff. 48-I98. "Relatione brevissima della Distruttione dell'Indie, fatta dal Rev" Vescovo D. Frà Bartolomeo de las Casas, o Casaus dell'Ordine di San Dominico all Alt ${ }^{\mathrm{mo}}$ e Potent ${ }^{\mathrm{mo}}$ Sigre el Principe di Spagna Don Filippo II."

838. pp. 525-546. "Relatione di tutti li Titoli di Spagna con Casate e Linguaggi dove discendono come dell'Intrate che hanno e dove tengono i loro Stati."

849. f. I6r. Rome, May, I564. J. Agostino di Cravelis, "Ragioni che pretende Spagna con Francia circa la Precedenza". Mentions the services of Spain in converting the Indies.

854. pp. 304-308. Oct. 26, I585. Report of the Marquis of Santa Cruz, on Drake and the war in the Indies.

860. ff. 272-275. "Se si debba credere, ch'il nuovo Rè d'Inghilterra, sia per esser Amico del Rè di Spagna." About I603. Briefly mentions relations of English and Spaniards in America.

861. pp. I 5O-I 54. "Ragioni più importanti che dovrebbero indurre*gli Stati Generali di non cedere alla Navigatione, et Trafico dell'Indie." Chiefly relates to the East Indies.

pp. 296-365. "Humili Significationi à N. S. circa il modo di convertire li Heretici alla Santa Fede Cattolica." Relates chiefly to the European situation at the beginning of the seventeenth century.

865. ff. 540-550. Mar. 25, I 588. Orders of Don Alonzo Perez de Guzman, duke of Medina Sidonia, and captain-general of the coast of Andalusia, to the general of the ocean sea, containing much about the navigation to the Western Indies.

866. ff. 512 seq. "Raccordi dell'Impre Carlo V. per suo Figlio fatto in Augusta l'anno MDXLVIII." See Ottobonian 1257.

867. ff. 34-8o. "Advertencias del Emperador Carlos Quinto que . . escritas de manu, al Rey Don Philipe $2^{\circ}$ su Hijo." This second guide to good government warns Philip of the maritime activity of the French, and the necessity of keeping up the fleet. $60 \mathrm{ff}$.

897. ff. 85-I I4. "Relatione di Spagna." I606. ff. 95-96 give an account of the Council of the Indies.

1038-1108. These numbers contain a series of news-letters from Antwerp, Paris, Rome, Venice, Milan, Constantinople, and other places, running continuously from I554 to I640. The series is completed to I648 by codices $1573-1581,1621$ (A-C), 1622 (A-C), 1623 (A, B), and 1690 , while codex 1727 contains letters of I679-I680. Everything relating to England has been copied for the Public Record Office of London, and is to be found there in Roman Transcripts, series II., numbers 1-7. Owing to pressure for time the copies corresponding to numbers $1038-1087$ were used. To give an idea of 
their contents, but not assuming that their American material is exhausted, these notes are given:

1039. f. 293. July 24, I56r. French corsairs intercept the fleet of the Indies.

1041. ff. 2-4, Jan. 3 ; ff. 9-Io, Jan. 23 ; ff. 2I-22, Feb. I 3 ; ff. 23-24, Feb. 7 ; f. 29, Feb. 27 ; f. 39, Mar. I2; f. 46 , Mar. I9; f. 52 , May I ; f. 55 , Apr. 8; f. I29, Aug. I ; f. I39, Aug. 8; f. I4I, Aug. 22 ; f. I66, Oct. 8 ; f. I8I, Nov. 8 ; all of I 569 ; f. 2 I3 3 Jan. 2 ; f. 24I, Mar. 8; f. 258, Apr. 9 ; f. 260, Mar. 26 ; f. 262 , Apr. I ; f. 265 , Apr. I6; f. 298, June 22 ; f. 303 , July 9; f. 328 , Aug. 5 ; f. 332, Aug. 30 ; f. 363, Oct. 3I ; f. 4I7, June I7; all of I 570. Maritime news chiefly from Antwerp, and relating to the French corsairs and the detention of Spanish ships in England.

1042. f. 35, Mar. 16, I 57 r, from Rome; f. 5 I, Apr. I4, I 57 I, from Brussels. Same subjects as in preceding, with references passim to Breton corsairs.

1048. Apr. 30, I 580 (no folio number given). English corsairs rob the fleet of the Indies.

p. 299, Nov. 26; p. 302, Dec. 3, I 580. News of "Dragh".

1049. July I, I 58r, from Venice. Suggestion of impending attack on the Indies by Don Antonio, aided by the French and English.

June I7, and June I9, I58I, from London. Rumors of attack on the Indies by Drake.

There is also much news of the maritime conflict in the Atlantic generally.

1053. Aug. 8, I585. Rumor that "Dragone" has taken an island belonging to the King of Spain.

Nov., I 585, from Cologne. Rumor of settlement by the English, " nell'Isola Florida presso Nerimberga in Terranuova, et pianura del paese Viganderon".

Nov. 2I, I585. News that the English fleet in Florida has taken a ship of the fleet of the Indies.

1054. Mar. I6, I586. Drake said to have disembarked a thousand soldiers in Florida.

Apr. 26, I586, from Venice. The English corsairs fortifying themselves in Florida, "d'impadronirsi dell' passo della Navig"ne delle flotte".

May 22, I 587 , from Cologne. Rumors that Drake will settle in the Indies with his family.

1057. Much of the Spanish Armada and Drake.

1060. f. 450. Aug. 29, I 582, from Venice. Intention of Captain Candis [Cavendish] to circumnavigate America.

1062. Sept., I 594, from Antwerp. Three Dutch vessels undertake a new and shorter route to the Western Indies.

1064. f. 47 I. Aug. 3, I 596, from Rome. Spanish discussions of the likelihood of English settlements in the Western Indies.

1072. Mar. I9, I604, from Antwerp; Mar. 26 and June 5, I604, from Venice; July $3 \mathrm{I}$ and Aug. I4, I604, from Rome; and Oct. 2, I604, from Venice; on the question of the Western Indies and the peace between England and Spain.

1075. Dec. I 5, I607, from Venice. On the finding of gold by the English in the Western Indies. 
1076. June 28, I608, from Venice. News from "Veginia".

Aug. 30, I608, from Venice. Rumor of rupture of relations between England and Spain, regarding "Isole nell'Indie".

Sept. 28, 1608, from Cologne. On the discovery of gold in the Indies by the English.

1077. Nov. 21, I609, from Venice. Report that the King of England is raising troops for Virginia.

May 8, I609, from Antwerp. On the sailing of a colony to Virginia.

1078. Mar. I2, I6 10 , from Rome. Sailing of ten vessels for Virginia.

1079. Feb. I8, I6 I I, from Antwerp. Twelve thousand English and Scots in Virginia.

June I0, I6I I, from Antwerp. English in Virginia increase daily.

Sept. 30, I6I I, from Antwerp. Spanish expedition against the English and Dutch in the Indies.

Nov. I I, I6I I, from Antwerp. Mention of "Nova Francia". Expedition of the English to China by way of "Nova Sembla".

1080. Aug. 30, I6I2, from Antwerp. James I., on the rights of the English to Virginia.

May I9, Aug. I8, I6ı2, from Rome. Dispatch of "Don Pietro Ginnica" to England concerning the Indies.

Oct. I 5, Oct. 28, I6 12. On Virginia.

1081. Feb. 8, I6I3, from Antwerp. The Spaniards prepare 80 vessels at Naples, to use against Virginia.

Mar. I, I6I3, from Antwerp. The Dutch prepare to help the English.

Mar. 29, I6I3, from Antwerp. 'The English prepare to meet the Spanish attack.

May 24, June 2I, I6I3, from Antwerp. Spanish successes in Virginia.

June 28, I6I3, from Antwerp. New discoveries near Virginia.

July 5, I6 13 , from Antwerp. Fighting near Virginia.

Sept. 6, I6I3, from Antwerp. Dispute between Dutch and English in "Nova Sembla".

Sept. I3, I6I3, from Antwerp. Negotiations relating to the Indies.

Oct. 6, I6I3, from Cologne. English fleet for the Indies.

Nov. 6, I6I3, from Antwerp. On Bermuda.

Nov. 29, I6I3, from Antwerp. English fleet for Virginia.

1082. Jan. 3, I6I3, from Antwerp. New system of proprietorship for the Indies.

1083. June 30, I6I5, from Antwerp. Spanish successes in Virginia.

1085. May 5, I6I7, from Antwerp. Sir Walter Raleigh sails for "I'Indie Occidentali ".

June 23, I6I7, from Antwerp. Arrival in England of vessels from the Western Indies, with valuable cargo.

1086. July I3, I6I8, from Antwerp. On "Compagnie d'Olandesi et Zelandesi destinate per 1'Indie Occidentali".

Oct. 28, I6I8, from Cologne. Differences between the Dutch and English.

1087. May 3I, I6I9, from Venice. Differences between the Dutch and English in the Western Indies.

1113. f. 610, Aug. 23, I 588, from Lisbon. News of the arrival of Drake from Florida.

f. 628. Apr. 7, I 586, from Madrid. Drake in Santo Domingo. 
ff. 672-676. Advice to Philip II. with regard to Drake. Also other news of the activity of Drake and the trade of the Indies.

1114. f. 34I. "Relacion de La Plata, et della Terrafirma, Nuova Spagna, e Honduras, I626, de Generale de las Indias."

1115-1117. Spanish news-letters, from Madrid and Paris. Much on Drake, but nothing was noted with regard to the English colonies.

1743. p. 74 seq. Extract from the history of India of P. Pio Pietro Maffei.

There are also many diaries of popes and of conclaves and much material on the Council of Trent.

\section{BIBLIOTHECA VATICANA.}

This title applies particularly to the central collection of manuscripts, which has formed a nucleus about which the special collections have been grouped. ${ }^{2}$ To it are added all accessions of manuscripts which do not obviously belong elsewhere, and which do not require to be preserved as special collections. It is then the growing member, and is miscellaneous in character. Thirteen volumes of inventories list 985 I manuscripts in Latin characters. The earlier numbers present some attempt at classification, as do similar inventories elsewhere, but the constant accession of new manuscripts, often singly or in small groups, has rendered the arrangement of the later numbers entirely promiscuous. There are several thousand manuscripts as yet not listed, or rather the lists of which are not yet made public; but where sufficient description can be given, they are brought for use. The inventory deserves remark for the splendid scholarship displayed in its preparation.

Of the volumes of the collection, the following numbers were examined without result: $1565,4807,5478,5565,5602,5649,6180,6206,7097,7252$, $7523,7900,8215,8246,8258,8322,8340,8498,8638,8879,9200,9260-9293$, 9398, 9792.

References to pertinent material follow:

3198. ff. I67-I68. Part of a relation of the Council of Trent, and treating of the privileges to be conceded to American bishops.

3738. This is the famous Rios Codex Mexicanus. The original and a copy of the reproduction made in 1900 are served by the same number.

3773. This is the famous Codex Mexicanus Vaticanus. The original and a copy of the reproduction of 1896 are served by the same number.

6227. f. 58. Jan. 25, I 597. Avvisi from Antwerp, on Queen Elizabeth and the plan to fortify a place in Spain or Africa to command Gibraltar.

f. 60. Feb. 20, I 597. Avvisi from Antwerp. "Rawleo" to transplant heresy to the Western Indies.

f. 68. Mar. 28, I 597. Avvisi from Antwerp. Expedition of "Rawleo" and the Dutch to the Western Indies. There are also other items on this subject.

ff. 94-96. Aug., I 599. "Los Cabos principales de la Apologia del Conte d'Essex", containing mention of the fleet of the Indies.

Dec. 26, I 598. Queen Elizabeth holds back expedition of Gilbert to Guiana. Indians in London.

6559. ff. I6I-I62. I533. Letter from Panama concerning gold sent from Peru to the emperor. See Castello, arm. XIV., no. 93, p. 23.

- Thus Pastor, Geschichte der Päpste, III. 125, mentions the libraries of Baronius, Orsini (Fulvio), and Sirleti, all of which seem to have been assimilated. This is the case also with the famous and important collection of Cardinal Mai. 
7210. “Memorie intorno alle Missioni di Asia, Africa ed America estratte dall' Archivio di Propaganda d'ordine di Clemente XI., da Nicolò Forteguerre Canonico di S. Pietro, e da lui a Benedetto XIII. dedicato", with preface and index. $484 \mathrm{ff}$. See Bolognetti 143.

7388. "Varia super Cruciata." Time of Philip II.

7586. Atlas of the world. I 536 (?). No. 6 gives America, Africa, and the Indies; no. 7 , the world. See Barberini 4431.

7750. ff. I 18-I24. "Todas las Rentas que el Rey Catholico tiene en España, Indias y los Regnos de Napola y Çiçilia, estado de Milan y los de Flandes y lo que de ellos esta empeñado fuera de los de Portugal y sus Señorias."

7902 and $7902 \mathrm{~A}$. Necrology of Jesuits who died outside the city. I557I750. Mere mention of deaths.

8064. Galetti collection. ff. 200-282, America. This is largely composed of copies from the Propaganda, and belonging to the eighteenth century.

ff. 220-227. Ristretto on letter of Abbé Isle-Dieu, vicar-general of the Bishop of Quebec, concerning chiefly the quarrels of the Jestuits and Capuchins.

ff. 228-229. July 9, I759. Notes on the same subject.

ff. 27I-278. On negro slavery.

8065. "Notitia Episcopatuum Titularium." Unimportant.

8638. ff. 8I-9I. Relation of Spain by Suriano, with notices of the Indies.

8847. Heroic poem on Amerigo Vespucci. Autograph. 48 ff., 298 lines. Sixteenth century. "Io cantero di quel gran Tosco ardito."

9201. ff. 9I-98 (or I86-I92). "C. Colon ad Raphaelum Sanctis." Unimportant copy.

9427. ff. 28-34. Miscellany on the collectorship of Spain, in time of Gregory XIII. Nothing specifically on America.

ff. 38-48. Instructions to Giovanni Batt'a Orfino, collector-general in Spain.

9450. Honorisiani Balsamini, "Della Patria, Familia e Vita di Christoforo Colombo". Seventeenth century. I65 ff.

9452. "Archeologia hoc est de Antiquitatium Ligurogenuensiū Libri quattuor ex veterum Scriptorum Schediis Historicis compacti a f. Johanne Maria Bolfino."

Part I., no. I2. "Cristoforo Colombo Maestro primo della Navigatione per il vasto y gia inaccesso Oceano .. Onorijiano Bolcamini." $29 \mathrm{ff}$.

Old edition of the letter of Columbus to Sanctis.

Pt. II. P. Borgino, "Delle Cose di Cristoforo Colombo". $30 \mathrm{ff}$.

No. I8. "Documenti Publici, Scrittū autentiche e Memorie certe", concerning the family of Columbus. Collected by Onorigiano Balziaminus. I $4 \mathrm{ff}$. and $2 \mathrm{I} \mathrm{ff}$.

No. 20. Fragment of the will of Columbus. $9 \mathrm{ff}$.

No. 21. Miscellaneous notes on Columbus. $4 \mathrm{ff}$.

No. 22. "Cristofor Colo. Inventor della Navigatione per 1'Alto." 6 pp. No. 23. Apr. 29, I493. Columbus to the Treasurer of the King. I f. After No. 23. Notes in Spanish on the family of Columbus. $4 \mathrm{ff}$.

No. 24. "De Ambitu Globi terraeque. F. Johannis Marie Botzini." $40 \mathrm{ff}$. 
9565. ff. I25-I53. From a report on all dioceses subject to the Propaganda, of about 1839. These pages concern America. The reports consist of outlined blanks filled in, and are mostly statistical. Note is made of the importance of the Associazione Leopoldina of Vienna, for America. P. I43, on Santo Domingo: "La trattativa degli affari di Religione de quest' Isola è stata trasferita da quel che anno alla Congr. degli affari ecclesi. Straord."

ff. I74-187. Catalogo de Vicari, Delegati, e Prefetti Apostolici dalla Santa Sede stabiliti in ogni parte del mondo. Printed, with some manuscript notes. About 1840 . From the collection of Cardinal Mai. On the assignment of districts by the Propaganda.

10364. "Differenza fra l'Inghilterra e le Colonie dell' America." 436 pp. From the Visconti collection, where it was numbered $79 \mathrm{~A}$. This volume consists of extracts and summaries of such news and documents relating to America as the collector, Mgr. Lazzari, was able to gather, forming a sort of diary of the Revolution. The work is well done, but the collector's opportunities were not such as to bring him anything of unique interest.

pp. I-3. Convention government in Massachusetts.

pp. 3-20. Congress at Philadelphia.

pp. 20-26. Treaty of peace with the Indians.

pp. 27-30. Battle of Kenhawa.

pp. 31-34. Battle of Oct. IO, I774, on the Ohio.

pp. 42-63. Concern of English manufacturers and merchants in the contest with the colonies, etc.

Not examined but of possible interest are the following:

9427. Instructions to nuncios during the sixteenth and seventeenth centuries. These are partly originals bearing manuscript corrections.

9435. A relation of France. I 570 .

\section{VISCONTI COLLECTION. ${ }^{10}$}

This collection was acquired by Leo XIII., in I888. It has been assimilated with the Biblioteca Vaticana, but the inventory listing the volumes with their new numbers is not yet ready. There exists, however, an "Elenco di Manuscritti e Carte appartenenti alla Eredità del Barone P. E. Visconti", prepared at the time it was offered for sale.

The following numbers were noted as of possible pertinence:

28. Income and expenditure of the Camera Apostolica. 1672-I69o.

79 A. See Biblioteca Vaticana 10364.

127. Minutes of letters of the nuncio in Spain. I62I.

145. Letters (62) of cardinals, bishops, nuncios and other prelates, to Cardinal Giulio Rospigliosi, later Clement IX.

${ }^{10}$ Saggio Bibliografico dei Lavori compinti nella Biblioteca Vaticana durante il Pontificato di Leone XIII. (Rome, I903, pp. 32) ; I. Carini, Di alcuni Lavori ed Acquisti della Biblioteca Vaticana nel Pontificato di Leone XIII. (Rome, I892, p. I87). 


\section{PROPAGANDA FIDE. ${ }^{1}$}

As early as 568 a congregation of four cardinals for the conversion of infidels existed, but this was apparently merely a temporary body, appointed for some special purpose ; ${ }^{2}$ nor did Sixtus V. create, as a part of his system of congregational government, any department charged with the important work of missions. The need for it, however, was soon and strongly felt; to such an extent that Clement VIII. (I 592-I605) called together and regularly consulted a committee on these subjects, although obstacles arose which prevented its being made a formal congregation. Finally, in I622, Gregory XV. established the congregation as it has since existed. It is characteristic of its history that its first meeting was on June I4, while the constitutio organizing it is dated June $22 .^{3}$ In fact this constitution does not define its duties and powers, and these have to be judged from a study of its activities. Once in existence, the Propaganda lost little time in growth, and under the care of the Barberini (1623-I644) speedily assumed the important rôle in the papal administration which it was to hold for two hundred and eighty-six years.

The duty of the Propaganda is not to infidels alone. In fact when it was founded the primary object was the conversion of heretics. Its field of labor, therefore, was well-nigh universal, and by no means confined, as it practically is to-day, to countries officially considered non-Christian. ${ }^{4}$ It was not intended that all this vast labor should be done directly by the Propaganda or its subordinates. The whole history of Christianity has been one of propagation, and the Catholic church was already well supplied with missionary organs. The business of the new congregation was the direction and correlation of these forces, and only secondarily actual missionary work. It might well be supposed that the difficulties of such a task would prove greater than if a clear field had existed. As concerns America, the first of these questions of adjustment was with Spain. The hostility of the Spanish government to any direct interference with its American possessions has already been pointed out, and its claim to direct the whole work of propagation in those continents. In I659 the nuncio was still in conflict, in behalf of the Propaganda, with the Council of the Indies, fearing to license missionaries lest it be taken as an affront. The financial difficulties of Spain in the next few years seem to have weakened its position; at least its claims were not so strenuously insisted upon.

A more permanent source of annoyance was with the various monastic orders, which considered the work of missions peculiarly their own. Here the question was not so much one of jurisdiction, for the orders seem to have cooperated easily with the new congregation and were in fact its chief agents; but as to the disputes between the several orders. In I673 the general of the Dominicans was refused permission to have certain copies made from the

${ }^{1}$ Joseph Frari, The Propaganda (Baltimore, I902, pp. 20) ; Th. Trede, Die Propaganda Fide in Rom: Ihre Geschichte und Bedentung (Berlin, I889, pp. 32).

${ }^{2}$ Nun. di Spagna IV., f. 82, Aug. I4, I568.

- Collectanea S. Congregationis de Propaganda Fide, I. I-3.

"See Casanatense, cod. 2046, "Relatione della Nunziatura di Francia", Oct. 27, I6́23, p. 292.

Scrit. Rif. Prop. Fide, 258, Apr. 30, 1659. See also Cause, 321. 
Propaganda archives: "Perche contengano molte querele contro i Gesuiti, capuccini, carmelitani, et altre religiosi, contro i Preti, contra i Governatori di quelle Provincie, e contro i Med ${ }^{i}$ superiori di quelli Dominicani, accusati di poco zelo per le missioni, e se si publicassero sarebbero di poco honore alla religione, e di poco edificatione al mondo." " The difficulty of regulating the relation of the members of the orders and the secular clergy was not light, while that of dealing with bishops within whose dioceses missionary work was carried on seemed at times almost insuperable. The fact, however, that the Propaganda proved able to deal successfully with these problems, soon gave it a commanding position in the hierarchy.

While the field of the Propaganda's labor was wherever unbelief existed, there were certain portions of the world which came to be particularly its own, and where it exercised special powers. Both the Americas fell under this category, although there was a distinction between those regions where episcopal government was fully organized under a friendly government, and where this was not the case. One of the first actions of the congregation was to divide the world into provinces and direct one of the nuncios to act as its representative in each. To him of Spain, fell naturally Spanish America; to him of France, the French colonies; and to the nuncio at Brussels, England and Holland with their respective American possessions. ${ }^{8}$ The business of the nuncio in this connection was not very laborious. He forwarded documents backwards and forwards, ${ }^{\circ}$ attended to the questions arising between the Propaganda and the government to which he was accredited, directly, if they were not important, or through the interposition of the secretary of state, if they were, and occasionally saw to the execution of decrees. ${ }^{10}$

How the Propaganda secured its control over the Spanish American bishops is not quite clear. The king possessed the right of nomination, and the earlier system was that the names he selected should go through the regular diplomatic channels. The bishoprics were not established on any special basis, and the ground for differentiation in treatment is not clear, as they were from the beginning part of the regular Spanish ecclesiastical system. Actually, however, in later practice, such nominations, instead of going to the Congregation of the Consistory, went to the Propaganda, which prepared and circulated among the cardinals the "proposition", and in the next consistory presented the name." Once appointed, the bishops paid little attention to the Propaganda, whose connection with their selection was in fact only formal; but some degree of control was maintained through the granting of special privileges, or facolta. 'These gave the recipient permission to perform certain functions not inherent to his position, but which properly belonged to the Roman authorities; such as to give absolution from certain sins reserved ordinarily to the penitentiary, or to permit marriage within certain prohibited degrees of affinity, or to celebrate mass in unusual places. The Propaganda soon arranged certain classes of facoltà, including different combinations of privileges ap-

- Atti, r673, May 8, no. 4.

${ }^{7}$ See series Cause, passim.

s Atti, vol. I., p. 3, Feb. 4, I622.

9 The missions in English America were, in fact, managed by the Vicar Apostolic in London. See Atti, r756, p. 352, Jan. 25.

${ }^{10}$ The line of division was perhaps rather based upon whether the case was apt to complicate the general relationship of the papacy, than on its intrinsic importance. See, for instance, the negotiations with Franklin which were carried on directly by the Propaganda through the nuncio.

11 See series Udienze, where the propositions appear. 
plicable to persons in different positions. ${ }^{12}$ The privileges granted to ecclesiastics in America were especially great owing to the impossibility of bringing even cases of considerable importance across the Atlantic, and were desirable for the holder as well as for those he served, because of the fees attached. At first granted for fifteen years, an act of I670 made the period seven: "... perche si e poi veduto, che non si ricordano più della Sacra Conge, finche non venga la necessità di rinovarle "..13

Over the Bishop of Quebec the control of the Propaganda was more direct, for that see was, after a struggle with the French government, attached directly to the see of Rome, and not made part of the general ecclesiastical organization of France. Its occupants, moreover, were ever mindful of this relationship, if one may judge from the constant regularity of their correspondence. The same was true of the bishops of the United States, although circumstances had almost determined that they should become a part of the French system, to which the French colonial bishops had never belonged.

Over the minor clergy and laity engaged in missionary work, whether secular or regular, the system of control was fairly effective. Every worker required a license. ${ }^{14}$ This was not always given directly by the Propaganda to the individual, as the power to grant a certain number was sometimes delegated, or one license given to a body of persons; but this was never carried to the point of laxity. Such workers, moreover, always needed some grade of facolta ${ }^{15}$ and this was often granted for a shorter period than in the case of a bishop, requiring its holder to keep in touch with Rome. Between the privileges of a vicar apostolic and those of a bishop there was sufficient difference at least to treble the number of cases which could not be settled in America; which fact brought not only the vicar apostolic himself, but his clergy and people, more directly under the eye of the Pope or rather the Propaganda. For cases arising in America came, in Rome, to the Propaganda, which, to use the common Italian expression, carried all the congregations in corpo. This was not true of every case, and of those that were presented to it, the Propaganda referred many to the appropriate congregation ${ }^{16}$ or tribunal, but probably the major portion it handled itself. Most of these cases, together with much of its business with bishops and with others, were dealt with by means of procurators, whose business papers, if they exist and could be found, would give a more intimate view of the working of the machinery of the church than any source now known.

On Nov. I, I908, all those portions of the United States and Canada where the episcopal organization is established, together with England, Holland, and other regions, passed from the control of the Propaganda; whose powers in the future will be limited to those regions where the church system is incomplete, and whose chief activity will doubtless be in the direction of the extensive educational organizations which have developed under its charge. ${ }^{17}$

It is obvious that for the direct relationship of the church with America after 1622 , the archives of the Propaganda are more important than all others

\footnotetext{
${ }^{12}$ Miscellanea di Missioni, XIII., p. II6; Missioni, Miscellanea, III., p. 49; Memoriali, 391, p. 293.

${ }_{13}$ Atti, 1670, p. 184, Sept. 15, 1670.

${ }_{14}^{14}$ Atti, I659, p. 16, Jan. I4, I659.

${ }^{15}$ See Atti and Memoriali, passim.

${ }^{16}$ See Lettere, passim, particularly the letters of the secretary rather than those of the congregation.

${ }^{17}$ See Gerarchia Cattolica, 1908. Recently its famous printing establishment passed into other hands.
} 
taken together. It is fortunate that these archives have always been preserved with especial care. In I7O7 it was proposed to appoint two officers with the title of procurators, each to take general charge of the affairs of one-half of the world; a plan which with slight differences was often discussed. In a paper arguing against it, the second reason was: "Che in caso di morte, ó altro accidente di Pro'ri vi puo esser periculo di perdersi le lettere e scritture, ó altre notizie, che ad essi se manderanno da Vescovi, e missionari, par presentarle alla Congne ; Mentre presentem ${ }^{\text {te }}$ si conservano tutti esattam ${ }^{\text {te }}$ nell' $^{\text {' }}$ archivio della me ${ }^{\mathrm{ma}} "{ }^{18}$ The archives of the congregation are practically complete.

These archives occupy rooms in the palace on the Piazza di Spagna which has been the seat of the Propaganda since 1633, and have been moved but once, when they were taken to Paris. ${ }^{10}$ For a short period toward the close of the nineteenth century they were open on the same terms as those of the Vatican, but have since been closed, ${ }^{20}$ and are now accessible only by special permission not readily granted. To such as have permission to use them the archives are open from Nov. I to the end of June, and as they are not closed on Thursdays, their use can be well combined with that of the Vatican. The most considerable publications from their contents have been made by, or in behalf of, the Propaganda itself, such as the Bullarium, and the Annals published periodically at Lyons ${ }^{23}$ since 1839. An English translation of the Relation by Cerri was published in London in $1715 .^{23}$ Of the studies made from them by European scholars, the only one of interest for American history is that by Professor Blok, "Lijst van Dokumenten betreffende ons Land, voorhanden in de Archieven van het S. C. di Propaganda Fide te Rome ". For American history they have been used by Father Hughes in his History of the Jesuits in North America, and by J. G. Shea for his Catholic Church in Colonial Days, and his Life and Times of the Most Reverend John Carroll. ${ }^{25}$ The best description of the archives is that by Anton Pieper, in the Römische Quartalschrift. ${ }^{20}$

${ }^{13}$ Atti, 1707, p. 377, Oct. 3.

${ }^{18} \mathrm{G}$. Bourgin, Les Archives Pontificales, p. 94.

${ }^{20}$ C. H. Haskins, "The Vatican Archives", in American Historical Review, II. 42.

${ }^{21}$ Bullarium Pontificinm Sacrae Congregationis de Propaganda Fide (Rome, I839), 5 vols., with 2 vols. of appendix, and one of index - this contains many documents prior to I622; Collectanea S. Congregationis de Propaganda Fide seu Decreta Instructiones Rescripta pro Apostolicis Missionibus, vol. I., I622-1866 (Rome, I893, pp. xi, 926); vol. II., I866-1906 (Rome, I907, pp. 573); Constitutnes Aplicae Sac. Congnis de Propada Fide. 292 pp., printed I72I, and found in the Archives of the Propaganda, Misc. Varie XVII.

2 Annali della Propagazione della Fede; Raccolta periodica delle Lettere dei Vescovi e dei Missionari nelle Missioni dei due Mondi, e di tutti $i$ Documenti concernanti lc Missioni e l'Opera Pia della Propagazione della Fede (Lyons, I837- ). There are also minor publications, statistical and descriptive, published from time to time, and based in part upon these archives; but none, I believe, using material prior to I8I5.

${ }_{23}$ This was widely circulated in manuscript, under slightly differing titles, and an English translation, with an introduction by Richard Steele, appeared in London, I7I5, under the title, An Account of the State of the Roman Catholic Religion throughout the World.

${ }^{24}$ In the Archief voor de Geschiedenis van het Aartsbisdom Utrecht, XXVII. 329-376, for the years 1622-1665; and XXVIII. 38-113, for the years 1665-1704. These extracts are taken from the Indici Generali.

${ }_{25}$ See also American Catholic Researches, XIII. 35-4I (Philadelphia, I896), and T. J. Shahan, "L'Histoire de l'Eglise Catholique aux Etats Unis", in Revue d'Histoire ECclésiastique, I. 679-684, a discussion of sources.

${ }_{28}$ "Das Propaganda-Archiv", in Röm. Quart., I. 80-99, 259-265. See also Hinojosa, Los Despachos, pp. xlix-1, and I. Kollmann, "O Archivu Sv. Kongregace de Propaganda Fide", in Ćasopis Musea Království Českého, LXVI. 423-442. 
The archives are very well and systematically arranged. They are kept in a large room with a gallery, containing between six and seven thousand volumes. The very complete and reliable set of indexes is in a separate room, the office of the archivist, and there is a small study-room with a few reference books on missions. Practically all volumes likely to contain American material were examined and their contents listed. The character of the several series will be discussed in connection with the extracts made from each. In the case of nearly all original letters, etc., the method of binding is such that the last sheet is often separated from the rest, and it is often a matter of difficulty to find the endorsement.

\section{ATTI.}

This series forms the official journal of the meetings of the full congregation. Each subject taken up is given a number to facilitate reference from the journal to accompanying documents. Each meeting or "congregation" as it is called, with its adjournments is a unit, and if a subject is taken up again it is renumbered. On each subject there is a "relation" by a cardinal to whom the matter has been referred, occasionally illustrative documents, and finally the rescriptum, or note of action ordered. Since 1650 the journal of each year has been kept in a separate volume. These volumes run generally to about five hundred folios, and are well indexed, there being also a general index to the whole series in the office. The original documents upon which the relations are based are preserved in two collections, the Scritture Antiche, including all those down to 1669 , which are arranged by countries, and to which reference from the Atti is irregular and difficult; and the Scritture Corrispondenti agli Atti, from 1669, which follow the arrangement of the Atti. The date of the congregation, and the number of the subject, afford an absolutely simple method of referring from the one to the other, after this date.

The whole of this series through 1830 was examined, and references to material pertinent to the subject follow:

I. ${ }^{27}$ I622-I 624 .

II. 1625 .

f. 3. Feb. 4, I622. Division of the whole world into provinces.

June 13. no. I5. That the nuncio be requested to urge upon the King of Spain the nomination of a bishop in the province of Vera Pace in the Western Indies.

no. 20. That the nuncio of Spain be requested to furnish the congregation with more frequent information.

July 21. no. I3. The mission of Father Bolivar to the Western Indies is ordered.

no. 25. An order for the sending of missionaries to North America.

Nov. I7. no. 24. Information from Father Simon Stock, regarding the island of Avalonia, between England and North America, and upon III. ${ }^{23}$ r $622-1625$. a passage found, through a river of North America, to China.

f. 43 , no. 5 . June 13,1623 . To secure the more ready admission by the royal ministers of missions of the Reformed Franciscans into the Indies.

${ }^{27}$ Volume number actually not given.

${ }^{28}$ This is for the most part a duplicate of the two preceding. 
f. 218, no. I6. May 2, I625. On the sending of missionaries to the Indies by the generals of the orders.

f. 233. On erecting in Spain a congregation for the propagation of the faith in the Indies.

f. 240 , no. 26. June 27, 1625. On the prohibition by Spain and Portugal of the sending of Italian missionaries to the Indies.

IV. ${ }^{29}$ I626-1627.

f. 34. Mar. I7, I626. That regulars exercising parochial duties in the Indies be subject to the bishops in matters relating to the cure of souls and the administration of sacraments.

f. 132. Nov. 9, 1626. On remedies for abuses in both Indies.

f. I56. Dec. 28,1626 . A decree on the same subject as the preceding.

VI. I628-1629.

f. 64, no. 4. May 6, I628. On the eradication of simony in the Indies. ${ }^{80}$

f. 67 , no. I3. May 6,1628 . Concerning ordinations in the Indies. ${ }^{30}$

f. $7 \mathrm{I}$, no. 28 . June 9, I628. On printing the declarations concerning simony, and sending them to the prelates of the Indies, ${ }^{30}$ as well regular as secular.

f. 78 , no. 23. June 20. Same subject. ${ }^{30}$

ff. I24-125, no. I5, Sept. 5, I628; f. I43, no. I7, Sept. 29, I628; and f. I62, no. 5, Nov. 24, I628. On the honoring of Father Petrus Nietus (Nieto), an Augustinian of Mexico, by the magistracy of that province.

f. I62, no. 5. Nov. 24, I628. Decree concerning the alternative ordination of regulars in the Indies, abuses in the Western Indies, and a provision approved by His Holiness for the abatement of these abuses.

f. I70, no. 29. Nov. 24, I628. Altar privileges for the Western Indies.

ff. I72-I73, no. 3. Nov. 29, I628. Writings of Father Petrus Nietus to be sent to the nuncio in Spain for verification.

f. I78, no. 8. Dec. 12, 1628. Father Zanudius, Augustinian, to be consulted concerning the proposition of Father Pedro Nieto on Indian affairs.

f. I86. Jan. 3, I629. Opinion of Father Zanudius to be sought on the affairs and conditions of the Western Indies.

f. 292, no. I3. June 22, I629. Provisions adopted by the general chapter of the Dominicans, at the instance of the Sacred Congregation, for the conversion of gentile Indians.

f. 293 , no. I 5. June 22, I629. Declaration concerning the migration of Christian Indians to gentile lands, to escape Spanish oppression.

VII. I630-I63I.

Pt. I. f. 99, no. 20. July 9, I630. On the sending of English Puritans to North America, and provisions concerning it.

f. 164, no. Io. Nov. 22, 1630. Missions of Capuchins in New England in North America.

Pt. II. f. I8, no. 22. Feb. 3, I631. The sending of Capuchins to New England confirmed.

f. I9, no. 27. Feb. 3, I631. The sending of Dominicans to New Mexico.

Volume V. is a duplicate of IV.

${ }^{80}$ Probably relating to the East Indies only. The term India Occidentalis occasionally applies to the Philippines. 
f. 26, no. I6. Feb. 25, I63I. Concerning the land of Avalonia in North America.

f. 30, no. 33. Feb. 25, I63I. Concerning the return of European missionaries from the Indies.

f. $3 \mathrm{I}$, no. 20. Concerning the erection of parishes in the Indies.

f. 53 , no. 8. Apr. 28, 1631. Concerning the sufferings of Indian converts, according to the relation of Father Raymundus Urtadus, Dominican.

f. 87, no. I8. July 5, I631. Concerning the kingdom of Canada in North America.

f. 9r, no. 6. July 5, r63r. Relation of New Mexico and of the conversion of 500 gentiles, by Father Benavides, Minor Observant: narrating the great miracles which God did there, especially in giving sight to those born blind.

VIII. ${ }^{81}$ 1632-I633.

f. 66, no. 5. May 3, 1632. On the progress of Canada, and three missions of the French there.

f. 269, no. 6. July 19, I632. On the mission of the Capuchins in Canada X. $1634-1635$. and their two hospitals.

ff. 2I-24. Feb. 9, I634. Special congregation on the affairs of the Indies, including Mexico.

f. 45 , no. 6. Apr. 4, I634. Concerning the sending of English priests to Maryland and North America.

f. 49, no. 24. Apr. 4, I634. Concerning the relation of New Mexico by Brother Alfonso Benavides.

f. 56, no. 28. June 5, I634. Rclation of Father A. Benavides, concerning New Mexico; and a decree founded on it; with benedictions and indulgences for New Mexico.

ff. 63-64. June 19, 1634. Concerning decrees of the Council of the Indies in Spain, on parishes held by regulars, in favor of bishops; on the security of conscience in the Indies; on the revoking of facoltà granted for the Indies; and on the state of the church in the Indies.

f. 73, no. 17. July 14, 1634. Concerning parishes in New Spain, and the resolutions of the Council of the Indies regarding them, and instructions to the nuncio in Spain on the subject.

f. II I, no. 27. Aug. 28, I634. Concerning certain apparitions, and the deaths of six brothers of St. Francis in New Mexico.

f. I69. Jan. I9, I635. Concerning the mission of French Recollets in Canada, and the state of that region.

f. I92, no. 23. Feb. 28, I635. Concerning the confirmation, and the reform of the mission of the Recollets in Canada.

f. 228, no. 35. Apr. 23, 1635. That heretics be prohibited from going into Canada.

f. 359 , no. 28. Dec. Io, 1635. Concerning abuses introduced into the Indies, and particularly in the celebration of mass in the ships sailing thither.

XII. I636-1637.

f. 222 , no. 16. Dec. 30, I636. Concerning the progress of Brother Lorenzo de Valdes, Augustinian of Mexico, in the Western Indies.

${ }^{81}$ Volume IX. is a duplicate of VIII. 
f. 234, no. 2I. Jan. I9, I637. Concerning Brother Lorenzo de Valdes, Augustinian, and favors sought by him for the Augustinian province of Mexico.

f. 369 , no. 29. Mar. 23, I637. Facoltà for the mission of the fathers of the Society of Jesus in Canada.

XIII. I638-I639.

f. I7, no. 28. Jan. 30, 1638 . On the mission made by the Archbishop of Tuam, with Irish priests, to the island of St. Christopher, whither many Irish have migrated. ${ }^{32}$

ff. 27-28, no. Io. Feb. IO, I638. On the special congregation on Indian affairs.

f. 28, no. 2. Feb. I0, I638. Concerning Brother Francisco de Oviedo, of the Order of S. Maria de Mercedes for the redemption of captives, in the Western Indies, and the convent of the said order in the city.

f. 46, no. I I. Mar. I6, I638. Rejection of petition from Jesuit missionaries in Canada.

f. 63, no. 36. Mar. 23, 1638. Concerning abuses in secular parishes in the Western Indies.

f. 64 , no. 39. Mar. 26, I638. Rejection of the petition of Brother Gasparo de Quintero, of Mexico, that he be promoted to the priesthood.

f. 83 , no. 46. Apr. 20, 1638. Concerning the mission of the Irish to the island of St. Christopher and "Virginiam Indiarum Occidentalium".

ff. 96-97, no. 28. May 24, I638. Concerning the cedula of the King of Spain concerning parishes of regulars in the Indies.

f. I22, no. 31, July I9, I638; and f. I48, no. 37, Aug. 9, I638. Concerning the seminary of the barefooted Augustinians in Mexico, for the training of missionaries to the Indies.

f. I25, no. 40, July, I638; and f. 228 , no. 23, Jan. I7, I639. Concerning Father Lorenzo de Valdes, Augustinian of Mexico.

f. 282 , no. 35. Apr. I8, I639. Concerning the spiritual state of the people of Canada.

f. 367. Sept. I9, I639. Concerning the barefooted Augustinians of the Western Indies, and the impediments placed by the curia of the King of Spain against their coming to the Roman curia.

XIV. I640-I64I.

f. 4I. Mar. I4, I640. On the mission of Brother H. Serranus to the Western Indies.

f. I2 I, no. 42. June 25, I640. Concerning two missions of Spanish Capuchins in the Western Indies. ${ }^{83}$

f. 28I, no. 24. Feb. 26, I64I. Mission in New France and Canada, resolved upon by "D. Carolo Camus Duperon praesbitero Lugdunensi".

f. 327, no. 34. Apr. 22, I64I. Concerning the removal of three Capuchin brothers from the mission of Canada.

f. 36, no. 8. July 2, I64I. The prefecture of the Capuchins of Canada, assigned to Father Pacifique de Provins. ${ }^{34}$

f. 373 , no. 27. July 2 I, I64I. Order to write to Rossetti for information concerning the mission of English priests in Maryland.

\footnotetext{
${ }^{34}$ This mission called for a disproportionate amount of attention, and the references to it are very numerous, but only a few of some general interest are noted.

${ }^{83}$ Apparently in the Philippines.
} 
f. 480 , no. 47. Oct. I7, I64I. On the state of the island of Maryland, near America, and the mission to be sent there. From the report of Rossetti.

XV. I642-I643.

f. 29, no. 21. Feb. I4, I642. Extension of the mission of Canada to the whole of New France, in accordance with a map sent therefrom.

f. 33, no. 35. Feb. I9, I642. Opinion of Rossetti on the sending of a mission to Maryland. ${ }^{34}$

f. I67, no. I3. Sept. I2, I642. On the sending of Capuchins from the province of Normandy, "ad caput de Nort Americae septemtrionalis".

f. 205, no. 25. Nov. 8, I642. The sending of Brother Carolus Arpineus, Recollet, "ad loca provinciae Franciae", subject to the approval of the nuncio.

f. 2 II, no. 42. Nov. 8, I642. On the mission of Brother Joannes de S. Jacobo, Dominican, in California.

f. 363 , no. I ; f. 364 , no. 2 ; f. 365 , no. 3 , all of June 27, I643. On the cedula of Philip IV. of $\mathrm{I} 635$, on the parishes of regulars in the Indies, and the prejudices resulting from it to the Holy See and the regulars; on the constitutions of Pius $V$. on the exemption of regulars in such cases ; and on the means of preserving ecclesiastical immunity and pontifical jurisdiction in the Indies.

f. 435. Sept. 7, I643. Facoltà for the Bishop of Porto Rico.

f. 437. Sept. 7, I643. Case of Father Diego Ybañez referred to the special congregation of the Indies.

f. 453. Oct. 23, I643. Special congregation on affairs of the Indies.

f. 454, no. 3. Oct. 23, I643. Concerning the sufferings of Franciscans of the Western Indies, at the hands of Juan de Palafox, Bishop of Tlaxcala (Puebla).

XVI. I644-I645.

ff. 26-27, no. 21. Feb. 23, I644. Concerning the mission of the Recollets of the province of the Conception in France, to Canada.

f. 47 , no. 27. I644. Confirmation of a hospice in Mexico, for the Dominicans of $\mathrm{S}$. Rosario in the Philippines.

ff. 72-73. Apr. 25, I644. Concerning Gasparo Nuñes, and moneys which he holds for the Sacred Congregation in Yucatan.

f. 77, no. I7. Apr. 25, I644. Concerning the oppression by Bishop Palafox of the regulars of the Indies.

ff. IO4-I05, no. I3. May 27, I644. Relation by Brother François de Provins, prefect of the Capuchin mission in Canada.

f. I4I, no. 4. July 5, I644. Concerning the confirmation of bulls of Pius $\mathrm{V}$. and Gregory XIV. on the administration of parochial sacraments by regulars in the Indies without the license of bishops; concerning the multiplication of bishops in the Indies; and concerning the establishment of an apostolic legate of the Indies.

f. 4I3, no. 40. Concerning the Congregation of the Blessed Virgin Mary for the propagation of the faith among the gentiles in the Western Indies.

st Printed in Hughes's History of the Society of Jesus in North America, Docs., vol. I., pt. I., pp. I82, I85, I86.

is There is a great deal of material on this and other moneys in Mexico, but only in a few cases is reference here made to it 
f. 47I. Dec. I5, I645. Note concerning the ordination of Indians, from the nuncio in Spain.

XVII. I646-I647.

f. 56, no. 37. Mar. I3, I646. Augmentation of the Capuchin mission in French America, by two Capuchins.

f. 72, no. 38. Apr. Io, I641. Facoltà for the Archbishop of Mexico, etc.

f. 90 , no. 25. May 7, I646. Concerning the mission of the Minimi to Canada.

f. 9I, no. 29, May 7, I646; and f. 328, no. 20, Feb. II, I647. Concerning the progress of the mission of Father Pacifique de Provins in North America and Canada.

f. I I 2 , no. 35. June II, I646. Concerning three Capuchin missionaries to be sent to French America, and a well-instructed new Christian American to be sent back thither.

f. I I4, no. 3. June I5, I646. Concerning the reasons because of which the Western Indians are not instructed nor ordained.

f. 382, no. I3. Apr. 9, I647. Concerning the mission of Father Maccarius of Paris of the third order of St. Francis, "ad loca concessa a Rege Chr'mo D'no de Ormellis in America".

f. 4II, no. I3. June 3, I647. Letter from Brussels concerning provisions for missions in "Nova Battavia" in North America.

f. 483 , no. I I. Aug. I9, I647. Concerning Capuchin missions to French America.

f. 503, no. 40. Sept. 7, I647. Same subject.

f. 580 , no. I8. Dec. Io, I647. Concerning a letter of the queen of France regarding Capuchin missions in America.

XVIII. I648.

ff. 99-IO0. June 22. Special congregation on affairs of the Indies.

f. IO7, no. 20. June 22. Concerning the entrance of alumni of the seminary of the church "SS. Angelorum vulgo della Puebla", into the University of Mexico.

f. I 52, no. 4. Sept. I. Resolution concerning the ordination of Indians.

f. I82, no. I8. Nov. I6. Facoltà for the Archbishop of Mexico.

$\mathrm{XIX}^{38}$ I649-I650.

f. 330, no. I5. Feb. 2I, I650. Concerning the authority granted the provincial of the Capuchin province of Paris to establish a mission of his order in New England or Virginia.

f. 346, no. I3. Apr. 25, I650. Facoltà conceded to the bishops of Havana (Santiago) and Guadalaxara, in customary form.

f. 347 , no. I6; and f. 378 , no. 4. Two Capuchins seek to be sent back to the missions of the Western Indies.

1651. ${ }^{87} \mathrm{ff} .87-88$, no. 5. Aug. 7. Concerning the petition of Jesuit missionaries in French America that facoltà be granted the superior of those missions.

1652. Nothing relevant.

1653. f. 92 , no. 3. July 28. Information concerning certain brothers of the Order of S. M. Mercedes for the redemption of captives, who desire to be sent as missionaries to America.

${ }^{80}$ This is paged consecutively with XVIII.

${ }^{87}$ From this point the volumes become annual, and the year gives the best reference. 
f. I29. Nov. I7. Request that the procurator general of the Society of 1654. Nothing relevant.

1655. ff. 37-38. July I2. Apportionment of provinces among the cardinals.

f. 67, no. I 5. Oct. 5. Requests to serve in the missions of America from brothers of the Order of Minor Observants.

1657. ff. I25-I29. June I4. Apportionment of the provinces among the cardinals.

ff. I42-I45. June I4. Question of the creation of bishops in French North America, with a discussion of the proper limits of their sees.

1658. ${ }^{23}$ f. I8, no. 25, Jan. I 5 ; f. 50, no. II, Feb. 21 ; and f. 94, no. I8, Feb. I8. On a new diocese in French North America.

ff. I24-I25, no. 15. Apr. I I. The establishment of a vicar apostolic in Canada.

f. I47, no. 9. May I3. Request of a monk to go as missionary to Mexico.

ff. I53-I54, no. 23. May I3. Request for a priest to accompany three hundred French who are going to America.

f. 232, no. I3. Aug. I9. Request for facoltà from the vicar apostolic of Canada.

f. 25 I, no. II. Oct. I. Bull for the vicar apostolic of Canada.

ff. $275-276$, no. I. Nov. 26. Impediments placed in the way of the vicar apostolic of Canada by the Archbishop of Rouen, who claims jurisdiction over him.

1659. f. $\mathrm{r} 6$, no. 35. Jan. I4. On the permission necessary to engage in missionary work.

f. I4O, nos. IO-I I. Sept. 23. From the nuncio at Cologne, on the desire of certain Dutch Catholic merchants to go to New Batavia, communicated through the imperial minister at the Hague.

1660. ff. 96-97, no. 27. Relation of the missions of Canada by Mons. Lambert.

f. I69, no. 20. June 28. Provision for Augustinians going to India by way of America.

f. I85, no. 38. July 28. Facoltà for certain American bishops, including Cuba.

1661. ff. 4-5, no. 9. Relation of the mission of Canada.

1662. ff. 69-70. May 22. Relation of the missions of that part of America inhabited by the English, being a portion of a relation of England by the prefect of the Jesuits.

f. 292. Nov. 22. On the mission of the Jesuits in Maryland.

1663. f. I62, no. 21. July 3. The Jesuit missions of English America.

f. 258 , 110. 24. Nov. 19. Facoltà for the bishop of Porto Rico.

1664. f. I8, no. I5. Feb. 4. Facoltà for the missions of America.

f. I9, no. I7. Feb. 4. Facoltà for the Archbishop of Santo Domingo.

ff. 98-99, no. 16. June 30. The vicar apostolic of Canada on the necessity of erecting a bishopric there.

f. I34, no. 38. Sept. 22. Facoltà for the Bishop of Cuba, etc.

1665. f. 66, no. 8. Apr. 20. Erection of a congregation of priests in Mexico.

f. I28, no. 22. June I6. Confraternity erected in the city of Mexico.

f. I78, no. 38. Aug. I7. Facoltà to the Bishop of Guadalaxara.

${ }^{33}$ This volume is referred to by Abbé Faillon in his Colonie Française, II. 322-327. 
1666. ff. 44-45, no. 5. Feb. 25. Relation of the state of missions in Canada, and appointment of a special congregation to consider the erection of a bishopric at Quebec.

ff. 263-265, no. 27. Sept. 20. Foundation of a mission in "terra australe incognita ", in connection with new company united with the French East India company. The mission was to be sustained by communication with America.

1667. f. 5, no. II. Jan. Io. On the erection of a bishopric at Quebec.

f. 49, no. I6. Mar. I. Request of the vicar apostolic of Canada, for a holy body.

ff. 203-204, no. I2. Sept. I2. On the erection of Quebec into an episcopal see.

ff. 252-253, no. I8. Nov. 28. Request of the Bishop of Petraea (Laval) for the erection into parishes of the church of Quebec and other rural churches.

1668. f. 74, no. 54. May 7. Facoltà for missionaries in the Western Indies.

1669. f. 47, no. I4. Mar. 2I. Foundation of a seminary for missions at Paris.

f. 55, no. 28. Mar. 26. Pierre de Neufville, missionary of Newfoundland, asks for certain facoltà. Nuncio at Paris to be requested to send information.

ff. I3O-I3I, no. 36. Apr. 2. Facoltà for priests accompanying French merchants to the islands of America.

f. I37, no. 42. Apr. 2. The vicar apostolic of Canada records the order for the erection of that church into a bishopric, discussing the attempt of the Archbishop of Rouen to exercise jurisdiction.

ff. 2I2-2I3, no. 43. May I3. Request of a French priest for facoltà to serve the French who go to Newfoundland.

1670. ff. I6-I7, no. 22. June 2. From the Bishop of Petraea (Laval) on certain nuns established in Canada.

ff. 68-69, June I7; and f. 234 , no. 29, Dec. I. On the erection of the church of Quebec into a bishopric.

1671. f. I6, no. 27. Jan. I2. Request of the Bishop of Petraea for the erection of the church of Quebec into a bishopric.

f. 88. Apr. 7. Petition of the Bishop of Petraea that the bull for the church of Quebec be expedited by the "via segreta".

ff. I26-I27, no. I9. Apr. 27. Decrees made at the request of the bishop, against the regulars in the diocese of Cuba.

ff. I37-I38, no. 29. Apr. 27. Deputation of Capuchin missionaries, for a station in "Lorenzo Vanheuskert" near the sea of "Corvia", called the Florida of the North, in North America.

f. 407, no. 42. Dec. I4. Request of the prefect of the mission of the Dominicans in the French islands of the West Indies, for the extension of the mission into the islands subject to England and Holland. ${ }^{20}$

1672. f. 3, no. 9. Jan. I I. Refusal of the request of Brother Dionisius of Piacenza to go as chaplain on the fleet that navigates the ocean.

ff. I49-I 50, no. 62. May 30. Considerations of the vicar apostolic of Holland, forwarded by the nuncio at Brussels, on requests for a mission in the American islands.

\footnotetext{
${ }^{80}$ There is much material relating to these islands, but only a few items are here given. Maryland and the island of Marie Galante were often confused, and their identity can be determined only by the context.
} 
f. 185 , no. 5o. July 4. The Bishop of Petraea requests money to aid in the expedition of the bull for the church of Quebec.

1673. ff. 98-99, no. 26. Apr. I8. Requests of a financial nature from the Bishop of Petraea, with regard to the church of Quebec.

f. I 55, no. 26. May 8. The internuncio at Brussels, on granting facoltà to the missionaries of the island of "Marilandia".

f. I66, no. 5. June I3. The nuncio at Paris writes that he has been solicited by the Bishop of Petraea to hasten the expedition of the bull for the church of Quebec.

f. 312, no. 8. Sept. 26. Father Philippe Beaumont made prefect of the American islands. ${ }^{40}$

1674. f. I I I, no. 8. June 26. Facoltà for the Bishop of Durango.

ff. 36I-362, no. 34. Nov. 27. The nuncio in Spain, having been instructed to urge his Catholic Majesty to set at liberty Indian slaves, has requested the Queen to remove the order enslaving them.

1675. f. 272, no. I2. Oct. Io. Canon Goggi, in the name of the clergy of New Spain and Peru, petitions that declaration be made that the bull of Clement IX., prohibiting ecclesiastics from engaging in business, be interpreted to apply only to missionaries. No action.

1676. f. 2I, no. 4. Mar. 4. Facoltà (for ten years) and relics for the Bishop of Quebec.

f. 72, no. 4. Apr. I3. Indulgence to the same, for not attending the jubilee at Rome.

f. I66, no. 9. Dec. I. Canon Goggi, going to the Western Indies on ecclesiastical business, requests certain facoltà.

1677. f. I83, no. 25. Aug. 2. Request from the Capuchins of the province of Normandy, for permission to exercise certain facoltà during the voyage to the French islands of America, the difficulties of which they describe.

1678. Nothing relevant.

1679. Nothing relevant.

1680. f. 23, no. IO. Jan. 23. Correspondence of the nuncios of Spain and Flanders regarding the sending of missionaries to the Indies. ${ }^{11}$

f. 33, no. 21. Jan. 23. On the facoltà of Canon Goggi and the jurisdiction of ecclesiastics in the Western Indies.

1681. Nothing relevant.

1682. Nothing relevant.

1683. f. Ioo, no. 20. May 3I. Facoltà for the Bishop of Cuba.

f. 218, no. 6. Nov. I6. Facoltà for the Bishop of Porto Rico.

ff. I I I-I I6, no. 34. May 31. On tumults among the negroes in the Western Indies caused by certain Capuchins.

1684. f. 3, no. 3. Feb. 21. Relation of what is done for the Catholic religion in the island of Santo Domingo.

f. 59, no. I3. May 2. The prefect of the Jesuits in America requests facoltà.

ff. 77-84, no. 29. May 20. Report of Canon Goggi on disorders and inconveniences in the relations between the royal ministers and ecclesiastics in the Western Indies.

\footnotetext{
40 These are the French islands. Later they include St. Pierre and Miquelon, but probably not until i763.

${ }^{* 1}$ Probably the East Indies.
} 
ff. I66-I67, no. 8. Nov. 27. Request for mission of four Recollets in "isola Louisiane", under the direction of the Bishop of Quebec.

1685. ff. 2O-2I. Jan. 8. On the discovery of an island to which has been given the name of Louisiana, and the sending thither of Recollet missionaries, at first placed under the direction of the Bishop of Quebec, but now, by reason of their distance from that see, placed under the prefect of the Recollets of French Santo Domingo.

f. 29 , no. I 4 ; ff. $35-37$, no. 26 ; f. 37 , no. 27 ; all of the congregation of Mar. I2. Representations of the Capuchins on the various unjust methods of enslaving negroes; on the commendam system; and on the condition of Indian slaves working in mines, in the Western Indies. "Ad sanctum officium."

f. 4I, no. 3I. Mar. I2. Doubts proposed by a missionary regarding matrimony.

f. 58, no. I6. May 7. Facoltà for the Bishop of Quebec.

ff. $84-92$, no. 24. Relation of the prosecution of two Capuchins, formerly missionaries in the Havana diocese, who preached that negroes, held as slaves, were free.

f. I 2 , no. II. July I6. Facoltà for the Bishop of Cuba and Havana.

1686. f. 67, no. 2. Mar. 26. Request of Father Massimiliano Sanvabriano, of the third order of St. Francis, for facolta, in the new mission of "Chebadentu" [Chedabuctu ?], two hundred leagues from Quebec.

f. 96, no. I8. May 6. Facoltà of the Bishop of Petraea, vicar apostolic in America, prorogued.

f. I24, no. 21. June I8. Facoltà granted Father Massimiliano, and his mission placed under the direction of the Bishop of Quebec.

ff. 224-225, no. 5I. Nov. I9. Father Felice d'Artassona, Capuchin of America, requests privileges and favors granted by Adrian VI., and reports on the heavy oppression which impedes the conversion of souls in those parts. He desires that the superiors be ordered not to hinder monks from going thither according to the concession of the King, and that in order to fulfil the number fixed by the Council of the Indies, four secular priests and two laics be allowed to go.

ff. 74-75, no. I9. Mar. 26. Father Antonio Linaz, Minor Observant, requests permission to erect certain convents.

f. II7, no. 2. June I8. Facoltà of the Bishop of Guadalaxara confirmed.

f. II8, no. 4. June I8. Facoltà of the Bishop of Durango confirmed.

ff. I6o-r62, no. 33. Sept. 3. D. Tomaso and Giovane Paolo Porzio petition to be recommended to the nuncio of Spain, with the object of obtaining for them the charge, formerly enjoyed by their father, but now by the Dutch, of introducing negro slaves into the Indies.

ff. 220-22I, no. 28. Nov. I9. A new letter in favor of the Porzii, and the sending of a brief to the King of Spain.

1687. ff. I4-I6, no. I6. Jan. I3. Further information from the Capuchins in favor of their request for the privileges conceded other regulars by the bull of Adrian VI.

ff. 20-2I, no. I9. Jan. I3. Request of Father Antonio Linaz, M. O., that missionaries in seminaries or colleges erected for missions be able to avail themselves of certain facoltà.

f. 84, no. 8. June I6. On missionaries in New Spain. 
ff. 89-9o. June i6. On the granting to the Bishop of Durango the facoltà of reconciling to his church the heretics and infidels of his diocese. "Ad sanctum officium."

f. I 57, no. 5. Sept. I 5. Facoltà for the Bishop of Quebec.

f. I59, no. Io. Sept. I5. Two Capuchins request to go to America as missionaries.

ff. I77-I78, no. 20. Sept. I 5. Petition from D. Nicolò Porzio, that renewed attempts be made in Spain to secure his reinstatement in the charge of introducing negro slaves.

1688. ff. I 49-I 5O, no. 30. Oct. 5. On a report from the Congregation of Bishop and Regulars, briefs of apostolic preacher are forwarded to four Minor Observants.

ff. I5O-I 5I, no. 3I. Oct. 5. Relations of spiritual progress from various missionaries in the Western Indies, including one from Felipe de Gahido, prefect of New Mexico.

f. I94, no. 28. Nov. I4. Reform of certain constitutions made for the erection of convents, seminaries, and colleges in the provinces of the Indies subject to the Catholic King, for the instruction of ecclesiastics for those missions. The affair brought forward by Linaz.

1689. f. 27 , no. 9, Feb. 8; and f. 84, no. 9, May 28. Request of a priest ordained by the Bishop of Puebla, and versed in the Mexican language, for permission to instruct the faithful.

ff. 49-50. Mar. I. The custodian of the missions of the Capuchins relates scandals, relaxation in customs, and the vacillation of Catholics in the faith, and requests facoltà.

1690. ff. 49-52, no. 23. Feb. 27. Nicolò Porzio, re-established in the right of furnishing slaves for the Western Indies, requests facoltà to select priests for the service of said slaves.

ff. 68-69, no. I9. Mar. I3. The missions in America, in places where there are no missionaries, particularly in the French islands, conceded to two missionaries.

f. 203 , no. 6. Sept. 4. Letters commending Nicolò Porzio given to the new nuncio in Spain.

1691. f. 53, no. I2. Sept. 24. Facoltà to the Bishop of Durango.

1692. ff. I76-I77, and f. I79, both of the congregation of Aug. 26. Facoltd to the superior of the Minor Observants in the Western Indies.

1693. ff. 82-83, no. I6, June 22 ; and f. 24I, no. I, Aug. I7. Request of Father Vittorio da Dola, Capuchin, that order be given that the missionaries of one order shall not involve themselves in the missions of another order.

f. I69, no. I 5. Oct. 6. Some Franciscans petition to be declared apostolic preachers in the Indies. ${ }^{42}$

1694. f. 94, no. 4. June 27. Names of superiors and missionaries in "Florida Popaien".

1695. f. 3, no. 6, Jan. II ; and f. I9, Feb. 8. License to the prefect of the Augustinian missions in the Western Indies.

ff. I2-I3, no. 25. Jan. II. Aggravations received by the Bishop of Guadalaxara from the Minor Observants who have usurped many parishes and assume to administer them independently of the ordinary.

${ }^{42}$ Probably the East Indies. 
ff. 22-24, no. I3. Feb. 8. On the mission of Father Fran. Romero, Augustinian, in the island and diocese of Cuba, etc.

f. I2I, no. I. June I9. Facoltà to the Bishop of Guadalaxara.

ff. I26-I27, no. I6. June I4. The Carmelites in North America request certain facoltà.

f. 235, no. 7. Nov. I 5. Father Michel Angelo of Rouen, provincial of Normandy, is given the prefecture of missions in America and its islands.

1696. ff. 22-24, no. I I. Jan. 30. Indulgences for missions in the Indies.

f. 53, no. 4. Mar. 20. D. Francesco Bullon requests missions in the Indies ; and Fathers Bartholomé and Raphael, French Capuchins, request missions in British islands.

f. I35, July 3. Facoltà to the Bishop of Cuba.

1697. Nothing relevant.

1698. ff. 38-39, no. I4. Feb. I7. Father Melchiorre degli Angeli, Minor Observant, is denied office of apostolic preacher and facoltà for all America.

f. 233, no. 7. July 28. D. André Garipault, parish priest in France, petitions for a patent as missionary in Canada. Ordered that the Bishop of Rochelle be written to.

1699. f. - The commissary general of the Recollets petitions that Father Atanasio (Anastase) Douay be made prefect of the mission of Florida, " a Gallis autem Louisiana ".

ff. 439-440, no. 21. Dec. 22. Prefecture of the Minor Observants in the Western Indies assigned.

1700. ff. I34-I35, no. 3. May 24. The barefooted Observants of the province of San Diego of Mexico, desiring to erect a new mission under their own prefect in territory for which there is another prefect of the same order, the secretary of the congregation is ordered to investigate the matter.

f. I35. May 24. Facoltà for the Bishop of "S. Giacomo di Cuba, Giamarca, e Florida" (Santiago, Jamaica, and Florida).

f. I75. July 5. Facoltà for the Archbishop of Mexico.

1701. ff. 2 I, no. I I, Jan. 25 ; and f. 80 , no. 7, Apr. 5. Thomas de Jaunin is declared a missionary in America, especially in the British islands, and the said islands are assigned for work to the several orders.

ff. 206-207, no. 3. Facoltà and powers for Carmelite missionaries in America, especially in the French islands; said missionaries to be under the provincial of Tours.

1702. f. 45, no. I. Mar. I3. Fiacoltà to the Bishop of Quebec.

ff. I2O-I22, no. 6. July I7. Founding of a mission in the provinces of the kingdom of Tampico and "Gran Chivira", under the prefecture of the provincial of the barefooted Observants of the province of San Diego in Mexico.

f. 287, no. 9. Nov. 22. José Anaga, of the diocese of Mexico, petitions to be dispensed from orders.

1703. f. 9, no. 9. Jan. 9. Father Michel Angelo of Rouen, Capuchin, provincial of Normandy, and prefect of the missions of his order in the islands of America not subject to bishops. ${ }^{43}$ requests the brief of the jubilee of holy year.

${ }^{48}$ Probably including Louisiana. 
f. I6, no. 8. Jan. 22. D. Gabriele Olivieri "Hennatense" is deputed missionary under the direction of the Bishop of Quebec.

ff. 2 I I-2I2, no. 7. Sept. 24. The French Jesuits petition that orders be given the Bishop of Quebec to assign to them a district in South America, called "Missisipi", because they are disturbed in all places where they go by the missionaries of foreign missions.

ff. 22-24, no. I4. Jan. 22. Doubts proposed by the Bishop of Quebec concerning matrimony, and whether it is lawful to take regulars for missions without the consent of their superiors; requests for a license for the abbot of St. André-au-Bois, Premonstrant, in the diocese of Arras, to erect convents and monasteries with the indulgences and privileges conceded to the mendicant orders in New France, for the grant of a privileged altar in all the churches of the diocese, for approval of reforms introduced into the monastery of St. Martin of the Order of Premonstrants in the diocese of Cambrai, and for dispensation for thirty ecclesiastics of the said monastery to take their vows on having completed one year of novitiate.

1704. f. 77 , no. 2. Apr. I4. The superior of the Capuchins in America asks whether it is possible to concede to secular priests the facoltà of confession, etc.

1705. f. 335 , no. I. Nov. 24. Facoltà to the Bishop of Durango.

1706. ff. 220-22I, no. 9. Aug. I7. Facoltà to D. Bonaventura di Rio, to act as missionary, and to take four secular priests as companions.

1707. ff. I6-I7, no. 23. Jan. 24. Request from D. Bonaventura Rio, concerning his mission.

ff. 360-374. Oct. 3. Letters from the Archbishop of Manila, lately chosen Bishop of Guadalaxara, concerning eastern affairs and seminaries in the churches of America.

ff. 373-379, no. 2. Oct. 3. Reasons for and against the appointment of two or three procurators for each of the four parts of the world. The decision being negative, the secretary is instructed to make reports, and the frequent appointment of special congregations is recommended.

ff. 440-44I, no. I 5. Dec. 5. The superior of the Capuchins in Martinique and other islands requests that ships' chaplains be prohibited from exercising ecclesiastical functions on land.

1708. Nothing relevant.

1709. Nothing relevant.

1710. f. 2I, no. 2. Jan. 27. Father Francisco del Rey, Minor Observant, petitions to be deputed apostolic preacher in the province of the Holy Gospel in Mexico.

f. Iog, no. 6. Apr. 8. The general of the Order of San Juan de Dios petitions for a declaration that the priests of his order in Martinique and other islands be allowed to administer the sacraments to the black slaves dependent on their establishments.

1711. Nothing relevant.

1712. ff. 6I-62. Jan. 25. Facoltà conceded to the head vicar of Mexico until the new bishop arrives.

1713. f. I8, no. 22. Petitions for facoltà to the Carmelites of French islands in America, from their former provincial, Father Massimino di S. Carlo. 
1714. f. I05, no. 5. Feb. I7. Prefecture of the Minor Observants in the Western Indies confirmed to Father Francisco Esteves.

f. I82, no. 33. Mar. 20. Facoltà to Mgr. Francesco, Capuchin, coadjutor of the Bishop of Quebec.

f. 436, no. 26. Father Michele di S. Francesco deputed prefect of the Carmelites in the French islands of America.

1715. ff. 82-83, no. 8. Feb. 25. The English Jesuits, missionaries in North America, petition for facoltà to dispense from impediments to matrimony.

ff. 9I-92, no. 23. Feb. 25. Certain bishops of the Western Indies request enlightenment on their facoltà.

f. 387 , no. 25. July 9. The Bishop of Rochelle requests power to approve missionaries for America and the Western Indies, when they pass through that city for regions in which there are no bishops or vicars apostolic.

1716. Nothing relevant.

1717. f. I94, no. 9. Father Eustache Dumay nominated prefect of the island of Santo Domingo.

1718. f. 85 , no. I6. Facoltà to the Bishop of Porto Rico.

f. 692, no. 4. Sept. I2. An Augustinian requests permission to go to the missions of the Western Indies.

1719. f. 321. Father Massimiliano, Carmelite, provincial vicar of the French islands of America, is given the prefecture of those islands.

1720. ff. 308-309, no. I3. June 3. Father Giacomo di S. Martino, barefooted Carmelite, is deputed prefect, with facoltà without prejudice to the Sacred Congregation and in dependence upon it, in the new mission of Louisiana, formally "Mysisipi".

1721. f. 86, no. 6. Mar. I7. Father Matteo, barefooted Carmelite, is deputed prefect of the friars of his order in the island of Louisiana, called "Misissipi".

f. I8I. June I3. Facoltà to the Bishop of Quebec.

f. 296, no. I9. Sept. I. Doubts proposed concerning the functions of missionaries without a parish.

1722. f. I38, no. 25. Apr. I3. The procurator general of the Capuchins requests that the provincial of the province of Champagne in France be declared prefect of the missions of the island of Louisiana. Ordered that the nuncio at Paris be requested to send information.

ff. I83-I84, no. 5. Apr. 21. The directors of the seminary of Paris, through Mgr. Maigrotte, petition that Dominic Despuylos, of their congregation, be sent as missionary to Canada.

f. 3I 3, no. 3. July 7. Facoltà for the Archbishop of Santo Domingo and the Bishop of Durango.

ff. 4IO-4II, no. 3I. Aug. 3. The nuncio at Paris disapproves the request of the Capuchins referred to him on April I3, on the ground that there are enough missionaries on the spot.

f. 458, no. 4. Sept. Facoltà to the Bishop of Guadalaxara.

f. 563 , no. 2. Nov. I6. Facoltà to the Bishop of Durango.

1723. f. I I, no. 20. Request showing why there should be conceded to the prefects of the missions of the islands of America the facolta of giving execution to apostolic briefs.

1724. ff. I86-I87. July 3. On the prefects of the missions of the Minor Observants in the Western Indies. 
f. 255, no. 23. Aug. 21. Facoltà to the Archbishop of Mexico.

ff. 255-26I, no. 24. Aug. 2I. The prefect of the Jesuits in the French islands of America publishes the jubilee. Discussion on the independence of those islands of any bishopric, and question as to whether they could not be comprehended in the dioceses of the Archbishop of Spanish Santo Domingo and his suffragans.

1725. Nothing relevant.

1726. f. 5, no. II. Jan. I4. The Spanish minister to the Holy See requests further facoltà for all bishops in the Western Indies.

f. I7I, no. 3. Deputation of a new prefect for the Carmelites in America.

f. I79, no. I8. Apr. 9. Facoltà to the Archbishop of Santo Domingo.

1727. f. 95, no. 2. Mar. 20. Facoltà to the Bishop of Porto Rico.

1728. ff. 77-78, no. Io. Requests that there be extended to the bishops of the Western Indies facollà to dispense from impediments to matrimony.

1729. f. 60, no. 5. Jan. 24. Facoltà to the Bishop of Cuba.

f. 83, no. I. Feb. I4. Facoltà to the Bishop of Quebec.

f. I4I, no. 2. May 2. Facoltà to the Bishop of Cuba.

f. 279, no. 7. July I9. Facoltà to the Bishop Coadjutor of Quebec.

ff. 466-470, no. 34. Oct. 6. Request of the Bishop Coadjutor of Quebec for certain facoltà.

f. 488, no. 4. Dec. 5. Facoltà to the Archbishop of Santo Domingo.

1730. f. 79, no. 5. July 3I. Facoltà to the Archbishop of Mexico.

f. I64, no. 7. Sept. 26. Facoltà to the Bishop of Cuba.

ff. I69-170, no. I 5. Sept. 26. Father Francesco di Castellon, Capuchin, recommended for the patent of missionary in the island of Cuba. Referred to the bishops of that island.

1731. ff. 23I-237, no. 43. Apr. I6. The Bishop Coadjutor of Quebec and New France renews the request to be allowed to ordain the natives of those parts.

f. 429 , no. 9 , and f. 566, no. 28 . On the division of the Jesuit missions in the West Indies into three prefectures. ${ }^{4 t}$

1732. ${ }^{45} \mathrm{f}$. I I I, no. 22. Jan. 28. The general of the Minor Observants asks confirmation of a patent for the good regulation of convents of his order erected in missionary colleges in Spain and the Indies.

1733. f. 38, no. 5. Jan. 26. Funeral oration delivered in the cathedral of Mexico, for the soul of Father Antonio Margil, founder of the colleges of the Propaganda in New Spain, and dedicated to the Sacred Congregation.

1734. ff. IO5-IO9, no. I8. Mar. I. To the Bishop of Quebec facoltà to ordain twenty foreign clergy " ad titulum missionis".

f. 368 , no. 9. Extension of the jurisdiction of the Jesuit prefect of the French islands.

1735. f. 6I. Feb. 7. Indulgences for those who instruct in the faith certain Indian neophytes of the dioceses of Guadalaxara and Oaxaca.

1736. ff. 55-58. Feb. 28. Division of the French possessions in the West Indies between the three Jesuit prefects, and assignment to them of facoltà for islands belonging to the Danes, English, and natives.

4t These probably included no territory on the continent of North America.

${ }^{45}$ From this point simple grants of facolta to bishops are not noted. 
f. 277, no. I. July 23. Father Andrea Mane, Dominican, confirmed in the prefecture in America.

1737. f. 5. Jan. 2I. State of the missions of the Reformed Minor Observants.

f. I I , no. I4. Apr. I. Father Ildefonso d'Ortega confirmed in the prefecture in the Western Indies.

f. I73, no. 7. May I7. Father d'Ortega requests enlightenment on certain doubts.

1738. f. 92. Apr. I4. Spiritual fruit in the Western Indies, particularly Peru, reported by an Observant.

f. 34I, 110. 20. Sept. 30. The Jesuit prefects in the regions of America inhabited by the French request simplification of facoltà regarding dispensations for marriage.

f. 375 , no. I I. Nov. Io. Permission to four Capuchins to go to Mexico to collect money for the missions of Thibet, and other financial arrangements concerning America.

1739. f. IO, no. IO, and f. 2 I, no. I4, both of the congregation of Jan. 27. On the mission of the aforesaid four Capuchins. ${ }^{46}$

1740. Nothing relevant.

1741. f. 360 , no. 4. Nov. 28. Amplification of facoltà to the Jesuit prefects in French America, with regard to service on board ships.

1742. f. I57, no. Io. May 7. Father Edmondo della Madre di Dio, Carmelite, new provincial of the province of Turenne, is given facolta for the island of Santo Domingo.

1743. f. 3I2, no. 35. Aug. I9. The prefect of the Minor Observants of the Western Indies asks power to exercise in foreign territory facoltà that have been granted him for his own territory.

1744. f. I43, no. 3. Apr. 20. The provincial of the Capuchins of Normandy requests facoltà.

1745. Nothing relevant.

1746. f. I76, no. Io. July 4. The missions in America in countries subject to England referred to the vicar apostolic of London.

f. 317 , no. 8. Dec. 5. Petition of the prefect of the Minor Observants in Mexico for confirmation of facoltà with arrangement for substitution in case of death.

1747. f. 273 , no. 5. Aug. 7. Confirmation to the Jesuits of America, for six years, of facoltà to serve as chaplains of ships in those missions.

1748. ff. 5O-5I, no. 2I. Mar. I I. Sending of two Italians to collect money in Mexico for the missions of Thibet, and other financial matters.

f. I57, no. 3. July I. To the provincial of the Capuchins of Turenne, facoltà and prefecture of the French islands of America.

1749. f. 35, Mar. 4, and f. I42, July 7. The French Capuchins of the islands of America request power to manage money; which is conceded to them in a limited degree.

ff. 255-256. Dec. I5. Facoltà of dispensation denied the provincial of the Capuchins of Turenne, as prefect of the missions of his order in America.

1750. Nothing relevant.

1751. f. 25, no. 2. Mar. I6. On colleges for the Western Indies and a new prefect for Santo Domingo.

\footnotetext{
${ }^{46}$ This mission occupies much attention for many years, but only a few references are here made to it.
} 
f. 38, no. 21. Mar. I6. A Dominican requests permission to go as a missionary.

1752. Nothing relevant.

1753. f. 24, no. 4. Feb. I2. Facoltà to Capuchins.

1754. Nothing relevant.

1755. f. 2, no. 3. Jan. 20. The superiors and prefects of the Jesuit missions in the French islands petition for transmissible facoltà.

f. I53, no. I. May I3. New prefect for Santo Domingo.

ff. 322-323. Sept. 22. An American priest of the diocese of Puebla de los Angeles asks to be declared apostolic missionary.

ff. 335-338, no. I9. Sept. 22. In certain provinces of America, where are Franciscan missionaries, donations and pious legacies are administered by the syndics.

1756. ff. $243-247$, no. I I. Aug. 2. Rules to be observed by the colleges of Spanish Franciscans designed for the missions of the Indies.

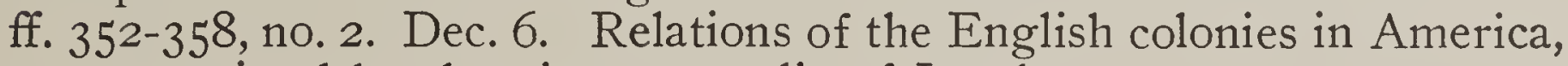
transmitted by the vicar apostolic of London.

1757. f. 408 , no. 5. Nov. 28. Facoltà to the prefect of the missions of the Minor Observants in the Western Indies.

1758. ff. IO9-I 12. Feb. 20. Provision taken that the Dutch Catholics in America have a missionary of their own nationality.

f. 293. Sept. I8. Concerning the abuses and better regulation of the colleges of the Minor Observants in America.

1759. f. 6r. Prefecture and facoltà to the superior of the French Jesuit missions in Santo Domingo.

f. 299, no. I 3. July 9. Dispute between the superior of the Jesuits, constituted vicar general with pontifical dispensation in "Luigiana" by the Bishop of Quebec, and the Capuchin missionaries there.

1760. f. 77. Mar. Io. Facoltà and prefecture in America to the provincial of the Capuchins of "Borgogne".

ff. 317-362. Aug. I8. Relations of the Dominican missions in Santo Domingo, with resolutions on the subjects of the baptism of infant and adult barbarians, and the obligations of the masters of such slaves.

1761. f. I28. June. The provincial of the Carmelites of Turenne made prefect of their missions in America.

f. 252. Sept. I 5. Facoltà to dispense from impediments to matrimony, given to various bishops of America.

1762. ff. 482-505. Sept. 20. Confirmation of the privileges of the college of San Diego in Mexico, in the province of S. Francesco di Pachuca.

1763. Nothing relevant.

1764. f. 215, no. 6. June 25. Facoltà and prefecture of the missions in America, granted to the provincial of the Carmelites of Turenne. ${ }^{47}$

1765. f. I, no. 3. Mar. 3. Prefecture of the Capuchin missions of New Orleans.

f. 96, no. I9. Apr. 28. The confirmation of a brief of Benedict XIV. conferring facoltà, requested by the general of the Jesuits, submitted to the Holy Office.

\footnotetext{
${ }^{47}$ The grants of facoltà to this provincial are no longer noted, as any possibility of connection with the continent seems to have vanished with the treaty of 1763 .
} 
1767. Nothing relevant.

1768. f. I27, no. I6. June I3. A Minor Observant requests the privilege of missionary, having been a missionary at Zacatecas for fourteen years.

f. I30, no. I5. June I3. Abuses in the college of S. Ferdinando of the Observants in Mexico.

1769. f. 438 , no. 6. Sept. 4. The procurator of the Minor Observants of the missionary colleges erected in North America requests that the prefecture of those missions be united with the office of commissary of the same.

1770. f. 74, no. 13. Apr. 2. The Bishop of Quebec says that the English government is not willing to consent to the naming of a coadjutor, and requests instructions on the point.

ff. 353-358. Nov. 19. The commissary of the missions of the Minor Observants in North America asks if he can depute, in every one of the four colleges, a vice commissary to make missions among the faithful.

1771. Nothing relevant.

1772. f. I2I, no. 6. July I3. On certain statutes of the colleges of the Minor Observants of America.

1773. Nothing relevant.

1774. f. 40, no. r6. Jan. 3I. The commissary of the missions under the care of the Minor Observants of the colleges of North America represents the necessity of granting him and his successors facoltà to confirm, there being thousands of unconfirmed Christians there.

1775. Nothing relevant.

1776. Nothing relevant.

1777. Nothing relevant.

1778. f. I. Jan. 26. On the suffrage in the colleges of America.

f. 5. Jan. 26. Correction of the abuse of castigating novices too severely in the college of Zacatecas in America.

f. 180. May II. Confirmation conferred by the prefect of the Minor Observant missions, in the province of Apollombamba, in Mexico [sic; Bolivia], subject to the Bishop of S. Maria della Pace, is null.

1779. f. 170. Sept. I5. Decrees for certain missionaries.

1780. Nothing relevant.

1781. f. 3. Jan. 29. A college of the Minor Observants in America using too great severity in punishing novices, the decree of 1778 is renewed.

f. I2. Jan. 29. The commissary of the four colleges of the Minor Observants in North America requests the customary facoltà.

f. 62. Apr. 23. The number of missionaries in North America having the power to confirm, not being sufficiently great, the request of the bishops to enlarge it is awaited.

1782. Nothing relevant.

1783. f. 335. July 2I. On the erection and privileges of various houses of refuge of the Minor Observants in Spanish America.

1784. f. 294. May 19. Father O'Donnell, Recollet, deputed superior of the mission of Newfoundland, with facoltà.

1785. f. II 5. May 30. To the Bishop of Quebec in Canada is given as coadjutor with episcopal character, D. Jean Hubert, with facoltà of consecrating him with the assistance of two simple priests. 
f. 493. Nov. 28. In the French colonies of America there is accorded a most ample diminution of feasts. ${ }^{48}$

1786. Nothing relevant.

1787. f. 231. June I8. Relation of the state of religion in Maryland.

f. 243. June I8. Rules for the seminary established there by Mr. Carroll.

f. 243. June 18. Dispensation of vows to an apostate Capuchin.

1788. f. 2, no. 3. Feb. I8. A grant to Mr. Carroll, superior of the missions of English America, of one hundred scudi ${ }^{49}$ for three years, for the benefit of his school.

ff. 2-3, no. 6. Feb. I8. Father Michael MacCormick deputed missionary in Newfoundland.

f. 316, no. I. Sept. Io. Father Charles François Bailly de Mefrein deputed coadjutor of the Bishop of Quebec.

1789. f. 249, no. 3. June 22. At the request of Mr. Carroll, superior of the missions of the United States of America, one hundred scudi for three years is granted to a school in Maryland.

ff. 378-38r, no. 5. Sept. I4. Institution of the bishopric of Baltimore in the United Provinces of America, and designation of John Carroll as first bishop of that see. (Printed in American Historical Reviere, XV. 826.)

1790. Nothing relevant.

1791. f. 6. Mar. 21. The Bishop of Quebec calls attention to the subject of his coadjutor.

1792. ff. I42-155, no. I3. Aug. I3. First relation of the church of Baltimore, and response to doubts concerning said church.

ff. I57-r66. Mar. I. Notes in the archives concerning the new Bishop of Baltimore, including extracts from his reports.

ff. I88-197, no. I4. Sept. I7. Reduction of feasts in Quebec.

ff. I98-I99. Sept. I7. On the facoltà of missionaries, and on the obligation of confession at Easter, in the diocese of Quebec.

f. I99. Sept. I7. On the expediency of erecting a new diocese in Canada.

ff. 199-225 (ff. 200-22I missing). Commission to the Bishop of Quebec with facoltà of secularizing the Minor Recollets of that diocese.

f. 200. Sept. I7. Notes in the archives regarding certain rights of the Bishop of Quebec.

ff. 227-233. Sept. I7. Copies of articles of the edict of the Bishop of Quebec.

ff. 234-235. Sept. I7. Facoltà of the first form for the same.

1793. f. 55. Apr. 22. Questions of the Bishop of Quebec regarding matrimony, and notes in the archives on that subject.

f. 77, no. 5. June II. Father Emmanuele da Silva of the seminary of Our Lady of Guadalupe in Zacatecas requests deputation of facoltà from the Sacred Congregation.

1794. ff. $442-446$, no. 8. June I6. Presentation by Mgr. Carroll of the acts of the first synod celebrated at Baltimore and postulations.

f. 445. June r6. Granted that the Bishop of Baltimore be accorded the same form of oath as that demanded of those of Ireland.

${ }^{13}$ This includes St. Pierre and Miquelon, and I believe was intended to include Canada.

${ }^{t 9} \mathrm{~A}$ scudo is equivalent to about one dollar. 
f. 448-45I. June I6. Notes on the postulations of Mgr. Carroll.

ff. 452-453. June I6. Formula of the oath of Mgr. Carroll.

ff. 454-469. June i6. Acts of the first synod of Baltimore.

ff. 607-608, no. I3. Sept. I. D. Pierre Denaut made coadjutor of Quebec.

1795. f. 8. Mar. 23. D. Leonard Neel (Neale) chosen coadjutor of the Bishop of Baltimore.

f. 224. Nov. 23. Father James O’Donel, Minor Observant, made vicar apostolic, with episcopal character, in Newfoundland.

1796. f. 20I. Aug. I. On the missions of the French Capuchins in North America.

1797. Nothing relevant.

1798 and 1799 . Not found for examination.

1800 and 1801 . Nothing relevant.

1802. f. 6I. Apr. I2. The vicar apostolic of London requests facoltà to send English missionaries to the island of Trinidad, this having passed into possession of England.

1803 and 1804. Nothing relevant.

1805. f. 2. Mar. I I. The request of Father Fenwick, Dominican, to institute a new Dominican province in the diocese of Baltimore, for the service of missions, is remitted to Mgr. Carroll, bishop of Baltimore.

f. 5. Mar. II. A coadjutor with episcopal character and future succession is granted to Mgr. O'Conel, bishop of Thyatira and vicar apostolic of Newfoundland, in the person of Father Stewart, Reformed Minor Observant.

1806. f. 243. Dec. 22. The Bishop of Quebec exposes the reasons for requesting certain concessions regarding matrimonial dispensations, and is conceded these concessions with certain limitations.

1807. Nothing relevant.

1808-1813. During these years the Propaganda was closed.

1814. f. 5 I, Sept. I9, and f. 98, Apr. I. Information given to the Cardinal Prefect, that negotiations are being held with the Pope for the confirmation of Father Connolly as Bishop of New York.

f. 95. Aug. I2. Letter of Mgr. Georgio d'Oria indicating the orders of the Pope in relation to the suspension of the confirmation of Connolly.

f. I53. Sept. I4. On the election of Mgr. Dubourg as Bishop of New Orleans, and on the boundaries, revenues, and decorations of that diocese.

f. I6r. Sept. I4. Doubts relative to the paper last mentioned, and on the expediency of erecting a new bishopric in that province.

f. I64. Sept. I4. Uncertainties concerning the aforesaid territory.

f. I66. Sept. I4. Authentic brief of the erection of four new dioceses in the United Provinces of America (New York, Philadelphia, Boston, and Bardstown).

f. I70. [Apr. 8, I808.] Brief elevating the see of Baltimore into an archbishopric.

f. I83. Dec. I4. Of the erection into an archbishopric of the see of Baltimore, of its suffragans, and of the new diocese to be created in Louisiana.

f. 2 I6. Dec. I4. Doubts on these aforesaid subjects.

f. 243. [Apr. 5, I808.] Brief committing to the archbishop of Baltimore the choice of an apostolic administrator in Louisiana. 
ff. 244 seq. (of various dates). Briefs of the erection of bishoprics in the United Provinces of America.

1815. ff. 62, 74, Feb. 6, and f. 285 , Dec. II. On the choice of a bishop for Philadelphia.

ff. 67, 74, Feb. 6. Projects of Mgr. Plessis on the erection of new bishoprics in Canada, and the resolutions of the Sacred Congregation.

ff. 65,74 , Feb. 6, and f. 287 , Dec. I I. On the succession to the vicarapostolic of Newfoundland, and the resolution of the Sacred Congregation.

f. 296. Dec. I I. On the erection of a new see in the province of Louisiana, and fixing the confines of the same.

f. 303. Dec. II. On the illegal jurisdiction of the Bishop of Havana in Florida.

f. 303. Dec. II. On the question whether the Bishop of Louisiana should be immediately dependent on the Pope; on the provision for the new bishop; and whether the parish of St. Louis should be given to the same.

ff. 304, 33I, 345, 347. Dec. II. Letters and decrees relating to the new bishopric of Louisiana.

f. 359. Dec. II. Report of audience on the spiritual administration of Florida.

1816 (all action relating to America being taken in the congregation of Apr. I).

ff. 2, II, I5. On a letter from D. Charles Nerinckx, parish priest of Bardstown, Kentucky, asking the confirmation of a society of the "Friends of Mary", erected in that state, and various questions raised by this request.

f. 2 I. Instructions to the Bishop of Bardstown on this subject.

f. 29. Report on the spiritual regulation of Nova Scotia.

f. 29. Questions raised by the aforesaid report: whether to assign Nova Scotia a vicar apostolic, to divide Lower Canada into bishoprics, or vicariates, whether to unite Nova Scotia with Quebec.

f. 36. Papers apparently containing the opinion of the cardinal in charge, on the matter of Nova Scotia above mentioned.

1817. ff. I I-I2. May I9. On the transfer of Mgr. Maréchal from Philadelphia to Baltimore, and the questions arising from it.

f. I2. May 19. Whether D. Jean David be made bishop coadjutor of Bardstown.

f. I3. May I9. Whether to appoint Mgr. Burche as vicar apostolic in Nova Scotia, with episcopal title.

f. I3. May 19. Whether the care of the Catholics of Bermuda be provisionally committed to the same.

f. I3. Whether a vicar apostolic with episcopal powers be established in the British islands of America.

f. r78. Sept. 23. Relation of the diocese of Quebec.

f. I83. Sept. 23. Note in the archives relative to matrimonial dispensations.

f. I85. Sept. 23. Whether the project of Mgr. Plessis for increasing the number of bishops, or the offer of the government, be most advisable. 
f. I85. Whether to procure the establishment of other vicariates apostolic in New Brunswick, Maddalena (Magdalen Islands), and Cape Breton.

f. I85. Whether to assign to the jurisdiction of the vicar apostolic of Newfoundland the island of Anticosti and part of Labrador.

f. I85. Questions and resolutions relating to the power of the Bishop of Quebec in the case of baptism by laics, etc.

1818. ff. $43 \mathrm{k}, 48$. Feb. 23. On the establishment of a vicariate apostolic in the English islands of America, and notes and questions related to the proposition.

ff. II7, II9, I24. Apr. 3. Report, with questions and illustrative documents, on the approval of the institute of the "Friends of Mary under the Cross of Christ", erected in Kentucky, including resolutions taken by the special congregation of I8I9.

ff. I8I-I87. Nov. 23. Report and illustrative documents on the situation in Quebec: whether the offer of the court of London be accepted; whether a bishop could be a member of a Protestant legislative council ; whether to erect into dioceses Upper Canada and Prince Edward Island, obtaining the consent of the government thereto, or into vicariates apostolic to be converted later into dioceses; whether to erect Quebec into a metropolitan see; who should be chosen for the new vicariates or dioceses.

1819 (all action relating to America being taken in the congregation of Aug. 2).

f. I 58. Appointment of a coadjutor to the vicar apostolic of Nova Scotia.

f. I7 I. On the erection of Virginia into a bishopric.

f. I79. Whether to accept the renunciation of Mgr. De Barth, elected Bishop of Philadelphia.

f. I80. On the erection into dioceses of "le due Georgie con la Carolina ".

f. I8o. Special congregation appointed to consider the difficulties of the Archbishop of Baltimore; how to calm seditious spirits, and quiet the pretensions of the Catholic Republicans of that diocese; whether it is better that funds there be held in the public name or the private; whether it is proper to define the rights of builders and patrons of churches.

1820. ff. 5-9. Jan. 24. Report on the accession of the Archbishop of Canada to the legislative council of that kingdom, on the institution of new bishoprics, and on the metropolitan dignity accorded that prelate.

ff. 36-39. Jan. 24. Acceptance by the vicar apostclic of Newfoundland of the jurisdiction over Labrador and Anticosti.

$\mathrm{ff} .42,50$. Report relative to the visitation of the arclidiocese of Baltimore.

ff. 54, 70. Questions proposed by the Archbishop of Quebec on matrimony, etc., with discussions and resolutions.

1821. ff. I6I-I62. Feb. I2. Concession of a patent of honorary missionary for Philadelphia to Father Harold, Dominican.

f. 274. May 2I. Proposition of D. Dennis Lyons, priest, for the apostolic vicariate of Nova Scotia.

f. 272. May 21. Institution of the bishopric of Cincinnati.

f. 272. May 21. Project of the erection of bishoprics in Detroit and Michigan. 
ff. 3IO-3Ir. May 2I. Questions of the Archbishop of Baltimore on the erection of a chapter, and on the subordination of European priests coming to America to American bishops.

ff. 437-439, 453. July 9. Questions of Mgr. Du Bourg relative to the rules for ordination in America

f. 456. July 3r. Report on the controversy between the Bishop of New York and the trustees.

ff. $463-472,493$. July 31. Questions and resolutions on the incident of Father French at "Molau".

ff. 494-496. July 3I. Suggestion of the Archbishop of Baltimore relative to the choice of bishops in the United States.

ff. 578-580. Sept. 27. Facts, questions, and decisions relative to the erection of the bishopric of Virginia.

1822. ${ }^{50} \mathrm{f}$. 57. Jan. 28. Brief giving the administration of Virginia to Mgr. Maréchal.

f. 199. Apr. 22. On the mode of criminal jurisdiction, etc., in Baltimore.

ff. 205-207. On the conferring of the baccalaureate degree in the college of St. Mary at Baltimore.

ff. 228-235. June 3. On the case of Father Hagan if he appeals to the secular law; how to impede the access of bad Irish priests; on the proposed agreement between the trustees and the bishops; on the confiding by $\mathrm{Mgr}$. Maréchal of a portion of the archdiocese to the Bishop of Louisiana; on the spiritual governance of Florida; on license to celebrate before those excommunicated.

pp. 42I-425. Dec. 3. Questions and resolutions regarding the spiritual administration of Florida.

1823. ff. $37,45-54,215-216$. Reports, queries, and resolutions relating to the diocese of Quebec, including: the taking of an oath by the bishop as member of the legislative council; questions relating to the seminary of St. Sulpice; and the creation of a vicar apostolic for New Brunswick and Nova Scotia.

ff. 227-237. June 9. On the revocation of a decree making Sig. Rosati vicar apostolic of Mississippi and Alabama.

ff. 250-253. July 29. Appendixes to the report on the affairs of Canada.

f. 375. Dec. I. On the erection of the new diocese of Michigan.

f. 375. Dec. I. The Bishop of Cincinnati requests a fixed subsidy, books, etc.

1824. ff. I68-I72. May Io. On the question of the cession of part of the property possessed by the Jesuits in Maryland to the Archbishop of Baltimore.

f. 571. Nov. 29. On the election of the vicar apostolic of Nova Scotia.

ff. 617-626. Dec. 22. On the selection of the vicar apostolic of Florida and "l'Albania" (Alabama); and on the transfer of Mississippi to another jurisdiction, it being removed from that of the Archbishop of Baltimore.

${ }^{50}$ In this and the successive volumes $J$. have not referred to the various sommarii or briefs on the controversy regarding the Jesuit property which are described, and many of which are printed, by Father Hughes in his History of the Society of Jesus in North America, Docs., vol. I., pt. I., sec. 3 . 
1825. ff. I52-I62. Mar. 28. On the selection of the Bishop of Boston. ff. 24I-253. May 30. On the erection of Upper Canada into a diocese. ff. 366-369. Aug. I. Relation of Mr. Secretary on the schism of Philadelphia.

ff. 6o9-6I7. New report on the erection of Upper Canada into a new bishopric.

1826. ff. 63-8I, I IO. Jan. 30. Report on the controversy aroused by the deputation of Mgr. Lartigue as vicar general of Montreal, with questions, resolutions, summary, and the reflections of the Sulpician Bedard.

ff. 220-227. May 6. On the selection of the Bishop of New York, and on the deputation of a coadjutor to the Bishop of Kingston in Upper Canada.

ff. 3I4-3I5. June 26. On the division of Louisiana into two bishoprics, and on the erection of Michigan and "Nordwest" into a bishopric.

ff. 338-343. Aug. I. Decrees of the synod of Bardstown on the baptism of heretics, with questions and resolutions.

ff. 439-444, Sept. 25 ; and ff. 503-505, Nov. 20. On the response of the Archbishop of Quebec to the letter written him concerning the controversy aroused by the deputation of Mgr. Lartigue as his suffragan at Montreal, with queries, resolutions, etc.

1827. ff. I43-I49. Feb. I9. On the proposed response of M. Roux, superior of the Sulpician seminary at Montreal in Lower Canada, to the project of Lord Bathurst for guaranteeing its rights against the pretensions of the government.

ff. I53-I58. Feb. I9. Whether to proceed with the publication of the brief erecting the see of Detroit in Michigan, and supplicate His Holiness to select as bishop D. Gabriel Richard, with resolutions, etc.

ff. I68-I72. Feb. I9. On the reasons of Mgr. Rosati for not accepting the bishopric of New Orleans; whether to petition the Holy Father to nominate Mgr. Rosati as Bishop of St. Louis in Missouri, and to promote the Flemish priest De Neckere; with letters and illustrative documents.

ff. I83-I93. Mar. 26. Questions and resolutions relating to the revision of the decrees of the synod of Bardstown, with illustrative documents, including notes by Abbé " Martial".

ff. 237-244. Apr. 30. Concordat concluded between Mgr. Henry Conwell, bishop of Philadelphia, and the fabricants of the church of St. Mary of that city.

ff. 367-372. July 30 . On the provisions to be taken to give a system to the church of Philadelphia.

ff. 538-541. Dec. I9. Reasons urged by Mgr. Maréchal, archbishop of Baltimore, why a coadjutor should be granted him.

1828. f. I. Jan. 29. Relation of Mr. Secretary on the business of the seminary of Montreal.

1829. f. IO3. Apr. 27. On the provisions necessary to systematize the affairs of the Catholic religion in Florida and Alabama, with the erection of a bishopric and the establishment of a place of residence for the bishop.

ff. I3I, I4I. June I. On the selection of a coadjutor for the vicar apostolic of Newfoundland. 
f. I48. June I4. The Bishop of Bardstown petitions for facoltà to unite in matrimony a Catholic with a non-Catholic.

f. 244. July 25. Selection of Mgr. De Neckere as Bishop of New Orleans.

f. 247. July I3. Request for the dismemberment of New Brunswick and Prince Edward Island from the diocese of Quebec, and their union into a new diocese; and the transfer of Cape Breton from the diocese of Quebec to the vicariate apostolic of Nova Scotia.

f. 298. Aug. I7. Relation of Mr. Secretary of some provision to be taken in favor of certain "Osagi" who had come to Rome.

f. 307. Aug. 23. Dispensation for a Catholic of Baltimore to marry a non-Catholic.

ff. 3I3-3I8. Aug. I7. Request of the administrator of New Orleans for the reduction of feasts, etc.

f. 324. Aug. I7. Request of Mgr. Fenwick, commissary general of the province of St. Joseph of the Dominicans of America, for the sale of the monastery of Santa Rosa in Kentucky.

f. 350. Sept. I 5. Request for permission to celebrate the vespers of the titular saints of the rural churches of Quebec, on the Sunday within the octave of All Saints.

ff. 383-385. Sept. I 5. Conduct of Mgr. Conwell, bishop of Philadelphia, after his coming to Rome, and that of the Propaganda after his departure from Rome.

1830. f. 37. Jan. 25. On provisions to systematize the diocese of Philadelphia.

f. 6o. Jan. 25. Whether to petition the Pope to nominate as coadjutor to Mgr. Conwell, bishop of Philadelphia, D. Francis Patrick Kenrick.

ff. 6o-64. Jan. 25. Various actions relative to the troubles of the church of Philadelphia.

ff. 72-84. Mar. I. On the protests of the clergy of Lower Canada against the transaction to be agreed upon between the Sulpicians and the British government for the sale of property held by the seminary of Montreal.

ff. 252-258. May 19. Request of Mgr. Du Bois, bishop of New York, with the object of obtaining aid for the erection of a seminary in his diocese.

ff. 396-4I7. On the revision of the decrees of the provincial synod of Baltimore, with illustrative documents, including its journal and decrees, instructions, votes, etc.

\section{SCRITTURE ORIGINALI RIFERITE NELLE CONGREGAZIONI GENERALI.}

These are the documents on which the decisions in the preceding Atti were based, in so far as such documents were not embodied in the Atti themselves. In most cases the original letters, etc., are found here, the report in the Atti being a summary from them, drawn up by the secretary or the cardinal to whom the matter was referred. In some cases these letters, however, represent an intermediate stage, having been prepared by procurators on the basis of letters sent them, and which never became a part of this archive. This collection is divided into two parts, the scritture antiche, embracing those before 1669 , and the scritture corrispondenti, extending from that date to the present. 


\section{SCRITTURE ANTICHE.}

The material in this series is roughly divided by countries, each volume having a title indicating the countries regarding which it contains something. Often the material in a single volume covers an area widely scattered, and few volumes concern one country alone. In general the material progresses chronologically from the earlier volumes to the later, but it is unsafe to rely on this too trustingly. All volumes containing material on the Indies, the Americas, Spain, France, and England were examined and all relevant material noted is cited in the following list. It is conceivable that there may be additional volumes containing Flemish material, among which there might be something relating to New York, and in one instance the nuncio at Cologne is found acting for the Dutch Catholics $;{ }^{51}$ but time did not suffice to test these more remote chances.

74. Letters of Germany, Cologne, Switzerland, France, Flanders, Spain, Portugal. I632.

Nothing relevant.

83. Letters of Germany, France, Flanders, and England. I64I.

ff. I80-I8r. Jan. 7. The provincial of the Capuchins of Paris speaks of the missions of Canada.

f. I99. Nov. "Cristoforo", a priest from Paris, requests permission to go as a missionary to North America.

89. Letters of Germany, Ireland, and France. 1644 . Nothing relevant.

97. Letters of Switzerland, Germany, Hungary, Bohemia, Belgium, Cologne, Münster, France, Hamburg, Spain, and Portugal. I648.

f. 6. Mar. 13. Sig. Damon has been designated by the King of France to establish a seminary in America, under the Capuchin fathers.

f. 7. Copy of the letter of the nuncio in behalf of M. Damon.

98. Letters of Spain, Portugal, Indies, Switzerland, and Cologne. I630. Nothing relevant.

99. Letters of Portugal, Indies, Syria, and Egypt. I631. Nothing relevant.

100. Letters of Spain, France, Flanders, England, Scotland, and Ireland. I63I.

f. 22. Jan. 25. On the bequest of the Archbishop of Myra, with mention of the fleet of the Indies.

f. I50. June I. Brother Simon Stock says that it would be a work of much honor to the Church to establish a colony of Italians in America, with their own bishop.

f. I57. June 25. The above mentioned Brother Stock rejoices at the mission of the Capuchins in America ordained by the Sacred Congregation.

101. Letters of England, Spain, Portugal, Flanders, and France. I626.

f. I4. Apr. 22. Brother Stock writes from London, saying that he has sent a map of America showing the probability of a passage through America to China, which would be of great advantage to the Church. Also that the best part of America is in the temperate zone, where are the best natives and mines, and which is possessed by the heretic English, who have founded the city of "Plimouth", situated, like Rome, on the hills, and whither in three years ten or twenty preachers have gone.

${ }^{51}$ See Atti, I659, f. I40. 
ff. I5-I6. The above mentioned Brother Stock speaks of the necessity of providing for a mission in "Avalonia " because of the easy passage thence to China, and answers inquiries of the secretary of the Propaganda, concerning the Catholic pilot who discovered this fact, and who is now thought to be in Spain.

ff. $2 \mathrm{I}-24$. Oct. 30, I625. On the missions of the island called "Avalonia".

f. 45. Feb. I, I626. The nuncio in Spain writes on the search, at the instance of the secretary of the Propaganda, for persons informed as to the voyage from England to China by means of the rivers of North America.

102. Letters of England, Scotland, Ireland, Cologne, Hamburg, Alsace, Spain, and Ethiopia. I628.

f. I I. June 27. Brother Stock sends two maps of America, and speaks of the missions of "Avalonia".

ff. I2-I3. Report and considerations on the preceding letter.

103. Letters of Spain, Indies, Egypt, Palestine, Ethiopia, and Africa. I633.

Nothing relevant.

104. Letters of Spain, Portugal, Armenia, Indies, Jerusalem, Syria, Tartary, and Egypt. I634.

Nothing relevant.

105. Letters of Spain, Indies, Flanders, England, and Ireland. I 635 .

f. - List of Capuchin ecclesiastics who desire to go on missions.

f. 54. July 8. Father Benavides, writing from Madrid, speaks of the missions of New Mexico. (Spanish.)

f. III. The procurator of the Minor Observants of the Indies requests to return to Rome, having treated in vain the affairs of the province of Mexico. (Latin.)

f. 197. Feb. 27. The nuncio at Paris will take care to provide that nonCatholics are not transferred to Canada.

f. 20I. May 24. The nuncio at Paris writes that facoltà for the Recollets of Canada have been received.

106. Letters of Spain, England, Scotland, Ireland, Indies, Persia, Syria, Georgia, and Tartary. 1637.

Nothing relevant.

107. Letters of Spain, Indies, Syria, Persia, Egypt, Ethiopia, and Tartary. I638.

f. 35. Apr. 22, I633. Account of how much Father Lorenzo Valdez has accomplished in New Mexico.

108. Letters of Spain, Flanders, Egypt, Ethiopia, Barbary. I645.

f. I3. Apr. I5, I643. From the nuncio at Madrid, on Father Bonaventura.

f. I6. Sept. I3. The nuncio writes from Madrid on the necessity of providing a bishop of New Mexico.

110. Letters of Spain and Portugal. I646.

Nothing relevant.

119. Letters of Barbary, Egypt, Palestine, Indies, Persia, Tartary, and Armenia. I640.

Nothing relevant.

120. Letters of Persia, Syria, Egypt, Ethiopia, Indies, and Africa. I64I.

Nothing relevant. 
123. Letters of Tartary, Mingrelia, Spain, Portugal, Indies, Syria, Egypt, Barbary, and Malta. I644.

f. 63. I643. A Dominican complains of having been deprived of a vicariate in Mexico.

f. 87. The nuncio at Madrid, on the grievances suffered by the Minor Observants at the hands of Bishop Palafox.

129. Letters of France, Flanders, Spain, Indies, England, and Ireland. I627. Nothing relevant.

130. Letters of France, Avignon, and Switzerland. I628.

Nothing relevant.

131. Letters of France, Avignon, Rhaetia, Switzerland, Flanders, England, Scotland, Spain, and Indies. I629.

f. I86, July, I629; f. I87, July, I628; f. I88, Aug. 9, I629. From Brother Simon Stock, from London, giving the latitude and longitude of the new island of "Avalonia", and the Mediterranean sea of North America, recently discovered; and speaking of the pilot who discovered it.

132. Letters of France, England, Poland, and Russia. I630.

f. I4I. Apr. 28. Brother Simon Stock gives notice of the great number of Puritans that have passed into America.

133. Letters of France, Flanders, Switzerland, England, and Ireland. I632.

f. I9. Feb. 22. The nuncio at Paris recommends that Father Giacinto, Capuchin, come to Rome to give an account of the mission of his order in France and Canada.

134. Letters of France, Flanders, England, Ireland, and Scotland. I634. Nothing relevant.

135. Letters of France, Flanders, England, Scotland, Ireland, Spain, Portugal, Indies, Poland, Wallachia, Egypt, Palestine, Persia, and Tartary. I636.

ff. I43-I47, I49-I 50. Feb. I2, I634; Jan. 30, Feb. I3, Feb. I4, I635. Attestation by Father Benavides, formerly missionary of the new kingdom of Mexico, with duplicates and letters.

136. Letters of France, Flanders, Switzerland, Poland, and Russia. I637.

ff. 27-29. The provincial of the Capuchins of Normandy sends the names of missionaries in America.

137. Letters of France, Flanders, Avignon, Savoy, Poland, Russia, Wallachia, England, and Ireland. I638.

Nothing relevant.

138. Letters of France, Spain, Portugal, Flanders, England, Ireland, and Indies. I634.

ff. I2, I8, 22-23. Feb. II. Father Virginio of Paris goes as missionary to New France, Virginia, and Florida.

ff. I62-I63. Compendium of the secret relation of the Western Indies by Father N., Augustinian of Mexico.

f. I64. On the parochial churches of the Indies, particularly South America.

ff. I65-I68. Discourse by Secretary Ingoli on the subject of sending an apostolic delegate to the Indies.

f. I75. Missions of the Augustinians in the Western Indies.

f. I83. Paul le Jeune gives account of conversions made in Canada.

ff. I84-I87. Brother Diego Ybañes, on the persecutions suffered by the ecclesiastics of the Western Indies at the hands of the royal ministers. 
139. Letters of France, Spain, Flanders, Poland, Wallachia, Ireland, and England. 1640.

ff. IO-I I (with inserted page). Sept. I. Missionaries proposed for the missions of Canada.

f. 52. List of twelve priests and two lay brothers, Capuchins, for the Canadian missions. (Latin.)

141. Letters of France, Avignon, Spain, Portugal, Flanders, Indies, England, Scotland, and Ireland. I642.

f. 26. May I4. The provincial of the Capuchins says, among other things, that the ambassador of Constantinople has been declared viceroy of North America.

f. 30. Jan. 20. The Capuchin missionaries of America designate a Capuchin priest as prefect of missions.

f. 31. May 28. The provincial of the Capuchins of France has received the decree for the extension of the missions in America.

f. 45. May 28, I640. The provincial of the Capuchins of Normandy gives account of the missions of America.

ff. 5I-52. May 26. The provincial of the Capuchins speaks of Canada and Florida, wishing to forestall the Dutch in occupying a place where the natives are docile and one can embark in February.

f. 67. Nov. 7. The above mentioned provincial gives a relation of Canada.

ff. 68, 73. Dec. 8, I64I. Another relation of the same mission by the same provincial.

ff. 69-72. Oct. 8, I64I. The same provincial sends a map ${ }^{52}$ of parts of America, made by a priest who lived there three years.

ff. 216-218. Note of fourteen candidates considered for the mission of Maryland, with a relation of Maryland of Nov. 7, I64I.

f. 222. Nov. I2, I64I. Decree of the Sacred Congregation on the expedition of missionaries to Maryland.

142. Letters of Avignon, France, Spain, Portugal, East Indies, England, and Ireland. I643.

f. 29. Mar. I3. Mattheo Darcelle, priest, writing from Paris, requests to go as missionary to America.

ff. 30-35. Mar. I3, I645. Recommendation of the aforesaid Darcelle, by a missionary of America.

f. 36. Mar. 6. The nuncio in France recommends two missionaries for America.

f. 93. Request of the aforesaid Darcelle, to go as missionary to America with companions.

143. Letters of France, Avignon, Portugal, Indies, Ireland, and Ethiopia. 1645.

f. I68 (with preceding and succeeding pages). Dec. 6. Whether Indians can be made priests and instructed in arts and sciences.

144. Letters of France and Avignon.

f. 7. Dec. 27, I645. The nuncio in France sends letters received from Capuchins in America.

f. 34. July I3. The nuncio in France speaks of the new mission in Canada, and of the necessity of establishing a fund for the sustenance of missionaries.

${ }^{32}$ Not found. In fact none of those mentioned as enclosed were found. 
f. I07. Mar. 8. A Capuchin speaks of a young man taken from Canada to Paris.

f. 108. Apr. 27. Luigi Francesco of Paris writes on the question of jurisdiction over the missionaries of America.

ff. I09, I I I, I I2, I22. Oct. 25. A Capuchin prefect of missions in America writes of various missions there, and of the lack of interest in the same. (French.)

145. Letters of France, Spain, England, Scotland, Ireland, and Indies. I647.

f. 26. May 3. The nuncio at Paris, on the promise of the provincial of the Capuchins to increase the mission of Father Pacifique de Provins in Canada.

ff. 37-38, 4I-42. Letter from Father Pacifique, Nov. 2, and from the nuncio, Nov. 8, on the embarkation of the former for Canada.

ff. 57, 64. Oct. 26, 1646. Father Pacifique on the missions of America.

ff. 58,59. French copy, and Italian translation, of a certificate of the King of France on the work of Father Pacifique in America.

ff. 60-63. June 26. Father Pacifique de Provins on discoveries and missions in America, and reports to the Sacred Congregation on the same.

f. I83. Letters from Father Morales, of Feb. 25 and Mar. 7, giving account of his arrival in Mexico, and of the missions there.

150. Letters of Aleppo, England, and Ireland. I632.

Nothing relevant.

189. Letters of Portugal, Indies, and Japan. I629.

ff. 62-79. I626. Relation of the inconveniences in the churches of Eastern and Western Indies, and of their remedies, by Father Gregorio Bolivar, Minor Observant. (Spanish.)

ff. $75-80$. Documents relating to the aforesaid relation.

ff. 8I-84. Annotations to the bull of Adrian VI., the first in the bullarium of Brother Emmanuel Rodericus, with a copy of the bull and other documents.

f. 87. List of Dominican ecclesiastics in the Eastern and Western Indies.

ff. 89-92. Points on which the Propaganda desires the advice of the general chapter of the Order of Preachers, concerning many Indian priests in both Indies.

ff. I05, I IO. Compendium of the writings of Father Pedro Nieto, Augustinian, on the ordination of Indians.

ff. Io6-ro9. The work summarized above. (Latin.)

ff. I I I-II3. Documents relating to Father Nieto.

ff. II4-I I5. Discourse of the secretary of the Propaganda on the ordination of Indians.

ff. II6-II8. Paper by Secretary Ingoli on the disorders and inconveniences in both Indies.

ff. II9-I22. Summary by Mgr. Ingoli of the writing of Father Zanudio on the election of regulars and the reception of novices in the Western Indies.

ff. I $21-127$, I $30-136$, I $38-139$. Documents on the alternation in the choice of provincials for the Western Indies.

ff. I37-I38. Writing of Father Nieto, demonstrating the ability of Indians for the priesthood.

ff. I4O-I 44. Compendium of the principal points in the relation of Mexico, by Father Nieto, Augustinian. 
ff. I43-I44. Discourse of Mgr. Ingoli on the ordination of Indians to the priesthood.

f. 145. Aug. 7, 1628. The nuncio at Madrid on the ordination of Indians. ff. $146-149$. Other letters and documents on the ordination of Indians.

ff. I53-I 59. Documents on the ecclesiastical disorders of both Indies, including a letter of Father Zanudio.

ff. I60-194. Documents relating to the aforesaid ecclesiastical disorders, particularly as concerning regulars.

f. 2 16. 1623. Description of the province of New Mexico.

f. 247. Relation from the English Carmelites on the missions in that part of Virginia called New England.

ff. 289-294, 4I4-4I8. June 25, and other dates of the year I625. Documents relative to the ecclesiastical disorders of the Indies, including instructions to the nuncio in Spain.

190. Letters of Indies and Japan. 1636.

ff. 9-ro. On provisions for the Indies.

ff. 84-85. Inconveniences and their remedies in facoltà for the Indies.

ff. 86-87. On conversions and the development of religion in New Mexico. (Spanish.)

f. I 52 (55 pages, printed). Relacion sobre las Religiones de las Ordenes Mendicantes en las Provincias del Pirù e Nueva España.

f. I53 (23 pages, printed). Response of the regulars regarding the privileges conceded to them in the said regions.

192. Letters of Indies, China, and Japan. I648.

ff. 3-5. Disorders and abuses in the Western Indies.

ff. 6-7. Abuses in both Indies.

ff. 9-IO. Report of the secretary of the Propaganda on abuses in the Western Indies.

f. II. Abuses in both Indies.

f. I3. Brief relation of Father Nieto, Augustinian, on North America.

ff. I7-I8. On the concord that ought to reign among those concerned in the evangelization of the Indians.

193. Letters of Indies, China, and Japan. I654.

Nothing relevant.

194. Letters of Indies and Japan.

This concerns the East Indies almost wholly.

ff. I60-162. Feb. I0, I638. Brother Francesco de Oviedo Pedrosa, procurator general of the provinces of Lima and Chili of the Order of Santa Maria della Mercede, on the relations between bishops and regulars.

ff. 298-302. Memorial on the damages suffered in body and soul by the natives, because of the holding of cures of souls by the regulars. (Spanish.)

198. Letters of France and Lothringia, to 1629.

Nothing relevant.

199. Letters of France, to 1648 .

f. 223. July I8, 1639 . State of the missions of the province of Paris. (Latin.)

200. Letters of France.

Nothing relevant.

201. Letters of France and Avignon.

Nothing relevant. 
202. Letters of France.

Nothing relevant.

203. Letters of France.

Nothing relevant.

204. Letters of France.

f. 6. June Io, I662. Memorial on the missions of the Capuchin province of Paris.

256. ${ }^{83}$ America, Canada.

ff. 3-4. May 27, I659. On the erection, in the island of Montreal in New France, of a parish.

f. 5. The minister resident of France petitions that the brief for the bishopric in partibus for François de Montigny be hastened as much as possible that he be able to go as vicar apostolic to New France.

ff. 7-I8. Relatio Missionis Canadensis anno I660 mense Octobri missa. I. Sent by Mgr. Laval, bishop of Petraea, vicar apostolic in Canada.

f. I8. June I3, I660. From Mgr. Laval, on the progress of the faith in Canada, and on the jurisdiction claimed by the Archbishop of Rouen.

f. 20. July 9, I66o. From the nuncio at Paris, on the attitude of the Archbishop of Rouen.

f. 22. Jan. 2I, I660. From the nuncio at Paris, advising that Abbé "Chelius" (Queylus), desirous of returning to Canada with new facoità, be not allowed to return.

f. 24. Oct. 29, I660. The vicar apostolic of Canada writes from Quebec, on the barbarity used against ministers of religion, and on the pretensions of Abbé Queylus.

ff. 26-3I. Oct. 21, I66I. Letter from the vicar apostolic of Canada enclosing "Informatio de Statu Ecclesiae Novae Franciae".

f. 3I. 1662. The King of France petitions for the institution of a bishopric at Quebec.

f. 33. Oct. 22, I66I. The vicar apostolic of Canada, on the good works of the priests, particularly the Jesuits, and on the designs of the Archbishop of Rouen.

ff. 35-36. Aug. 24, I663. On the conflict of jurisdiction in Canada between the vicar apostolic and Abbé Queylus.

ff. 37-40. Relation of the state of the church among the Algonquins, in Canada, New England, New Belgium, Acadia, and New Sweden.

f. 55. Nov. I663. The vicar apostolic of Canada announces his arrival at Quebec, and urges the erection of a bishopric.

ff. 57-59. Aug. 26, I664. Letter of the same enclosing "De Ecclesia Huronica in Nova Francia".

f. 6I. Oct. 24, 1665. Id. requests that Quebec be erected into a bishopric.

ff. 63-64. Nov., 1665. Id. speaks of the conversions made, and the institution of a seminary.

ff. 65-66. Nov., I665. Id. requests that a bishopric be instituted, that the seminary of Quebec be united with that of Paris, and that the parish of Quebec be united with the said seminary.

ff. 67-69. Nov., I665. Id. speaks of the many Europeans coming to Canada, and the necessity of erecting a bishopric; also of the great good done by the seminary.

\footnotetext{
${ }^{53}$ This volume is constantly referred to by Abbe Faillon, in his Histoire de la Colonie Française en Canada, and some extracts of documents are printed there, but the majority of them are short.
} 
ff. 7I-77. Dec. I5, I666. Considerations on the creation of a bishopric in Canada, with the advice of the cardinals on the subject.

f. 78. Oct., I666. The vicar apostolic of Canada reviews the letters formerly written, fearing that they have been lost.

ff. 80-83. Oct. I4, I666. From the same, on what is done for the diffusion of the faith, on how much more will be done when the Iroquois have been subjugated, and on the ability of the region to pay decimae.

ff. 87-94. Relation prepared in the Propaganda from foregoing documents and perhaps others, on the missionary work accomplished in Canada.

ff. 97-IOO. Considerations on the proposal of the King of France to erect a bishopric in Canada.

f. I04. Dec. I4, I662. "Copie du Brevet du Roy pour 1'Erection et l'Union d'une Abbaye à l'Évêché de la Nouvelle France."

ff. I05-I07. Sept. 25, I667. The vicar apostolic of Canada writes from Quebec on the erection of a bishopric and the progress of missions.

f. Io8. Unsigned sheet, in same hand, on the decimae.

ff. I09-I I4. Dec., I667. Copy of the minute of the erection of the church of Quebec for the Consistorial Congregation, with summaries of material on the subject.

ff. I I5-I I6. Whether the nomination to the diocese of Quebec ought to belong to the King of France.

f. I I9. Considerations to be presented to the Consistorial Congregation regarding the erection of Quebec into a diocese.

f. I2I. Dec. I5, I666. Decree of the congregation: "Erigatur in titulum Vicariatus Apostolicus Canadiensis, et nominatio illius Ecclesiae concedatur regi Galliarum tanquam fundatori".

f. I23. The vicar apostolic of Canada petitions for a holy body to be exposed to the veneration of the faithful.

f. I27. Jan. 20, I667. Cardinal Piccolomini, writing from Ravenna, warmly recommends the vicar apostolic of Canada.

ff. I3I-I 34. Oct. I5, I666. The vicar apostolic of Canada gives a relation of Christianity there, and represents the necessity of erecting the several churches into parishes-that of Quebec in union with the seminary.

ff. I35-I44. Sept. 9, I672. Minute of the bull on the erection of the church of Quebec into a bishopric, with annotations by the Consistorial Congregation, and messages from the court of France, and note from the nuncio, in cipher, on the friction with the king, and the rooo scudi promised by the Bishop of Petraea for the expedition of the bull.

257. America. ${ }^{54}$

f. I6. Mar. I8, I664. Juan de Sotomayor, presbyter of Cuba, asks missionary facoltà.

f. 74. Facoltà for the Bishop of Guadalaxara.

ff. 78-80. Nov. 23, I663. Relation of the Western Indies.

ff. I39-I4I. Requests for facoltà, from the Archbishop of Mexico, Sept. 7, I664; and from the Bishop of Santiago de Cuba, Sept. 22, I664.

ff. 232-234. Sept. I3, I663. Request for facoltà from the Bishop of Porto Rico.

According to an older classification this volume is marked, America IV.: Cayenna, etc. The material is arranged by provinces. 
ff. 254,267 . June 28, I660. Grant of facoltà to the Bishop of Santiago de Cuba.

258. Lettere di America. ${ }^{.5}$

ff. I-4. Curious division of America into twenty-two parts.

f. 8. Jan. I4, I659. French Oratorians request facoltà for priests going to America.

f. Io. Apr. 30, 1659. The nuncio in Spain speaks of missionaries sent to the Indies.

f. 12. Oct. 3, I66I. The procurator of the Society of Jesus requests facoltà for the Western Indies.

259. America.

f. I. Sept. 2I, I630. The nuncio at Brussels sends a relation of what he has found out about the Puritans who are transferring themselves to North America, and says that it would be possible to send French Capuchins to impede their progress.

f. 2. Enclosed with the above, "Descriptio Novae Angliae sive terrae recen[ter] inventae", which includes a reference to the activity of Lord Baltimore.

ff. 30-60. I635 circa. Relation of the provinces and convents of the Franciscans in the Indies, addressed to Cardinal Barberini, their protector.

f. 62. I636. Relation of Father Nieto, missionary in North America, of the peoples of California.

ff. 62-63. June 26, I633. Document relating to Father Nieto.

f. 68 (80 pages). "Tractatus quartus. De Catholici Hispaniae Regis in Indiis Occidentalibus Ecclesiastico Patronatu." (Translated from the Spanish.)

f. 70. I648. Father F. de Cohomiers of Chasteau suggests a method of making conversions in America.

f. I09. Jan. I9, I635. Memorial for the use of the nuncios in France, to the end that heretics be not permitted to go to Canada.

ff. IIO-II4. I634. State of missions in Canada.

ff. II5-I33. I639. Relation of the progress of religion in Canada.

ff. I35-I36. Compendium of the relation on folios 30-60.

f. I38. Note of the missions of five Jesuit priests in Canada.

ff. I4O-I4I. I644. A Capuchin priest speaks of the missions of Canada, and wishes to extend them to other regions of North America.

ff. I45-I47. June 5, I664. Abstract of the relation of New Mexico made by Father Alfonso Benavides.

f. I53. List of privileges for the Indians.

ff. I 58-188. Relation of Father Benavides on New Mexico, describing its situation, climate, soil, the customs of the Indians, the discovery, the revolt and pacification.

f. I9o (54 pages, printed). Treatise compiled by the procurator general of the province of the Holy Gospel in New Spain, to prove that the regulars are not subject to the jurisdiction of bishops.

ff. 195-I97. Aug., I629. Writing of Father Pedro Nieto, Augustinian, on the means of propagating the Catholic faith in the Western Indies, with suggestions.

${ }^{35}$ This is also marked, America I, 2: Arequipa, Bresile, e S. Salvatore. 
ff. 20I-202. Note of the Franciscan missionaries of the province of Mexico. Printed, with manuscript notes.

ff. 213-276. I628. Father Nieto, "De Ritibus Gentium Occidentalium earumque Moribus, Regionibus, Civitatibus et Oppidis, ac de instituendo Conversionis Infidelium modo, et Propagandae Fidei in illis partibus Incrementis".

ff. $278-285,301-303$. Abstract and two compendiums of the relation just preceding.

ff. 285-300. I628. Secret relation of Father Nieto, showing the necessity of having nuncios in the Western Indies.

ff. 25I-273. Conversions made by the Franciscans in New Spain, including New Mexico.

ff. 392, 398. On the progress of religion in New Spain.

ff. 393-397. Conversions made by the Franciscans in New Spain.

ff. 407-408. Archbishoprics and bishoprics of the Western Indies.

260. America.

f. 7. 1656 (?). Catalogue of the Jesuits of the Western Indies.

ff. I6-20. Mar. I, I650. "Relatio earum omnium quae gesta sunt per sex annos in Missione PP. Cappuccinorum apud Indos in America."

f. I7. I650. Two Capuchins relate the progress made in the Western Indies, and request permission to return thither.

f. I8. I650. The Bishop of Havana requests facoltà.

f. 20. I650. The Bishop of Guadalaxara requests facoltà.

ff. 2I-22. I649. A young Indian, born in Santo Domingo, is conducted to Rome.

ff. 33-37. "Descriptio Missionis Accadiae in Nova Gallia." "so

f. 63. I650. Two Capuchins say that there is necessity of making missions in the islands of Marie Galante, Dominica, St. Vincent, etc. Of some general interest.

f. 73. Brother Juan de San Buenaventura, Minor Observant of Spain, requests to be declared missionary for the Western Indies.

f. 75. I65I. The Jesuits of the French islands ask facoltà. Apparently they included Canada.

f. 76. "Facultates concessae a ... Superiori Missionis seu Residentiae Patrum Societatis Jesu in Canada Indiarum Novae Galliae."

ff. 90-9I. The French Dominicans request the amplification of their missions among the Indians of North America.

f. 95. Joannes le Rat de Villaviride, priest of Brittany, having learned many languages of the Indians, requests permission to return to the mission among them.

f. 96. May 6, 1650. The nuncio at Paris recommends the priest just mentioned.

f. 97. The nuncio at Paris is requested to recommend to the Propaganda the continuance of the mission of the Capuchins in America.

f. 98. Aug. 30, I652. The nuncio at Paris sends information on the spiritual needs of the Christians of "America Occidentalis".

f. I40. Nov. 3, I65I. Proposition of the Duc de Ventadour, to erect in France a seminary for the service of the missions of America. (Translation.)

A photographic reproduction of this has been made, but I do not know where it has been published. 
f. I4I. French original of the above.

f. I42. Nov. 3. M. de Noëlly, on the same subject.

ff. I43-I 45, I 5I-I 52. Letters from the Duc de Ventadour, on the said seminary, of Nov. 3, 1651, Apr. 19, 1652, and three without date.

ff. I53-I58. Statuta Seminariorum ad Propagationem Fidei in Partibus Infidelium. (Two copies.)

f. I60. Jan., I653. The nuncio at Paris writes that there has not been made any assignment of annual revenue for a bishop in Canada.

f. I6r. Father Dulong, Recollet, requests to go as missionary to Canada.

f. I62. Sister Margherita, Dominican, having obtained the permission of the King of France, requests the license of the Propaganda to go and found a convent in Canada. (Apparently Sœur Marguérite Bourgeoys, but she was not a Dominican.)

f. I63. Apr. 3, I654. Attestation in favor of the said sister.

ff. $250-25 \mathrm{I}$. The Dominicans request facoltà for missions in the islands of North America.

f. 272. $165 \mathrm{I}$. A Franciscan of the kingdom of Mexico requests facolta as missionary.

f. 28I. June IO, I652. Facoltà are requested for the prefecture of Canada.

f. 285. I65I. The Jesuits of the islands subject to the King of France request facoltà.

ff. 286-289. Oct. 28, I652. Relation of Quebec.

f. 378 . I650. The procurator general of the Capuchins, at the instance of the Queen of England, petitions the Sacred Congregation to concede facoltà to the provincial of Paris to institute a mission in New England, called also Virginia, for the conversion of those souls.

ff. 379-380. Notes on the same subject.

297. Anglia.

Nothing relevant.

\section{SCRITTURE CORRISPONDENTI.}

The date of the congregation, and the number of the subject, as given in the $A t t i$, is always sufficient reference to this series, and it was not, therefore, examined in detail. In some cases there are found almost no documents, in others many. Their character may be gathered from those of the earlier collection just listed. This collection runs from 1669 to the present day, and contains over a thousand volumes.

\section{SCRITTURE RIFERITE NEI CONGRESSI;}

or Scritture non Riferite.

These are documents not referred to the general congregation, but considered and acted upon by the secretary and cardinal prefect. They include matters of routine, and, as the policy of the Congregation became more and more established, matters of greater and greater importance. The question of reference depended more on the intricacy of the subject than its intrinsic significance, and consequently this series often contains matter of great value. The action taken is often endorsed on the documents. References are made to all the material in these volumes that seemed relevant. The material is arranged geographically in this series. 
America Settentrionale-Canada, Nuova Bretagna, Terra Nuova, dal 1668 al I79r. I. ${ }^{87}$

f. I A ( I I pages). A case of conscience concerning matrimony in Canada, with discussions at the Sorbonne.

f. 4. Oct. 26, I668. Vicar apostolic of Canada, from Quebec, on the foundation of a seminary.

ff. 7-9. I669. Legal document on trade.

f. II. Expenses for vestments.

f. I2. Apr. 26, I669. From the nuncio at Paris, on Canada.

f. I3. Memorial of De Neufville, to go to Canada as missionary.

f. I 5. Sept. I 5, I669. Cardinal Piccolomini, writing from Rome, speaks of the prefecture of the American missions.

f. I7. Aug. 27, I670. The Bishop of Canada writes to the Pope of his poor circumstances, and the establishment of the episcopal see at Quebec.

f. I9. Sept. 22, I670. Rome. The general of the Jesuits, on members of his order for the missions of Canada.

f. 21. Dec. I7, I670. From A. Favoriti, on the original letter of the king on the suppression of the abbacy in relation to the Bishop of Petraea.

f. 23. I67I. Facoltà for America.

ff. 24. Feb. 3, I67I. Difficulties with regard to the erection of the church of Quebec.

f. 26. I67I. Old notices on the erection of the church of Quebec.

ff. 28-33. Letters of the Bishop of Petraea on the expedition of bulls for the church of Quebec.

f. 34. Sept. I6, I672. Letter of the nuncio at Paris on the bishopric of Quebec.

f. 36. Jan., I673. Letter of the Propaganda to the nuncio at Paris on the erection of the church of Quebec.

ff. 37, 39. Feb., I673. Letters of the nuncio at Paris on the same subject.

f. 40. Considerations on the suppression of an abbacy in favor of the church of Quebec.

f. 45. Oct., I676. Letter of thanks from Franciscus (Laval), the first bishop of Quebec, to the cardinals.

f. 47. Oct., I676. Another letter of thanks from the same.

f. 49. May 30, I678. Letter of thanks from the Propaganda to the Bishop of Quebec.

ff. 5I-52. Nov., I678. The Bishop of Quebec to the Pope, relating to the establishment of the parishes.

f. 55. Mar., I679. The Bishop of Heliopolis gives an account of an affair with the Bishop of Quebec.

f. 57. I682. Brother Epiphanius de Moyrans requests to return to America, where he was prisoner for some years.

f. 59. Feb. 26, i688. Freiburg. Letter of recommendation from Clemen Scherer.

f. 6r. Nov. 3, I688. The Bishop of Quebec exposes the afflicting state of his diocese.

f. 62. Mar., I68I. Port Louis. The Bishop of Heliopolis sends a relation.

f. 65. Nov. 28, I670. Propaganda. Cardinal Casanata calls attention to the minute of the bull of Quebec.

${ }^{87}$ This volume is referred to by Abbé Faillon in his Colonie Française en Canada. 
f. 67. Madrid. I70I. Ramirez requests facoltà.

f. 68. "Facultates et Dispensationes petendae ab Episcopo Quebecensi."

f. 7I. Feb., I673. Letter to the nuncio at Paris on the maintenance of the bishopric of Quebec.

f. 73, Nov. I5, I673; f. 75, Jan. Io, I673. Same subject, with proposition to provide for it by means of the convent of Maubec.

f. 76. Sept. 27, I703. The Pope orders that a district be assigned to the Jesuits in Quebec.

ff. 77-79. Information on the abbacy, and on the reputation of the Bishop of Quebec in Paris.

f. 8r. I678. Assignment of the abbacy to the Bishop of Quebec, and question of funds for the chapter.

f. 83. Act of the chapter accepting three thousand lire from the king.

f. 84. Fontainebleau, Sept. 22, I7 I4. The King of France on the application of the abbacy to the bishopric of Quebec.

f. 85. Information for the bull of Quebec.

f. 89. Versailles, Feb. 22, I7 I5. "D. Toum. Thibault", on the division of the goods of the chapter and Bishop of Quebec.

ff. 9I-92. On jurisdiction in the church of Quebec.

f. 95. Instructions for the erection of the bishopric of Quebec.

f. I05. Request to the Pope for changes in the bull of Quebec.

f. I09. On the expenses necessary in the expedition of a bull for a cathedral church.

ff. I I I-I I2. Considerations in the Consistorial Congregation for the erection of the church of Quebec.

f. II3. Sept., I7I5. Other resolutions of the Consistory on the same subject.

ff. I I9-I2O. On the revenue of the church of Quebec.

f. I23. I7OI. Copy of an order of the King of France for the union of three abbacies, for the sustenance of the bishop and chapter of Quebec.

ff. I25-I32. I704. Bull of Clement XI. for the same object.

ff. I37-I38. Fontainebleau, Sept. 22, I7 I4. Copy of a letter of the King of France on the church of Quebec.

ff. I39-I40. I7I3. Letter patent of the King of France giving three thousand lire to the chapter of Quebec.

f. I4I. I7I5. Renunciation by the general of missions, for himself and the missionaries, his dependents, of possession of the canonries.

f. I43. Diploma of the King, regarding Quebec, confirmed in I704 by the Pope.

ff. I47-I 52. New instructions on the affairs of the bishopric of Quebec.

ff. I 53-I 54. Facoltà of the Bishop of Quebec.

f. I53. I723. Father Bonaventura Eyston, English, says that missionaries are being provided for Canada.

ff. I 58-I 59. May 5, I732. The bishop coadjutor of Quebec requests permission to ordain those not under his jurisdiction; and a brief of his letter.

f. I62, Paris, Feb., I734; f. I64, Paris, May, I734; f. I66, Paris, May, I74I ; f. I69, Compiègne, Aug., I755. Letters of the nuncio on facoltà of the Bishop of Quebec.

f. I7 I, Quebec, Nov. I5, I756; ff. I73-I74, Paris, I757. On baptism in Canada, with a decree of the Sorbonne. 
ff. 175, I76. On the request of Brother Bartolommeo, Capuchin, to go as missionary to Canada.

f. I8I. "Numerus Missionariorum Societatis Jesu qui laborabant in variis Novae Franciae regionibus exeunte anno I76I."

ff. I82-I83. The Bishop of Quebec on the state of religion in French America.

f. I86. Apr. I6, I764. Davoust requests certain briefs of indulgence for Canada.

f. I9o. May, I764. The prefect of the Propaganda sends a case presented by the Bishop of Quebec to the Holy Office.

ff. I92-193. July 8, I765. Abbé de l'Isledieu, vicar general of the colonies, on the jurisdiction of the bishop and chapter of Quebec.

f. I94. Feb. I7, I766. The nuncio at Paris gives notice of having received the brief for the new Bishop of Quebec.

f. I95. I766. "Forma juramenti emissa ab Episcopo Quebecensi."

ff. I96-197. I766. Facultates concessae a Clemente P.P. XIII. Joanni Olivier Briand episcopo electo Quebecensi. Printed.

ff. 200-204. Paris, Mar., I766. The new Bishop of Quebec makes certain requests for his diocese.

f. 204. Letter of the Propaganda to the nuncio at Paris, requesting information on the case pending between the missionaries and vicars apostolic against the directors of foreign missions.

ff. 205-206. The Bishop of Quebec on the same subject.

f. 208. Mar. 3, I766. Decree of the Sacred Congregation for the continuance of the support of the chapter of Quebec after the passing of these countries under English dominion.

ff. 2I0-2II. Paris, Mar., I766. The Bishop of Quebec is pained at the condition of his diocese, and requests facoltà.

ff. 2I2-2I 5. Misplaced papers on Mexico, referring to local affairs.

f. 220. Mar. 24, I766. From the nuncio at Paris, on the consecration and departure of the Bishop of Quebec.

ff. 222-223. Rome, Apr. 9, I766. Privileges conceded to the Bishop of Quebec.

f. 224. Aug. 20, I766. The companion of Mgr. Briand recounts the voyage, etc.

f. 226. On the brief for the seminary church of Quebec.

ff. 228-230. Feb. 24, I766. Abbé de l'Isledieu, on liberty of worship and religion in Canada.

f. 231. Mar. 7, 1768. From the nuncio at Paris, acknowledging the receipt of briefs of indulgence for Quebec.

f. 233. Jan., I769. The nuncio at Paris sends a letter from the superior of missions.

f. 234. Paris, Jan., I769. The said superior requests certain indulgences.

ff. 235-236. Indulgences for Quebec.

ff. 24I-244. Paris, Mar. I4, I769. Advice from Abbé de l'Isledieu on Canada.

ff. 246-247. Request from the same for a dispensation for matrimony.

f. 247. June 6, i 769 . Request from the same for favors.

f. 255. The same, on the nomination of two vicars apostolic in America.

ff. 258-259. Aug. 21, I769. The same, on the revolution in Louisiana.

ff. $260-262$. Oct. 29, I769, and one without date. Facoltd for the Bishop of Quebec. 
ff. 264-265. Jan. I8, I770. The vicar apostolic of Quebec gives a relation of that diocese.

f. 266. Paris, Feb. I9, I770. Abbé de l'Isledieu, on the nomination of a prefect apostolic and a vice-prefect.

ff. 278-279. Oct. 22, I 772. Ludovicus Lotbinière, a Canadian priest, appeals from the bishop.

ff. 282-283. Notes on indulgences for the churches of Quebec.

ff. 292-294. Jan. 22, I772. Brief nominating D. F. Mariaucheau to the coadjutorship of Quebec.

ff. 298-30I. Oct. I 5, I772. The Bishop of Quebec, on his coadjutor:

ff. 302-307. Paris, Dec., I772. Abbé de 1'Isledieu gives a relation of French missions.

ff. 3IO-3I3. July, I773. Oath and consecration of the bishop coadjutor of Quebec.

ff. 3I 5-32I. Paris, Mar., I774. Abbé de l'Isledieu, on the Bishop of Quebec and his coadjutor.

ff. 32I-322. Mar., I774. The vicar general of Quebec, on the calumnies against the bishop and coadjutor.

f. 323. Nov. 8, I774. The Bishop of Quebec defends himself and his coadjutor.

ff. 324-325. The superior of foreign missions, remitting the preceding letter.

f. 327. List of indulgences asked for the different churches of Canada.

ff. 329-33I. July 22, I778. The Bishop of Quebec presents a case.

ff. 332-335. Paris, Nov. 9, I778. The director of the seminary of foreign missions, enclosing an account of the various acts of Parliament regarding the Catholics of Canada.

ff. 337-338. I 788. The court of Turin, at the request of that of London, asks permission to send priests, its subjects, as missionaries to Canada.

f. 339. Paris, Feb., I78I. The director of foreign missions sends a letter from the Bishop of Quebec.

ff. 34I-343. Letter from the same, on the diocese of Quebec.

f. 345. I78I. Summary of letters of the said director.

f. 346. May 30, I 78I. Portion of a letter of the court of Turin regarding missionaries in Canada.

ff. 348-349. July I8, I78I. The Archbishop of Turin writes of four missionaries requested by the court of London for Canada.

f. 350. Annecy, Aug. 7, I78I. The Bishop of Geneva, on sending priests, his subjects, to Canada. (Frenci.)

f. 35I. "Liste des Prêtres envoyés au Canada par l'Evêque de Genève."

ff. 353-354. Jan. I 5, I782. The superior of the seminary of foreign missions at Paris, enclosing a note requesting indulgences for Canada.

f. 356-357. Jan. I5, I782. Brief relation of Canada by the same.

ff. 360-363. Nov., I782. Request from the same for indulgences for Canada.

ff. 364-365. Dec., I782. From the same, on the sending back from Quebec of the four Sardinian missionaries, and the permission given by the English to the Catholics to build a church at Halifax.

ff. 368-369. Feb., I 783 . From the same, on the return of the aforesaid priests to France. 
ff. 370-373. Aug. 26, 1783. From the same, on the sickness of the Bishop of Quebec.

ff. 374-375. Paris, Aug. 26, I783. The same, on two priests of the seminary of St. Sulpice placed at liberty and given permission to return to Quebec.

f. 376. Sept., I783. Pius VI. asks the whereabouts of the bishop coadjutor of Quebec.

f. 378 . I783. A Capuchin asks to go as missionary to Canada.

ff. 380-38I. Sept. 27, I783. Abbé Villars, director of the seminary of foreign missions, gives news about Canada.

f. 382. Turin, Oct., I783. On the succession of the Bishop of Dorylaeum to the see of Quebec.

ff. 384-385. Dec. 8, I783. Abbé Villars, on the bishopric of Quebec.

ff. 386-387. Dec. 9, I783. The same, requesting indulgences.

f. 390. Jan. I9, I784. The same, on the sending of his subjects to Canada.

ff. 392-393, 396. Paris, Feb. I, I784. On the restitution of the abbacy of Maubec to the possession of the bishop and chapter of Quebec.

ff. 397-398. Abbé Villars, asking the renewal of indulgences for Quebec.

ff. 402-404. On the succession to the bishopric of Quebec.

ff. 408-409. June 7, I784. Abbé Villars, on the departure of three missionaries for Canada.

f. 4IO. June I5, I784. The bishop coadjutor of Quebec writes that he has all the votes for the bishopric.

f. 4I I. Aug. 2, I784. Abbé Villars refers to the bad health of the Bishop of Quebec, and the ill-will of the governor toward Catholics.

ff. 4I3-4I4. Indulgences for Quebec.

ff. 4I7-4I8. Sept. 20, I784. Abbé Villars, on the request of the English at Halifax for a priest.

ff. 419-420. Jan. 5, I785. Renunciation of the bishopric of Quebec by Mgr. Briand, because of ill health.

f. 42I. Jan. I7, I785. Abbé Villars, on missionaries for Canada.

f. 423. Jan. I7, I785. The same, on the same subject, and on the bishopric.

ff. 425-426. New York, Jan., I785. Father Whelen recounts his life and the conversions he has made.

ff. 429-430. Feb. 6, I785. Relation of Quebec by Abbé Villars.

f. 432 , Apr. I8, and f. 435 , July i6, I785. Abbé Villars on the expedition of the bull for the coadjutor of Quebec.

f. 436. London, Aug. 6, I785. Father Hussey, almoner of the ambassador of France, on the consecration of Mgr. Hubert.

f. 438 . The same, on the coadjutorship of Quebec.

ff. 440-44I. Paris, Aug. I9, I785. Abbé Villars, on the recovery of the abbacy for Quebec.

f. 442. Paris, Oct. I8, I785. The same, on the coadjutorship of Quebec.

ff. 444-445. Indulgences for Quebec.

f. 447. Paris, Dec. I2, I785. Abbé Villars on the coadjutor of Quebec.

f. 449. "Précis des Nouvelles venues de Quebec concernant le Clergé et la Religion."

f. 450. Paris, Jan. 16, I786. Abbé Villars, on the abbacy of Quebec.

ff. $452-453$. I 786. " Extracta ex Epistola transmissa ex Hibernia Romam relativa ad actualem Statum Catholicorum in America Septentrionali et praesertim in Nova Scotia." 
f. 454. Paris, July I2, I786. Abbé Villars, on the territory subject to the Bishop of Quebec.

f. 458. Indulgences for Quebec.

f. 459. "Litteras consecrationis R. D. Hubert Episcopi Almerensis et coadjutoris Quebecensis."

f. 46 I. Paris, Dec. I2, I786. Abbé Villars, requesting indulgences for Quebec.

f. 462. Facoltà for the Bishop of Quebec.

ff. 464-465. Paris, Dec. I2, I786. Relation of Canada.

ff. 466-467. "Etat de la Mission de 1'Acadie en I787."

ff. 468-469. "Mémoire au sujet de la Mission des Tamarois dans la diocèse de Québec Ann. I787."

ff. 47I-472. Dec. I7, I787. Relation of Quebec and the mission to the Tamaroas, by Abbé Villars.

f. 474. I788. Attestation of the entombment of Mgr. Mariaucheau at the Isle d'Orleans.

f. 476 . June, I788. Attestation of the taking possession of the diocese by Mgr. Hubert.

f. 477 . June 26, I788. Attestation concerning the life and works of Mgr. Bailli, coadjutor of Quebec.

ff. 479-487. June 16, I788. Letter of the Bishop of Quebec.

f. 489. Sept. 26, I788. Bull for Mgr. Bailli, coadjutor of Quebec.

ff. 497-501. Oct. 24, I789. The Bishop of Quebec gives news concerning the diocese.

ff. 504-508. Nov. 8, I790. Relation of the diocese by the Bishop of Quebec.

ff. 508-5I2. "Fêtes observées dans le Diocèse de $Q . "$

ff. 5I3-5I6. I792. "Mandement de Mgr. l'Évêque de Québec qui permet de travailler à certains jours de fêtes."

ff. 5I7-520. "Mandement de Mgr. l'Év. de Queb. touchant la Juridiction des Prêtres de son Diocèse."

ff. 52I-524, 525-528. I79I. Two letters of the Bishop of Quebec containing relations of the diocese.

Canada, Nuova Brettagna, Labrador, Terra Nuova. II. I792-I830.

f. I. Extent of diocese of Quebec. 2 pp.

f. 3. Notice of Louisiana.

f. 4. Project of a seminary in Virginia.

f. 6. Facoltà for Mexico.

f. 8. Notice of the diocese of Quebec.

f. 9. July 4, I793. Letter of praise and advice from the Propaganda to the Bishop of Quebec. $22 \mathrm{pp}$.

f. I9. Formula of oath to King George.

f. 20. I793. Extract from the journals of the council of state of England, regarding Canada.

f. 2I. July 4, I793. Letter of the Bishop of Quebec, on cases of matrimony and usury. I 3 pp.

f. 29. I793. Mandate of the Bishop of Quebec. Printed. I3 pp.

f. 38. June I2, I794. Letter from the Bishop of Quebec, on the state of religion and the need of a coadjutor.

f. 40. Attestation in favor of the promotion of M. Denaut, vicar general, to the coadjutorship, enclosed with above. 
f. 4I. Extracts from the Atti, regarding sepulchres and Mgr. Bailly. $2 \mathrm{pp}$.

f. 42. I793. Relation of the diocese of Quebec, by the bishop. I8 pp.

f. 5I. Nov. 2I, I794. From the Bishop of Quebec, enclosing mandates. $5 \mathrm{pp}$.

f. 55. I795. Facoltà to Bishop of Quebec.

f. 56 . Doubts regarding holy days. 2 pp.

f. 57. Jan., I797. A Dominican, on Vicar-General Burke of Quebec. 3 pp.

f. 59. Note on the same. 2 pp.

f. 6o. Aug. I 5, I 797. Vicar-General Burke, on the necessity of a bishopric at Montreal, etc. $22 \mathrm{pp}$.

f. 7r. Sept. I, I797. From the Bishop of Quebec, resigning in favor of his coadjutor. $2 \mathrm{pp}$.

f. 72. Sept. IO, I797. The Bishop of Quebec recommends M. du Plessis as coadjutor, with enclosures. $7 \mathrm{pp}$.

f. 76. Sept. I6, I797. Letter from said Du Plessis, on the same subject. $2 \mathrm{pp}$.

f. 77. I797, I799. On the coadjutorship of Quebec, including testimonials, professions of faith, briefs, letters of consecration, etc.

f. 96. Cases proposed by Rev. Dr. O. du Plessis, coadjutor elect of Quebec. 2 pp.

f. 97 . I801. Oath of fidelity of the same. $5 \mathrm{pp}$.

f. IOI. Feb., I80I. Letter of Mgr. du Plessis, with thanks for indulgences. $4 \mathrm{pp}$.

f. I04. May 25, 1802. Profession of faith of the same. 3 pp.

f. I06. May 25, I802. Request for facoltà from the same. 4 pp.

f. I08. Facoltà granted to the same. $2 \mathrm{pp}$.

f. I09. Apr. 26, I803. Letter from the Bishop of Quebec on the coadjutor, the erection of a new diocese, etc. $6 \mathrm{pp}$.

f. I I3. Sept., i8o3. Copy of reply to the same.

f. II4. Aug., I804. Attestation of magistrates and others of Newfoundland, in favor of James O'Donel, missionary at St. John's. $5 \mathrm{pp}$.

f. I 7. I806. Concerning the death of Mgr. Denault, bishop of Quebec. II $\mathrm{pp}$.

f. I23. I806. Letter of Mgr. du Plessis, requesting Rev. Claude Panet as coadjutor. $4 \mathrm{pp}$.

f. 126. Jan. 27, I807, from London. Letter on the opening of a house of education in Nova Scotia.

f. 127. I808. On the observation of certain holy days in Canada. 3 pp.t $5 \mathrm{pp}$.

f. I32. Recognition of Mgr. du Plessis as Bishop of Quebec, by George III. 5 pp. See also f. I38.

f. I35. Sept. I2, I 809. Relation of Quebec, by the bishop. 4 pp.

f. I37. Information regarding a missionary of Canada. $2 \mathrm{pp}$.

f. I40. I8I I. Note on the attitude of England toward ecclesiastical affairs in Canada. 2 pp.

f. I43. Dispensation and facoltà for Bishop of Quebec.

f. I44. I8II. Extract of instructions to the lieutenant-general in the province of Lower Canada. 7 pp. (English, with translation into Italian.) 
f. I5I. I8I4. Memoir on the condition of the diocese of Quebec. $8 \mathrm{pp}$.

f. I 56. I8I4. Request of vicar apostolic of Newfoundland regarding dismissions.

f. I57. Jan. 2, I8I4. The Bishop of Quebec, on the printing of a catechism. 2 pp.

f. I62. Mar. 2I, I8I4. Kensington Palace. Letter from "Edward" (duke of Kent) on the affairs of Canada. 3 pp.

f. I64. I8I4. Instructions of the Parliament of England on the Catholics of Canada.

f. I65. I8I4. Requests of the Bishop of Quebec for facoltà and presentation of cases.

f. I70. Sept. 6, I8I4. The vicar apostolic of London on religious affairs in Newfoundland. 4 pp.

f. I72. Letter of the Bishop of Quebec presenting cases of jurisdiction, etc., and on the action of the English government relative to Catholics. $29 \mathrm{pp}$.

f. I87. Matrimonial cases. $4 \mathrm{pp}$.

f. I90. London, Sept. I6, I8I5. Relation of the state of religion " in partibus Americae Aquilonaris", by the vicar-general of Nova Scotia. $26 \mathrm{pp}$.

f. 202. Dec. 7, I8I 5. Request for indulgences from the Bishop of Quebec.

f. 204. Rome, Dec. I2, I8I 5. Note on the relation beginning on $\mathrm{f}$. Igo.

f. 205. Propositions by the Bishop of Quebec.

f. 206. "Relatione dello Stato attuale della Religione Cattolica nelle Colonie Inglesi in America Settentrionale." 9 pp.

f. 212. Nov. 23, I816. From the Bishop of Quebec, sending an extract of the instructions of the English government to that of Canada, against Catholics.

f. 213. Facoltà to the Bishop of Quebec.

f. 2 I6. I8I6. Letter from the Bishop of Newfoundland announcing his consecration. $2 \mathrm{pp}$.

f. 216 bis. Note on the churches near Montreal.

f. 217. Nov. I5, I8I7. From the Bishop of Quebec, announcing that he has a place in the legislative council. $4 \mathrm{pp}$.

f. 2 Ig. From the same, concerning his recognition by the governor. $2 \mathrm{pp}$.

f. 22I. Dec. 22, I8I8. The erection of the see of Quebec into an archbishopric.

f. 222. Nov. 9, I8I9. Relation of his districts, by the suffragan Bishop of Quebec. 22 pp.

f. 234. Election of vicar apostolic of Nova Scotia, with title and character of bishop.

f. 236. Rome, Dec. I2, I8I9. Request of the Archbishop of Quebec for two suffragans. 2 pp.

f. 237. Rome, Jan. 4, i820. From the same, on indulgences.

f. 238 . From the same, with request for the early settlement of his affairs.

f. 240. I820. On the sending of monks to Newfoundland.

f. 244. Observations on doubts proposed by the Bishop of Quebec.

f. 247. London, June 5, I820. From the Archbishop of Quebec, hoping that the court of London will recognize his title. 2 pp.

f. 249. Quebec, Sept. 6, I820. From the same, on the dismemberment of the diocese. 
ff. 25I-252. "Confidentielle." “Courtes Réflexions sur l'Etat Présent de la Religion dans le Canada."

f. 255. Rome, Feb. 20, I822. The Archbishop of Baltimore, on the peril of the seminary of St. Sulpice.

ff. 256-257. "Observationes in Praesentem Statum Religionis Catholicae in Provincia Canadensi."

ff. 26I-262. Duplicate of ff. $25 \mathrm{I}-252$.

ff. 262-263. I822. Relation of his vicariate, by the vicar apostolic of Newfoundland.

f. 265. Quebec, I822. Queries.

ff. 266-27I. "Mandements de Mgr. l'Év. de Québec au Clergé."

ff. 278-28I. The Archbishop of Quebec, on the Sulpicians of Montreal.

f. 282. Dec. I7, I822. The same, on the same subject.

f. 286. "Relazione dello Stato attuale della Religione Cattolica nelle Colonie Inglesi in America Settentrionale."

f. 287. The deputies of the Archbishop of Quebec, on the reconciliation effected in the church of Canada.

f. 288. The Archbishop of Quebec has a place in the legislative council without compromising his conscience.

ff. 289-303. "Mémoire en faveur de l'Ile et Maison de Montreal."

f. 304. I823. The chargé d'affaires of the seminary of Montreal presents papers in its favor.

ff. 319-338. I823. Questions suir le Gouvernement Ecclésiastique du District de Montréal. Printed.

ff. 340-353. Documents on the question of Montreal.

ff. 354-382. Information relative to the Canadian Company for the purchase of the Crown and Clergy Reserves in that Province. Printed.

ff. 384-386. On the erection of a bishopric at Montreal.

ff. 387-391. "De Religionis Statu in Superiori Canadae Provincia Narratio anno I825."

ff. 393-394. Discord in Canada.

ff. 395-396. I825. The vicar apostolic of London, on the discord between the Bishop and the Sulpicians of Quebec.

f. 397. I825. The Archbishop of Quebec, on the collections for the rebuilding of St. Paul's (at Rome).

f. 398. The same, on the affair of Montreal.

f. 399. Information on a priest named Weld.

ff. 400-409. June 12, 1826. Representation made by the curates of the diocese of Quebec in favor of the establishment of a suffragan at Montreal.

f. 409. I826. The Archbishop of Quebec, on the affairs of Montreal.

ff. 4II-4I2. Marianopolis, Lower Canada (Montreal), Aug. 4, I826. The Bishop of Telmissus (Bishop Lartigue) speaks of the election of a coadjutor for Quebec, and of the controversy with the Sulpicians.

ff. 4I3-4I4. I826. The coadjutor of Upper Canada says that he has been consecrated bishop.

ff. 4I 5-4I6. Downing St., London, Oct. 24, I826. Lord Bathurst, on the seminary of Montreal.

${ }^{88}$ Printed in the History of the Society of Jesus in North America, by Father Thomas Hughes, Docs., vol. I., pt. I., Pp. 585-590. 
ff. 4I7-4I8. Nov. I5, I826. The Bishop of Quebec, on the expedition of bulls, and the affairs of Montreal.

ff. 419-420. Nov. I6, I826. The Bishop of Quebec on his suffragan.

ff. $42 \mathrm{I}-422$. Dec., I826. Notices of religion in the islands of Prince Edward and "Madalina".

ff. 423-424. Profession of faith of the coadjutor of Quebec.

f. 425. Copy of the letter of the Governor of Canada to the procurator of the seminary of Montreal.

ff. 426-428. Documents on the Sulpicians at Montreal.

ff. 429-435. I827. Observations d' un Catholique sur l'Histoire du Canada. Printed.

ff. 436-440. Jan. 29, I827. The Archbishop of Quebec, on the affairs of Mgr. Lartigue.

ff. 440-442. Jan. 29, I827. Documents on the coadjutorship of Quebec.

f. 444. Nova Scotia. Attestation of consecration.

ff. 445-446. Nov., I827. The Archbishop of Quebec requests facoltà.

ff. 447-448. St. John's, Newfoundland. The vicar apostolic of Newfoundland requests a coadjutor.

f. 450. Facoltà for the Archbishop of Quebec.

ff. $45 \mathrm{I}-45^{2}$. I 827 . The vicar apostolic of Nova Scotia sends the attestation of his consecration.

ff. 453-456. London, Oct. 24, I824. Lord Bathurst, on the seminary at Montreal.

ff. 457-490. Other documents relating to the same matter.

ff. 497-503. I827. "Memoria concernente il Canada."

f. 498. I829. The Bishop of Kingston sends young men to be educated in the Collegio Urbano.

f. 504. Happenings in the church of Philadelphia.

ff. 505-506. New York, I829. Father Browne, Augustinian, complains of a suspension inflicted on him.

f. 508. The Archbishop of Quebec makes queries concerning facoltà and rites.

f. 509. I829. Notices on the feeble hopes of obtaining in England a subsidy for Canada.

f. 5I0. "Seconde Mémoire à presenter au Comte Bathurst."

f. 5I2. Extract from La Minerva, a Canadian newspaper, of Nov. I2, I829, on the dispute in Montreal concerning goods.

ff. 5I3-5I6. Note to accompany the request to alienate the goods of St. Sulpice at Montreal.

f. 5I7. Facoltà for Newfoundland.

f. 522. Note of the powers and memorials presented to the Sacred Congregation by two priests, deputed by the Bishop of Lower Canada.

f. 523. Various liturgical doubts.

f. 527. Requests of the Archbishop of Quebec regarding matrimonial dispensations.

f. 530 bis. May, I829. Discussion at Rome on the ecclesiastical law in force in the diocese of Quebec.

ff. 53 I-536. Opinion of the advocate Amici relative to the Sulpicians of Montreal.

ff. 548-555. "Consultation de douze des plus célèbres Avocats de Paris touchant les droits de propriété du Séminaire de Montréal en Canada." 
ff. 558-565. "Second Mémoire sur l'Affaire de Montréal."

ff. 566-627. Other documents on the case of the Sulpicians of Montreal.

America Centrale, dal Canada all'Istmo di Panama, dal 1673 al 1775 . I.

ff. 5-6. Relation by the Carmelites of England, concerning the mission proposed by Father Simon Stock.

f. I5. The Scalzetti of San Diego, Mexico, ask facoltà to erect a new mission in Tampico.

f. 6o. July 30, r693. Father Romeno, Capuchin, on a decree of the Sacred Congregation, and the affairs of missions, and the conflict with the King of Spain.

f. 62. Sept. I0, I693. The same, on the royal patronage in the Indies.

f. 64. Nov. I9, I693. The same, on permission received from the Council of the Indies to carry fourteen missionaries to America.

f. 78. June I8, I70o. On the erection of a new mission in Mexico at Casas Grandes and Flumen Nortis.

f. 8o. "Ultima pars, in qua sunt Missionarii vocati Domus Magnae, ubi adsunt Franciscani Provinciae de Zacatecas."

ff. 86-93. July I7, I7or. Informe del Estado de la Nueva Christianidad de California, by Father Francisco Maria Picola. Printed.

f. 94. Nov. 22, I706. State of Christianity in California.

f. 99. Toulon, May 28, I720. Brother Antonio Oudeardo, a Minor Conventual, departing for the Mississippi as chaplain, requests a patent as missionary.

f. I25. Sept. IO, I729. On decrees for differences in worship in Quebec.

ff. I38-I39. Lisbon, Aug. I 5, I730. Letter of the priest Francis Nicolson, on the affairs of Christianity in America where he was for many years before being converted.

ff. I82-I83. I75I. Cardinal Portocarrero, in the name of His Catholic Majesty, on the subjection of regulars to bishops in America.

ff. I84-186. Spanish original of the same.

ff. 188-199. Notes on the same.

ff. rg6-r99. Letters on the same subject, discussing the reply of the Pope.

f. 290. ${ }^{50}$ London, Aug. 2, I763. The vicar apostolic of London, on the missions of English America, suggesting the extension of the jurisdiction of the Bishop of Quebec.

ff. 292-293. Catalogus Missionum Societatis Jesu in Statibus Unitis Americae.

f. 296. I753. On the subjection of regulars charged with parish work, to their bishops.

f. 384-385. Apr. 24, I764. The nuncio at Madrid, on the departure of all the Spaniards from Florida.

ff. 424-429. I 65 (?). Copy of a "Mémoire abrégé sur les Missions de la Colonie nominée Louisiane, composé par le P. Philibert François Watrin, Jésuite, cy devant Missionaire à Louisiane".

f. 431. Facoltà for the French Capuchins of Louisiana.

f. 538. Dec. 5, I770. Notices on the facoltà for missionaries in Florida, for a colony of thirteen hundred from Minorca.

ff. 540-54I. Mar. 30, I77I. On the establishment of a prefect apostolic in the English possessions in America.

${ }^{29}$ Portions of this are printed in Shea, Life of Carroll, p. 57. 
ff. 544-545. June 4, I77I. Extract of a letter of the vicar apostolic of London to his agent in Rome, on the affairs of English America.

f. 602. Feb. 4, I772. Request from the secretary of state for information on the method of expediting circulars to America.

f. 608. Sept., I773. Relation of the state of religion in the province of Maryland, by George Mattingly.

f. 6r8. May 24, I774. Criticism of certain constitutions introduced in the college of the Minor Observants at Pachuca.

ff. 622-625. July 24, I774. The above mentioned constitutions. (Spanish.)

ff. 675-677. Compendium of a secret relation of fourteen pages of the Western Indies, given by an Augustinian of Mexico.

America Centrale, dal Canada all'Istmo di Panama, dal 1776 al r79o. II.

f. 5. Feb. 3, I776. The agents at Cadiz speak of matters of interest, and send a letter from the Archbishop of Mexico.

f. 6. Letter of the Bishop of Quebec, mentioning the troubles in the English colonies.

f. 60. July 29, I778. Brief of facoltà for the bishops of Spanish America.

f. 6r. I778. A Capuchin requests to go as missionary to America.

f. I I8. June I3, I780. The nuncio at Brussels writes that he has counselled the English ex-Jesuit, Leonard Neale, not to return to America.

ff. I83-I84. Decree on the voting in the election of a superior in the college of San Ferdinando in Mexico.

ff. I86-I87. Feb. Iо, I783. From the nuncio at Paris on his efforts to guarantee religion in the peace negotiations, and on his conversations with Franklin. ${ }^{\circ 0}$

ff. I93-I98. Letters from the nuncio at Paris, dated July I and Sept. 27, I783, on the same subject.

ff. 206-2I I. Sept. I, I783. Letters from the nuncio on the same subject. (Copy.) ${ }^{61}$

f. 2I2. Observations on the notes of the nuncio at Paris.

f. 213. Note of the nuncio at Paris to Dr. Franklin. ${ }^{32}$

ff. 22I-222. Oct. 9, I783. Sentiments of the court of Turin on the coadjutor of Quebec.

ff. $223-226 .^{\text {.8 }}$ Nov. IO, I783. The missionaries of Maryland on freedom of worship.

f. 230. Fontainebleau, Oct. 20, I783. The nuncio in France states that, after an interview with $\mathrm{M}$. Vergennes on the establishment of missions in North America, he will continue to hold discourse with Dr. Franklin.

f. 240. Jan. 3I, I784. From Chev. Luzerne to Vergennes, on the sending of a bishop to America, and the propositions of Dr. Franklin.

f. 245. Mar. I, I784. The nuncio at Paris writes that he will endeavor to secure the restoration of the abbacy to the Bishop of Quebec.

${ }^{80}$ Printed in American Historical Review, XV. 804.

${ }^{61}$ Printed ibid., p. 805.

${ }^{92}$ Printed ibid., p. 807; translation in J. Sparks, Diplomatic Correspondence of the American Revolution, IV. 158-160.

${ }^{63}$ Printed in Shea, Life of Carroll, pp. 209-21 I. 
f. 253. Copy of a note of May I2, I784, from the nuncio at Paris to Chev. Luzerne, on the establishment of some other regulation of the affairs of religion in the United States.

f. 256. Copy of a note of the same date, from the same to the same, on the choice of a bishop or vicar for the United States.

f. 257. Translation of the preceding.

ff. 258-260. May I7, i784. The nuncio at Paris, on the establishment of a mission in the provinces of the new republic of the United States.

f. 26r. Same subject.

f. 266. May 3I, I 784. The nuncio at Paris, on his efforts for the missions of North America.

ff. 268-269. June 9, I784. Origin of Catholic missions in countries subject to the King of England.

ff. 272-274. July 5, I784. The nuncio at Paris, on the choice of Mr. Carroll as vicar apostolic in America.

f. 275. Passy, Aug. I8, I784. From Dr. Franklin to the nuncio, enclosing a copy of the instructions received from Congress.

ff. 276-278. The above mentioned enclosure, dated May II, I784, with French translation.

ff. 279-28o. Aug. 23, I784. The nuncio at Paris, on his efforts for the establishment of religion in the United States.

f. 284. Nov. I5, I784. The nuncio at Paris has conferred the first tonsure upon an American in the seminary of St. Sulpice.

f. 287. Two Franciscans, Recollets, request facoltà for the missions of America.

ff. 288-294. "Ragguaglio dello Stato della Religione Cattolica nelle Colonie Inglesi di America."

ff. 297-300. "Memoria circa la Pretensione dei Francescani sulla Prefettura nell'America Settentrionale."

f. 30I. New York, Jan. 28, I785. Father Ferdinand Farmer speaks of facoltà and other matters.

f. 304. New York, Feb. I5, I785. The French consul, on the state of religion in that city.

f. 305. June 2I, I785. Note of the Count de Vergennes on the missions of America.

ff. 306-3 I I. Maryland, Feb. 27, I785. John Carroll on the state of religion.

ff. 3 I 2-315. ${ }^{64}$ Mar. I, I785. "Relatio de Statu Religionis in Unitis Foederatae Americae Provinciis ", by John Carroll, and followed by a sheet on matrimonial dispensations for the United States.

ff. 316-317. Mar. 27, I785. Translation of a letter of M. de Marbois, chargé d'affaires of His Christian Majesty in the United States, written from Philadelphia, on the state of religion.

ff. 322-323. Brother Fermino da Olite of Mexico desires to be ordained as a priest.

f. 324. Sept. 5, I785. The internuncio at Paris, on the sending of an enclosure to America.

f. 342. Paris, Mar. I2, I787. M. Villars, on the missions of Mississippi, New York, etc.

${ }^{8 *}$ Printed in Shea, Life of Carroll, pp. 255-26I. The documents mentioned above against ff. 230, 24I, 253, 257, 258-260, 26I, 266, 268-269, 272-274, 275, 279-280, 284, and 324, are printed in American Historical Revieze, XV. 810-826 passim. 
f. 342. Apr. 16, I787. The nuncio at Paris sends a letter of Mr. Carroll, ecclesiastical superior of the United States, containing a full relation of Catholicism in that country.

ff. 344-346. Oct. 8, I787. The nuncio at Paris, on the French missionaries, the expenses of the voyage to America, etc.

f. 347. Maryland, July 28, I787. On two young Americans to be put in the Collegio Urbano.

ff. 349-350. Nov. 5, I787. The nuncio at Paris, on the politeness of the Archbishop of Bordeaux to the said Americans.

f. 353. Nov. 7, I787. Extract of a letter of Abbé Carroll, in which he describes the embarrassment occasioned him by Father Nugent, to whom has been accorded the facoltà for New York.

ff. 335-336. Dec. 3I, I787. The nuncio at Paris sends a note of the expense incurred for the two young Americans.

f. 358. Baltimore, Mar. I2, I788. The missionaries of Baltimore request a vicar apostolic with episcopal character.

f. 359. Jan. 6, I788. From the Archbishop of Bordeaux, returning thanks for the praise received for his reception of the two young Americans.

ff. 360-36r. News of the arrival at Cività Vecchia of the aforesaid young Americans.

ff. 363-366. Maryland, Mar. 18, r788. From Mr. Carroll, on the unworthy conduct of a Capuchin.

ff. 367-368. Apr. 19, I788. From the same, on the same subject.

f. 369. Aug. II, I788. From the same, requesting that Father Whelan be left in America, where he has done so much good.

ff. 370-37I. On the Jesuits in America.

f. 373. An alumnus of the English College requests permission to go to America as a missionary.

f. 374. Gubbio, May 4, r789. The Bishop of Gubbio, on the advantages of religion in America.

f. 375. May 28, I789. The nuncio at Lisbon, on Father Fleming, who ought to depart for Philadelphia.

ff. 376-378. Boston, Jan. 6, I790. Claude de la Poterie, founder of the Catholic Church of Boston, on Carroll and the Jesuits.

f. 378. Mar. 29, I790. The nuncio at Paris, on the departure of certain French families for America, where they have bought land.

f. 379. The said families request as their spiritual director Father Didier, a Benedictine.

ff. 380-381. Father Didier, on the said society. (French with translation.) ff. 384-385. May Io, I790. The nuncio at Paris, on the French colony which is to be established in Virginia, and on Father Didier.

f. 387. May I7, I790. The nuncio at Paris, on the departure of Father Didier.

ff. 388-389. Request of the French that are to found a new colony in Virginia, for a bishop.

ff. 390-392. July, I790. Mgr. Carroll, bishop elect of Baltimore, gives news.

ff. 394-398. Paris, May I7, I790. Relation of the Indians of North America, by Jean de la Mahotière, agent of the Oneidas.

ff. 399-400. Aug. 2, r79o. The nuncio at Paris gives account of a request for the establishment of a mission among the Oneidas. 
f. 40I. "Supplicatio Oneidae Nationis Indicae ad Papam Pium VI.", to obtain a bishop.

f. 404. London, Sept. 27, I790. The Bishop of Baltimore to the Pope, demonstrating his obedience and zeal.

America Centrale, dal Canada all'Istmo di Panama, dal I79I a tutto il I8I7. III.

ff. I-8. I79I. On the colleges of the Franciscans in Mexico.

f. Io. On the necessity of erecting an archbishopric beyond the Alleganies in the United States.

f. II. Jan. 20, I79I. The nuncio at Lisbon writes that he will forward the defense of $\mathrm{Mgr}$. Carroll against the accusations made against him.

ff. I2-I 5. Feb. 3, I79I. The nuncio at Lisbon sends the apology of Mgr. Carroll.

ff. I6-I7. Paris, Feb. I8, I79I. The director of the seminary of St. Sulpice, on the establishment of a seminary at Baltimore.

ff. 23-27. Mar. I3, I792. Bull of Pius VI. erecting the convent of Pachuca into a seminary.

f. 31. Leghorn, Oct. 8, I792. Receipt of enclosure for the Bishop of Baltimore.

ff. 33-36. I794. Relation of the Americans of the United Provinces, made by M. Filicochi, who was for three years in the said provinces.

ff. 37-38. July 3, I794. The Bishop of Baltimore, on the death of his coadjutor and other subjects.

ff. 39-40. Baltimore, Aug., I794. "Forma Juramenti praestandi ab Episcopo in sua Consecratione."

ff. 4I-46. London, Nov. I I, I794. Relation of the state of religion in the Britannic provinces.

ff. 46-47. I795. Extract of a letter of a parish priest of Philadelphia, showing the great necessity of priests in those provinces.

f. 49. June 2I, I796. The nuncio in Spain writes that he desires to send to the United States a French priest of whom he has favorable information.

f. 58. July 12, I796. On the request of the priest Micheau that he be accorded the title of apostolic missionary.

ff. 56-57. May 7, I796. Same subject.

f. 58. Expenses of vesting two American alumni.

f. 60. Leghorn, Oct. I6, I797. Celesia says that he has charged himself with the embarkation of the two American alumni.

ff. 6r-62. Mexico, Dec. 3, I797. Father Olmedo sends the act of the election of three commissaries.

f. 63. The said act.

f. 65. Oct. I6, I798. Mr. Dougherty, an alumnus of the College of the Propaganda, sends a relation of himself.

ff. 66-69. Aug. 30, I799. The Bishop of Baltimore gives a relation of his diocese.

ff. 70-72. Duplicate of the above.

ff. 75-94. I799. Dispute between the Bishop of Baltimore, and a German Conventual, and the nation.

ff. 95-96. I789. Of a French priest established at Boston.

ff. 97-98. Philadelphia, Nov. 5, I799. William Elling tells of his surroundings, and would be glad to have a monastery there. 
ff. 99-Ioo. The same speaks against Mgr. Carroll, and on the election of bishops.

ff. IO8-I I3. "Mémoire relatif au Mexique."

f. I I4. On the failure of the Bishop of Baltimore to receive replies to his letters.

ff. II5-II6. On the publication of the decrees of the Council of Trent, regarding matrimony, in Baltimore.

ff. II7-II8. On the building of a new church for the Germans at Baltimore.

f. I20. Jan. I2, I8oo. The coadjutor of Baltimore thanks the Pope for his dignity.

f. I2I. Rome, Jan. 25, I80o. Brother Luke Concanen speaks of the German priests who have revolted against Mgr. Carroll.

f. I23. Ellingen, Mar. 28, I8oo. The Elector of Cologne, on the German Conventual, Father Caesar Reuter.

ff. I24-I25. Cologne, Oct. 5, I80o. Father Reuter, on the Germans of Philadelphia, Mgr. Carroll, etc.

f. I26. Novesü (?), Jan. 24, I80I. Father Reuter requests permission to return to Baltimore.

f. I27. Vienna, Feb. 7, I8or. The Elector of Cologne, on Mgr. Carroll and Father Reuter.

ff. I28-I34. Notes and letters of Dec. 28, 30, I80I, on the same subject.

ff. I35-I37. Feb. IO, I802. The Bishop of Baltimore, on the renewal of facoltà, Father Reuter, etc.

f. I38. Simon Gallagher, parish priest of Charlestown, in behalf of his parish, appeals to the Holy See from Mgr. Carroll.

f. I39. Apr. 24, 1802. The secretary of state transmits the petition of Father Reuter.

f. I40. Apr., I802. Cardinal Brancadoro sends in a letter received from America.

ff. I44-I 45. Nov. 25, I802. The Bishop of Baltimore answers the accusations made by the parish priest Gallagher.

ff. I46-I48. Nov. 27, I802. The Bishop of Baltimore requests facoltà, and speaks of the jubilee, of monks, and of induigences.

f. I50. Madrid, June 30, I803. Cardinal Casoni, on the facoltà of conferring confirmation conceded to the president of the California missions.

ff. I55-I 56. Philadelphia, Dec. II, I803. Letters of Brother Michael Egan, curate of St. Mary's, requesting facoltà ; and of Mgr. Carroll, recommending it.

ff. I62-163. Feb. I4, I804. The Bishop of Baltimore, relating the affairs of his diocese, and requesting facoltà.

ff. I65-I66. Philadelphia, Mar., I804. Father Egan, of St. Mary's, requesting facoltà, and with recommendation from Mgr. Carroll. (English with translation.)

ff. I69-2I5. I805. Questions on the administration of the goods of the parochial church of New Orleans.

ff. 216-218. May II, I805. Translation of letter of Father Egan on the new province of Franciscans established at Baltimore, with cover.

f. 2I9. Paris, May 26, I804. The legate gives notice that for two or three years the Bishop of Baltimore has not received answers from the Sacred Congregation. 
ff. 220-22I. Resolution of the Sacred Congregation on the request of Father Egan, with the letter of the same, and the recommendations of Mgr. Carroll.

f. 223. On the Trappists gone to Baltimore.

f. 225. Aracoeli, Rome, July I7, I804. The procurator-general of the Franciscans, on Father Egan.

f. 226. I805. Father Baldomero Lopez requests for his five missionary colleges in North America all the privileges conceded those of South America.

ff. 227-230. Bardstown, June 7, I805. The Rev. Stephen Badin, on the development of religion in Kentucky.

ff. 232-233. Louvain, Oct. 22, I805. M. Beamans says that Mgr. Carroll has written that the German priests for his diocese have not arrived.

f. 234. Paris, Nov. 3, I805. From Cardinal Caprara, enclosing the above. ff. 235-260. I806. The missionary Nerinckx describes his voyage to America, and the development of religion there.

ff. 263-264. Cardinal di Pietro, on the decree for the Bishop of Baltimore, etc.

f. 265. Paris, May I5, I806. Cardinal Caprara writes that he will do what has been insinuated to him regarding Louisiana.

ff. 266-268. Paris, July I7, I806. From the same, sending a letter of M. Beamans, recounting the exertion of the missionary Nerinckx in the diocese of Baltimore; and a copy of a letter of the Bishop of Baltimore recounting the death of Nerinckx's companion.

ff. 268-269. On the division of the United States into dioceses, and the proposition of Father Egan for that of Philadelphia.

ff. 270-27I. Apr. 8, I808. Brief naming Mgr. Egan Bishop of Philadelphia. (Copy.)

ff. 272-274. Apr. 8, I808. Brief making the church of Baltimore metropolitan. (Copy.)

ff. 275-279. Apr. I 5, I808. Abstract of facoltà given to archbishops, bishops, vicars apostolic, and prefects of missions in America and the Western Indies.

f. 280. July I0, I808. Father Fenwick on Father Badin.

ff. 28I-284. I8Io. On the contest between the Catholics and the Archbishop of Baltimore, because he removed a French priest.

ff. 285-286. On the death of Mgr. Concanen.

f. 288. Sept. 30, i8 1o. From the Archbishop of Baltimore, on a donation for the erection of a metropolitan church.

ff. 289-302. "Sundry documents submitted to the consideration of the Pewholders of St. Mary's church, by the Trustees of that church."

f. 303. Testimonial of the Bishop of Philadelphia, in favor of Father Harold, who returns to Ireland.

f. 304. I8I3. The Bishop of Bardstown requests certain favors, and gives notice of the state of his diocese.

ff. 306-307. I8I4. Note on the see of Baltimore.

f. 308. Bordeaux, Oct. 7, I8I4. The Rev. William Harold proposed as Bishop of Philadelphia.

f. 3I5. The Bishop of New Orleans speaks of a subsidy of six hundred scudi. 
f. 3I6. Feb. 24, I8I5. The Archbishop of Baltimore, on his failure to receive answers, and recommending a priest of Louisiana who goes to Rome.

f. 3I7. Feb. 20, I815. The Archbishop of Baltimore, on facoltà.

ff. 320-32I. Mar. 2I, I8I 5. The Bishop of Bardstown, on the good conduct of Karl Nerinckx.

f. 322. Montreal, Mar. 26, I8I5. On the sickness of Mgr. Larose.

ff. 323-326. Apr. II, I8I5. The Bishop of Bardstown relates the state of religion in his diocese.

ff. 327-329. Apr. II, I8I5. The Bishop of Bardstown requests that Father Nerinckx be returned to him.

ff. 330-332. Apr. 29, I8 I 5. Letter of a parish priest of Louisiana on questions of jurisdiction.

ff. 333-334. Bordeaux, July I2, I8I5. The administrator of Louisiana finds it necessary to go to Rome.

ff. 335-336. July I 5, I8I 5. Pius VII. to the Archbishop of Baltimore, on the administration of Louisiana.

f. 337. July I8, I8I5. The Archbishop of Baltimore, on the coming to Rome of Mgr. Brurius.

ff. 338-339. July I7, I8I5. The Archbishop of Baltimore, on the choice of bishops for vacant sees, etc.

ff. 340-342. Sept. 8, I8I 5. State of the diocese of Bardstown.

f. 343. Sept. 20, I8I 5. Minute to be made, to obtain from the Dataria a subsidy for the new Bishop of New Orleans.

f. 344. Sept. 2I, I8I5. On the Ursulines of New Orleans.

f. 345. On the diocese of New Orleans.

ff. 349-350. Oct. IO, I8I5. The Archbishop of Baltimore speaks of bishops consecrated, facoltà, etc.

f. 35I. Dec. 30, I8I5. The Bishop of New Orleans speaks of a book given to be reviewed, by the master of the apostolic palaces.

f. 352. Florence, Jan. 9, I8I6. The same, on a subsidy, and on the death of the Archbishop of Baltimore.

f. 355. Rome, Jan. 6, I8I6. The same, recommending Edmund Burke.

f. 358. The same, proposing certain queries.

ff. 358-359. Bologna, Feb. 9, I8ı6. The same, on a subsidy, and asking a brief for the erection of a chapter, and for the consecration of Mgr. Maréchal.

ff. 360-364. Georgetown, D. C., Feb. 4, I816. From the Archbishop of Baltimore, on the obsequies of Mgr. Carroll; requesting the Bishop of Boston as coadjutor; and on facoltà.

f. 364. Information on Father Jeremiah O'Flynn, formerly a Trappist.

f. 365. Baltimore, Mar. 30, I8I6. The rector of the seminary of St. Sulpice requests certain favors.

ff. 367-368. Lyons, Apr. II, I8ı6. From the Bishop of Louisiana, on money received, and on certain intrigues.

ff. 369-370. Lyons, Apr. I I, I8I6. From the same, on the subsidy received, and on various projects.

f. 371. Father Nerinckx requests approval for an institute founded in America.

ff. 372-373. Bordeaux, June 24, I8I6. The Bishop of Louisiana wishes to fix his residence at St. Louis. 
f. 374. Paris, June 28, I8I6. Representation that the Pope takes so many subjects of the seminary of St. Sulpice for bishops, that the seminary will become barren.

ff. 377-378. Baltimore, Apr. 9, I816. Ambrose Maréchal prays not to be made bishop of Philadelphia.

ff. 379-380. Pittsburg, Aug. 26, I8I6. De Andreis makes a relation.

ff. 382-383. Pittsburg, Sept. 22, 1816. De Andreis recounts his voyage to America. See also f. 386.

f. 384. Sept. I, I8r6. The Bishop of New York speaks of himself and of the scarcity of priests.

ff. 387-388. 1816. The Bishop of New Orleans gives his reasons for wishing to be transferred to Paris, and exposes his projects.

ff. 389-390. Georgetown, D. C., Nov. 24, 1816. The Bishop of Boston, on the news that he has been made coadjutor of the Archbishop of Baltimore.

ff. 39I-392. From the same, giving his reasons for not wishing to accept the said coadjutorship.

ff. 393-395. Baltimore, Dec. I, I8r6. Mgr. Maréchal renews his objection to being made bishop of Philadelphia, and makes recommendations for that see. Two letters.

ff. 396-399. Georgetown, D. C., Dec. 20, I8r6. The Archbishop of Baltimore, on the receipt of the pallium, the coadjutorship, the schism in South Carolina, the translation of the Bishop of Bardstown, etc.

ff. 400. I8r6. Mgr. Du Bourg, "De Magistratus Licentia in Foederatis Americae Provinciis, ad Matrimonii Celebrationem requisita".

ff. 402-405. Votes on the suspension of Father Robert Browne, Augustinian, by Mgr. Maréchal.

ff. 406-409. May 3r, r8r7. Petition of the Roman Catholics of the state of Virginia to His Holiness, on the spiritual needs of that state.

f. 4IO. Jan. I5, I8I7. The deputy of the mission of Bardstown asks to be excused from coming to Rome.

f. 4I5. May, I8r7. The Bishop of Boston petitions to be allowed to remain in his diocese.

ff. 4I6-4I7. Feb. 7, I8I7. From the same, with the same request, and reporting the state of the diocese.

f. 4 I8. From the same, that he is content that he has been made Archbishop of Baltimore, and on the publication of the decrees of the Council of Trent concerning matrimony.

ff. 419-420. Mar. I5, I817. Mgr. Maréchal on the coadjutorship.

f. 425. Paris, Mar. 29, I817. The bishop of Louisiana, on his reasons for coming to Paris, and his delay in returning to his diocese.

f. 427-428. Georgetown, D. C., Apr. I I, I817. From Mgr. Neale, opposing the publication of the decrees of the Council of Trent on the subject of matrimony.

ff. 43I-432. Quebec, Apr. 26, I8I7. The Bishop of Quebec requests facoltà on matrimonial dispensations.

ff. 433-434. Apr. 27, I817. The minister of Spain writes that Mgr. Du Bourg has presented him a request directed to the King of Spain that the two Floridas be comprised in his diocese.

f. 435. Sept., I817. Recommendation of the Rev. Father Cooper for his visit ad limina apostolorum, from the Archbishop of Baltimore. 
f. 436. Georgetown, D. C., May 9, I8I7. Mgr. Neale, requesting a dispensation, and speedy action in the case of the coadjutorship.

ff. 437-438. May Io, I8I7. Relation of Bardstown, by De Andreis.

ff. 442-447. Norfolk, Va., May 31, r8I7. 'The claims of the trustees.

ff. 448-449. Norfolk, Va., June I, I8I7. Other documents on the above subject.

ff. 453-454. Bordeaux, June I6, I8I7. Request for priests in Lower Louisiana.

ff. 455-457. Boston, June I8, I8I7. From the Archbishop of Baltimore, on the coadjutorship of Baltimore, on the state of his own diocese, and requesting facoltà.

f. 458. June I8, I8I7. The vicar-general of Baltimore announces the death of Mgr. Neale.

ff. 459-460. Baltimore, June 25, I8I7. Mgr. Maréchal, on the same subject.

ff. $461-462$. From the same, on the archbishopric.

ff. 463-464. Baltimore, June 27, I8I7. The same, dissuading from his own nomination for Baltimore, and urging the choice of Mgr. Cheverus for that see, and of Mgr. David for Philadelphia.

ff. 467-468. July I5, I8I7. Relation of Kentucky, by De Andreis.

f. 469. New York, July 30, I8r7. Father Thomas Carbery, on the evil state of the diocese of Baltimore.

ff. 472-473. Baltimore, Aug. 9, I8I7. Mgr. Maréchal, on the seizure of the administration of the church of Norfolk, Virginia, by six false Catholics.

ff. 474-477. Lyons, Aug. I8, I8I7. Letter of Father Grassi to Mgr. Maréchal, on the desire of many ecclesiastics to go to America, etc. (Translation.)

ff. 478-479. English original of the above.

ff. 480-48I. Bardstown, May 20, I8I7. Relation of Kentucky, by De Andreis.

ff. 482-483. Relation of Kentucky, by Father Rosati.

f. 495. Dec. I6, I8I7. The Bishop of Boston, on the consecration of Mgr. Maréchal as Archbishop of Baltimore.

f. 496. Baltimore, Dec. 26, I8I7. The Archbishop of Baltimore requests the pallium, and speaks of Father Gallagher, of Mr. Browne, and of a certain deputy of Virginia.

America Centrale, dal Canada all'Istmo di Panama, dal 1818 a tto il 1820. IV.

No. I. ${ }^{65}$ I8I8. Translation into Italian of a letter written by an Englishman to Thomas Jefferson, attacking the Sulpicians, etc., and religion in general, especially in the election of bishops. ${ }^{66}$ I4 pp.

No.2. I8I8. Note on the synod of Baltimore of I8ro. 9 pp.

No. 3. "Difficultates quaedam propositae ab Episcopo Bardensi." 5 pp.

No. 4. Notice of Dominicans who are to go to America and who claim to share revenues with those who remain in Europe. $5 \mathrm{pp}$.

No. 5. Observations on cemeteries and goods acquired in the United States. $3 \mathrm{pp}$.

${ }^{65}$ The documents are not paged or numbered. For purposes of convenience I numbered them, but not definitively.

${ }^{83}$ It is noted that this was printed in the United States, and distributed to members. of Congress. 
No. 6. Queries on seminaries in America. 7 pp.

No. 7. Response of Mr. Armstrong, minister plenipotentiary of the United States in France, on toleration in America.

No. 8. Prospectus, by Michael Joseph Fay, of a seminary in Virginia. $3 \mathrm{pp}$.

No. 9. On the establishment of a mission in Illinois. 3 pp.

No. Io, and no. II. On the college of San Ferdinando, Mexico. 5 pp.

No. I2. Memorial of Joseph Harent, in behalf of the Sulpicians of Baltimore. 3 pp.

No. I3. Plan of the cathedral of Baltimore.

No. 14. From the Bishop of Kentucky, on whether it is lawful to swear on the Bible of the heretics.

No. I5. Matrimonial cases from Kentucky.

No. I6. Jan. 3, 1818. The Archbishop of Baltimore, on the receipt of the bull of nomination.

No. 18. Feb. 7, I818. Letter of the Rev. Father Rosati, on the seminary of St. Thomas, at Bardstown. I8 pp.

No. 19. I818. Relation of "Louiziana ossia Nuova Orleans". 6 pp.

No. 20. Feb. 21, I8I8. The Archbishop of Baltimore, on his consecration. 4 pp.

No. 2r. New York, Feb. 26, I8r8. Mgr. Connolly, on religion in America.

No. 22, and no. 23. The mission of Rosati to America, from Milan.

No. 24. Rome, Apr. 24, I8I8. On a new mission to America. (English.)

No. 25. Translation of the same.

No. 26. The Bishop of Bardstown, to Madam Moore of Bruges, on Father Nerinckx.

No. 27-no. 35. Letters of the missionary Rosati.

No. 35. 1818. Relation of De Andreis, on Louisiana. I4 pp.

No. 36. 1818. Another relation by the same, of same subject. Io pp.

No. 37. "Catalogo delle Lettere scritte dall'America Settentrionale dai Preti della Congregazione della Missione."

No. 38. Sept. 19, I818. The Bishop of New Orleans requests facoltà.

No. 40. Oct. 2, I8I8. Brief of Pius VII., to the Archbishop of Baltimore.

No. 4I. Oct. 8, 1818. On the congregation of the Friends of Mary, in Kentucky.

No. 42-no. 44. From Sig. Sicardi, on the mission of New Orleans.

No. 45. New York, Nov. 22, 1818. From Father Carbery, Dominican, on South Carolina. I3 pp.

No. 46. 1818. Relation of Kentucky. I2 pp.

No. 47. Relation of Louisiana. 4 pp.

No. 5I. I8I8. From Mgr. David, with thanks for dignity conferred upon him. 4 pp.

No. 52. I8I9. Translation of the pastoral letter of the Archbishop of Baltimore. I80 pp.

No. 53. "Ratio Status Religionis Catholicae in Diocesi Baltimorensi reddita ab Ambrosio Archiepiscopo, I818." I5 pp.

No. 54. Pastoral Letters of Archbishop Carroll to the Congregation of Trinity Church in Philadelphia, I797, and of Archbishop Maréchal to the Congregation of Norfolk, Virginia, I819. Printed at Baltimore, $1820.85 \mathrm{pp}$. 
No. 55. Pastoral letter of the Archbishop of Baltimore to the Roman Catholics of Norfolk, Virginia. Printed at Baltimore, I820. $62 \mathrm{pp}$.

No. 56. I8I9. "Extrait du Journal, L'Ami de la Religion. . . sur l'Etat de la Religion Catholique dans le Kentucky et dans les Territoires voisins." I I pp.

No. 57. St. Louis, I8I9. Relation of Louisiana, by the vicar-general. $20 \mathrm{pp}$.

No. 58. The Dominicans request permission to constitute a prefect general in Ohio.

No. 59. I8I9. On the Dominican missions of America. $3 \mathrm{pp}$.

No. 66. I8I9. Relation of Father De Andreis, on Louisiana. 7 pp.

No. 67. St. Louis, Feb. I6, I8I9. The Bishop of St. Louis (i. e., of New Orleans) gives a relation on the state of religion. $4 \mathrm{pp}$.

No. 68. Another brief relation from the same. $3 \mathrm{pp}$.

No. 69. Relation of the seminary of St. Mary, by Sig. Rosati. 4 pp.

No. 70. Another letter, on the same subject. 4 pp.

No.72. May I2, I8I9. The Bishop of St. Louis requests a coadjutor. $6 \mathrm{pp}$.

No. 75. Mar. 25, I820. Letter of thanks from Henry Conwell, the new bishop of Philadelphia.

No. 76, and no. 77. Letters of the Archbishop of Baltimore in 1819, seemingly of small importance.

No. 78. Apr. IO, I8I9. Sig. Rosati writes from Louisiana, on the conversion of heretics, and on the savages who have requested priests of the American government. $3 \mathrm{pp}$.

No. 8o. Origine et Progrès de la Mission de Kentucky. Printed at Paris, I82I. $32 \mathrm{pp}$.

No. 8I. I8I9. Advice of the Portuguese minister regarding the election of Sig. Obermer to the church of Philadelphia. $3 \mathrm{pp}$.

No. 82. Sept., I8I9. Father Hayes has denounced a conspiracy made in North America to have bishops independent of the Holy See. 4 pp.

No.83. Discovery and denunciation of the attempt of Thomas Carbery to secure the consecration of a Franciscan at Utrecht, and his installation as Bishop of Carolina. 4 pp.

No. 87. Letter on Thomas Carbery and the new Bishop of Charleston. $4 \mathrm{pp}$.

No. 88. June 7, I8I9. The Bishop of Louisiana requests facoltà.

No. 89. June I4, I8I9. Mr. Fagan, secretary of the Catholic congregation of Philadelphia, to Father MacCarmick at Rome, petitioning to have Father Harold as bishop, and on the conditions of the diocese.

No. 90. June I6, I8I9. The Archbishop of Baltimore, on the disturbances at Charleston and Philadelphia. 3 pp.

No. 9I. Father Ryan, the rector of the Dominican college at Lisbon, says that Father O'Connor Hai (Hayes?) is unworthy of being made bishop of Philadelphia. $3 \mathrm{pp}$.

No. 92. I8I9. Relation of Louisiana, by Father De Andreis. I I pp.

No. 93. Philadelphia, June 2I, I8I9. The missionary Rosati on the development of missions. $4 \mathrm{pp}$.

No. 94. The Bishop of St. Louis requests a coadjutor. 3 pp.

No. 96 and no. 97. Two letters of June 7 and June 25, I8I9, the latter confidential, from the Bishop of St. Louis, regarding the naming of a coadjutor. $6 \mathrm{pp}$. 
No. 98. July 5, I8I9. From Mgr. Maréchal, on a young man who wishes to be ordained priest.

No. 102. July 7, 1819. Letter of Father De Andreis, on the state of religion in Louisiana. $8 \mathrm{pp}$.

No. 104-no. 108. Documents relating to a missionary going to America.

No. 109. July 30, I8I9. Mgr. Maréchal, on the schism of Norfolk, and on Father Carbery and Father Browne.

No. IIO-no. I 44. Documents on the congregation of the Friends of Mary, in Kentucky.

No. I 5. I8I9. A Catholic of Norfolk writes of the disorders in Virginia. I3 pp.

No. I I9. Sept. I8, I8I9. Mgr. Maréchal, on Father Gallagher, and other subjects. (Translation.) $7 \mathrm{pp}$.

No. I2I. Original of the above in English.

No. I22. I819. Relation of Father De Andreis, on Louisiana. 3 pp.

No. 124. Bardstown, Oct. I8, I819. Relation by the bishop.

No. I25. Philadelphia, Nov. 5, I819. From Father Rosati. (Translation.)

No. I26. Original of the above in French.

No. I29. On the miserable state of bishops in America. 3 pp.

No. 130. Dec. 19, I819. From Father Ryan, on the bishopric of Philadelphia and the schism there.

No. I32. English original of the above.

No. I34. I820. "Relazione dello Stato attuale dei Bisogni e Progressi delle Missioni degli Stati Uniti." 7 pp.

No. 135. "De Calamitatibus quibus Ecclesia Dei in Foederatis Americae Statibus opprimitur et de Mediis quibus averti possunt." 7 pp.

No. I36. "Contra Abusum Authoritatis Civilis quam Fideles aliquando committunt Temporalibus Administratoribus Bonorum Ecclesiae." 9 pp.

No. I37. Note on Spanish seminaries of America. I7 pp.

No. 138. Kentucky, Mar. 6, I820. Extracts from letters of Dominican missionaries of Kentucky and Ohio.

No. 139. Nov. 6, I820. The Bishop of Bardstown, on the erection of new dioceses in Cincinnati and Detroit, and on nominations for then. 4 pp.

No. I40. Feb. 4, I820. The Archbishop of Armagh, on the new Bishop of Philadelphia. (Translation.) 5 pp.

No. I4I. Feb. 2, I820. The Bishop of New Orleans writes of the coming of Father Ercolani, and of the prudence necessary in the affairs of the United States.

No. I42. Extract of a letter of James Neil, on the state of religion in New York.

No. I43. English original of no. I40.

No. I45. On matrimonial dispensations for Baltimore.

No. 146. Certain parish priests and administrators of the diocese of Armagh ask Mgr. Conwell to renounce the dignity of the bishopric of Philadelphia.

No. I5 I. Brief relation of Maryland.

No. I52. Mar. I, I820. The Bishop of Bardstown asks for the erection of two new dioceses, and proposes some queries. $4 \mathrm{pp}$.

No. I54. From the Archbishop of Baltimore, on five Jesuits coming there. 
No. I 55. Suggestions for nominations to bishoprics in America. $3 \mathrm{pp}$.

No. I 56. June 6, 1820. A missionary of New York, on the ills that afflict that church. (Latin.)

No. I 57. June 27, I 820 . Charles Nerinckx, on the institute of the Friends of Mary, etc. 4 pp.

No. I 59. Birchfield, Kilkenny, Ireland, July I6, I820. Patrick Kelly hopes not to be made bishop of Virginia. (English.) $5 \mathrm{pp}$.

No. I60. Translation of no. I59.

No. I6I. Nov., I820. Mgr. Conwell will depart for Philadelphia as soon as consecrated, and asks facoltà.

No. I66. Birchfield, Kilkenny, Ireland, Aug. 3I, I820. Mgr. Kelly speaks of his consecration, etc. $4 \mathrm{pp}$.

No. I67. English original of no. I56.

No. I74. Sept. I4, I820. Father Wilson, provincial of the Dominicans of Kentucky, to Father Hill, on the state of religion in Kentucky. $3 \mathrm{pp}$.

No. I75. Oct. I7, I828. The Archbishop of Baltimore, on the new bishops. (Latin.) 3 pp.

No. I77. William Taylor, missionary of New York, on the sending of a visitor, etc. (Latin.) $4 \mathrm{pp}$.

No. I78. Nov. 28, I820. Extract of a letter from Mgr. Poynter, vicar apostolic of London, to Robert Gradeville (?), on Quebec, and on conditions in the United States. 4 pp.

No. I79. Nov. 22, I820. "Freedonia vicino Barrens 20 miglia lungo il Mississippi." From Rosati, on the establishment of a seminary. 3 pp.

No. I80. Baltimore, Dec. 4, I820. From Demetrius A. Gallitzin, on his experiences, etc. (French.) 3 pp.

No. 18I. Request for a recommendation.

No. I82. Baltimore, Dec. 27, I820. Letter regarding the plantation of Pipe Creek, sold by the Jesuits, to build the college of Georgetown, D. C. 4 pp.

America Centrale, Carolina, Causa di Browne e Galligher che appellano alla S. Sede, dal I8I3 a tt. il $1820 . V^{67}$

No. I. Sept. 20, I8I9. Short relation of the schism of the church of Philadelphia. (Translation of English original.) $22 \mathrm{pp}$.

No. 2. Original of no. I.

No. I3. Feb. I I, I82 I. "Accusa Pastorale avanzata dal Vescovo di Filadelfia." $20 \mathrm{pp}$.

No.I4. Printed copy of no. I3.

No. 26 and no. 27. Dec. I8, I822. Copy of the National Gazette of Philadelphia, with translation. $72 \mathrm{pp}$.

No. 29, no. 30, and no. 32. Letters of Aug. 24, I822, Mar. 3, I823, and Apr. I2, I823, from the Sardinian consul-general at Leghorn.

No. 39. Sept. 3, I823. From the Sardinian consul-general at Philadelphia. Io pp.

No. 52. Jan. 9, I824. From the Sardinian minister at Rome.

\footnotetext{
${ }^{67}$ This should properly be volume $\mathbf{6}$, and the succeeding 5 ; and should be entitled "Scisma di Filadelphia". As the documents of this volume relate almost wholly to this cause, only a few are cited by way of illustration of their character.
} 
No. 6r. Philadelphia, Jan. I, I825. From the Abbé Inglesi. Io pp.

No. 62. Copy of the will of. Peter Gill, dated Jan. I, I795.

No. 63-no.69. Apr. I8, 1825. Copies of legal documents relating to the "jus patronatus".

No. 79. July 23, I825. Audience of the Propaganda.

No. 97. Oct. 9, 1826. On the concordat concluded. 8 pp.

No. 98-no. 99. Concordat, with translation.

No. roo. Project of a concordat.

No. 127. July 26, r8o8. Copy of a Philadelphia deed. 4 pp.

No. 135. Documents relative to the church at Philadelphia (copies and translations): "I Documenti sequenti dimostrano e specificano $i$ diretti distintivi del Clero, da quelli della corporazione. L'Infrazione di questi diritti tragettava $i$ fondamenti di tutte le molestie che hanno sperimentato negli ultimi 20 anni i membri della rispettabile congregazione della chiesa di S. Maria ". 3 pp.

No. 142 . Project of a concordat, about 1828 .

No. 144. Feb. 23, 1828. Project of Father Kohlmann. 6 pp.

No. 146. Philadelphia, Apr. 19, I828. Legal summons, and other documents, on one of which is a note: "The tryal is again postponed till after the election in April I828".

No. I 58. Aug., I 828. Letter from the Archbishop of Genoa, forwarding one from Washington.

No. I6o. Oct. II, I828. Copy of letter from William Matthews to Henry Clay. 4 pp.

No. 163. July 7, 1828. Copy and translation of the appeal from the priests of Philadelphia to the United States government.

No. I66. Latin copy of the ecclesiastical summons to Fathers Harold and Ryan, to come to Rome.

No. 168. Aug. 29, 1828. Letter of the Secretary of State of the United States, forwarded through the nuncio at Paris.

No.I75. Sept. 26, r828. Letter from the Bishop of Genoa, with account of interview with Mr. [James] Brown, "Ministro degli Stati Uniti presso S. M. C [ristianissimo] ", on the views of the president. $4 \mathrm{pp}$.

No. I8I. Nov. 3, I829. Appeal of the builders to the Pope. (Translation.) $24 \mathrm{pp}$.

America Centrale, Scisma di Filadelphia, dal I8I9 a tt. il I820. VI. ${ }^{08}$

America Centrale, dal 1823 a tt. il 1829 . VII. ${ }^{99}$

America, Antille, dal 1634 a tto il 1760 . I.

ff. I-7. Historical notes on the discovery of America.

ff. 8-9. "Archiepiscopatus et Episcopatus in America."

f. 30. The general of the Dominicans petitions that in the Indies priors of parish priests be chosen not by the parish priests themselves, but by the provincials of the provinces.

${ }^{68}$ The number of this volume should be 5 , and its title, "Carolina, Cause di Browne e Galligher che appellano alla S. Sede, dal I8I3 att. il I820". Time did not suffice to list the documents in this volume, which are of not quite as general interest as those in the preceding.

co This volume contains many documents on the schism of Philadelphia, and others of a miscellaneous scope. Time did not suffice to list them. They all seem to relate to the United States. 
f. 259. Martinique, Apr. I, I677. Attestation to Father Fremont to undertake the conversion of the savages of America.

f. 383. The bishop of Cuba requests facoltà.

f. 387. Aug. I2, I695. State of the Catholics in the islands and continental possessions of the King of England.

f. 388. The Bishop of Cuba requests facoltà.

f. 389. Havana, Dec. 8, I698. The Bishop of Cuba commits the visit ad limina to a Jesuit, being himself prevented by sickness.

f. 4I2. Feb. I5, I753. Notice of the Catholics in the islands and mainland of America, subject to the English.

\section{America, Antille, dal I76I a tto il I789. 2..$^{70}$}

ff. 24-25. Aug. 2, I763. From the vicar apostolic of London, on the limits of his jurisdiction. (Latin.)

ff. 26-28. Documents relating to the same.

ff. 29-30. Mar. I5, I764. Extract of a letter from the same.

ff. 7I-72. May 26, I767. From Abbé L'Isledieu, on St. Pierre and Miquelon.

ff. I08-I09. Mar. 7, I769. From the nuncio at Paris, on Canada.

ff. I 52-I 54. Jan. I 5, I772. From Abbé L'Isledieu, on his correspondence with the Bishop of Quebec.

ff. I76-I78. Aug. 5, I772. From the same, on the Ursulines of Louisiana. (French.)

ff. I85-I86. Mar. I3, I773. From the same, on St. Pierre and Miquelon.

ff. I99-200. From the same, enclosing letter from the Bishop of Quebec, dated July 24, I774.

ff. I96-20I. Fron Abbé L'Isledieu, enclosing documents that seem to have been lost.

ff. 239-24I. Jan. I7, I776. From the same, on St. Pierre and Miquelon.

f. 248. Apr. I4, I777. From the nuncio at Paris, on St. Pierre and Miquelon.

f. 255. Sept., I778. On the Capuchin mission of New Orleans. (Latin.)

ff. 306-309. Mar. 2I and Mar. 22, I783. From the director of the seminary of foreign missions at Paris, and vicar-general of the Bishop of Quebec, on St. Pierre and Miquelon. (French.)

ff. 3I3-3I4. Aug. 4, I783. From the same, on the same subject. (French.)

f. 326. June 2r, I784. From the nuncio at Paris, referring to the "Nuova Repubblica Americana".

f. 343. May I7, I783, and Apr. I8, I785. Memorial on the French missions of Newfoundland.

ff. 360-361. Apr. IO, I786. From the director of the seminary of foreign missions at Paris, on St. Pierre and Miquelon.

f. 372. I787. From Abbé Tomson to Montague, vicar apostolic of Scotland, on the Scotch settlers at St. John's.

f. 373. Paris, Feb. I3, I787. From M. Bequet, on St. Pierre and Miquelon.

f. 408. July 28, I788. Concerning James Lewis O'Donnel, Recollet, of Newfoundland. (Latin.)

ff. 409-4IO. Sept. 25, I787. Letter from the above mentioned O'Donnel, on Florida.

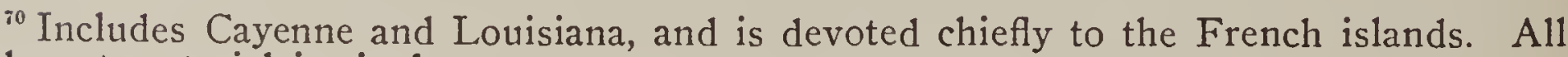
relevant material is cited.
} 
ff. 4I I-4I2. "Ferryland", North America, Nov. IO, I789. From Patrick Power, on his troubles with Father O'Donnel. (Latin.)

ff. 4I3-4I4. July I, I789. From Father O'Donnel, on the state of Newfoundland. (Latin.)

ff. 4I5-4I6. Dec. I8, I789 (?). From the same, on the same subject.

America, Antille, dal 1790 a tto il 1819. 3.

ff. 5I-53. St. John's, Newfoundland, Dec. I4, I790. On the dispute be tween O'Donnel and Power.

f. 64. Halifax, N. S., Apr. 2, I797. From Peter Torris and others, relating to a shipwreck, and the return of French prisoners.

f. 26I. May I4, I8or. The general of the Capuchins, on the need of missionaries in Spanish America, owing to the interruption of navigation.

f. 3I6. Wexford, Ireland. From Father Patrick Lambert, vicar apostolic elect of Newfoundland.

ff. 330-332. St. John's, Newfoundland. From the same.

ff. 379-380. I8I6. From Francis Jeremiah O'Flynn, on the jurisdiction of the Archbishop of Baltimcre over Santa Cruz.

ff. 395-398. Sept. 19, I8I9. From the same, on the same subject. (English, with translation.)

ff. 434-435. "Colonies Françaises." List of clergy, including the island of St. Pierre.

America, Antille, dal 1820 a tto il $1834 \cdot 4 .^{71}$

No. 2. "Isole dell'America Settentrionale ", by Jacob Buckley, vicar apostolic for the English islands. Mention is made of St. Pierre.

No. 76. Dec. I2, I826. Extract of a letter of Mgr. Eneas MacEachern, vicar apostolic of New Brunswick, etc., on Prince Edward Island. $2 \mathrm{ff}$.

No. I34. I83I. List of priests, including those of St. Pierre.

No. I 57. Baltimore, Mar. Io, I833. From Jacques Nicolas, concerning negroes and mulattoes. (French.) $2 \mathrm{ff}$.

No. 187. Aug. 4, 1833. From the nuncio in Spain, on Porto Rico.

No. I9I. Baltimore, Oct. 30, I833. From .. Joubert, on the conflicts between the French and Irish clergy. $2 \mathrm{ff}$.

America, Antille, dal 1834 al $1836 . \quad 5 .^{72}$

America Meridionale, dall'Istmo di Panama allo Stretto di Magellano, dal 1649 al 17 r3. I.

ff. I-23. "Relazione delle Indie Occidentali. Missioni, cattedrali, vescovati, facoltà", etc.

ff. 25-26. "Ordinationes pro Fratribus."

f. 210. June 3, I684. Pope Innocent XI. to the King of Spain, on the placing of members of orders holding parishes under the jurisdiction of bishops.

${ }^{11}$ This volume is neither paged nor numbered. The figures given represent my counting of the documents. In addition to the material listed there is a great deal on Hayti, and some general documents relating to the French islands as a whole.

${ }^{72}$ This volume is almost wholly taken up with documents relating to the two missions of the Right Rev. John England, bishop of Charleston, S. C., as apostolic legate to Hayti. There are also a few papers relating to the French islands, but none relevant to the subject. 
America Meridionale, dall'Istmo di Panama allo Stretto di Magellano, dal I7I4 a tto il 1744.2.

ff. 56-57. I72I. Note on petition: "Non e solita la Sa. Congrega. di Propaganda di concedere ai Religiosi semplici . . . Facoltà per le Missioni nell'Indie Occidle dove sono i Vescovi ". See also f. 70.

ff. I86-I9I. On the separation of missionary jurisdiction in Peru from that of New Spain.

f. 234. Oct. I3, I733. From the Bishop of Treviso, recommending Brother Mario di Belluno for the missions of America.

ff. 328-329. Pro Episcopis Americae, et Indiarum Orientalium. Printed facoltà.

America Meridionale, dall'Istmo di Panama allo Stretto di Magellano, dal i745 a tto il 1766.3 .

f. I . Note with references on America, as follows: Greg. XIII., Annali, lib. 8, no. 32 ; Bullar. Ord. Praed., vol. 4, p. 593 ; idem, vol. 4, p. 295 ; Paul III., Bull., 59, no. 8; Guillaume de l'Isle, Geographica, lib. I, cap. 3 .

ff. I4-30. Notes and queries regarding seminaries in America, addressed to the Sacred Congregation.

ff. 33-34. From Fra Giuseppe Torrubia, Commissario General di Curia del Ord. St. Fran., on the separation of the missionary jurisdiction in Peru from that of Mexico.

ff. 242-257. Statuta et Sanctiones pro Missionibus Capuchin. Americanis (Rouen, I752, printed, I2mo).

f. 267. Aug. I, I752. From "C. Carolus Franciscus à Rothomago Prôalis", on confirmation in America.

America Meridionale, dall'Istmo di Panama allo Stretto di Magellano, dal i767 a tto il $1803.4 .^{73}$

No. I. Extract from briefs of Benedict XIV., I74I, constit. 38, "Immensa Pastor $\bar{u} "$; and, I745, constit. I I8, "Jam pridem dilecto filio", dealing with the question of the sale of slaves and the eating of meat.

No. 3. "Articolo del Preve di Paolo III. sì li Digiuni dei Neofiti dell'Indie Occidentali."

No. 4, and no. 5. Documents relating to the same subject.

No. 6. Notes on a brief of Adrian VI., expedited at the request of Charles $\mathrm{V}$., and granting him permission to send Franciscans to the Indies. $3 \mathrm{ff}$.

No. ro. "Lettera responsiva del R. P. Fra. Pier Giuseppe Lopes de la Huerta Lettore giubilata ed Ex Provinciale de' Minori Osservanti della Provincia di S. Antonio de los Charcas nell' America Meridionale, all'Ill ${ }^{\mathrm{mo}}$, e $\mathrm{R}^{\mathrm{mo}}$ Sigre $^{\mathrm{re}}$ Monsigr ${ }^{\mathrm{r}}$ Vescovo de Pace Don Gregorio Francesco Campos, I767." $94 \mathrm{ff}$.

No. I2. "Rationes, quibus Episcopus Pacensis intendit probare nullitatem Sacramenti Confirmationis administrati in Missionibus de Apolobamba à R. Pe Provinciale Fr. Petro Josepho Lopez de la Huerta, S. F. O." $8 \mathrm{ff}$.

No. 84. I785 circa. Note on the foundation of colleges in Chili and Mexico.

${ }^{75}$ This volume is neither paged nor numbered. The figures given represent my own counting of the documents. 
America Meridionale, dall'Istmo di Panama allo Stretto di Magellano, dal I804 a tto il $1825.5 .^{73}$

No. II3. Jan. 23, 1816. On the good relations between the Pope and the Prince Regent of England, with reference to communication with missions.

No. 168. Dec. 14, 1819. From the commissioner of the missions of the Indies, concerning colleges in New Spain. $2 \mathrm{ff}$.

No. 198. July 17, 1822. From Abbé Cappacini, of the office of the secretary of state, on the expedition of a brief concerning the Jesuits of Maryland.

No. 243. A separate enclosure of documents relating to Chili, including I6 numbers with a total of several hundred folios.

This volume and, to a certain extent, the preceding, as well as the volumes of America Centrale for the same period, bear tacit testimony to the interruption of communication with Spanish America during the Napoleonic wars and the internal troubles that followed, as nearly all the documents relate to Brazil. While the relations of England and Portugal, and later the establishment of a recognized dynasty in Brazil, permitted continuous correspondence there, the presence of an active mission of Italian Capuchins doubtless fostered it. The number last cited marks the reestablishment of active relations between the Papacy and Chili, as the volumes $\mathbf{4}$ and $\mathbf{5}$ of America Antille record the efforts in the same direction in the case of Hayti.

\section{Dal 1627 al r707. Anglia. I.}

ff. 321-322. Dec. I4, I669. Request for secular priests to be sent to Maryland. ${ }^{74}$

Dal 1708 a tutto il 1727 . Anglia. 2.

f. 434, Dec. 6, I726; f. 437, Dec. I3, I726; f. 439, Dec. 20, I726; f. 448, Jan. 24, I727; f. 45 ob, Feb. I4, I727; f. 452 b, Feb. 28 , I727; and f. 454, Mar. 7, r727. Letters on the relations of England and Spain in the Western Indies.

f. 520 , Sept. I9, I727; and f. 549, Dec. 26, I727. Letters on the relations between England and Spain in America generally.

ff. 523-524. Sept. 26, I727. On the relation between England and Spain in Florida.

Dal I728 al I740. Anglia. 3.

f. 4, Jan. 2, I728; f. 24b, Feb. I7, I728; f. 25, Mar. 5, I728; f. 33, Mar. 26, I728; f. 35 , Apr. 2, I728; f. 38b, Apr. I6, I728. News-letters from London, on the war between England and Spain.

f. 43b. Apr. 30, 1728. News-letter from Lima, on the war.

f. 53. May 28, r728. Letter from London, on the sale of Carolina to the King of England.

f. 59. June II, I728. News-letter from London, concerning Maryland. f. 75, July 30, I728; f. 76, Aug. 6, r728; f. 81, Aug. 20, r728; f. 82, Aug. 27, I728; f. 87, Sept. 10, I728; f. 93, Oct. 22, 1728; ff. 95-96, Oct. 29, I728. News-letters from London, on the war in the West Indies.

f. roo. Nov. I2, I728. News-letter from London, on the transportation of criminals to America.

7. Printed in Hughes, History of the Society of Jesus in North America, Docs., vol. I., pt. I., pp. 197-198. 
ff. IOI-I02. Nov. 26, I728. News-letter from London, on emigration from Ulster to New England.

f. I48, Apr. 8, I729; f. I56, Mar. 6, I729; f. I60, May 20, I729; ff. I77I79, July I, I729; f. I88, Aug. I2, I729; f. 204, Oct. 7, I729; f. 324, Sept. 29, I730. News-letters from London, on the war in the West Indies.

Nothing relevant.

Dal I74I al I760. Anglia. 4.

\section{Dal r76r al r800. Anglia. 5.}

Nothing relevant.

Francia dal I62I al I720. I.

ff. 93-94. Extract from the register of the privy council of the king, on the Dominicans in the islands.

f. I37. Apr. 29, I664. Letter from Piquet to Cardinal Facchenetti, on Canada.

Francia dal I72I al 1847. 2.

Nothing relevant.

Spagna, Gibilterra, e Portugalla, dall'Anno I666 al 1835.

Nothing relevant.

Missioni, dal I646 al I707. I.

ff. I6-20. On the distribution of provinces.

f. 397. Description of Capuchin missions.

Missioni, dall'Anno ${ }_{728}$ a tutto il 1740.3.

f. 22. July I7, I728. Catalogue of prefects of the missions of the Propaganda.

ff. 2II-2I3. Sept. I2, I733. Notes on missionaries to be sent.

Missioni, dal I74I al I760. $40^{75}$

ff. 2I4-224. I752. Summary of decrees of the Sacred Congregation.

f. 274. I750 circa. Summary of French Jesuit missionaries in Louisiana, Mississippi, New Orleans, Illinois, and Canada.

\section{LETTERE DELLA SACRA CONGREGAZIONE. ${ }^{76}$}

These letter-books are divided inte two series. The first fifty-three volumes cover the period down to 1669, corresponding to the Scritture Antiche. The second is a regular series, with one volume or two for each year, the letters of each year being arranged by the provinces to which they were directed and those of each province chronologically. There is also united with each volume of the letters of the Congregation a number of letters of the secretary of the Congregation. The material in these volumes is not listed here, as it is extremely well indexed, and letters were seldom sent except as a result of action in the Congregation or by the prefect and secretary, and therefore references given to the Atti and the Scriture Riferite serve as a rough index to the let-

\footnotetext{
There are other volumes in this series of "Scritture riferite nei Congressi, Missioni", but only seven, extending to I799, were examined. The material relates for the most part to persons desiring to go on missions.

${ }^{76}$ These letter-books have been used by Father Hughes in his History of the Society of Jesus, Docs., vol. I., pt. I., pp. I49, I83, 185.
} 
ters. The letters are directed to nuncios and other persons with whom the Congregation had business. The letters of the secretary are of interest for the study of administration, as they are concerned largely with the relations of the Congregation with other departments of the church government at Rome.

\section{UDIENZE DI NOSTRO SIGNORE.}

This is a series of volumes briefly recording cases of certain kinds where the decision is reserved to the Pope. It begins with I666. The volumes examined were 18-22, covering the years $1780-1786$. These volumes are not indexed, and the material is mostly of a formal character. It includes grants of ecclesiastical graces, indulgences, and facoltà, propositions of churches, and decrees of other congregations on points on which their opinion was asked by the Propaganda. All discussion on these points appears to have taken place elsewhere, and this is simply a record of the action decided upon, endorsed with the papal sanction. The relevant material in this series was not listed.

\section{CAUSE.}

This series contains the documents relating to cases of a judicial character tried in the Propaganda. Many such cases occupy a whole volume, other volumes contain the cases of a single year, and some, those coming from a single province. A disproportionately large amount of this material relates to the East Indies. This whole series was examined and the relevant material is listed.

\section{Cause dell'Anno I637. Vol. 3 I9.}

ff. 367-372. Three hundred Parisians, going to America, ask the Society of Jesus for three priests.

Cause dell'Indie. r643. Vol. 321.

ff. I06-I I2. Memorial relating to the case of the Bishop of Tlascala.

ff. I13-r22. Sept. I5, I643. Compendium relating to the facoltà for regulars in the Indies.

ff. II6-II7. I635. Note of Secretary Ingoli on the Cedula Regia of the King of Spain, on the Indies.

f. I 18. June 27, I643. A document on the same subject.

ff. I24-125. Nov. I9. On Bishop Palafox.

ff. I27-23I. Documents relating to the patronage of the Catholic king, including a manuscript compendium of $33 \mathrm{ff}$., a printed work of I06 ff., and another printed work of 6I ff., by Brother Diego Ibañes, procurator of the province of the Holy Gospel.

ff. 246-I 49. I633. Madrid. Propositions of Brother Diego Ibañes. Printed.

ff. 247-250. Documents on the oppression of monks by bishops in the Indies.

f. 304. Sept. I5, I643. Report of a meeting at the palace of the Propaganda, on the same subject.

\section{MEMORIALI.}

This series contains memorials sent to the Propaganda, for the most part copies, on all kinds of subjects. The series is in $4 \mathrm{I} 7$ volumes, and extends only to I669, such material, after that date, being bound with the Scritture Corrispondenti. All relevant material is here listed. 
Memoriali del I63I. Vol. 391.

ff. 4-5, 62-63. Feb. 3. From the Dominicans to be sent into New Mexico, from the provinces of Castile and Mexico.

ff. I2-I3. Feb. 3. On the mission of the Capuchins in New England.

Memoriali I632. Vol. 392.

ff. I07, I43. Brother Domenico, an Indian, wishes to go home to convert his family.

Memoriali I633. Vol. 393.

ff. I52-I 53. July I9, I633. "Postulata ad Sacram Congregationem de Propaganda Fide, pro incremento Missionis Capucinorum in partibus Orientis, atque etiam in Anglia, et Nova Francia: Itaque dubia quaedam declaranda."

ff. I60-163. Copy of the same.

Memoriali I635. Vol. 395.

ff. 320-32I. From the provincial of the Recollets of Paris, for the better ordering of missions in Canada. See also f. 55 .

Memoriali 1638 . Vol. 399.

f. I55. From Pietro Nieto, provincial of the Augustinians of Mexico, asking favors for Gasparo de Quintero.

f. 257. Concerning the English, Scotch, and Irish in the island of St. Christopher, "seu partes Virginiae".

Memoriali I64I. Vol. 402.

f. 29. From the Capuchins of Paris, on the sending of a priest and twelve laymen to Canada.

ff. $5^{\mathrm{I}-56}$. Response to a memorial of the ambassador of Spain, concerning missions.

f. I68. From the procurator-general of the Capuchins asking facoltà for missionaries in Canada.

f. I93. Request for facoltà for two priests in Maryland, with power to transmit it to others.

f. 200. Request from Charles Camus du Peron, for special privileges in Canada.

f. 20I. Jan. 7. Memorial on the same subject as f. 200 .

Memoriali I642. Vol. 403.

ff. 260-262. Memorial for the general improvement of Capuchin missions.

ff. 336-337. Concessions to Brother Gio. di Santiago, Dominican of Mexico.

Memoriali I645. Vol. 409.

f. 422. "Don Gio. della Croce dell'Indie Occidli si ritrova in questa citta di Roma negotiando il bene commune, facendo sapere come nelle Indie ogni' uno attende alla Fatica dell' Oro, Argento, et altri Essercitii temporali, non curandosi insegnar la Lingua Latina . . ."

Memoriali I646. Vol. 4I2.

f. 4I9. Sept. I5. Petition of a Jesuit to go to the Western Indies. Memoriali 1648 . Vol. 417.

f. 287. Petition from the Jesuits in Canada for transferable facoltà.

\section{CONGREGAZIONI PARTICOLARI.}

This series of volumes contains documents used by, and relating to, the various congregazioni particolari, held from time to time. As in the case of the cause, a disproportionate amount concerns the East Indies. All material relating to our subject is listed here. 
20. ff. 195-198. Dec. 15, I666. Congregation for the creation of a bishop of Canada. Discussion of the jurisdiction of the Archbishop of Rouen. "Rescriptum, Erigatur in titulum Vicariatus Apostolicus Canadiensis, et nominatio illius Ecclesiae concedatur Regi Galliarum tanquam fundatori."

30. (I682-I700.)

ff. 99-109. Summary of a congregation held May I6, I684, regarding the weakening of the Catholic faith in America. With this are letters from bishops in America requesting greater authority over monks.

31. ( I686-i707.)

ff. 98-I I I. Documents relating to the congregation held Apr. 2, I686, on the business of erecting missionary colleges in Mexico. Reference is made to the congregazione generale of Mar. 26, 1686.

137. (I $764-178 \mathrm{r}$.)

ff. I-7. Mar., I764. "Super rebus Americae Septentrionalis." On the spiritual government of the French colonies.

f. 9. Mar. 17, I764. Letter from the cardinal prefect, suggesting the necessity of a special congregation on the "gravissimo affare del Canada".

ff. II-I2. Jan. 30, I764. From the nuncio at Paris, on the demands made of the English government by the chapter of Quebec.

ff. I3-I4. Feb. 20, I764. Abbé de l'Isledieu to the nuncio at Paris, requesting information on Canada.

ff. I5-I7. "Mémoire sur l'État présent de l'Église de Québec."

ff. 18-22. "Second Mémoire sur les Démarches du Clergé et des Peuples du Canada depuis la vacance du Siège de Québec."

ff. 23-26. "Dénombrement particulier des différentes Missions Françaises et Sauvages de l'Isle Royale, l'Isle St. Jean, de l'Acadie, de la Rivière St. Jean, Pentagouet, Miramichi et Restigouche avec le nombre de leurs Eglises et leur Position."

ff. 27-28. Petition to the Pope, on matrimonial dispensations for Canada.

f. 29. Decree on allowing variations in the form of worship.

ff. 3I-42. Letters of Abbé de l'Isledieu, on Canada, the English court, etc.

ff. 43-44. "Forma Juramenti Professionis Fidei habita a Stephano Montgolfier praesentato ad ecclesiam Quebecensem."

ff. 47-50. On the right of the chapter of Quebec to nominate the bishop.

ff. 5I-52. Paris, Feb. 27, I764. From Abbé de l'Isledieu to the nuncio at Paris, on the election of the Bishop of Quebec.

ff. 53-54. Power from the chapter of Quebec to Mgr. de Montgolfier, to secure a bishop.

ff. 55-56. I765. The nuncio in France, on the nomination of a bishop for Quebec, and his negotiations with the court of London.

ff. 57-59. The dean of the chapter at Quebec to the Pope, on the nomination of a bishop for that see.

ff. 6r-65. Memoir from the said dean, on the same subject.

f. 68. "Ex audientia SSmi Januar. I766 confirmatur D. Briand in episcopum Quebecensem."

f. 7I. Jan. 22, I 766. The cardinal prefect orders that a brief be prepared for Mgr. Briand. 
145. "Atti della Congregazione Particulare de 4 Marzo I808. America Settentrionale."

ff. I-37. Abstract of a congregation held for the erection of a bishopric, subject immediately to the Holy See, to hold in check certain contumacious ecclesiastics who refuse to obey a simple vicar, and to better propagate the Catholic religion in the United States.

f. 40. Extract from the Moniteur de la Louisiane, of Feb. 21, I807, on the bishopric of New Orleans.

f. 42. Process undertaken by Abbé de l'Espinasse, before the prefect apostolic, to secure the suppression of the ancient chapel founded by Spanish Catholics at Kingston. Printed.

ff. 42-43. Two copies of the Moniteur de la Louisiane on the disorders produced by the Rev. Father Walsh.

ff. 44-49. New Orleans, Mar. 6, I807. Letter of the administrators of the goods of the church of the parish of New Orleans, to Mgr. Carroll, as administrator of Louisiana.

ff. 64-68. Two matrimonial dispensations made by the parish of St. Louis.

ff. 69-70. July 4, I787. From the Bishop of Santiago de Cuba, constituting Father Antonio de Sedella parish priest of New Orleans.

f. 7 I. May 9, I806. From the King of Spain, naming the aforesaid priest as curate.

ff. 75-77. Copy of document on the foundation of the bishopric of Baltimore.

f. 79. Father Concanen requests the most ample facoltà for some prelate of the British Empire, for the spiritual good of the American portion of that empire.

f. 80. I808. Father Concanen urges that the affairs of North America be hastened.

ff. 8I-82. Father Concanen, on the naming of certain Catholic bishops in the United States.

ff. 85-86. From the same, on the same subject.

ff. 9I-93. Nov. 2I, I806. Translation of a letter written in English by Mgr. Carroll to Father Concanen, on the divisions of dioceses in America.

ff. 95-96. Apr. I2, I805. From the Rev. Patrick Walsh, vicar general of New Orleans, on Father Antonio de Sedella, who excites the people against him.

ff. 97-IOO. I805. Two letters from a priest of St. Sulpice at Baltimore, proposing certain queries.

ff. I02-I05. Nov. 22, I806. The Bishop of Baltimore writes of how many dioceses it would be possible to found.

ff. I06-I08. From the same, suggesting nominations for the said proposed dioceses.

ff. I08-III. Considerations on making bishops.

ff. I65-176. "Rescripta Sacrae particularis Congregationis . . pro resolutione dubiorum [on the nomination of bishops] ad Americam Septentrionalem, praesertim vero ad Foederatas ejusdem Americae Provincias pertinentium."

f. I84. Briefs for the making of new dioceses.

ff. I87-I88. Erection of four dioceses, and names of the bishops.

ff. I9I-I97. The cardinal charged with the affair (Cardinal Litta) responds to doubts on the erection of new dioceses. 


\section{MISCELLANEA.}

There is a considerable amount of material of a miscellaneous character, under various titles. This material was examined, and references to all that seemed relevant are listed.

\section{Miscellanea, Missioni.}

1. f. 65. On the Capuchin missions.

f. I I $2 \mathrm{~b}$. On the Dominican missions.

ff. II $\mathrm{b}, \mathrm{I} 3 \mathrm{I}$. On the missions of the French Capuchins.

ff. 22I-222. I730. Catalogite of prefects of missions.

f. 228. I775. List of the bishops and archbishops who are accustomed to send to the Propaganda relations of their dioceses. Quebec is the only American see named.

f. 234. May 3I, I794. On the Dominicans in California.

ff. 252-255. I758. Notes of the archbishops, bishops, and prefects to whom was sent a questionnaire from the Propaganda.

f. 256. Similar note, of those to whom was sent a circular letter of Sept. 24,1802 .

f. $270 \mathrm{~b}$. 1802. List of vicars apostolic.

ff. 278-279. Notes of the missionaries apostolic, who exercise the ministry with a patent from, and in dependence upon, the Sacred Congregation.

ff. $357-365$. On the religions dominant in various parts of the world.

f. 368. Questionnaire for missionaries. Printed.

f. 388. Ten forms of facoltà. Printed.

ff. 396-399. Names of Jesuits in Canada after I763.

ff. 404-4I8. I760 circa. General observations on missions.

ff. 442-444. Note of prefects, of vicars apostolic, and of the nuncios responsible for various provinces.

f. 450 . List of missionaries of the Propaganda.

2. f. 3 II. I826. List of the provinces of the Propaganda.

3. f. 49. New plan of deputation of facoltà, approved by the Pope Mar. I6, I8I7. List of places to which it applies.

4. ff. I47-I62. I743 circa. Plan of a work on the extension of the Catholic faith under the Propaganda.

12. "Decreta et Regulae pro Missionariis." This contains two hundred and seventy-seven items.

13. "Notizie e Luoghi di Missioni." Miscellaneous notes on America, of little value.

?. Volume without number, but apparently belonging to this series, and entitled, "Relationi di varie Missioni : Stato del Collegio Urbano, Missioni e Missionari".

Near the beginning is: "Brevis Relatio Missionis FF. Praedicatorum in Insulas Septentrionales Americae". Following a little after: "Catalogus Missionum". A little beyond the middle: "Missione de" Padri Capuccini ".

\section{Miscellanea di America.}

1. "Causa Angelopolitana." Bishop Palafox against the Jesuits.

2. Relazione della Missione Cattolica in Terra Nuova (1837). Printed.

3. Relatio Missionum Occidentalium sub Vexillis Seraphici Instituti (I700). Printed. 


\section{Miscellanea Varia.}

1. "Relazioni di Varie Provincie della Christianità."

f. 3. A few dates of briefs relating to America; as I74I, on slaves and negroes; 1766, on the bishop of Quebec.

Quaderno IV. List of foreign missions committed to the Capuchins. I I ff.

Quaderno XXXI. I764 circa. "Stato della Religione Cattolica nell'America Inglese." 2 ff.

8. f. 96 to the end of the volume. Documents relating to America, on such subjects as taxes and the granting of honors; but not particularly touching the territory covered by this report.

11. ff. I-243. "Relazione di Mons ${ }^{\mathrm{r}}$ Urbano Cerri alla Santità di N. S. P. P. Innocenzo XI. dello Stato di Propaganda Fide." Written between I679 and I689. Folios I48-I7I are on America, I7I-I79 are on the state of the Congregation, with many suggestions for improvements. ff. 326-383. The American portion of a longer relation, apparently that made to Clement XI.

13. ff. I I8-I43. Relation by Mgr. Cerri. Substantially, if not wholly, like that in vol. 11.

18. f. "Divisio Provinciarum pro Illmis et $R^{\mathrm{mis}} \mathrm{DD}$. Cardinalibus Sacre Con"gregnis de Propaganda Fide." I624-1625.

\section{ISTRUZIONI.}

Istruzioni Diversi degl' Anni 1623-1638.

ff. 66-67. June 21, 1625. To the nuncio in Spain, on the affairs of religion in both the Indies.

f. 217. 1635. To the nuncio in Spain, on the parishes of the Indies.

\section{Istruzioni dall'Anno 1639 sino al 1648.}

f. 4. Mar. 3, I639. To the nuncio in Spain, on the parishes of the Indies. ff. 49-5 I. Apr. I4, I644. To the nuncio in Spain, on the interpretation of the bull of Alexander VI., granting the patronage of the Indies to the King of Spain.

f. 5 I. Mar. 5, I644. To the nuncio in France, on missions.

\section{Istruzioni.}

1. ff. 29-40. Mar. 2, I767. To the nuncio at Paris, on the bishopric of Quebec.

ff. $4 \mathrm{I}-44$. Jan. I5, I783. To the same, on the peace negotiations of that year. ${ }^{\text {j7 }}$

f. 343. General instruction to the prefects of missions, on the oath demanded by the national assembly of France.

ff. 385-389. Jan. I4, I785. To the nuncio in France, on the affairs of America. ${ }^{78}$

2. ff. 584-588. Instructions on the facoltà of the Capuchins in their missions.

3. ff. 568-579. 1823. Instruction on certain doubts proposed by the Archbishop of Quebec.

ff. 588-594. July 4, I793. Instruction to the Bishop of Quebec.

f. 607.1840 circa. Instructions to the apostolic delegate in Hayti.

"Printed in American Historical Review, XV. 8oI.

is Printed in American Historical Review, XV. 825. 


\section{SCRIPTA VARIA.}

Decreta S. C. de Prop. Fide I6z2.

ff. 49-52. "De Cura Animarum in Novo Orbe commissa Religiosis Ordinum Mendicantium a Sede App ${ }^{\text {ca }}$ media designation' Missione Regum Cath."

f. 61. "Divisio provinciarum."

Stati delle diverse Missioni appartenenti alla $S . A$.

This series contains for the most part printed blanks filled in with information. The headings are: "Città e Luoghi", "Clero Secolare suo Rito e Qualità ", "Clero Regolare suo Rito e Qualità ”, “Parrocchie, Residenze, Chiese, Numero de Catholici, e loro Rito ", "Relazioni e Lettere", "Scuole e Collegi" "Potenze di Congregazioni, Cose notabile, Resoluzioni da prendarsi", "Sussidi ordinari, straordinari, e Rendite fisse, Facoltà ordinari, straordinari, e Indulti".

I. (I794-I 805.)

II. (I794-I805.)

This contains data on Newfoundland, about 1805 .

III. (I794-I808.)

This contains data on Newfoundland, about I808.

This contains data on Canada in 1807 and 1808 , and on the United States for the same years. There are no other volumes, but filed reports.

Informationum lib. I36 pro Missionibus diversis.

ff. I 54-I 55. I697. On the need of facoltà to dispense in matrimonial cases, in the French islands.

f. 570. Paris, Oct. I2, I6Io (?). Letter from Father Petrus Braidus to Father Enemondus Massaus (Ennemond Massé), on certain ecclesiastical necessities for the Canadian mission.

f. 57 I. Notes regarding the Jesuits in North America, from the history of Brother T. Bresciano (F. G. Bressani ?).

\section{VISITE E COLLEGI.}

This collection of about forty volumes contains nothing relevant to the subject in the period open to inspection, except possibly an occasional reference to Americans in some of the colleges, for the first college subject to the Propaganda and special to America was founded only in I857. This was the "Collegium Americanum Immaculatae Conceptionis Lovanii", for missions in America, particularly among immigrants from Belgium, Holland, and Germany. This was followed, in I859, by the "Collegium pro Statibus Foederatis Americae de Urbe" ; and in I888, by the "Collegium Canadense". Also under the care of the Propaganda, has been the "Seminarium Sancti Joseph pro Missionibus Societatis Sancti Joseph a SSmo Corde ad Negros in Statibus Foederatis Americae Septentrionalis", at Baltimore, which is connected with that at Mill Hill, London, founded in I866. Whether this remains under the direction of the Propaganda, I could not ascertain. The eldest college, the Collegio Urbano ( 1627 ), takes students from all nationalities, particularly those desiring to enter the field of gèneral missions.

MUSEO ETNOGRAFICO DE LA S. C. DE PROPAGANDA FIDE.

This museum contains the Borgia Mexican manuscripts, ${ }^{i n}$ and the two wellknown maps of the new world. The Borgia collection of manuscripts has been transferred to the Vatican Library, and is described under that head.

${ }^{79}$ See Kingsborough, Antiquities of Mexico, vol. III., and Anales del Museo Nacional de Mexico, IV. 264, and V. I2. 


\section{OTHER ECCLESIASTICAL COLLECTIONS IN ROME.}

In the following sketch of the other ecclesiastical collections, the several institutions are discussed in the order in which they are given in the Gerarchia Cattolica.

\section{THE CONGREGATIONS. ${ }^{1}$}

\section{Sancti Officii.}

The Congregatio Sancti Officii, or, as it is more commonly known, the Holy Roman and Universal Inquisition, should not be confounded with the various inquisitorial bodies which preceded it. In its present form it was established in I 536 by Paul III., and fully organized by Paul IV. in I558. Its general function is the preservation of the faith in relation to heresy and heretics. As a powerful congregation it attracted to itself many matters not necessarily pertinent to it, and in particular its reputation for secrecy caused it to be given the handling of many affairs of delicacy. A great deal of English business passed through its hands, and with it possibly something relating to America. The material relating to Spanish America is scant because of the extraordinary independent powers granted to the more venerable Spanish Inquisition, ${ }^{2}$ but still the correspondence of the Holy Office contains something. Matters relating to the Indies were also occasionally referred here by the Propaganda. At the present time the Holy Office has ceased to deal with matters not strictly falling to it; and its jurisdiction has been reduced by the creation of the Congregation de Disciplina Sacramentorum, and by the transfer of all that relates to abstinence, feasts, etc., to the Congregation of the Council, and of everything relating to the election of bishops to that of the Consistory.

The archives of this congregation suffered severely at the time of their transfer from Paris, ${ }^{4}$ when a great mass of them was destroyed under the

\footnotetext{
${ }^{1}$ Nearly all the facts relating to the activities of the several congregations are taken from Les Congrégations Romaines, by Félix Grimaldi (Siena, I890, pp. xii, 556), and from Constitutio Apostolica de Romana Curia, by Pius X. (Rome, 1908, pp. 69). Grimaldi at the time he wrote this work had a wide practice before the congregations and was well acquainted with all the details and technicalities of their methods. Owing to an over-indulgence in a rather characteristically Roman love of sarcasm, he was led into statements which caused his book to be placed on the Index; but it remains the one modern work on the subject. Since its publication changes in organization have been numerous and important, but it seemed hardly within the subiect to follow them in detail. The new state of affairs is summarized in the bull and laws included in the above-mentioned pamphlet of 1908 , which represents a condition that will probably be fairly permanent. For the earlier period there are several works chiefly formal in character. In addition to those mentioned in connection with specific references, the following were of some use; Cohellius, Notitia Cardinalatus (Rome, I653, pp. 328), particularly pp. 4I-I53 on the congregations, and $192-198$ on the vice-chancellor; and Colomiatti, Codex Juris Pontificii seu Canonici, vol. II. (Turin, I893), which gives the bulls incorporating and regulating the congregations. The information obtained from these sources was supplemented by conversations with many of those now actually. engaged in affairs, and by the particular references which follow.

${ }^{2}$ Hinojosa, Los Despachos, p. liii.

${ }^{3}$ See Barberini 6334-6336.

${ }^{4}$ See inventory of the archives, in the Archives Nationales, Paris, cartons 390-395. I96
} 
direction of the papal agent. ${ }^{5}$ Some few of those consigned to destruction escaped and are found in Paris, and some are at Trinity College, Dublin. ${ }^{\circ}$ There remain, however, over 7000 volumes, extending from the middle of the sixteenth century to the present day, in the palace of the Inquisition, on the Via Santo Uffizio. They are entirely inaccessible at present. ${ }^{8}$

\section{Consistorialis.}

The primary and obvious purpose of this congregation was to prepare material for presentation before the consistories of the Sacred College. It acquired control also of the granting of certain honors of an ecclesiastical character, such as the pallium. I know nothing of its archives, if there be any, other than those in the Archivio Consistoriale, but they would scarcely be likely to contain anything of importance for American history, as the preliminary steps in the case of American dioceses were, until Nov. $x, 1908$, in the hands of the Propaganda instead of this congregation.

For the future, however, its archives will be important, not only because all American episcopal nominations will pass through its hands, but because its functions have been extended in number as well as in territorial application. It seems destined, in fact, to become the chief of all the congregations. It has the power, in cases of conflict of jurisdiction, of determining the competency of the several congregations; and has had transferred to it certain duties previously exercised by the congregations of Bishops and of the Council. It will have the examination of the relations of dioceses sent by the bishops, and, after consultation with the Pope, its prefect, the preparation of measures called for by these reports. It will have charge of all that pertains to the government, discipline, and studies of seminaries. In personnel it is closely joined with the Congregation of the Holy Office and the secretariate of state.

\section{Visitationis Apostolicae.}

The functions of this congregation were local to the diocese of Rome, and have been now transferred to a commission.

\section{Episcoporum et Regularium.}

This congregation has been for many years the most active in the Curia. In the first place it acted as a tribunal for the settlement of causes arising between bishops and the regulars of their dioceses. The conflicts between these have been innumerable and universal, and have made this congregation one of the greatest judicial tribunals of the Church. In addition, a still greater portion of its attention was devoted to the second branch of its activity, the supervision of regulars, including the examination and approval of all propositions for new institutions, of their constitutions and rules, and of all changes in the same. By the recent constitutions this congregation has been abrogated. In its place has been established the congregation "Negotiis Religiosorum Sodalium ", which takes over its work of supervision, including the judging of cases of discipline. The remainder, and by far the more important portion of its judicial authority, goes to the Rota. The archives of this congregation

"Delisle, "Les Archives Pontificales", in Journal des Savants, I892, p. 432. The agent received 4300 francs from the paper-maker who boiled them down.

"C. Corvisieri, "Compendio dei Processi del Santo Uffizio di Roma", in Arch. della Soc. Rom. di Stor. Pat., III. $263-267$.

${ }^{7}$ Hinojosa, Los Despachos, p. liii.

${ }^{8}$ Copies of particular documents might possibly be obtained. 
are very extensive, as its rules of pleading were well developed and elaborate. There are said to be 16,000 volumes, extending from the end of the sixteenth century, but they seem as yet to have been kept secret. In the Borgia collection, numbers $66,70,71$, and 77 give a compendium and index to the material from $\mathrm{I}_{582}$ to $\mathrm{I} 644$. No cases arising in America were noted. The collection is apparently arranged by subjects, as the interest was in cases and not in the localities from which they arose. In the records of the Propaganda there are notices of cases referred from that congregation to this.

\section{Super Disciplinam Regularium.}

The particular function of this congregation was to settle cases arising between two members of the same order, those involving two orders going to the preceding congregation. Originally given powers only in Italy, its work rarely extended out of that field, although it was given general jurisdiction in I645. At first a rival of the Congregation of Bishops and Regulars, it became later an adjunct, having the same prefect, and was in 1906 annexed to it. $^{10}$ The two archives have undoubtediy been joined.

\section{Super Statum Regularium.}

This congregation, established in 1846 to revise the legislation affecting all orders, was in 1906 dissolved by Pius X., as having accomplished its purpose. ${ }^{11}$ It was always connected with the Congregation of Bishops and Regulars, and their archives are doubtless joined; but those of this congregation would scarcely chance to have anything local to America.

\section{Concilii.}

This congregation was formed originally to interpret the decrees of the Council of Trent, and to propose new legislation. Its field of activity was with the secular clergy and the people. This gave it supervision of diocesan and parochial property, of the observation of feasts and fasts, and of pious unions and other ecclesiastical societies not monastic. It acquired other functions, such as the examination of bishops and the revision of the decrees of provincial councils. These two latter duties were at one time assigned to subordinate congregations; but these need not receive the attention of the American historian, as the jurisdiction of the first did not extend to America, and the latter, doubtless with its archives, was in 1908 annexed to the Congregation of the Council. The constitutions of 1908 leave this congregation with much the same field it has previously occupied, although no specific reference is made to the Council of Trent. The duty of examining the reports of bishops, and of making recommendations upon them, has been transferred to the Congregation of the Consistory, and all judicial powers, except in linea disciplinari, to the Rota. Its archives, which consist of about 4000 volumes, should contain a fair proportion of material relating to America. ${ }^{12}$

\section{Super Residentiam Episcoporum.}

This was a congregation, subordinate to the preceding, whose purpose was to regulate the residence of bishops. It may well have discussed the cases

\footnotetext{
'Hinojosa, Los Despachos, p. liii.

${ }_{11}^{10}$ Pius X., Pontificis Maximi Acta, vol. III. (Rome, 1908) ; May 26, I906.

${ }^{11}$ Ibid.

${ }^{12}$ Hinojosa, Los Despachos, p. liii.
} 
of at least one bishop of Mexico, ${ }^{13}$ and one of Quebec. ${ }^{14}$ After having been long practically united with the parent congregation, it was in I904 suppressed, the field of its work having almost vanished under modern conditions.

\section{Immunitatis Ecclesiastici.}

This congregation, which was founded in $\mathrm{I} 626$, was also subordinate to that of the Council. It was in effect a tribunal for the adjudication of cases arising from the violation of ecclesiastical immunity inherent either in persons or places. These arose for the most part in the Papal States, ${ }^{15}$ but occasionally cases from Spanish America were referred to it from the Propaganda, ${ }^{16}$ though none were noted except from the provinces of South America. This congregation is noted by Grimaldi in I890 as no longer existing, but in the Gerarchia of 1908 it is mentioned. Doubtless with the disappearance of the rights with which it dealt, it became merely titular. In the Constitutions of 1908 it is not mentioned. Its archives, doubtless now united with those of the congregation of the Council, amount to about 3000 volumes. ${ }^{17}$

\section{Indicis.}

This congregation was established in $\mathrm{I} 57 \mathrm{I}$. Before that date its functions had been performed by the Holy Office, or by the Pope without the mediation of a congregation. Its purpose is to determine the character of books brought to its notice and to place those detrimental to faith upon the Index of prohibited books. Its archives are not extensive, amounting to only 500 volumes. ${ }^{18}$ Its decrees have, of course, always been widely published, and some material relating to it is to be found among the Bandi. ${ }^{10}$ For the future, its initiative is increased; and on the question of prohibiting books, the cardinals of this congregation are to confer with those of the Holy Office.

\section{Sacrorum Rituum.}

This congregation has two fields of work. In the first place it has jurisdiction over the forms of worship and their execution. This does not, however, include the right of advising changes in liturgies, which are usually framed and adopted without its interposition. In connection with this part of its duties it had often to deal with questions arising from countries in which new missions were being introduced. The majority of such questions arose from the East Indies, but occasionally they came also from those of the West, as concerning the kind of oil to be used in baptism. ${ }^{20}$.

The other branch of its duties is that of judging cases of beatification and canonization, and such cases were frequently presented from America, the most notable being that of Bishop Palafox.

\footnotetext{
${ }^{13} \mathrm{Nun}$. di Spagna 34, see page 64 .

14 See page I63.

${ }^{15}$ Angelica 1866, "Resolutiones Sac. Congregationis Ecclesiasticae Immunitatis, anno I702 ad I704."

${ }^{10}$ See Lettere, letters of the secretary.

${ }^{17}$ Hinojosa, Los Despachos, p. liv.

${ }^{18}$ Ibid.

${ }^{10}$ Its archives are apparently entirely inaccessible, as they are not referred to by Helgers in his Der Index der Verbotenen Bücher. (Freiburg i. B., 1904, pp. 638); or in his Die Bücherverbote in Papstbriefen (Freiburg i. B., 1907, pp. 107).

${ }^{20}$ See Barberini 1496 and 1497; Vallicelliana L 22.
} 
The archives of this congregation consist of about 2000 registers, dealing chiefly with its first class of duties, and about 4000 processes of canonization. In addition, as is mentioned on page $I 7$, there are in the Bibliothèque National at Paris about 2000 volumes of processes, left there in 1817.

\section{Indulgentiarum et Reliquiorum.}

This congregation was established in 1669 but held few meetings before I7IO. It was charged with the granting of spiritual indulgences and with the attestation and the regulation of the adoration of relics. Its greater favors were granted in the form of briefs, but minor ones it conferred upon its own authority. As each bishop on his consecration received certain indulgences there must be a certain amount of American material in its archives, which seem to be in good condition. This congregation is not mentioned in the Constitutions of 1908 .

\section{Pro Negotiis Ecclesiasticis Extraordinariis.}

This congregation was established in $\mathrm{I} \mathrm{I} 4 \mathrm{4}$ to assist in the re-establishment of the Church after the upheaval of the French Revolution. Its special field is the making and oversight of concordats and other treaties with secular powers. This work naturally brought it into close touch with the secretary of state, and it has come to be in effect a consulting board acting with him. This has tended largely to extend its activity, which actually includes much the same field as that of the State Department in the United States of America; while its close dependence upon the secretary of state differentiates it from the other congregations which have more independent powers.

It had the charge of the re-establishment of relations between the Church and most of the republics of South America, though the cases of Chili and Hayti were dealt with by the Propaganda; and its archives undoubtedly contain much of interest, but of course are not open, as they are practically all subsequent to 18 I5. They are apparently kept with those of the secretary of state and will probably be opened when the latter are.

The other congregations past or still existing can scarcely have had anything to do with America, but that of Studies will doubtless play an important part in the future.

\section{Commissions.}

The numerous commissions which now exist are all of comparatively recent origin, and have to do, moreover, with general questions of administration or scholarship. Their archives, therefore, would be neither available nor of local interest to America.

\section{TRIBUNALS.}

\section{Sacra Poenitentiaria.}

The business of this tribunal is purely spiritual. ${ }^{22}$ It absolves sins reserved from the jurisdiction of the ordinary confessors and the bishops; grants dispensations, commutations, sanctions, condonations, etc.; and deals with questions of conscience, such as the purchase by Catholics of ecclesiastical goods condemned by the state, and usury. Its archives, consisting of about 4500 volumes dating from the end of the sixteenth century, have been, and are apt

\footnotetext{
${ }_{22}^{21}$ Hinojosa, Los Despachos, p. liv.

${ }^{22}$ See also H. C. Lea, $A$ Formulary of the Papal Penitentiary in the Thirteenth Century (Philadelphia, I892, pp. xxxviii, I83), pp. xxviii-xxx; A. Gottlob, "Das Vaticanische Archiv", in Historisches Jahrbuch, V. 272.
} 
to be in the future, reserved, for those of no other department are of so confidential a nature. I am unable to state whether any American cases came to the Penitentiary or whether they were all arrested in America, by the broader faculties given the bishops, and in the Propaganda.

\section{Sacra Romana Rota.}

The history of this tribuna! is summed up in the preamble of the Constitution of I908 reorganizing it: "Quum Sacrae Romanae Rotae tribunal, anteactis temporibus omni laude cumulatum, hoc aevo variis de causis judicare ferme destiterit, factum est ut Sacrae Congregationes forensibus contentionibus nimium gravarentur". Although it remained in theory a sort of supreme court for spiritual causes, its work, after the rise of the congregations, was actually confined almost entirely to civil causes arising in the Papal States, and with the fall of the temporal dominion of the Pope, it became moribund. The Constitutions of I908, with previous letters of Pius X., re-established its importance, ordering that "causae omnes contentiosae non maiores" come before it. Its archives are in the Palazzetta in the garden of the Vatican, and are well ordered though not regularly accessible. ${ }^{23}$ As is evident, it is scarcely possible that they contain American material. ${ }^{24}$

\section{Signatura Apostolica.}

This tribunal, formed in 1908 to act as a court of appeal from the Rota, succeeds two ancient tribunals, the Signatura Papalis Gratiae and the Signatura Papalis Justitiae, which served to some extent as courts of equity. ${ }^{25}$ Their archives are in the same building as those of the Rota, but there is even less chance than in the case of the latter that American material may be found in them.

\section{OFFICES.}

\section{Cancellaria Apostolica.}

I know nothing of what archives there may be in the keeping of this office in its palace on the Corso Vittorio Emanuele. It would seem that there could be nothing essential, that is, nothing not represented elsewhere, except office accounts. One would suppose, however, that there must be preserved here warrants or mandates for the bulls which it has issued, and the original minutes of the same signed by the Pope. ${ }^{26}$

\section{Dataria Apostolica.}

The extensive archives recently transferred to the Vatican from the Lateran would seem to contain all the essential records of this office to a period even later than those for which general access is allowed. ${ }^{22}$

\footnotetext{
${ }^{23}$ Hinojosa, Los Despachos, p. lii; Sagnori, Relazioni sull' Ordinamento dell'Archivio degli Uffici Rotali (Rome, I888).

${ }_{24}$ Barberini 1538, containing an index to the decisions of the Rota, $1557-1618$, and 1596, containing selected decisions and index, $1600-1626$, were examined and no pertinent case found. The decisions of the Rota made popular reading and copies are found in almost every library.

${ }^{25}$ Bourgin, Les Archives Pontificales, p. 89; A. Gottlob, "Das Vaticanische Archiv", in Historisches Jahrbuch, V. 272; Hinojusa, Los Despachos, p. lii.

${ }^{20}$ See page $2 \mathrm{I}$.

${ }^{27}$ See page 24 for archives. For functions see T. Amyclenus, Tractatus de Officio et Jurisdictione Datarii, necnon de Stylo Datariae (Cologne, I70I, pp. 46I).
} 


\section{Camera Apostolica.}

It is not quite clear whether the archives of this office taken by the Italian government include all its records. Some series extend to the date of the seizure, others apparently do not. ${ }^{28}$ At the present time its duty is the care and administration of papal goods and lands during vacancies in the Holy See.

\section{Secretaria Status. ${ }^{20}$}

With this office is now united that of the secretary of briefs. ${ }^{30}$ All the essential archives of both seem to be in the Archivio down to 1815 . Those of the secretary of state down to 1850 are also actually there though not yet generally accessible. These latter are in the same room as the consistorial archives and the room preceding. These later records are not in registers, but in loose covers or mazzi, of which there are about 425 for the period between I8I 5 and I850. They run in series labelled: "Nunziature", "Ministri ", "Consoli ", some having in addition the name of the country, and others being marked miscellaneous.

\section{Secretariae Brevium ad Principes et Epistolarum Latinarum.}

I know nothing in addition to what has already been said ${ }^{31}$ of the archives of these two departments which have long been joined. It seems probable that the recent transfers of records include all of historical importance.

\section{ARCHIVIO DEI MAESTRI DELLE CEREMONIE. ${ }^{32}$}

The Master of Ceremonies is a very important officer of the papal court, and many who have occupied the office have been men of much weight outside their regular functions. The archives are preserved beneath the Sistine Chapel, and are under the direct control of the Master. There are about $65^{\circ}$ volumes, among them four manuscript volumes of indexes. ${ }^{33}$ There is also an inventory by Fornici, printed in 1803 , Ristretto delle principali Indicazioni sotto le quali sono raccolte in molti Volumi e descritte con Indici tutte le Istruzioni, Memorie e Manuscritti che si conservano nell'Archivio dei Maestri delle Ceremonie Pontificie-a tutto l'anno I803. This was reprinted and brought to date by Palmieri in $1893 .{ }^{34}$ Also indice 148 of the Vatican archives by Bissaigha is: "Index Rerum Notabilium collectarum ex viginti sex libris Diariorum Pontificum", I489-1644.

The material consists of accounts of funerals of popes, kings, etc. ; receptions of kings and viceroys ; controversies regarding the treatment of cardinals by temporal powers; voyages of the popes; and diaries of popes, conclaves, the Council of Trent, and other councils, I294-I799. The diaries are the most

29 See page 34 .

${ }^{29}$ See page 52 .

${ }^{30}$ The archives of the secretary of briefs have been at his office near the Amina, in the Borgo. Such archives as remained after the transfer of the register of briefs and bulls mentioned on pages 42 and 43, were unimportant. Hinojosa, Los Despachos, p. lii; Wirz, Bullen und Breven, p. xxvii.

:See pages 30-3I.

3 Abbé G. Constant, "Les Maitres de Cérémonies du XVIe Siècle: Leurs Diaires", Mélanges d'Arch. et d'Hist., XXIII. I6I-290, 319-345; Ehrle, "Zur Geschichte des Papstlichen Hofceremoniells im I4. Jahrhundert; das Archiv des Päpstlichen Cerimonienmeisters", in Archiv für Litteratur - und Kirchengeschichte des Mittelalters, V. 565, 602 (gives list of material) ; Hinojusa, Los Despachos, pp. li, lii.

${ }^{33}$ Hinojosa, Los Despachos, p. li, gives 653.

${ }^{34}$ Gregorio Palmieri, Brevis Notitia et Catalogus Archivi Sacrae Congregationis Caeremonialis (Rome, I893, pp. 49). 
interesting portion of the collection. Copies are to be found in almost every library of manuscripts, and some, as that of Burchard, have been printed. It does not, however, seem probable that any American material is to be found in them. Except for the first, that begun by Burchard in I484, and to a smaller extent the following by De Grassis, they are purely formal in character, simple accounts of the ceremonies of the papal court. ${ }^{35}$ There are, however, in the archives consistorial acts, volumes 393-407, those of Agostino Favoriti, I49I-I633; 408 and 409, those of Cardinal Severino, I 563-1 565 and I 585-I 588 ; and 410, those of Cardinal Cesarius, I628-r642.

\section{MONASTIC ORDERS.}

The various monastic orders played scarcely a less important part in the early history of America than in the development of Europe during the Middle Ages. As missionaries, explorers, and reporters of primitive life, they were almost omnipresent; and few contributions to American history would be more welcome than a complete record of their activity. Unfortunately there seems to be less material at Rome for such a record than might be supposed. The organization of the orders, with the exception of that of the Jesuits, was in fact not close. The branches belonging to the various countries were often semi-independent, and always had large local powers; while distance and danger of communication with America loosened this bond, as all others binding the people of the two continents. Such Italian monastic provinces, moreover, as engaged in missionary work in America were interested in Brazil and other portions of South America, so that their local records do not fall within the subject.

The monastic archives, also, have suffered more severely than those of the central papal administration. In addition to the ordinary buffetings of time, there have been the two great cataclysms of 1797 and I870. The French invasion led in the first place to the collection of a mass of documents from various monastic libraries and archives, which ultimately reached the Archivio Vaticano, where it exists today as the "Instrumenta Monastica". There was also a certain amount of destruction, and much loss through confusion. Many were transferred from their usual repositories to places doubtless safe, but, in the disturbances of the next eighteen years, forgotten. It is probable that such material will be coming to light for many years. ${ }^{37}$

The seizures by the Italian government after 1870 have been confined chiefly to convent libraries, and among the collections which it has opened to the public is comparatively little archive material. ${ }^{3 s}$ The archives in the possession of the several orders from the Napoleonic period to the present day are, in fact, extensive and fairly complete, and from them a history of the rapid spread of religious organizations through the United States and Canada might be written, particularly as the improvement in the means of communication has rendered the bonds between the central monastic administration and the American provinces so much more effective. Fear of further seizures, however, has retarded the advance of the policy of publicity, and they are so closely guarded by their custodians that in many cases even their location is known to but few.

${ }^{35}$ Constant, "Les Maitres de Cérémonies", pp. 32I-322; Il Diario di Leone X. di Paride de Grassis (Rome, 1884); L. Thuasne, ed., Johannis Burchardi . . . Diarium (Paris, 1883,3 vols.).

sn See page 98.

${ }^{37}$ Most of this information was gathered from conversations.

${ }^{39}$ See page 218. 
Some have been but poorly kept, and are not more easy of use than of access. At the present time nearly all the orders are alive to their value and are preparing to present the more important of their contents to the world, each by the activity of its own members and in its own publications. It is, of course, a misfortune for American students that attention is nearly always devoted first to the documents of the earliest period. While outside students can under proper auspices obtain entrance into such archives, it is extremely improbable that any one student could secure the use of a large enough number to serve satisfactorily for a study of the growth of orders generally.

\section{Carmelites, Scalzi.}

The headquarters of this order are at S. Teresa, 39 Corso d'Italia, and are said to contain archives of interest to American history. ${ }^{89}$

\section{Dominicans.}

The Dominicans have moved several times since the Italian occupation, and are now only temporarily located at Io Via S. Sebastianello, a new and more permanent convent being in construction. This has prevented a complete ordering of their archives, which are nevertheless used by a few scholars. Access is very closely guarded, even members of the order being admitted only with saution. For the period before 1800 there is much valuable material, but not connected and complete archives, and few if any registers of correspondence. For the later period the archives are satisfactory. The index notes two hundred numbers on American history. Particularly important are the reports of the procurators of the several provinces. Material from the collection is printed in the Monumenta of the order. ${ }^{40}$

\section{Franciscans.}

Minor Observants. St. Isidore. This house of the Irish Franciscans and home of Luke Wadding has been remarkably free from disturbance and its records are fairly complete. Here are a few references to America, and items might be gleaned for the biographies of students in residence here, who subsequently worked in America.

St. Quarante. ${ }^{41}$ This house belongs to the Spanish branch, and contains the general archives of the order ${ }^{42}$ besides an interesting library of eighteenthcentury books. Both have long been neglected but the archives are now being ordered. It is probable that they will be moved to the new Collegio di San Antonio, in the Via Merulana, the residence of the general of the recently reunited branches of the order. The amount of American material is relatively large. I note two numbers: lcg. 54, "Documentos referentes á la Procuración de las Indias ... á la Provincia del S. Evangelio de Mejico"; leg. 65, "Descripción Topografica, Phisica, Natural, Politica y Metalurgica de las Missiones de Propaganda Fide, y del Colegio de Guadalupe, Zacatecas". The reports of the provincial procurators, where they exist, are of great impor-

\footnotetext{
${ }^{29}$ The Carmelites unsuccessfully tried to establish a mission in America about 1635 . They do not seem to have re-entered the field until I864.

${ }^{40}$ See Momumenta Ordinis Fratrum Praedicatorum, vols. II. and IV., for slight references to these general archives.

${ }^{41}$ The entrance is hard to find; it is in the Via di San Francesco, to the left of the church of St. Quarante.

${ }^{42}$ See $V$ allicelliana N. 39, No. 2, for an index to certain manuscripts in this collection. This index was not examined but is probably of no present value. These were moved from Sta. Maria in Ara Coeli, at the time of the Italian occupation.
} 
tance. Documents from this collection are published from time to time in the Archivum Franciscanum Historicum.

Conventuals. The archives of this order, which are in connection with the church of SS. Apostoli, on the piazza of the same name, are said to contain much American material.

Capuchins. The headquarters of this order are in the convent at $7 \mathrm{I}$ Via Boncompagni. The archives are contained in a small room, and contain nothing of interest to the subject. On the other hand, this order is particularly well represented in the archives of the Propaganda. ${ }^{4}$

\section{Jesuits.}

The archives of this order are not at Rome, and are absolutely closed to outsiders, although copies of special documents known to exist may sometimes be obtained. ${ }^{44}$ When their Monumenta reaches a later period, it will doubtless make public a great deal of American material.

\section{COLLEGES.}

\section{Capronica.}

This library was left by Cardinal Capronica to the college which he founded and which bears his name. It is indexed in indice 218 of the Archivio Vaticano. ${ }^{45}$ As it obviously contained nothing relating to the subject, its present location and accessibility were not investigated. ${ }^{46}$

\section{English College.}

The archives of this college are extensive, but the chance of finding American material did not seem great enough to warrant investigation. All records of importance have been copied, and the transcripts are now in the Public Record Office of London, under the title of "Roman Transcripts".

\section{Collegium Urbanum.}

The extensive and valuable library of this college does not contain any manuscripts pertinent to the subject.

\section{College of the United States.}

The American College, founded by Pius IX. in I859, has not reached the age when even its early records may properly be claimed for historical study. Some years ago there was bequeathed to it a library collected by an American, long resident in Rome, and which was rich in manuscripts; but I do not know what disposition has been made of it. It has not been made public.

\section{Canadian and Other Colleges.}

The other colleges for Americans at Rome are all younger than that just mentioned, and have not accumulated important collections, nor has the time come for opening those that they have.

\footnotetext{
${ }^{43}$ See P. Rocco da Cesinale, Storia delle Missioni dei Cappucini (Rome, I873), III. 673-68I.

${ }^{4}$ These archives are apparently well ordered, and are systemactically cited by those who use them; J. B. Nundwiler, "Deutsche Jesuiten in Spanischen Gefängnissen im I8. Jahrhundert", in Zeitschrift für Katholische Theologie, 1902, pp. 62I-672; Hughes, History of the Society of Jesus in North America, vol. I., Documents.

ts "Biblioteca di Cardinale Domenico Capronica."

${ }^{41}$ See L. Pastor, Geschichte der Päpste (Freiburg i. B., I886), I. 617.
} 


\section{CHURCHES. ${ }^{47}$}

Many Roman churches possess notable collections of archives, but they are, naturally, for the most part of local importance only. Those of S. Maria Maggiore, ${ }^{48}$ owing to its close connection with the Spanish government, might have something.

St. Peter's. ${ }^{40}$ For this small, but ancient and curious collection there exists an index in the Vatican, indice 218, "Index Librorum Manuscriptorum Archivi Basilice $S^{\text {ti }}$ Petri ", in 5 folios. This reveals no American material.

${ }^{77}$ P. Kehr, "Papsturkunden in Rom", in Nachrichten der K. Gesellschaft der Wissenschaften zu Göttingen, I900, pp. I29-I38 and 397-40I, gives the best description of these.

${ }^{49}$ Id., p. 135.

${ }^{49}$ Id., pp. I25-1 28. 


\section{PUBLIC ARCHIVES AND LIBRARIES IN ROME.}

\section{BIBLIOTECA ALESSANDRINA.}

This library is located in the Università della Sapienza. Its entrance is from the Via dell'Università. It is open to the public from Nov. I to June 30, from 9 to 2, and from 6 to 9 . There is a rather crowded ground-floor room for reference and the consultation of ordinary books, but those who use manuscripts and rare volumes are taken above to the spacious and stately original library. This library was founded by Alexander VII., I655-I667, who presented to it a large portion of the printed books left by the Duke of Urbino." Later there were secured the manuscript collection, largely Oriental, of one of the Caetani family, a monk of the Benedictine order, and that of Peter Francis de Rubeis, dean of the college of consistorial advocates. There is a catalogue of manuscript codices by Narducci. ${ }^{2}$

None of the manuscripts were examined, as none seemed to have any relation to the subject, with the possible exception of the following:

68, or I. f. 14. ff. I-II2. "Relationi del Trattato della Tregua di Fiandra che concluse in Anversa alli 9 d'Aprile r6o9, fatta dal Cardinale Bentivoglio." ${ }^{3}$

There are two pieces relating to the Philippines.

\section{BIBLIOTECA ANGELICA. ${ }^{4}$}

This library was founded by Angelicus Rocca and was in 1605 given to the Augustinians. It is magnificently housed in their former monastery adjoining the church of San Agostino on the piazza of the same name. It is open from 8 to 2 every day, except the holidays usually observed by government institutions and the last two weeks in October. It contains 2190 manuscripts in Latin characters, which have been elaborately catalogued by E. Narducci. This catalogue is in three volumes, of which the first has been printed. ${ }^{\circ}$ There is also an index on cards. There are two systems of reference : one by a continuous numeration, the other by letters and numbers. Many of the documents relating to English history have been transcribed and copies are in the Public Record Office of London. ${ }^{7}$ Numbers 1216 (S-6-8), 1218 (S-6-10), 1219 (S-6-I I), 1222 (S-6-I4), 1224 (S-6-I6), 1229 (S-7-3), 1230 (S-7-4), 1239 (S-7-I3) , 1323, 1598, 1681, 1747, 1866, 1908, 2036, and 2083 were examined without result. References to material found follow, but none of the documents can be considered important.

111 (B-2-5). “Epistolae et Brevia ad Principes", Urban VIII. and Gregory XV. $663 \mathrm{ff}$.

f. 378. "Archiepiscopo Mexicano."

992 (R-6-7). "Sac. Rituum Cong.; Beatificat is et Canonizatis Servi Dei D. Jōis de Palafox e Mendoza Epi.”. 5 I ff.

${ }^{1}$ Enrico Narducci, Notizie della Biblioteca Alessandrina (Rome, 1872, p. 50).

'Enrico Narducci, Catalogus Codicum Manuscriptorum praeter Orientalium qui in Bibliotheca Alessandrina Romae adservantur (Rome, 1877).

${ }^{3}$ This is probably to be found in the Nunziatura di Fiandra.

${ }^{4}$ Blok, Verslag (1901), pp. 67, 68; L. Pastor, Geschichte der Päpste (Freiburg, 1886), III. 125 .

Tablet in entrance hall.

'Rome, I893.

'Roman transcripts (Stevenson), no. 15. 
1129 ( $\mathrm{S}-3-25)$. Material relating to the same case as $992 . \quad$ Io7 $\mathrm{ff}$.

$1215(\mathrm{~S}-6-7)$. This is the first of a series of volumes written to nuncios by Porfirio Feliciano, secretary to Cardinal Borghese during the pontificate of Paul V. All volumes of possible interest to American history were examined, here, or in the Nunziature, but this pontificate was little interested in American affairs and the only items found are those referred to in the following notes and those already given in the volumes of the Nunsiature examined.

1218 (S-6-IO). f. 205. Dec. I3, I610. To the nuncio in Spain, requesting information concerning the Indies.

1220 (S-6-12). Jan. I9, I6r3. To the nuncio in Spain, on the importance of news of the fleet.

1222 (S-6-I4). May 22, I6r3. To the nuncio in Spain on the anxiety of the Duke of Lerma to hasten the expedition of the bull appointing the new Archbishop of Mexico, that the latter may depart with the fleet. May 24, I6г3. To the same, with news of the sending of the said bull.

1276 (T-2-2). "Cronologia de' Anni del Signore del Principio del Mondo in fino ai Tempi Nostri."

f. I 56. Discovery of America.

ff. I 59-I62. Conquest and exploration of America.

1331 (T-3-22). "I Viaggi di Francesco Carletti" (I59I-I606). These voyages were printed in Florence by G. Manni in I7OI, but in a mutilated condition, particularly in the case of the portions dealing with the slave trade which are of particular interest to American history. This manuscript is a copy, apparently a good one.

1332 (T-3-13). ff. 25-37. Apr. 30, I582. Instructions of the Cardinal of Como to the newly designated nuncio in Spain, of which ff. 28-29 are on the Indies, "che sana stato dovere, di essendo le chiese delle Indie crescente in ricchezza, et [-?] si augmentan' ancora le tasse fino ad una honesta somma, ma no parve a Mons ${ }^{\text {re }} \mathrm{ch}^{\prime}$ parlare di q... non havesse scoperta la mente di S. M. nel parl' del Min'tro".

1551. Chartaceus folio, $88 \mathrm{ff}$. Seventeenth century.

ff. I-8. "Icones coloribus ornatae Idolorum Mexicorum, Aegyptorum . . addita Declaratione Hispanica."

ff. 9-74. "Effigies et Usus Barbarorum quarundam regionum Asiae, Americae, et Insularum . . . Meliori . . . sunt Icones Regum Peruvanorum, subiectis Notis Biographicis Hispanica Lingua."

1844. Apr. 16, I581. "Avvisi da Roma." Notes the discovery of gold and silver mines in the Indies.

Sept. IO, I 583 . From Venice. On the arrival of the fleet from the Indies.

Sept. I3, I 584. From Lyons. On the arrival of the fleet from the Indies.

1983. f. I77. Short account of Christopher Columbus, with references to books from which it is taken. Unimportant.

ff. I78-I79. Similar account of Amerigo Vespucci.

2106. "Lettere del Conte Lorenzo Magolotti sopra le terre Oderose d'Europa e d'America dette volgarmente Buccheri, scritte alla Sigra Marcha Ottavia Renzi Strozzi a Roma." 38r pp.

1658. No. 35. "Avvisi di Parigi."

Volumes not examined but of possible interest are the following:

1659. Miscellaneous instructions to nuncios.

2071. Collection of biographies. I $8 \mathrm{ff}$. 


\section{ARCHIVIO DI STATO. ${ }^{3}$}

The Archivio di Stato at Rome is at present located partly in three scattered houses, partly in the Palazzo del Gesir. Permission to use it is granted, as is usual in the case of government archives, by the director on the presentation of credentials, preferably a letter from the ambassador or consul. The director is in his office from II to 2, except on Thursdays, and the usual government holidays. The study room is open every day except holidays from ro to 3 , and there is no summer vacation. The government archives are, of course, all modern, as those before 1870 are at Turin and Florence; and are consequently opened only for exceptional reasons. There are preserved here, however, certain ecclesiastical archives which were seized by the government when it occupied Rome. These consist: first, of certain documents from suppressed monasteries, but the great mass of such material is at the Biblioteca Vittorio Emanuele; secondly, there is an enormous amount of material taken from the Palazzo Ugolini, and consisting of records of the Camera. These were doubtless taken on the ground that the business of the Camera was chiefly the administration of the finances of the Papal States, and that they were, therefore, temporal records, and probably the greater portion answer to this description and are void of other interest. Mixed with these, however, are many ecclesiastical records, for the papacy never differentiated its ecclesiastical and temporal functions; and many scholars have worked profitably here, on the general administration of papal finances.' All these studies are unfortunately for periods too early to be of much value to the American historian. Lack of resources has left this collection wholly unorganized. By way of catalogue there exists only an "Elenco dell" Archivio Camerale", which consists of a single folio, and in which the designation of series is often misleading, if not incorrect. It is, therefore, impossible to form an exact idea of how far this collection supplements that at the Vatican, and how far the two together may be lacking in completeness, without examining the whole, volume by volume. It would, in fact, be an altogether hopeless maze, were it not for the courtesy of the personnel.

Note is here made of all the series having possible relation to the subject, with mention of all pertinent references found.

Libri Resignationum. 286 volumes, divided into two sub-classes ; a, Libri Resignationum et Consensuum, 39 volumes, I457-I 599; b, Libri Consensum, 247 volumes, I528-I869. The volumes of this series examined, I7O3-I707, and 1867-1869, contained no American items. Resignations are, of course, of exceptional and not of regular occurrence, and were most frequent in the Papal States, being usually coupled with some stipulation regarding pension, or an understanding concerning the successorship. The series is apparently

\footnotetext{
${ }^{8}$ W. Bliss, English Historical Review, VI. 810-8II; P. J. Blok, Verslag van Onderzoekingen naar Archivalia in Italië, I901, pp. 62-64; G. Bourgin, Les Archives Pontificales, pp. 54-57; Hinojosa, Los Despachos, pp. 43, 64, 75; F. Gregorovius, "Staatsarchiv", in Historische Zeitschrift, XXXVI. I4I-I73 (best account, although written in 1876 ; in fact, little has been done in the way of organization since that time). See also pages 3I-34. In r910 new rooms were added at the Gesù. See Ernesto Ovidi, Gli Archivi Pubblici Romani, inaugural lecture (Rome, r910, pp. 40), and p. 9, supra.

${ }^{\circ}$ Particularly Dom U. Berlière, Inventaire Analytique des Libri Obligationum et Solutionum (for the dioceses of Belgium), (Rome, 1904, pp. xxvii, 315); and Dr. A. Gottlob, Aus der Camera Apostolica des 15. Jahrhunderts (Innsbruck, I889, pp. 317.)

${ }^{10}$ The modern portion of the elenco is printed by Bourgin in the reference just noted, together with a table of contents arranged by A. Meister, in his "Ausziuge aus der Camera Apostolica zur Geschichte der Kirchen des Bistums Strassburg, 1415-1513", in Zeitschrift für Geschichte des Oberrheins, I892, N. S., VIII. I05.
} 
complete and full, and any resignations of bishoprics in America are doubtless noted.

Libri Obligationum pro Servitiis. 3I volumes, I408-I798, with many lacunae. This series records the payments made by newly appointed bishops for various customary expenses incurred at Rome. For the earlier period such records are considered the best from which to compile a series episcoporum, but for the period since the discovery of America the Lateran series of bulls should be better, although lacunae there might be supplemented here. It is difficult to see what other use these purely formal records of payments could serve. The volumes for the period I697-I798 were examined. 'There were six volumes, and a lacuna for the years I729-I755. The volumes are written in a difficult hand, but are systematically arranged and are not difficult to use. The payments for the bishoprics of Spanish America seem to occur regularly, but none were noted for Quebec or Baltimore. The "Elenco" notes as lacking, for the earlier period, volumes for I 503-I 5 I 2 , I 5 I 7 -I 522 , I $55^{\text {I-I } 587, ~ I 604-~}$ I6 $2,1653-1660$, and $1672-1678$.

Taxarum." This series records payments made for the grant of the pallium. For the eighteenth century and after, there are two volumes only, I756-I777 and I778-I8I5 (except I8og-I8I5). Both of these were examined and numerous payments noted by the bishops of Mexico, Lima, La Plata, and Manila, but none by those of Canada or the United States.

Of the other series there were examined:

Annate-Quindennii, 1696-I710, two volumes. These contain no American items except one quinquennial payment, Apr. I6, I697, by a monastery at Lima, and it seemed safe to conclude that nothing relating to the subject would be found.

Decretorum, I7o9-I I I , containing decrees of various kinds relating to matrimony and divorce, did not contain American material nor presage such in other volumes.

Entrata e Uscita delle Decime, I702-I7I4, I7I6-I7I8, one volume, did not contain American material, and it was obvious that the other volumes would be equally barren.

The other series it seemed safe to leave unexamined. ${ }^{12}$

In addition to the archives of the Camera, certain volumes described as "Archivio dei Gesuiti" ${ }^{13}$ exist here, and have been used, but are negligible for American history.

\section{BIBLIOTECA CASANATENSE. ${ }^{14}$}

This library was formerly the property of the Dominicans, and is located in the block of buildings, before I 870 their headquarters, immediately behind S. Maria sopra Minerva, from which it took the name it bore previous to its

\footnotetext{
${ }^{11}$ This series is not noted, at least by this title, in the elenco or the table by Meister; I can, therefore, describe only the volumes examined.

${ }^{12}$ The series of "Formatarum" was not examined; vols. XI. to XIV. cover the period r 492-1524. See L. Schutz, "Die Libri Formatarum der Camera Apostolica", in Römische Quartalschrift, VIII. 45I-472. These relate to general ordinances and special dispensations for conferring orders, and could hardly contain American material.

${ }_{13}^{13}$ Blok, Verslag, rgor, pp. 62-64, notes volumes for Belgium and Holland.

${ }^{14} \mathrm{P}$. J. Blok, Verslag van Onderzoekingen naar Archivalia in Italië, pp. 69-70; A. C. Voglio and G. Colaneri, La Biblioteca Casanatense; Cenni Storico-Bibliografici (Rome, I896, pp. I8).
} 
seizure by the state, and by which its documents are cited in all older works. Its entrance is at number $52 \mathrm{Via} \mathrm{S}$. Ignazio, and the public rooms are on the second floor. The open hours are from 9 to 2, every day except festivals, national or religious, and except the first fortnight in October, when it is closed for cleaning. Its use is public. There is an alphabetical index to the manuscripts, in which they are referred to by an old numeration, and a concordance between the old and new numerations. ${ }^{15}$

The present name is derived from that of Cardinal Casanate of the Dominican order, who served in the sacred college from I673 to I700, and who collected many of the manuscripts. He was for years a member of the congregations of the Inquisition, Propaganda, Immunity, Bishops and Regulars, the Council, and Rites, and the library is rich in documents appertaining to them. There is also much diplomatic material. The whole collection was carefully examined in so far as the index served, and many volumes were examined individually, which proved to have nothing on the subject. ${ }^{13}$ References to the material found follow:

1570 (X. VII. 42). ff. I6I-I92. " Apocalipsi d'Olanda di Bambone." About 1630. A few references to the Indies.

2046. ff. I7I-I92. Instructions to Mgr. Sachetti, bishop of Gravina, nuncio in Spain, from Urban VIII. Refers to the Indies and the Congregation of the Propaganda. See no. 4245.

f. 262. Instructions to the Archbishop of Patras, nuncio in Spain, from Urban VIII. On the effect of the marriage of a French princess to Charles I., with relation to the Spanish empire.

f. 319. " Memorie à V. S. Illmo S. Cardinal Barberini destinato Legato de latere à due Rè per andare prime in Ragione di Negotio e di Viaggio al Christianissimo, raccolte da proprii Ragionamenti di Ns̄o Sigre et di V. S. Illmo." Discusses the dependence of Spain on the commerce of the new world.

2097. ff. I93-218. "Relatione di Spagna, et del Viaggio fatta per Mons. Borghese, auditor della R. Camera, l'anno I594." Gives an account of the officers of the Indies, and a few general statements as to the revenues thereof.

2324. (XX. V.) "Relazione riguardante le Svolgimenti d'Europa per la Monarchia delle Spagne pretesa con diversi motivi dalle Case d'Austria e di Borbone." $47 \mathrm{ff}$., of which f. 4 gives a brief analysis of the Spanish empire.

2375 (XX. VI. 30). ff. 65-I07. "Breve Raguaglio d'alcuni Abusi introdotti nella Chiesa Anglicana, delle Cause di essi, et del modo d'estirparli, dal quale si raccoglie il miserissimo Stato di Cattolici in Inghilterra sinche saranno senza Vescovi." ff. 87-88, on the marriage of Lord Baltimore. This is copied in Pub. Rec. Off. Transcripts, 108, p. 35 seq.

2659. P. F. Navarrette, "Conservazione delle Monarchie e Discorsi Politici, sopra la gran Consulta fatta dal Consiglio Supremo di Castiglia, d'ordine del Re Don Filippo III. Per trovar rimedio alla Spopolazione di quel Regno". From the Spanish, which was printed I625; pp. 422, 34. Some mention of the Indies.

15 "Nuove Segnature di Manoscritti, Biblioteca Casanatense, Ruma."

${ }^{16}$ Codices 1616, 2304, 2385, 2394, 2435, 2672, 4203. 
2670 (X. VI. 37). No. I4. "Istruzione dello Stato della medesima S. Congne de Propaganda con le Notizie delle particolari Missioni di tutto il Mondo, data ad Innocenzo XI." This is the relation of Cerri so often cited. See Propaganda.

2980 (XX. IV. 5). "Relatione di Spagna del Clarmo Sig. Michele Suriano, Ambre al Rè Filippo, l'anno I 560." $40 \mathrm{ft}$. Found in nearly all libraries of manuscripts; contains several pages on the Indies.

4245 (XX. IV.9). Instructions from Cardinal Barberini to Mgr. Sachetti, appointed nuncio for Spain; pp. 7-8 urge him to press the exercise of his functions in the Indies; p. Io discusses the question of "spoils"; f. I4 defines the relations of the nuncio and the Congregation of the Propaganda.

In addition, the following may contain pertinent material:

145 (X. IV. 20). Consistorial acts. I676-I680.

746, 2361, 2440-2441, 3454, 3483, 4321-4326. Decrees, decisions, and resolutions of the Congregation of the Council of Trent.

1024, 2434, 2437-2439. Decrees of the Congregation of Bishops and Regulars, from its foundation to 1656 , and from 1700 to 1728 , with many important papers relating to that congregation.

2617. "Variarum Sac: Congregationum Decreta pro Missionariis instruendis ab an. 1623 ad I654", pp. 659, with index.

2618-2619. "Decreta Sacrae Congregationis de Propaganda Fide pro Missionariis, Alumnis." Codified about r700.

339 A. Decrees of the Congregation of Rites, in the seventeenth century.

3492. Decrees of the Congregation of Ecclesiastical Immunity.

\section{CORSINI LIBRARY.}

The Corsini library occupies a portion of the Corsini palace on the Lungara. It was founded by Clement XII. (Corsini, I730-I740), and was added to by other princes of the Corsini family, from whom it was acquired by the national government. It is administered by the Royal Lyceum, which is correspondent of many learned societies, in whose publications of the last thirty years it is very rich. It contains a miscellaneous but valuable collection of about 2600 manuscripts, in addition to those donated by Rossi which are separately catalogued. This latter fondo contains nothing pertinent to the subject. For the main collection there is an index by authors, an index of subjects, and an inventory, which is not descriptive, but which it is necessary to use to collate the old numeration with the new. The library is open from I to 4 , from Oct. I to Mar. 3I ; and from 2 to 5, from Apr. I to June 3o. It is closed during July, Aug., and Sept., and the customary holidays. It has been used by many students, of whom Laemmer has listed the consistorial material, ${ }^{1 \bar{i}}$ and Gachard that important for the history of Belgium. ${ }^{18}$ In the search for American material, which was as exhaustive as possible, volumes $112,156,157,158$, $172,244,245,360,371,457,467,470,473,479,504,505,585,680,682,686$, $687,689,713,718,722,742,818,822,894,944,1099,1184,1271$ were found

${ }^{17}$ Analecta Romana (Schaffhausen, I86r), p. 37.

${ }^{13}$ "La Bibliothèque Corsini à Rome", in Bulletins de la Commission Royale d'Histoire, third series, vol. XI., no. I (Brussels, I869). 
to contain nothing relating to the subject; volume $\mathbf{8 5 7}$ was lacking. References to items found follow:

57, 58 (col. 4I-D-2, 3). "Taxa et Descriptio Patriarchalium, Pristialium, Archiepiscopalium, et Abbatialium Ecclesiarum." An alphabetical list with brief descriptions in two volumes, A-L, M-Z. Volume I. only was examined, in which Cuba, Durango, and Guadalaxara were noted.

59-62 (col. 39-F-I-4). "Praeconia, secundum Diocesum Denominationes ordine alphabetico dispositas in quatuor libros distributa." About I660. Copies of the praeconia prepared for the consistories, describing the dioceses to be erected or supplied. In four volumes, A-C, D-L, M-R, S-Z. Volume 2 only was examined, from which Durango and Guadalaxara were lacking.

283 (col. 40-7-F-30). "Relazione dello Stato della Congregazione e Missioni di Propaganda Fide fatto alla S. M. d'Innocenzo XI. da M. Urbano Cerri." See Propaganda, Miscellanea Varia 11.

299 (col. 34-A-9). ff. I-57. “Tromba d'Europa-Ipocrisia svelata-Spagna avvisata-Verità dichiarata." About I703. f. 52, design of France on the fleet of the Indies mentioned.

468 (col. 38-A-2I). Instructions to nuncios. f. 2 I 4 seq. Apr. I3, I6I3. To the Archbishop of Capua, destined nuncio in Spain, on the difficulty of obtaining news of the Indies.

469 (col. 38-A-25). "Discorso di Francesco Campanella circa il modo, come i Paesi Bassi volgar. detti di Fiandra si possono ridure sotto l'Ubedienza del Re di Spagna." About I6oo. Mere mention of the Indies and of sea power.

472 (col. 38-A-IO). f. 277 seq. Considerations in favor of the marriage of the princess of Spain and Prince Charles of England, sent as additional instructions to the nuncio, Massimi, in which mention is made of the greater security it would give the Indies.

475 (col. 34-D-3). ff. 68-77. Instruction and letter of Santa Croce to Cardinal Borromeo, r560-156r. News of the arrival at Lisbon of a ship from the Indies supposed to have been lost, and of the appointment of a viceroy of the Indies, June $27,156 \mathrm{I}$.

477 (col. 35-D-I I). Relation of England, by Sig. Pietro Mocenigo. I670. ff. I 49-I 53 discuss its commerce and colonies.

ff. I65-176. Relation of France, by Sig. Gio. Morosini. I670. f. I73 refers to Colbert's attention to the commerce of both the Indies.

488 (col. 35-C-I6). ff. 63-94. Relation of Spain, by Suriano. See Casanatense 2980.

491 (col. 36-G-I4). ff. I-46. Instructions to Mgr. Scotti, nuncio in France, under Urban VIII. ff. 4I-43 refer to the missions of the French Congregation of the Propaganda.

506 (col. 33-E-I2). "Registro di Lettere della Nunziatura di Spagna sotto Pontificato di Pio V. dall'anno I568 fino al I57 I, di Monsigr. Gio. Batt ${ }^{a}$ di Castagna all'ora Archivescovo di Rossano e Nunzio Apostolico à Filippo II." Vol. I. 639 ff.

pp. I39-I40. Oct. I, I 568. Discussion of a special committee held before Cardinal Spinosa on the affairs of the Western Indies, and the proposition to sell in perpetuity grants then held in commendam. 
pp. 222. Nov. 20, I568. News of demands to be made by the council for the Indies, of His Holiness, for the establishment of new churches and the grant of additional powers to the bishops.

p. 28r. Dec. 29, I568. Letter enclosing one from the conservators of the Indies.

pp. 32I-322. Feb. 9, r569. Note of conversation with the king concerning the Indies, and the proposed change of land system.

pp. 495, Aug. I ; 5I4, Aug. 23, I 569. Reasons for keeping the reports of the visitation of monasteries in Spain, rather than sending them to Rome. There were no American reports, but notice is taken of the letter as it illustrates one reason for gaps in papal archives.

507 (col. 33-E-I3). Vol. II., following 506.

pp. 70-7 I. Jan. I8, I570. Letter forwarding one from a bishop of the Indies.

p. 206. Aug. 4, I 570. Threatened attacks on the fleet of the Indies, and disastrous results which would follow.

pp. 2r4-2r5. Aug. r6, I570. General rejoicing over the safe arrival of the fleet from the Indies.

p. 218. Aug. I6. Letter forwarding one from the newly appointed viceroy of New Spain.

pp. 407-408. Apr. I, I 57I. Fear of attack on the fleet of the Indies by the Algerines and by the Huguenots.

p. 493. June 25, I57I. Notes having forwarded the bull of jubilee to the Indies.

p. 555 seq. "Istruzione lasciata da Mons. A. B. di Rossano al suo successore." [ [ $57 \mathrm{I}$ ?.]

pp. 567-569 discuss at length the relation of the nuncio to the Indies.

p. 653. The activity of the English corsairs is to be used with the king as a motive for the overthrow of Elizabeth.

p. 709. Navigation of the Indies.

577 (col. 3I-D-6). Letters and ciphers to nuncios in Spain, I7I7-I72I, with other writings on various questions pending between the courts of Rome and Spain.

Correspondence relative to the use of papal indulgences by the Spanish government and their suspension by the Pope.

ff. 42-43. Cipher to the nuncio at Madrid. Oct. r6, r717.

ff. 47-48. Cipher to the nuncio at Madrid. Oct. 5, I7 I7.

ff. 51-52. Cipher to the nuncio at Madrid. Oct. 5, I7 I7.

f. 53. Cipher to the nuncio at Madrid. Oct. I9, r7 I7.

f. 55. Cipher to the nuncio at Madrid. Oct. 26, r7r7.

ff. 59-60. Cipher to the nuncio at Madrid. Nov. 2, r7r7.

ff. 6I-62. Cipher to the nuncio at Madrid. Nov. 9, r7r7.

f. 63. Cipher to the nuncio at Madrid. Nov. 23, I7 I7.

f. 64. Cipher to the nuncio at Madrid. Nov. 30, I7 I7.

f. 82. Cipher to the nuncio at Madrid. Jan. Ir, I7r8.

ff. 264-268. "Memoriale del Re di Spagna al Papa sopra la Sospensione degl'Indulti concessi a suoi Predecessori." Translated from the Spanish.

ff. 272-289. "Risposta a Motivi addotti nel sudetta Memoriale."

ff. 326-329, 330-333. Bull of suspension.

ff. 334-345. "Istruzione per il Nunzio di Spagna sopra la Collettoria di Spogli." 
673 (col. 33-B-2). "Discorso degl'Affari di Francia.” Oct. 3, I593. f. I6. Effect of the succession in France on the safety of both the Indies.

686 (col. 35-B-I 5), f. 248 ; 705, f. 454 seq. "Ragionamento di Carlo V. Imperator al Rè Filippo suo figluolo nella Consignatione del Governo di suoi Stati e Regni." See Ottobonian 1257.

691 (col. 35-B-20). Instructions.

p. 887 seq. Instructions to the Patriarch of Alexandria, nuncio in Spain, on the propagation of the faith.

p. 888. On the danger to the Indies from Holland.

p. 890 . On the policy of the Church with regard to the Indies and the Indians.

p. 89i. On the extension of the functions of the nuncio to the Indies.

694 (col. 35-B-2.3). No. I. "Apocalipse di Olanda esposta e interpretata da Bambone." See Casanatense 1570.

699 (col. 33-D-24). f. 323 seq. "Abusi che occorrono nel Tribunale della Nuntiatura di Spagna e suoi Rimedii." Eighteenth century. I1lustrates the methods of the Spanish nuntiature.

704 (col. 35-A-4). ff. 276-28I. "Discorso Medico Politico sobra la Flaquera di la Monarquia-Carta à un Amigo." On Spain. f. 279 refers to the Indies.

851 (col. 33-A-I8). ff. 256-302. Relation of Spain by Sig. Moro, Venetian ambassador, in the time of Philip IV. Contains scattered references to the Indies.

1185 (col. 32-B-Io). "Memorie negli Affari, Negoziati, e Casi occorsi nella Corte di Roma colla Corte di Spagna, dall'anno i730 al i739." Vol. V. $550 \mathrm{ff}$. Original letters with much in cipher.

f. 402. June 10, I738. From Mgr. Valenti Gonzaga, on Spanish threats "contra la nuova Giorgia".

ff. 5I4-5I5. Aug. I I, I739. From the same, on the motives of Spain in the recent agreement with France.

f. 516. Aug. I7, I739. From the same, on the escape of the fleet.

There are also a few additional references to the war in the letters of the years 1738 and 1739 .

In addition there are certain series which may be grouped as follows:

Consistorial Acts.

42-56 (col. 4O-G-12-27). These fifteen numbers form a complete series covering the years $1498-16,73$.

384 (col. 38-E-I6). The records kept by Cardinal Gambara. I 563-I 565.

385 (col. $38-\mathrm{E}-\mathrm{I} 5$ ). The records kept by Cardinal S. Severina. I $570-$ I 574 .

683 (col. 35-B-I2). f. I29 seq. “Acta." I 5 I7-I634.

696 (col. $35-\mathrm{C}-2$ ). ff. $382-383$. Secret consistory of Feb. 12, 1674. Reference to Guadalaxara was noted.

744 (col. 33-B-I6). ff. I22, I3I, I33. Scattered acts of I5I7, I589, I720. Decrees of the Congregation of the Council.

27-29. Compendium of all decrees. I 596-I7II.

30-39. Collection of declarations and decrees. I596-I7I I.

Decrees of the Congregation of Rites.

26 (col. 4I-A-7). I605-I6I 5.

Documents relating to the Camera.

686 (col. 35-B-I 5). f. 232. State of the revenue. I677.

706 (col. $33-\mathrm{D}-2)$. State of the revenue under Benedict XIII. 
714 (col. 39-B-I3). f. I 50, Entrata, I587 ; f. I74, Entrata under Gregory XIII.

881 (col. 34-C-24). State of the revenue. I66[?].

942 (col. 34-C-I2). f. 491. State of the revenue. I724.

1168 (col.34-A-7). f. 260 . State of the revenue under Innocent XI.

1164. f. 275. State of the revenue under Innocent XIII. and Clement XII.

Relazioni. The following are so closely and illegibly written as to have rendered it impossible to exhaust them, though no reference to America appeared on a cursory examination:

242 (col. 38-A-I7). "Relazione Diario de' Viaggi di Francia e di Spagna dell' $\mathrm{Em}^{\circ}$ e Rmo Sig. G. Francisco Barberino." I632. I96 ff.

243 (col. 38-A-I8). "Relazione della Legazione in Francia del Sig. Cardinale Flavio Chigi l'anno I664, di Monsig. Ravizzi." $209 \mathrm{ff.}$

\section{BIBLIOTECA LANCISIANA.}

This library, situated on the first floor of the Ospedale di S. Spirito in the Borgo S. Spirito, is open every day, except the customary governmental holidays, from $9: 30$ to $2: 30$. The manuscript material for the modern age is almost wholly medical. The catalogue gives manuscripts and printed books in one list which is alphabetically arranged by authors and subjects. A hasty examination revealed no American material, but a systematic search might yield something on American herbs and drugs.

\section{BIBLIOTECA VALLICELIIANA. ${ }^{19}$}

The Biblioteca Vallicelliana was founded by Achilles Statius Lusitanus, and belonged to the Filippini, or priests of the Oratory of St. Philip Neri. It is housed in their former oratory next the Chiesa Nuova on the Corso Vittorio Emanuele. The approach is to the left through an interior court, up two flights, through an interior court to the right, and by a small door and office rooms, to the splendid central hall or library proper. It is at present in the charge of the Società Romana di Storia Patria. It is open Tuesdays, Thursdays, and Saturdays from to to 3 . The manuscripts are indexed alphabetically in three volumes and three appendixes, ${ }^{20}$ but there remain recent acquisitions which have not yet been assimilated to this plan. ${ }^{21}$ The collection has been, and still is, enriched by continuous accessions, and is stronger in manuscripts of the eighteenth and first half of the nineteenth centuries than any other in Rome. Particularly important are the collections made by Baronius and Bianchini. On the other hand, the great bulk of the material, at least that touching America, consists of copies rather than originals, and these copies are often extracts in the form of notes, rather than copies in mass such as are found in other Roman libraries. References to pertinent material found follow.

\footnotetext{
${ }^{10}$ Origine, Progresso e Stato della Biblioteca Vallicelliana nel I838; also, "Relazione presentata a S. E. il Ministro della Pubblica Istruzione su lo Stato della Biblioteca Vallicelliana", in Atti della R. Società Romana di Storia Patria (Rome, I885), pp. 30; Blok, Verslag, I90I, pp. 68,69; L. Pastor, Geschichte der Päpste (Freiburg, I886), III. I25. 20 "Index Alphabeticus Universalis Cognominum, Auctorum, Sanctorum, et Virorum Illustrium, Actorum, Vitarum, et Monumentorum quae in Codicibus manuscriptis Graecis et Latinis Bibliothecae Vallicellianae continentur, MDCCXLIX", and others with similar titles. These are found at a standing desk to the right of the entrance in the main room.

${ }^{21}$ See e. g., "I Manuscritti di Costantino Corvisieri", in Archivio della R. Soc. Rom. di Stor. Pat., 1908, pp. 409-430.
} 
L. 22. ff. I35-I36. Brief of Pius IV. on oil in baptism in the Western Indies. ff. I79-I8n. Relation of war in Peru. I6r5.

ff. $252-256$. Catechism adopted in 1585 by the provincial council of Mexico. This copy, or the one from which it was made, was taken May I I, 1586.

f. 283. July 27, I 592. Grant of the pallium to the Archbishop of Santo Domingo.

N. 30. f. 2. Jacomo Romallotto, "Notitiae Historicae spectantes ad Mexicanum, et Regiones adnexas", written for the Duchess Sforza. Unimportant.

N. 32. ff. I5, 24. "De Redditibus Regum Hispaniarum, qui colliguntur ex Regnis et Provinciis Europae, ac etiam ex Indiis Orientalibus et Occidentalibus."

f. I25. Instructions of Charles V. to his son Philip at the time he transferred his kingdoms to the latter. Many other copies are to be found here.

ff. 247, 267, 289. Last instructions of Philip II. to his son who became Philip III.

R. 99. ff. II7-I23. Letter of Columbus to Gabriel Sanchez. May 3, I495. Another copy is noted in R. 104, ff. I29-I 36 , but this volume could not be found.

S. 43. f. 590. From a collection of annals; note of the voyage of Martin Frobisher to North America. I577.

S. 45. From a collection of annals; many references to South America, and on $\mathrm{f}$. 167 a note of indulgences by Paul V. to the Indies.

In addition there are relations of Spain in N. 31 and N. 32; copies of consistorial acts in I. 60, I. 61, I.62, I. 63, and T. 30; and many collections of notes, historical and geographical, by Jacopo Lodiochi and others, and some of which relate to America, particularly S. 31 , S. 38 , S. $42-$ S. 45 , S. 80 , S. 81 , and T.37. Of these $S 42, S 43$, and S. 45, were examined and found to be quite unimportant. Z.15 and Z. 54 contain decrees and other material relating to the Congregation of Bishops and Regulars.

\section{BIBLIOTECA NAZIONALE CENTRALE VITTORIO EMANUELE.}

This library is housed in the Collegio Romano and the entrance is on the Via Collegio Romano. No special permission is required to use it, but an introduction is desirable. Serious students will work in the Sala Riservata to the left of the principal entrance. Here is found an exceptionally good collection of bibliographical and reference works in all languages, American publications being well represented. The hours are from 9 to 3 in the summer months, and from 9 to 6 for the remainder of the year, but are liable to change.

The manuscript collections of this library consist largely of documents brought together from 54 cloistral libraries which were closed and taken over by the state in 1873 . A subject catalogue on cards for the combined collection exists, but is not open to public use. The collection of greatest importance for the history of the United States and Canada is the Fondo Gesuitico, from the library of the Jesuit Collegio Romano. The Fondo Sessoriano from Santa Croce di Gerusalemme contains a few items of interest. Manuscript inventories for each of these collections are to be found in the Sala Riservata. These inventories are carefully made, but there is no serious attempt to establish the date and provenance of the various documents. For purposes of reference the 
documents of each collection have a separate arabic numeration, except that the last seventeen documents of the Fondo Gesuitico, 1652 to the end, have an independent Roman numeration. There is also an arabic numeration conprehending all the manuscripts in the library.

These collections do not contain the archives of the religious orders, but miscellaneous documents from many sources, many of them copies. An inventory of those in the Fondo Gesuitico relating to the history of France has been published by $M$. Georges Bourgin. ${ }^{22}$ An inventory of those in any way touching the history of the United States follows. There seem to be none relating to the history of Canada. The documents are arranged in the order of, and with, both the numerations referred to above.

\section{Fondo Gesuitico.}

150 or 2279. ff. 228-229. "Relatione et Memoria di quel che fruttano al Rè di Spagna ogni anno un anno per l'altro le Bolle delle Cruciada et altre Bolle di Chiese et Monasterii." See also Fondo Sessoriano, 493 or 1274 . Mention of the Indies.

177 or 2306. "Istruzioni Diverse." I62I-1622. Copies; ff. 69-70, instruction to the nuncio in Spain. See also Fondo Sessoriano, 381 or 1447, and many other places.

269 or 2398. ff. I2-48. "Dialogue entre un Anglais et un Français sur les richesses, les forces et le gouvernement de la Grande Bretagne." About I740. Contemporary copy.

ff. 275-308. Letter relating to the controversy between the English and Spaniards over the seizure of English vessels in America. June I5, I778.

1226 or 3355 . No. I4. Testimony relative to the marvellous cure of " Signora Anna Mattingly", in the city of Washington in the District of Columbia, Mar. IO, I 824.

1248 or 3377. No. 5. "La Felicidad de las Americas de Espagna." Seventeenth century.

1255 or 3384 . No. I. [Stephen L. Dubuisson], "Courte Notice sur la Province de la Compagnie de Jésus au Maryland pour MM. les Directeurs de l'Association pour la Propagation de la Foi ". Oct. 22, I84I. Confidential. 4 pp.

No. 2. "Viaggi di Capitano Giovanni Meares alla Costa Nord Ouest d'America negli anni I786, I787, I788, I789." Unimportant fragment. 2 pp.

No. 22. "Observationes Nonnullae PP. Revisorum Generalium circa constitutionem Innocentis XI. de Missionariis qui sunt in Indiis." 1678.

No. 24. List of missions and colleges of the Society of Jesus in the United States of America. I833. 9 pp.

No. 29. Letters and writings pertaining to the question of the location of the terrestrial paradise in America. Seventeenth century.

1259 or 3388. Giuseppe du Mouteis, S. J., "Martyrologium Societatis Gesu: Beatis Martiribus Votiva Tabella ex voto saepius renovata ab anno r605". About r631. Cart., I95 X 140. $25^{8} \mathrm{pp}$.

23 "Inventaire Analytique et Extraits des Manuscrits du Fondo Gesuitico de la Biblioteca Nazionale Vittorio Emanuele de Rome concernant l'Histoire de France", in Revue des Bibliothèques, Jan.-Feb., 1906, pp. 80. 
1293 or 3422. " Catalogo de los Nombres, Patrias, Edades, Entrados y Grados de los Sugetos de la Compania de Jhesus de esta Provincia de Nueva Espana." Mayo I9 de I766. Cart. I50 X 210. 70 pp.

1331 or 3410 . No. 2. "Catalogo de la Provincia de Mexico: Nombre, Patria, Nacimiento, Entrada en Religion, Grado, Colegio, Habitacion en el destierro, Lugar, Dia de la Muerta de los Sujetos, que existian en dia 25 de Junio de I767." 2 I ff.

No. 17. "Sacratissimo Patri Nostro Summo Pontifici Pio Nono in celebrationem octogesimi Diei Natalis, XIII Mai MDCCCLXXII, Socii Confraternitatis S. Petri in Paroecia S. Josephi, S. Ludovici in Statu Missouri, in Statibus Foederatis Americae." Original. Io ff.

1353 or 3482 . No. I. Celebration at the College of Georgetown, S. J., of the disembarkation of the Catholic pilgrims at St. Mary's, Md. May 20,1842 .

1363 or 3492. No. 3. Felice de Andreis, Register of letters written from various missions in the United States, to P. Colucci, in the years I8I6 and $1818 . \quad 3^{8} \mathrm{pp}$. See pages $177-181$.

1383 or 3512 . No. 25. "Informacion de los Daños, que reciben de la Barbaridad los Indios y del Remedio para impedirlos." Eighteenth century. I $2 \mathrm{ff}$. Mexico.

1411 and 1412 or 3540 and 3541. "Destierro de Misioneros de la America Septemtrionale Espanuola por Dn. A. S. olim Misionero de Norogachic en la Provincia de Tarahumara Alta." Cart. $210 \times$ I40. Vol. I., 520 pp. ; vol. II., 400 pp. Seventeenth century.

"Dividido en dos partes. En la primera se contiene el destierro de Cinaloa y Sonora, donde se dan varias Noticias al estado temporal, Regulamento civil y publico de los pueblos de las Misiones y particularmente de California. Al fin de esta primera parte se añadirá una breve Relacion escrito par un Misionero de Senora, en la qual paren los principales sucesos de su tiempo. En la segunda parte se contiene el destierro de los Misioneros de la Nacion Tarahumara, y se dá razon de los Indios Apaches implacables enemigos del nombre Español, y de la Resistencia vigorosa, q $q^{\mathrm{e}}$ hacian á esos, y á otros Barbaros los Indios de las Misiones en defensa de los Españoles. Le tratta tambien de los sucesos posteriores á la expulsion de los Jesuitos acerca del pretendido subjugamiento de esas Naciones enemigas y de los gravisimos daños q han sobrevenido á los Españoles de aquellas partes con otras noticias dignas de saberse." 1413 and 1414 or 3542 and 3543 . Corrections and additions to the Noticia de la California (Madrid, I757), of Fernando Consag, S. J., made by an unknown writer about 1770 , in preparation for a second edition. Three volumes bound as two. Cart. $208 \times$ I50. Vol. I., 323 pp.; vol. II., $400 \mathrm{pp}$.

1459 or 3588. No. 9. Fragment of the journal of Father Point during his sojourn in the country of the Blackfeet. July 28-Aug. 22, I 849. 4 pp. 1472 or 3601 . No. 2. "Noticias de las Conquistas Espirituales y Trabajos de las Misiones de la America Septemptrional e Imperio de Mescico." Eighteenth century. $52 \mathrm{pp}$.

No. 3. "La Causa de la Maravellosa Despoblacion en estas Naciones en la Barbaridad." Eighteenth century. $97 \mathrm{pp}$.

No. 4. "Cartas sobra las Irreflexiones del Sig. Ab. Aviz en sus Reflectiones sobre la Despoblacion de las Americas reducidas solamente a la America Septemptrional." Eighteenth century. 90 pp. 
1477 or 3606 . No. Io. Manuscript map of a portion of the United States, drawn about 1850 , and giving the dates of the foundation of the various Catholic dioceses.

1541 or 3670 . "Catalogo de los Nombres, Grados, Patrias, Nacimientos, Entrada en la Religion, con la Muerte, el Lujar, Año, Mes y Dia de los Sugetos, que compoñian la Provincia de Mexico el Dia del Arresto XXV del Mes de Junio MDCCLXXVII." A carefully collated copy made at Rome in the month of Jan., I78I. Cart. I95 X 295. I08 pp.

\section{Fondo Sessoriano.}

195-197 or 1280-1282. "Decisiones Sacrae Congregationis Concilii Tridentini." I 574-I660. Vol. I., 400 pp. ; II., 3 I8 pp. ; III., 232 pp. Volume I., ff. IO, I I, I 5, 29-3I, treats of the case of the Bishop of Paraguay, involving the rights of American bishops. Volume II., ff. I I6 and I53, and vol III., f. 246, treat of cases arising in America but not of local peculiarity.

229 or 2061. ff. 373-379. "Particulares Positiones Sacrae Congregationis, I672-1676; Indiarum decimarum." Contains an enclosure of 22 pages, with Spanish case urging the granting of this revenue to the king for the fortification of the Indies.

377 or 1554. ff. I-32. Conte Luigi Rilli Orsini, "Notizie sulla Scoperta dell'America, e Religione, Origine e Derivazione di quei Popoli, divisa in tre Ragionamenti scritti dal Conte Luigi de Rilly-Orsini, Parisio Romano e Fiorentino, Firenze l'anno della Riparazione del Genere Umano MXCCCXIX".

443 or 1274. ff. 76-I25. "Relatione del Clarissimo M. Giovanni Correro retornato Ambasciatore del Christianissimo Re di Francia, dell'anno I 568." Especially ff. 46, I I 4-I I 5.

452 or 2056. pp. 353-358. Don Alvaro de Bazan, Marques de Santa Cruz, "Carta del Marques de Sta. Cruz a Su Magd. sobra la Navigacion de la India, cū que representa sus servicios".

\section{Fondo Risorgimento.}

This collection, of which there is a good manuscript inventory, contains material relating to the whole movement for the unification of Italy. It was not examined in detail, but contains some little American material which has been used by Mr. H. Nelson Gay in an article on a diplomatic incident between the governments of the United and the Papal States.

\section{MUNICIPAL COLLECTIONS.}

In the palace of the Conservators on the Capitol are fairly important manuscript collections belonging to the municipality of Rome. These consist for the most part of the records of the commune. In addition is the recently acquired archive of the Orsini family. ${ }^{24}$ This is not yet in a condition to use, and could scarcely by any possibility contain American material.

The library of St. Cecilia was not examined.

${ }_{23}$ "Uno Screzio Diplomatico fra il Governo Pontificio e il Governo Americano e la Condotta degli Svizzeri a Perugia il 26 Giugno I859", from Archivio Storico del Risorgimento Umbro, anno III. (Perugia, 1907), pp. I I3-20I. He publishes, on pages I4I177, thirteen documents of which the originals are in number $\mathbf{7 3}$ of this collection.

Bourgin, Archives Pontificales, pp. I02-103. Its importance is here apparently exaggerated. 


\section{EMBASSIES AND RELIGIOUS INSTITUTIONS OF FOREIGN GOVERNMENTS AT ROME.}

Embassy records are the most closely guarded of all classes of public documents, and the great majority of them should be duplicated in the home archives of the governments represented. No special effort was made, therefore, to exhaustively describe this material, but such information as was obtained on these collections, actual or suppositious, relating to the United States and Canada, is here given, with a few notes on religious institutions maintained at Rome by France and Spain.

\section{ARCHIVES OF THE AMERICAN LEGATION.}

The archives of the American legation are preserved at the Embassy on the Piazza San Bernardo. Those for the mission to the present kingdom of Italy, established in 1860, are complete, and are preserved for current use in the offices of the ambassador and the first secretary. Permission to examine them can be obtained only from the Department of State at Washington. Mr. $\mathrm{H}$. Nelson Gay has made them the foundation of several interesting studies ${ }^{2}$ preparatory to his forthcoming general work on the relations of the United States and Italy. The series into which they are divided are as follows:

Instructions from the Secretary of State. April I7, I860, to May 3I, Ig08. 39 volumes.

Dispatches to the Secretary of State. Apr. I3, I86I, to June I8, I907. 27 volumes.

Notes to the Minister of Foreign Affairs. Jan. 29, I86I, to Jan. 2, I908. I5 volumes.

Notes from the Minister of Foreign Affairs and from the prefect of the palace. May 25, I86I, to Dec. 3I, I908. 24 volumes.

Letters to consuls and others. Jan. 2I, I86I, to Apr. I4, I905. I volume.

Letters from consuls and others. Jan. I, I86I, to Jan. I, I905. 2 volumes.

Register of miscellany; marriages; " mulla acta"; formulas for legislative acts; extradition of criminals; etc. I87 I-I 882. I volume.

Register of letters sent, and copies of translations forwarded, to the Department of State. I885-I889. I volume.

Record-book of letters and of publications of the Italian government received. I886-I890. I volume.

Journal of letters received from the Department of State and from the Foreign Office. I894-I904. I volume.

Newspaper clippings. July, I900, to Apr., I903. I volume.

Letter-book with copies of miscellaneous letters. I887-I890.

There are also a few volumes belonging to earlier missions to the various governments of Italy, as follows:

Sardinia. Diplomatic and other correspondence of the United States legation to Sardinia. Sept. 4, I840, to July, I86I. I3 volumes.

Passport record of the legation. I84I-I863. 2 volumes.

Journal of the legation. Apr., I848, to Aug., I850. I volume.

1 "Le Relazioni fra l'Italia e gli Stati Uniti", in Nuova Antologia, I6 Febbraio, I907, pp. I5; Relazioni fra gli Stati Uniti e l'Italia negli anni 1847-I87I, pt. I. (Turin, I907, pp. 94). 
Naples. Letter-book of legation. July, I845, to Aug. 3, I853.

Papal States. Letter-book of the legation to the Holy See. Dec. Io, I 858 , to June 4 , I86I.

There have long been also at the embassy sixteen packing-cases of materials sent to the legation at the time of the unification of Italy, from the closed legations to the several Italian states. It was long supposed that these contained valuable material, but on being opened there was found only one volume of archives, a passport-book. Of what legation, and for what years, time did not suffice to discover.

\section{FRENCH EMBASSY TO THE HOLY SEE.}

The archives of the French embassy to the Holy See contain no documents earlier than the beginning of the eighteenth century. It seems hardly probable, therefore, that they contain anything relative to American history.

They are at present in the apartments of the late embassy in the Farnese palace, and have been inventoried by the members of St. Louis des Français; with the closing of the embassy all means of access at Rome have disappeared; but it seems probable that they will be transferred to Paris, and placed under the rules which govern the national archives there.

\section{SPANISH EMBASSY TO THE HOLY SEE.}

This archive is the oldest and the richest of those of the embassies at Rome. Since I647 the Spanish ambassador has occupied the palace from which the Piazza di Spagna takes its name, and the collection has been spared removals, so destructive of material. ${ }^{2}$ The scholarly archivist, Professor Santa Maria, has been for many years at work upon an index, which renders the work of investigation comparatively light. Access, of course, is by special permission only, and is permitted only in the case of special classes of documents.

The following references to material relating to American history are probably not all bearing on that subject, but are all that were apparent on the hasty examination possible. It was to be expected that more records of a routine character, as of nominations of bishops, would be found here; but as a matter of fact there seem to be only those of an exceptional nature, as of the erection of new sees. Note is made of those taken from the index, and of those actually examined. All these documents should be found, in original or in copy, in the archives of Spain. As is the case with nearly all diplomatic records of the period, they consist of loose sheets, preserved in covers; doubtless those of an earlier period are in registers, and bound volumes. The references are arranged in chronological order.

R. C. May I4 [I680?]. L. 439, no. 2. Prohibition against the entrance of members of religious orders in the Indies into trade and commerce.

End of seventeenth century. L. 439, no. 21 . On the ecclesiastical subsidy for the defense of America. Many documents.

R. C. Apr. I5, I689. On the funeral office for soldiers dead in the Indies.

Despachos 1717. f. Igo. On the appointment of an auxiliary bishop for Florida.

Despachos 1766. ff. 202, 204, 216, 223. Facoltà to bishops for dispensations of the second grade.

Despachos 1768. On bull issued to auxiliary bishop of Cuba.

\footnotetext{
"Ramón de Santa Maria, La Fiesta de la Concepción, en la Antigua Iglesia de Santiago y San Ildefonso de los Españoles en Roma, el año I7I5 (Roma, I908, pp. II3). See also an article by the same author in the Römische Quartalschrift, XIII. 368-372.
} 
Despachos 1770 , f. $249 ; 1771$, f. I8I ; 1772, f. 46. Grants of facoltà for the colonies.

Despachos 1774. f. 72. Facoltà for the administration of the sacrament of confirmation in Florida.

Despachos 1778. ff. I79, 214. Same.

Despachos 1779. ff. $74,76,84$. This bundle was examined. It bore the number L. 115. It contains, in the order given: (a) a letter of May I3, I779, from the papal secretary of state to the Spanish ambassador on the expedition of a bull creating a new diocese of California, Sonora, and Sinaloa in the northern portion of New Spain, with a note of the expense of the same; (b) a letter of May II, I779, from the Spanish ambassador to Floridablanca on the appointment of three custodians for the Minor Franciscans of the Pueblo de Anepe, of the city of Chiquagua, and of California ; and (c) a letter of May I3, I779, from the Spanish ambassador to Floridablanca, on the receipt of the abovementioned bull.

Despachos 1779. ff. I $5 \mathrm{I}, \mathrm{I} 56$. On the administration of the sacrament of confirmation in Louisiana.

Despachos 1781. f. 64. This bundle was examined. It bore the number L. 117 . It contains : a letter of Aug. 7, I78I, from Floridablanca to the Spanish ambassador, containing news of the fall of Pensacola; and one of Aug. 30, I78I, from the latter to the former, with congratulations on that event.

Despachos 1781. No. I2. A translation of a history of California.

Despachos 1791. f. 3. Facolta for the administration of the sacrament of confirmation in Florida.

Despachos 1791. f. 44. Sending of English alumni of the college of Salamanca to Louisiana.

Despachos 1793. This bundle was examined. It bore the number L. 312. f. 35 contains the following documents on the dismemberment of the provinces of Louisiana and Florida from the jurisdiction of the bishop of Havana, and the erection of a new bishopric at New Orleans: (a) letter of May I, I793, from the Spanish ambassador to his secretary of state, with note of the charges involved; (b) letter of Apr. 26, I793, from the secretary of the consistory to the Spanish ambassador, on the approval of the proposition by the Pope; (c) letter of Mar. II, I793, from the Spanish ambassador to S. Dr. Joseph Nicolas de Azara; (d) "Instruccion á que deberá arreglarse el Ministro de S. M. C. en Corte de Roma para impetrar de la Silla Apostolica la Aprobacion Pontificia de la nuova ereccion resuelta de Obispado en las Provincias de la Luisiana y Florida, segregandolas del de la Havana, á que hasta ahora hán estato anexas".

\section{ENGLISH DIPLOMATIC ARCHIVES.}

Only for very short periods did England maintain a representative near the Holy See, and such archives as may have existed are not at Rome. Business between the two governments was conducted through a consul-general, who was often forced to exercise diplomatic functions. The records of this office can have nothing of interest for the United States, and probably nothing for Canada. Access to these records was not obtained, and I am not certain as to whether they are at the present embassy to the kingdom of Italy, or at the consulate. 
Archives of both these offices subsequent to the incorporation of Rome with the kingdom of Italy are, of course, organic archives of Great Britain, but probably contain little of significance, and are not accessible. No attempt was made to locate the archives of the former English embassies to the various Italian governments outside Rome.

\section{ARCHIVO DE LOS REALES ESTABLECIMIENTOS ESPAÑNOLES EN ROMA.}

This archive is in the church of Santiago y San Ildefonso de los Españoles; it was not visited. It is well ordered and has been used by Professor Santa Maria for his La Fiesta de la Concepción. While the material is nearly all local in character, something might be found of interest for Spanish-American biography.

\section{ST. LOUIS DES FRANÇAIS.}

The archives of this institution consist only of the house accounts and contain nothing relative to America. 


\section{PRIVATE LIBRARIES IN ROME.}

\section{ARCHIVIO CAETANI. ${ }^{1}$}

The Prince of Teano, present head of the family of Caetani, whose historical work is so well known, and whose knowledge of the collection is complete, graciously gave permission to state on his authority, that it contains no reference whatever to America, North or South.

\section{CHIGI LIBRARY.}

The Chigi library in the Chigi palace at the corner of the Corso and the Piazza Colonna is the most important of the libraries at Rome still remaining in private hands. Fabio Chigi, Alexander VII., was Pope from I655 to I667, at the time when the interest in collection of manuscripts and particularly of archive material was at its height; and furnished his family library with copies of nearly all the important records of his reign, and with many originals, particularly of his own correspondence. These have been preserved, added to, and ordered with the utmost care until at present the library consists of about 16,000 printed and 3000 manuscript volumes in the best condition. The library was regularly accessible to students with proper introduction, on Thursdays from Io to I2, until a few years ago; since then it has been seldom opened. It is still, however, possible to say something of its contents. Indici 200-209, and 218, in the Archivio Vaticano, ${ }^{2}$ give accounts of it, and Gachard in his report to the Royal Commission of History of Belgium inventories the diplomatic material. ${ }^{3}$ The library itself contains a catalogue of the date I764 with two supplements. ${ }^{4}$

The most important material is the diplomatic, which is inventoried by Gachard, who does not, however, discuss the extent to which it consists of originals and of copies, and how far it is duplicated in the Vatican and other libraries. So far as could be judged from the inventories in the Vatican the library contains no relations not duplicated elsewhere in Rome, but contains

${ }^{1}$ Notizie dell'Archivio Caetani scritti da G. B. Carinci, Archivista della famiglia Caetani (Rome, I868, pp. 7). Hinojosa, Los Despachos, pp. 35I-352, refers to a volume of correspondence between the Patriarch of Alexandria and the secretary of state, necessary to complement the Nunziatura di Spagna.

200. "Indice delle Materie che si contengono in diversi Tomi di MSSti in folio essistenti nella Libraria dell'Eccmo Sig. Principe Chigi."

201. "Nominum et Cognominum rerumque omnium quae in Codicibus Manuscriptis continentur Index Generalis à Vincentio Mannaiono ordinatus et conscriptus."

202. "Index brevis Auctorum", by same hand.

203. "Inventarium Manuscriptorum."

204. Duplicate of 205.

205. "Inventario de Manuscritti della fel. memoria dell'Em. Signore Cardinale Flavio Chigi, che si ritrovano nella Biblioteca dell'Eccma Casa Chigi."

207. "Index Manuscripturum quae in Bibliotheca Chisiano asservantur."

209. Fragment of a bibliography relating to books in the Chigi library on Spain and Naples.

218. pp. Io ff. "Inventario de Manuscritti della fel. mem. dell'Emo Sigr Cardinale Sigismondo Chigi esistenti nella Libraria de Manuscritti di Casa Chigi."

${ }^{3}$ Bulletin de la Commission Royale d'Histoire, third series, X. 219-224, "La Bibliothèque des Princes Chigi, à Rome".

"Ibid. The description is, "Codicum Manuscriptorum qui in Bibliotheca Chigiana Romae adservantur Catalogus, cui praemittitur numeri antiqui cum recentiori Consensus ". This is alphabetically arranged by names of authors and subjects; it was by C. Assemani. 
much original correspondence for the period during which Cardinal Fabio Chigi, later pope, was in public life. The inventory of Gachard classes the material in seven groups. The numbers of possible interest for the history of North America under each are as follows:

Group I. Letters, instructions, etc., of the sixteenth century.

Q, I., 6. Instructions, etc., of Sixtus IV., Paul III., and Julius III.

Q, I., 1. Instructions. I 550-I $55 \mathrm{I}$.

L, III., 61. Letters addressed to the cardinal sub-datario. I562-I585.

Q, I., 11. Instructions of the nuncio in Spain. I58r.

J, III., 74. Letters of Sixtus V. to princes. I 585-I 59 I.

M, II., 43-47, 50-54. Ciphers to nuncios. I 586-I 590.

M, II., 55. Ciphers to Gregory XIV.

M, II., 56. Key to above ciphers.

M, III., 58-60,62-72. Letters of nuncios to Cardinal Aldobrandini. I $592-1605$.

M, I., 11. Letters to Cardinal Aldobrandini. I594.

M, III., 57. Letter of Agucchio, etc., to the secretary of briefs. I597I599.

Q, I., 17. Instructions by Agucchio, etc.

Group II. Letters, instructions, relations, etc., under Paul V. I605-I62I.

M, III., 75. Ciphers from nuncios. I605-I606.

Q, III., 77. Ciphers to divers persons. I605-1606.

Q, I., 16. Correspondence relating to France. I605-I607.

M, I., 15-16. Letters to Cardinal Borghese. I607-16ı6.

J, III., 76. Letters of Paul V. to divers persons. I6IO-I620.

J, III., 75. Miscellany. I604-I62I.

Group III. Letters, instructions, relations, etc., under Urban VIII. I623I644.

M, I., 21. From Agucchio to Corsini, nuncio in France. I62I-I629.

A, I., 19-20. Alexander VII. to Cardinal Barberini.

L, III., 56-57. Letters to nuncios. I634-I642.

M, I., 24. Letters to divers persons. I642.

R, I., 16. Letters from Flanders. I642-I6 62.

J, III., 83-84. Instructions and other writings of Urban VIII.

Group IV. Correspondence of Fabio Chigi (afterward Pope Alexander VII.) while nuncio in Cologne.

Q, II., 46-49. Miscellany.

Group V. Material relating to the peace of Münster, of which none seemed likely to refer to America.

Group VI. Material relating to the pontificate of Alexander VII. I655$\mathrm{I} 667$.

C, III., 75-78; D, I., 1-11. Cipher correspondence with nuncios. I655I667.

C, III., 62. Letters of cardinals, etc., to Alexander VII. I655-I666.

F, I., 4-41. Letters from divers persons to Cardinal Mario Chigi. I6561662.

E, I., 15-50; E, II., 31-35. Ciphers to divers persons.

D, I., 12. Ciphers to nuncios. I658-I667.

E, III., 64. Letters of Cardinal Mario Chigi to divers persons.

$P, I ., 15$. Ciphers to nuncios. I659-I667.

N, II., 27-28. Ciphered correspondence with nuncios in Spain.

E, II., 36-38. Voyage of Flavio Chigi to France. 
O, III., 34. News-letters and political miscellany. I653-1667.

E, II., 57. Letters to Cardinal Sigismondo Chigi.

A, I., 33. Various letters of Alexander VII.

Group VII. Letters, instructions, relations, etc., of miscellaneous dates.

Q, I., 13-14. Instructions. I $550-1607$.

N, I., 7. Letters and ciphers from nuncios. I60o-I639.

J, III., 80. Instructions and relations under Gregory XV.

J, I., 18. Letters, relations, instructions, etc. I625-I660.

O, I., 1-13. Miscellaneous political material. I625-1656.

M, I., 27-29; M, II., 30-31. Letters of Cardinal Mazarin. I646-I650.

A, I., 8. Letters of Alexander VII. I65I-I652.

B, I., 7-8. Letters of Alexander VII. while cardinal.

L, III., 58; Q, I., 12. Miscellany.

$\mathrm{Q}, \mathrm{I} ., 21$. Miscellaneous instructions to nuncios.

In addition there were noted in indice 201, of the library of the house of Chigi, number 744, "Memoriali, Lettere e Scritture diverse appartenenti alla Congregatione de Propaganda Fide". Also in indice 205, of the manuscripts of Cardinal Flavio Chigi, arm. C, ord. 5, no. 646, "Propaganda Fide Congregazioni Varie". Also in indice 218, of the manuscripts of Cardinal Sigismondo Chigi, numbers 1-3, consistorial acts, I 563-I 565, I 575-I 595, and I 566-I 585; 12, decrees of the Congregation of Ecclesiastical Immunity, 1604-1644; 13, decrees of the Congregation of Bishops and Regulars; 28-30, miscellaneous political material; 35-37, 40, miscellaneous instructions and relations; 50, news-letters, I633-165I ; 51, news-letters of I 676 .

\section{ARCHIVIO DORIA-PAMPHILI.}

The archivio of the Doria-Pamphili family is in the palace of the same name, on the Corso. It contains papers of the Doria family brought from Genoa, of Pope Innocent X. (Pamphili, I649-1655). and many cardinals. The most important portion is that brought from Genoa, and belonging to the first half of the sixteenth century, when the family was closely associated with Spain. This consists of about 300 bundles, each with a list of the writers whose letters are included. These papers were not examined, but might contain a few items on America. ${ }^{5}$ Access is not encouraged.

\section{PRIVATE LIBARIES NOT INVESTIGATED.}

It is impossible to give a complete list of the private libraries in Rome containing archive and manuscript material, but notes on a few are added." To judge from the many such libraries examined, it seems probable that, of ordinary manuscripts, there would be in all these libraries but comparatively few not copies of those found elsewhere. Of archives, they probably contain much for family and local history, and, in the case of ecclesiastical families, many relating to the Church; though most of these, also, are likely to be copies, or originals of which copies are known. It is not likely that altogether they would furnish half a dozen fresh items for American history.

${ }^{8}$ Many copies taken from this archivio by W. H. Bliss are in the library of the Massachusetts Historical Society.

- To my mind most of the accuunts of such libraries. whether general or special, seem to exaggerate their importance. There are undoubtedly many such libraries not yet brought to light, but a general card-catalogue of the contents of all of them would show an amazing amuunt of duplication. The best general account is by Dr. Ludwig Pastor, "Le Biblioteche Private e specialmente quelle delle Famiglie Principesche di Roma", in Atti del Congresso Internazionale di Scienze Storiche (Rome, I903), III. I23-I30. 
Aldobrandini. Clement VIII. of this family was pope from I592 to 1605 , and Cardinal Aldobrandini was active for many subsequent years. Their archives are partly in the possession of the family, partly in the Borghese collection, and are extensive.

Colonna. ${ }^{8}$ Permanently connected with the Church, the interests of the Colonna family have rarely strayed beyond the Mediterranean, and their archives, the most extensive princely archives in Rome, are not apt to be useful for American history. In the Barberini library, 3166, folios $45^{-64}$, is a catalogue of all the books in Latin script in their library.

This list, not a very trustworthy one, contained no relevant items.

Boncompagni. This library, formed by D. Baldassarre Boncompagni, and of which a description by Enrico Narducci was published in I892 (pp. viii, 520 ), is chiefly composed of manuscripts of a mathematical character. The following items of possible interest were, however, noted:

118. ff. 2-6. Gargani, "Notizie intorno alla Famiglia Toscanelli ".

247. "Instruttioni data à nome della Santità di Nostro Signore del Cardinale

Ludovisi Nipote à i Nuntii e Ministri." I62I-I623. 940 pp.

Boncompagni-Ludovisi. Ugo Boncompagni was pope as Gregory XIII. from I 572 to I585, and Alessandro Ludovisi, as Gregory XV., from I62 I to I625. The two families subsequently united and their archives are now in the Palazzo Piombino, 39 Via Scrofa. They are opened to scholars properly introduced.

Gay. Mr. H. Nelson Gay has collected in the Orsini palace an important body of material for the history of the Risorgimento, among which are manuscripts bearing on the relations between the United States and Italy during that period.

Odescalchi. Innocent XI. of this family was pope from I676 to I689. Archives are in the possession of the family at their palace on the Piazza SS. Apostoli. Innocent XI. was much interested in American affairs, especially in relation to Spain.

Rospigliosi. ${ }^{10}$ Clement IX. of this family was pope from $\mathrm{I} 667$ to 1669. Archives are in the possession of the family in their palace on the Quirinal hill. Clement IX., before his elevation, was the member of the Propaganda specially charged with the affairs of the Spanish empire.

Santa Croce. This family was active in the diplomacy of the papacy in the last half of the sixteenth and the first part of the seventeenth century. I do not know where their archives are, but Pastor in 1903 reported some in the possession of the family. The same is true of the Sforza Cesarini ${ }^{11}$ and the $S p a d a^{12}$ archives, and the Azzolini and Corvisieri collections, ${ }^{13}$ which would, perhaps, be a shade less likely to contain American material.

Tolomei. This collection is inventoried in indice 218 of the Vatican archives, which made plain the absence of American material.

\footnotetext{
${ }^{7}$ See Bulletin de la Commission Rovale d'Histoire, LXXVIII. 59.

${ }^{8} \mathrm{P}$. Kehr, in Römische Quartalschrift, XV. I75-176.

${ }^{-}$These archives yielded nothing for P. O. von Törne's life of Cardinal Como, secretary of state under Gregory XIII., and probably have nothing for American history. Some material on the foundation of the Propaganda might be found.

${ }^{10}$ These have been used for historical work by Ch. Terlinden, Le Pape Clément IX. et la Guerre de Candie d'après les Archives Secrètes du Saint Siège (Louvain-Paris, 1904).

${ }_{11}^{11}$ Kehr, Papsturkunden in Rom (Göttingen, I90I), pp. 247-248.

${ }_{12}$ Apparently not the collection referred to on page $7 \mathrm{I}$.

${ }^{13} \mathrm{Kehr}$, Papsturkunden in Rom, pp. 247-248. The latter is now in the Biblioteca Vallicelliana; Arch. della R. Soc. Rom. di Stor. Pat., 1908, pp. 409-430.
} 


\section{NAPLES.}

The manuscript collections of Naples, though less important, are almost as numerous as those of Rome. Professor Kehr in his Papsturkunden in la Cava und. Neapel, mentions besides the Archivio di Stato, the archives Capitolare, della Curia Arcivescovale, Ruffo, Brancacciano, Municipale; the libraries Nazionale, San Martino, Brancacciana, della R. Società Napoletana di Storia Patria, dei Girolamini, and the Museo Filangieri. ${ }^{1}$ Of these the Archivio di Stato only was used. Of the others Professor Blok briefly describes the libraries Nazionale and Brancacciana. ${ }^{2}$ Enrico Mandarini has published a description of the codices of manuscripts of the Biblioteca Oratoria di Napoli on the Via del Duomo, of which cod. CCIV., " Discorso o Trattato Storico-politico degli Stati d'Europa, I570-I 573", might conceivably contain mention of America. ${ }^{3}$ Carlo Padiglione has described the manuscripts of the museum of the Certosa di S. Martino," among which he mentions the "Relazione e Giornale del Viaggio dell'Ecc. Sig. Principe di Santo Buono Vicerè del Perù con li vasselli che partirono dalla Bahia di Cadice il I4 Novembre I7I5 sino a Cartagena dell'Indie Occidentali ". Nothing more nearly relating to America appears, although there are various pieces relating to Oriental missions. There is also a printed catalogue ${ }^{\circ}$ of the manuscripts of the library of Camillo Minieri Riccio, of which I do not know the present location, which mentions, "Respuesta Fiscal, que en Vista del IV. Concilio Provincial de Mexico dio en su Aprovacion Dn. Pedro de Pirina, Mago Fiscal del Peru, en Agosto I774 ".? Printed catalogues of other collections have been examined which revealed no American material.

\section{ARCHIVIO DI STATO.}

The archives are commodiously hidden in the convent building behind the church of San Severino. The entrance is by an unassuming door on the Vico San Severino, marked by an iron sign. One passes two courts to the left hand and enters a third to the right, at the extreme corner of which is the Sala di Studio, where further directions may be obtained. The archives are open from Io to 3 with exception of the usual holidays and half holidays. The administration is extremely courteous, and the accommodations for study are convenient. The usual work-room for students is the Sala Diplomatica on the second floor. The accounts of the archives by Trinchera ${ }^{\circ}$ and Capasso

\footnotetext{
${ }^{1}$ In Nachrichten der K. Gesellschaft der Wissenschaften zu Göttingen, 1900, heft 2, pp. 207-219.

${ }^{2}$ Verslag van Onderzoekingen naar Archivalia in Italië, I901, pp. 75-77.

-I Codici Manuscritti della Biblioteca Oratoria di Napoli (Naples and Rome, I897, pp. xviii, 4OI). This refers to an index of the manuscripts of the library, not all of which are in codices and described in this publication. This library is not in the possession of the government.

${ }^{4}$ La Biblioteca del Museo Nazionale nella Certosa di S. Martino in Napoli ed $i$ suoi Manuscritti (Naples, 1876, pp. xcii, 805). This is the library of the "clerici regolari Teatini".

${ }^{5}$ No. 332, p. $345 ; 31$ ff. A manuscript of the eighteenth century.

${ }^{6}$ Naples, I868. Three vols., buund as two; pp. 310, I60.

${ }^{7}$ See vol. III.. no. 32 ; pp. 144 .

${ }^{8}$ Alfonso Miola, Notizie di Manuscritti Neolatine ... Francese, Provenzale, Spagnuoli, Catalane e Portoghese della Biblinteca Nazionale (Naples, I895, p. IOI). 689).

${ }^{\circ}$ Francesco Trinchera, Degli Archivi Napoletani, Relazione (Naples, I872, pp. viii,
} 
give a general idea of their contents. ${ }^{10}$ The collection is much larger than that in any depository of other national archives in Italy, and forms, in fact, one of the largest masses of manuscript material in the world. In addition to the archives of the kingdom of Naples, which are well preserved, are those of many suppressed monasteries and many documents not properly archives of Naples or Neapolitan institutions. These are stored and indexed separately and their accessibility varies greatly. On the whole not as much difficulty was encountered as I had been led to expect.

\section{ARCHIVIO FARNESIANO. ${ }^{11}$}

The Farnese archives were collected at Parma from many places. A large portion was brought from Brussels by Margaret of Austria, and others from Rome. In 1734 the greater portion of this collection was removed to Naples, ${ }^{12}$ where since I868 it has occupied a room to itself in the Archivio di Stato. The manuscripts on paper, which are the only ones of possible interest to the subject, are inventoried in indice 63, which has been corrected to date. In addition to certain volumes separately cited and relating mostly to local Neapolitan affairs, ${ }^{13}$ the collection consists of a main body of 1842 fasci or bundles and 9 additional fasci. The interests of the Farnese family were widely extended throughout Europe during the second and third quarters of the sixteenth century. Alexander Farnese was pope as Paul III. from I 534 to I 55 O. In I 545 the duchy of Parma was acquired by Pier Luigi Farnese, whose son married Margaret of Austria, the daughter of Charles $V$. and for many years vicereine of the Low Countries. These wide-spread connections are reflected in the archives, which also illustrate the diminished range of family influence after the death of Duke Alexander in 1592.

The best ordered part of the archives consists of a portion of the papers having relation to Rome, which have been separated and classed. ${ }^{14}$ These are arranged in nine fasci, within which the papers of a single year are found in separate folders. Of these I., the papers of Pier Luigi, I53O-I547; and of II., which contains those of Pasino dei Giusti, I55I-I560, the years I55I, I 558-I 560, were examined without result. The only other fasce which might contain American material is VI., news-letters, I 526-I 593.

In the main archive the fasci are roughly divided into groups by the countries to which they chiefly refer, but this classification can not be wholly relied upon. Each fasce is numbered, and some very brief description of its contents is given, with the extreme dates covered. These notes are often corrected and enlarged in other hands, not as a result of a re-examination of the whole, but as scholars have from time to time contributed something in passing.

\footnotetext{
${ }^{10}$ B. Capasso, L'Archivio di Stato in Napoli fino a tutto il 1808.

${ }^{11}$ In addition to the references above, Nicola Barone, Notizie risguardanti l'Archivuo Farnesiano ora conservato nell' Archivio di Stato in Napoli (Naples, 1898, pp. iv, 24).

${ }^{12}$ Bonaini, Relazione sugli Archivi delle Provinzie dell'Emilia (Florence, 186r), pp. I59 seq.

"Elenco delle Rubriche diverse preesistenti in Archivio (Farnesiano) e non riportate nell'ultimo Inventario di Consegna delle Carte Farnesiane." Dr. Giulio Coggiola, "Proposta di Reintegrazione nella Sede Naturale dei Fondi Farnesiani, degli Archivi di Napoli e di Parma", in Rivista delle Biblioteche e degli Archivi, XIV. 78 (Prato, I903, pp. II); Ronchini, "Relazione sull'Archivio di Parma", in Archivio Storico Italiano, V. I82-234 (1867).

14 "Nell'ordinamento delle scritture farnesiane rubrica col titolo Roma, si commincirono a riunire i carteggi di Pier Luigi Farnese e di coloro che tennero corrispondenza col Card. Alessandro, si constituirono a nuovi fascie."
} 
It is necessary, in spite of the inventory, to run through almost the entire collection to exhaust a subject, as each fasce contains letters from a great variety of persons and extends over many years, often more than a century. Within the fasce, however, the letters of a single writer are usually together. The extreme dates of the collection are I27I and I734. The documents of Margaret of Austria might contain something on America, but the ones most likely to be of interest are those of Cardinal Alexander Farnese, vice-chancellor under Paul III., which contain much properly belonging to the papal nunciature, particularly between I 54I and I544; and much intimate correspondence with nuncios and other papal officers. The bulk of this material relates to the Council of Trent, but references to America may exist. Hinojosa ${ }^{15}$ states that numbers $688,690,696,708,710,711,712,713,716$, $717,721,723,725,728,729,731,746,748,753,756$, and 955 , contain, in addition to other material, letters properly belonging to the nunciature of Spain. Of these $688,690,696,753$, and 756 were examined without result. In addition 689,696 bis, 715, 732, and 750 were examined without result. A list of the fasci remaining, which may possibly contain American material, with the exception of those just cited as mentioned by Hinojosa, follows. Very useful in examining them are the analytical indexes which have been or are being prepared. Of these eleven have been finished and a twelfth is in preparation. Number I. is for Rome, containing an alphabetical index of names of correspondents, with date and place of the letters; a chronological index; and an index of places from which letters are written. Series II., number I, inventories fully the material in each fasce belonging to the Spanish group; number 2 does the same for "Milano, Fiandra e Spagna, Parma e Spagna ". The remaining numbers treat the material in other groups of fasci, upon one or the other, or a combination of these systems, as follows: (3) "Parma e Toscana"; (4) "Genova, Siena, Toscana"; (5) Vienna; (6) "Venezia, Lione, Alta Italia, Boemia, Portogallo"; (7) "Francia "; (8) "Londra" ; (9) "Parma "; ( Io) "Parma"; (I I) "Parma". " These recent and admirably prepared aids were not used, owing to the lack of time, and to the fact that, as references to American topics would be incidental, the giving of names, dates, and places would still leave so much open to examination that little would be gained. For such items, a dogged examination of one fasce after another is probably still necessary.

1. Poggio to Ott. Farnese. I 539-I 543.

2. Ardinghelli to Margaret, etc. I $557-$ I 564 .

5, 6. Spanish ministers to Margaret. I 558-I 563 , I $586-$ I 599.

7. Peter Aldobrandini to members of the Farnese family from Lisbon, Madrid, and Flanders. I 567 - I 585.

11. Franc. Guillamas to Ott. Farnese, from Flanders. I 580-I 588.

14. Same to same, from Madrid. I 589-I 599.

75. Carteggio of Margaret on affairs of Spain and Flanders. I550I 584 .

${ }^{15}$ Los Despachos, pp. 77-78.

${ }^{16}$ Alfred Cauchie, and L. Vander Essen, "Les Archives Farnésiennes de Naples au point de vue des Pays-Bas", in Annales du XXe Congrès Archéologique et Historique de Gand, I907 (Ghent, I907, p. 24); A. Cauchie, "Inventaires des Archives de Marguerite de Parme .... à Naples", in Bulletin de la Commission Royale d'Histoire, LXXVI. 6r-r35 (Brussels, I907). The Royal Historical Commission of Belgium will shortly publish an Inventaire des Archives Farnésiennes de Naples, by MM. Cauchie and Vander Essen. 
76. Divers Spaniards to Margaret. I 559-I 580.

185. Correspondence with the king, queen, and princes of France. I 529I 595 .

186. Correspondence with Farnesian representative in Paris. I562I 589 .

398. Letters of Farnese family and popes, without dates.

399. Alexander Farnese to Margaret. I 539-I569.

429. Relations of affairs of England, particularly while Cardinal Alexander Farnese was protector.

687-956. Writings pertaining to Rome, of which the following only may be of use.

691. Letters of princes to Paul III. I $534^{-\mathrm{I}} 55^{\circ}$.

692. Letters of nuncios, etc. I $535^{-}$I 560.

695. Letters of divers persons, chiefly relating to the Council of Trent.

699. Cardinal Alexander Farnese to the Duke. I536-I580.

700, 701. Divers letters and draughts to Cardinal Alexander. I536I 584 .

702. Letters of nuncios. I $536-$ I 584 .

703. Letters of Farnesian agents in Paris, etc. 1536-I 584 .

705. Cardinal Alexander to Margaret. I 536-I587.

706. News-letters. I536-I 593 .

707. Correspondence of Cardinal Alexander with nuncios. I537-I593.

714. The Duke, princes, Margaret, etc., to Cardinal Alexander. I533I 573 .

718, 719. Pier Luigi to Cardinal Alexander, etc. I $537-\mathrm{I} 584$.

720. Cardinal Farnese to the Duke. I 537-I 584.

722. Relations of nuncios, etc. I $537-1584$.

726. Correspondence of divers persons with Cardinal Alexander, the Duke, etc. I 537-I627.

737. Letters of divers kings, etc. I $537-1584$.

741-743. Correspondence of cardinals with Cardinal Alexander and the Duke. I537-I 588, I 537-I 59I, I 539-I 594.

744. Letters of the Marquis of Pescara on affairs of Spain, France, Portugal, and Germany. I 539-I 568.

747. Correspondence of Cardinal Alexander, chiefly from the Council of Trent. I540-I 568.

752. Correspondence of ambassadors, etc., with Cardinal Farnese. I 54 II 580 .

757. Pier Luigi to Alexander his son. I $547-1575$.

759. Letters of divers royal persons, etc. I $544-$ I 585 .

765. Cardinal Alexander from Madrid, Paris, etc. I $550-1562 .{ }^{27}$

767. Letters of ambassadors of Spain, France, etc. I550-I592.

773. Correspondence of Cardinal Rusticucci with Margaret. I5571585 .

797. Correspondence of divers cardinals with Cardinal Alexander.

801. News-letters from Naples, England, etc. I 570-I7 I I.

861. Pontifical briefs, secret instructions, etc. I60I-I725.

1324. Miscellany of France, etc. I537-I700.

1402, 1403. News-letters, copies of gazettes, etc. I 540-I 580, I 550-I 592.

${ }^{17}$ The inventory here refers to Corr. Aff. Pol., no. 12488. 
$1404,1405,1410,1418,1420$. News-letters, etc. I567-I 598, I $568-1585$, I6I3-1633, I700-1706, I 7 I I-I734.

1666. Correspondence of Margaret with the Archbishop of Rossano, etc. I 579 -I 595 .

1707-1711. Correspondence of Duke Alexander with the nuncio of Cologne concerning England. I587-I59I.

\section{AFFARI ESTERI.}

With the improbable exception that there may be a few documents relative to the subject among the manuscripts of the suppressed monasteries, the only other collection of interest to the student of American history is that of the Affari Esteri. This begins in $\mathrm{r} 734$, with the separation of the kingdom of Naples from Spain, and ends in I860, with its absorption into that of Italy. A brief schedule of material is found in Trinchera, table XXI., and there is an inventory dated 1895 .

The material relating to the legations consists of 1420 fasci and 794 volumes. The fasci are unusually large, containing each two fasci of an older arrangement, when the numeration was by countries, instead of, as now, continuous. They have on the average 2000 folios, and contain, without careful sorting, letters to ministers in foreign countries, letters home from these ministers, and letters of foreign ministers of state to Neapolitan envoys resident at their courts.

There are six volumes of correspondence with the United States of America. Volumes 4-6 contain that of the American legation in Naples, for the years I8I6-I824, I833-I852, I855-I860, respectively; volumes 1-3, that of the Neapolitan legation in America, I847-I852, I855-1856, and I857-I860. These were not examined, as they fall within the period to which access can be obtained only by special permission.

The correspondence with England is contained, as to the English legation in Naples, in fasci 588-672, covering the years I733-1860; as to that of Naples in England, in fasci 673-704, covering the years I734-I798, and I8I5-I860. Of these the following were examined:

617. Inghilterra, no. 21.

Sept. I2, 28, I762. Neapolitan jealousy of the part played by Turin in the negotiations.

Oct. 29, Nov. 12, I762. On the cession of Florida or of Porto Rico.

Nov. 29, I762. On the treaty closing the Seven Years' War: " un vasto tratto di Paese, quale puo dirsi non conosciuto da chi si cede, nè da chi sarà posseduto per l'avvenire".

621. In ghilterra, no. 29. I772. In this, in a letter of July $24, \mathrm{I} 772$, the Gaspee affair is referred to.

Aug. 7, I772. References to the Ohio Company.

Aug. I4. A full plan of the Ohio project with annotations.

Inghilterra, no. 30. I772-I774, with some letters of 1783 . The letters in this bundle are not chronologically arranged. They are referred to in the order of their occurrence. The Neapolitan minister, Count Michele Pignatelli, seems to have followed the American Revolution with unusual interest, and with assiduity. While his letters are in a way merely news-letters, they have a higher value than might be expected. At the same time three-quarters of their material is such as could be found in any gazette, copies of many of which are bound with them. 
Nov. II, I774 (letter no. 27I). This is the first containing American news; after this date it forms the bulk of the material. After mentioning the Articles of Association, he writes: "In questi riscontri saran confermati, siccome agevolmente de credersi, è presta la gran risoluzione, e s'ella serà effettuata con quella esattezza e costanza, che fin'ora $i$ colonisti han dimostrato in ogni altra azzione, migliajo e migliajo di manufattori saranno ridotti alla mendicità in questi Regni ".

Nov. 25, I774. "Si compiace V. E. di darmi in R. Nome, nel primo de sudetti ven ${ }^{\text {mi }}$ Dispacci, che l'accuratezza, e la distinzione, colla quale sin'ora ho procurato di referire le circonstanze tutte, ch'accompagnano l'importante disputa colle Colonie, non solamente non è dispiacente al Rè N. S., ma ch'abbia incontrato la benigna approvazione della M. S. la connessione delle antecedenti e delle ultime notizie in proposto à disturbie in quelle Colonie; e ch'essendo naturale, che la Corte di Lisbona scarichi, e carichi in questa le sue querele contro quella di Madrid in occasione delle differenze insorte su i confini del Paraguaj, e del Brazile, sia bene il tendervi le orecchie, ho l'onore di assicurarre L'E. V., che, animato da sè lusinghevole riscontro, non daró certamente risposo al mio zelo nell'indagare, e nel riferirle quanto mi riesca possibile rispetto a si importante assunti."

May 6, I774 (letter no. 236). Boston Port Bill.

May 27, June 3, I7, 24, I774. Quebec Act.

July I, I774. General Gage in Boston.

July 8, I774. Continental Congress.

July I 5 , I774. Comparison of forces of England and the colonies.

July 29, I774. Quebec Act.

Aug. 5, 1774. Action of Congress.

Aug. I2, I774. General colonial rising; trouble in La Plata, relations of England and Portugal.

Aug. I9, I774. Indian troubles.

Sept. 2, 9, I774. Trouble between England and Spain regarding island of Balambanca (between Borneo and the Philippines).

Sept. 16, 1774. Non-consumption and non-importation.

Sept. 23, I774. News of American colonies; and of island of Balambanca.

Sept. 30, Oct. 4, 7, I4, 28, Nov. 4, I774. News of the American colonies and of the relations between Spain and Portugal.

622. Inghilterra, no. 31. I775-1776. Not examined.

Inghilterra, no. 32. I777-I778. Bulk of material consists of news from America; only a few letters are here noted.

Feb. 7, I777. On the English suspicions of France, and their effect on English politics and policy.

Mar. 2I, I777. Washington to be made Lord Protector.

Aug. 29, I777. On the seizure of Dutch vessels with contraband on the way to St. Eustatius.

623. Inghilterra, nos. 33 and 34. I779-I780. As before, nearly every letter relates to America, and only a few items are noted.

Jan. 8, I779. On mercantile arrangement between England and Holland. Jan. 29, Feb. I2, I779. Danger to American cause from internal discord. Quarrel of the Lees and Deane. 
Mar. 28, I780. On the attempt of the King of Naples to mediate between England and Spain.

Oct. 6, I780. The Prince of Caramanico succeeds Pignatelli as minister in London. His instructions do not mention America. His letters are somewhat less full and less valuable. There is, however, a great deal on the subject of neutrality and nettral trade. He seems somewhat more favorable to England.

The correspondence with Spain is found: as to the Neapolitan legation in Spain, in numbers 1716-1907, which form a somewhat irregular series, extending from I734 to I8I4, and I8I7 to I860; as to the Spanish legation at Naples, in numbers 1908-1924, which form a regular series, and 1925-1928, an irregular one, extending from I734 to 1805 , and I8I3 to I86o. Of these the following were examined:

1805. Spagna, no. 89. I776-I777. The Neapolitan minister in Spain confined himself more closely to the affairs of the country to which he was accredited than his colleague in England. Neither does he seem to have been at all in the confidence of the Spanish court, and his letters are therefore of much less value for American affairs. There is something on the not entirely unrelated troubles between Spain and Portugal in South America, and in addition the following items were noted:

July 29, I777. News of the arrival of American vessels at Bordeaux and Bilbao.

Aug. I2, I777. Conference between Floridablanca and the English ambassador concerning American vessels.

1809. Spagna, no. 91. There are some printed documents, as, Exposé des Motifs de la Conduite de Sa Majesté Très Chrétien, and in addition the following items were noted:

Mar. 23, June 6, I779. Firm neutrality of Spain.

June I5, I779. Speculation regarding war.

Apr. 20, I779. Case of the polacca, SS. Nunziata e Giuseppe of Naples, Melchiorre Casace, master, from North Carolina, laden with tobacco and other American products, which was seized by English privateers, carried into Gibraltar, and condemned on the ground that the cargo belonged to the United Colonies.

The correspondence of the Neapolitan legation in France is found in numbers 280-477, extending from I753 to I806, and I8I 5 to I86o. That of the French legation in Naples is in numbers 478-583, and extends from I733 to I789, I797 to I806, and I8I 5 to 1860 . Number 583 bis contains an index to it, prepared in the eighteenth century. None of these volumes were examined, but they should be more important than those of England for the period of the Revolution, especially after the arrival in Paris of Count Pignatelli in I780. There should be one or more letters of Franklin.

The material relating to consulates was not examined but the following references are given:

2408-2415. Neapolitan consulates in America, I8I8-I86I, without distinction of city.

3142-3194. This is miscellaneous material relating to Neapolitan consulates in foreign countries, I734-I806, and I836-I847, without distinction of country or city.

3196-3197. Material relating to American consulates in Naples, I797-I8I3, and I8I5-I829. 
$3255-3289$. These contain all the material from 1830 to 1860 relating to foreign consulates in Neapolitan territory.

3289 bis. Patents, etc.

Of possible biographical or genealogical interest are the two following series:

3697-3792. "Affari Riservati." I833-1860.

3793-3836. "Espulsi." I820-1833.

3833-3874. Id. 1848 and following.

3883 bis. This forms an index to the "Espulsi", I821-1856.

There follow in the inventory a number of miscellaneous volumes, of which the following are the only ones pertinent to the subject:

4195. "Danni della Guerra combattuta in Sicilia: Corres. della Alta Commissione, suoi Processi Verbali, Determinazioni", etc. I850-I853. This was a commission on American claims.

4210. "Progetti di un Trattato di Commercio con l'America."

4464-4465. "Crediti degli Stati Uniti di America." I812-1817, 1824-1829.

There follows a collection of treaties containing 240 fasci, numbered continuously with the preceding series and extending from I758 to I860. Here are found:

4485. "Trattato di Commercio e Navigazione con gli Stati Uniti di America." r846.

4502. "Trattato di Amicizia, di Navigazione e di Estradizione con gli Stati "Uniti di America." I855.

4503. "Convenzione di Neutralità sul Mare con gli Stati Uniti di America." 1855 .

4612-4697. These contain miscellaneous treaties, I280-1860; there follow certain fasci of ciphers without date, of which the following are noted:

4718. From New York.

4721. From Cavaliere Martuscelli. I846.

4735. "Sorveglianza dei Consoli Napolitani all'Estero sulle Morse dei Frati." I845.

5247. "Circolar 9 Giugno 1848 circa la Navigazione Commerciale; Corrispondenza tenuta con diversi Consoli di America per l'Incremento del Nostro Commercio in quelle parti." I849.

The documents of the French occupation are even less well arranged than the other. Numbers 11-12 have American material, 1806-1809, and 1816; and numbers 311-358, containing miscellaneous material, may, of course, have anything.

The collection of passports, numbered I-520, extends from I8I 5 to 1860 . 


\section{VENICE. ${ }^{1}$}

\section{ARCHIVIO DI STATO.}

The state archives at Venice form the most important, and, except those at Naples, the most extensive, collection belonging to the Italian government. They have been, however, more used by scholars than those elsewhere and offer perhaps less new material. They are preserved in the monastery of Santa Maria Gloriosa dei Frari, formerly belonging to the Minor Conventuals, and are more conveniently arranged than the other government collections. Permission to use them is obtained from the director, on presentation of credentials. The hours are from 9.30 to 12 , and from $\mathrm{I}$ to 3.30 , with exception of the usual government holidays.

The archives are arranged in sections corresponding to the several branches of the Venetian government, and inventories, on the whole satisfactory though somewhat old-fashioned, exist for the several sections. In Venice more than elsewhere the name of a department of government tells little of its duties, and some knowledge of their several functions is necessary. The most useful guides are those by Armand Baschet, Les Archives de Venise, and Rawdon Brown's L'Archivio di Venezia. ${ }^{3}$ There are two government publications which contain accounts of the material in the archives, but without sufficient explanatory matter: Il R. Archivio Generale di Venezia (Venice, I873), and Statistica degli Archivii della Regione Veneta '(I88I).

The only series which seemed of possible interest to the American historian are the following, the items actually found being noted with the general description of each series.

\section{LETTERE DUCALI.}

These are listed in indice 214. Those to 595 are contained in 3 I buste, in which the only letters of possible interest are I9 to the orator in Spain, I 586 to I588. There follow filze numbered from 32 to 71 and containing letters extending to I797. The contents of these latter are not listed, and they were not examined, as the letters of this whole series seem to be chiefly formal in character, like those of the popes to princes.

\section{DELIBERAZIONI SECRETE DEL SENATO.}

This series contains official copies of the letters and despatches regularly addressed to the ambassadors and other representatives of the state. They begin in I4OI and extend to I630. The volumes are large, with heavy wooden covers, and are of parchment. Each volume is indexed, and this is followed by lists of the letters sent to each country. Ten volumes, numbered R 34$\mathbf{R} 43$, and extending from I 489 to $\mathrm{I}_{5} \mathrm{IO}$, were examined, and nothing pertinent found; though the sudden demonstration of affection for Portugal after the voyage of Vasco da Gama is of interest.

\footnotetext{
${ }^{1}$ P. J. Blok, Verslag von Onderzoekingen naar Archivalia in Italië, pp. 6-2I; Rawdon Brown and others, Calendar of State Papers and Manuscripts relating to English Affairs existing in the Archives and Collections of Venice and in other Libraries of Norlhern Italy [Public Record Office] (London, I865-I904, II vols.)

${ }^{2}$ Paris, 1870, pp. 708.

${ }^{3}$ Venice and Turin, 1865 , pp. 326.

${ }^{4}$ This is of little use.

SThis serves as the only general inventory to the archives.
} 
CORTE.

In I630 the series of Deliberasioni was divided into two, of which that of Corte contains the material relating to foreign affairs. This series contains generally one volume for each year, and is complete to the extinction of the ducal government of Venice. The following volumes were examined:

160. (I783). f. 160. Aug. 30. To the ambassador in France approving his conduct regarding the call of Dr. Franklin.

f. 225. Nov. 22. To the same, expressing interest in his discussions of the questions of the royalists and of paper money.

161 ( I784). f. 99. May I2. To the same, commenting on the treaty of peace of Versailles.

f. 532. Feb. I9. To the same, commenting on the request of the United States for a treaty of commerce, and ordering him to collect information on the subject.

\section{RELAZIONI.}

The famous relations of the Venetian ambassadors have perhaps been too highly regarded as a source of history, for a glance at any important library of manuscripts in Italy, if not in Europe, at once shows that few of them remained long secret, and the relations in fact bear evidence that an audience wider than the Venetian Senate was addressed. Those copies in the Roman libraries have been, for the most part, noted and commented on, and few are to be found in Venice, of which those libraries have not copies. Nearly all of them, moreover, have been printed. ${ }^{6}$ It is true, however, that there are considerable differences between the originals and the copies, and revised editions will some time be necessary, based upon a widespread study. The relations in the archives are listed in indice 174, which notes those that have been published. Only those were examined which remain unpublished.

\section{Francia.}

There are six unpublished relations of France, contained in busta 10, and for the years I708, I723, I733, I737, I740, and I743. The fourth and fifth contained no references to America: references in the others follow:

Aug. I I, I708, by Lorenzo Tiepolo, mentions the trade of France in the Western Indies on $\mathrm{f} .5$.

Apr. I3, I723, by Nicolo Foscarini and Nicolo Tiepolo, discusses the South Sea Bubble and the West India Company, in the first ro pp.

Feb. I8, I733, by Alvise Mocenigo, comments on the trade of Spanish America, and the rivalry of France and England for it. He notes royal revenue from the colonies.

\footnotetext{
"Eugenio Alberi, Le Relazioni degli Ambasciatori Veneti al Senato durante il Secolo Decimo Sesto (1839-1863. I5 vols.); Nicolo Barozii and Guglielmo Berchet, Relazioni degli Stati Europei lette al Senato degli Ambasciatori Veneti nel Secolo Decimo Settimo (1856-1870, 7 vols.); M. Gachard, Relationi des Ambassadeurs Vénitiens (of Charles V. and Philip II.; Brussels, I855, one vol.); [Sir Henry Layard,] Dispatches of Michele Suriano and 'Marc' Antonio Barbaro, Venetian Ambassadors at the Court of France, 1560-1563 (Lymington, I891, pp. xii, 107, clvi); Brieven van Lionello en Suriano wit den Haag aan Doge en Senaat van Venetië in de jaren 1616, 1617, 1618 (Utrecht, r883, pp. vii, 472), no. 37 in the Werken of the Historisch Genootschap te Utrecht; "Verslag van den Ambassadeur in den Haag Francesco Michiel aan Doge en Senaat, 27 Mai, 1638", in the Bijdragen en Mededeelingen, VII. 67-68, of the same society. There are also many relationi printed separately, and other collections not bearing on the subject.
} 
Sept. 5, I743, by Andrea da Lezze, discusses the struggle of France, England, and Spain for the commerce of America, and the threats of Spain which brought France into the war.

\section{Spagna.}

There are ten unpublished relations of Spain, for the years I 557, I 564, I 568 , I7II, I725, I733, I735, I738, I747, and I754. The first three are copies, and were not examined, the others are contained in busta 29, and are originals. Those for I7II and I733 contain nothing on America.

May 24, I725, by Daniele Bragadin, contains a few unimportant references to the Indies.

Dec. I7, I735, by Francesco Venier, contains slight reference to English commerce in the Indies.

Jan. 22, I738, by Pietro Capello, discusses the beginnings of King George's War, and mentions a fort in Florida, and English commerce in the Indies.

Nov. 30, I747, by Francesco Morosini, gives a general account of Spanish policy at the death of Philip V., with scattered references to the Indies.

Feb. 20, I754, by Antonio Ruzzini, gives a good account of the Indies, including their trade, defence, and revenues.

Inghilterra.

The relations of England are in the Biblioteca Marciana.

\section{DISPACCI AL SENATO.}

The dispatches of the Venetian ambassadors to the senate were regular, carefully prepared, and exhibit an unusual faculty for obtaining information. There was no such elaborate system of ciphered letters as that prevailing in the Roman court, but portions of the ordinary letters were often in cipher. Translations of these nearly always exist, though they are sometimes difficult to find, as they were written in, or added on separate sheets, with little regard to location. The dispatches are arranged in filze, and are generally in good condition. They are listed in inventory 254 .

\section{Francia.}

The dispatches of this series are contained in filze A-E and 1-269, extending from I 530 to 1797 , with a lacuna from I 533 to I 539 . Those before I 560 are not regularly arranged and are incomplete. Notes on those examined follow :

5 (1563-1565). Many ciphers here are untranslated.

June 26, I 565. Rumor that the Catholic queen, on behalf of Philip II., has made three demands of France, one of which is that the French no longer impede the navigation of the Indies. Desire of Spain to monopolize the same, "Ne solam ${ }^{t}$ di quello ch si é scoperta fin quà, ma anco di quel, che resta à scopirsi, come se fusse stata loro assignata da Dio quella parte di mondo ne la maniera che fú à gli Hebrei la terra di promissione".

6 ( I 566-I 568). Nothing.

39 ( I608). Nov. 20. Arrival of the Spanish fleet. Dec. 22. Effect of the same on negotiations. Also many references to the Dutch and Spaniards in the Indies.

179 ( I688-1689). Nothing. 
243 ( I753-I755). Dec. I6, I753. Delegation from Canada asking aid against the English and Indians.

No. I44 (without date). On danger of war in America.

Nov. IO, I754. General account of hostilities in America.

Mar. 23, I755. On the claims and plans of the French and English in America.

244 ( $1755^{-1756)}$. July 6, I755. American question before the French ministers.

July 20, 27, I755. Naval affairs off Newfoundland.

Aug. 24, I755. War in America discussed at Paris.

Aug. 3I, I755. Defeat of Braddock.

Sept. 7 (two numbers), Sept. I4, I755. Same subject as above.

No. 223 (without date). Military news from America.

Oct. 5, Nov. 9, I755. News from London of the defeat of Braddock and of Baron Dieskau, with gazettes.

May 9, I756. On neutral rights in connection with the war in America.

Also much naval news, and copies of many documents.

248 ( I760-1762). June 29, July 7, I760. French attack on Quebec.

Sept. 29, I760. French reinforcements in Canada.

No. 2I (without date). Oct. 20, I760. Fall of Montreal, with comments.

250 ( I764-I766). Aug. 27, Sept. 3, I0, I7, Nov. I9, I764. On the neutrality of Turks Island.

Mar. 4, Dec. I6, I765. On financial questions arising out of the cession of Canada.

Sept. I6, I765. Agitation in America over the failure of England to prevent the exclusion of English goods from the French West Indies.

257 ( $1776-1778$ ). Dec. 30, I776. Considerations on the arrival of Franklin.

June 2, 16,1776 . On the violation of neutrality.

July 28, I776. "Comincianno a spandersi le notizie dell' apertura della campagna in America, e il mio dovere vi si applica a depurarle dagl' inviluppi, che la distanza, e lo spirito dei partiti s'insrecciano."

Dec. 8, I776. "Un Vescello americano approdato a Nancy ha recato al Dottor Franklin, che continua a resiedere in questa Capitale, Lettere, e avisi della più grande importanza in favore delle armi delle colonie: e tale e il concetto, che gode questo uomo grave, e scienziato, che niuno sa dubitare di esaggerate parzialita."

May 25, I778. The action of the diplomatic corps with regard to the American representative.

There is also news of the war in all its various relations in nearly every letter, forming, in fact, the bulk of the matter contained in this filza; and many copies of documents, as the treaties between France and the United States; together with interesting speculations as to the action of France before war was declared.

260 ( I782-I784). July I 5, 22, I782. On the beginning of peace negotiation. Aug. I2, I782. Failure of Carleton's negotiations with Congress, and effect on English attitude.

Aug. 26, I782. English desire to separate the colonies from France.

Sept. 2, I782. Franklin has apoplectic stroke; attitude of Jay.

Dec. 9, I782. On the preliminaries between the colonies and England, with supposition that Vergennes and the Spanish ambassador knew they were to be signed. 
Dec. I6, I782. Difficulties of Vergennes because of the number of parties to the war.

Jan. 27, I783. Cession of Florida by England to Spain, with desire to involve the latter with the United States. Predictions as to the future of America. "Chiedo umilmente perdono all' Ecc'mo Senato se oso avanzare questo pronostico."

Feb. 3, I783. On Franklin, "questo vecchio rispettabile, di cui godo la familiarita ", and Abbé Mably.

Feb. IO, I783. Terms of peace, "che contengano la più strepitosa e importante rivoluzione di questo secolo".

Mar. 24, I783. Courting of the United States by various powers. "Nelle accidentali frequenti occasioni, che mi si presentano di vedere, e conversare col celebre Signor Franklin che è poi quello, che ha il maggior credito appresso il Congresso, non pretermetto attenzioni, e modi valevoli [?] ad obligarlo, attendendo, che spieghi formalmente il proprio carattere a tutto il Corpo Diplomatico per reconoscerlo poi legalmente dietro l'esempio degli ambassciatori delle Primavie Potenze neutrale a tenore delle istruzioni ricevute colle Sovrane Ducali del il primo Febbraio decorso."

Mar. 31, I783. Question of American trade before the English Parliament.

May I9, I78.3. Revival of trade between England and the United States. July 2I, I783. Packet service between France and the United States.

Aug. I I, I783. Formal calls of Franklin, Adams, and Jay. Report of long conversation with Franklin.

Jan. 26, I784. On the order of the Cincinnati.

There is also a great deal on naval affairs, on the peace negotiation, and on trade, and copies of many documents.

261 ( I784-I786). This volume seems to have been used previously for American material, as nearly all items are marked.

f. 96. I784. Letter of Adams, Franklin, and Jefferson to Chevalier Delfino, Venetian ambassador, suggesting a treaty between the two republics. English with translation.

f. 97. Dec. 27, I784. Response of the Venetian ambassador to the preceding.

Aug. 30, r784. Arrival of Jefferson, with full powers to treat regarding commerce.

May 23, I785. Jefferson succeeds Franklin.

June 20, I785. Reception of Adams by George III.

June 27, I785. Compliment of Louis XVI. to Franklin.

Sept. 26, I785. Departure of Mr. Temple to reside as minister (consulgeneral) in the United States.

There are also many minor notices of American affairs, but, of course, not so many as in the filze immediately preceding.

Inghilterra. 1602 .

These are contained in filze 1-140; I554-I797, with a lacuna from 559 to

34 (1629). Sept. 6, Oct. 19, Nov. 30, I629. Hostilities between the English and the French in the Western Indies.

35 ( 1630 ). Feb. 21, I630. On the cession of Canada. 
112 (I754-I756). Nov. I4, I754. Rivalry of the English and French in America.

Nov. 28, I754. Despatch of troops to America.

Dec. I2, I754. French ambitions in America.

Jan. 2, I6, I755. Activity from Ohio to Cape Breton.

Mar. 6, I3, 27, I755. Rival claims in America.

May 29, June 3, I9, 26, I755. Plans of Braddock.

July IO, I755. Rumor of defeat of Braddock.

Aug. 25, Sept. 4, I I, I8, I755. Defeat of Braddock and its results.

Nov. 23, I755. Indians on the frontiers of Virginia and Pennsylvania.

Nov. 30, I755. Defeat of Dieskau.

July 9, 1756 . Subsidence of interest in American affairs.

There are also many minor notices of hostilities in America, of naval affairs, and of negotiations.

126. (I773-I775). Nov. I9, I773. On the emigration of skilled mechanics to America.

Dec. I7, I773; Jan. 7, 28, I774. The tea question, the Congress at Philadelphia, and non-importation.

Mar. 2, I I, I8, 25, Apr. I, I 5, 22, 29, May I3, I7, June 3, I0, I7, 29, July I, I774. English politics and America.

July 8, I774. The united character of American resistance.

July I3, I774. Arrival of Governor Hutchinson in England.

July 22, I774. The American Congress.

Aug. 5, I774. Parties in the colonies.

Aug. I9, I774. Spain and England in America.

Sept. 2, 16, 23, Oct. 7, 21, 28, Nov. 4, 25, I774. News from America.

Sept. 9, 30, Nov. II, Dec. 2, 9, 1774. American questions in English politics.

All these notices are rather of the character of news than of discussion.

\section{Spagna.}

Contained in filze 1-192, and extending from I554 to I797, with a lacuna from 1575 to 1578 , and quite irregular before 1579 .

6 ( I 566-I 568). Mar. I 5, I 566. " Sermo Principe. L'essersi intesa più certa la presa del forte della Florida in India, et la uccisione fatta da Spagnuoli de I200 Francesi, che per caso di fortuna si sparsero per quelle spiaze, se che senza arme, et quasi morte da fame domandando humilente misericordia, passarono tutti per fil di spada; fà che quà si senta l'ambasciator del $\operatorname{Re} \mathrm{X}^{\mathrm{mo}}$ dolersi accerbrisimente di una crudeltà cosi grande, ne hà rispetto di parlarne publicamente. Queste lamentationi delle $\mathrm{amb}^{\mathrm{r}}$ mettono sospetto in questi $\mathrm{s}^{\mathrm{ri}}$ et l'e accresciuto dall' intendere, che la casa di Ghiza si sia pacificata con l'armiraglio, alquale era ascrita la morte di quel Duca, della qual unione, par loro, di poter dubitare et molto più in questi tempi, che si stà in aspettatione dell' armata Turchesca con tanto apparato. Questa nuova della pace è stata portata da un cavalliero Francese mandato à posta da quella corona."

Apr. I I, I 566. "Quanto manca il sospetto dell' armata Turchesca, tanto accrescie quello che hanno di Frencia, perche sentendosi pur tuttavia,

${ }^{7}$ This and the following extract are given in full because the condition of the manuscript renders its longer preservation problematical. 
che à s. Pietro Corso i Corsica ne manca aiuto di denari, et di cosa le bisogna per qlla parte, et l'intendere ch' i principali in q'1 Regno bravano assai per la cosa della Florida, et che di più parte della Normandia et della Bretagna s'armino Navilii sino al di 18 per mandarli alla Florida contro Pietro Melendez a vendicarsi della morte dei stoi Francesi, et a ricuperare il forte si potranno. Tutte q'ste corse insieme causano che questi $\mathrm{s}^{\mathrm{ri}}$ stiano nel sospetto gia presso, anzi che se sia augmentato assai più."

Apr. 22, I 566. News of the discovery of a new archipelago in the Indies, rich in gold.

Aug. 6, 1566. Fears for the fleet of the Indies.

Mar. I9, I567. News of a rising in New Spain, attributed by some to the French.

July 19, I567. Note of the arrival at court of Pedro Menendez, sent from Cuba by the governor, to report that there were Io French ships off Cuba.

July 27, I567. Note of conversation between Philip II. and the French ambassador on the same subject.

Aug. 2I, I 567. Effect of uncertainty concerning the fleet from the Indies on the Spanish, French, and Italian merchants.

Mar. 28, I 568. Rumors that the French and English prepare to meet the fleet of the Indies. Description of the fleet.

July I2, I 568. News of the arrival at Rochelle of two vessels of the fleet sent to revenge the death of the French in Florida, with report of success and of plans to resume occupation.

July 24, I568. More exact and later news of the fleet. Philip II. " non ne é per mover parola co $1^{\prime} \mathrm{X}^{\text {mo }}$ ne con soi ministri mali provederà lui, et cherchera per altra strada di farne vendetta contra coloro".

38 (I606). Very frequent and detailed accounts of the movements of the fleet of the Indies, of the activity of the Dutch, and of the negotiations between the Spaniards and Dutch.

79 ( I664). News of the fleet of the Indies and of their commerce.

179 ( I776-I779). Sept. 30, I 777. Arrival at Madrid of Count Montmorin. Relation of American affairs. Reception of American armed vessels.

Dec. 9, I777. Settlement of South American difficulties.

Jan. 20, I778. Preoccupation of the cabinet with American affairs.

Feb. I7, I778. Activity of English privateers.

Mar. IO, I778. Plans of Spain and France to profit by the weakness of England.

May 5, I2, June 9, 23, I778. Situation of England and France.

July 7, I 778 . France and Spain.

July I2, I778. Great Britain and the colonies.

Aug. 4, I778. Declaration of war.

Aug. 25, Sept. 8, Dec. I, I778. The mediation of Spain.

Sept. I5, I778. French on the coast of America.

Mar. I, May II, I779. Conquest of Georgia.

June I, 22, I779. The neutrality of Spain.

June 29, July I3, I779. Spain enters the war.

July 20, I779. English attack on Louisiana.

July 27, I779. England and the colonies.

There is also much on naval warfare, and many Spanish documents relating to the war. 
180 (I779-I78I). Sept. I4, I779. News of Count D'Estaing, brought by American vessel from Carolina in 32 days.

Oct. I2, I779. Plans of Washington against New York.

Dec. 21, I779. Americans and French in Georgia.

Dec. 28, I779; Jan. 4, Feb. 16, r780. Capture of Pensacola.

Feb. I, I780. Arrival of Jay.

Feb. 29, I780. Jay's secretary and Gerard in Madrid.

Apr. II, I780. Jay in Madrid, and his negotiations.

Aug. 29, I780. Jay and the recognition of American Independence by Spain.

Sept. I9, I780. News from Newport by American packet boat to Bilbao.

Nov. 2I, I780. On the archives of the embassy in Madrid.

There is also much on the question of neutral rights, on the armed neutrality, on naval affairs, on the Cumberland mission to Madrid, and many documents.

The series of correspondence with other countries did not seem likely to contain anything of significance, but it is possible that there may be something in that of Holland, which consists of 53 flze, running 1-38 (including 4 bis), I610, I6І6-г643, I668-I669, and another series, 1-14, I709-I745. Unfortunately these lacunae occur where American material would be most likely to exist.

\section{RUBRICHE.}

These belonged to the Collegio, but are now inventoried with the dispacci. They consist of analyses of documents, chiefly dispatches of ambassadors for the use of the Collegio. The series is practically complete, and is therefore useful in supplying lacunae in the series of dispacci, but would scarcely be used for the periods for which the latter exist.

\section{AVVISI.}

This series belonged to the Inquisitors, and is referred to as Inquisit-avvisi. 880 volumes are noted, extending from $\mathrm{I}_{525}$ to $\mathrm{I} 797$. The series is not well ordered, and was disappointing considering the abundance of news reaching Rome and other places by way of Venice. This may have been due, however, to the slight attention which could be given it. There is no inventory, and bundles are called for by the name of the country, which means that from which the news came, and the year. Calling for England, I630, I received a volume covering the years 1657 to 1703 , in which the only American news was of an ambassador from Florida, whose coming to England was delayed by shipwreck, Dec. 28, I657. This document was in triplicate. Doubtless news from France and Spain would be better ordered, but the character of such material has already been commented upon, and no more time could be spared for it.

It is hard to conceive of American material in the other series, though, of course, scattered items may exist. It is perhaps proper to mention the Chiavi di Cifre, referred to as Cifre, chiavi, many of which exist for the sixteenth, seventeenth, and eighteenth centuries. The Esposizioni Principi, belonging to the Collegio, of which there are 307 numbers, might seem likely to contain something, being audiences with foreign ambassadors, but actually they are so formal in character as to render mention of America most improbable. 


\section{BIBLIOTECA MARCIANA. ${ }^{8}$}

This library occupies a building between the royal palace and the lagoon, with its entrance through the old library from the Piazzetta. It is open from 9 to 4. It contains the famous Diario di Marino Sanuto, in 58 volumes, which is such a valuable supplement to the archives and fills so many of their lacunae. This was not examined, as, besides the printing of the whole, it seems probable that all the references to America which it contains have been given in the Raccolta di Studi e Documenti Colombiani, volume III., part I, pages 39-45. Of the other manuscripts there were examined only those listed in "Index Rerum Venetam Historiam Spectantium quae in Appendice ad Catalgum Codicum MSS. Lat. hujus D. Marci Bibliothecae continentur", and the only numbers that seemed of interest were those containing unprinted relations of England. Of those mentioned in the inventory of the archives as existing in this library that by Pietro Contarini, 1618, could not be found in the index; and the references to that of Pietro Mocenigo ${ }^{9}$ proved incorrect. Of the others those of Carlo Capello, I533, and Domenico Balloni, I534, contained nothing pertinent. Notes on the others follow:

Cl. VII cod. DCCCCIII (or number 7829). Pp. 250-318, by Nicolo Molin, r607. Pp. 254-255 mention the desire of the English to trade with the Western Indies, and its relation to the Spanish treaty.

Same volume, pp. 155-177, by Giovanni Sagredo, 1657. This barely mentions Barbadoes.

s La Biblioteca Marciana nella sua nuova Sede (Venice, 1906).

${ }^{9}$ Corsini 477. 


\section{TURIN.}

\section{ARCHIVIO NAZIONALE.}

These archives are rather shabbily housed at no. I2 Piazza Castello, fourth floor. A note from the consul affords the most convenient means of obtaining admission. Col. Buronzo Berzetti di Murazzano, Marchese Adriano, address Trofarello, is a reliable copyist.

A useful guide to the archives is that of Nicomede Bianchi, Le Materie Politiche relative all'Estero degli Archivi di Stato Piemontese (Bologna, I876, pp. 750). A shorter description is that in Professor P. J. Blok's Verslag van Onderzoekingen naar Archivalia in Italië, pp. 77-84.

\section{DIPLOMATIC CORRESPONDENCE.}

The lists of ministers, of letters from them, and of registers of letters to them as given by Bianchi are exhaustive. There is also a manuscript inventory, "Lettere Estere". The correspondence with England extends from I 538 to I8I4, and is practically complete after I69I; that with France begins in I 510 , extends to I8OI, and is very full after I 550 ; that with Spain is more irregular but is very extensive for the eighteenth century. A testing of this material brought to light nothing before I700, though it is probable that stray references to American affairs exist.

During the eighteenth century the court of Turin began to find the centre of its interest in the affairs of Europe rather than of Italy. The far-seeing vision of Piedmontese diplomacy, its insistence that its state be reckoned as a small power, rather than as a great principality, and the skill of its agents as well as its directors, were already then in evidence. Ever alert to future possibilities, the Sardinian ministers quickly noted the rising importance of America, and their correspondence becomes valuable. For the Seven Years' War and the wars of the American Revolution it distinctly deserves attention. The Sardinian minister at London during the latter period was in sympathy with England, and was tolerably well informed; and nearly every letter from the outbreak of hostilities to the peace contains news and discussions of American events. The correspondence after the year I8I 5 , which is open to examination only by special permission, includes the dispatches of the minister of the United States to the Sardinian foreign office for the years I838-I846 and I850-I859, inclusive.

\section{TREATIES.}

These are found in two collections, each with a manuscript inventory, "Trata [sic] Diversi", and "Tratta [sic] Diversi Addizione".

\section{MISCELLANEOUS DOCUMENTS.}

Other documents relating to foreign affairs are found in two collections, with corresponding manuscript inventories, "Inventario delle Scritture relative alle Corti Straniere", and "Inventario delle Scritture relative alle Corti Straniere Addizioni". These contain a great variety of documents including many copies of treaties, and of relations of various foreign courts by ministers 
resident at them. The mazzi or covers containing this material have two or more numbers and some confusion may occur in calling for them. The pieces of significance for the history of the United States and Canada are the following:

\section{Corti Straniere, Spagna.}

Mazzo 2. f. I3. "MSS. Politici concernanti la Monarchia di Spagna, racolti dal Commendatore Opecti nel tempo della sua Ambasciata di I4 anni presso quella Corte." No. 87, "Relazione toccante all'Interesse di S. M. nell'Indie". I703. $44 \mathrm{pp.}$

Mazzo 3. f. I6. "Descrizione della Monarchia di Spagna." I7I2. March. di Trivie, "Inviato straordinario alla corte di Spagna". I7O7-I7II. I68 ff. This touches on Spanish interests in America.

\section{Corti Straniere, Addizioni, Francia.}

Mazzo 1. f. I8. "Discours de la Prééminence des Roys de France et de leur Préséance sur tous les autres Roys de l'Europe et principalement sur ceux d'Espagne." 88 pp. Mentions Spanish empire in America.

Mazzo 2. f. 3o. "Plan économique, guerrier et politique pour la France", par M. de Truderie. I75I. $66 \mathrm{pp}$. Includes plans for the colonies.

f. 37. Writings relative to the mediation of the King of Prussia for the adjustment of differences between the courts of France and England with regard to their respective possessions in North America. I755I756. Copies of letters and notes.

f. 42. Letter of the Minister of Marine of France to the Chamber of Commerce touching the provisioning of the colonies, and the exportation of their products. I756.

f. 43. Declaration of the States General to the court of France relative to the differences of the same with England. I756.

\section{Corti Straniere, Addizioni, Inghilterra.}

Mazzo 1. f. 32. Relation of the actual state of the court and ministry of London, by the Sardinian minister. Apr., I775. 5 pp.

f. 35. Proposition made by the United States of America by means of their ministers plenipotentiary Adams, Franklin, and Jefferson, for a treaty of friendship and commerce between his Majesty the King of Sardinia and the same states. Sept. 22, I784. Copy.

f. 36. Relation by the Marquis of Cordon of his two missions to Holland and to England, in which he describes the origin of the war between the latter country and its colonies, and of the rupture with France. Dec. 6, i784. 6i pp.

Mazzo 2. f. 2I. "Observations sur les Finances, la Navigation et la Commerce d'Angleterre." Oct., I747. 59 pp.

f. 32. Memoirs regarding the origin and state of the differences that divide England and France concerning America, and the negotiations resulting from the Spanish attempt at mediation. I755-I756. II pieces.

f. 33. Relations, letters, capitulations, and memoirs concerning the war between the French, Spaniards, and English in North America. (Seven Years' War). I7 pieces. 
Mazzo 3. f. 29. Preliminary articles of peace signed at Fontainebleau between France, Spain, and England, I762 ; with letters, notes, and other pieces which served in the negotiations. " $N$. B. Cette Negociation a eû lieu, et a été commencée et suivie par l'intremise de M. le Comte de Viry, et de M. le Bailli Solar, Ministres de S. M. aux Cours de Londres et de Versailles." 6 pieces, some originals and some copies. Mazzo 4. f. 9. Extracts of letters, of gazettes, and other pieces relative to the affairs of New York and New England. I765-1768. Unimportant.

Mazzo 5. f. 7. "Observations concernants les treize États Unis de 1'Amérique Septentrionale.” M. de C. I779.

\section{MUSEO STORICO DELL'ARCHIVIO DI STATO. ${ }^{1}$}

Here are preserved autographs of Presidents Tyler, I844, Polk, I845, and Buchanan, I859; and the ratification of the treaty of commerce of Nov. 26, I838, between the United States and Sardinia.

\section{BIBLIOTECA NAZIONALE.}

This library is situated in the University of Turin, no. I7 Via di Po. Admission is free. The manuscript collections suffered severely in the fire of I904. ${ }^{2}$ The only manuscript relating to the United States or Canada belongs to the Italian collection, which has not been fully put in order.

"Lettere scritte da Mons. Nicola Armanetto [Ormaneto], Vescovo di Padova, Nunzio in Ispagna, al Sigr. Cardinale di Como negli A. I 572-I 573. Copia."

ff. 186, I88. On the defence of the Western Indies.

${ }^{1}$ Catalogo (Turin, i881, pp. 62).

${ }^{2}$ Giovanni Gorrini, L'Incendio della Biblioteca Nazionale di Torino (Turin, 1904, pp. 292); G. Bourgin, "L'Incendie de la Bibliothèque de Turin", in the Bibliothèque de. l'École dcs Chartes, LXV. I32-I40, 68I-685. 


\section{FLORENCE.}

\section{ARCHIVIO DI STATO.}

Of the many collections in Florence, ${ }^{1}$ the only one investigated was the Archivio di Stato, in the Palazzo Uffizi. ${ }^{2}$ A note from the consul will serve as an introduction. At the time of the International Historical Congress at Rome, a brief general description of those archives was published with the title, Inventario Sommario del Reale Archivio di Stato di Firenze, ${ }^{3}$ which is useful, although not sufficiently detailed to serve as a basis for study. There are also separate manuscript inventories of the many collections included, and for some of them elaborate printed descriptions. The regular series of state archives is subdivided by periods into those of the Republic, extending generally to about I 532, although some series include later documents; of the House of Medici, I532 (circa)-I734; of the Regency, I735-I765; of the House of Lorraine, I765-I800 ; and of the House of Lorraine, restored, I8I5-I859.

Repubblica. Judging from the inventory only, it does not seem probable that there is any American material for this period, unless perhaps some reference on Toscanelli or Vespucci.

Medici. The portion of this collection most apt to contain American materials is that relating to foreign affairs. The correspondence with England, France, and Spain is fairly complete. Numbers 4696.6, 4597.7 (France, I 565I 569), 4623.33 (France, I609-I6I I), and 5043.26 (Spain, I 586-I 592) contained nothing. 4595.5, part 2 (France, I $562^{-} \mathrm{I} 564$ ), contains two letters, folios 62-67, July 6, I 562, on Coligny, and of some possible interest in relation with Huguenot colonizing activity. 4642.52 (France, I629) contains a letter, folio 75, from Paris, Mar. 9, I629, on a new English fleet, and conjecturing as to whether it was to be used against France or the Indies.

As this material is unsystematically arranged, and is of such slight importance for American history, it seemed unnecessary to give a detailed description of it.

Reggenza. The inventory of this section does not reveal anything of apparent pertinence unless 984, filza I, no. 4, a plan of the consoli di Mare of I770 to improve the condition of Leghorn, may contain something on American trade.

Lorenese. This section is more systematically arranged, and there is a separate inventory for Affari Esteri. It actually includes records of various provisional governments, as well as that of the Grand Duke. The correspondence of the ministers in England, France, and Spain during the period of the American Revolution contains a great deal on the events of that war. This is particularly true of France, where the minister was well acquainted with Franklin, from whom he received much of his news and in whom he had implicit confidence. Except for this period there seems to be no significant

1 P. J. Blok, Verslag (Igor), pp. 23-37.

${ }^{2}$ The Raccolta di Documenti e Studi della $R$. Commissione Colombiana, III., Fonti Italiane, prints material from the Accademia del Cimento, the Biblioteca Magliabecchiana, and the Biblioteca Riccardiana.

${ }^{3}$ Florence, I903. 
amount of material. The inventory is so unreliable that it does not seem desirable to list this correspondence.

The following American document seems to exist alone:

1196. " Carteggio Sovrano con la Republica di Lucca ... Stati Uniti d'America", etc., filza I9, no. 5. Letter of James Madison to the Grand Duke, congratulating him on his restoration, Nov. 20, I8I5. Original. Copies of the letter of the Grand Duke announcing his restoration, and to the Marchese Ghisilieri, thanking him for forwarding the letter of President Madison.

Of possible importance are the following:

Buste 1505-1540 (2104-2139, old numbers). Relations with consuls, etc., in foreign countries, $1832-1851$.

Manoscritti Torrigiani. These manuscripts are very fully described in a work published in $1878 .^{4}$ They contain many registers of letters written by Pietro Ardinghelli, while serving as secretary of state under the direction of Cardinal Giulio de' Medici, which are, therefore, properly archives of the papacy. There are eleven such registers, extending from Mar. 4, I5I5, to Dec. 23, I520; and other volumes of bulls, briefs, treaties, instructions, etc. These were not examined, and one would judge from the character of similar material elsewhere, that they contain nothing, but they must be searched before an absolute negative can be given.

Other Collections in the Archivio. The Royal Columbian Commission, Raccolta di Documenti e Studi, volume III., notes items in the Strozziana, filza 129, A. 26, and in the Riformazioni, Dieci di Balia, filza 24, C. $183 ;{ }^{5}$ but these and other collections were not examined for the purpose of this study. ${ }^{6}$ Among the maps there was noted number 15, including, with Europe and northern Africa, "America, parte di Terranova, Florida", etc.; Membr., M. I.22 $\times 0.78$, early sixteenth century.

${ }^{4} I$ Manoscritti Torrigiani donati al $R$. Archivio di Stato di Firenze, Descrizione $e$ Saggio (Florence, 1878).

${ }^{5}$ Pp. 217, 219.

- See Archivio Storico Italiano, fifth series, XXI. 316-3I8, for reference to Toscanelli in the "Archivio del S. Verdiana di Firenze", in the Archivio di Stato. 


\section{CITIES UNVISITED. ${ }^{1}$}

Some indications are here given of documents of possible interest to American historians in collections which were not personally visited. In such cases it is not possible of course to determine the absence of material, but only to point out such as has come to notice. It has not seemed worth while, moreover, to call attention again to documents cited in the various publications on Columbus, Toscanelli, Vespucci, etc., which are primarily contributions to American history, and as such known to American historians. The chief guide to the smaller archives of Italy is, Gli Archivi della Storia d'Italia, by Giuseppe Mazzatinti, published at Rocca S. Casciano, in I897, and subsequent years. All documents seeming of possible relevancy mentioned in the first seven volumes of this work are listed, together with some of which notice was obtained in other ways:

Arezzo. From the Biblioteca della Fraternità di S. Maria; I83, no. 24. "Voyage faict en Groenland en l'an MDCLII."

Forli. Biblioteca Communale, Antico Fondo, 9 and 1o, Avvisi, I679-1729, 296 and $316 \mathrm{ff}$.

Museo del Risorgimento, II. "Stances sur le Départ de M. Maroncelli pour le Nouveau Monde", with a letter from the same from New York, June 29, I840.

Lucca. ${ }^{2}$. Archivio di Stato. Conceivably something might be found in Affari Esteri, nos. 229 and 230, correspondence of the secretary of state, 1818 and 1820 ; and in R. Intima Segreteria di Gabinetto, nos. 477-484, Lettere Diplomatiche e Particolari dirette a S. M. la Duchessa Maria Luisa, I817-1824, and to Carlo Ludovico, I824-1847.

Biblioteca. Nos. 45 and 46 contain relations of Venetian ambassadors and others, altogether 1289 pages. Of these the only ones of possible interest are, volume I, pp. 461-474, a relation of Marc Antonio Colonna to the Catholic king; and volume II., p. $972 \mathrm{ff} .$, a relation of the affairs of France and the Huguenots.

Milan. ${ }^{3}$ Archivio della Camera di Commercio e dell'Università dei Mercanti. There are here a few documents of the Philadelphia and Chicago Expositions ; and some mercantile statistics which might be of value.

Biblioteca Ambrosiana. Indice 219 of the Archivio Vaticano is entitled an index of the Italian manuscripts of this library, and exhibits nothing pertinent. It is, however, incomplete, and something might be found among the I 50 volumes of original despatches, etc., belonging to St. Carlo Borromeo, and covering the years I 566-1584. These documents are not chronologically arranged and are difficult to use.

\footnotetext{
${ }^{1}$ Of the many scholarly itineraries the most useful is perhaps that of Professor Blok, $V$ erslag van Onderzoekingen naar Archivalia in Italië (I90I, pp. 85). The exhaustive researches of Director Kehr, published from time to time in the Nachrichten der $K$. Gesellschaft der. Wissenschaften zu Göttingen, relate to so much earlier a period that they are but of incidental use.

${ }_{2}$ Inventario del R. Archivio di Stato in Lucca (Lucca, I872, I876, I880, I888, 4 vols.).

Blok, Verslag (I9or), pp. 3-6.

- Hinojosa, Los Despachos, p. 195.
} 
Parma. ${ }^{\circ}$ Archivio di Stato. Portions of the Farnese papers still remain here, and among them some belonging to the nunciature of Spain.

Perugia. Biblioteca Communale. 210 and 211 (D. 28 and 29) are a miscellany of ecclesiastical and diplomatic material on the relations of England and the Holy See during the seventeenth century. 261 (E. 8) is a copy of the relation of missions by Cerri.

Biblioteca Dominicana. Relations of England, by Giovanni Michiel and Daniele Barbaro.

Ravenna. Biblioteca Classense. 325 to 330 are: "Acta Sacrae Congregationis de Propaganda Fide", for the years I622-I628, I635-I636, I637-I638, I64I-I642, I643, I646-I647.

Savignano di Romagna. Biblioteca Communale. 33 and 34 are a miscellany relating to the printing establishment of the Propaganda, and to the foreign languages used there, collected by G. C. Amaduzzi. Printed and manuscript.

Volterra. Biblioteca Guarnacci. 79 (5706) filze 1-4, are documents on political subjects relating to Spain, I 508-I644; filze 5-8, similar documents relating to France, I333-I809; and filza 11, to America, the Low Countries, and England, I 500-I770.

${ }^{5}$ Ibid., p. 78. 


\section{APPENDIX.}

There follow the references given by Garampi to the dioceses of Cuba and Quebec, and a few others. These are given partly for their intrinsic value, and partly by way of illustration of the character of his work. There exist also series of references to the dioceses of Guadalaxara, Mexico, and Santo Domingo, which have some relevance to the subject, and references to Mexico in the Miscellanea. The references are modernized wherever possible. They were not verified.

Cubensi in sub. Hispalensi.

\section{INDICE 454. BENEFICI IO.}

1530, I2 Cal. Dec. an 7. Michaeli electo Cubensi Ind. concedit consecrationem recip. a quor.

Arm. 29, vol. 97, p. 54 .

1533, $5 \mathrm{Jan}$. Michael electus ... consecratur ab Alfonso Card. Manrique archiepiscopo Ispalensi praesentibus Balthasare Scalensi et Ludovico Arbensi episcopis.

Arm. 29, vol. 97, p. 54 .

1535, 3 Non. Junii An. I. Armator de Sumano prov. de Abbatia Saec. de Jamaica .... $\mathrm{d}^{\mathrm{r}}$ de jurepatronatu regis Cast.

Paul III., Bulls, lib. 25, p. 200.

\section{INDICE 488. VESCOVI I4.}

1516, Anno IV. Leonis $X$. Ad supplicationem Ferdinandi regis Castelle erecta fuit ecclesia Cubensis in Indiis reservato eidem regi eiusque successoribus iure patronatus.

Castello, Arm. XII., caps. III., 4.

1517, Mar. 25. Joannes episcopus Cubensis prov. 3. Idus Februarii an. 4. obl. fl. .

Provisiones secretae Curiae, 12, p. I56.

1517, Mar. 25. Johannes episcopus Cubensis habuit bullas 3. Idus Februarii anno 4 Leonis $\mathrm{X}$. provisionis eiusdem ecclesiae noviter in cathedralem erectae. Taxanda remanet in prima vacatione.

Obligationes Camerae Apostolicae, p. 53.

Pro Joanne Cubensi episcopo dispentio ad incompatibilia Cubensia. Arch. Brev., Leo X., year 6, vol. 24, p. 294.

Erectio oppidi Cubani in Indiis in civitatem et in ea Cathedralis, et Joannes fit episcopus Cubanus. Pro eodem absolutio et remissio. Arch. Brev., Leo X., year 8, vol. 19, pp. I57-I58.

1522. d. Bernardus de Mesa ordinis Praedicatorum episcopus Cubensis in eiusdem nominatione Insula Americae. Brevi 4, p. 4 r6.

1525. d. Sebastianus Salmaticensis ordinis Praedicatorum episcopus Cubensis in eiusdem nominatione Insula Americae.

Brevi 4, p. 528 .

1529. Frater Joannes de Vitte ordinis Praedicatorum episcopus Cubensis in eiusdem nominatione Insula Americae.

Brevi 4, p. 532. 
Michael Ramirez fit episcopus Cubensis per cessionem. Arch. Brev., Clement VII., year 7, vol. 105, pp. I65-167.

Pro Michaele Cubano electo abbatia saecularis Cubana. Arch. Brev., Clement VII., year 7, vol. 62, p. 2 I6.

1530. Frater Michael Ramirez Salmaticensis ordinis Praedicatorum episcopus Cubensis. Cuba in eiusdem nomine Insula Americae. Brevi, 4, p. 53 .

1530, Nov. I6. Michael ordinis Praedicatorum fit episcopus Cubensis per cessionem Johannis.

Consist. 108, p. 2 Iо.

1531, Jan. 25. Michael Ramires electus Cubensis solvit.

Provisiones Secretae Curiae, 31, p. 200.

1531, Feb. II. Clemen. Papa F. Brevis indulti suscipiendi consecrationem pro Michaele electo Cubensi. Minutes of Briefs, lib. 32, no. I29.

1533, Jan. 5. Michael Pereira episcopus Cubensis juramentum praestitit. Arm. 29, vol. 97, p. 54.

1533, Apr. 9. Joannes de Antisio electus Cubensis solvit.

Provisiones Secretae Curiae, 31, p. 220.

1535, Oct. 20. Didacus Sarmiento ordinis Cartusianorum fit episcopus Cubensis in novis Indiis per obitum Michaelis Ramirez.

Consist. 108, p. 260.

Didacus Sarmiento fit episcopus Cubensis per obitum. Arch. Brev., Paul III., lib. 2, Provisiones, p. I4.

1546, Jul. 23. Didacus Sarmiento ordinis Cartusianorum episcopus Cubensis visitat limina per procuratorem. Arm. 29, vol. 146, p. 26.

1550, Jul. 4. Ferdinandus de Uranga providetur de ecclesia Beatae Mariae in Insula Cubensi per obitum Didaci Sarmiento episcopi Cubensis.

Corr. "Sarmiento". Consist. 109, p. 36.

Ferdinandus de Uranga fit episcopus Cubensis per obitum. Arch. Brev., Julius III., vol. 2, Provisiones, p. 73.

1550. Cubensis episcopus.

D. C. Julii III., 160 , p. I I 3 .

1551, Apr. 19. Julii Papae 3. Brevis indulti consecrationis pro Ferdinando de

Uranga electo Cubensi in Indiis occidentalibus. Minutes of Briefs, Julius III., lib. 60, no. 284.

1561, Jun. 27. Bernardus Vilalpando ordinis S. A. fit episcopus Cubensis per obitum Ferdinandi de Uranga.

Consist. 109, p. 280.

1561, Jun. 27. Barnardinus a Vilalpando fit episcopus Cubensis per obitum Ferdinandi de Uranga al. Thome de Sancto Martino. Consist. 109, p. $289 ; 158$, p. Ioo.

1564, Apr. 28. Joannes de Castillo fit episcopus Cubensis per translationem Bernardini ad Guatimalensem.

Consist. 109, 321 ; 158, $32 \mathrm{I}$.

1578, Sept. 5. Joannes de Castello episcopus Cubensis cedit. Consist. 109, p. 528.

1578, Oct. 3. Vacatio ecclesie Cubensis per cessionem episcopi in manibus Suae Sanctitatis sponte et libere factam ob adversam valetudinem. Cons. S. C., p. I2. 
1580, Mar. II. Joannes Antonius Diez fit episcopus Cubensis in Indiis per cessionem Joannis de Castello.

Consist. 109, 556; 144, I $30 ; 143,233$.

1580, Mar. I4. Frater Antonius Diez ordinis Sancti Francisci de observantia presbiter, theologus, fit episcopus Cubensis in Indiis maris oceani per cessionem Joannis de Castello.

Cons. S. C., p. 6.

1584. Joannes de Castillo Cubensis quondam episcopus.

Castello Arm. XI., caps. III., no. I7.

1597, Nov. 2. Bartholomeus Plaza ordinis Minorum fit episcopus Sancti Jacobi de Cuba per translationem Antonii Diaz ad Nicaragua.

Consist. 120, p. 223; 160, p. I23.

1597. Propositio Sancti Jacobi de Cuba per translationem Antonii Diaz de Salzedo ad Nigaraguam pro Bartholomeo Plaza. Consist. 145 , p. 495.

1601. D. Johannes Cabez de Altamira ordinis Praedicatorum episcopus Sancti Jacobi de Cuba in eiusdem nominatione Insulae Americae. Brev. 5, p. 627.

1602, Apr. I5. Joannes de Las Carceras ordinis Praedicatorum fit episcopus Sancti Jacobi de Cuba per translationem Antonii ad Nicaraguam. Consist. 128, p. 75 .

1610, Aug. 30. Alfonsus Sidonicensis ad de Cuba translatus per translationem Joannis ad Guatimalensem.

1626, $A p r$. 29. Gregorius de Alarcon fit episcopus Sancti Jacobi de Cuba per translationem Alfonsi ad Mecoacanensem.

Consist. 130, p. $24 ; 136$, p. 26.

Propositio Sancti Jacobi de Cuba per translationem Alfonsi Enriquez ad Mecoacanensem pro Gregorio de Alarcon.

Consist. 145, p. 443.

Alphonsus Henriquez episcopus Sancti Jacobi de Cuba ad Mecoacanensem translatus, v. I6I.

1625, Dec. I. Leonellus de Cerbantes de Sancta Marthe ad Sancti Jacobi de Cuba translatus per obitum Gregorii de Alarcon. Consist. 130, p. $55 ; 136$, p. 55 .

1630, Jan. 7. Jeronimus de Lara fit episcopus Sancti Jacobi de Cuba per translationem Leonelli de Cerbantes ad de Guadalaxara. Consist. 130, p. I $32 ; 136$, p. I43.

1645, Nov. 20. Martinus de Zelaia Ocariz fit episcopus Sancti Jacobi de Cuba per obitum Jeronimi de Lara. Consist. 131, p. 23.

1649, Sept. I3. Nicolaus de la Torre fit episcopus Sancti Jacobi de Cuba per cessionem Martini de Celaya alias Celaya Ocariz.

Provisiones Secretae Curiae 11, p. I58; Consist. 131, p. 99.

1655, Maii I4. Joannes de Monis alias Montiel fit episcopus Sancti Jacobi de Cuba per obitum Nicolai de la Torre.

Provisiones Secretae Curiae 11, p. 262 ; Consist. 132, p. 3.

1659, Nov. Io. Petrus de Reina Maldonado fit episcopus Sancti Jacobi de Cupa [sic] per obitum Johannis Montiel. Consist. 132, p. I05.

1661, Aug. 8. Joannes Soenz alias Saenz de Manosca fit episcopus Sancti Jacobi de Cuba per obitum Petri de La Reina. Consist. 132, p. I68; Provisiones Secretae Curiae 13, p. II2. 
1668, Sept. I7. Alfonsus Bernardi fit episcopus Sancti Jacobi de Cuba per translationem Johannis Sanz ad Guatimalensem.

Consist. 133, p. 56.

1671, Dec. I4. Gabriel Diez Bara Calderon presbiter fit episcopus Sancti Jacobi de Cuba per translationem Alfonsi Bernardi de los Rios ad Civitatensem.

Consist. 133, p. $208 ; 138$, p. 90.

1677, Sept. I3. Joannes Garcia de Palacios presbiter fit episcopus sancti Jacobi de Cuba per obitum Gabrielis Diaz.

Consist. 136, p. 27.

1683, Mar. IO. Baltasar de figuira [Figueroa] ordinis Cisterciensis fit episcopus sancti Jacobi de Cuba per obitum Johannis Garzia. Consist. 134, p. I 52.

1685, Jun. 4. Didacus de Hebbelino [Evellino] presbiter fit episcopus sancti Jacobi de Cuba per obitum Baltassaris de Figueroa. Consist. 134, p. I88.

1705, Dec. I4. Hieronimus de Waldes episcopus de Portorico transfertur ad ecclesiam sancti Jacobi de Cuba in Indiis occidentalibus per obitum Didaci Evellini.

S. C., p. I49.

1705. Suffraganeus Cubanus. $V$. Adranisten.

1707. Cubanae Ecclesiae provisio. $V$. Portorico.

1730, Sept. I I. Per obitum Hieronimi de Valdes fit episcopus Sancti Jacobi de Cuba Gaspar de Molina presbiter fratrum Heremitarum Sancti Augustini.

Cons. S. C., p. 24.

1731. Gaspar de Molina ex episcopatu Cubensi fit Barcinonensis. Aymerick, p. 43 r.

1731, Nov. I9. Per translationem Gasparis de Molina ad Barchinonensem ecclesiam fit episcopus sancti Jacobi de Cuba in Indiis occidentalibus frater Johannes Lasso de La Vega presbiter ordinis Minorum.

Cons. S. C., p. I73.

1746, Sept. I3. Buen Retiro. Nominatur ad episcopatum Cubensem vacantem per translationem episcopi ad Merida Yucatan. Petrus Ponce y Carrasco provisor et vicarius generalis in eodem episcopatu.

Nominat., vol. 3, p. 37 .

1753, Mar. 30. Buen Retiro. Nominatur ad episcopatum de Cuba vacantem per obitum Johannis de Laso de La Vega Petrus Augustinus Mored de Sancta Cruce episcopus in Nicaragua.

Nominat., vol. 3, p. 64.

INDICE 503. VESCOVI 29.

Ludovicus Franciscus de Mornay et Petrus Herman Dosquet Quebecensis episcopus.

Gall. Ch., X. 490. B.

Quebecensis. Franciscus de Laval de Montmorency Kebecensis episcopus.

Gall. Ch., VI. 673. C.

Quebecensium episcoporum catalogus:

Franciscus de la Val fit anno I674 renunciavit anno I685. Obiit I708.

Johannes Baptista LaCroix Chevrière obiit I727. 
Ludovicus Franciscus de Mornay cessit anno I733.

Petrus Herman Dosquet cessit anno I738.

Franciscus Ludovicus de Lauberivière obiit anno I739.

Henricus Maria du Breil de Pontbriant creatur anno I740.

Gall. Ch., vol. VII., p. 1032.

1659, Jul. 3I. Quebeci. Francisci de Laval episcopi vicarii apostolici in nova Francia epistola.

Lettere, Vescovi, 44, p. 145.

1668, Oct. 26. Epistola Francisci episcopi Petrensis vicarii apostolici Quebecensis.

Letter, Vescovi, 53, p. 324.

1674, Oct. I. Erectio oppidi de Quibec in civitatem.

Consist. 133, pp. 333, 334; 138, p. I52.

1675, Feb. 8. Franciscus episcopus de Petren. ad dictam ecclesiam transfertur.

1675, Feb. 8. Francisci episcopi Quebecensis epistola.

Letter, Vescovi, 61, p. I75.

1677, Oct. I5. Francisci episcopi Quebecensis epistola.

Lettere, Vescovi, 63, p. 428.

1678. Francisco episcopo Quebecensi qui laudaverat Jesuitas.

Brev., Inn. XI., year 2, p. 69.

1680, Nov. I3. Francisci episcopi Quebecensis epistola.

Lettere, Vescovi, 66, p. 276.

1679. Francisco episcopo Quebecensi ad litteras 27. Jan. quibus nunciavit se ad Galliae regem profecturum pro nonnullis tractandis circa catholicam religionem.

Brev., Inn. XI., year 3, p. 209.

1681. Francisco episcopo Quebecensi ad eius litteras Nov. I680.

Brev., Inn. XI., year 5, p. 24I.

1685, Maii 20. Francisci primi episcopi Quebecensis epistola.

Lettere, Vescovi, 71, pp. I36, I39.

1687. Joanni a Cruce designato episcopo Quebecensi de prosperis catholicae fidei successibus in dicta dioecesi.

Brev., Inn. XI., year I2, p. I.

1687, Jul.7. Joannes Baptista de Croix presbiter fit episcopus Quebecensis per cessionem Francisci de la Val.

Consist. 134, p. 220.

1687, Aug. II. Parisiis. Joannis designati episcopi Quebecensis epistola. Lettere, Vescovi, 53, p. 195 .

1695, $A p r$. 8. Parisiis. Joannis episcopi Quebecensis epistola. Lettere, Vescovi, 87, pp. 77, 79.

1695, Maii I2. Joanni Quebecensi episcopo datur pensio 500 librarum Turonensium super bonis monasterii de Gimont Auxitanensis dioecesis.

S. C., p. II 2 .

1703. Joanni episcopo Quebecensi.

Brev., Clem. XI., year 3, p. 79.

1703, Jan. 3. Commendatur aliquibus cardinalibus in Gallia Joannes Baptista episcopus Quebecensis a sua ecclesia reversurus.

Brev., Clem. XI., year 3, pp. I 5-17.

1703, Mar. 5. Parisiis. Joannis episcopi Quebecensis epistola.

Lettere, Vescovi, 97, p. I66.

1705. Lettere, Vescovi, 54, pp. 309, 3II, 34I. 
1714, Feb. I6. Ludovicus Franciscus de Mornay presbiter ordinis fratrum Cappuccinorum episcopus Eumeniensis coadiutor cum futura successione Joannis Baptista de la Croix de Saint Vallier episcopi Quebecensis in Indiis occidentalibus.

Cons. S. C., p. 167.

1730, Jul. 24. Petrus Hermannus Dosquet episcopus Samiensis fit coadiutor Ludovici Francisci de Mornay episcopi Quebecensis in Indiis occidentalibus cum futura successione.

Cons. S. C., p. I 5 .

1739, Jul. 20. Per liberam dimissionem Petri Hermanni Dosquet fit episcopus Quebecensis in Indiis occidentalibus Franciscus Ludovicus de Pourroy de Lauberiviere presbiter Gratianopoliensis dioecesis. Cons. S. C., p. 203. 


\section{INDEX.}

Abbacy, and bishopric of Quebec, I59, I60, I63, I70 Abbreviator, apostolic, in Spain, 45

Acadia, inhabitants of, 80 ; Indians of, 80 ; missions of, I54, I57, I64, I9 I

Acapulco, port of, 68

Acta, or Acts, consistorial, 37, 38, 42, 50, 97, 9899, I02, IO7, III, 2I2, 2I 5, 2I7, 227 ; miscellaneous, 40, 4I, 42

Acta Camerarii, 39

Acta Cancellarii, 39

Acts, legislative, formulas for, $22 \mathrm{I}$; of the Council of Trent, 99

Adams, John, arrival in France, 74, 75, 24I ; letter of, 24I ; reception by George III., 24I ; treaty with Sardinia, 247

Adrian VI., annotations to bull of, I52; brief of, I86; bull of, I32; consistories of, 39 ; favors granted by, 132

Advices, see Avvisi

Affari Esteri, 233-236

Affari Riservati, 236

Africa, Dutch in, 90; map of, II7; missions of, I I7 ; plan of fortification in, I I6

Agreements, books of, 209

Agucchio, Mgr. Giovanni Battista, instructions by, Io9; letters, 48 , I I0, 226

Aix-la-Chapelle, letters from, 84; peace of, 74

Alabama, church affairs in, I46; vicar apostolic of, 145

Alarcon, Gregorio de, bishop of Santiago de Cuba, election, and death of, 255

Albani, Giovanni Francesco, see Clement XI.

Albani family, papers of, 8

Albani library, $94 \mathrm{n}$

Albemarle, Earl of, dispute of, 80

Albergati, Marchese Francesco, instructions to recommend, 73

Alberi, Eugenio, Le Relazioni degli Ambasciatori $V$ eneti, $238 \mathrm{n}$

Aldobrandini, Cardinal Pietro, papal secretary of state, letters, 96, 97, 99, 105, 107, 226, 228, 23I ; register of, 106

Aldobrandini family, archives of, 228

Alessandrino, Cardinal (Michele Bonelli), letters, $6 \mathrm{I}, 92$

Alexander VI., briefs of, I07; bulls of, 59, $60 \mathrm{n}$, 82 , I94; consistorial acts of, III ; register of, $23-24$

Alexander VII. (Fabio Chigi), briefs of, 29; bulls of, 35 ; collection of, 8,225 ; consistorial acts of, 99 ; establishment of archives by, 52; France and, 48; letters of, 226, 227 ; library founded by, 207 ; material relating to pontificate of, 226

Alexander VIII. (Pietro Ottobuoni), bulls of, 35 ; collection of, 8 , IO9-III; correspond- ence, as secretary of state, $68,93,95$; letter to, 93 ; transfers to archives by, 52

Alexandria, Patriarch of, see Caetano, Mgr. Camillo

Algerines, and fleet of Indies, 2I4

Algonquins, in Canada, I54

Alleghany mountains, necessity of archbishopric beyond, I73

Almyra, Bishop of (Jean François Hubert), consecration of, I64; see also Hubert

Altieri, Cardinal Emilio, see Clement X.

Alumni, American, I73

Amaduzzi, G. C., paper by, 252

Ambassadors, correspondence, 232; see also names of countries, governments, and individual ambassadors, e. g., Spain, Ambassador of; Venetian ambassadors; Suriano, Michele, Venetian ambassador

Ambruno, A. P. di, relation by, 103

America, II2, II3; archbishops and bishops in, I83; arrival of vessels from, $67,67 \mathrm{n} ; \mathrm{Bel}-$ gian nuncio and, 78; Bible distributed in, 96; bishops of, letters, I9I ; briefs relating to, $30,3 \mathrm{I}, 43$, I94; bulls relating to, $23,25-$ 26; Capuchins in, I28, I35, I50, I5 I, I57 ; Carmelites in, 137 , I39; church relations with Rome, 7; circumnavigation of, II4; colleges of, I40; commerce of, $66,74,84$ 92,239 ; confirmation in, I86; conquest and exploration of, 208 ; consistorial material concerning, 37-38, 39; conversions in, I56, I84; customs of, II2; difficulty of securing news of, 60-6I; dioceses of, II8; discovery of, I09, I83, 208, 220; division of, I56; Dutch Catholics in, I39; Dominicans for, I78; earthquake in, I04; ecclesiastical revenues of, 67, 94, 96, 138, 210; English in, 79, I39; erection of bishoprics in, 4I, I43; evacuation of places in, 79; faculties for, I29, I38, I39, I56 ; forwarding letters to, 66; Franciscans in, I39; French in, I29; Huguenots in, 47 ; immunity in, 67 ; institute founded in, I76; Italy and, I-2; Jesuits in, I00, I3I, I38; maps of, I03, I I7, I49, I5 I, 250; military operations in, 74; Minor Observants in, I39; missionaries for, I36, I4I, I5 I, I52, I72; missions in, 92, II7, I28, I29, I33. I38, I52, I79; naval contest in, 66 ; Neapolitan consulate in, 235 ; news-letters concerning, 54-55; nominations of bishops in, I82 ; nunciature for, 60,61 ; nunciature material relating to, 56-57; petition concerning, 27 ; pirates in, $67,8 \mathrm{I}$; plans of parliament concerning, 80; Portuguese in, 82; prefecture for, I34, I38, I39, I69; privateers in, 82 ; privileges granted ecclesiastics in, I2I ; pro- 
curators for, I04; Propaganda and, II9, I2O, I2I ; Puritans in, I50; regulars in, discipline of, I05; relations between England and Spain in, 82, II3, I87; relations of, 92, I04, I29; rights of bishops of, 220; route to the Philippine islands from, II3; rumor of war with Portugal, 74; seminaries in, I35, I48, I8I, I86; slave contracts in, 84; state of bishops in, I8I; state of religion in, IOI; subsidies for defence of, 94 ; terrestrial paradise in, $2 \mathrm{I} 8$; vicars apostolic in, I6I; visitation in, 59; volume relating to, 95; see also North America; South America; United States; names of particular places

America, islands of, faculties for, $31,95,136$; Capuchins in, I38; Carmelites of, I35, I36; Jesuits in, I37; missions in, 130 ; prefecture for, I3I, I36; voyage to, I3I

"America Occidentalis", spiritual needs of, I57 American Catholic Historical Society, Philadelphia, Records of, 38

American College (Rome), 195, 205

American Historical Review, I06, I4I, \I70 n, I7 I $\mathrm{n}, \mathrm{I94} \mathrm{n}$

American history, usefulness of Italian archives for, I3-I4

American legation (Rome), archives of, 22I222

American Revolution, material relating to, 74 , 75, 84-85, 97, I I8, 233, 240, 24I, 246, 249

Amice, advocate, opinion of, I68

Amyclenus, T., Tractatus de Officio Datarii, $201 \mathrm{n}$

Anaga, José, petition of, I34

Analecta Bollandiana, I7 n

Analecta Vaticano-Belgica, 26 n

Anales del Museo Nacional de Mexico, i95 n

Ancel, R., "La Secrétairerie Pontificale sous Paul V.", $52 \mathrm{n}$; "Etude Critique sur quelques Recueils d'Avvisi ", 55 n, 78 n

Andalusia, orders of captain-general of coast of, II 3

Andrada, Gaspar de, bishop of Honduras, oath of, 65

Anepe, Franciscans of, 223

Angelelli, Ottavio, bishop of Gubbio, paper by, I72

Angeli, Father Melchiorre degli, favors denied, I34

Angelo, Father Michel, prefect of Capuchin missions, I34

Anna and Gioacchino, Saints, monastery of, 95 Annali della Propagazione della Fede, I22

Annates, 5, 34, 210

Anne, queen of England, demands of, 84

Anticosti, jurisdiction over island of, 144

Antioch, Patriarch of, in Mexico, 3 I ; letters of, 82

Antisio, Juan de, and bishopric of Santiago de Cuba, 254

Anti-Spanish party, $73 \mathrm{n}$

Antonio, Don (called king of Portugal), attack by, II 4
Antwerp, as news-centre, 78 ; news-letters from, 90, I08, II3, II4, II 5, II6; rejoicing in, 78; relation of peace of, 207

Apaches, hatred of, 219

Apalache, province of, 95

Apocalypse of Holland, Ioo, I09, 2II, 215

Apochae, 39

Apollombamba, missions in, I40, I86

Appendix, 253-258

Aragon, bull granting rights in, 24

Archbishops, in America, I83; letters and papers of, 69, 86, I93; see also particular sees; names of individual archbishops, e. g., Baltimore, Archbishop of ; Carroll, John, archbishop of Baltimore

Archinto, Cardinal Giuseppe, nuncio in Spain, letters of, 94

Archives, condition of material in, IO-II ; consistorial, 36-42; guides to Roman, I2-I3; monastic, 8-9, 203-205; national, 9; of American legation, 22I-222; of Avignon, 33, 34, 90; of Doria-Pamphili family, 227 ; of Florence, 209, 249-250; of kingdom of Italy, 9; of kingdom of Sardinia, 9; of secretary of briefs, $42-43$; of secretary of state, 52-89; pontifical, 7-8; public, in Rome, 207220; Vatican, 20-100; see also under Archivio; libraries, and collections of persons, places, and orders

Archives Nationales, Paris, I7

Archivio Castello, see Castello Sant' Angelo

Archivio Consistoriale, 39-42

Archivio della Camera di Commercio e dell' Università dei Mercanti (Milan), 25I

Archivio de los Reales Establecimientos Españoles en Roma, 224

Archivio di Bolle, see Regesta Lateranensia

Archivio di Stato, Florence, 249-250; Lucca, 25I ; Naples, 229-236; Parma, 252; Rome, 34, 209-210; Venice, 237-244

Archivio Farnesiano, 230-233

Archivio Nazionale, Turin, 246

Archivio Proprio, of the consistories, $38-39$

Archivio Segreto, I8, 20-5I, 90

Archivio Vaticano, see Vatican Archives

Archivum Franciscanum Historicum, 205

Ardinghelli, Giuliano (?), letters of, 23I

Ardinghelli, Pietro, secretary of state, 53 ; letters of, 250

Arezzo, archives of, $25 \mathrm{I}$

Armagh, Archbishop of (Patrick Curtis), letter of, IBI

Armagh, priests and administrators of, I8I

Armstrong, John, minister in France, response of, I79

Arnold, Robert, Repertorium Germanicum, 24 n, $28 \mathrm{n}$

Arpineus, Brother Carolus, mission of, I27

Arras, diocese of, I35

Artassona, Father Felice d', letter of, I32

Arundel, Earl of, see Howard, Thomas

Asia, barbarians of, 208; missions of, II7

Assemani, C., index by, $225 \mathrm{n}$

Association, Articles of, 234

Associazione Leopoldina (Vienna), i I8 
Atlantic Ocean, island discovered in, ror

Atlas, see Maps

Atti series, I23-I47

Auberivière, François Louis de 1', bishop of Quebec, 257, 258

Audiences, papal, 36,180

Auditors, letters, 69, 108

Augustine, Saint, order of, see Augustinians

Augustinians, bulls relating to, 35 ; documents of, 98 ; in West Indies, I50; library given to, 207; license to prefect of, $\mathrm{r} 33$; province of, I05; provincial of, papers, 93 , I90; provision for, I29; relation by, I70; request of, 136

Austrian Institute, work of, II, 57

Avalonia, island of, I1O, I23, I25, I50; missions of, I49

Avignon, archives of, 33, 34, 90; legation of, 85 ; registers, 42

Aviz, Abbé, reflections of, 219

Avvisi, 90, 93, 97, III, II6, 244; see also Newsletters

Ayuvale, English heretics at, 95

Azara, Dr. Joseph Nicolas de, letter to, 223

Azores, English in, 63; French in, 61, 62, 63; Portuguese in, 63 ; victory off the, I04

Azzolini collection, 228

Bacha, Eugène, "Les Collections Historiques des Archives du Vatican", $45 \mathrm{n}$

Badin, Rev. Stephen, letters concerning, I75

Bagno, Guidi del, archbishop of Patras, nuncio in Flanders, rog; nuncio in France, $72 \mathrm{n}$; nuncio in Spain, 2II

Bailly de Messein, Charles François, bishop coadjutor of Quebec, appointment of, I4I ; attestation concerning, I64; bull for, I64; sepulchres and, 165

Balambanca, island of, 234

Balloni, Domenico, relation by, 245

Balsamini (Bolcamini; Balziaminus), Onorigiano, documents of, II7

Baltimore, Archbishop of, brief to, I79; cession to, I45; choice of administrator committed to, I42; contest of, I75; death of, I76; difficulties of, I44; jurisdiction of, I45, I85; letters, I67, I75, I76, I77, I78, I79, I80, I81, 182, 185, 192; questions of, I45; see also names of individual archbishops of Baltimore

Baltimore, Bishop of, correspondence, 86, I4I, I72, I73, I74, I75; decree for, I75; dispute of, I73, I74; faculties for, I74; oath of, I4I ; see also Carroll, John

Baltimore, Lord, activity of, 156 ; see also Calvert, Cecil

Baltimore, brief for archbishopric of, I42, I75; cathedral of, I79; church for Germans at, I74; coadjutorship of, I73, I74, I77, I78; college at, I45, 173, 176, I95; criminal jurisdiction in, I45; foundation of bishopric of, I4I, I92; Franciscans at, I74; German priests for, I75; letter of vicar-general of, I78; matrimonial dispensations for, I8I ; note on see of, I75; publication of decrees in, I74; relation of church of, $\mathrm{I} 4 \mathrm{I}$; request for Dominican province in, I42 ; state of religion in, I78, I79; Sulpicians of, I79, I92 ; synod of, I4I, I42, I47, I78; Trappists for, I75 ; vicar apostolic requested for, I72 ; visitation of archdiocese of, $\mathrm{I} 44$; see also Baltimore, Archbishop of; Baltimore, Bishop of ; Maryland; names of individual archbishops of Baltimore, e.g., Neale, Leonard

Bandi collection, 90, I99

Baptism, brief concerning, 2I7; resolutions on subject of, 139

Barbados, 245

Barbaro, Daniele, relation by, 252

Barberini, Cardinal Francesco, 47, I0I ; correspondence, 85,85 n, 102, 105, 106, 107, 108, 212, 226; memoirs of, 2 II ; relations, I04, I56, 216; voyage of, 107

Barberini, Cardinal Maffeo, see Urban VIII.

Barberini archives, IOI

Barberini family, IOI; Propaganda under the, II9

Barberini library, 8, 54, 8I, 85, ror-108; Colonna material in, 228; transcripts in Public Record Office, I05

Barcelona, transfer of bishop to, 256

Bardstown, Bishop of, coadjutor of, I43; difficulties proposed by, I78; letters and papers of, I43, I47, I75, I76, I79, I8I ; translation of, I77; see also names of individual bishops of Bardstown, e. g., David, Jean

Bardstown, decrees of synod of, I46; deputy of mission of, I77; erection of diocese of, I42; letter from priest of, I43; relation of, I78; seminary of, I79; state of diocese of, I76; see also Bardstown, Bishop of ; Kentucky

Barone, Nicola, Notizie risguardanti l'Archivio Farnesiano, $230 \mathrm{n}$

Baronitus, Cardinal Cesare, collection of, i $6 \mathrm{n}$, 216; volume addressed to, II2

Barozzi, Nicolo, Relazioni degli Ambasciatori Veneti, $238 \mathrm{n}$

Bartoli, $M g r$. Cesare, letters, 80

Bartolommeo, Brother, request of, I6I

Baschet, Armand, Les Archives de Venise, 237

Basilians, documents of, 98

Bathurst, Lord, letters of, I67, I68; project of, 146

Baumgarten, $M g r$. P. M., Untersuchungen über die Camera Collegii Cardinalium, $34 \mathrm{n}$

Bazan, Don Alvaro de, letters of, 220

Beamans, M., letters of, I75

Beatification, jurisdiction in, 199

Beaumont, Father Philippe, prefect, I3I

Bedard, Father, questions and resolutions of, I 46

Belgian Institute, II

Belgium, functions of nuncios in, 78

Belluno, Brother Mario di, recommended as missionary, 186

Benavides, Father Alfonso, attestation by, I50; letter of, I 5 ; relations by, I25, I56

Benavides y Bazan, Antonio, patriarch of the Indies, letters to, 68 
Benavides y la Piedrola, Antonio, bishop of Carthagena, case of, 67,68 ; letters from, 67 Benedict XIII., bulls of, 25

Benedict XIV., briefs of, I39, I86; bulls of, 25; letters to, 87 ; matters consistorial of, $5 \mathrm{I}$

Benefices, 34

Benfratelli, suppression of convents of, $67 \mathrm{n}$

Benigni, $M g r$. Umberto, $75 \mathrm{n}$

Bentivoglio, Cardinal Guido, letters of, 99 ; relations by, I00, 207

Bequet, M., letter of, 184

Berchet, Guglielmo, Relazioni degli Ambasciatori Veneti, $238 \mathrm{n}$

Berger, Elie, "Léon XIII. et les Etudes Historiques", 9 n

Berlanga, Father Thomas de, request for appointment of, 44

Berlière, Dom Ursmer, Aux Archives Vaticanes, II n; Inventaire Analytique des Diversa Cameralia, $32 \mathrm{n}$; Inventaire Analytique des Libri Obligationum et Solutionum, $5 \mathrm{n}, 32 \mathrm{n}, 34 \mathrm{n}, 42 \mathrm{n}, 209 \mathrm{n}$; Suppliques de Clément VI., $26 \mathrm{n}$

Bermuda, II5; capture in port of, $8 \mathrm{I}$; care of Catholics of, I43; marriage of Charles I. and islands of, 102

Bertignières, M. de, speech of, 75

Bertrando, Saint Ludovico, relation of miracle by, 103

Berzetti di Murazzano, Col. Buronzo, copyist, 246

Bessaigha, Joannes, index by, $46 \mathrm{n}$; see also Bissaigha

Bethlehem, bishops of, 95

Bianchi, Nicomede, Le Materie Politiche degli Archivi di Stato Piemontese, 246

Bianchini collection, 216

Bible, of the heretics, 96

Biblioteca Albani, 94

Biblioteca Alessandrina, 207

Biblioteca Ambrosiana, 25I

Biblioteca Angelica, 207-208

Biblioteca Bolognetti, 9I-92

Biblioteca Carpegna, 93-94

Biblioteca Casanatense, 210-2I2

Biblioteca Ciampini, 94

Biblioteca Classense (Ravenna), 252

Biblioteca Communale (Forli), 25I

Biblioteca Communale (Perugia), 252

Biblioteca Communale (Savignano di Romagna), 252

Biblioteca di Consultazione, see Vatican Library of Consultation

Biblioteca della Fraternità di S. Maria, 25I

Biblioteca Dominicana (Perugia), 252

Biblioteca Guarnacci (Volterra), 252

Biblioteca Lancisiana, 216

Biblioteca Marciana, 239, 245

Biblioteca Nazionale (Naples), 229

Biblioteca Nazionale (Turin), 248

Biblioteca Nazionale Centrale Vittorio Emanuele, 35, 209, 217-220

Biblioteca Oratoria di Napoli, 229

Biblioteca Pio, 40, 4I, 98-100

Biblioteca Ronconi, roo
Biblioteca Vallicelliana, 216-217

Biblioteca Vaticana, see Vatican Library

Bibliotheca Vaticana, Ir6-I I8

Bibliothèque Nationale (Paris), I2, 17, 200

Biche, $M g r$., instructions to, 99

Biglia, Giovanni Battista, letters of, 65

Biglietti e Memorie, 89

Bilbao, American vessels at, 235

Binus, Jo. Franciscus, 39

Biographies, collection of, 208

Biord, Jean P., bishop of Geneva, letter of, I62

Birchfield, Ireland, letters from, I82

Bishoprics, erection of, I92; titular, II7; see also particular dioceses and bishops

Bishops, agreement of trustees and, I45; appointments of, 50 ; bulls to, 25-26; conflicts with regulars, I95; correspondence of, 69 , $86,87,88$, I07, I08, II8, I9I ; election of, I74, I76, I78, I80, 182, I97; grant of additional powers to, 2I4; papers of, 50, 5I, I93; payments made by, 210; rights of, 220 ; state of, in America, I8I ; subordination of priests to, I45; see also names of particular places and bishops, e. g., Quebec, Bishop of; Connolly, John, bishop of New York

Bissaigha, index by, 202; see also Bessaigha

Blackfeet Indians, mission to, 219

Bliss, W. H., I2

Blok, P. J., studies by, I22; Verslag van Onderzoekingen naar Archivalia in Italië, 13, $207 \mathrm{n}, 209 \mathrm{n}, 210 \mathrm{n}, 216 \mathrm{n}, 229,237 \mathrm{n}, 246$, $249 \mathrm{n}, 25 \mathrm{In}$

Blosius, letters of, 39

Bogotá, see Santa $\mathrm{Fe}$ de Bogotá

Bohemia, material relating to, 23I

Bolfino, Giovanni Maria, compilation by, II7

Bolivar, Father Gregorio, mission of, I23; relation of, I52

Bologna, council of, see Council of Bologna; legation of, 85

Bolognetti, Cardinal Mario, manuscripts of, 9I Bolognetti Cenci, Count, library of, 9I

Bolognetti collection, list of, 50

Bonaini, Archivi dell'Emilia, $230 \mathrm{n}$

Bonaventura, Father, letter concerning, I49

Boncompagni, Cardinal Ugo, see Gregory XIII.

Boncompagni library, 228

Boncompagni-Ludovisi family, archives of, 8, 228

Bonelli, Michele, see Alessandrino, Cardinal

Bonet, Father Felice, request for bishopric for, 68

Boniface VIII., consistorial acts, III

Bonziananni, M., letter of, 65

Bordeaux, American vessels at, 235; matrimonial bull for diocese of, 26 ; reception of students by archbishop of, I72

Borghese, Cardinal Camillo, see Paul V.

Borghese, Cardinal Scipione, manuscripts of, 93 Borghese family, collection of, 8, 85, 92-93, 228 Borgia, Cardinal Gasparo, attack by, ro3

Borgia, Mexican manuscripts, 195

Borgia collection, 108-109, 198

Borgino, P., treatise by, II7

Borromeo, Saint Carlo, secretary of state, 5 ; papers of, $8,213,25 \mathrm{I}$ 
Boston, Bishop of, see Cheverus, Jean Lefèvre de

Boston, English at, 75, 234; erection of diocese of, I 42 ; founder of Catholic church of, I72; letter of priest at, I73; selection of bishop of, 146

Boston Port Bill, 234

Bottini, registers of, 33

Botzini, Giovanni Maria, paper by, II7

Bourgeoys, Sxur Marguérite, I58

Bourgin, Georges, Les Archives Pontificales et l'Histoire Moderne de la France, I2 et passim; "L'Incendie de la Bibliothèque de Turin", $248 \mathrm{n}$; "Liste des Nonces", 7I n; Manuscrits du Fondo Gesuitico, 218 '

Braddock, General Edward, defeat of, 240, 242

Bragadin, Daniele, relation by, 239

Braidus, Father Petrus, letter of, 195

Brancacciano archives, 229

Brancadoro, Cardinal, letter of, I74

Brazil, documents relating to, 187 ; missionary work in, 203

Breil de Pontbriand, Henri Marie, bishop of Quebec, 257

Bressani, Brother F. G., history by, I95

Bretons, corsairs, II4; in Florida, I03; see also French

Briand, Olivier, bishop of Quebec, brief for, I6I ; consecration of, I6I ; correspondence of, I40, I6I, I70, I84; election of, I9I; faculties for, I6I; form of oath of, I6I; renunciation by, I63; sickness of, I63; voyage of, I6I

Briefs, 250; episcopal, I75, I94; faculties for executing, I36; for Canada, I6I; for the making of new dioceses, I92; in archives of secretary of briefs, 43 ; information concerning, 4, 20-2I ; Lateran, 3I ; minutes of, 43; of indulgences, 49, I6I; on slaves and negroes, I94; pontifical, 232 ; register of, 27-30; secretary of, $4-5,27-28$; to Charles II., I32; to princes, 30-3I, IO6; see also names of popes, e. g., Urban VIII., briefs of

British Empire, see Great Britain

British islands, assigned to religious orders, I34; request for missions in, I34; vicar apostolic in, I43; see also England

Brom, Dr. G., Archivalia in Italië, I3 n, 26 n; Guide aux Archives du Vatican, I3

Brooke, Lord, see Greville, Robert

Brown, James, U. S. minister, interview with, 183

Brown, Rawdon, L'Archivio di Venezia, 237, $237 \mathrm{n}$

Browne, Father Robert, case of, I68, I77, 178, I8I, I83 $n$

Brunetti, Corsino, relation by, 92

Brurius, $M g r$., letter concerning, I76

Brussels, letters from, II4, I28; nunciature of, $60,77-78$, I20; papers of nuncios at, $80, \mathrm{I} 3 \mathrm{I}$, I56, I70

Buccheri, 208

Buchanan, James, autograph of, 248
Buckley, Jacob, vicar apostolic for English islands, volume by, I85

Buglione, Cardinal, letters of, 48

Buil, Fray Bernardo, bull to, 23

Bullarium de Propaganda Fide, I22

Bullon, Father Francesco, request of, I34

Bulls, I06, 250; for California, 223; for erection of dioceses, 155, I59, I79, 223; for vicar apostolic of Canada, I29; in archives of secretary of briefs, 42-43; information concerning, 20-2I; matrimonial, 26; of churches, 218 ; of indulgences, 35 ; of jubilee, $2 \mathrm{I} 4$; of monasteries, 230 ; of motu proprio, 35 ; of sixteenth and seventeenth centuries, 35 ; of suspension, $2 \mathrm{I} 4$; pertaining to Spain, 24, 35; registry of, 22-23; to Augustinians, 35 ; to auxiliary bishop of Cuba, 222 ; to Bernardo Buil, 23 ; to bishops, 2526 ; to Ferdinand and Isabella, 23, 24; see also names of popes, e. g., Paul V., bulls of Buoncompagni, Count Hugo, $94 \mathrm{n}$

Buoncompagni-Ludovisi family, papers of, 8, 228

Burchardus, Johannes, Diarium, 203

Burgoyne, General John, capture of, 75

Burke, Edmund, vicar apostolic of Halifax, I43, I76; vicar-general of Quebec, I65

Cabezas, Juan, bishop of Santiago de Cuba, election, and transfer of, 255

Cabio, Mario, letter of, 65

Cadiz, agents at, I70

Caetani family, collection of, 207, 225

Caetano, Camillo, patriarch of Alexandria, nuncio in Spain, 9I ; correspondence, $59 \mathrm{n}$, 92, 105, I07, 215

Calendar of State Papers, Venetian, $237 \mathrm{n}$

Caleppi, Mgr., letter to, 97

California, 219; bull for, 223; Christianity in, 169; Dominicans in, 193; Franciscans of, 223; Jesuits in, 91; missions of, I27, I74, 219

Calvert, Cecil (Lord Baltimore), I02 ; marriage of, $2 \mathrm{II}$; oath of, $8 \mathrm{I}$, IO5; papers concerning, $8 \mathrm{I}$

Calvert family, 8I

Camacho y Avila, Didaco, bishop of Guadalaxara, letters from, I35

Cambrai, monastery in diocese of, I 35

Camera, accounts, 3I, 90, II8; archives, 3I-34, 202 ; described, 5 ; documents relating to, 45 , III, 209, 2I5; letters of secretary of, I05, 108

Camerarius, sce Chamberlain

Camerino, Pietro, letters of, I05

Camerlingo, see Chamberlain

Campanella, Francesco, treatise by, 2 I 3

Campelli, letters of, 69

Campos, Gregorio Francesco de, bishop of La Paz, letters, I86; missions subject to, I4O

Camus du Peron, Dom Charles, mission of, I26, I90

Canada, I03, II5; Albergati in, 73; Algonquins in, I54; attitude of England towards Catholics of, $162,164,165,166$; baptism in, 160 ; 
briefs for, I6I; Capuchins in, I25, I26, I5I ; case of conscience concerning matrimony in, I59; cession of, 79, 240, 24I; change in Propaganda control over, I2I; conflict of jurisdiction in, I54; conversions in, I5O; creation of bishoprics in, I4I, I43, I55, I9I; delegation from, 240; discord in, I67; Europeans in, I54; faculties for, I49, I58; fall of, 74; French reinforcements in, 240; governor of, I63, I66, I68; history of, I68; indulgences for, I62; Jesuits in, 73, 92, I26, I59, I88, I90, I93; kingdom of, I25; liberty of worship in, I6I ; matrimonial dispensations for, I9I; missionaries for, I34, I36, I5I, I58, I59, I60, I6I, I62, I65 ; missions of, I25, I26, I27, I28, I29, I30, I48, I 50, I 5I, I52, I54, I55, I56, I63, I90, I95 ; non-Catholics and, I25, I49; nuns in, I30, I58; observation of holy days in, I65; papers and letters concerning, I45, I6I, I66, I68, I84, I88, I9I, I95; Recollets of, I49; relations of, I29, I30, I5I, I64; religious organizations in, 203; request for privileges in, I90; revenue for bishop in, I58; state of religion in, I26, I67; subsidy for, I68; vicar apostolic of, I29, I54, I55, I 59; see also Lower Canada; Upper Canada; Quebec

Canadian College (Rome), I95; collections of, 205

Canadian Company, I67

Canary Islands, I Io

Cancellaria, see Chancellor

Cancellarius Brevium Apostolicorum, 28

Canonization, jurisdiction in, I99; of Bishop Palafox, I99, 207, 208; of Rosa of Lima, 44

Capasso, B., L'Archivio di Stato in Napoli, $220-230$

Cape Breton, capture of, 74; diocesan transfer of, I47; treaty concerning, 95 ; vicar apostolic in, I44

Capello, Carlo, relation by, 245

Capello, Pietro, relation by, 239

Cape Verde islands, spoils in, 83

Capitolare archives, 229

Cappacini, Abbé, letter of, I87

Capponi, Marchese Alessandro Gregorio, collection of, Iog

Capponi, Marchese Gino, library of, Iog n

Caprara, Cardinal, correspondence, 77, I75

Capronica College, library of, 205

Capua, Archbishop of, see Gaëtano, Cardinal Antonio

Capuchins, archives of, 205; conduct of, I3I, I72; dispensation for, I4I; dispute with Jesuits, II7, I39; faculties for, I3I, I33, I38, I39; for America, I30, I33, I5I, I70; French, I38, I69; in the Indies, 60 n, 63; Italian, I87 ; missions of, I24-I28, I34, I38, I42, I48, I50, I5 I, I54, I 56, I57, I63, I86I88, I90, I93, I94; prefecture of missions of, I26, I38, I39; procurator general of, I36, $\mathrm{I} 58$, I85; prosecution of, I32; Puritans and, I56; removal of, I26; representations of, I32 ; request of, for privileges, I32 ; semi- nary under, I48; see also names of countries and places, e. g., Canada, Capuchins in Caraffa, Cardinal Carlo, consistorial acts of, 98

Caraffa, Cardinal Pietro Luigi, letters of, I06; records by, $4 \mathrm{I}$

Caramanico, Prince of, minister to London, 235

Carbery, Father Thomas, I8I; bishopric of Carolina and, I80; letters of, I78, I79

Cardinal nephew, secretary of state, 53

Cardinals, apportionment of provinces among, I29, I94; college of, see Curia; controversies regarding, 202; correspondence, 85 , 88 , II 8, 226, 227, 232 ; creation of, 50 ; records of, 36-42; see also names of individual cardinals

Carga, Giovanni, "Informatione del Secretario e Secretaria di Nostro Signore", 27 n, 52 n

Carinci, G. B., Notizie dell'Archivio Caetani, $225 \mathrm{n}$

Carleton, Sir Guy, negotiations of, 240

Carletti, Francesco, voyages of, 208

Carlo II. Ludovico, duke of Parma, letters to, $25 \mathrm{I}$

Carmelites, English, I53; faculties for, I34, I35, I36, I38, г39; prefecture for, I36, I37, г39; relations by, 93, I53, I69; see also names of countries and places, e. g., Mexico, Carmelites of

Carmelites, Scalzi, archives of, 204

Carolina, proposed diocese of, I44; sale of, I87; see also North Carolina; South Carolina

Carpegna, Cardinal Gasparo, collection of, 93; vote of, 96

Carroll, John, archbishop of Baltimore, acts of synod presented by, I4I ; appointed bishop, I4I ; as vicar apostolic, I7I ; coadjutor of, I42; death of, I76; decree for, I75; disputes of, I73, I74, I75; grant to, I4I ; institution of Dominican province and, I42; Jesuits and, I72; letters and papers of, 86, I4I, I7I-I76, I79; oaths of, I4I, I42, I73; seminary established by, I4I; see also Baltimore

Cartago Nova, archbishopric of, 44

Carte Farnesiane, 97

Carthagena, Bishop of, letters of, 67,94 ; church of, 44, 46; English at, 66; Miguel Antonio, bishop of, 94 ; siege of, 66 ; voyage to, 229

Caruero, Don Alonzo, letter of, 88

Casace, Melchiorre, master of polacca, 235

Casagna, $M g r$., letter of, $60 \mathrm{n}$

Casanate, Cardinal Girolamo, collection of, 2 r I ; letter of, I59

Casas Grandes, mission at, I60

Cases, ecclesiastical, I65, I66, I89; maritime, 68; matrimonial, I59

Casoni, Cardinal, letter of, I74

Castagna, Giovanni Battista, archbishop of Rossano, see Urban VII.

Castello Sant'Angelo, collection, 43-45, 98

Castellon, Father Francesco di, recommendation of, I37 
Castile, Augustinian province of, I05; bull granting rights in, 24; contributions by clergy of, 9I; Dominicans of, I90; favors regarding, I04; supreme council of, 2 I I

Castilla del Oro, Franciscan friars for, $26 \mathrm{n}$

Castillo, Juan del, bishop of Santiago de Cuba, 254 ; resignation of, 254,255

Catalomini, Abbé, correspondence, 76

Catechism, of council of Mexico, 2I7; printing of, 166

Catharine, of Sienna, Saint, 90

Catharine II., empress of Russia, letter of, 66

Cauchie, Professor Alfred, "Archives de Marguerite de Parme", 23I n; De la Création d'une Ecole Belge à Rome, II n, I3, $32 \mathrm{n}$, $77 \mathrm{n}$; "Instructions aux Nonces", $77 \mathrm{n}$, $78 \mathrm{n}$; Inventaire des Archives Farnésiennes, 23 I n; "Les Archives Farnésiennes de $\mathrm{Na}$ ples", 23I n; Mission aux Archives Vaticanes, $52 \mathrm{n}$

Cause, 189

Cavalli, Marino de, relation of, 9I

Cavendish, Captain Thomas, circumnavigation of America by, II4

Cedula Regia, I89

Celesia, letter of, I73

Cemeteries, observations on, I78

Cena collection, 48, 55

Cena, $M g r$., nuncio in France, correspondence of, 49 , I Io

Cenci, Count Bolognetti, library of, 9I

Censum, 5

Cerri, $M g r$. Urbano, letters of, $60-6 I$, III ; relations by, 50, 9I, I03, 122, I94, 212, 213, 252; Stato della Religione Cattolica, 6 I 11

Cervantes, Leonello, bishop of Santiago de Cuba, transfer of, 255

Cesarius, Cardinal, consistorial acts of, 203

Cesi, Cardinal Bartolommeo, books of, 4I

Challoner, Richard, vicar apostolic of London, documents relating to, 184

Chamberlain (Camerarius; Camerlingo), office of, 5 ; records of, $39,40,4 \mathrm{I}$

Champagne, provincial of, 136

Champion de Cicé, Jérome M., archbishop of Bordeaux, reception of students by, I72

Chancellor, records of, 39, 201

Chancery, papal, work of, 4

Charles, Archduke (called Charles III.), and Philip V., 9I

Charles I., of England, material for period of, 80; proposed marriage of, as Prince of Wales, I02, 105, 2 I I, 213

Charles II., of Spain, brief to, 132 ; papers and letters of, $88,93,96,185$; subsidy granted to, 94

Charles III., of Spain, memorials from, 96; motives of, regarding war with England, 66 ; relations of, 46

Charles IV., of Spain, letter of, I92

Charles V., Emperor, 84; letters and papers of, $44,45,92$, IO7, IO9, I I I, II 3,2 I 5,2 I7 ; nuncios under, 58 ; request of, concerning Franciscans, I86
Charles IX., of France, letters of, 88

Charles François, provincial of Rouen, I86

Charleston, S. C., appeal of priest of, I74; bishopric of, I8o; disturbances at, I80

Chebadentu, mission of, I32

Chedabuctu, mission of, I32

Cherokees, news concerning, 79

Cheverus, Jean Lefèvre de, bishop of Boston, coadjutorship and, I76, I77, I78

Chevriêre, Jean Baptiste de la Croix, bishop of Quebec, 256, 257 ; letters of, 257 ; requests of, 135 ; return of, 73,257

Chiavi di Cifre, 244

Chicago Exposition, 25I

Chigi, Fabio, see Alexander VII.

Chigi, Cardinal Flavio, manuscripts of, 216, 227 ; voyage of, 226

Chigi, Cardinal Mario, letters to, 226

Chigi, Cardinal Sigismondo, papers of, 227

Chigi family, library of, 225-227; papers of, 8

Chili, colleges in, I86; documents relating to, I87; license to governor of, 30 ; relations of church with, 200; spoils of the bishop of, 105

China, Dominicans for, 64 ; expedition to, II 5 ; material relating to, 93; passage to, 123. I 48, I 49

Chiquaqua, Franciscans of, 223

Chisi, acts of the legation of, 99

Christina, Queen, of Sweden, library of, II I-II2 Christopher, Father, of Paris, request of, I48

Church, abuse in temporal administration of, I8I

Churches, archives of, 206 ; bulls of, 2 I 8 ; establishment of, 214; list and description of, 49, 2 I 3 ; propositions of, 50, 5 I

Ciampini, library of, 49, 50, 94

Cinaloa, see Sinaloa

Cincinnati, erection of bishopric of, I44, I8I ; request of Bishop of, 145

Cincinnati, order of the, $24 \mathrm{I}$

Cities unvisited, 25I-252

Cività Vecchia, arrival of students at, I72

Clay, Henry, letter to, 183

Clement VII. (Giulio de' Medici), briefs of 28, 106, 254; correspondence and papers of, $8,39,44,47,85,88$; papal secretary of state and, 53,250

Clement VIII., Borghese collection and, 92; briefs of, 28, 29, 106; bulls of, 35 ; decretals of, 35 ; letters and papers of, $30,40,228$; Propaganda Fide and, II9

Clement IX. (Giulio Rospigliosi), briefs of, 29 ; bull of, I3I; consistories of, 5I, 99; letters and papers of, $8,1 \mathrm{I} 8,228$

Clement X. (Emilio Altieri), briefs of, 29, III ; bull of, 44 ; consistorial acts of, 99 ; correspondence of, 76, IO3, I59; register of, 36

Clement XI. (Giovanni Francesco Albano), briefs of, 43,94 , I6o; bulls of, 25 , I60 ; collection of, 94 ; correspondence and papers of, 8, 3I, 9I, 92, 95, 96, I60, I94; secretary of special congregation, 96

Clement XII., bulls of, 25 ; letters to, 49 ; library founded by, $2 \mathrm{I} 2$ 
Clement XIII., faculties granted by, I6I

Clergeac, A., "Inventaire des Lettere di Vescovi", 86

Coadjutors, matters concerning, 5I; see also names of dioceses and of individual coadjutors

Codex Mexicanus Vaticanus, i 6

Coggiola, Giulio, Reintegrazione dei Fondi Farnesiani, $230 \mathrm{n}$

Cohellius, Notitia Cardinalatus, $196 \mathrm{n}$

Cohomiers, Father F. de, letter of, I56

Colaneri, G., La Biblioteca Casanatense, 2Io n

Coligny, Gaspard de, letter on, 249

Collado, Father Diego, information sent by, $\mathrm{IO}_{3}$

Collectoriae, 33

Collectors, papal, functions of, 53 ; correspondence, 62, 108; in Spain, 99

Collectors-general, functions of, 53-54

College of the Propaganda, relation by alumnus of, 173

Colleges, archives of, 205; privileges for, 175; subject to Propaganda, I95

Collegio di San Antonio, 204

Collegio Romano, library in, $2 \mathrm{I} 7$

Collegio Urbano, I95; library of, 205 ; state of, I93; students for, I68, I72

Collettorie dei Spoglie, 34

Cologne, correspondence of nuncio at, 48, I29, 226, 233; dispensations of, 80 ; Dutch Catholics and nuncio at, I48; Elector of, letters, I74; letters of, II4, II5, I48; nunciature of, $57,8 \mathrm{I}, 85$

Colomiatti, Codex Juris Pontificii seu Canonici, I $96 \mathrm{n}$

Colonies, 92; comparison of forces of, 234; English, I39, I66, I67; English policy towards, 75, 240; faculties for, 223; French, 247; Great Britain and, 243; news of, 234 ; war, trade, and Indian affairs in, 79; see also names of particular colonies; United States

Colonna, Marc Antonio, relation by, 25I

Colonna family, archives of, 228

Colucci, P., letters to, 219

Columbian Commission, Raccolta di Studi e Documenti, 245, 249 n, 250

Columbus, Balthasar, inheritance of, 103

Columbus, Christopher, account of, 208; estate of, IO3; grants to, I03; letters of, II7, 2I7; notes and papers concerning, II7, 25I; will of, II7

Comayagua, vacancy in see of, 68

Commerce, in Indies, 239; of America, 236, 238, 239

Commission, on American claims, 236

Commissions, in papal administration, 6-7, 200; registers of, 36

Commune, records of, 220

Como, Cardinal di (Tolomeo Gallio), secretary of state, 53 ; correspondence, 62,63 , $99,208,248$

Company of the Coronation of Christ Our Lord, petition of, 95

Concanen, Luke, bishop of New York, death of, I75; letters of, I74, I92
Conclaves, diaries of, II6, 202

Concordats, 44, I83, 200

Condiotti, Sig., letters to, 7 I

Confalonieri, Giovanni Battista, arrangement of Castello collection by, 44; collection of, 96-97

Confirmation, in America, I40, I86; in California, 174; in Florida, 223; in Louisiana, 223

Confraternities, indulgences for, 26

Congregation concerning the Discipline of Regulars, 198

Congregation concerning the Residence of Bishops, I98-199

Congregation concerning the State of Regulars, I98

Congregation de Propaganda Fide, 2 II ; acts of, 252; archives of, 93, II9-I95; assignment of districts by, 78, II8; audience of, I83; case sent by prefect of, I6I ; change in control of, I2I; colleges subject to, I95; decrees of, 50, 8I, III, I5I, I55, I6I, I69, I88, I95, 2I2; dioceses subject to, II8; efforts of, to obtain information concerning America, 6o-6I ; history of, II9-I2I ; letters and papers of, 8I, I03, I05, I08, IIO, I6I, I64, I68, 227 ; letters and papers of secretary of, 89,152 , I53; miscellanea of, I93-I94; missions of, 2I3; museum of, I95; printing establishment of, 252 ; publication of books and approval of, III; relations of nuncios with, I04; resolutions of, I43, I75; use of archives, I22-I23; work of, in episcopal appointments for America, 37

Congregation for Examination of Bishops, 37

Congregation for Extraordinary Ecclesiastical Affairs, 200

Congregation for the Affairs of Religious Societies, 197

Congregation for the Conversion of Infidels, II9

Congregation of Bishops and Regulars, I97198; decrees of, 108, 212, 217, 227; records of, 49; report of, I33

Congregation of Confines, volumes relating to, 50

Congregation of Ecclesiastical Immunity, I99; decrees of, 212, 227; note of secretary of, 96

Congregation of Holy Rites, I7, I99-200; decrees of, I02, 2I2, 215 ; records, 50

Congregation of Indulgences and Relics, 200

Congregation of Studies, 200

Congregation of the Apostolic Visitation, 197

Congregation of the Blessed Virgin Mary, mission of, 127

Congregation of the Consistory, papers of, 50, 160, 196, 197, 198

Congregation of the Council, I96, I98; decrees of, 93, 106, 212, 215, 220; letter to, 94

Congregation of the Holy Office, $3 \mathrm{n}, 5 \mathrm{O}$, 105, 196, 197, 199

Congregation of the Immaculate Virgin Mary delle Dolori, Mexico, petition of, 95

Congregation of the Index, I99; acts of, I07

Congregation of the Inquisition, see Congregation of the Holy Office 
Congregation of the Instruction of the Sacraments, 196

Congregation of the Missions, see Lazarists

Congregation of the Oratory, see Oratorians

Congregation of Visitation, records of, 49

Congregations, consistorial, 37; collections of, 196-200; decrees of, 212 ; procedure of, 3-4; special, see Congregazioni particolari; see also names of particular congregations, e. g., Congregation de Propaganda Fide

Congregazioni Particolari, 93, 94, 96, 190-192

Congress, see Continental Congress

Connolly, John, bishop of New York, confirmation of, I42 ; controversy with trustees, I45; letters of, 177, 179

Consag, Father Fernando, notes of, 219

Consalvi, Cardinal Ercole, correspondence of, $67 \mathrm{n}, 77$

Conservators, Palace of, library in, 220

Consistories, kinds of, $36-37$; material relating to, 51, 106, 223; work of, 3; see also Acta, or Acts, consistorial

Constant, Abbé G., Diario di Paride de Grassis, $203 \mathrm{n}$; "Les Maitres de Cérémonies", $202 n, 203 n$

Constantinople, ambassador of, declared viceroy, I5I; news-letters of, II 3

Consulates, Neapolitan, 235

Consuls, letters, 221 ; of America, 236; records of, 202 ; relations with, 250

Contarini, Pietro, relation by, 245

Contarini, Tommaso, relations by, 9I, I04, II3

Contelarius, Felix, index by, $46 \mathrm{n}$

Continental Congress, I7I, 234, 242

Convents, establishment of, I 58 ; suppression of, $67 \mathrm{n}$

Conventuals, archives of, 205 ; German, dispute with member of, I73, I74

Conwell, Henry, bishop of Philadelphia, coadjutor of, I47; concordat of, 146 ; conduct of, I47; letters of, I80, I82; renunciation proposed to, I8I

Conza, Archbishop of, instructions to, 49

Cooper, Father, recommendation of, I77

Copies, of documents at Rome, securing of, and charges for, I3

Cordon, Marquis of, missions of, 247

Cordova-in-Tucaman, Bishop of, letter relating to, 65

Correro (Correr), Giovanni, relations by, 46 , 92, IOO, III, II 2, 220

Corsairs, French and English, I I4

Corsini, Cardinal, letters of, 99

Corsini, $M g r$., archbishop of Tarsus, instructions of, $72 \mathrm{n}$; letters to, 226

Corsini library, 212-216

Corte, series, 238

Coruña, Agostin de, bishop of Popayan, letter relating to, 64

Corvisieri, Constantino, collection of, $2 \mathrm{I} 6 \mathrm{n}$; 228; "Compendio dei Processi del Santo Uffizio ", I97 n

Costa di Arignano, Cardinal Victor, archbishop of Turin, letter of, I62

Coster, Maurus, index by, II2
Council of Bologna, 97

Council of Spain, ecclesiastical controversies in, I03

Council of the Indies, II2; account of, IIO, II3; Archbishop of Mexico and, 64; Bishop of St. Martha and, 64; decrees of, I25; demands of, 214; Franciscans and, I05; letter to, 47 ; number of missionaries fixed by, I32, r69; objection of, 63; relations of nuncio with, II9; rights of, 59

Council of Trent, acts of, 99; collection of, 35 ; decrees of, I06, I74, I77; history of, 107; interpretation of decrees of, 198 ; letters relating to, 232; material relating to, 97 , II6, 202, 23I ; system of episcopal appointments and, 37; see also Congregation of the Council

Covarrubias, Balthasar de, bishop of Mechoacan, letter of, 108

Cravelis, J. Agostino di, paper by, II3

Creeks, news concerning, 79,80

Criminals, extradition of, $22 \mathrm{I}$; transportation of, 187

Cromwell, in the Indies, I00

Cruciata, see Subsidies

Cuba, I02; churches of, 49, 213; Drake near, 64; French in, 79; French ships off, 243; military operations in, 66 ; mission in, I34; missionary in, I37; request of presbyter of, I 55

Cumberland mission to Madrid, 244

Cuñega, Juan de, Spanish minister at Rome, 62

Cuneo, George, correspondence of, 8I

Curia. business of. 3 : letters to. 88

Curia Arcivescovale, archives, 229

Curtis, Patrick, archbishop of Armagh, letter of, I8r

Cybo, Cardinal Alderano, letters of, 67, 68

Damon, Sig., establishment of a seminary by, I48; letter in behalf of, I48

Dandini collection, 97

Dandini de Cesena, Count, 97

Danes, faculties for islands of, I37

Darcelle, Father Mattheo, letters of, I5

"Darengo", 36

Darien, Scotch expedition to, $75 \mathrm{n}$

Dataria, archives of, 20I ; work of, 6

David, Jean Baptiste, bishop of Bardstown, coadjutorship and, I43; letter of, I79; petition of, 147 ; proposed for bishopric, 178

Davoust, request of, I6I

De Andreis, Father Felice, letters of, 219; relations by, I77, I78, I79, I80, I8I

Deane, Silas, reception of, 75 ; quarrel of, with Lees, 234

De Barth, $M g r$. , bishop elect, renunciation of, I 44

Decimae, 33, 210; in Canada, 155 ; in West Indies, 58, 93, 96; of the Indies, 220

Declaration of Independence, 75

De Grassis, diaries of, 203

Delegates, papal, list of, I 8 
Delfino, Chevalier, Venetian ambassador, correspondence of, $24 \mathrm{I}$

Deliberazioni Secrete del Senato, 237

De l'Isle, Guillaume, geography, I86

Delisle, Léopold, "Les Archives du Vatican", I6 n; "Les Archives Pontificales", I97 n

Demarcation line, between Spanish and Portuguese possessions, 48

Denaut, Pierre, bishop of Quebec, as coadjutor, I 42 ; promotion of, I64; death of, I65

De Neckere, Leo, bishop of New Orleans, selection of, I 46, I 47

De Neufville, Father, memorial of, I59

Denifle, H., Désolation des Eglises de France, $26 n$

Department of State (U. S.), 22I

De Pretis, Pietro D., index of, I8-35 passim, 43-58 passim, 7I, 77-98 passim

Despuylos, Dominic, petition concerning, 136

D'Estaing, see Estaing, Admiral Count Charles d'

Detroit, proposed diocese of, I44, I46, I8I

Diari, 89

Diaries, 49,89 ; of conclaves, II 6,202 ; of Council of 'Trent, 202 ; of councils, 202 ; of masters of ceremonies, Io6; of popes, III, II6, 202

Diaz de Salcedo, Juan Antonio, bishop of Santiago de Cuba, election, and transfer of, 255

Diaz Vara y Calderon, Gabriel, bishop of Santiago de Cuba, election, and death of, 256

Didier, Father, letters concerning, I72

Dieskau, Baron Ludwig, defeat of, 240,242

Dioceses, division of, I92; foundation of, 220 ; relations of, I97; report on, II8; see alsio names of particular dioceses

Dionisius, Brother, of Piacenza, request of, I30

Diplomatic correspondence, 99-IOO, IOI; of Turin, 246

Dispatches, to Venetian senate, 239-244

Dispensations, 36 ; bulls of, 35 ; faculties for 222; for Quebec, I60, I65; matrimonial, 3I, I37, I42, I43, I47, I6I, I68, I7I, I77, I8I, I9I, I92, I95; of Cologne and Flanders, 80; of the priesthood, $26,27,30,31$; of vows, I4I; to Indians, 30

Diversorum, 22

Divorce, decrees relating to, 2 Io

Dola, Father Vittorio da, request of, I33

Domenico, Brother, request of, Igo

Dominica, island of, mission in, I 57

Dominicans, advice sought of general chapter of, I52; Biblioteca Casanatense, property of, 210; collection of, 98, 204; college of, I80; complaint of, I50; dispute of, 83 ; for America, I78; for New Mexico, I24, I90; for New Spain and China, 64; French, I57; hospice for, I27; in French Islands, I88; in Kentucky, I8I, I82; in Ohio, I80, I8I; in the Indies, 44, I52; letter of, I65; missionary permission requested by, I39; missions of, I30, I39, I57, I80, I93; petition of general of, I83; Propaganda archives and, II9-I20; proposed province of, for Balti- more, I42; provisions adopted by chapter of, I24; request of, for faculties, I58; sale of monastery of, I47

Doria-Pamphili family, archives of, 227 ; papers of, 8

Dorothea Margherita, ship, 67

Dorylaeum, Bishop of (Louis Philippe Mariaucheau), succession of, to see of Quebec, I63; see also Mariaucheau

Dosquet, Pierre Herman, bishop of Quebec, $256,257,258$; letter of, as coadjutor, I6o

Douay, Father Anastase, petition concerning, I34

Dougherty, $M r$, relation by, I73

Downing, Sir George, memoir of, 73

Drake, Sir Francis, 55, 82 ; activities of, IIO; arrival of, I 5 ; commerce of the Indies and, 65 ; fleet of the Indies and, 62; in Florida straits, 64; in Santo Domingo, II 5 ; in the Indies, 64,83 ; in West Indies, 63 ; letter of nuncio on, 64 ; news of, II4, II6; report on, I 13

Dubois, John, bishop of New York, request of, concerning seminary, I47

Dubourg, Louis Guillaume, bishop of New Orleans, election of, I42; letters and papers of, I76, I77, I79, I80, I8I ; questions of, I 45 ; subsidy for, 176 ; transfer of jurisdiction to, $\mathrm{I} 45$

Dubuisson, Stephen L., note by, 2 I 8

Duchesne, L., "Rapport sur la Publication des Registres Pontificaux", 20 11, 2I 11, 54 n

Dulong, Father, request of, I 58

Dumay, Father Eustache, nomination as prefect, 136

Durango, 36 ; churches of, 49, 21 3 ; faculties for Bishop of, I3I, I32, I33, I35, I36

Durazzo, Cardinal Marcello, nuncio to Spain, letters to, 67

Dutch, activity of, 243; as allies, II5; dispute between England and, II5; documents of, 83, 9I : English success and trade of, 79 ; expedition against, II5; fleet from Peru and, 65; fleet of Indies and, I05; in Indies, I04, II 5, 239; in West Indies, 90, I00, II5, II6 ; missionary for, I39; navigation of Indies and, 62; negotiations of, with Spaniards, 243; peace with Spaniards, 90 ; plans of, 90; slaves and, 67, 84, I32; trade, I02; vessels, I I4, 234; see also Netherlands

Dutch Institute, work of, II

East India Company, Dutch, I Io; English, 8I, I06; French, I30

East Indies, churches of, I 52; commerce of, II3; Dominicans in, I52; ecclesiastical cases from, I89; faculties for, I86; history of, II 2 ; letters concerning, I52; material relating to, 93, I90; missions in, I99; pirates in, 8I ; see also Indies

Echevarria y Elguezua, Diego de, bishop of Santiago de Cuba, letter, of, I92

Edmondo della Madre di Dio, Father, faculties for, 138 
Egan, Michael, bishop of Philadelphia, election of, I75; letters and papers of, I74, I75

Egypt, idols of, 208

Ehrle, Father Franz, I5; Historia Bibliothecae Romanorum Pontificum, I6 n; "Zur Geschichte des Päpstlichen Hofceremoniells", $202 \mathrm{n}$

Ehses, Dr. Stephan, 37; "Aus den Consistorialakten", $38 \mathrm{n}$; Das Römische Institut der Görres-Gesellschaft, i I n

Elizabeth, Queen, of England, expedition of Gilbert and, II6; plan of fortification and, II6; proposed overthrow of, 214

Elling, William, letters of, I73, I74

Embassies, at Rome, 22I-224

Emigration, of skilled mechanics, to America, 242 ; to New England, I88

England, John, bishop of Charleston, missions of, to Hayti, I85 n

England, 48; ambassador of, conference of, 235 ; arrival of vessels in, II5; assigned to nuncio at Brussels, I20; attitude of, towards colonies, 75, 240, 243; Belgian nuncio and, 78 ; boundary commissioners of France and, 74; cession to, 79; change in Propaganda control over, I2I; commerce of America and, 66, 239, 240; commerce of Indies and, 239 ; comparison of forces of, 234; controversy between Spain and, 218; corsairs of, II4, 2I4; designs of, on America, 79; detention of Spanish ships in, II4; diplomatic archives of, 223-224; discovery by missionaries of, IIo; Dutch as allies to, I 5 ; faculties for islands of, I37; finances, navigation, and commerce of, 247 ; fleet of, $62,65,74,96$, I05, II4, I I5, 243; government of, and Catholics of Canada, I66, I9I ; history of, IO7; journals of council of state of, I64; letter on Queen of, 8I ; letters and documents concerning, $78,79,82,83,91,95$, I05, I08, I I0, 232, 233, 24I-242, 244, 246, 247 , 252; Medici correspondence with, 249 ; mercantile arrangement between Holland and, 234; mission of Marquis of Cordon to, 247; missions of, I30, I38, I69, I7I, I94; nunciature of, $80-82,85$; papal representatives in, letters from, 78 ; peace between France, Spain, and, 248; peace between Spain and, $69,78,84$. II 4 ; permission of, for church, I62; planting of tobacco in, 79; politics of, and America, 242; provincial of, letters of, $8 \mathrm{I}$; raising of troops by, II 5 ; relation by ambassador of, 73 ; relations between France and, 74, 75, 82, 84, 241, 242, 243, 247; relations between Portugal and, 234; relations between Spain and, 73, 82, II3, II5, 234, 242; relations between the papacy and, 252 ; relations of, 92 , I04, II2, 187, 213, 232, 239, 245, 252; relations of colonies of, I39; religious conditions of, $8 \mathrm{I}$, 102, I84, 2II ; rivalry between Netherlands and, 79; sale of Carolina to, 187 ; state of religion in colonies of, I66, I67; trade between United States and, 24I ; Urban VIII. and, I06; vicar apostolic for islands of,
I44; voyage to China from, I49; war between Netherlands and, 73, 79, I Io; war between Spain and, 66, 68; see also British islands; English; Great Britain

English, at Carthagena, 66; attack on Louisiana, 243; at Tehuan, 67; Bible distributed by, 96 ; capture of "Nuova Olanda" by, 79 ; capture of St. Eustatius by, 73; capture of vessel by, 65 ; discoveries by, 90, II4, II5 ; expedition against, II5; expedition of, II5; in Florida, 83, II4; in St. Christopher, I90; in the Azores, 63; in the straits of Magellan, 64; in Virginia, I I5; in West Indies, 74, 90, II4; loss of vessels by, 73; movements of, 75 ; repulses of, at St. Augustine, 66; slave contracts of, 84 ; successes of, 79; see also England

English America, see England

English College, archives of, 205; request of alumnus of, I72

Enriquez de Almendariz, Alfonso, bishop of Santiago de Cuba, transfer of, 255

Ercolani, Father, coming of, I8I

Esposizioni Principi, 244

Espulsi, 236

Essen, L. Vander, Inventaire des Archives Fiarnésiennes, 23I n; "Les Archives Farnésiennes de Naples", 23I n

Essex, Earl of (Robert Devereux), apology of, I 16

Estaing, Admiral Count Charles d', news of, 75, 244

Esteres, Father Francisco, prefecture confirmed to, 136

Estimates, military, 80

Eugenius IV., consistorial acts of, I I I

Europe, historical treatise of states of, 229; people of, in Canada, I54

Evellino de Compostela, Didaco, bishop of Santiago di Cuba, election, and death of, 256

Expectatio, 22

Extradition, treaty of, with America, 236

Eyston, Father Bonaventura, letter of, I6o

Fabre, Paul, "Archives du Château SaintAnge", 44 n; Etude sur le Liber Censunm, $32 \mathrm{n}$; La Bibliothèque du Vatican, I6 n; La Bibliothèque Vaticane, I6 n

Facoltà, see Faculties

Faculties, 35 n, 95, I03, I20-I21, I26-I4I passim, 147, I49, I53, I55-I6I passim, I64, I65, I66, I68-I72 passim, I74, I75, I76, I80, I86, I89, 190, 193, 222, 223

Fagan, $M r$., secretary, letter of, I8o

Faillon, Abbé, Colonie Française en Canada, I29 n, I54 n

Faith, in America, weakening of, I9I

Falconieri, Lelio, archbishop of Thebes, instructions to, 49, I04, I07, I09

Farmer, Father Ferdinand, letter of, I7 I

Farnese, Cardinal Alessandro, letters and papers of, 40, 88 n, 23I, 232

Farnese, Alessandro, duke of Parma, correspondence of, 232,233 
Farnese, Ottavio, letters to, 23I

Farnese, Pier Luigi, duchy of Parma and, 230; letters and papers of, 230, 232

Farnese family, papers of, 8, 97, 230-233, 252

Farnese palace, archives in, 222

Fast, brief concerning, I86; substitutes for days of, 30

Favoriti, Agostino, consistorial acts of, 203 ; letter of, I59; transcriptions made by, 40

Fay, Michael Joseph, prospectus by, I79

Feasts, reduction of, I4I, I47; see also Holy days

Feliciano, Porfirio, letters by, 78 n, 208

Fenwick, Edward, bishop of Cincinnati, letters of, I42, I45, I47, I75

Ferdinand II., letters of, 88

Ferdinand III., emperor of the Holy Roman Empire, letters of, 88

Ferdinand III., of Tuscany, letter of, 250

Ferdinand V., king of Aragon and Castile, bull to, 24 ; petition of, 253

Ferdinand and Isabella, bulls to, 23, 24

Fernandez de Castro, Pedro, subcollector of Seville, letter of, 65

Ferrara, 35 : legation of, 85

Ferryland, N. F., letter from, I85

Fiennes, William (Lord Saye), punishment of, $8 \mathrm{I}$

Figueroa y Guinea, Baltasar de, bishop of Santiago de Cuba, election, and death of, 256

Filippini, see Oratorians

Finance, papal, 3I-34

Fiocchi, inventory by, 25

Fishing, rights of, 84

Flaget, Benedict Joseph, bishop of Bardstown, correspondence and papers of, I43, I75, I76, I78, I79, I8I

Flanders, affairs of, 23I ; dispensations of, 80 ; letters and references concerning, 82, I08, 226, 23I; minister in, correspondence of, 80 ; nunciature of, letters and papers relating to, $48,49,57,77-80,85$, 104, I07, I09, IIO, I3I ; revenues of, II7

Fleet, French, 62, 74; of England, 62, 65, 74, 80,96 , I05, I I4, I I5, 243 ; of Holland, $85 \mathrm{n}$; of Indies, $62,63,64,65,66,73,78,79,83$, I05, I I4, II6, I48, 208, 2I3, 2I4, 243; of New Spain, 90, 96; Spanish, 45, 5I, 78, I04, I IO, II I, 2 I5; see also Galleons

Fleming, Father, letter on, I72

Florence, Cardinal of, see Leo XI.

Florence, archives of, 209, 249-250; nunciature of, 85

Florida, ambassador from, 244; auxiliary bishop for, 222; Bretons in, IO3; cession of, 67 , 233, 24I ; confirmation in, 223 ; corsairs in, II4; departure of Spaniards from, I69; Drake in, 64, II4, II5; English settlement in, 83 , II 4 ; faculties for, I34; fleet for, 80 ; folios relating to, 47 ; fort in, 239 ; French in, 47, 242-243; Huguenot settlement in, 37 ; illegal jurisdiction in, I43; letter on, I84; map of, 250 ; missionaries in, I50, I69; prefect of missions of, I34; relations be- tween England and Spain in, 187; religious government of, I43, I45, I46, I77, 223; rumor of 'Turks in, 6I; shipwreck near, IIo; vicar apostolic of, I45

Floridablanca, Count of (José Moñino), conference of English ambassador and, 235; correspondence of, 66, 223

"Florida Popaien", superiors and missionaries in, 133

Flumen Nortis, mission at, 169

Fondo Gesuitico, 2I7, 218-220

Fondo Risorgimento, 220

Fondo Sessoriano, 217, 220

Fontainebleau, letter from, I70; peace signed at, 248

Forbin de Janson, Cardinal Toussaint de, representation of, 73

Foreign Affairs, papal, minister of, correspondence of, $22 \mathrm{I}$

Forli, archives of, $25 \mathrm{I}$

Fornici, inventory by, 202

Forteguerri, Nicolò, accounts of missions by, 92, I I 7

Foscarini, Nicolò, relation by, 238

Fox, George, maritime case of, 68

Fraikin, Abbé J., "Les Comptes du Diocèse de Bordeaux", $32 \mathrm{n}$; Nonciatures de Clément VII., $57 \mathrm{n} ;$ Nonciatures de France $7 \mathrm{I} \mathrm{n}$

France, advocacy of Philip V. by, 84 ; Alexander VII. and, 48; ambassador of, correspondence of, 77,232 ; ambitions of, in America, 242; bishops of, note of, 95 ; boundary commissioners of England and, 74; Capuchins of, I5I ; Cardinal Barberini and, 47 ; cession of Florida to, 67 ; cessions of, 83,84 ; colonies of, 185 ; commerce of America and, 66, 239; conflict of clergy of, I85; consul of, letter of, I7 I ; corsairs of, I I4; demands of England upon, 84 ; differences between England and, 82, 24I, 247; diplomatic correspondence with, 246; Dominicans in islands of, I88; embassy of, archives of, 222; English suspicions of, 234; faculties for islands of, I95; families of, for America, I72; feasts in colonies of, I4I ; fleet of, 62, 74; fleet of Indies and, 2I3, 243; gift of king of, I60; history of, I07; Innocent XI. and, 48; Jesuits in islands of, I39, I57; king of, correspondence and papers of, 88, I52, I 54, I60, 232 ; legate in, letters of, 75, 99, I06; letters and other material relating to, $36,46,47,49,75,76$, I07, 226, 23I, 232, 247, 252; maritime activity of, II3; Medici correspondence with, 249; merchants of, and Spanish galleons, 45; minister of, letters and papers of, 7273, 77, I54; Minister of Marine of, letter of, 247; missionaries of, I62, I72; missions of, 94, I25, I50, I62, I84, I9I ; national assembly of, I94; Neapolitan legation in, 235 ; neutrality of, 75 ; nunciature of, $47,7 \mathrm{I}-77$, 85, IIO; nuncios of, correspondence and papers of, $57,69,72-73,85,97,100,104,105$, I07, I5I, I56, I94, 2I3; packet service of, 
with United States, 24I; peace between Spain, England, and, 248; plan of, 247 ; preeminence of kings of, 247 ; princes of, correspondence of, 88, 89, 232; Propaganda assignment of colonies of, 120 ; province assigned to nuncio of, I20; Quebec and king of, I55; queen of, correspondence of, I28, 232; register of ciphers with, IO7; relations between England and, 75, 242, 243; relations between Spain and, 2I5, 243 relations of, 48,49 , I00, IO7, I I I, I I8, 21 $3,216,25 \mathrm{I}$; religious wars in, 46; revenue of nuncios of, 59 ; rivalry of Spain and, 8I ; seminary proposed for, I57, I58; spiritual government of colonies of, I9I; state of religion in colonies of, I6I; succession in, $2 \mathrm{I} 5$; terms of peace proposed by, 73 ; trade of, in West Indies, 238; treaties of, with United States, 75, 240; union of, to Spain, 84; Venetian ambassador in, correspondence and papers of, 238, 239-24I ; war between England and, 74; work of nuncios of, 72-73; see also French

Francesco, $M g r$., bishop coadjutor of Quebec, faculties to, 136

Francesco, Luigi, letter of, I52

Francis, St., order of, see Franciscans

Franciscans, archives of, 204-205; bishopric of Carolina and, I80; colleges of, I39, I73; conversions by, IO2; Council of the Indies and, I05; deaths of, I25; documents relating to, 98; generals of, letters of, I05, I75; in America, I39; in Mexico, I57; in New Spain, I57 ; in Peru, narrative of, I02; in the Indies, I04, I56, I86; library of, in Guadalaxara, 43; of Zacatecas, I69; petition of, I33; pretensions of, to prefecture, I7I ; protector of, letters of, IO2, IO4; province of, at Baltimore, I74; Reformed, in the Indies, I23; request of, for faculties, I 58 ; sufferings of, I 27

Franklin, Benjamin, 97; arrival of, 75, 240; as source of American news, 74, 75; calls of, 74,238 ; conversations with, I70, $24 \mathrm{I}$; correspondence of, I70, I7I, 24I ; illness of, 240 ; letters regarding, 75 ; Louis XVI. and, $24 \mathrm{I}$; mission of, 240, 24I ; propositions of, I70; reception of, 75

Frari, Joseph, The Propaganda, ing n

Frari, Santa Maria Gloriosa dei, monastery of, 237

Fredonia, letter from, I82

Freedom, of worship, I7o

Freiburg, letter from, I59

Fremont, Father, attestation to, I84

French, Father, incident of, I45

French, for America, I29; in Cuba, 79; in Florida, 242-243; in Georgia, 244; in the Azores, 63 ; in the Indies, III; invasion of Italy by, 203; in Virginia, I72; school, at Rome, II ; see also France

French America, see France

French and Indian War, documents relating to, 240,242
Friedensburg, Dr. Walter, director of Prussian Institute, II; Das Königlich Preussische Institut, I I n; Nuntiaturberichte, 87 n, $97 \mathrm{n}$ Friends of Mary, congregation of, I43, I44, I79, I8I, I82

Frobisher, Martin, voyage of, $2 \mathrm{I7}$

Fruffino, Stephano, letters concerning, 6I

Gachard, L. P., inventory by, 225, 226; "La Bibliothèque Corsini ", 212; Les Archives du Vatican, I3, $78 \mathrm{n}$, IOI; Relationi des Ambassadeurs Vénitiens, $238 \mathrm{n}$

Gaëtano, Cardinal Antonio, archbishop of Capua, instructions to, $2 \mathrm{I} 3$

Gage, Gen. Thomas, in Boston, 234

Gahido, Felipe de, relation from, I33

Galetti collection, I I7

Gallagher, Father Simon, case of, I74, I78, I8I, $\mathrm{I} 83 \mathrm{n}$

Galleons, Spanish, arrival of, 45 , I Io; raising of treasure from, 82; shipwreck of, 93; see also Fleet

Gallio, Tolomeo, see Como, Cardinal di

Gallitzin, Demetrius A., experiences of, I82

Gama, Vasco da, voyage of, 237

Gambara, Cardinal Giovanni, records by, 4I, I I I, 2 I5

Gams, P. B., Series Episcoporum, 38, 6o n

Garampi, Cardinal Giuseppe, collection of, 97; index by, I8, 29, $35 \mathrm{n}, 38,45,52,93$, 100, 253 ; Miscellanea, 86

Garcia de Palacios, Juan, bishop of Santiago de Cuba, election, and death of, 256

Garcia Salzedo, Diego, estate of, 65

Gargani, notes by, 228

Garipault, Dom André, petition of, I34

Gasparolo, F., "Constituzione dell" Archivio Vaticano", I6 n

Gaspee affair, 233

Gay, H. Nelson, collection of, 228; "Relazioni fra l'Italia e gli Stati Uniti", 22 I ; "Screzio Diplomatico", 220

Geffroy, M. A., L'Ecole Française de Rome, I I $\mathrm{n}$

Geneva, Bishop of (Jean P. Biord), letter of, I62

Genoa, Archbishop of (Lodovico Lambruschini), letters from, I83

Genoa, material relating to, $23 \mathrm{I}$; nunciature of, 85

Geography, material on, 97, 186, 2I7

George III., oath to, I64; reception of Adams by, 24I; recognition of Bishop of Quebec by, I65

George IV., Prince Regent of England, Pius VII. and, I87

Georgetown, D. C., college of, I82, 219; letters from, I76, I77, I78

Georgia, Acadians in, 80; Americans and French in, 244; proposed diocese of, I44

Georgia, New, Spanish threats against, 2 I5

Gerarchia Cattolica, 4 n, 5 n, I96, I99

Gerard, Conrad Alexander, in Madrid, 244

Germans, of Baltimore and Philadelphia, I74 
Germany, material relating to, 36,232 ; nunciature of, 84,85 ; priests of, for Baltimore, I75

Gesù, Palazzo del, 209

Ghisilieri, Marchese, letter to, 250

Giacinto, Father, account of, I50

Giangolini, Carlo, treatises by, I05

Gibraltar, anxiety concerning, 67; fortification to command, iा6

Gilbert, Sir Humphrey, expedition of, i 16

Gill, Peter, will of, I83.

Ginetti, Cardinal Marzio, instructions to, 84

Ginnica, Don Pietro, dispatch of, I I5

Giocanelli, $M g r ., 88$

Giornale o Diario Universale, 9 I

Giovanni della Croce, Don, work of, I9o

Giovanni di Santiago, Brother, concessions to, I90

Girolamini library, 229

Giry, A., Manuel de Diplomatique, $20 \mathrm{n}$

Giusti, Pasino dei, papers of, 230

Giusticiani, $A b b e ́$, index by, 7 I n

Giustiniani, relation by, Ioo

Goa, Archbishop of, powers of visitation for, 62

Goemans, L. V., "Nunziatura di Fiandra", $78 \mathrm{n}$

Goggi, Canon, faculties for, I3I ; writings of, I3I

Göller, Emil, "Der Liber Taxarum”, 32 n

Gondi de Retz, Cardinal Henri de, letters of, 86

Gonzaga, $M g r$. Valenti, letter from, 2 I 5

Görres-Gesellschaft, I I, 46, 57, 57 n

Gorrini, Giovanni, L'Incendio della Biblioteca Nazionale di Torino, $248 \mathrm{n}$

Gottlob, Dr. Adolf, Aus der Camera Apostolica, 32 n, 209 n; "Das Vaticanische Archiv", $6 \mathrm{n}, 20 \mathrm{I} \mathrm{n}$

Graces, ecclesiastical, I89

Gradeville, Robert, letter to, 182

"Gran Chivira", mission in, I34

Grassi, Father, letter of, I78

Gravina, Bishop of (Giulio Sachetti), instructions to, 2 I I

Great Britain, faculties for American portion of, I92; forces and government of, 218 ; see also England.

Greenland, voyage to, $25 \mathrm{I}$

Gregorovius, F., "Staatsarchiv", 209 n

Gregory VIII., briefs of, 29

Gregory XIII. (Ugo Boncompagni), brief of, 94 ; correspondence and papers of, 8, 30, 44, $62,88,93$, I10, I86, 228 ; privileges granted by, 86 ; secretary of state under, 53

Gregory XIV., bulls of, I27; correspondence of, $35 \mathrm{n}, 89$, 106, 226

Gregory XV. (Alessandro Ludovisi), 48 ; briefs of, 28, 87, 106, 207 ; consistorial acts of, 99 ; correspondence and papers of, 8, 30, 207, 228 ; Propaganda established by, I I9; Spanish nunciature and, 9I

Greville, Robert (Lord Brooke), punishment of, $8 \mathrm{I}$

Griccioli, Abbé, cipher from, 66

Grimaldi, Félix, I99; Les Congrégations Romaines, $3 \mathrm{n}, 20 \mathrm{n}, 2 \mathrm{I} \mathrm{n}, 27 \mathrm{n}, 36 \mathrm{n}, 53 \mathrm{n}, 54 \mathrm{n}$, $196 \mathrm{n}$
Guadalaxara, Bishop of, aggravations received by, I33; faculties for, I28, I29, I32, I34, I36, I55, I57; letters from (Didaco Camaco y Avila), I35

Guadalaxara, I02, 2I5; churches of, 49, 213; diocese of, 253; Indians of diocese of, I37; library of Franciscans in, 43

Guadalupe, college of, 204

Gualtieri, Sebastiano, bishop of Viterbo, letters of, 99

Guatemala, ecclesiastical troubles in, 68 ; report of an ex-Jesuit from, 66

Gubbio, Bishop of (Ottavio Angelelli), paper by, I72

Guérard, Louis, Inventaires des Archives du Vatican, I7 n

Guiana, expedition to, II6; missions in islands of, 96

Guidi del Bagno, Giovanni Battista, archbishop of Patras, instructions to, 104

Guillemeva d'America, story of, 9I

Guinea, commerce of, 92

Guise, House of, 242

\section{Hagan, Father, case of, I45}

Hague, letters from the, 79,83

Halifax, English at, 75 ; erection of church at, I62 ; letter from, I85; request for priest at, 163

Harent, Joseph, memorial of, I79

Harlay de Champallon, François de, archbishop of Rouen, jurisdiction of, I29, I30, I54, I9I

Harold, Father William, patent of honorary missionary to, I44; proposed as bishop, I75, I80; summons to, I83; testimonial in favor of, I75

Haskins, C. H., "The Vatican Archives", II n, I3, I22 n

Havana, Bishop of, faculties for, I28, I32, I57; jurisdiction of, 143,223 ; see also Santiago de Cuba, Bishop of

Havana, capture of, 74; expedition against, 79; shipwreck near, 93

Hays, Father O'Connor, letters concerning, I80

Hayti, apostolic delegate in, I85 n, I94; material concerning, $185 \mathrm{n}$; relations of papacy with, I87, 200

Helgers, Die Bücherverbote in Papstbriefen, I99 n; Index der Verbotenen Bücher, I99 n

Heliopolis, Bishop of, writings of, I59

Henrietta Maria, queen of England, letter on, $8 \mathrm{I}$

Heretics, bible of, 96; manner of converting, I 3

Hergenröther, Cardinal J., Leonis X. Regesta, $26 \mathrm{n}$

Hill, Father, letter to, 182

Hinojosa, Ricardo de, Los Despachos de la Diplomacia Pontificia, I2 et passim

Historical societies, indexed under particular name

Holidays, observed by libraries, to

Holland, Apocalypse of, I00, I09, 2 I I, 2 I5; see also Netherlands

Holy Apostles, church of, Rome, 205 
Holy Cross, college of, pamphlet by physician of, IOI

Holy days, doubts regarding, I65; observation of, I64, I65

Holy Office, see Congregation of the Holy Office

Holy See, see Papacy

Holy Sepulchre, money collected for, 67

Holy Trinity, islands of, missions in, 96

Honduras, Bishop of (Gaspar de Andrada), oath of, 65

Honduras, relation of, II6

Howard, Thomas (Earl of Arundel), plan of, $8 \mathrm{I}, \mathrm{106}$

Howard, Thomas, fourth Duke of Norfolk, marriage of, 6I

Hubert, Jean François, bishop of Almyra and Quebec, attestation by, I64; coadjutorship of, I40, I63, I64; instruction to, I94; letters and papers of, I4I, I64, I65

Hudson's Bay, differences concerning, 82

Hughes, Father Thomas, History of the Society of Jesus in North America, 8I, 122, I27 n, I45 n, I67 n, I87 n, I88 n, $205 \mathrm{n}$

Huguenots, colonizing activity of, 249; designs of, on the Indies, III; fleet of the Indies and, 214; in Florida, 37, 242; interruption of navigation by, 46 ; preachers in America, 47 ; relation of, $25 \mathrm{I}$

Hungary, historical work of, in Rome, II; money for war against Turks in, 67

Hussey, Father, letter of, I63

Hutchinson, Governor Thomas, in England, 242

Ibañes, Brother Diego, documents of, I89

Ignazio, P., instructions to, 99

Illinois, Jesuits in, I88; mission in, I79

Immaculate Conception, letters concerning the doctrine of, 49

Index Codicum MSS. Latinorum et Occidentalium, IOI

India, folios relating to, 47 ; history of, II6; voyage to, III

India Occidentalis, see West Indies

Indians, conversion of, I24, I37, I53, I84; dispensation to, 30; in American colonies, 79; in London, II6; methods of warfare among, 84; migration of, I24; missions among, I57; of Acadia, 8o; of Canada, I9I ; of Mexico, 219 ; on frontiers of Virginia and Pennsylvania, 242 ; ordination of, I28, I5 I, I52, I53; pictures and customs of, I56, 208; policy of Church regarding, 59, 2I5; priests requested by, I80; privileges for, 156 ; relation of, I72; request of, I90; sufferings among, I25 ; treaty with, II 8 ; troubles concerning, 234; writings concerning, 49; see also names of individual tribes, $e$. g., Creeks

Indies, Patriarch of (Antonio Benavides y Bazan), letters to, 68

Indies, 46, 92, 212; administration of sacraments in, I27; apostolic delegate to, I27, I50; audiences in, I03, bishops of, letters from, I27, $2 \mathrm{I} 4$; bull of jubilee to, $2 \mathrm{I} 4$; capture of vessels from, 96; churches in, 49; collections in, IO2; commerce of, $65,73,79$,
9I, II3, II6, 2I3, 239 ; commissioner of missions of, 187 ; concessions in, 62 , 104; congregation for propagation of faith in, 124 ; congregation of Holy Office and, I96; conservators of, letter from, $2 \mathrm{I} 4$; controversies regarding, I03; convents, seminaries and colleges in, 133, 137, 139; conversation with king concerning, $2 \mathrm{I} 4$; conversions in, 64 , II3; Cromwell in, IOO; customs of, III; decimae of, 220 ; defence of, 62, 73, 9I, 239; demarcation of, 48 ; difficulty of collecting news of, 83,213 ; discovery of archipelago in, 243; dispatch concerning, II5; documents on, I89; Drake and, 62, 64, I I4; Dutch and, I04, 2I5, 239; ecclesiastical disorders in, 66, I24, I25, I53; election of priors in, I83; English fleet for, II 5 ; expedition against English and Dutch in, I I5; faculties for, I25, I53, I89; fleet of, 62, 63, $64,65,66,73,78,79,83$, I05, I I4, I I6, I 48, 208, 2I3, 2I4, 243; Franciscans in, IO4, I23, I56, I86; French and, 47, I I I ; funeral office for, 222; General of, relation of, I 6 ; gold and silver in, II5, 208; government of, 93, I09, I I I, II 5 ; idolatry in, 65 ; immunity in, I27; indulgences for, I34, 217 ; Jesuits in, 62 ; letter concerning, 208 ; Lisbon as newscentre of, 82 ; map of, II7; matrimonial bulls for, 26; medical herbs of, IOI ; military order in, 65; Minor Observants of, I 49 ; missionaries of, $60 \mathrm{n}, \mathrm{I25}, \mathrm{I} 3 \mathrm{I}, \mathrm{I} 56,2 \mathrm{I} 8$; missions in, I34; naval supremacy of England in, 47 ; navigation of, $46,61,62,68$, 90, IIO, 2I4, 220, 239; negotiations relating to, II5; nuncio for, 6r, 63, 2I5 ; offices of, $2 \mathrm{II}$; oppression of monks in, I89; ordinations in, I24; parishes in, I25, I26, I27, I50, I94; patronage in, I69, I94; pirates in, 45 ; policy of the Church regarding, 2I5; pontifical jurisdiction in, I27; preachers, apostolic, in, I33; president of, 62 ; provincial in, 44 ; provisions for, 63 , I53; regulars in, 124,127 ; relation of nuncio to, 214 ; relations between England and Spain regarding, I I5 ; religion in, 9I ; religious orders in, 222 ; revenues of, 88 , II7, 239; ruin of, II3; security of conscience in, I25; seminary for missionaries to, I26; simony in, I24; slaves of, I3I ; Spaniards in, III, 239, 247 ; special congregation for, 125, 126, 127; spoils in, 66, 83; subsidies in, 94, 96; succession in France and, 2 I 5 ; taxes of, 69 ; union of, to France, 84 ; vacancies in, $62,64,66$; viceroy of, 213 ; visitation in, 62, 63, 64; war in, I13; work in, I90; see also East Indies; West Indies; America

Indulgences, bulls of, 35 ; for Baltimore, I74; for Canada, I6I, I62; for confraternities, 26; for Guadalaxara and Oaxaca, I37; for New Mexico, I25; for Mexico, 65, 95; for Quebec, I6I, I63, I64, I66; for superior of missions, I6I ; for the Indies, I34, 217 ; for West Indies, 68; grants of, I89; suspension of, $2 \mathrm{I} 4$; to Jesuits, 49

Inglesi, $A b b e ́$, letter from, I83 
Ingoli, $M g r$. Fran., secretary, writings of, I Io, I5O, I52, I53, I89

Innocent VIII., creation of secretarius domesticus by, 52 ; instructions from, 47

Innocent IX., briefs of, ro6; bull of, 44

Innocent X., briefs of, $28,29,49$; consistorial acts and decrees of, 99; letters and papers of, 8 , I06, 227

Innocent XI., correspondence and papers of, 8 , $48,67,88$, I59, I85, I94, 21 $2,213,218,228$; France and, 48

Innocent XII., brief of, 94 ; bull of, 53 ; letters and papers of, 70, 95, I04

Innocent XIII., bulls of, 25

Inquisit-avvisi, 244

Inquisition, history of office of, I09; letters concerning, 67; see also Congregation of the Holy Office

Institutes, historical, in Rome, II; see also names of particular institutes, e. g., GörresGesellschaft

Institutions, religious, at Rome, 22I-224; jurisdiction over, 197

Instrumenta Cameralia, 33

Instrumenta Miscellanea, 45

Instrumenta Monastica, 98, 203

International Historical Congress, at Rome, 249

Introduction, I-I4

Introitus et Exitus, 32, 34

Inventario Sommario del Reale Archivio di Stato di Firenze, 249

Ireland, clergy of, I45, I85; in St. Christopher, I26, 190

Iroquois, conversion of, 155

Isabella, of Castile, bulls to Ferdinand and, 23,

Isabella, of Valois, queen of Spain, demands of,

Isidor, St., archives of, 98

Isle d'Orléans, burial at, I64

Istruzioni, to nuncios, I94

Italy, 23I ; archives of the kingdom of, 9; colony of, proposed for America, I48; fleet of Indies and merchants of, 243; seizures by, 203; unification of, 220; United States and, 228

Jamaica, Bishop of, faculties for, I34; see also Santiago de Cuba, Bishop of

Jamaica, abbacy of, 253; bull concerning abbey in, 24; freedom of commerce in, 79; negotiations concerning, 73

James I., of England, paper of, II 5

James II.,, of England, material for period of, 80

Janson, Cardinal, see Forbin de Janson, Cardinal Toussaint de

Jaunin, Thomas de, as missionary in America, I34

Jay, John, attitude of, 240; calls of, 74, 24I ; in Madrid, 244; secretary of, 244

Jefferson, Thomas, correspondence of, $178,24 \mathrm{I}$; in France, 24I; treaty with Sardinia and, 247

Jerusalem, Patriarch of, letters to, 96, 97
Jesuit Collegio Romano, library of, 217

Jesuits, archives of, 205, 210, 217, 218-220; at

Georgetown, I82; Bishop Carroll and, I72;

Bishop Palafox and, I93; cession to, I45;

disputes of, II7, I39; faculties for, I3I, I38, I39, I56, I58, I90; for Baltimore, I8I; French, I35, I88; general of, letters of, 49, 93. 159 ; in America, I00, I31, I 38,172 ; in California, 9I ; in Canada, 73, 92, I26, I54, I56, I57, I88, I90, 193; indulgences to, 49 ; in French America, I28, 137, 138, 139, 157, $\mathrm{I} 6 \mathrm{I}$; in Illinois, I88; in Indies, 62 ; in Louisiana, I88; in Maryland, 8I, I29, I45, I87, 2I8; in Mexico, 63; in Mississippi, I35, I88; in New Orleans, I88; in North America, I36, I95 ; in Philippines, 9I ; in Quebec, I60; in Santo Domingo, I39; in United States, 169, 218; in West Indies, 64, 102, I37, I56, I57, I90; martyrology of, 218; necrology of, II7; of English America, I29; of New Spain, I02, 219; of Peru, 95; organization of, 203 ; prefect of, relation by, I29; report on missionaries of, I29; requests for, 44, I 89

Jesus, Society of, see Jesuits

Joannes de S. Jacobo, Brother, mission of, I27

John, bishop elect of Lantiqua, bull to, $26 \mathrm{n}$

John XXII., Rota organized by, 6 ; secretary of briefs under, 27

John of God, St., papers of monks of, 95, I 35

Joseph I., Emperor, refuses to negotiate, 84

Josephites, college of, I95

Joubert, J., letter of, I85

Journal des Sçavans, 55

Juan de San Buenaventura, Brother, request of, I 57

Julius II., briefs of, 28; bulls of, 35 ; papal representation under, 54

Julius III., briefs of, 254 ; correspondence of, 30,226 ; signaturae of, 36

Juramenta Fidelitatis et Professiones Fidei, 38

Jurisdiction, ecclesiastical, 166, I76, 197

Kealy, Malachi, archbishop of Tuam, mission of, 126

Kehr, Dr. Paul F., director of Prussian Institute, Aeltere Papsturkunden, 24 n, 25 n; Bemerkungen zu den Päpstlichen Supplikenregistern, $26 \mathrm{n}$; Papsturkunden in la Cava und Neapel, 229; Papsturkunden in Rom, I8 n, 43 n, 44 n, 45 n, 206 n, $228 \mathrm{n}$; researches of, II, I3, 25I n

Kenrick, Francis Patrick, coadjutor of Philadelphia, I47

Kent, Duke of, Edward, letter of, I66

Kentucky, Dominicans of, I8I, I82; Friends of Mary in, I79, I8I ; matrimonial cases from, I79; mission of, I80; relations of, I78, I79; state of religion in, I75, I80, I82

King George's War, 239

Kingsborough, Lord, Antiquities of Mexico, I95 $n$

Kingston, Bishop of, coadjutor to, I 46 ; students sent by, 168

Kingston, chapel at, 192 
Kirsch, J. P., "Administration des Finances Pontificales", 34 n

Knott, Father Edward, letter of, 8I

Kohlmann, Father, project of, I8 3

Kollmann, I., "O Archivu Sv. Kongregace de Propaganda Fide", I22 n

Korzeniowski, Joseph, Excerpta Archivi Consistorialis, $3 \mathrm{n}, 36 \mathrm{n}, 37 \mathrm{n}, 38$

Kropta, Camelli, "Acta Urbani VI. et Bonifatii IX.", 2I n

Labrador, jurisdiction over, I44

Lacumensis, Bishop, letter of, 83

Laemmer, Analecta Romana, 212; Monumenta Vaticana, I7 n, $27 \mathrm{n}, 52 \mathrm{n}$

Lafayette, Marquis de, departure of, 75

Lagonissa, Fabio, archbishop of Conza, instructions to, 49

Lambert, Patrick, vicar apostolic and bishop of New foundland, consecration of, I66; letters of, 166 , I85; relation by, I29

Lambruschini, Cardinal Lodovico, archbishop of Genoa, letters of, 183

L'Ami de la Religion, I8o

La Minerva, extracts from, 168

Lantiqua, John, bishop elect of, $26 \mathrm{n}$

La Paz (S. Maria della Pace), Bishop of (Gregorio Francesco Campos), letters of, I86; missions subject to, I 40

La Plata, archbishopric of, vacancy in, 68 ; bishops of, payments of, 210 ; relation of, II6; trouble in, 234

Larose, $M g r$., sickness of, I76

Lartigue, Jean Jacques, bishop of Telmissus and suffragan bishop of Montreal, affairs of, I68; as vicar general, controversy concerning, I46; letter of, I67

Las Casas, Bishop Bartolomé, relation by, II 3

Laso de la Vega y Cansino, Juan, bishop of Santiago de Cuba, election, and death of, 256

Lauri, $A b b \dot{e}$, notes from Paris by, 45

Laval Montmorency, François de, bishop of Petraea and Quebec, 256; abbacy and, I59, $\mathrm{I} 60$; Bishop of Heliopolis and, I59; faculties of, I32, I60; goods of the chapter and, I60; letters of, I30, I3I, I54, I59, 257 ; money promised by, I55; reputation of, I60; sustenance of, 160

Law, maritime, cases of, 66

Layard, Sir Henry, Dispatches of Suriano and Barbaro, $238 \mathrm{n}$

Lazarists, letters to, I79

Lazzari, Mgr., diary by, i i8

Lee, Arthur, reception of, 75; quarrel with Deane, 234

Lee, General Charles, capture of, 75

Lee, Richard Henry, quarrel with Deane, 234

Legates, correspondence of, 88,97 ; a latere, 53 , 58

Legations, material relating to, 48

Leghorn, plan concerning, 249; Sardinian consul-general at, I82

Le Jeune, Paul, account of, I50
Leo X., briefs of, 28; bulls of, $24,26 \mathrm{n}, 253$; consistories of, 39; correspondence and papers of, $8,44,88$; papal representation under, 54 ; secretary of briefs and, 27 ; secretary of state under, 5,53

Leo XI. (Alessandro de' Medici, cardinal of Florence), briefs of, 28 ; letters and papers of, 8, 99, I04

Leo XIII., acquisition of Visconti collection by, I 8 ; Dandini collection and, 97 ; opens archives, 9

Leon, bull granting rights in, 24

Leopold I., letters of, 88

Le Rat de Villaviride, Father Jean, request of, I 57

Lerma, Duke of, anxiety of, 208

Lersandus, Georgio, letter to, I02

L'Espinasse, $A b b e ́$ de, suppression of chapel by, I92

Lettere, $85-90$

Lettere dei Cardinali, 85

Lettere dei Particolari, 89

Lettere della Sacra Congregazione, I88-I89

Lettere Ducali, 237

Letters, Latin, register of, 30-3I

Lewger, John, secretary to Lord Baltimore, questions proposed by, 8I

Lezze, Andrea da, relation by, 239

Libraries, private, 9, 225-228; public, 207-220; uninvestigated, 227-228; use of, 9-10

Libri Cedularum et Rotulorum, 38

Libri Censuum. 32-33

Libri de Curia, 22

Libri Officiorum, 22

Libri Patentium, 22

Libri Secretarum, 22

Licenses, granted by Propaganda, I2I

Lima, Archbishop of, conflict of, 68; decree for canonization of, 25 ; order concerning, I02

Lima, benefices of, 34 ; briefs for, 29; church of, 50 ; earthquake at, I04; erection of cathedral in, 36; letters from, I87; monastery at, 210; payments by bishops of, 2 IO; priest of, proposed for bishopric, 68; requests from, IO2

Liñan Cisneros, Melchior de, archbishop of Lima, letter concerning, 68

Linaz, Father Antonio, requests of, I32, I33

Lionello, letters of, $238 \mathrm{n}$

Lisbon, as news-centre, 78,82 ; Dominican college at, I80; fleet kept at, 96 ; letters from, I 15, I69; nuncios at, 60, I72, I73

L'Isledieu, Abbé, vicar-general of Quebec, correspondence and papers of, II7, I6I, I62, I84, I9I

Litta, Cardinal, response of, I92

Litterae communes, 22

Liturgy, changes in, I99

Lodi, Bishop of (Luigi Taberna), instructions to, 46 ; letter of, 82

Lodiochi, Jacopo, historical and geographical notes by, $2 \mathrm{I} 7$

London, Indians in, II6; letters from, 79, I04, I08, II4, I87, I88; material relating to, 23I; 
missions referred to vicar of, I38; Quebec and court of, I44, I9I; vicar apostolic of, communications, 78, 139, 142, 166, 167, 169, I70, I82, I84

Lopez, Father Baldomero, request of, I75

Lopez de la Huerta, Father Pedro Joseph, letters of, 186

Lorraine period in Tuscany, documents, 249

Lotbinière, Father Ludovicus, appeal of, 162

Louis XIV., of France, edict of, IO2; gift of, I60; interview with, 45 ; papers of, I54, I60; story of court of, $9 I$

Louis XVI., Franklin and, 24I

Louisiana, Bishop of, see New Orleans, Bishop of

Louisiana, apostolic administrator in, I42, I76, I92; Capuchins of, I69, I84; Cardinal Caprara and, I75; cession of, 79 ; confirmation in, 223; diocesan division of, I46, 223; English alumni for, 223; erection of new see in, I43; Jesuits in, I88; Lower, priests requested for, I78; missions of, I32, I36, I69; notice of, 164 ; priests of, 176 ; relations of, I79, I80, I8I; revolution in, I6I ; Ursulines of, I84; vicar general of, dispute of, I39; see also New Orleans

Louvain, college at, I95

Low Countries, documents relating to, 252

Lower Canada, instructions to lieutenant-general in, I65; protests of clergy of, $147 ;$ see also Quebec

Loye, Joseph de, Les Archives de la Chambre Apostolique, $32 \mathrm{n}, 45 \mathrm{n}$

Lucca, archives of, $25 \mathrm{I}$; republic of, correspondence with, 250

Ludovico, proposition of, I04

Ludovisi, Cardinal Alessandro, see Gregory XV.

Ludovisi, Cardinal Luigi, instructions by, 48

Luzerne, Chev. de la, correspondence of, I70, I7I

Lyons, Father Dennis, proposition of, I44

Lyons, letter from, 208; material relating to, 231

Mably, Abbé, paper on, $24 \mathrm{I}$

Maccarius, Father, mission of, I28

MacCarmick, Father, letter to, I80

MacCormick, Father Michael, missionary to New foundland, I4I

MacDonell, Alexander, bishop of Kingston, students sent by, I68

MacEachern, Eneas, vicar apostolic, letter of, 185

"Madalina", 168

Madison, James, letter of, 250.

Madrid, archives of embassy in, 244; Cumberland mission to, 244; Jay and Gerard in, 244 ; letters from, 93, 94, II5, II6; nuncio at, correspondence of, $60,70,71,150,153$, I69, 2 I4

Maere, R., "Instructions aux Nonces", 77 n, $78 \mathrm{n}$; "Les Origines de la Nonciature de Flandre", $78 \mathrm{n}$

Maffei, Pio Pietro, history by, il6
Magdalen Islands, vicar apostolic in, I44

Magellan, Ferdinand, route of, 103

Magellan, straits of, English in, 64 ; fortification of, 65

Magolotti, Conte Lorenzo, letters of, 208

Mahotière, Jean de la, agent of the Oneidas, I72

Mai, Cardinal Angelo, collection of, I I6 n, I 8 Maigrotte, $M g r$, petition of, 136

Malagascar, colony in, Io6

Malani, Abbé, letters of, 77

Malparrida, Don Diego, letters of, 95

Malta, nunciature of, 85

Malvasia, $M g r$, letters of, 80

Managa, Father Bernardino, request for pension for, 65

Mandarini, Enrico, inventory by, 229

Mandata, 42

Mane, Father Andrea, prefecture confirmed to, I38

Mangarit, Juan, letter of, 65

Manila, Archbishop of, correspondence of, 67 , I35; payments made by, 210

Manila, diocese of, matrimonial bull for, 26

Manni, G., voyages printed by, 208

Manoscritti Torrigiani, 250

Manrique, Cardinal Alfonso de, consecration by, 253

Manrique de Lara, Jerónimo, bishop of Santiago de Cuba, election, and death of, 255

Manzera, Marchese di, letter of, 94

Maps, 95, I09; of Africa, II7, 250; of America, IO3, I I7, I48, I49, I5 I, 250; of Europe, 250; of Florida, 250; of Indies, II7; of Newfoundland, 250 ; of the new world, I95; of the world, I03, II7; of United States, 220

Marbois, M. de, chargé d' affaires, letter of, I7 I

Maréchal, Ambrose, archbishop of Baltimore, administration of Virginia given to, 145 ; brief to, I79; bull of nomination of, I79; cession to, I45; coadjutor proposed for, 146 ; consecration of, I76, I78, I79; difficulties of, I44; jurisdiction transferred by, I45; letters of, I67, I77, I78, I79, I80, I8I ; questions of, I45; relation by, I79; transfer of, I43

Maretti, papers of, 47

Margaret of Austria, Farnese archives and, 230 ; letters and papers of, 231, 232, 233

Margherita, Sister, request of, 158

Margil, Father Antonio, funeral oration for, I37

Maria Louisa, duchess of Parma, letters to, $25 \mathrm{I}$

Mariano, Bolognetti collection and, 9I

Mariaucheau d'Esglis, Louis Philippe, bishop of Dorylaeum and Quebec, burial of, I64; coadjutorship of, I62; inquiry of Pope concerning, I63; letter of, I63; succession of, to Quebec, I63

Marie Galante, island of, Maryland and, I30 n ; mission in, 157

Marini, Gaëtano, Memorie Istoriche degli Archivi della Santa Sede, I7 n

Maroncelli, departure for America, 251 
Martinique, religious orders in, I35

Martinis, Raphael de, Juris Pontificii de Propaganda Fide, $43 \mathrm{n}$

Martuscelli, Cavaliere, ciphers from, 236

Mary, Qucen of Scots, paper on marriage of, 6I

Maryland, faculties for, 8I, I3I, I90; foundation of, 8I ; freedom of worship in, I70; Jesuits in, 8I, I29, I45, I87, 2I8; letters relating to, 8I, I06, I72, I87 ; Marie Galante island and, I30 $\mathrm{n}$; missions of, I26, I27, I5I ; relations of, 8I, I05, I5I, I8I ; schools in, I4I ; secular priests for, 125,187 ; state of religion in, I4I, I70, I7 I

Mas Latrie, Count de, "Les Eléments de la Diplomatique Pontificale", 20 n

Massachusetts, convention government in, I I8 Massachusetts Historical Society, copies in library of, $12,227 \mathrm{n}$

Massé, Father Ennemond, letter to, I95

Massimi, Giulio, nuncio in Spain, abuses of, 9I ; cipher from, III; instructions to, IIO, 2I3

Masters of Ceremonies, archives of, 202-203; diaries of, 50 , I06; duties of, 5

Master of the Chamber, duties of, 5

Matienzo, Juan de, history by, I03

Matrimony, cases concerning, I 59, I64, I66, I79; decrees relating to, I74, I77, 210 ; dispensations for, $3 I, I 37$, I42, I43, I47, I6I, I68, I7I, I77, I8I, I9I, I92, I95; license for, I77; register of, 221

Matteo, Father, prefecture confirmed to, I36

Matteucci, $M g r$, letters of, 80

Matthews, William, letter of, 183

Matthias, Emperor, letters of, 88

Mattingly, Anna, cure of, 2 I8

Mattingly, George, relation by, I70

Maubec, abbacy of, I60, I63

Mazarin, Cardinal Jules, letters of, I07, 227

Mazarini, Cardinal Giulio, see Mazarin, Cardinal Jules

Mazzatinti, Giuseppe, Gli Archivi della Storia d'Italia, 25I

Meares, John, voyages of, 2 I 8

Mechoacan, Bishop of (Balthasar de Covarrubias), letter of, Io8

Mechoacan, archbishopric of, vacancy in, 68

Medici, Cardinal Giulio, see Clement VII.

Medici, Cardinal Leopoldo de', relation given to, 92

Medici family, papers of, 8, 249

Medina Sidonia, Duke of, orders by, II 3

Meister, Aloys, "Auszüge aus der Camera Apostolica", 209 n; Die Geheimschrift der Päpstlichen Kurie, 54 n; "Zur Spanischen Nuntiatur", $57 \mathrm{n}$

Melampo, F., inventory ordered by, 98

Memoriali, I89-I90

Menéndez, Pedro de, viceroy of Florida, French and, 243 ; letter to, 47

Mengacci, Francisco, letter of, 83

Mercedes, Santa Maria de, Order of, convent of, $\mathrm{I} 26$; information concerning brothers of, I28; petitions from, I05; procurator general of, paper by, I53; vicar general of, relation by, 93

Merinero, Juan, general of Franciscans, letter of, I05

Mesa, Bernardo de, bishop of Santiago de Cuba, election of, 253

Messia, Father Idelfonso, relation by, 95

Mexico, Archbishop of, absence of, 62, 64, I99; appointment of, 208 ; created patriarch, 44 ; correspondence of, $31,35 \mathrm{n}, 44,64,65,83$, 86, I08, I70, 207; Council of the Indies and, 64; Dominicans and, 83; faculties to, $35 \mathrm{n}$, I28, I34, I37, I55; payment by, 210; powers of, 62

Mexico, Viceroy of, letters to, 3I, 6I

Mexico, apostolic preacher in, I35; Augustinians of, 126, I50, I70, I90; briefs for, 29; Carmelites of, 66 ; catalogue of province of, 219,220 ; colleges in, I26, I39, I40, I70, I73, I86, I9I ; confraternity erected in, I29; congregation on affairs of, 125 ; diocese of, 253; dispensation for, 26; Dominicans of, I9o; ecclesiastical troubles in, 65; faculties for, I35, I64; Franciscans in, I57, I73; historical notices of, 217 ; hospice in, 127 ; idols of. I34; Indians of, 219; Jesuits of, 63; Minor Observants in, I38, I40, I49; missionary jurisdiction in, I86; missionary to, I29; missions in, I52, I69, 219; monarchs of, 63; papers on, 6о-6I, I6r, I74; permission to collect money in, I38; petitions and letters from, 95, I34; province of Augustinians in, 105, I26; province of Holy Gospel of, 204; provincial councils of, 65,217 , 229 ; relation of, $I 52$; revenues of, 63 ; rites in, I02; trial of monks of, 62 ; university of, I28; uprising in, $5 \mathrm{I}$; vicariate in, I50; see also New Spain

Micheau, Father, request of, I73

Michiel, Francesco, relation of, 238 n

Michiel, Giovanni, relation by, 252

Michigan, erection of diocese of, I44, I45, I46

Milan, Archbishop of (Giuseppe Archinto), letters of, 94

Milan, 23I ; archives of, 25I ; news-letters of, II3; revenues of, II 7

Milini, $M g r$. Pietro, letters of, 69

Mill Hill, London, college at, I95

Miltenberger, M., $26 \mathrm{n}$

Mimbella, Jacobo de, bishop of Santa Croce della Sierra, papers of, 95

Minieri Riccio, Camillo, library of, 229

Minimi, mission of, I28

Ministers, correspondence and records of, 47 , $85,201,228,233$

Minorca, colony from, I69

Minor Observants, briefs to, I33; colleges of, I37, I39, I40, I70 ; commissioner general of, 93: custodians for, 223; faculties for, I33, I 38, I39, I40; grievances of, I 50; houses of refuge of, I 40; Irish, 204; missionary privilege requested by, I40 ; missions of, I29, I34, I38; prefecture of, I34, I36, I40; procurator of, requests, I40, I49; Spanish, 204; usurpa- 
tions of, I33; see also names of places, and countries, e. g., West Indies, Minor Observants of; and Franciscans

Minutoli, Antonio, relation by, ro4

Minuzii, Mgr. Minuzio, letters of, 99

Miola, Alfonso, Manuscritti della Biblioteca Nazionale, $229 \mathrm{n}$

Miquelon, I3I n, I4I n, I84

Miramichi, missions of, Igr

Mirto, Ottavio, bishop of Tricarico, collection pertaining to, 80

Miscellanea, inventories of, I8; of Archivio Segreto, 45-5I ; of Propaganda, I93-I94

Missionaries, 219; decrees for, I93, 212 ; list of, I93; questionnaire for, I93; see also names of particular places, $e$. g., Canada, missionaries for

Missions, affairs of, I69; development of, I80; information concerning, I95; miscellaneous material of, r93; oriental, 229 ; prefects of, I88, I93; relations of, 212, 252; see also names of places, and religious orders, e. $g$., Mexico, missions in; Jesuits, missions of

Mississippi, Jesuits in, I35, I88; missionary to, I69; missions of, I36, I7I ; transfer of jurisdiction over, I45; vicar apostolic of, I45

Mocenigo, Alvise, relation by, 238

Mocenigo, Pietro, relations by, 92, 2I3, 245

Molin, Nicolo, relation by, 245

Molina, Alfonso de, bull to, 24

Molina y Oviedo, Gaspar de, bishop of Santiago de Cuba, election, and transfer of, 256

Mollat, G., La Fiscalité Pontificale en France, $32 \mathrm{n}$

Monachelis, F. Bernardino de, letter in favor of, 44

Monasteria Consistorialia et Cameralia, 50

Monasteries, archives of, 230; bulls of, 2I8; documents from, 98, 209

Money, paper, discussions of, 238

Moniteur de la Louisiane, 192

Monks, jurisdiction over, I9I ; trial of, 62 ; vices of, 236

Montague, vicar apostolic of Scotland, letter to, I84

Montalto, Cardinal (Alessandro Peretti), correspondence of, $64,65,89,97$

Monte, Juan del, letter of, 83

Montgolfier, $M g r$. Etienne de, papers relating to, I9I

Montiel, Juan de, bishop of Santiago de Cuba, election, and death of, 255

Montigny, François de, episcopal brief for, I54

Montmorin, Count, at Madrid, 243

Montreal, Bishop of, see Lartigue, Jean Jacques

Montreal, affairs at, I67, I68; bishopric of, I65, I67; churches near, I66; dispute at, I69; ecclesiastical government of, 167 ; erection of parish in, I54; fall of, 240; memoir of, I67; seminary of, I46, I47, I67, I68; Sulpicians of, I67, I68; vicar general of, controversy concerning, I46

Monumenta Ordinis Fratrum Praedicatorum, 204
Moore, Madam, letter to, I79

Moors, fleet of the Indies and, I05

Morales, Father, letters of, I52

Morel de Santa Cruz, Pedro Augustino, bishop of Santiago de Cuba, election of, 256

Mornay, Louis François, bishop of Quebec, 256, 257,258

Moro, Leonardo, Venetian ambassador, relations by, II2, 2I5

Morocco, proclamation of emperor of, 66

Morocco Company, ro6

Morosini, Francesco, relation by, 239

Morosini, Giovanni, relations by, roo, 2 I3

Motu proprio, bulls relating to, 35

Mouteis, Giuseppe du, martyrology by, 218

Moxos, relation of the mission to, 95

Moya de Contreras, Pedro, archbishop of Mexico, absence of, 62, 64; dispute of, 83 ; faculty to dispense conceded to, $35 \mathrm{n}$; letters of, $35 \mathrm{n}, 44,65,83$

Moyrans, Brother Epiphanius de, request of, I 59

Mulattoes, negroes and, I85

Municipal collections, 220

Münster, peace of, 84,226

Müntz, Eugène, La Bibliothèque du Vatican, I6 $n$

Museo Borgia, 108, I09

Museo del Risorgimento (Forli), 25I

Museo Storico dell'Archivio di Stato (Turin), 248

Museum, of the Propaganda, I95

Myra, Archbishop of, bequest of, I48

Naples, American consulates in, 235; American legation to, 222, 233; collections of, 229236; fleet at, I I5; French legation at, 235 ; mediation of king of, 235; news-letters from, 232 ; nunciature of, 60,85 ; polacca of, 235 ; revenues of, II7; Spanish legation at, 235

Napoleon I., I6

Narducci, Enrico, Catalogus Manuscriptorum in Bibliotheca Alessandrina, 207; description of library by, 228; Notizie della Biblioteca Alessandrina, 207

National Gazette (Philadelphia), I82

Navarrette, P. F., paper of, 2 II

Navies, of Europe, 73

Navigation, treaty with America, 236

Neale, Leonard, archbishop of Baltimore, chosen coadjutor, I42; death of, I78; letters of, I74, I76, I77, I78; return to America of, I70

Negroes, administration of sacraments to, 235 ; agreements concerning, 67,68 ; as slaves, II7, I32, I33; methods of enslaving, I32; mulattoes and, 185 ; opinion of missionaries concerning, I32; society for missions to, I95

Neil, James, letter of, I8I

Nerinckx, Father Charles, death of companion of, I75; letters of, I43, I82; work of, I75, I76, I79

Nerli, Signori, 38 
Netherlands, Belgian nuncio and, 78, I20; change in Propaganda control over, I2I; commerce of, I02; correspondence with, 79, 244 ; danger to Indies from, 215 ; fleet of, $85 \mathrm{n}, 88 \mathrm{n}$; mission of Cordon to, 247 ; mission to islands of, I30; navigation of, 68 ; relations with England, 79, 234; war with England, 73, 79; war with Spain, I04, I Io; vicar apostolic of, I30; see also Dutch

Neufville, Pierre de, faculties for, I30

Neutrality, 244; in French and Indian War, 240 Neutrals, rights of, 66, 68, 240, 244

New Batavia, desire of merchants to go to, I29; missions in, 128

New Belgium, state of the Church in, I54

New Brunswick, creation of vicar apostolic for, I44, I45; request for diocese of, I47; vicar apostolic of (Eneas MacEachern), letter of, 185

New England, affairs of, 248; Capuchins in, I28, I90 ; description of, I56; emigration to, I88; missions in, I24, I53, I58; relation of, IIO; state of the Church in, I54

Newfoundland, Bishop of, see Newfoundland, Vicar apostolic of

Newfoundland, Vicar apostolic of, coadjutor for, I46, I68; jurisdiction of, I44; letters of, $\mathrm{I} 66$; relation by, I67; selection of, I42, I43; see also names of individual vicars, e. $g$., O'Donnel, James Lewis

New foundland, attestation in favor of missionary at, I65; capture of, 79; data on, I95; faculties for, I68; French missions of, 130, I84; map of, 250; missionary deputed for, I4I ; naval affairs off, 240; Recollet of, I40, I84; relation of mission of, I93; religious affairs in, I66; sending of monks to, I66; state of, I85; treaty concerning, 95

New France, bishopric of, I37, I55; convents and monasteries in, I35; Jesuits in, I6I ; missionary to, I50; missions of, 126, 127; state of the Church of, I54; vicar apostolic of, I54; see also Canada

New Granada, miracle performed in, I03; recommendation of gentleman of, 62

New Mexico, bishop proposed for, I49; conversions in, I57; death of Franciscans in, 125; description of, I53; Dominicans for, I24, I90; indulgences for, 125; missions of, I49; prefect of, I33; relations of, IIO, I25, I56; religion in, 153

New Netherland, Belgian nuncio and, 78 ; capture of, 79

New Orleans, Bishop of, letters of, I75, I76, I77, I79, I80, I8I ; renunciation of, I46; selection of, I47; subsidy for, I76; transfer of jurisdiction to, 145 ; see also names of individual bishops, e. g., Dubourg, Louis Guillaume

New Orleans, administration of, I47, I92; Capuchins of, I84; diocese of, I42, I73, I92, 223; Jesuits in, I88; missions of, I39, I79; parochial church of, I74; priests of, I92; Ursulines at, I76; see also Louisiana
Newport, news from, 244

News-letters, 55, 90, 107, I08, I87, I88, 227, 230, 232, 233; see also Avvisi; names of places, $e$. g., Antwerp, news-letters from

New Spain, clergy of, petition of, I3I ; colleges in, 187 ; description of, I03; Dominicans for, 64 ; fleet of, 90, 96; funeral oration for founder of colleges in, I37; Jesuits in, IO2, 2I9; language of, II2; missionaries in, I32, I53; missionary jurisdiction of, I86; navigation of, 90; progress of religion in, 157 ; regulars in, I53, I56; relation of, II6 ; revenue of, I Io; rising in, 243 ; viceroy of, letters from, 6I, 214; see also Mexico

New Sweden, state of the Church in, I54

New York, Bishop of, confirmation of, I42; controversy of, I45; death of, I75; letter of, I77; request of, I47; selection of, 146 ; see also names of individual bishops, $e . g$., Connolly, John

New York, affairs of, 248; ciphers and letters from, 236, 25I ; discontent in, 80 ; erection of diocese of, I42; faculties for, I72; missions of, I7I; state of religion in, I7I, I8I, I82; Washington's plans against, 244

Nicholas V., endeavors concerning Vatican Library, I6

Nicolas, Jacques, letter of, 185

Nicolson, Father Francis, letter of, I69

Nieto, Father Pedro, honoring of, 124; writings of, $124,152,153,156,157,190$

Nimeguen, letters from, 83 ; treaty of, 84

Noëlly, M. de, letter of, I 58

Norfolk, Duke of, see Howard, Thomas

Norfolk, Va., letters from, I78; pastoral letters to, I79, I80; schism of, I8I; seizure of church of, I78

Normandy, Capuchins of, I38

Norte, Rio del, see Flumen Nortis

North America, Capuchins for, 127 ; Carmelites in, I34; confirmation in, 140 ; creation of bishops in, I29, I80; English possessions in, 247; French possessions in, I9I, 247; Indians of, I72; islands of, I85; Jesuits in, I36, I95; Minor Observants in, I40; missionaries for, I23, I25, I30; missionary colleges in, I40, I75; missions of, I28, I58, I70, I7I, I93, 2 I9; Puritans for, I24; relation of, I53; special congregation on affairs of, I92; viceroy of, I5I; voyages to, I49, $2 \mathrm{I} 7$; see also America

North Carolina, case of polacca from, 235; troops for, 8o; see also Carolina

Northwest, proposed bishopric of, I46

Notitiae Ecclesiarum, 39

Nova Batavia, see New Batavia

Nova Francia, see New France

Novara, Bishop of (Cesare Spaciani), letter of, 82

Nova Scotia, boundary line of, 74 ; house of education in, 165 ; spiritual regulation of, I43; state of Catholics in, I63; treaty concerning, 95; vicariate apostolic of, I43, I44, I45, I47, I66, I68 
Nova Sembla, see Nova Zembla

Nova Zembla, dispute in, II5; expedition by way of, II5

Nugent, Father, embarrassment caused by, I72

Nunciatures, $53-57$; miscellaneous, $48,84-85$; of Cologne, 57, 81, 85; of England, 80-82, 85; of Flanders, $77-80,85$; of Florence, 85 ; of France, 47, 7I-77, 85, IIo; of Germany, 84, 85 ; of Malta, 85 ; of Naples, 85 ; of Peace, $83-84$; of Poland, 85 ; of Portugal, $58,82-$ 83,85 ; of Savoy, 85 ; of Spain, $47-48,57-71$, $85,91,97$, IO9, 2I3, 2I5, 252; of Switzerland, 85 ; of Venice, 85

Nuncios, accounts of, 34 ; as representatives of Propaganda, I20; at peace conferences, 8384; correspondence and papers of, 46-49 passim, 53-85 passim, 88, 89, 97, 99, I00, I05, I07-III passim, II8, I23, I25, I93, 208, 213, $226,227,228,232$; functions of $54-56$; see also names of particular countries and places, $e . g$. , France, nuncios of

Nundwiler, J. B., "Deutsche Jesuiten ", 205 n

Nuñes, Gasparo, moneys held by, I27

Nuñez de Haro y Peralta, Ildefonso, archbishop of Mexico, letter from, I7o

Nuntiaturberichte aus Deutschland, $57 \mathrm{n}$

Nuovo Olanda, see New Netherland

Oath, to be taken by bishop, I73

Oaxaca, Indians of diocese of, I37

Obermer, Sig., election of, I80

Obligationes et Solutiones, 34

Obligationes pro Servitiis, 2 IO

Observants, see Minor Observants.

Odescalchi family, papers of, 8,228

O'Donnel, James Lewis, bishop of Thyatira and vicar apostolic of Newfoundland, attestation in favor of, I65; coadjutor granted to, I42 ; deputed superior of mission, I40 ; dispute of, I85; letters concerning, I84, I85

Office, funeral, 222

Offices, papal, 20I-202

O'Flynn, Francis Jeremiah, letters of, I85

O'Flynn, Father Jeremiah, information on, 176

Ohio, Dominicans in, I80, I8I

Ohio Company, 233

Ohio River, battle on the, II 8

Olgiati, Giuseppe, bishop of Parma, letter of, 86

Olite, Brother, Fermino da, request of, I7 I

Olivares, Count, conversation with, 66

Olivieri, $D$. Gabriele, deputed as missionary, I35

Olivieri, Father Orazio, letter to, 95

Olmedo, Father, document sent by, I73

Oneidas, mission among, I72; petition of, I73; relation by agent of, I72

Opecti, ambassador to Spain, 247

Orange, Prince of, see William I.

Oratorians, faculties requested by, I56; memorials of, 95 ; library of, 216

Order of Preachers, see Dominicans

Orders, religious, archives of, 8-9, 203-205; generals of, sending of missionaries by, I24; in Indies, 222 ; in West Indies, 126; mendi- cant, I53; Propaganda and, II9-I20; see also names of particular orders, $e$. g., Franciscans

Ordinations, $46, \mathrm{I} 53, \mathrm{I} 85$

Orfino, Giovanni Battista, instructions to, II7

Oria, $M g r$. Georgio di, letter of, I42

Orleans, Isle of, burial at, I64

Ormanetto, Nicola, bishop of Padua, letters of, 62 , III, 248

Orsini, Fulvio, collection, I I I, I I6 n

Orsini family, archive of, 220

Orsini palace, collection in, 228

Ortega, Father Ildefonso di, prefect in West Indies, I38

Ortega y Montañes, Juan, archbishop of Mexico, letters from, 86

Osage Indians, at Rome, I47

Ospedale di S. Spirito, library in, 216

Ottenthal, E. von, "Bemerkungen über Päpstliche Cameralregister", 32 n; "Die Bullenregister von Martin V. und Eugen IV.", 2I n; Regulae Cancellariae Apostolicae, $20 \mathrm{n}$

Ottobonian collection, 8, I09-I I I

Ottobuoni, Cardinal Pietro, see Alexander VIII.

Oudeardo, Brother Antonio, missionary to Mississippi, I69

Ovidi, Ernesto, Gli Archivi Pubblici Romani, $209 n$

Oviedo Pedrosa, Brother Francesco de, letters concerning, I26, I53

Pachuca, college at, I70, I73

Padiglione, Carlo, inventory by, 229

Padua, Bishop of (Nicola Ormanetto), correspondence of, 62 , III, 248

Palafox y Mendoza, Juan de, bishop of Puebla de los Angeles, canonization of, 199, 207, 208; complaints against, I27, I50; Jesuits and, I93; memorials regarding, 65,189

Palata, Duke of, viceroy of Peru, edict of, 68

Palatine library, II I

Palazzetta, archives in, 20I

Palazzo Ugolini, material from, 209

Paleotti, Cardinal Gabriele, acts of, 99

Pallium, payments for grant of, 2 ro

Palmieri, Gregorio, Ad Vaticani Archivi Regesta Manuductio, I7 n, 21 n, 22; Brevis Notitia Archivi Congregationis Caeremonialis, 202

Pamphili, Cardinal Camillo, letters of, ro6

Panama, letters from, 45, II6

Pando, Felipe, archbishop of Manila, letter to, 67

Panet, Bernard Claude, archbishop of Quebec, letters of, I46, I67, I68; recommended as coadjutor, 165 ; relation by, $\mathrm{I} 66$

Panzani, Gregorio, correspondence of, I05; relation by, I02

Panzirola, correspondence, 84

Papacy, accounts of, I03; administration of, 27 ; concession to Spain by, 73; documents relating to, 5I ; relations with England, 252

Papal States, American legation to, 222; archives of, I7; court of appeal of, 6 ; docu- 
ments relating to, 33 , 108 ; government of, 49. 86; immunity in, I99; maritime cases affecting, 68; revenues of, 5, 32; Rota and, 201 ; United States and, 220

Paradise, in America, 2 I8

Paraguay, Bishop of, case of, 220

Paris, Capuchins of, I54, I90; Farnesian representation in, 232; missions of, I 53, I 54 ; news-letters from, 97, II3, I I6, 208; nuncios at, correspondence, $70,7 \mathrm{I}, 86,95,96, \mathrm{I} 3 \mathrm{I}$, I36, I49, I54, I57, I58, I60, I6I, I70, I7 I, I72, I84, I9I, I94; Recollets of, I90; seminary of, I30, I36, I54, I62, I63, I84; transfer of archives from, I96-197

Parisano, Cesare, letter of, 64

Parisians, for America, I89

Parliament, American plans of, 80; Canadian Catholics and, 162, I66; question of American trade before, 24I; report of proceedings of, 95

Parma, Bishop of (Giuseppe Olgiati), letter of, 86

Parma, Duke of, letters of, 232 ; relation by, 92

Parma, archives of, 252; duchy of, 230 ; material relating to, $23 \mathrm{I}$

Passionei, $A b b \dot{e}$, letters of, $83-84$

Passionei, $M g r$., letters of, 76

Passionei, Cardinal Domenico, article addressed to, II I

Passports, records of, 22I, 222, 236

Pastor, Ludwig, "Biblioteche Private di Roma ", 227 n; Geschichte der Päpste, 38, $92 \mathrm{n}$, I I6 n, $205 \mathrm{n}, 207 \mathrm{n}, 216 \mathrm{n}$; report of, 228

Pasture. Abbé Alexandre, "Inventaire du Fonds Borghèse", $92 \mathrm{n}$

Patents, 236

Patras, Archbishop of, see Bagno, Guidi del

Patronage, 183 ; in Indies, 169

Paul II., bulls of, 35

Paul III. (Alessandro Farnese), brief of, I86; bulls of, 35, 186; Inquisition established by, $3 \mathrm{n}$, 196; letters and papers of, $8,85,226$, 230,232

Paul IV., briefs of, 29, 107; bulls of, 35 ; Inquisition and, 196 ; instructions from, 106

Paul V. (Camillo Borghese), archives of Avignon and, 90; Borghese collection and, 92 ; briefs of, $28,29,87$, ro6; bulls of, 16 ; consistorial acts of, 99 ; letters and papers of, $8,30,85,106,211,217,226$

Peace negotiations, $83-84,85$, I70, I94, 240, 24I

Penitentiary, tribunal of, $6,200-201$

Pennsylvania, Indians on frontiers of, 242

Pensacola, capture of, 244

Pentagouet, missions of, ror

Pereira, Miguel, bishopric of Santiago de Cuba and, 254

Peretti, Cardinal Alessandro, see Montalto, Cardinal

Pérez de Guzman, Don Alonzo, orders of, II3

Pérez de la Serna, Juan, archbishop of Mexico, appointment of, 208 ; letter of, 108
Peru, clergy of, I3I ; commodities of, 45 ; erection of cathedral in, 44 ; fleet of, $62,64,65$, 83, I03; folios relating to, 47 ; Franciscans in, I02; gold from, II6; government of, I03; images of rulers of, 208; inquisition in, 67 ; Jesuits of, 95 ; jurisdiction in, 67 , I86; mendicant orders in, I53; missions in, I38; Moxos of, 95 ; Order of Mercedes of, 105, I53; proposition to send nuncio to, $6 \mathrm{I}$; regulars in, I53; report of ex-Jesuit of, 66 ; viceroy of, 68, 229; war in, 217

Perugia, archives of, 252

Pescara, Marquis of, letters of, 232

Petraea, Bishop of, see Laval Montmorency, François de

Philadelphia, Bishop of, appointment of, I75; coadjutor for, I47; concordat of, 146 ; conduct of, I47; letters and papers of, I75, I8o, I82; renunciation of, I44, I8I; see also names of individual bishops, $e$. g., Egan, Michael

Philadelphia, bishopric of, I42, I43, I74, I75, I77, I80, I8I ; congress at, II8; deed, I83; disturbances in Church of, $146,147,180,181$, I82; documents concerning church at, I68, I83; election to church at, I80; Exposition at, $25 \mathrm{I}$; honorary missionary for, I44; letters from, I7 r, I73, I74, I80, I81, I83; newspaper of, I82; provisions concerning diocese of, I47 ; St. Mary's church of, I46, I74, I75; Sardinian consul-general at, I82; Trinity church in, I79

Philip II., of Spain, briefs to, 30; conversations with, 2I4, 243; counsels to, II3, II6, 2I5; ecclesiastical revenues under, 58 , edict of, 46; King of Portugal, 64, 82, II2; letters of, $47,62,88,92,107,109,217$; oration to, 46 ; relations of, 104, II 3

Philip III., court of, relation of, 102 ; instructions for, 217

Philip IV., cedulae of, 126, 127, I89; favors granted, I04, I94; letters to, 67; memorial of, 91 ; patronage of, 99, I89; relation of, 104

Philip V., accession of, 83,84 ; Charles III. and, $9 \mathrm{I}$; indulgence requested by, 96 ; letters of, 9I, 95; maintenance of missions by, 96; memorial of, 214 ; relations of, 46 ; subsidies for, 94, 95

Philip Neri, St., Oratory of, see Oratorians

Philippines, discovery of, 83 ; ecclesiastical immunity in, 67; Jesuits in, 9I ; papers relating to, 93, 207; relation of, Ir 3

Phips, Sir William, 82

Piacenza, Bishop of, letters of, 63, i I I

Piccolomini, Cardinal Celio, letters of, 106, I55, I 59

Picola, Father Francisco Maria, paper by, I69

Piedmont, division of, 246

Pieper, Anton, "Das Propaganda-Archiv", I22; Die Päpstlichen Legaten und Nuntien, 53 n; Zur Entstehungsgeschichte der ständigen Nuntiaturen, $53 \mathrm{n}$

Pieracchi, $A b b \dot{e}$, letters of, 77

Pieralisi, Alessandro, librarian, roI 
Pietro, Cardinal di, letter of, I75

Pignatelli, Count Michele, letters of, 233

Pinckney, Charles, minister to Spain, letter introducing, $67 \mathrm{n}$

Pio di Savoia, Cardinal Carlo, collection of, 94, 98-100

Piombino, Palazzo, archives in, 228

Pipe Creek, plantation of, I82

Piquet, letter from, I88

Pirates, edict against, 46 ; in Indies, 45, 8I, 88, 93

Pirina, Pedro de, fiscal magistrate of Peru, 229

Pistolesi, work of, I8

Pittsburg, letters from, I77

Pius III., bulls of, 24

Pius IV., addresses of, 37, I03; briefs of, 29, $30,2 \mathrm{I} 7$; bulls of, 35

Pius V., briefs of, 106; bulls of, $60 \mathrm{n}, \mathrm{I} 27$; constitutions of, I27; letters of, 46, 47, I06

Pius VI., appointments of bishops by, 5I; bull of, I73; letters of, I63, I73

Pius VII., appointments of bishops by, 5I; brief of, I79; chancery and, 4 ; faculties approved by, I93; letter of, I76; petition to, I77; Prince Regent of England and, I87

Pius VIII., appeal to, 183

Pius IX., college founded by, 205; greetings to, 219

Pius X., Acta, I98 n; congregation dissolved by, I98; Constitutio Apostolica de Romana Curia, $28 \mathrm{n}$, I96 n; Rota and, $20 \mathrm{I}$; reorganization of papal administration by, 6, 7

Plaza, Bartolo de la, bishop of Santiago de Cuba, election of, 255

Plessis, Joseph Octave, bishop and archbishop of Quebec, coadjutorship of, I65; chosen bishop, I65; faculties for, 165, I77; letters of, I65, I66, I67; mandates of, I67; projects of, I43; questions proposed by, I44, I94; relation by, 165

Plymouth, letter concerning, I48

Poggio, $M g r$. Giovanni, nuncio to Spain, letters of, $88 \mathrm{n}, 23 \mathrm{I}$

Point, Father, journal of, 219

Poland, historical work of, in Rome, II ; nunciature of, 85

Political miscellany, 227

Polk, James Knox, autograph of, 248

Pometti, F., "Pontificato di Clemente XI.", gI n

Ponce y Carrasco, Pedro, bishop of Cuba, transfer of, 256

Popayan, Bishop of (Agostin Coruña), scandal concerning, 64

Popayan, vacancy of see of, 68

Popes, diaries of, III, II6, 202; funerals, receptions, and voyages of, 202 ; lives of, III; power in papal administration, 2-3; see also names of individual popes

Port Louis, letter from, I59

Portocarrero, Cardinal Joaquin Fernando de, paper of, I69

Porto Rico, Bishop of, faculties for, I27, 129, I3I, I36, I37, I55

Porto Rico, I02; cession of, 233 ; letter on, I85
Portugal, King of (Philip II.), 82; income of, II 2 ; letter of, 64

Portugal, affairs of, 232 ; collector of, letters, $54-55,60,65,83$; ecclesiastical jurisdiction in, 97 ; England and, 48, 234; history of, IO7; income of, IO9, II7; in the Azores, 63; Italian missionaries and, I24; marine of, 79; marriage, and trade of, I04; material relating to, I08, 23I ; minister of, advice of, I80; nunciature of, papers, $56,58,82-83$, 85 ; relations of, 187 ; rumor of war with America, 74 ; Spain and, 234, 235 ; subsidies in, 96; taxes of, I03

Porzio, Giovane Paolo, letter and petition concerning, $\mathrm{I} 32$

Porzio, $D$. Nicolò, reinstatement of, I33

Porzio, Tomaso, letter and petition concerning, I32

Positiones Congregationis Emmor. Capitum Ordinum, 38

Posserini, indexes by, 92-93

Poterie, Claude de la, letter of, I72

Power, Patrick, letter of, I85

Poynter, $M g r$. William, vicar apostolic of London, letter from, 182

Praeconia, 37, 38, 213

Preachers, Order of, see Dominicans

Prefects, apostolic, II8, I62; cardinal, I9I ; of the palace, 22I

Premonstrants, monastery of, I35

Prince Edward Island, proposed diocese of I44, I47; letter on, I85; religion in, I68, I9I

Prince Regent of England, see George IV.

Princes, briefs to, 106, 207; correspondence with, 30, 87-89, 99, 108, 207, 226, 232 ; title of, 87

Privateers, letters concerning, 66

Processi, of consistories, 37

Processus Ecclesiarum, 38

Procurationes, 5

Procurators, appointment of, 135 ; business of, I2I, 122

Pro-Datario, 6

Propaganda, see Congregation de Propaganda Fide

Propagation of the faith, seminaries for, 158

Propositions, consistorial, III ; of churches, I 89

Protestants, speech concerning laws against, 75

Provinces, distribution of, I88

Provins, Father François (Pacifique) de, letters of, 152 ; mission of, I28, I52; prefecture assigned to, I26; relation by, I27

Provisiones, 40,42

Prussian Institute, examination of Borghese collection by, 92, 93; work of, II, 57

Public Record Office, London, transcripts of, I2, 80, I05, II3, 205, 207, 2 II

Puebla de los Angeles (Tlascala), Bishop of, see Palafox y Mendoza, Juan de

Puebla de los Angeles, alumni of seminary of I28; monastery in, 95 ; requests of priests of, I33, I39

Puritans, in America, I24, I50; relations concerning, I04, I56 
Quebec, Archbishop of, deputies of, I67; faculties for, I68; legislative council and, I44; letters of, I46, I66, I67, I68; mandates of, I67; questions proposed by, I44, I94; see also names of individual archbishops, e. g., Panet, Bernard Claude

Quebec, Bishop of, absence of, 73; assignment of abbacy to, r6o; Bishop of Heliopolis and, I59; briefs for, $16 \mathrm{r}, \mathrm{I} 94$; commission to, I4I ; consecration of, I6r ; death of, r65 ; dispensations for, I42 ; edict of, I4I ; election of, I9I ; faculties for, I3I, I32, I33, I34, 136, I37, 160, 16r, 164, I65, I66; George III. and, 165 ; goods of the chapter and, I60; instructions to, 194 ; jurisdiction of, $\mathrm{r} 4 \mathrm{I}$, I44, I6I, I64, I69; letters and papers of, I31, I35, I40, I4I, I59, I6I, I62, I64, I65, I67, I70, I77, I84; missions under, I32, I35; oath of, I6I; Propaganda control over, I2I ; relics for, I3I; reputation of, I60; vicar general constituted by, I39; see also names of individual bishops, $\varepsilon$. g., Briand, Olivier

Quebec, abbacy of, I59, I60, I63, I70; archbishopric of, I66 ; attack on, 73, 79, 240 ; bishopric of, $95,130,135,154,159,160,163,256-$ 258 ; bulls for, $26,130,131,159,160$; chapter of, I60, I6г, I9г ; coadjutorship of, 137 , I40, I4I, I42, I60, I62, I63, I64, I65, I67, I68, I70, I99; condition of diocese of, I66, I9I; differences in worship in, I69; diploma regarding, I60; Easter obligation in, I4I; ecclesiastical law in, I68; erection of parishes in, I30, I59; extent of diocese of, 164 ; feasts observed in, I4I, I64; indulgences for, $161,162,163,164$; Jesuits in, I60; jurisdiction in, 147,160 , 161 ; letters and papers on, I45, I62, I82; queries from, I67; relations of, I43, I58, I62, I63, I64, I65, I93; representations of curates of, 167 ; revenue of church of, I6o; Sardinian missionaries from, I62 ; seminary of, I45, I54, I59, I6I ; siege of, I9I; spiritual administration in, I44; Sulpicians in, I63, I67; vespers in rural churches of, 147 ; vicar general of, I 17, I39, I62, 165, 184; see also Canada

Quebec Act, 234

Quellen und Forschungen aus dem Gebiete der Geschichte, II, $57 \mathrm{n}$

Quellen und Forschungen aus Italienischen Archiven, II

Queylus, $A b b e$, conflict with, 154

Quindenae, 5, 33, 34, 38, 4I

Quintero, Brother Gasparo de, favors for, I9o; petition of, 126

Quivira, see "Gran Chivira"

Raleigh, Sir Walter, in West Indies, I I6; voyage of, II5

Ramírez de Salamanca, Miguel, bishop of Santiago de Cuba, consecration of, 253 ; death of, 254 ; election of, 253,254

Ramos, Nicolas, archbishop of Santo Domingo, pallium for, $2 \mathrm{I7}$

Ravenna, archives of, 252
Ravizzi, $M g r$, relation by, 2 I6

Recollets, commissary general of, I34; faculties for, I7I ; in Canada, I25, I4I, I49; in Louisiana, I32; of Paris, I90

Regency, of Florence, documents, 249

Regesta Cancellaria, see Regesta Lateranensia

Regesta della Dataria, see Regesta Lateranensia

Regesta Lateranensia, 24-26

Regesta Supplicationum, 26-27

Regesta Vaticana, 2I-24

Registers, Papal, 20-2I

Regulae Cancellariae Apostolicae, $20 \mathrm{n}$

Regulars, jurisdiction over, 169, 197

Reina Maldonado, Pedro de, bishop of Santiago de Cuba, election, and death of, 255

Relations, 47, 48, 51, 73, 93, 100, 104, 122, 127, 132, I46, I47, 156, I77, 194, 207, 218, 220, $227,232,247,251$; America, 92, r39; Baltimore, I4I, I73; California, I56; Canada, I5 I, I54, I55, I62; Council of Trent, I I6; England, 92, 102, 104, I 12, $213,232,239$, 245, 252; France, 48, 49, IOO, IO7, I IO, I I I, I $8,213,216,238$; Indies, I03, I I3, I 16, I52, r56; Kentucky, r78, r79; Louisiana, r79, I80, I8I ; Maryland, 8I, I05, I4I, I70, I8I ; Mexico, r52 ; missions, 50, 9r, 94, 95, r29, I30, I53, I54, I62, I66, I69, I73, I80, I93, 213, 252; New England, I Io, I53; Newfoundland, I67; New Mexico, I25, I56; North America, I53, I67, I72; Philippines, I13; Quebec, I43, I58, I62, I64, I65, I66; Rome, 47; Santo Domingo, I31, I39; Spain, $46,47,91,92,97,100,102,103,104,107$, I09, IIO, II2, II3, II7, 2II, 2I 2 , 213,215 , 2I6, 239; Sweden, Iro; United Provinces, I73; United States, I7I, I8I ; Venetian ambassadors, 46, 47, I00, IIO, III, II 3,215 , 238, 25I; West Indies, I02, 104, II3, I33, I 50, I 55, I 57, I70, I 85

Renaissance, history of, 228

Renzi Strozzi, Marchesa Ottavia, letters to, 208

Resignations, books of, 209-210

Restigouche, missions of, I9I

Retz, Cardinal, see Gondi de Retz

Reuter, Father Caesar, letters concerning, 174

Revenue, state of, 2I5, 216

Rey, Father Francisco del, petition of, I35

Richard, Father Gabriel, proposed as bishop, I 46

Richard, P., "Origines et Développement de la Secretairerie d'Etat Apostolique", $52 \mathrm{n}$; "Origines de la Nonciature de France" 53 n, 7 I n; "Origines des Nonciatures Permanentes", 52 n, 53 n, 58 n, 71 n, 82 n

Richemont, Vicomte de, Correspondance de Salomon, $77 \mathrm{n}$

Richmond, bishopric of, 182

Riganti, Commentaria in Regulas Cancellariae Apostolicae, $20 \mathrm{n}$

Rilli Orsini, Count Luigi, note by, 220

Rinuccini, $M g r$. , sub-collector general for Spain, instructions to, 46

Rio, Balthasar del, bishop of Scala, at consecration, 253 
Rio, $D$. Bonaventura di, mission of, I35

Rios, Bernardo Alfonso de los, bishop of Santiago de Cuba, election, and trarısfer of, 256

Rios Codex Mexicanus, i I6

Ripa, Bishop of (Filippo Sega), letters of, 62 Rites, requests and orders regarding, IO2

Riva, "Lettres de Muratori", 87 n

Rocca, Angelicus, library founded by, 207

Rocco da Cesinale, P., Storia delle Missioni dei Cappucini, $205 \mathrm{n}$

Rochelle, Bishop of, order concerning, I34; request of, I36

Rodericus, Emmanuel, bullarium of, I52

Romagna, legation of the, 85

Romallotto, Jacomo, paper by, 2I7

Rome, Archivio di Stato, 34, 209-210; Congregation of Visitation in, 49; jubilee at, I3I ; letters from, 95, I05, I08, II3, II4, II5, I82, 208 ; material relating to, 23I, 232 ; municipality of, collections, 220 ; relation of, 47

Romeno, Father, letters of, I69

Romero, Father Fran., mission of, I34

Römische Quartalschrift, $28 \mathrm{n}, 38$, I09, I22

Ronchini, "Relazione sull'Archivio di Parma ", $230 \mathrm{n}$

Ronconi, Filippo, library of, roo

Rosa, Santa, of Lima, canonization of, 44

Rosati, Giuseppe, bishop of St. Louis, letters and papers of, I78, I79, I80, I8I, I82 ; mission of, $\mathrm{I79}$; renunciation of, $\mathrm{I} 46$; revocation of decree concerning, I45

Rosi, M., "Documenti relativi ai Turchi presi a Lepanto", 87 n

Rospigliosi, Cardinal Giulio, see Clement IX.

Rospigliosi family, papers of, 8,228

Rossano, Archbishop of (Giovanni Battista Castagna), see Urban VII.

Rossetti, Mgr. Carlo, correspondence of, 8I, 85, I05, 106, I27

Rossi, $M g r$. di, collection of, roo; manuscripts donated by, 2 I2

Rossi, G. B., La Biblioteca della Sede Apostolica, $\mathrm{I} 6 \mathrm{n}$

Rota, 6, 20I ; decisions of, ro6; jurisdiction of, I97, I98

Rouen, Archbishop of (François de Harlay de Champallon), jurisdiction claimed by, I29, I30, I54, I9I

Rouen, Provincial of, 186

Roux, M., proposed response of, I46

Royal Commission of History of Belgium, 225

Royale, Isle, missions of, I9I

Royalists, discussions of, 238

Rubeis, Peter Francis de, collection of, 207

Rubriche, 244

Rudolph II., letters of, 88

Ruffo archives, 220

Russia, Empress of (Catherine II.), letter of, 66

Russia, relations with Spain, 66

Rusticucci, Cardinal Girolamo, correspondence of, $61,62,63,64,70,82,232$

Ruzzini, Antonio, relation by, 239

Ryan, Father, letters of, I80, I8I ; summons to, 183
Sacco, Antonio, Biblioteca Leonina, I $5 \mathrm{n}$

Sachetti, Cardinal Giulio, bishop of Gravina, instructions to, 59, $59 \mathrm{n}, 9 \mathrm{I}, 104,2 \mathrm{II}, 2 \mathrm{I} 2$; letters of, $5 \mathrm{I}$

Saënz de Mañosca, Juan de S. Matia, bishop of Santiago de Cuba, election, and transfer of, 256

Sagnori, Archivio degli Uffici Rotali, $201 \mathrm{n}$

Sagredo, Giovanni, relation by, 245

St. André-au-Bois, license for abbot of, I35

St. Augustine, repulses of English at, 66

St. Cecilia, library of, 220

St. Christopher, English, Scotch, and Irish in, I90; mission to, 126

St. Eustatius, capture of, 73

St. Isidore, Minor Observants of, 204

St. John Isle, missions of, I9I ; see also Prince Edward Island

St. John of Jerusalem, military order of, 65

St. John River, missions of, I9I

St. John's, N. F., Vicar apostolic of, letters of, 185

St. John's, N. F., capture of, 74; Scotch settlers at, 184

St. Joseph, college of, I95; society of, see Josephites

St. Louis, Bishop of, see New Orleans, Bishop of

St. Louis, Mo., confraternity of, 219 ; control of parish of, I43, I92 ; episcopal residence at, I76; proposal for bishopric of, I46

St. Loutis des Français, archives of, 224; historical work at, I I, 222

St. Martha, Bishop of, letters concerning, 64

St. Martin, monastery of, I35

St. Mary, seminary of, I8o

St. Mary (Baltimore), college of, I45

St. Mary (Philadelphia), church of, I46, I74, I75

St. Mary's, Md., disembarkation of pilgrims at, 219

St. Paul's (Rome), collections for, 167

St. Peter's (Rome), archives of, 206

St. Pierre, I3I n, I4I n; clergy of, I85 ; fishing and, 80 ; letters on, $\mathrm{I} 84$

St. Quarante, Franciscans of, 204-205

St. Sulpice, seminary of, I45, I7 I, I73, I76, I77

St. Thomas (Bardstown), seminary of, 179

St. Vincent, island of, mission in, I 57

Sala Diplomatica, 229

Salamanca, college of, 223

Sala Riservata, 2 I7

Salcedo, Francisco de, bishop of Chili, spoils of, 105

Salomon, Abbé, letters to, 77

Samaran, Ch., La Fiscalité Pontificale en France, $32 \mathrm{n}$; "La Jurisprudence Pontificale", 32 n

San Carlo, Father Massimino di, petitions from, I35; prefecture confirmed to, I36

Sanchez, Gabriel, letter to, 2 I7

San Diego, Mexico, college of, I39; Observants of, I34; Scalzetti of, I69

San Ferdinando, Mexico, college of, I40, I7o, I79 
San Francesco, Father Michele di, prefecture confirmed to, I36

Sanioseff, Bastiano, commander, 82

San Martino, Father Giacomo di, prefecture confirmed to, 136

San Martino, Naples, library of, 229

San Miguel, fighting at, 83

San Severina, Cardinal di (Giulio Antonio Santori), records of, $37 \mathrm{n}, 40,4 \mathrm{I}, 42,98$, I I I, $2 \mathrm{I} 5$

Santa Croce, Cardinal Prospero di, letters of, 99, 2 I 3

Santa Croce della Sierra, Bishop of (Jacobo de Mimbella), papers of, 95

Santa Croce di Gerusalemme, 2 I7

Santa Croce family, archives of, 228

Santa Cruz, Marquis of, report of, II3; victory of, 104

Santa Cruz, jurisdiction over, 185

Santa $\mathrm{Fe}$ de Bogotá, rites in diocese of, I02

Santa Maria, Ramón de, La Fiesta de la Concepción, $222 \mathrm{n}, 224$; index by, 222

S. Maria Maggiore (Rome), archives of, 206

Santa Marta, 64; erection of church in, 36

Santa Rosa, Kentucky, sale of monastery of, I47

SS. Nunziata e Giuseppe, polacca, case of, 235

Santiago de Cuba, Bishop of, appointments of, 253-256 : auxiliary, bull to, 222; dispute of 80 ; faculties for, I29, I3I, I32, I34, I37, I55, I56, I84; letter of, I92; powers of, 88 ; sickness of, 184 ; see also Havana, Bishop of

Santiago de Cuba, diocese of, I3O, 253-255

Santiago y San Ildefonso de los Españoles, archive in church of, 224

Santo Buono, Prince of, voyage of, 229

Santo Domingo, Archbishop of, faculties for I29, I36, I37, I38; jurisdiction of, I37; pallium granted to, $2 \mathrm{I} 7$

Santo Domingo, case of Indian born in, I57; Catholic religion in, I3I; diocese of, 253 ; Drake in, II 5 ; fleet sent to, 74 ; missions in, I39; prefects for, I36, I38, I39; report on, II8; Recollets of, I32

Santori, Cardinal Giulio Antonio, see San Severina, Cardinal di

Sanuto, Marino, diary of, 245

Sanvabriano, Father Massimiliano, faculties for mission of, I32

Sanxis, Raphael (i. e. Gabriel), letter to, II7

Sardinia, kingdom of, archives of, 9 ; consulsgeneral of, letters, I82; diplomatic correspondence with, 221, 246; ministers of, papers, I82, 247 ; treaties with United States, 247,248

Sarmiento, Didacus, bishop of Santiago de Cuba, 254

Savignano di Romagna, archives of, 252

Savoy, nunciature of, 85

Saye, Lord, see Fiennes, William

Sayre, Stephen, imprisonment of, 74

Scallan, Thomas, vicar apostolic of Newfoundland, relation by, 167 ; request of, 168
Scalzetti, of San Diego, I6o

Scappi, Alessandro, bishop of Piacenza, letter to, I I I

Scherer, Clemen, letter of, I59

Schlecht, $D r$. inventory by, 46

Schutz, L., "Libri Formatarum", 2 io n

Scotland, Vicar apostolic of, letter to, I84

Scotland, settlers of, at St. John's, I84; in St. Christopher, I90; in Virginia, II 5

Scotti, $M g r$, instructions to, 72,213 ; relations by, 49,91

Scripta Varia, of Propaganda, I95

Scritture Antiche, I47, I48-I58

Scritture Corrispondenti, I47, I58

Scritture non Riferite. I58-I88

Scritture Originali Riferite nelle Congregationi Generali, I47-I 58

Scritture Riferite nei Congressi, I 58-I 88

Sebastian, bishop of Santiago de Cuba, election of, 253

Secretarius domesticus, 52

Secretary of briefs, archives of, $42-43$; letter to, 226 ; office of, 4-5, 27-28, 202

Secretary of ciphers, office of, 54

Secretary of Latin letters, 202

Secretary of letters to princes, 87

Secretary of memorials, office of, 6

Secretary of state, papal, archives of, I8, 52-89, 202 ; correspondence of, $54,58,59,60,6 \mathrm{I}$, 89,99 , IOO, I70, 223 ; office of, $5,52-53$; see also names of individual secretaries, $e . g$., Como, Cardinal di

Secretary of state (U. S.), letter of, 183

Sedella, Father Antonio de, appointment of, I92

Sega, Cardinal Filippo, bishop of Ripa and Piacenza, letters of, 62,63

Segnatura, cardinals di, 53

Segnatura Papale di Giustizia, 6

Seminaries, establishment of, I82; government of, I97; notes and queries on, I79, I86; Spanish, I8I

Sepulchres, I65

Sera de Castros, Girolamo, relation by, IO4

Seraphic Institute. I93

Seria, Abbé de la, letter of, 97

Serranus, Brother H., mission of, I26

Servitiae Communes, 5

Seven Years' War, papers concerning, 246, 247 ; treaty closing, 233

Severino, Cardinal, consistorial acts of, 203

Seville, subcollector of, letter of, 65

Sfondrati, Cardinal Paolo Emilio, letter to, 65

Sforza, Duchess, paper written for, 2 I7

Sforza Cesarini, archives, 228

Shahan, Mgr., T. J., "L'Histoire de l'Eglise Catholique aux Etats Unis", I22 n

Sharp, pirate, capture of, 8I

Shea, John G., Catholic Church in Colonial Days, I22; Life of Carroll, I22, I69 n, I70 n, I7 I n

Shirley, Anthony, discourse by, I02

Sicardi, Sig., letter of, I79

Sicily, revenues of, II7; war in, 236 
Sickel, Th., Bericht über Istituto Austriaco, II $\mathrm{n}$

Siena, material relating to, 23I

Signatura Apostolica, 20I

Signaturae, 2I, 36

Signay, Joseph, coadjutor (aft. archbishop) of Quebec, profession of faith of, I68

Silva, Father Emmanuele da, request of. I4I

Simeoni, Cardinal G., Juris Pontificii de Propaganda Fide, $43 \mathrm{n}$

Sinaloa, bull for diocese of, 223; missions of, 219

Sirleti, library, ir6

Sistine Chapel, archives beneath, 202

Sixtus IV., founding of Castello collection by, 43 ; instructions of, 226

Sixtus $V$., briefs of, I06; congregations established by, $3,3 \mathrm{n}$; letters and papers of, 46 , $64,65,89,226$; papal administration under, 37, I 19

Slaves, brief on, I94; contracts for, 84 ; manuscript concerning, 208; sale of, I86; see also Negroes

Società Napoletana di Storia Patria, library of, 229

Società Romana di Storia Patria, 216

Society of Archives of the Religious History of France, 57

Society of Jesus, see Jesuits

Solano, Father Francesco, narrative by, I02

Solar, Bailli, peace negotiations of, 248

Soldati, 89

Sonora, bull for diocese of, 223; missions of, 219

Sorbonne, decree of the, 160

Sotomayor, Juan de, request of, I55

South America, Church and republics of, 200; colleges of, I75 ; immunity in, I99; missionary work in, 203; parochial churches of, I5O; references to. 217 ; settlement of difficulties in, 243; troubles between Spain and Portugal in, 234, 235; vacancies in, 68

South Carolina, Acadians in, 80; Creeks in, 79; Dominican of, letter, I79; schism in, I77; see also Carolina

South Sea Bubble, 238

South Sea Company, 83

Spaciani, Cesare, bishop of Novara, letter of, 82

Spada, Cardinal Bernardo, books from library of, $7 \mathrm{I}-72$

Spada, archives, 228

Spada, Fondo, 77

Spain, King of, brief to, I32; cedulae of, I26, I89; conflict with, I69; conversation with, 2I4; decimae demanded by, 96; discourse to, I IO ; favors of, 94, 99, I04; impediments of curia of, I26; income and expense of, I 2 ; letters and papers of, $69,88,93$, I77, I85, I92, 2I4; patronage of, I89, I94; treasurer of, II7; see also names of individual kings, e. g., Philip V.

Spain, Queen of, letters of, 69, 88, I3I
Spain, affairs of, 23I, 232; ambassadors of, papers, 48, 67, 190, 223, 232; bishops and archbishops of, letters to, 95 ; bulls pertaining to, 35 ; collectorship of, 99, I05, I I2, I I7 ; colleges in, I37; commerce of America and, 2II, 239; concordats with, 44; congregation in, I24; correspondence of Turin with, 246 ; councils of, I09; court of Rome and, 215; departure of, from Florida, I69; depopulation of, 2I I ; dispatches concerning, 242-244; distribution of possessions of, 73 ; division of empire of, 84 ; ecclesiastical jurisdiction in, 97 ; embassy of, at Rome, 222-223; empire of, IIO, 2II ; England and, 66, 69, 73, $78,82,84,95$, II 3 I I 5, I87, 234, 242; fears of, 79; fleet of, 45, 5 I, 78, I04, I IO, I I3, I I4, 239; fleet of Indies and merchants of, 243; forces of, I03; France and, 8I, II3, 2I5, 243; Franciscans in, 98; government of, I04; grandees of, letters, 69 ; grants to dominions of, $23,24,30,73,93$; history of, I07; importance of nuncio to, 58 ; in Indies, II3, II5, 239, 247; inquisitor-general of, letter, 96; instructions to nuncios in, 94, 99, I04, 106, I07, I09, I23, I25, I53, 2 II, 2I2, 2I3, 2I5, 2I8; interests of, in America, 247; in Virginia, II5; in West Indies, 90; Italian missionaries prohibited by, I24; letters and papers of nuncios to, $34,45,46$, 55, 56, 57-71 passim, 99, I00, I05, I08, I10, III, II 8 , I24, I28, I33, I49, I56, I73, 208, 226; mediation of, 243; Medici correspondence with, 249; military affairs in, 66 ; minister of, papers, 70, 7I, 93, I37, I77, 23I ; miscellaneous material relating to, 36,46 , $47-48,49,58,69,70,7$ I $88,89,94,96$, то2, I08; monarchy of, 48, Io9, 2I I, 247; monasteries in, $2 \mathrm{I} 4$; navigation privileges granted by, 68; Neapolitan legation in, 235; Netherlands and, 90, IO4, I I5, 243; neutrality of, 235, 243; nunciature of, $48,58,85$, 9I, 97, 109, 213, 215, 252 ; peace at Fontainebleau and, 248 ; plan of fortification in, II6; policy of, 239; political subjects relating to, 66, 252; Portugal and, 234, 235; Propaganda and, II9, 228; province assigned to nuncio of, I20; register of ciphers with, I07; relations of, 46, 47, 91, 92, 97, 100, 102, 103, I04, I07, I09, IIO, II2, II3, II7, 2II, 212 , 213, 215, 216, 239; revenues of, I09, II7, 217; revenue of nuncios to, 58-59; rumor concerning island of, II4; Russia and, 66; seizure of vessel by, 218; seminaries in America, I8I; subcollectors in, 96, ro4; subsidies in, 96; taxes of, 69, I03; threats of, 239; trial of monks in, 62; United States and, 243,244 ; voyage to, 217

Spanish America, appointment of bishops in, 37 ; commerce of, $73,74,238$; faculties for, I70; government of, 46 ; houses of refuge in, 140; immunity in, I99; Inquisition in, I96; insecurity of, 79; missionaries in, I85, 219 ; payments for bishoprics of, 210; Propaganda and, I20, 187; propagation of faith 
in, 46 ; prosperity of, 218 ; Spanish nuncio and, 59

Spanish Armada, 46, II4

Spanish Succession, war of, 9I

Spannocchi, Tiburtio, writings of, I07, I Io

Sparks, J., Diplomatic Correspondence of the American Revolution, I70 $\mathrm{n}$

Spina, $M g r$, correspondence, 77

Spinola, Cardinal Giovanni Battista, trial before, 46

Spinosa, letter of, 45

Spinosa, Cardinal Diego, discussion before, 2 I3 ; letter to, 47

Spinosa, Juan, general of Franciscans, letter of, 105

Spoils, see Spolia

Spolia, 5, 83, 99, I04, I05, II I, 2I2, 2 I4

States General, Dutch, declaration of, 247

Statistica degli Archivii della Regione Veneta, 237

Statius Lusitanus, Achilles, library founded by, 216

Steinberg, S., "Die Facultäten eines Päpstlichen Nuntius", $53 \mathrm{n}$

Stewart, Father, coadjutor, I42

Stock, Father Simon, letters of, I23, I48, I49, I50; mission proposed by, I69

Stormont, Lord, the insurgents and, 75

Stornajolo, Cosimus, Codices Urbinates Latini, I I2 $\mathrm{n}$

Stübel, B., "Die Instructionem Carls V. für Philipp II.", rog n

Students, American, I72, I73

Study in Roman archives, conditions of, 7-I4

Sub-datario, cardinal, letters to, 226

Subsidies, for America, 222 ; for New Orleans, 175, 176; in Indies, 94, 96; in Portugal, 96; in Spain, 96; in West Indies, 94, 96; suspension of, 95

Substitutus pro Negotiis Ordinariis, 28

Sulpicians, attack on, I78; of Baltimore, I79; of Montreal, I67, I69; of Quebec, I63, I67; proposed sale by, I47; seminaries of, I47, I63, I67; see also St. Sulpice, seminary of

Suriano, Michele, Venetian ambassador, commentaries by, Ioo; letters of, $238 \mathrm{n}$; relations by, 9I, IIO, II3, II7, 2I2, 2 I 3

Surrel de Saint-Julien, Abbé H., 86; "Documents ..... Mazarin", 87 n

Sweden, Queen of (Christina), library of, I I II 12

Sweden, relation of, I IO

Switzerland, address to people of, I03; Camera material concerning, 33 ; nunciature of, 85

Sybel, H. von, "Vorwort", $57 \mathrm{n}$

Taberna, Ludovico, bishop of Lodi, instructions to, 46; letter of, 82

Tacchi Venturi, P., Diario Consistoriale di Cardinale di S. Severina, $37 \mathrm{n}$

Tamaroa Indians, mission to, I64

Tamayo de Vayas, $D r$. Tomas, library of, Io3

Tampico, mission in, I34, I69
Tarsus, Archbishop of, instructions to, $72 \mathrm{n}$; letter to, 8I; see also Corsini, $M g r$.

Taxae, 33, 51, I03, II7, I94, 210, 2 I8

Tax book of Churches, 49,50

Taxes, see Taxae

Taylor, William, letter of, I82

Teano, Prince of, statement of, 225

Tea question, 242

Tehuan, English at, 67

Telmissus, Bishop of, see Lartigue, Jean Jacques

Temple, Sir John, consul general in United States, departure of, 24I

Teneriffe, grant for hospital at, $26 \mathrm{n}$

Terlinden, Ch., Le Pape Clément IX. et la Guerre de Candie, $228 \mathrm{n}$

Ternay, Chevalier de, flight of, 74

Thebes, Archbishop of (Lelio Falconieri), instructions to, 49, 107, 109

Thibault, $D$. Toum., letter of, I6o

Thibet, missions of, 138

Tiepolo, Antonio, relations by, 47, 9I, i ro

Tiepolo, Lorenzo, relation by, 238

Tiepolo, Nicolo, relation by, 238

Tierra Firme, relation of, I 16

Thyatira, Bishop of, see O'Donnel, James Lewis

Tiro, Father Thomas de, nomination of, 44

Tlascala (Puebla de los Angeles), Bishop of, see Palafox y Mendoza, Juan de

Tobacco, prohibition of planting of, 79

Toledo, Francisco de, viceroy of Peru, letter to, 47

Toleration, I79

Tolomei collection, 228

Tomson, $A b b e ́$, letter from, I84

Tonsure, conferring of, I7 I

Törne, P. O. von, Ptolérnée Gallio, Cardinal de Como, $53 \mathrm{n}, 228 \mathrm{n}$

Torre, Nicolas de la, bishop of Santiago de Cuba, election, and death of, 255

Torris, Peter, letter of, 185

Torrubia, Giuseppe, commissary general of Franciscans, I86

Toscanelli, Paolo, 249. 250 n, 25I

Toscanelli family, notes concerning, 228

Trade, cases and orders regarding, 66; documents on, I59, 24I ; neutral, 235 ; prohibition of religious orders concerning, 222

Trappists, for Baltimore, I75

Treaties, 246, 250; commercial, $84,236,238,247$, 248; miscellaneous, Io6; negotiations for, 73 ; of $I 763,79,248$; of $I 783,67$; of Utrecht, 83,84 ; of Versailles, 74,238 ; with Indians, 79, 1 I 8

Trede, Th., Die Propaganda Fide, ing

Trent, Council of, see Council of Trent

Treviso, Archbishop of (Augusto Zacco), letter from, I86

Tribunals, 200-20I ; see also names of particular tribunals, e. g., Rota

Tricarico, Bishop of (Ottavio Mirto), collection of, 80

Trinchera, Francesco, Degli Archivi Napoletani, 229, 233

Trinidad, missionaries to, $\mathbf{I} 42$ 
Trinity Church, Philadelphia, pastoral letters to, I79

Trinity College, Dublin, archives at, 197

Tromba d'Europa, 91, 2I3

Troops, for America, 242

Trustees, controversy of, I45

Tuam, Archbishop of (Malachi Kealy), mission of, 126

Turenne, Capuchins in, I38; Carmelites of, I39

Turin, Archbishop of (Victor Costa di Arignano), letter of, I62

Turin, archives of, $209,246-248$; coadjutorship of Quebec and court of, I70; jealousy concerning, 233; library in university of, 248 ; request of court of, 162

Turkey, council of, I09; income and expense of, Iog, II 2 ; money for war against, 67

Turks Island, neutrality of, 240

Tuscany, Grand Duke of, restoration of, 250

Tuscany, 23I

Tyler, John, autograph of, 248

Ubaldini, Cardinal Roberto, letters of, 92, 99, I06

Udienze di Nostro Signore, I89

Ugolini, M., Biblioteca Leonina, i6 n

Ugolini, Palazzo, material from, 209

Ulster, emigration from, I88

Unigenitus, bull, 95

United Provinces, Americans in, I73

United States, appeal to, I83; attention shown to, 24I ; College of, see American College; conditions in, I82; correspondence of Florence with, 250; credits of, 236 ; data on, 195; dioceses in, I75; election of bishops in, 145, I7I, I92; France and, 75, 240; goods acquired in, I78; independence of, 74 ; Italy and, 228; Jesuits in, I69, 218; map of, 220 ; matrimonial dispensations for, I7I ; minister of, papers, I83, 246: missions of, I7I, I8I, 2 I9; Morocco and, 66; Neapolitan correspondence with, 2.33; observations concerning, 248; Papal States and, 220; Propaganda and, I2I ; propagation of faith in, 192; religious organizations in, 203; secretary of state of, letter, I83; trade with England, 24I; treaties of commerce of, 238,247 , 248: see also America; Colonies

Università della Sapienza, 207

Upper Canada, bishopric of, I44, I46, I67; state of religion in, 167 ; see also Canada

Uranga, Fernando de, bishop of Santiago de Cuba, election, and death of, 254

Urban VII. (Giovanni Battista Castagna, archbishop of Rossano), instructions of, 59, 214 ; letters of, 46, 61, 62, 91, I03, 21 3, 233

Urban VIII. (Maffeo Barberini), briefs of, 28, 29, 106, 207; bulls of, 107; England and, I06; favors granted by, I04; instructions of, 99, IIO, 2II; letters and papers of, 8 , 91, IOI, 105, 106, I08, 207, 226; relations of, 102, I03; sheets and draughts of, I07; signaturae of, 36

Urbinate Collection, 90, I12-I16
Urbino, Duke of, books of, I 12, 207

Urbino, 35; legation of, 85

Ursulines, of Louisiana, I76, I84

Urtadus, Father Raymundus, relation by, 125

Usury, cases of, I64

Utrecht, treaty of, 83,84

Valagnino, see Vavassori

Valdes, Jeronimo de, bishop of Santiago de Cuba, transfer, and death of, 256

Valdez, Father Lorenzo, mission of, I25, 126, I 49

Valdiniesso, Manillo de, letter of, 95

Valenti, nuncio, ciphers from, 66

Vanheuskert, Lorenzo, I30

Varia Politicorum, 46-47.

Vatican Archives, Archivio Segreto, 20-52; general information concerning, 7,15 , I6; indexes and inventories of, I7-19, 225; loss by fire and removal, I7; minor collections of, 90-I00; monastic documents in, 203; of the Secretary of State, $52-90$

Vatican collections, I5-I9; information about the use of, I5-I6

Vatican Library, I5, I6, IOI-II8

Vatican Library of Consultation, 15, I6; papers of the Camera in, 90

Vaudreuil, Marquis de, attempt on Quebec by, 79

Vavassori, Giov. Andrea di, map by, I03

Vendramino, relation by, I04

Venezia, Il R. Archivio Generale di, 237

Venice, ambassadors of, letters, 107, 237, 239; archives of, $237-245$; material relating to, 23I; news-letters from, I08, II3, II4, II 5 , 208 ; nunciature of, 85 ; relations of ambassadors of, 46,47 , IOO, I IO, I I I, I I 3,2 I 5,238 , $25 \mathrm{I}$

Venier, Francesco, relation by, 239

Ventadour, Duc de, proposition of, I57, I 58

Veragua, Duchess of, letters regarding, 61

Vera Paz, nomination of bishop in, I23

Vergennes, Count de (Charles Gravier), interview with, I70; letters of, I70, I7I; treaty of I783 and, 240,24 I

Versailles, peace of, 74,238

Vespers, permission to celebrate, I47

Vespucci, Amerigo, 249; account of, 208; poem on, II7; publications on, 25I

Vessels, American, arrival of, 235 ; conference concerning, 235

Vestments, expenses for, I 59

Vicars apostolic, case of missionaries and, I6r ; instructions to, III ; list of, II8, I93; nomination of, I6I; privileges of, I2I; see also names of places, and individual vicars

Vice-chancellor, office of, 4 ; records of, 40, 4I

Vienna, material relating to, $23 \mathrm{I}$

Viganderon, II4

Villagran, Marshal Franc. de, brief to, 30

Villagran y Maban, Don Garcia de, letter by, 88

Villalpando, Bernardino, bishop of Santiago de Cuba, election, and transfer of, 254

Villars, Abbé, letters of, I63, I64, I7I 
Virginia, bishopric of, I44, I45 ; deputy of, I78; disorders in, I8I; discoveries near, II5; English in, II5, I90; fighting near, II5; fleets for, II5; French colony in, I72; Indians on frontier of, 242; Irish in, I90; marriage of Charles I. and occupation of, I02; mission for, I28, I50, I58; news from II5 ; religious administration of, I45; sailing of colony and vessels to, II5; Scotch in, II5, I90; seminary in, I64, I79; Spanish successes in, II5; spiritual needs of, I77; troops for, II 5

Virginio, Father, missionary, I50

Viry, Count de, peace negotiations of, 248

Visconti, $M g r$. Carlo, relations by, 46, 9 I

Visconti, Baron P. E., collection of, I I8

Visitationes, 5

Viterbo, Bishop of (Sebastiano Gualtieri), letters of, 99

Vittoria, Franc. de, bishop of Cordova-in-Tucaman, letter relating to, 65 ; voyage of, I II

Vivaldis, Ludovico de, bishop of Arba, at consecration, 253

Voglio, A. C., La Biblioteca Casanatense, 2 Io n

Volterra, archives of, 252

Vossius, Doctor Gerardus, volume by, I I2

Walker, Admiral Sir Hovenden, departure of, 84

Walsh, Father Patrick, disorders produced by, I92; letter of, I92

Washington, George, defeat of, 75; plan of, 244 ; proposed as Lord Protector, 234

Washington, D. C., cure in, 2I8; letter from, I83

Weld, Father, information on, I67

Wenzel, Mgr. Pietro, death of, 42, 97 ; inventory of indexes by, I7, I8

West India Company, I Io, 238; Dutch, 79, 90, I I0; French, 73, I02

West Indies, Patriarch of, creation of, 44, 60

West Indies, IIo; abuses in, I24, I26, I53; affairs in, I24; altar privileges for, I24; archbishoprics and bishoprics of, I57; Augustinians in, I25, I26, I33; baptism in, 2I7; churches in, 49 ; colleges for, I38; commerce of, 238,245 ; decimae in, $25,58,93,96$; defence of, 248 ; description of, I02; Dominicans in, I30, I52; Drake in, 63, 83; Dutch in, 79, 90, II5, I I6; English in, 74, 79, 90, II4, II 5, I87, 24I ; faculties for, I30, I33, I36, I37, I56, I75; fast in, I86; flect of, 73 , 96, I I5; Franciscans of, I27 ; French in, 81, 24I ; gold discovered in, II4; inconveniences in churches of, I52; indulgences for, 30,49 , 68; Jesuits in, 64, I02, I.37, I56, I57, I90; jurisdiction in, I3I ; military operations in, 66, 73, 79, I88; Minor Observants in, I33, I34, I36, I38; missions of, 86, I23, I26, I28, I36, I37, I38, I39, I50, I57, I86, I99; navigation to, II3, II4; nuncio for, IIO, I57; Order of Mercedes in, I26; papal collector in, 46 ; patronage of, 59 , I56; pension for missionary of, 65 ; persecutions in, I50; prefecture of, I38; propagation of faith in, 127 , I56; provincials for, I52; Raleigh in, II 5 , II6; rebellion in, II 3 ; reception of novices in, 63 , I 52 ; relations of, IO2, I04, II 3, I 33 , I50, I55, I57, I70, I85; revenue of, IIO, 2 I7 ; rivalries in, 79, 8I, 24I ; slaves in, I32; I33; Spanish in, 8I, 90, I87; special congregation for, 2I3; spoils in, 64, 9I; subsidy in, 94; taxes of coadjutors in, 50 ; tumults among negroes in, I3I ; vacancies in, 64 ; visitation in, 62 ; volume relating to, 95 ; Zealanders in, II 5 ; see also Indies

West Indies, French, dispensations for, 3I ; exclusion of English goods from, 240

West Indies, Spanish, IIo; bishops and archbishops of, 94; description of, II2; Dutch in, 100

Whelan, Father, autobiography of, I63; request concerning, I72

Whitfield, James, archbishop of Baltimore, letter of, $\mathrm{I} 82$

William I., prince of Orange, material relating to, 46

Wilson, Father, letter of, I82

Wirz, Caspar, Bullen und Breven, 33, 33 n, 45 n, $85 \mathrm{n}, 90,92 \mathrm{n}, 97 \mathrm{n}$, IOO n, $202 \mathrm{n}$

Witte, Juan de, bishop of Santiago de Cuba, election of, 253

Xerley, Conde Don Antonio, see Shirley, Anthony

Ybañez, Father Diego, case of, I27; letter of, I5O

Ybarra, Diego de, brief for, 30

Yucatan, money held for Propaganda in, I27

Zacatecas, college of, I40, 204; missionary at, I 40 ; request of priest of, I4I

Zacco, Augusto, archbishop of Treviso, letter of, 186

Zane, Domenico, relations by, 47, 92, 109

Zañudio, Father, letters and papers of, I24, I52, I53

Zealanders, for West Indies, II5

Zelaia Ocariz, Martino de, bishop of Santiago de Cuba, election, and resignation of, 255 







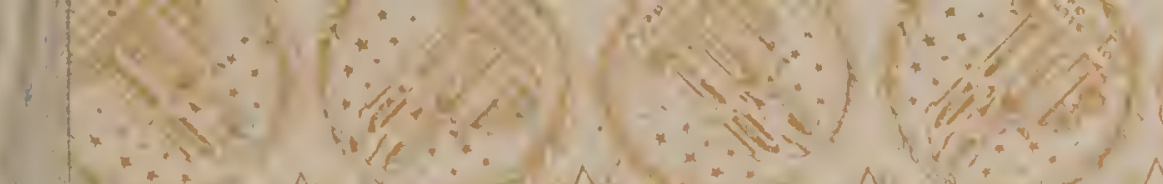

作

(n)

Ant

(1)

(1)

(4)

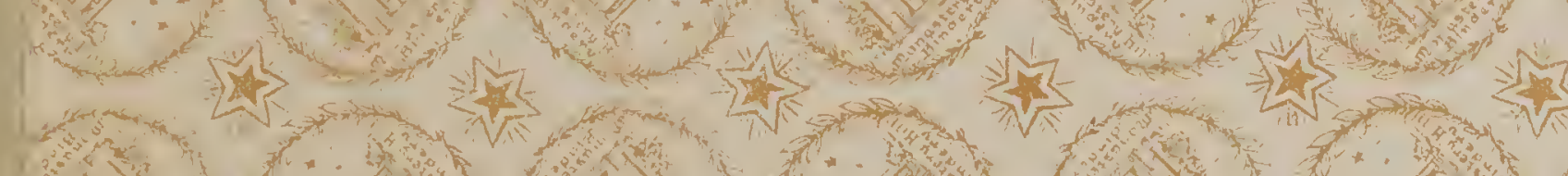

(1)

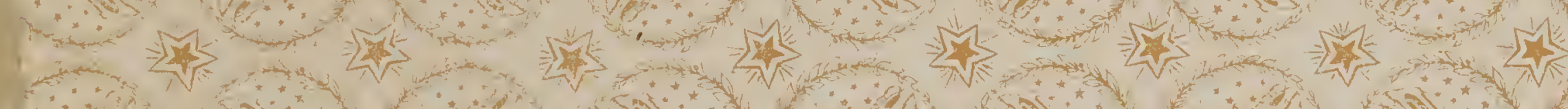

(1)

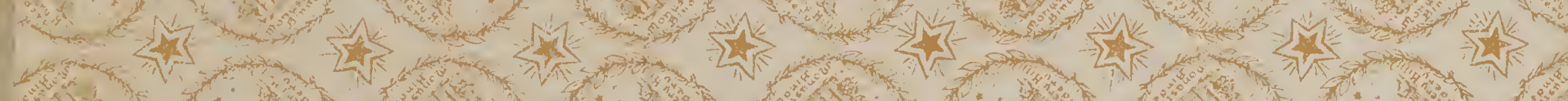

(1)

a

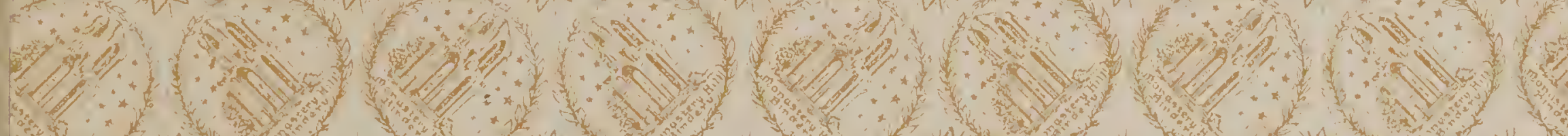

(n)

(1)

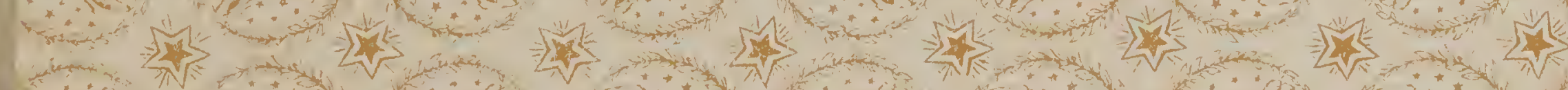

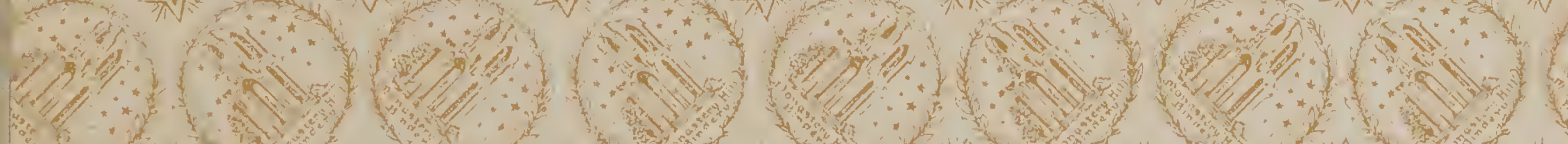

,

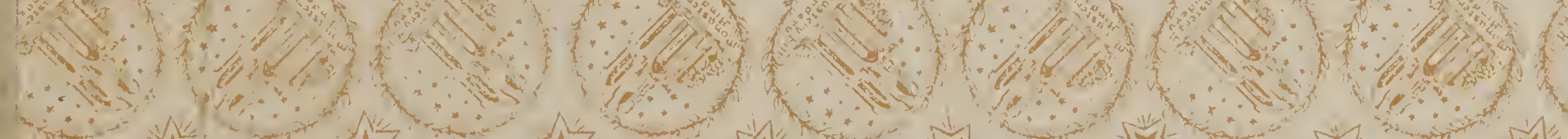

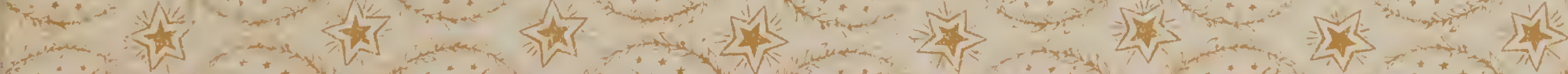

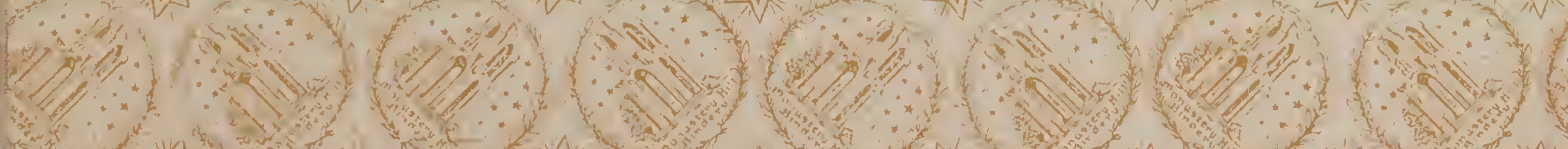
-23 , 
